\title{
Geologic Studies in Alaska by the U.S. Geological Survey, 1990
}

\section{U.S. GEOLOGICAL SURVEY BULLETIN 1999}

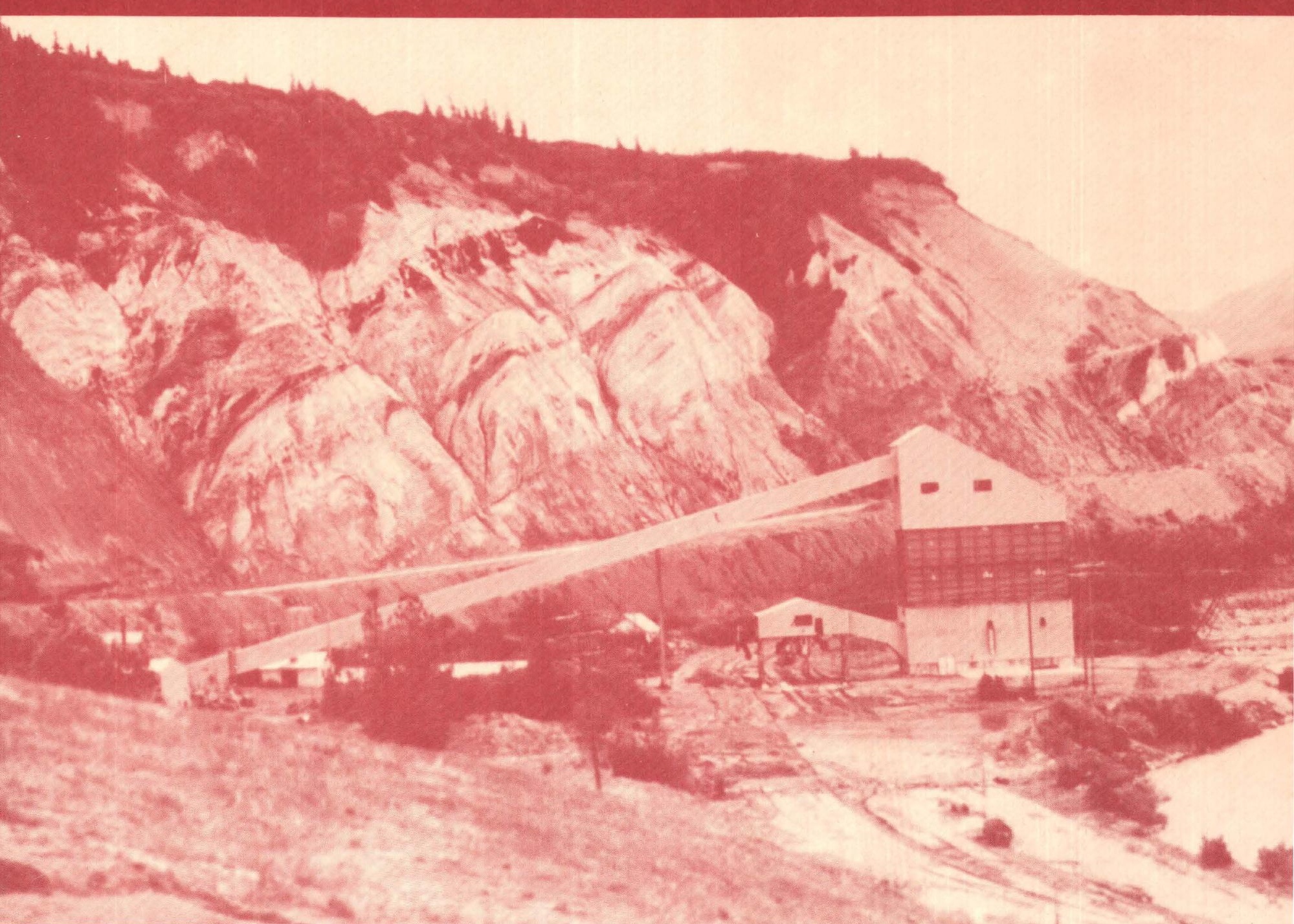




\section{AVAILABILITY OF BOOKS AND MAPS OF THE U.S. GEOLOGICAL SURVEY}

Instructions on ordering publications of the U.S. Geological Survey, along with the last offerings, are given in the current-year issues of the monthly catalog "New Publications of the U.S. Geological Survey." Prices of available U.S. Geological Survey publications released prior to the current year are listed in the most recent annual "Price and Availability List." Publications that are listed in various U.S. Geological Survey catalogs (see back inside cover) but not listed in the most recent annual "Price and Availability List" are no longer available.

Prices of reports released to the open files are given in the listing "U.S. Geological Survey Open-File Reports," updated monthly, which is for sale in microfiche from U.S. Geological Survey Book and Open-File Report Sales, Box 25425, Denver, CO 8022.

Order U.S. Geological Survey publications by mail or over the counter from the offices given below.

\section{BY MAIL}

\section{Books}

Professional Papers, Bulletins, Water-Supply Papers, Techniques of Water-Resources Investigations, Circulars, publications of general interest (such as leaflets, pamphlets, booklets), single copies of periodicals (Earthquakes \& Volcanoes, Preliminary Determination of Epicenters), and some miscellaneous reports, including some of the foregoing series that have gone out of print at the Superintendent of Documents, are obtainable by mail from

\section{U.S. Geological Survey, Book and Open-File Report Sales Box 25425 \\ Denver, CO 80225}

Subscriptions to periodicals (Earthquakes \& Volcanoes and Preliminary Determination of Epicenters) can be obtained ONLY from

\section{Superintendent of Documents}

U.S. Government Printing Office Washington, DC 20402

(Check or money order must be payable to Superintendent of Documents.)

\section{Maps}

For maps, address mail orders to

$$
\begin{gathered}
\text { U.S. Geological Survey, Map Sales } \\
\text { Box } 25286 \\
\text { Denver, CO } 80225
\end{gathered}
$$

Residents of Alaska may order maps from

$$
\begin{aligned}
& \text { U.S. Geological Survey, Map Sales } \\
& \text { 101 Twelfth Ave. - Box } 12 \\
& \text { Fairbanks, AK } 99701
\end{aligned}
$$

\section{OVER THE COUNTER}

\section{Books}

Books of the U.S. Geological Survey are available over the counter at the following U.S. Geological Survey offices, all of which are authorized agents of the Superintendent of Documents.

- ANCHORAGE, Alaska--4230 University Dr., Rm. 101

- ANCHORAGE, Alaska--605 West 4th Ave., Rm G-84

- DENVER, Colorado--Federal Bldg., Rm. 169, 1961 Stout St.

- LAKEWOOD, Colorado-- Federal Center, Bldg. 810

- MENLO PARK, California--Bldg. 3, Rm. 3128, 345 Middlefield Rd.

- RESTON, Virginia--National Center, Rm. 1C402, 12201 Sunrise Valley Dr.

- SALT LAKE CITY, Utah--Federal Bldg., Rm. 8105, 125 South State St.

- SAN FRANCISCO, California--Customhouse, Rm. 504, 555 Battery St.

- SPOKANE, Washington--U.S. Courthouse, Rm. 678, West 920 Riverside Ave.

- WASHINGTON, D.C.--U.S. Department of the Interior Bldg., Rm. 2650, 1849 C St., NW.

\section{Maps}

Maps may be purchased over the counter at the U.S. Geological Survey offices where books are sold (all addresses in above list) and at the following Geological Survey offices:

- ROLlA, Missouri--1400 Independence Rd.

- FAIRBANKS, Alaska--New Federal Building, 101 Twelfth Ave. 
CORRECTIONS FOR

U.S.Geological Survey Bulletin 1999

[GPO Jacket No. 685-041 (FY 92); program 1970-S;

print order 40007]

Page 45: Table 1 is incorrect as printed;

the correct table appears below.

Table 1. Amino-acid ratios for Hiatella arctica, Portlandia arctica, and Mya truncata

\begin{tabular}{|c|c|c|c|}
\hline Taxon & Locality' & alle/lle ${ }^{2}$ & $\begin{array}{c}\text { Number of } \\
\text { analyses }\end{array}$ \\
\hline Hiatella arctica -...........- & $\begin{array}{l}\text { Bigbendian beds at site } 1 \\
\text { Bigbendian beds at site } 3\end{array}$ & $\begin{array}{r}0.126 \pm 0.016 \\
.120 \pm 0.012\end{array}$ & $\begin{array}{r}23 \\
3\end{array}$ \\
\hline Mya truncata -.............. & Bigbendian beds at site 1 & $.121 \pm 0.021$ & 4 \\
\hline Portlandia arctica -.......-. & $\begin{array}{l}\text { Bigbendian beds at site } 1 \\
\text { Bigbendian beds at site } 2 \\
\text { Bigbendian beds at site } 3\end{array}$ & $\begin{array}{l}.136 \pm 0.015 \\
.155 \pm 0.007 \\
.165 \pm 0.009\end{array}$ & $\begin{array}{l}5 \\
5 \\
4\end{array}$ \\
\hline Hiatella arctica -............ & Fishcreekian beds at site 2 & $.085 \pm 0.010$ & 10 \\
\hline Hiatella arctica -........... & Colvillian beds at site 3 & $.227 \pm 0.026$ & 19 \\
\hline
\end{tabular}

'Sample localities shown on fig. 1.

${ }^{2}$ Total acid hydrolysate.

Page 50: The value $-10_{-5.4}^{+26}{ }^{\circ} \mathrm{C}$ (line 10, second full paragraph, left column) should read $-10_{-5.4}^{+2.6}{ }^{\circ} \mathrm{C}$.

Page 201: The value 4.4 trillion $t$ (third line from the bottom, right column) should read 3.7 trillion $t$.

Page 202: The values for metric tons of coal in table 2 are given in billions $\left(\mathbf{1 0}^{9}\right)$, not hundreds $\left(1^{2}\right)$ as shown. Thus, the correct heading for the last column should be: 


\section{Geologic Studies in Alaska by the U.S. Geological Survey, 1990}

DWIGHT C. BRADLEY and ARTHUR B. FORD, Editors

A collection of reports on recent research studies on Alaskan geology, geochemistry, paleontology, geochronology, and resources 


\section{U.S. DEPARTMENT OF THE INTERIOR}

MANUEL LUJAN, JR., Secretary

U.S. GEOLOGICAL SURVEY

Dallas L. Peck, Director

Any use of trade, product, or firm names

in this publication is for descriptive purposes only

and does not imply endorsement by the U.S. Government

For sale by the

Books and Open-File Reports Section

U.S. Geological Survey

Federal Center, Box 25425

Denver, CO 80225

Cover - Suntrana coal tipple on Healy Creek, Nenana coal field, about $120 \mathrm{~km}$ southwest of Fairbanks. Miocene coal-bearing strata of the Usibelli Group exposed in background. See report by R.G. Stanley, R.M. Flores, and T.J. Wiley for description of the Usibelli Group at this locality. Photograph by Hugh McLean, August 1986. 


\section{CONTENTS}

Introduction 1

Dwight C. Bradley and Arthur B. Ford

\section{ARTICLES}

The Mount Copleston Limestone, a new Lower Devonian formation in the Shublik Mountains, northeastern Brooks Range, Alaska 3

Robert B. Blodgett, James G. Clough, Anita G. Harris, and Mark S. Robinson

Depositional and biostratigraphic framework of the Upper Cretaceous Kuskokwim Group, southwestern Alaska 8

Stephen E. Box and William P. Elder

Deformation history of the McHugh Complex, Seldovia quadrangle, south-central Alaska 17

Dwight C. Bradley and Timothy M. Kusky

Occurrence of platinum-group elements in some gold-mining districts of Alaska 33 John B. Cathrall and John C. Antweiler

Age of the late Cenozoic Bigbendian marine transgression of the Alaskan Arctic coastal plain: Significance for permafrost history and paleoclimate 44

L. David Carter and John W. Hillhouse

Tectonic implications of the Albatross sedimentary sequence, Sitkinak Island, Alaska 52

William S. Clendenen, William V. Sliter, and Tim Byme

Discrepancies between geologic evidence and rotational models - Talkeetna Mountains and adjacent areas of south-central Alaska 71

Béla Csejtey, Jr.

Clay mineral depositional facies and uranium resource potential in part of the Tertiary Kenai Group, Kenai Peninsula, Alaska 81

Kendell A. Dickinson and Gary L. Skipp

Early Holocene calcretes from the subarctic active Nogahabara Sand Dune field, northern Alaska 100

John P. Galloway, Mark Huebner, Robert Lipkin, and Jos W.A. Dijkmans

Tectonics and petroleum potential of the Brooks Range fold-and-thrust belt $-\mathrm{A}$ progress report 112

David G. Howell, Kenneth J. Bird, Lu Huafu, and Mark J. Johnsson

Tectonic evolution of the Kandik region, east-central Alaska: Preliminary interpretations 127

David G. Howell, Mark J. Johnsson, Michael B. Underwood, Lu Huafu, and John W. Hillhouse 
Arc and extensional basin geochemical and tectonic affinities for the Maiyumerak basalts in the western Brooks Range 141

Susan M. Karl

Geochemically anomalous areas in the eastern Goodnews Bay $1^{\circ}$ by $3^{\circ}$ quadrangle, southwest Alaska 156

James E. Kilburn, Stephen E. Box, Richard J. Goldfarb, and John E. Gray

Early Middle Miocene mollusks and benthic foraminifers from Kodiak Island,

\section{Alaska 163}

Louie Marincovich, Jr. and Shigehiro Moriya

Reconnaissance sandstone petrology and provenance of the Cantwell Formation, central Alaska $\mathbf{1 7 0}$

Hugh McLean and Richard G. Stanley

${ }^{40} \mathrm{Ar}{ }^{\beta 9} \mathrm{Ar}$ isotopic ages from the combined Wrangellia-Alexander terrane along the Border Ranges fault system in the eastern Chugach Mountains and Glacier Bay, Alaska 180

S.M. Roeske, T.L. Pavlis, L.W. Snee, and V.B. Sisson

Reevaluation of coal resources in the Late Cretaceous-Tertiary Sagavanirktok Formation, North Slope, Alaska 196

Stephen B. Roberts, Gary D. Stricker, and Ronald H. Affolter

Fluvial facies architecture in the Tertiary Usibelli Group of Suntrana, central

Alaska 204

Richard G. Stanley, Romeo M. Flores, and Thomas J. Wiley

\section{GEOLOGIC NOTES}

A postulated new source for the White River Ash, Alaska 212

Robert G. McGimsey, Donald H. Richter, Gregory D. DuBois, and Thomas P. Miller

Preliminary interpretation of vegetation and paleoclimate in northern Alaska during the Late Pliocene Colvillian marine transgression 219

Robert E. Nelson and L. David Carter

Electrical resistivity cross sections in east-central Alaska $\mathbf{2 2 3}$

Jay A. Sampson, Victor F. Labson, and Carl L. Long

Gold placers, gold source, and high terrace gravels in the Fortymile River area, Alaska 228

Warren Yeend

\section{BIBLIOGRAPHIES}

U. S. Geological Survey reports on Alaska released in 1990231 Ellen R. White

Reports about Alaska in non-USGS publications released in 1990 that include USGS authors 236

Ellen R. White

Contributors to this bulletin 243 


\title{
Geologic Studies in Alaska by the U.S. Geological Survey, 1990
}

\author{
By Dwight C. Bradley and Arthur B. Ford, Editors
}

\section{INTRODUCTION}

This collection of papers continues the annual series of U.S. Geological Survey (USGS) reports on geologic investigations in Alaska. From 1975 through 1988, the series was published as USGS circulars. The first of these appeared under the title "The United States Geological Survey in Alaska: Accomplishments during 1975," and the series continued to the last annual circular entitled "Geologic studies in Alaska by the U.S. Geological Survey during 1987," which reflects a title change made in 1986. This 1990 volume continues the bulletin format started in 1988. As in 1989, this volume separates shorter contributions as Geologic Notes from more extensive Articles.

This 1990 volume of 18 Articles and 4 Geologic Notes represents the broad range of USGS research activities carried out in Alaska over the past few years. These studies include topics on mineral and other resources such as gold (Yeend), platinum-group elements (Cathrall and Antweiler), coal (Roberts, Stricker, and Affolter), and petroleum (Howell, Bird, and others). Many other investigations provide background geochemical (Kilburn, Box, and others) and geologic data needed for resource evaluation as well as for determining the general geologic framework of Alaska, as in stratigraphic, sedimentologic, and paleontologic and radiometric age studies (Blodgett, Clough, and others; Box and Elder; Dickinson and Skipp; Marincovich and Moriya; McLean and Stanley; Stanley, Flores, and Wiley; Roeske, Pavlis, and others); geophysics (Sampson, Labson, and Long); structure and tectonic evaluations (Bradley and Kusky; Clendenen, Sliter, and Byrne; Karl; Csejtey; Howell, Johnsson, and others); and geomorphic and late Quaternary studies (Carter and Hillhouse; Galloway, Huebner, and others; McGimsey, Richter, and others; Nelson and Carter). These studies span nearly the entire State from the North Slope and Brooks Range to interior, southwestern, and south-central Alaska (fig. 1).

Two bibliographies (White) at the end of the volume list (1) reports about Alaska in USGS publications released in 1990 and (2) reports about Alaska by USGS authors in publications outside the USGS in 1990. A bibliography and index of papers in past USGS circulars that are devoted to geologic research and accomplishments in Alaska (1975 to 1986) is published as USGS Open-File Report 87-420. 


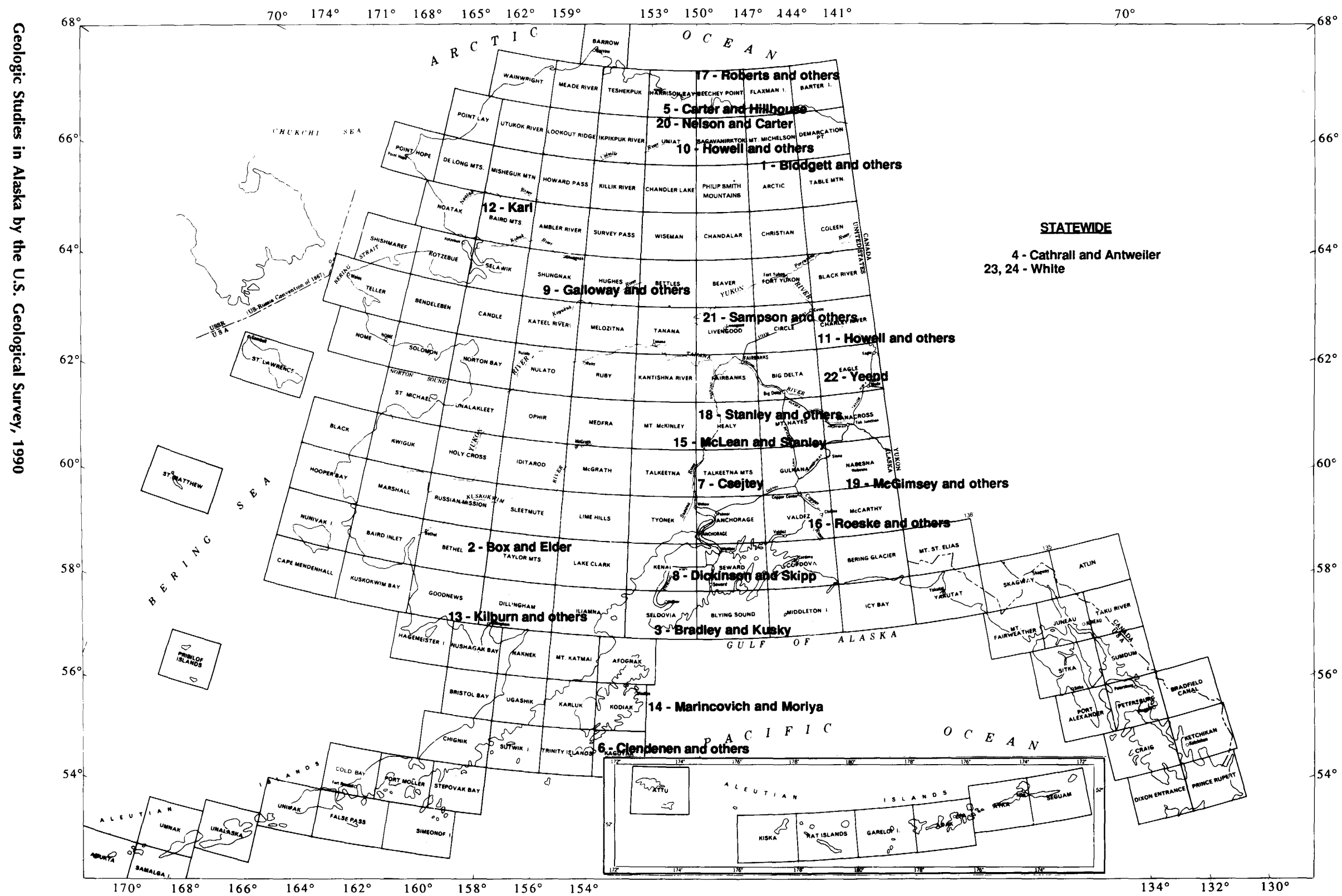

Figure 1. Index map of Alaska showing 1:250,000-scale quadrangles and general locations of study areas discussed in this bulletin. Numbers indicate order of papers in the volume; names of authors follow numbers. 


\title{
The Mount Copleston Limestone, a New Lower Devonian Formation in the Shublik Mountains, Northeastern Brooks Range, Alaska
}

\author{
By Robert B. Blodgett, James G. Clough, Anita G. Harris, and Mark S. Robinson
}

\section{Abstract}

A new stratigraphic unit, the Mount Copleston Limestone, is proposed for the rocks that heretofore comprised the Devonian part of the uppermost member of the Nanook Limestone. The Mount Copleston Limestone is recognized only in the Shublik Mountains of the northeastern Brooks Range, Alaska. It is bounded by unconformities, so that it overlies beds of the Nanook Limestone that range in age from as old as Middle(?) Ordovician to as young as Late Ordovician and underlies Lower Mississippian strata of the Endicott Group (Kekiktuk Conglomerate and succeeding Kayak Shale). The maximum thickness of the formation is $71.6 \mathrm{~m}$ at its type section. It is of Emsian (late Early Devonian) age, and conodonts from the unit indicate a biostratigraphic range from the gronbergi to serotinus Zones, inclusive. The fauna and carbonate rock types of the Mount Copleston Limestone suggest that it formed in a shallow-water, partially restricted, inner-platform environment.

\section{INTRODUCTION}

In this paper, we propose a revision of the stratigraphic nomenclature of the Devonian carbonate strata that form the upper part of the uppermost member (member 8) of the Nanook Limestone as defined by Dutro (1970). The data presented here result from field studies conducted during 1985, 1987, and 1989.

Dutro (1970) named the Nanook Limestone for a sequence of carbonate rocks presumed to be about 915 $m$ thick and which were subsequently found to be more than 1,220 $\mathrm{m}$ thick (Clough and others, 1990). The formation is well exposed along the crest of the Shublik Mountains, where its type section (consisting of the composites of three partial sections) is situated, and it is also exposed in the adjacent Sadlerochit Mountains to the north. The areal distribution of the (unrestricted) Nanook Limestone was shown in Dutro (1970), Reiser and others (1970, 1971), Bader and Bird (1986), and Robinson and others (1989). It is separated by a probable disconformity from the underlying Katakturuk Dolomite, also named by Dutro (1970), and is overlain unconformably by the Kekiktuk Conglomerate. The angular unconformity separating the Kekiktuk Conglomerate from the underlying Nanook Limestone has significant erosional relief; locally, at least $610 \mathrm{~m}$ of the Nanook are truncated. The Nanook was subdivided into eight informal members by Dutro (1970). The uppermost member (member 8) was described as "Upper limestone member-about 700 feet thick; mostly thick-bedded, light-gray limy mudstone except for upper 100-200 feet, which is dark and thin-bedded; upper beds contain a coral-stromatoporoid faunal assemblage" (Dutro, 1970, p. M2). Corals and a stromatoporoid from the uppermost beds of the Nanook were thought to indicate a Middle Devonian, possibly Eifelian age for the upper part of the unit. The entire formation was suggested to be of Middle Devonian age based on reputed fossils (Dutro, 1970) in the lower members. Blodgett and others (1986a, b) later significantly revised the age of member 8 on the basis of new fossil collections. Their new paleontologic data show member 8 to consist of beds of Late Cambrian, Early Ordovician, Middle and (or) Late Ordovician, and late Early Devonian (Emsian) and (or) early Middle Devonian (Eifelian) age. In addition, one collection from what is now section 87NA-1 (fig. 1) suggested some strata to be of Early Silurian (Llandoverian) age. Subsequent studies of sections $87 \mathrm{NA}-1$ and $87 \mathrm{NA}-2$ (figs. 1, 2) have demonstrated that no Silurian strata are present-the reputed Lower Silurian beds are actually of Late Ordovician age, a disconformity separates Upper Ordovician and Lower Devonian strata within member 8, and the Devonian part of member 8 is restricted to the Emsian (upper Lower Devonian)(Blodgett and others, 1988).

Field work conducted by Blodgett and Clough in 1989 extended the Devonian part of member 8 westward 
in the Shublik Mountains. Lithologic and faunal evidence now suggest that the lower unconformity is even more substantial than previously believed because Emsian strata rest on Middle(?) Ordovician strata in the western end of the outcrop belt. Because the relatively thin (as much as $71.6 \mathrm{~m}$ thick) Devonian part of member 8 of the Nanook Limestone is lithologically distinct as well as bounded by unconformities, we propose to stratigraphically exclude these rocks from the Nanook Limestone and reassign them as a new, separate unit described below.

\section{MOUNT COPLESTON LIMESTONE}

We here name the unit excluded from the Nanook Limestone the Mount Copleston Limestone for nearby Mount Copleston, which is situated approximately 1.8 $\mathrm{km}$ to the west of the westernmost outcrop belt of the new formation. The Mount Copleston Limestone appears to be restricted to two outcrop belts in the Shublik Mountains (fig. 1) in the Mount Michelson B-4, C-3, and C-4 quadrangles. The type and reference sections are shown in figure 2 . Both belts are on the same general structural trend, but they are separated by an area in which pre-Kekiktuk erosion has removed the Mount Copleston rocks. The smaller, western, arcuate belt is near- ly $2 \mathrm{~km}$ long. The eastern outcrop belt is approximately $12 \mathrm{~km}$ long and contains the type and reference sections of the unit. Although at least part of member 8 of the Nanook Limestone (containing Early Ordovician fossils) can be recognized in the adjacent Sadlerochit Mountains to the north, no strata assignable to the Mount Copleston Limestone have been recognized there. Reiser and others (1970, table 1, collection 1) report a fossil locality of Devonian(?) age from what they mapped as the Katakturuk Dolomite of the Sadlerochit Mountains, Mt. Michelson C-4 quadrangle. In a reexamination of this locality, Blodgett and Clough have shown that the Lisburne Group (Carboniferous) directly overlies the Katakturuk Dolomite (Proterozoic), with no intervening lower or middle Paleozoic strata.

The Mount Copleston Limestone consists of thinto medium-bedded, dark-gray lime mudstone and bioclastic wackestone and packstone. The dark-gray limestones of this unit are easily distinguished from the much lighter gray Ordovician strata beneath the unconformity surface. The formation ranges from $71.6 \mathrm{~m}$ thick at its type section (87NA-2) to a feather edge where it has been removed by pre-Kekiktuk erosion. At the type section (fig. 2), two-holed crinoid ossicles, indicative of an Emsian and Eifelian age, form a 0.3-m-thick encrinite bed immediately above the unconformity. The Mount Copleston Limestone rests unconformably on Upper
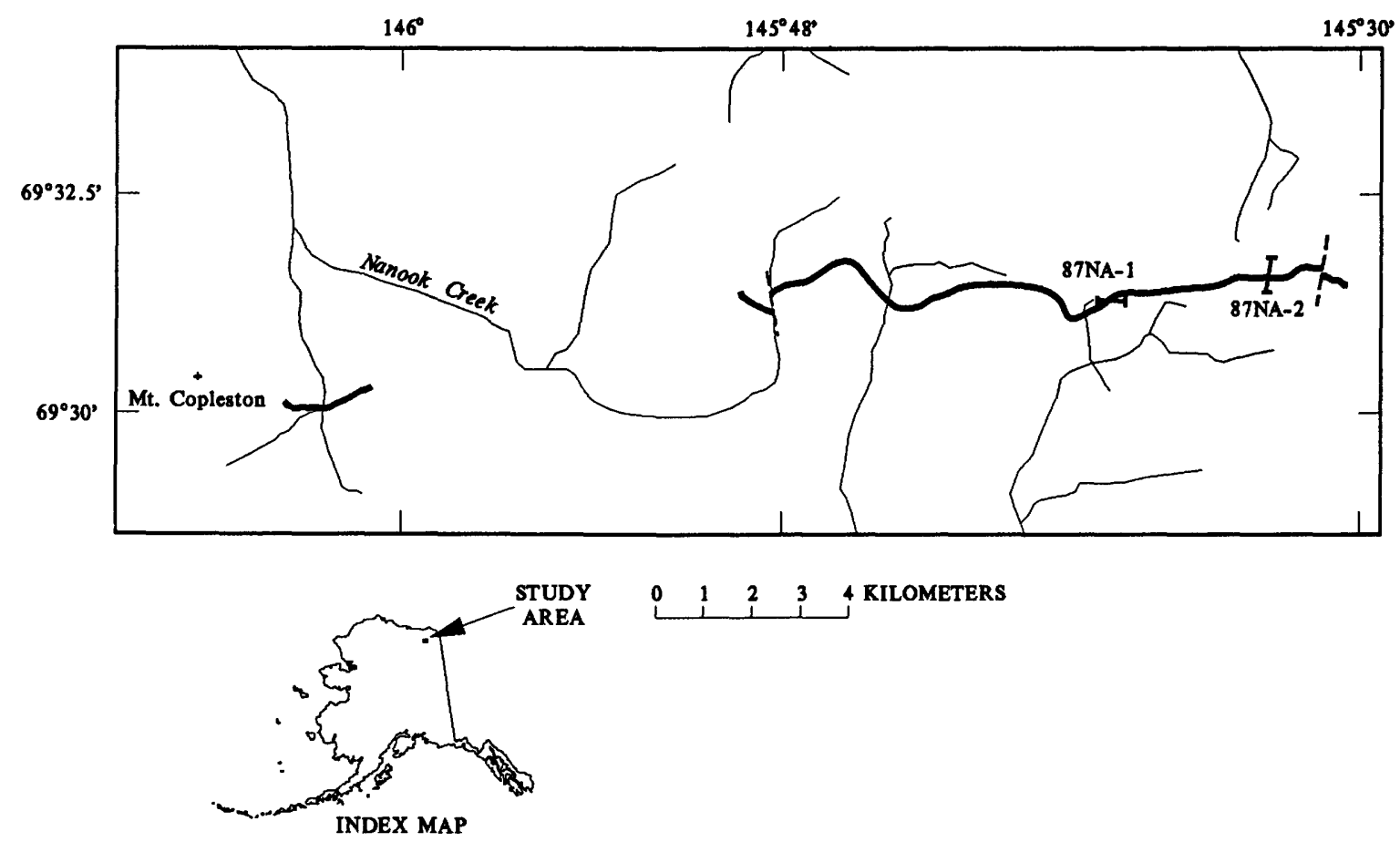

Figure 1. Areal distribution of Mount Copleston Limestone in Shublik Mountains. Sections 87NA-1 and 87NA-2 (see fig. 2) are reference and type sections, respectively, for this newly named stratigraphic unit. Dashed line, break in section. Base modified from Mt. Michelson B-4 (1983 edition), C-3 (1955 edition), and C-4 (1955 edition) quadrangle maps (scale 1:63,360). 
Ordovician strata at its type and reference sections in its eastern outcrop belt (Blodgett and others, 1988). However, in the western belt, the Mount Copleston appears to overlie strata lithogically comparable to Middle Ordovician strata of the eastern belt. Two large samples were collected for conodonts from the uppermost part of the Nanook Limestone lying immediately below the Mount Copleston Limestone in the western belt. These samples yielded only a few, poorly preserved, relatively long- ranging conodonts (Ansella sp. indet., Panderodus sp., and Periodon sp. indet.) that merely indicate a Llanvirnian to early Ashgillian (Middle to early Late Ordovician) age. The Mount Copleston Limestone appears to be everywhere unconformably overlain by the Kekiktuk Conglomerate of the Endicott Group of Early Mississippian age. This contact, however, has not been actually observed. The uppermost beds of the Mount Copleston at its type section are overlain by talus rubble consisting of

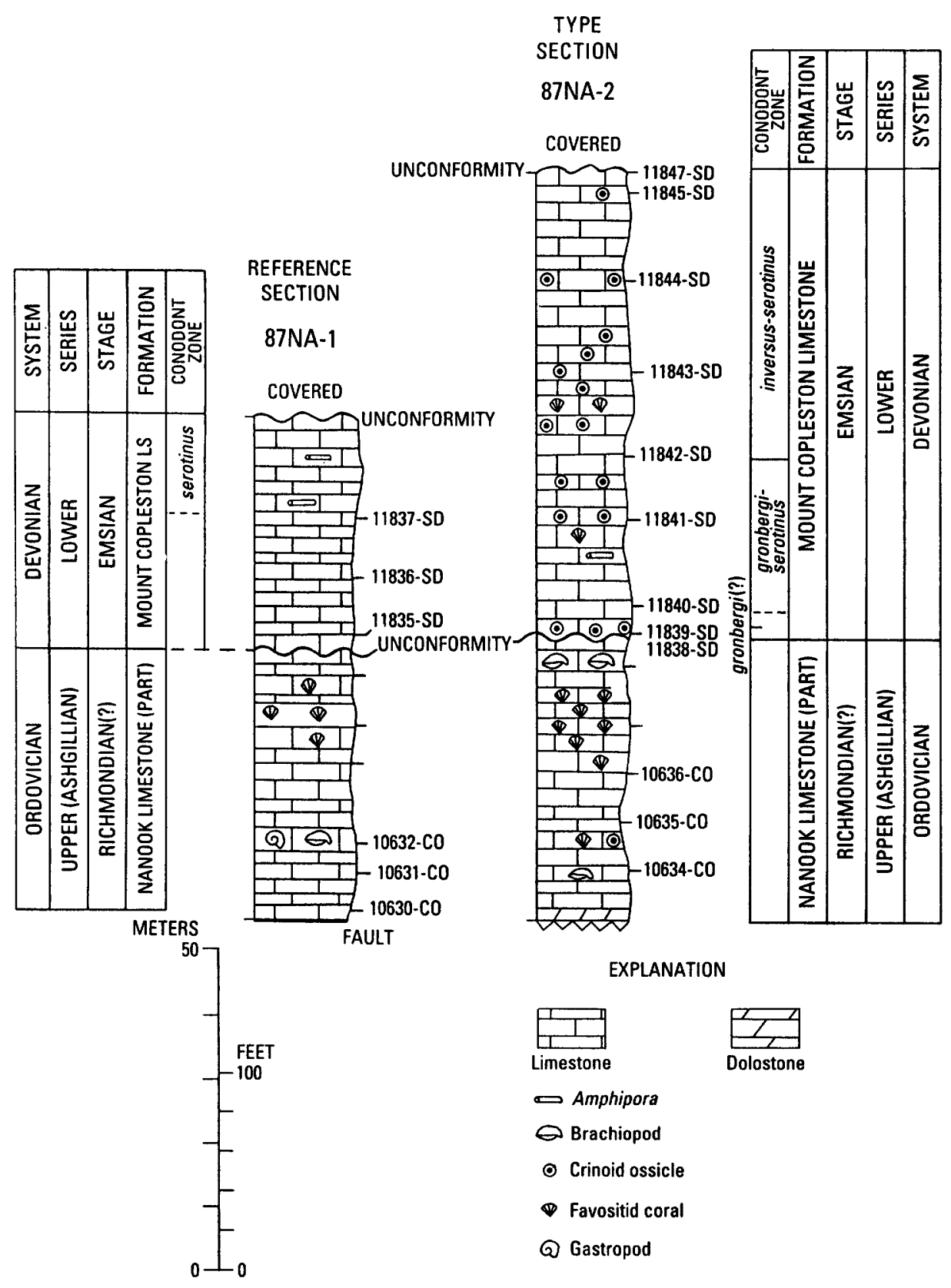

Figure 2. Columnar sections showing correlation of type and reference sections of Mount Copleston Limestone. Location of sections shown on figure 1. Ticks to right of each column indicate conodont sample. Ticks accompanied by USGS collection number indicate that sample yielded relatively biostratigraphically useful conodonts. Figure slightly modified from Blodgett and others (1988, fig. 2). 
Lisburne Group carbonate rocks and a minor component derived from the Kayak Shale. At the reference section, the topmost beds of the Mount Copleston are succeeded by a thick covered interval. Several hundred meters along strike in either direction, however, this same interval contains small exposures of the Kayak Shale along creek banks. Nevertheless, it seems likely that the Kekiktuk Conglomerate is mostly continuous throughout the region, as float and rubble of this unit occur in many places between its sporadic outcrops.

The type section of the Mount Copleston Limestone is designated as section 87NA-2 of Blodgett and others (1988) and this report. It lies along a north-trending ridge in the NE $1 / 4 \mathrm{SW}^{1 / 4} / 4 \mathrm{sec} .17$, T. $2 \mathrm{~N}$., R. 27 E., lat $69^{\circ} 31.6^{\prime}$ N., long $145^{\circ} 33.2^{\prime}$ W., Mt. Michelson C-3 quadrangle (fig. 1). The unit is $71.6 \mathrm{~m}$ thick here, which is the maximum known thickness of the formation. Section 87NA-1 of Blodgett and others (1988) and this report is designated as a reference section for this formation. It lies along an east-west transect near the southern boundary of the SE $1 / 4 \mathrm{SW}^{1 / 4} / 4 \mathrm{sec} .13$, T. 2 N., R. 26 E., lat $69^{\circ} 31.3^{\prime}$ N., long $145^{\circ} 38.3^{\prime}$ W., Mt. Michelson C-3 quadrangle (fig. 1).

\section{FOSSIL DATA}

Megafossils are easily recognizable in the Mount Copleston Limestone. The most commonly observed forms are tabulate and rugose corals, followed in abundance by stromatoporoids, crinoid ossicles, brachiopods, gastropods, and trilobites. Because fossils do not usually weather free from this unit, most of the materials studied are "crack-out" specimens. When freed from the highly indurated, dominantly fine-grained matrix, none of the gastropods retain external shell material intact. Hence, even their generic identification is difficult to impossible. Brachiopods recovered to date from the unit are not age definitive by themselves. Tabulate and rugose corals comprise the most easily studied elements of the fauna for future investigations; they are relatively abundant and easily recognized in the field. Oliver and others (1975, p. 28 , Table 10) provided a list of rugose and tabulate coral taxa (plus the sticklike stromatoporoid Amphipora) for four collections from the (unrestricted) Nanook Limestone. These were considered to be of Middle(?) Devonian age. None of these species were illustrated in their paper. The only illustrated elements of the Mount Copleston fauna are conodonts (Blodgett and others, 1988, fig. 3G-K). Illustrated species included representatives of Pandorinellina expansa Uyeno and Mason, Ozarkodina cf. $O$. paucidentata Murphy and Matti, Polygnathus inversus Klapper and Johnson, and $P$. aff. $P$. perbonus (Philip). Other conodont species were listed in the same paper but not illustrated.

\section{AGE AND ENVIRONMENT OF DEPOSITION}

The Mount Copleston Limestone appears to be restricted to the Emsian (upper Lower Devonian) on the basis of conodonts. The conodonts indicate a range from the gronbergi to serotinus Zones, inclusive [see Blodgett and others (1988) for more detailed discussion of the conodont faunas found in sections 87NA-1 and 87NA-2]. Associated megafossils are less age definitive, but the most distinctive faunal elements recognized to date are the two-holed crinoid ossicles, typically considered indices of Emsian and Eifelian strata in western and Arctic North America.

Lithologies ranging from bioclastic packstone and wackestone to peloidal-laminated mudstone with fenestrae suggest that the Mount Copleston Limestone was deposited in a shallow subtidal to locally intertidal setting (Clough and others, 1988). The abundance of the sticklike stromatoporoid Amphipora, in places forming biostromes with only a few other accessory faunal elements, further suggests deposition under partially restricted, lagoonal conditions. This is also supported by the general absence to scarcity of conodonts, at least in the reference section of the Mount Copleston Limestone, where the only conodonts recovered represent post-mortem transport of shallow-water forms. Conodonts and rugose and tabulate corals are more abundant and relatively diverse in the type section, suggesting more normal marine conditions occurred in this area. The abundance and diversity of corals throughout most sections suggest that the Mount Copleston Limestone was deposited on a shallow-water, partially restricted carbonate platform.

Acknowledgments.-The Committee for Research and Exploration of the National Geographic Society kindly made available funds that helped support the early phases of the work of Blodgett. Field work was logistically supported by the Alaska Division of Geological and Geophysical Surveys. We also wish to thank John Decker, formerly with the Alaska Division of Geological and Geophysical Surveys, whose encouragement and support during the preliminary phases of our field studies made possible our subsequent results.

\section{REFERENCES CITED}

Bader, J.W., and Bird, K.J., 1986, Geologic map of the Demarcation Point, Mt. Michelson, Flaxman Island and Barter Island quadrangles, northeastern Alaska: U.S. Geological Survey Miscellaneous Investigations Series Map I-1791, 1 sheet.

Blodgett, R.B., Clough, J.G., Dutro, J.T., Jr., Ormiston, A.R., Palmer, A.R., and Taylor, M.E., 1986a, Age revisions for the Nanook Limestone and Katakturuk Dolomite, northeastern Brooks Range, in Bartsch-Winkler, Susan, and Reed, K.M., eds., Geologic studies in Alaska by the U.S. 
Geological Survey during 1985: U.S. Geological Survey Circular 978, p. 5-10.

Blodgett, R.B., Clough, J.G., Dutro, J.T., Jr., Palmer, A.R., Taylor, M.E., and Ormiston, A.R., 1986b, Age revision of the Katakturuk Dolomite and Nanook Limestone, northeastern Brooks Range, Alaska [abs.]: Geological Society of America Abstracts with Programs, v. 18, no. 2, p. 87.

Blodgett, R.B., Rohr, D.M., Harris, A.G., and Rong Jia-yu, 1988, A major unconformity between Upper Ordovician and Lower Devonian strata in the Nanook Limestone, Shublik Mountains, northeastern Brooks Range, in Galloway, J.P., and Hamilton, T.D., eds., Geologic studies in Alaska by the U.S. Geological Survey during 1987: U.S. Geological Survey Circular 1016, p. 18-23.

Clough, J.G., Blodgett, R.B., Imm, T.A., and Pavia, E.A., 1988, Depositional environments of the Katakturuk Dolomite (Proterozoic) and the Nanook Limestone (Proterozoic to Devonian), Arctic National Wildlife Refuge, Alaska [abs.]: American Association of Petroleum Geologists Bulletin, v. 72, p. 172.

Clough, J.G., Robinson, M.S., Pessel, G.H., Imm, T.A., Blodgett, R.B., Harris, A.G., Bergman, S.C., and Foland, K.A., 1990, Geology and age of Franklinian and older rocks in the Sadlerochit and Shublik Mountains, Arctic National Wildlife Refuge, Alaska [abs.]: Geological Association of Canada and Mineralogical Association of Canada Annual Meeting, Program with Abstracts, v. 15, p. A25.

Dutro, J.T., Jr., 1970, Pre-Carboniferous carbonate rocks, northeastern Alaska, in Adkison, W.L., and Brosgé, W.P., eds., Proceedings of the geological seminar on the North Slope of Alaska: Los Angeles, California, American Association of Petroleum Geologists, Pacific Section, p. M1-M8.

Oliver, W.A., Merriam, C.W., and Churkin, M., Jr., 1975, Ordovician, Silurian, and Devonian corals of Alaska: U.S. Geological Survey Professional Paper 823-B, p. 13-44.

Reiser, H.N., Brosgé, W.P., Dutro, J.T., Jr., and Detterman, R.L., 1971, Preliminary geologic map, Mt. Michelson quadrangle, Alaska: U.S. Geological Survey open-file Map 490, 2 sheets.

Reiser, H.N., Dutro, J.T., Jr., Brosgé, W.P., Armstrong, A.K., and Detterman, R.L., 1970, Progress map, geology of the Sadlerochit and Shublik Mountains, Mt. Michelson C-1, C-2, C-3 and C-4 quadrangles, Alaska: U.S. Geological Survey open-file map 440,5 sheets.

Robinson, M.S., Decker, J., Clough, J.G., Reifenstuhl, R.R., Bakke, A., Dillon, J.T., and Rawlinson, S.E., 1989, Geology of the Sadlerochit and Shublik Mountains, Arctic National Wildlife Refuge, northeastern Alaska: Alaska Division of Geological and Geophysical Surveys, Professional Report 100, 1 sheet.

Reviewers: Randall C. Orndorff and John E. Repetski 


\title{
Depositional and Biostratigraphic Framework of the Upper Cretaceous Kuskokwim Group, Southwestern Alaska
}

\author{
By Stephen E. Box and William P. Elder
}

\section{Abstract}

The Kuskokwim Group was deposited in a deep marine basin following an Early Cretaceous period of oceanic terrane accretion and preceding the latest Cretaceous establishment of Pacific seafloor subduction in roughly its present geometry. Removal of Tertiary right-lateral separation across the Iditarod-Nixon Fork and Togiak-Farewell fault systems reveals the approximate original basin geometry of two northeast-trending subbasins (the Kuskokwim River subbasin to the northwest, and the Mulchatna River subbasin to the southeast) connected by a northwest-trending corridor (Nushagak Hills corridor). Coarse-grained, nearshore to slope facies units flank most of the present margins of exposure of the Kuskokwim Group, except along the southeast side, where a fine-grained facies is faulted against the Peninsular terrane. Turbidite paleocurrents indicate paleoflow out of the northern and southern ends of the Kuskokwim River subbasin, turning southeastward through the Nushagak Hills corridor, and joining southwestward paleoflow out of the northern end of the Mulchatna River subbasin.

Fifteen inoceramid species are identified from 40 localities within the Kuskokwim Group and range in age from early or middle Cenomanian to early Santonian. Most of the species are found in other regions of the North $\mathrm{Pa}$ cific (particularly Japan and the eastern Soviet Union) or are found throughout the Northern Hemisphere. The Kuskokwim fauna, however, differs markedly from age-equivalent faunas in both northern and south-central Alaska. Only one species, Inoceramus kuskokwimensis n. sp., is new and may be endemic. The early to middle Cenomanian fossil localities are restricted to the coarse marginal facies rocks at the northeastern end of the Kuskokwim River subbasin. Deposition in the southern end of the Kuskokwim River subbasin began later than to the north (late Cenomanian to middle Turonian). Deposition occurred throughout the Kuskokwim basin by middle Turonian time. The southern arm of the Kuskokwim River subbasin may have been infilled to shallow marine depths by early Coniacian time. Deep-water sedimentation continued in the Nushagak Hills corridor at least until early Santonian time.

\section{INTRODUCTION}

The Upper Cretaceous Kuskokwim Group (Cady and others, 1955) consists of a thick sequence of predominantly deep-water marine turbidites with immature, lithic-rich compositions and underlies a broad area of about $60,000 \mathrm{~km}^{2}$ in southwestern Alaska (fig. 1). The Kuskokwim Group was deposited during a time of tectonic transition after a widespread episode of oceanic and continental terrane accretion in Early Cretaceous time (Box, 1985) and before the latest Cretaceous establishment of Pacific seafloor underthrusting in roughly its present geometry (Wallace and Engebretson, 1984). The tectonic setting and driving mechanism(s) of Kuskokwim basin subsidence are poorly understood. The basin has been related by various authors to strike-slip faulting (Pacht and Wallace, 1984), back-arc spreading behind the Alaska Range-Aleutian arc (Decker, 1984), and subsidence along a continent-oceanic arc suture following collision (Wallace, 1984; Wallace and others, 1989). Deciphering the depositional history of the Kuskokwim Group is critical to understanding the consolidation of the mass of accreted island-arc and continental fragments into the present Alaskan subcontinental landmass.

Stratigraphic analysis of the Kuskokwim Group has been hampered by scattered exposures, strong deformation, lack of distinctive marker horizons, and a general dearth of fossils (particularly those of age-diagnostic value). Ammonites are very rare within the sequence and are essentially limited to heteromorph species having durations of a stage or more. In contrast, inoceramid bivalves are considerably more abundant and commonly allow age determinations at the substage level. Early attempts by T.W. Stanton, R. W. Imlay, and J.B. Reeside, Jr., to identify the inoceramids (see Imlay and Reeside, 1954; Cady and others, 1955) were hampered by generally poor material and by the early developmental stages of the North Pacific inoceramid taxonomy and biostratig- 
raphy. Continued fossil collection in the Kuskokwim Group, coupled with further refinement of the North Pacific and European inoceramid taxonomy and biostratigraphy, has allowed the refined taxonomic and age as- signments outlined here and presented in detail elsewhere (Elder and Box, 1992). This paper reviews the geology of the Kuskokwim Group, outlines the new biostratigraphic data, and discusses the implications of

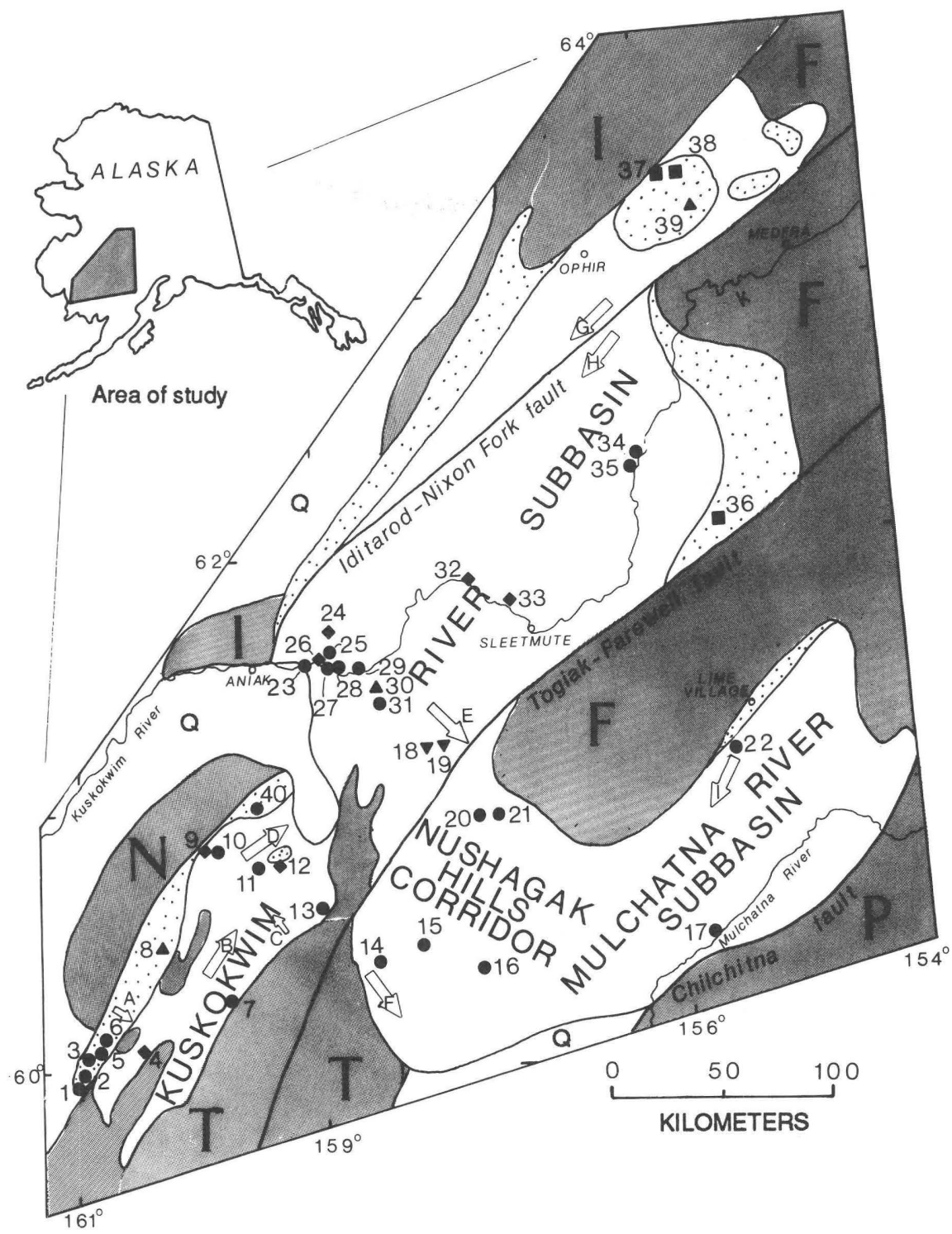

Figure 1. Locality map of the depositional basin of the Kuskokwim Group (unshaded, deep marine; stippled, shallow marine to nonmarine). Lettered arrows showing generalized paleocurrent directions (letters keyed to paleocurrent data for each site given in fig. 2). Numbered localities denote studied fossil localities (table 1), with age-significant symbols as follows: $\mathbf{\square}$, localities of early to middle Cenomanian age; $\diamond$, localities with age resolution spanning through part, or all, of the Cenomanian into part, or all, of the Turonian; , localities confined to part, or all, of the Turonian; $\boldsymbol{\Delta}$, localities with age resolution spanning from the late Turonian to the early Coniacian; $\boldsymbol{\nabla}$, localities of late Coniacian to Santonian or early Santonian age. Flanking older terranes (dark shading) consist of (terrane terminology of Jones and others, 1987; Decker and others, in press): N, Nyac terrane; I, Innoko terrane, including smaller areas of Ruby terrane, and Portage and Idono complexes; F, Farewell terrane; T, Togiak, Tikchik, Goodnews, and Kilbuck terranes; P, Peninsular terrane. Areas of extensive Quaternary cover, Q. 
these data on the age and basin evolution of the Kuskokwim Group.

\section{REGIONAL GEOLOGIC SETTING}

The Kuskokwim Group was deposited in a successor basin, in the sense that it overlies a number of diverse basement terranes that experienced intense Early Cretaceous deformation (fig. 1). Early Cretaceous metamorphic cooling ages characterize the Ruby, Kilbuck, and Goodnews terranes (Turner and others, 1983; Patton and others, 1984; Box and Murphy, 1987; Miller and others, 1991). Deformed Lower Cretaceous sedimentary rocks unconformably underlie the Kuskokwim Group within the Nixon Fork, Innoko, Togiak, and Goodnews terranes (Hoare and Coonrad, 1978; Patton and others, 1980; Box and Murphy, 1987; Murphy, 1987). Strata of the Kuskokwim Group were themselves severely deformed in the Late Cretaceous and are unconformably overlain by 76 - to 60 -Ma subaerial andesitic volcanic fields and crosscut by coeval granitoid plutons (Cady and others, 1955). Thus, the overall age of the Kuskokwim Group is constrained by underlying rocks as young as Aptian (119-113 Ma)(Patton and others, 1980) and by overlying volcanic rocks as old as $76 \mathrm{Ma}$ (Miller and Bundtzen, 1988).

The original basin geometry has been significantly altered by Late Cretaceous shortening across predominantly northeast-trending folds and thrust faults and by Tertiary right-slip faulting along the Iditarod-Nixon Fork and Togiak-Farewell faults. The degree of shortening across the Kuskokwim exposure area is heterogeneous (for example, Cady and others, 1955) and poorly documented, so restoring the unshortened basin geometry is not yet possible. Restoration of Tertiary right-lateral separation on the Iditarod-Nixon Fork fault $(90 \mathrm{~km}$ : Miller and Bundtzen, 1988) realigns the contact between the Kuskokwim Group and the Farewell terrane across the trace of the fault. The amount of post-Kuskokwim right-lateral offset across the Togiak-Farewell fault is less well understood. A total of $153 \mathrm{~km}$ of post-Devonian offset is suggested by displacement of a Silurian to Devonian reef trend in the Farewell terrane (Blodgett and Clough, 1985). How much of that offset postdates Kuskokwim sedimentation is ambiguous. Reed and Lanphere (1974) have documented $38 \mathrm{~km}$ of post-Eocene offset along the Farewell fault to the northeast. Removal of either amount of right-lateral offset results in a configuration of the Kuskokwim basin that can be divided into two subparallel, northeast-trending subbasins (the Kuskokwim River subbasin to the northwest, and the Mulchatna River subbasin to the southeast), connected by a northwest-trending corridor (Nushagak Hills corridor) (fig. 1).

\section{LITHOFACIES DISTRIBUTION}

In most places along the margins of its present-day exposure, the Kuskokwim Group consists of conglomeratic to coarse-grained sandstones whose compositions generally reflect those of the adjacent older rocks. Shallow-marine to nonmarine facies are known along most of the western margin of the Kuskokwim River subbasin (Patton and others, 1977; Miller and Bundtzen, 1988; S.E. Box, unpubl. data, 1989). Sandstones along this flank are composed of lithic clasts of chert and lowgrade metasedimentary rocks, derived from the adjacent Innoko and uppermost part of the Ruby terranes (S.E. Box, Bethel quadrangle, unpubl. data, 1989; M.L. Miller, Iditarod quadrangle, oral commun., 1990). However, the western contact of the Kuskokwim Group with older rocks is nowhere known to be depositional and could be interpreted as a postdepositional fault or series of faults. Shallow-marine conglomeratic facies flank the Farewell terrane (terrane terminology of Decker and others, in press; combined Nixon Fork, Dillinger, Minchumina, and Mystic terranes of Jones and others, 1987) along the northeast side of the northern Kuskokwim River subbasin (Spurr, 1900; T.K. Bundtzen, oral commun., 1990). Shallow-marine to nonmarine conglomeratic rocks unconformably overlie the Farewell terrane along the western flank of the Mulchatna River subbasin (Wallace and others, 1989). Coarse, sandy to conglomeratic, channelfill deposits composed exclusively of volcanic and volcaniclastic rock fragments occur in slope and base-ofslope facies along the southeastern margin of the Kuskokwim River subbasin and the southwestern margin of the Nushagak corridor.

Coarse-grained marginal facies are lacking in two areas: the northeast side of the Nushagak Hills corridor and the southeastern side of the Mulchatna River subba$\sin$. The former contact is marked by a northeast-dipping thrust fault that places Paleozoic rocks of the Farewell terrane over strata of the Kuskokwim Group (Decker and others, 1984a); any original marginal facies may have been either eroded from the upper plate and (or) structurally buried beneath the upper plate. Along the southeastern side of the Mulchatna River subbasin, Wallace and others (1989) reported shaley basin-plain turbidites adjacent to the Chilchitna fault. These authors suggested that open ocean lay to the southeast of the position of the Chilchitina fault during deposition of the Kuskokwim Group, and that the Peninsular terrane was moved into place along the postdepositional right-slip fault.

The Kuskokwim River subbasin was apparently a continental embayment connected to the open ocean only through the Nushagak Hills corridor. The presence of coarse marginal facies around most of the outcrop area of the Kuskokwim River subbasin suggests that subaerially exposed uplands surrounded that subbasin, except 
through the deep-water connection of the Nushagak Hills corridor with the Mulchatna River subbasin. The apparent outflow of paleocurrents from the Kuskokwim River subbasin through the Nushagak Hills corridor supports such an interpretation.

More than 90 percent of the Kuskokwim outcrop area appears to consist of sub-wave-base turbidites and associated facies. These predominantly shale-rich strata are thought to be distal equivalents of the coarse proximal facies flanking the margins of the basin. Sandstoneturbidite paleoflow (figs. 1,2) was northeasterly out of the southern Kuskokwim River subbasin and southwesterly out of the northern Kuskokwim River subbasin, turning southeasterly through the Nushagak Hills corri-

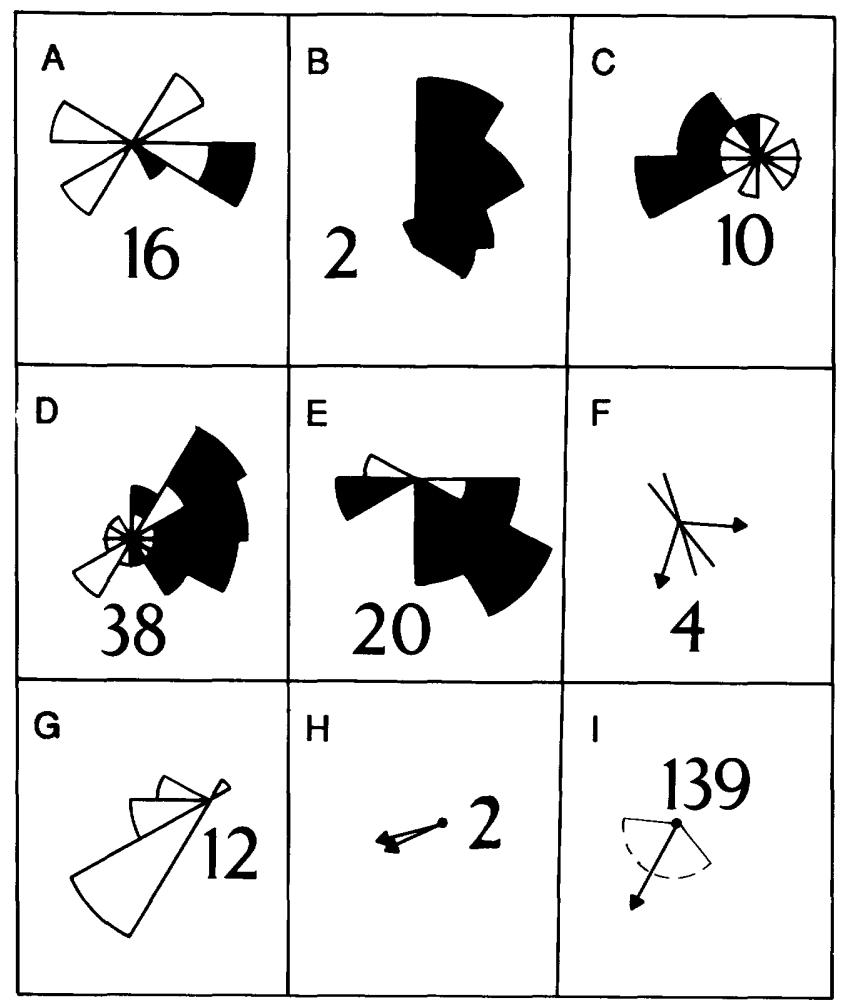

Figure 2. Rose diagrams summarizing paleocurrent data from Kuskokwim Group (all data from this report, except where otherwise referenced). Locations keyed to lettered arrows on figure 1 . Numbers indicate total measurements at each site. Open fans denote current indicators that lack a sense of direction [groove marks (G), current lineations (L), perpendicular to ripple crests (R)]; solid portions of fans indicate unidirectional current indicators [flute marks $(F)$, crossbedding $(X)$, cross-lamination $(X \mathrm{~L})$, pebble imbrication (I)]. Types of indicators measured at each site are as follows: (A) $X=6, G=2, R=4, L=3, I=1$; (B) $F=22$; (C) $G=4, F=3, X=2$, $I=1$; (D) $F=22, G=14, R=2$; (E) $F=3, G=2, X L=15$; (F) $X L=2$, $\mathrm{G}=2$ (unidirectional, arrow; bidirectional, unornamented line); (G) from Bundtzen and Laird (1983), paleocurrent indicator types not specified; $(H)$ from Bundtzen and Laird, (1983), paleocurrent indicator types not specified (shown as unidirectional arrows); (I) average paleocurrent direction $\left(208^{\circ}+/-66^{\circ}\right)$ from T.E. Moore (oral commun., 1991); paleocurrent indicator types not specified. dor. Paleoflow in the northern part of the Mulchatna River subbasin was to the southwest (Moore and Wallace, 1985). Coarse inner-fan channel turbidite facies are known in the upcurrent parts of the two subbasins (Bundtzen and Laird, 1983; Moore and Wallace, 1985; Murphy, 1987; Box and Murphy, 1987; Wallace and others, 1989) and apparently grade downcurrent into finer, mid- and outer-fan turbidite facies in the paleocurrent direction (Decker and Hoare, 1982; Wallace and others, 1989; S.E. Box, Bethel quadrangle, unpubl. data, 1989). Strata of the Nushagak Hills corridor consist mostly of medium- to fine-grained sandstones of mid- to outer-fan facies, although some conglomeratic facies are known (Mertie, 1938; Decker and others, 1984b).

\section{STRATIGRAPHY}

Inoceramid and ammonite fossil collections from 40 localities within the Kuskokwim Group were examined and identified. The location of each fossil locality and a list of the species or subspecies found at each site are given in table 1. Fifteen inoceramid species were identified and are discussed and illustrated in detail elsewhere (Elder and Box, 1992). The fossil localities are shown on figure 1, with symbols indicating the age range of each collection.

Using this new biostratigraphic information, rough time-stratigraphic sections are compiled for four areas within the Kuskokwim basin (fig. 3). Section A is from the southern end of the Kuskokwim River subbasin in the Bethel quadrangle (Hoare, 1961; Murphy, 1987; S.E. Box, unpubl. data, 1989). A basal conglomeratic unit $(0-550 \mathrm{~m})$, deposited in sub-wave-base environments (Murphy, 1987) and locally displaying a thin, basal, shallow-marine section (Box and Murphy, 1987), overlies an angular unconformity that truncates rocks as young as Valanginian (138-131 Ma). This basal unit is abruptly overlain by a dilute turbiditic shale unit (estimated 1,000-3,000 m) with fossils near the base that are of late Cenomanian and (or) early Turonian age (fig. 1, locs. 4,9 ); this supersedes the previous age assignment of middle Albian for locality 4 reported in Murphy (1987). This shale unit grades upward into a sandy turbidite unit (3-6 km) with fossil assemblages ranging from middle to late Turonian in age (fig. 1, locs. 10, 11). Along the western side of the southern basin, prograding shallow-marine to nonmarine facies rocks interfinger with the middle to late Turonian turbidites and finally are prograded over them in latest Turonian or early Coniacian(?) time (fig. 1, locs. 8, 40).

Patton and others (1977) showed a generalized stratigraphic section for an area near the northern end of the Kuskokwim River subbasin (fig. 3, sec. B). Poorly exposed, fine-grained, sub-wave-base(?) deposits are 
Table 1. Checklist of macrofossils present within the Kuskokwim Group at the studied localities

[Map numbers refer to locality numbers shown in figure 1. Age abbreviations: $E$, early; $M$, middle; L, late; Cen., Cenomanian; Tur., Turonian; Con., Coniacian; San., Santonian; " $x$ " indicates presence of identified species. "?" indicates questionable identification. "-" indicates not present; "aff." indicates specimen has affinities with listed species, but some subtle differences; "cf" indicates specimen is comparable to listed species, but preservation limits certainty]

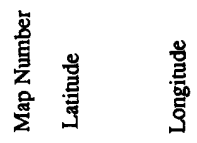

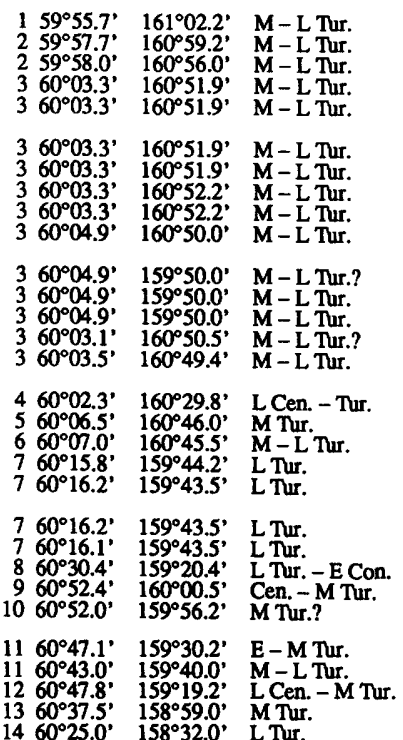

$1560 \circ 28,158^{\circ} 95, \quad$,

16 60 23.5, 157.41.6. M Mur.?

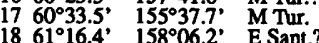

$1961^{\circ} 16.5^{\prime}, 157^{\circ} 57.3^{\prime}$, L Con. - Sant.

$2060^{\circ} 58.7$ ', 157 $40.8^{\prime}, \quad$ L Tur.

$2160^{\circ} 58.1,157^{\circ} 31.1$, L T Tur.?

$2261^{\circ} 11.7^{\prime}, 155^{\circ} 30.4^{\prime}, \quad$ M Tur.?

$2361^{\circ} 35.0^{\circ}, 1^{\circ} 9^{\circ} 00^{\circ} 0^{\prime}$, E-M Tur.

$246^{\circ} 45.8^{\prime}, 157^{\circ} 50.0^{\prime}$ L L Cen. - E Tur. $2561^{\circ} 37.4^{\prime}, \quad 157^{\circ} 50.9^{\prime}$, Tur.? , Thur. $2661^{\circ} 35.7, \quad 159^{\circ} 0.0^{\prime}$, Cen $-\mathrm{M} T$ $2861^{\circ} 34.5^{\prime}, 1_{158^{\circ} 48.0^{\circ},}, \mathrm{E}-\mathrm{M}$ Tur.

$2861^{\circ} 34.5^{\prime}, \quad 158^{\circ} 48.0^{\prime}$, E $-M$ Tur. $2961^{\circ} 32.5,158^{\circ} 35.8, \quad E-M$ T Tur. $2961^{\circ} 33.0^{\prime}, 158^{\circ} 35.0^{\prime}, \quad$ M Tur.?

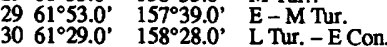

31 61 $25.5^{\prime}, 158^{\circ} 26.7$, Tur.?

$326^{\circ} 53.3^{\prime}, 157^{\circ} 38.1$, L Cen. - E Tur.

$3361^{\circ} 48.5^{\prime}, 157^{3} 19.0^{\prime}$, L Cen. - E Tur.

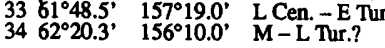

$3562^{\circ} 18.4^{\prime}$ 156 $12.3^{\prime}$ ' M Tur.

$362^{\circ} 04.8^{\circ}, 155^{\circ} 30.0^{\prime}, \quad$ M Tur.

$3662^{\circ} 448^{\prime}, 155^{\circ} 30.0^{\prime}, \quad$ E - M Cen.

$3763^{\circ} 28.0^{\circ}, 155^{\circ} 55.0^{\circ}, \mathrm{M}$ Cen.

$3863^{\circ} 27.0^{\prime} 155^{\circ} 39.0^{\prime}$ M Cen.

$3963^{\circ} 18.0^{\circ}, \quad 155^{\circ} 32.0^{\circ}$, L Tur. - E Con
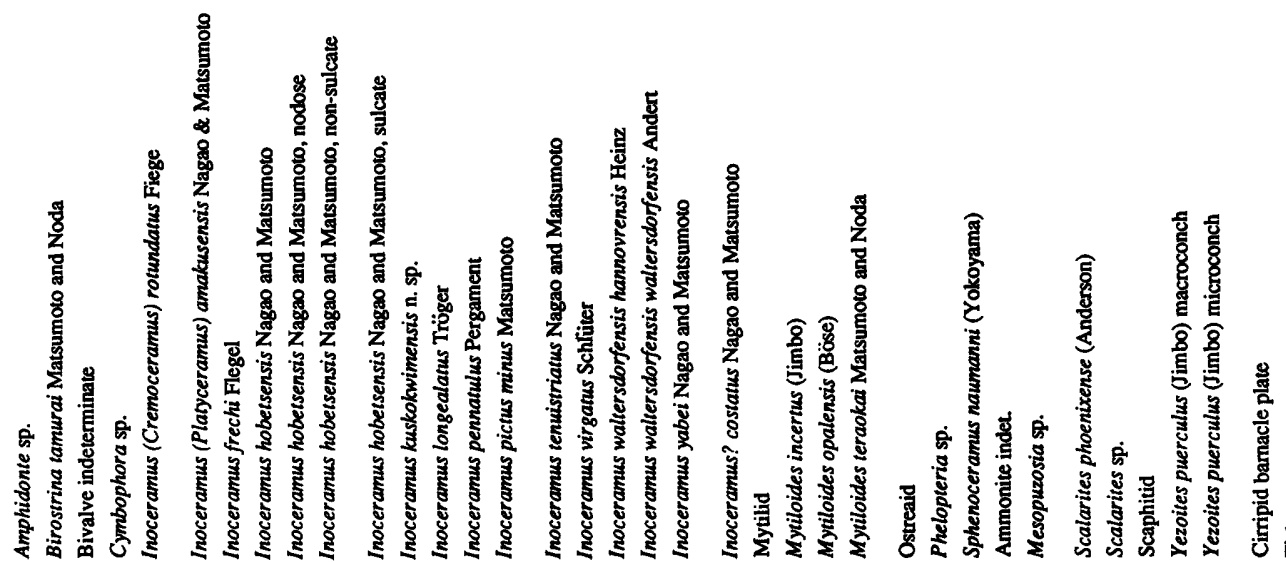

ニニニニニ ニャニニニ ニ×ニニニ ニニニニニ

ニニニニニ

\section{$-\frac{1}{2}-=$}

$-x--=$

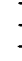

ーーーーーーーーーー ー 一ーーー

ニニニニニ

ニேニニニ

- $\times$ 프-二

ニニニニニ

ニニニニニ

ニニニニニ

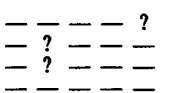

ニேニニニ

- - - -

ニニニニニ

ニニニニニ

$=\frac{-}{x}=\bar{x}$

ㅍㅡㅡㅡ

- - - -

$=-\bar{x}=$

ニニニニニ

ニニニニニ

ニニニニニ

ニニニニニ

ニேニニ二

프ニ

$x=-ニ=$

$x=\bar{x}= \pm$
$-\bar{x}$

$--x-1$

ニニニ二

ニニニニニ

$---?-$

二ニ-二

즌

ニーーニニ

ニニニニニ

ニニニニニ

ニニニニニ

$= \pm x=-$

ニニニニニ

二ニニ二?

ニニニニニ

ニニニニニ

- ---

?ㅡㅡ⼆

ニニニニニ

ニニニーニ

ニニニニ二

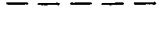

二ニ픈

ニニニニニ

$----$

ニニーニニ

ニーニニ

ニーニニニ

ニㅡㅡㅡ

二-二

二ニニ二

프ニニ

$---\cdots$

ニニニニ

- - -

ニニニニニ

ニニニニニ

ニニニニニ

ニニニニニ

ニニニニニ

- $--=$

ニニーニニ

ニニニニニ

ニニニニ

ニニニニ $x$

- - - -

-ニーーー

픈

픔- - - - - - - - -

$\times \times==$

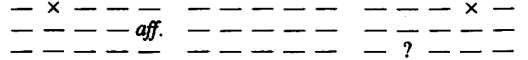

ニーニーー

ニーーーー

$-x=-z$

ーーーニニ

ニニニニニ ニニニニニ

ニニニニニ ニニニニニ

ニニニニニ ニニ

ニニニニニ

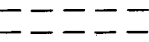

-ニニニニ

$----$

ニニニニニ

ニニーーー -

ーニニニニ

ニニーー ーーーニ

ニニニニニ ニニニニニ

ニニニニニニニ

ニニニニニ

ニニニニ

ニニニニニ ニニニニニ

ニニニニニ ニニニニニ

ニニニニニ

ニニニニ二

$-1$

ニニニニニ

ニニニニニ ニニニニニ

ニニニニニ ニニニニニ

- - - -

$-----$

ーニニニニ ニニニニニ

二ニ二 aff.

ニニニニニ

프ニㅡㅡ

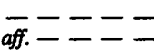

ニニニニニニ

ニニニ

ニニニニ

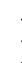

ニニニニ

ニニニニニ

ニニニニニ

ニニニニニ

ニニニニニ

ニニニニニ ニニ

ーニニニニ ニニ

$---x-$

ニニニ

ーーーーー

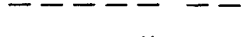

ニニニニニ

ニニニニ的.

ニニニニニ

ニニニニニ

ニニニニニニニ

Ex゙ேニニ ニニ

ニニニニニ

ニニニニ

$x---$

$x=x=x=-$

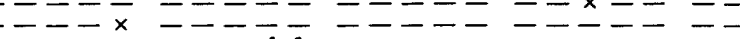
ニニニニニ ニニニ $c$ c. ? ニニニニニ ニニニニニ ニニ

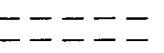

$---c f$.

$---1$

- - - - - -

ニーーーニ

ニニテテニ

二ニニ $\frac{\text { cf. }}{c f}$

二

ニニニニニニニニ ニニ

ニニーーニ

ニ $ニ ニ=$

- - - - - - x-- - ニーーーニニニニニ ニニニニメ $\mathrm{x} x$ ニニニニニ ニニニニニ ニニニニニ ーニ $--\cdots--\cdots---\cdots$ ニニニニニニニニニニ ニニニニニ ニニ ニニニニニ ニニニニニ ニニニニニ ニニ
ニニッニニ
ニニニニニ

ニニニニニ ニニニニニニニ 
overlain by over $3,000 \mathrm{~m}$ of shallow-marine strata, grading upward into nonmarine strata near the top of the section. Rocks underlying the Kuskokwim Group in that vicinity are as young as Aptian in age (Patton and others, 1980). Two fossil collections from near the base of the shallow-marine section are middle Cenomanian in age (fig 1, locs. 37, 38). Marine fossils from just below the upper nonmarine strata are of late Turonian or early Coniacian age (fig. 1, loc. 39).

A generalized stratigraphic section for the central Kuskokwim River subbasin and western Nushagak Hills corridor (fig. 3, sec. C) is based on Decker and Hoare
(1982) and Decker and others (1984b). The entire section consists of interbedded shale and silty to sandy turbidites, reflecting typical outer-fan or mid-fan-lobe depositional environments. Fossils range from late Cenomanian and (or) early Turonian (fig. 1, loc. 24) to early Santonian (fig. 1, locs. 18, 19). Stratigraphic thickness is difficult to estimate; Decker and Hoare (1982) estimated a thickness of about $12 \mathrm{~km}$. They pointed out that the time-averaged subsidence rate must have roughly kept pace with the time-averaged sedimentation rate in order to maintain the sediment surface below the wave base throughout that interval.

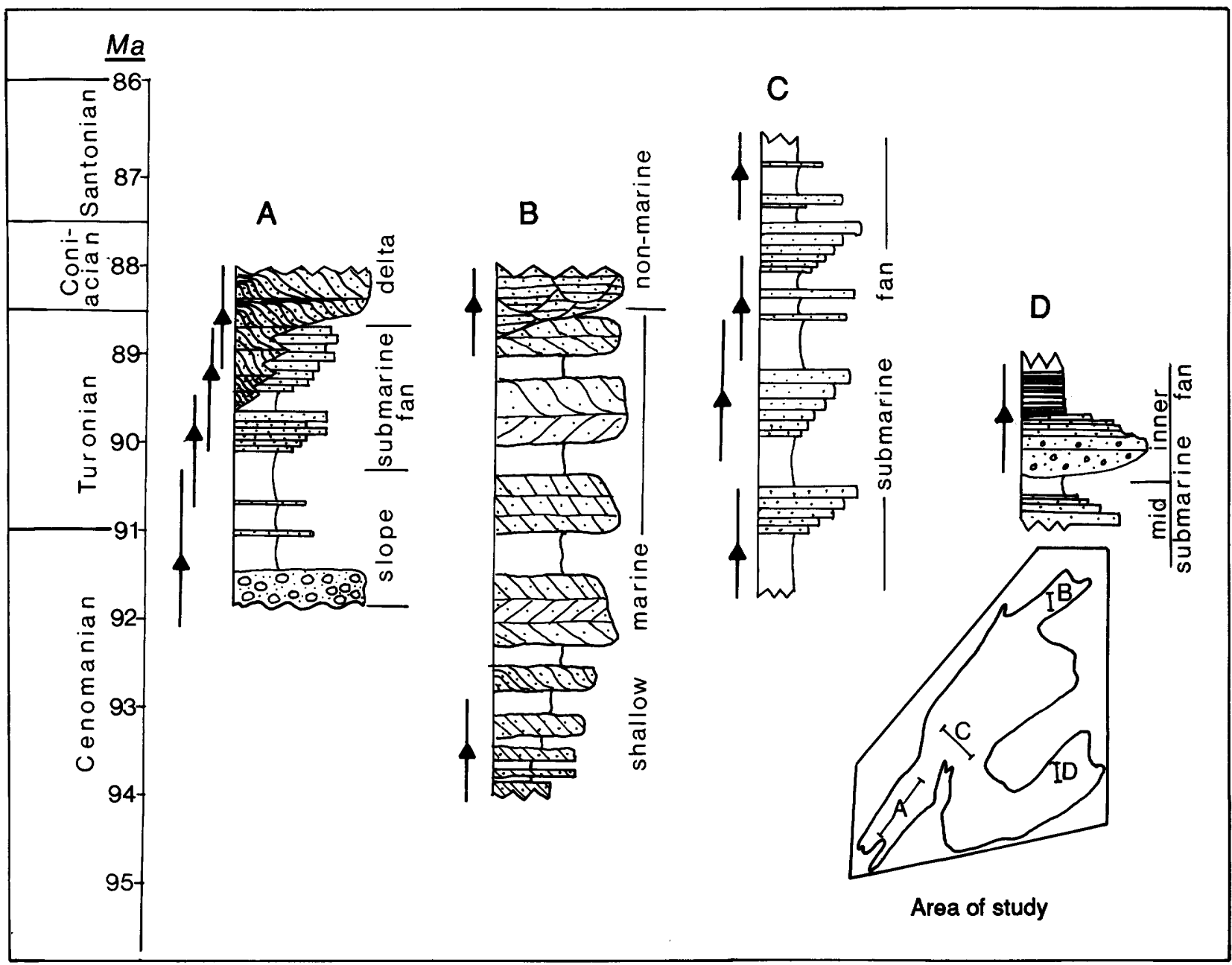

EXPLANATION

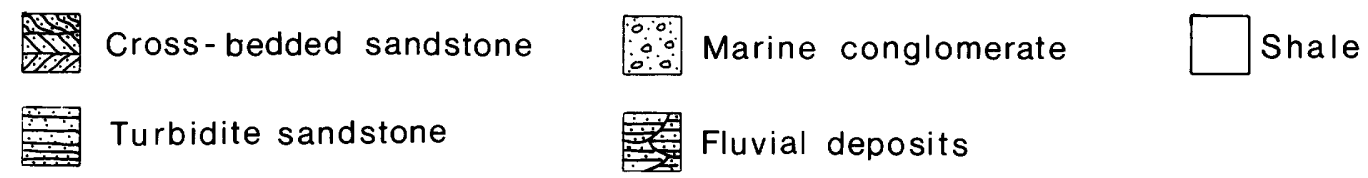

Figure 3. Generalized time-stratigraphic sections from four areas of Kuskokwim Group. Locations of sections shown in inset map from figure 1 in lower right corner. Approximate stratigraphic positions of fossil biostratigraphic control shown by triangles to left of stratigraphic columns, with vertical line representing possible age ranges (data sources and approximate thickness estimates given in text). 
Moore and Wallace (1985) discussed a stratigraphic section (fig. 3, sec. D) near the northwest side of the Mulchatna River subbasin (fig. 1, loc. 22). A lower unit consists of about $5,000 \mathrm{~m}$ of shale, siltstone, and interbedded sandstone turbidites and is interpreted as a midfan, turbidite, channel-and-levee complex. The lower unit contains an arenaceous foraminifera assemblage similar to North Slope faunas of Albian age (R.L. Brooks, ARCO, written commun. to T.E. Moore, 1985). An upper unit of massive sandstone and pebble conglomerate, thinning southwesterly from 6,000 to $750 \mathrm{~m}$ thick, is interpreted to consist of southwesterly thinning, inner-fanchannel deposits. Middle to early late Turonian fossils were recovered from near the top of the upper unit. The progradation of turbidite fan facies suggests that sedimentation rates exceeded subsidence rates, although the great thickness of the sub-wave-base strata indicates very rapid subsidence synchronous with deposition.

\section{IMPLICATIONS FOR BASIN EVOLUTION}

The age range of sedimentation within the Kuskokwim basin, based on the inoceramid fossil collections, spans the interval from early or middle Cenomanian to early Santonian time (that is, 95-86 Ma, using the time scale of Harland and others, 1982). This age range should be considered a minimum estimate, because the early or middle Cenomanian localities occur at uncertain distances above the stratigraphic base of the section, and the top of the section is everywhere eroded. Although the basal part of the Kuskokwim Group is commonly considered to range into Albian time (Decker, 1984; Wallace and others, 1989), no fossil collections of that age were identified in the USGS collections. If the arenaceous foraminifera age assignment mentioned above is valid, the lower strata in the Mulchatna River subbasin are of Albian age.

The age of initiation of sedimentation within the Kuskokwim basin appears to have been diachronous. Sedimentation at the northern end of the Kuskokwim River subbasin (fig. 1, locs. 36-38) began by early or middle Cenomanian time (95 Ma), whereas sedimentation at the southern end of the Kuskokwim River subba$\sin$ (fig. 1, locs. 4,9 ) did not begin until late Cenomanian or early Turonian time (92-90 Ma). Two fossil collections from the eastern side of the southern Kuskokwim River subbasin near the base of the section (fig. 1, locs. 13,7) are of middle and late Turonian age, respectively. Similarly, progradation of shallow-marine sandstones over deeper water prodelta deposits is older in the north (middle Cenomanian) than in the south (middle to early late Turonian; fig. 1 , locs. $1-3,5,6,40$ ). These age contrasts suggest that the onset of both sedimentation and shelf progradation began earlier at the northern, as compared with the southern, end of the Kuskokwim River subbasin.

The predominance of Turonian fossils from most of the collections from the Kuskokwim Group suggests that the great bulk of the sedimentation occurred during that relatively short (91-88.5 Ma) stage. Turonian turbidite deposits are found throughout the entire basin, and coeval shallow-marine to nonmarine deltaic deposits are present along both the southern (fig. 1, locs. 1-3, 5, 6, 8, 40) and northern (fig. 1, loc. 39) ends of the northwestern margin of the Kuskokwim River subbasin. Patchy exposures of lithologically similar deltaic deposits of middle or late Turonian age (fig. 1, loc. 40), overlying slightly older turbiditic deposits (fig. 1, loc. 12), occur across the width of the southern Kuskokwim River subbasin, suggesting that the southern arm of the subbasin was filled to sea level by the end of the Turonian.

The youngest fossils found in the Kuskokwim Group are of late Coniacian to early Santonian age. These occur in turbidite deposits within the western Nushagak Hills corridor. Therefore, a deep-water basin existed into Santonian time in that area and presumably also in the downcurrent direction to the southeast in the Mulchatna River subbasin, although no fossils of that age have been recovered from strata exposed there. As mentioned above, the southern arm of the Kuskokwim River subbasin appears to have been infilled by deltaic deposits prior to the Coniacian, but the degree of infilling of the northern arm of the Kuskokwim River subbasin by that time is uncertain.

\section{INOCERAMID BIOGEOGRAPHY}

Most of the taxa identified in the Kuskokwim Group are found in other regions of the North Pacific (particularly Japan and the eastern Soviet Union) or throughout the Northern Hemisphere (Elder and Box, 1992). Only one species, Inoceramus kuskokwimensis $\mathbf{n}$. sp., is new and may be endemic. North Pacific taxa predominate in the Kuskokwim region, but intervals near the Cenomanian-Turonian stage boundary and in the upper part of the Turonian contain taxa characteristic of Europe and the western interior of North America; some of these taxa have not been recorded previously in the North Pacific region. Turonian heteromorph ammonite assemblages associated with inoceramids in the finer grained facies of the Kuskokwim region are similar to those found in coeval rocks of Japan and Germany.

There is little or no similarity between the inoceramids of the Kuskokwim Group and of age-equivalent strata either in the Colville basin north of the Brooks Range (Jones, 1960) or in the nearby Matanuska Valley of south-central Alaska (Jones, 1967). The general lack of similarity between inoceramids of the Kuskokwim 
Group and of the Colville basin is not surprising, since there is little evidence of macrofaunal interchange between the North Pacific and the Arctic Ocean during the Cretaceous after the Barremian (Jeletsky, 1971), except for possibly during the early Turonian (Cobban and Gryc, 1961). The general lack of correspondence between inoceramids from the Kuskokwim Group and the Matanuska Valley is more difficult to explain. The Matanuska Formation was deposited in a forearc basin southeast of a magmatic arc, both of which form part of the Peninsular terrane. Wallace and others (1989) suggested that the Peninsular terrane was emplaced into its present position at least by $74 \mathrm{Ma}$ and may have been moving from the south prior to that time. Therefore, at least some of the lack of faunal similarity between the Kuskokwim and Matanuska regions may be due to the greater distance between the regions. Possible physical barriers within the Peninsular terrane during the early part of the Late Cretaceous (for example, the magmatic arc) may also have played a role in separating distinct inoceramid faunas in the Kuskokwim and Matanuska areas.

\section{REFERENCES CITED}

Blodgett, R.B., and Clough, J.G., 1985, The Nixon Fork terrane - Part of an in-place peninsular extension of the North American Paleozoic continent [abs.]: Geological Society of America Abstracts with Programs, v. 17, no. 6, p. 342.

Box, S.E., 1985, Early Cretaceous orogenic belt in northwestern Alaska: Internal organization, lateral extent and tectonic interpretation, in Howell, D.G., ed., Tectonostratigraphic terranes of the circum-Pacific region: Houston, Texas, Circum-Pacific Council for Energy and Mineral Resources, Earth Science Series, v. 1, p. 137-145.

Box, S.E., and Murphy, J.M., 1987, Late Mesozoic structural framework, eastern Bethel quadrangle, Alaska, in Hamilton, T.D., and Galloway, J.P., eds., Geologic studies in Alaska by the U.S. Geological Survey during 1986: U.S. Geological Survey Circular 998, p. 78-82.

Bundtzen, T.K., and Laird, G.M., 1983, Geologic map of the Iditarod D-1 quadrangle, Alaska: Alaska Geological and Geophysical Surveys Professional Report 78, scale $1: 63,360$.

Cady, W.M., Wallace, R.E., Hoare, J.M., and Webber, E.J., 1955. The central Kuskokwim region, Alaska: U.S. Geological Survey Professional Paper 268, 132 p.

Cobban, W.A., and Gryc, G., 1961, Ammonites from the Seabee Formation (Cretaceous) of northern Alaska: Journal of Paleontology, v. 35, p. 176-190.

Decker, J.E., 1984, The Kuskokwim Group: A post-accretionary successor basin in southwest Alaska [abs.]: Geological Society of America Abstracts with Programs, v. 16, no. 5, p. 327.

Decker, John, Blodgett, R.B., Box, S.E., Bundtzen, T.K., Clough, J.G., Coonrad, W.L., Gilbert, W.G., Miller, M.L.,
Murphy, J.M., Robinson, M.S., and Wallace, W.K., in press, Geology of southwestern Alaska, in Plafker, George, Jones, D.L., and Berg, H.C., eds., The Cordilleran orogen-Alaska: Boulder, Colorado, Geological Society of America, The Geology of North America, DNAG Series.

Decker, J.E., and Hoare, J.M., 1982, Sedimentology of the Cretaceous Kuskokwim Group, southwest Alaska, in Coonrad, W.L., ed., The United States Geological Survey in Alaska: Accomplishments during 1980: U.S. Geological Survey Circular 884, p. 81-83.

Decker, John, Reifenstuhl, R.R., and Coonrad, W.L., 1984a, Compilation of geologic data from the Sleetmute A-5 quadrangle, southwestern Alaska: Alaska Division of Geological and Geophysical Surveys, Report of Investigations 84-29, scale 1:63,360.

Decker, J.E., Robinson, M.S., Murphy, J.M., Reifenstuhl, R.R., and Albanese, M.D., 1984b, Geologic map of the Sleetmute A-6 quadrangle: Alaska Division of Geological and Geophysical Surveys, Report of Investigations 84-10, scale $1: 63,360$.

Elder, W.P., and Box, S.E., 1992, Late Cretaceous inoceramid bivalves of the Kuskokwim basin, southwestern Alaska and their implications on basin history: Paleontological Society Memoir, in review.

Harland, W.B., Cox, A., Llewellyn, P.G., Pickton, C.A.G., Smith, A.G., and Walters, R., 1982, A geologic time scale: Cambridge, England, Cambridge University Press, $131 \mathrm{p}$.

Hoare, J.M., 1961, Geology and tectonic setting of Lower Kuskokwim-Bristol Bay region, Alaska: American Association of Petroleum Geologists Bulletin, v. 45, p. 594 611.

Hoare, J.M., and Coonrad, W.L., 1978, Geologic map of the Goodnews and Hagemeister Island quadrangles region: U.S. Geological Survey Open-File Report 78-9-B, scale $1: 250,000$.

Imlay, R.W., and Reeside, J.B., 1954, Correlation of the Cretaceous formations of Greenland and Alaska: Geological Society of America Bulletin, v. 65, p. 223-246.

Jeletsky, J.A., 1971, Marine Cretaceous biotic provinces and paleogeography of western and arctic Canada - Illustrated by a detailed study of ammonites: Geological Survey of Canada Paper 70-22, 92 p.

Jones, D.L., 1960, Upper Cretaceous pelecypods of the Genus Inoceramus from northern Alaska: U.S. Geological Survey Professional Paper 334-E, p. 149-165.

1967, Cretaceous ammonites from the lower part of the Matanuska Formation, southern Alaska: U.S. Geological Survey Professional Paper 547, p. 1-49.

Jones, D.L., Silberling, N.J., Coney, P.J., and Plafker, George, 1987, Lithotectonic terrane map of Alaska (west of the 141st meridian): U.S. Geological Survey Miscellaneous Field Studies Map MF-1874-A, scale 1:2,500,000.

Mertie, J.B., Jr., 1938, The Nushagak district, Alaska: U.S. Geological Survey Bulletin 903, 96 p.

Miller, M.L., Bradshaw, J.Y., Kimbrough, D.L., Stern, T.W., and Bundtzen, T.K., 1991, Isotopic evolution for Early Proterozoic age of the Idono complex, west-central Alaska: Journál of Geology, v. 99, p. 209-223.

Miller, M.L., and Bundtzen, T.K., 1988, Right-lateral offset so- 
lution for the Iditarod-Nixon Fork fault, western Alaska, in Galloway, J.P., and Hamilton, T.D., eds., Geologic studies in Alaska by the U.S. Geological Survey during 1987: U. S. Geological Survey Circular 1016, p. 99-103.

Moore, T.E., and Wallace, W.K., 1985, Submarine-fan facies of the Kuskokwim Group, Cairn Mountain area, southwestern Alaska [abs.]: Geological Society of America Abstracts with Programs, v. 17, no. 6, p. 371.

Murphy, J.M., 1987, Early Cretaceous cessation of terrane accretion, northern Eek Mountains, southwestern Alaska, in Hamilton, T.D., and Galloway, J.P., eds., Geologic studies in Alaska by the U.S. Geological Survey during 1986: U.S. Geological Survey Circular 998, p. 83-85.

Pacht, J.A., and Wallace, W.K., 1984, Depositional facies of a post-accretionary sequence: The Cretaceous Kuskokwim Group of southwest Alaska [abs.]: Geological Society of America Abstracts with Programs, v. 16, p. 327.

Patton, W.W., Jr., Dutro, J.T., Jr., and Chapman, R.M., 1977, Late Paleozoic and Mesozoic stratigraphy of the Nixon Fork area, Medfra quadrangle, Alaska, in Blean, K.M., ed., The United States Geological Survey in Alaska: Accomplishments during 1976: U.S. Geological Survey Circular 751-B, p. 38-39.

Patton, W.W., Jr., Moll, E.J., Dutro, J.T., Jr., Silberman, M.L., and Chapman, R.M., 1980, Preliminary geologic map of the Medfra quadrangle, Alaska: U.S. Geological Survey Open-File Report 80-811-A, scale 1:250,000.

Patton, W.W., Jr., Moll, E.J., Lanphere, M.A., and Jones, D.L., 1984, New age data for the Kaiyuh Mountains, west-cen- tral Alaska, in Coonrad, W.L., and Elliot, R.L., eds., The United States Geological Survey in Alaska: Accomplishments during 1981: U.S. Geological Survey Circular 868, p. $30-32$.

Reed, B.L., and Lanphere, M.A., 1974, Offset plutons and history of movement along the McKinley segment of the Denali fault system, Alaska: Geological Society of America Bulletin, v. 85, p. 1883-1892.

Spurr, J.E., 1900, A reconnaissance in southwestern Alaska in 1898: U.S. Geological Survey 20th Annual Report, pt. 7, p. 31-264.

Turner, D.L., Forbes, R.B., Aleinokoff, J.N., Hedge, C.E., and MacDougall, Ian, 1983, Geochronology of the Kilbuck terrane of southwestern Alaska [abs.]: Geological Society of America Abstracts with Programs, v. 15, no. 5, p. 407.

Wallace, W.K., 1984, Mesozoic and Paleogene tectonic evolution of the southwestern Alaska Range-southern Kuskokwim Mountains region [abs.]: Geological Society of America Abstracts with Programs, v. 16, no. 5, p. 339.

Wallace, W.K., and Engebretson, D.C., 1984, Relationships between plate motions and Late Cretaceous to Paleogene magmatism in southwestern Alaska: Tectonics, v. 3, p. 295-315.

Wallace, W.K., Hanks, C.L., and Rodgers, J.F., 1989, The southern Kahiltna terrane: Implications for the tectonic evolution of southwestem Alaska: Geological Society of America Bulletin, v. 101, p. 1389-1407.

Reviewers: Thomas E. Moore and William W. Patton, Jr. 


\title{
Deformation History of the McHugh Complex, Seldovia Quadrangle, South-Central Alaska
}

\author{
By Dwight C. Bradley and Timothy M. Kusky
}

\section{Abstract}

Detailed mapping (scales 1:1,140 and 1:6,000) at three large, recently deglaciated exposures in the Seldovia quadrangle, south-central Alaska, has clarified aspects of the structural history of the McHugh Complex. At Grewingk Glacier, the McHugh Complex consists of multiple fault slices of relatively coherent basalt, chert, and graywacke, each up to a few tens of meters thick, bounded by zones of mesoscale mélange. We interpret the mesoscale mélanges as having formed in thrust zones, and the map pattern as resulting from thrust repetition of an originally simple oceanic-plate stratigraphy. Late brittle faults belong to six sets, some of which are significant enough to cause mappable offsets. A prominent set of dextral faults strike east-northeast (set I), and a conjugate set of sinistral faults strike north-northwest (set II); displacement on fault sets I and II resulted in orogen-parallel extension. Minor eaststriking normal faults that dip north and south (sets $V$ and VI) also were responsible for some orogen-parallel extension. Minor north-striking, west-dipping late thrust faults (set IV) are subparallel with the present convergent margin. North-striking dextral faults (set III) offset the earlier dextral faults of set I. Displacement on fault set I was approximately coeval with injection of silicic to intermediate dikes of early Eocene age. Poles to dikes and dike transforms together indicate a mean extension direction of $345^{\circ}$. We interpret the dikes and associated strike-slip faults of sets $I$ and presumably $I$ as the result of subduction of the Kula-Farallon Ridge. The origin of the other late structures is not yet clear; they might relate to northward strike-slip motion of the Chugach terrane, formation of the southern Alaska orocline, critical taper adjustments of the accretionary wedge, or some other cause.

\section{INTRODUCTION}

The McHugh Complex of south-central Alaska (fig. 1) is generally interpreted as part of a Mesozoic accretionary prism, the Chugach terrane, that formed by offscraping and (or) underplating at an ancient subduction zone, outboard of the composite Peninsular-Wrangellia-Alexander superterrane (Plafker and others, 1989). Regional geologic relations, plate-circuit reconstructions, and paleomagnetic data together suggest that several important younger events also may have affected the McHugh Complex. These include northward coastwise strike-slip of the entire Chugach terrane (Coe and others, 1985), oroclinal bending to form the southern Alaska orocline (Coe and others, 1985), subduction of the KulaFarallon Ridge (Marshak and Karig, 1977), and piecemeal or wholesale accretion of Upper Cretaceous and Cenozoic flysch that now occupies the region between the McHugh Complex and the Aleutian Trench (Plafker and others, 1989).

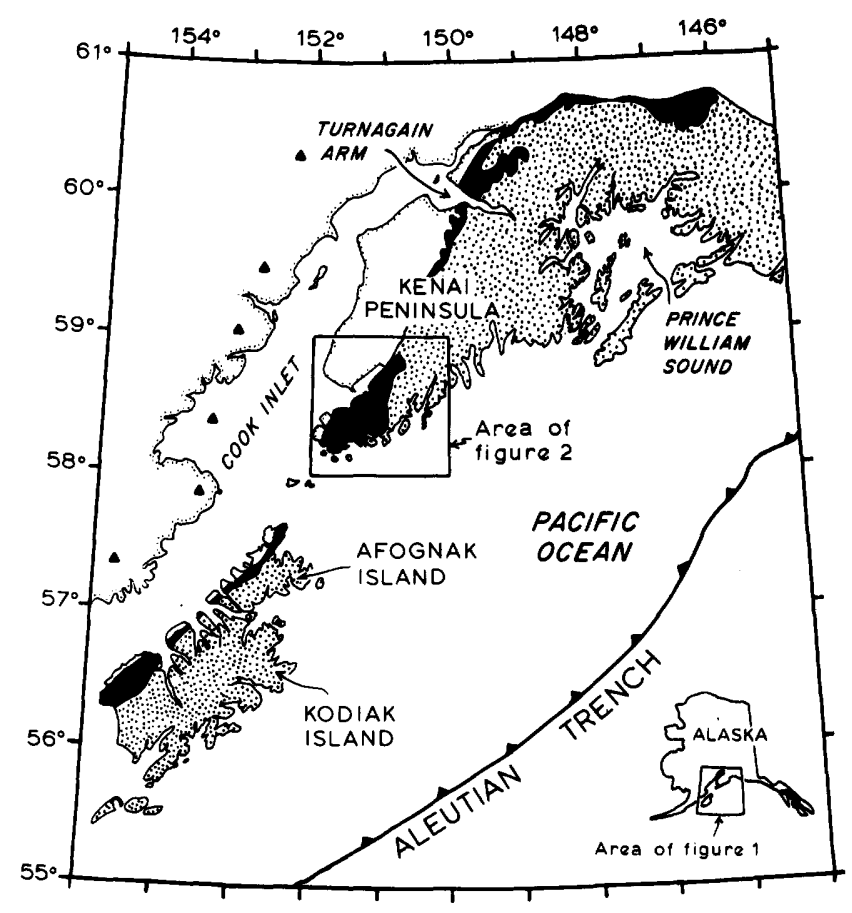

Figure 1. Locality map of south-central Alaska. Triangles, volcanoes of Aleutian arc; black, McHugh Complex, including Kachemak "terrane," and correlative Uyak Complex in Kodiak and Afognak Islands; stipple, other parts of Mesozoic-Cenozoic accretionary complex, including Valdez Group of Chugach terrane and Orca Group of Prince William terrane. 
This paper presents new structural data from the Seldovia quadrangle (figs. 1,2 ) bearing on these postulated events. Our findings on the early deformation history mainly stem from detailed (1:1,140 scale) mapping at the terminus of the Grewingk Glacier (fig. 2, loc. 2). Conclusions about the nature of late deformation at Grewingk Glacier are supplemented by less detailed 1:6,000-scale mapping at the termini of the Dixon and Wosnesenski Glaciers (fig. 2, locs. 1 and 3, respectively). Rapid ice retreat (up to $1.3 \mathrm{~km}$ in the last $40 \mathrm{yr}$ ) has left polished roche moutonee, hundreds of meters across, of nearly 100 percent bedrock exposure at the three areas. The structure of the McHugh Complex in these areas is complicated but not entirely chaotic, and can be resolved through detailed mapping.

\section{REGIONAL GEOLOGY}

The Seldovia quadrangle (fig. 1) lies in the arctrench gap of the present-day Aleutian subduction system; our detailed map areas are about $35-40 \mathrm{~km}$ above the Benioff Zone (for example, Jacob, 1986). We have subdivided Mesozoic rocks in figure 2 into six belts. (1) Mesozoic volcanogenic strata of magmatic-arc affinity (Kelley, 1980) lie farthest inboard and comprise the Peninsular terrane of Jones and others (1987); younger Tertiary strata in this area define the Cook Inlet Basin, which is the active forearc basin of the Aleutian arc. (2) The McHugh Complex (Clark, 1973) is part of the Chugach terrane of Jones and others (1987), a Mesozoic accretionary wedge. Rock types include variably disrupted greenstone, chert, argillite, graywacke, conglomerate, outcrop-scale mélange, and rare limestone. (3) The Valdez Group, also part of the Chugach terrane, flanks the McHugh Complex on the southeast. It consists of Upper Cretaceous turbiditic graywacke, slate, and conglomerate, and mélange belonging to type I of Cowan (1985).

Included within the limits of the area mapped as the McHugh Complex in figure 2 are three additional map units of problematic tectonic affinity; whether these rocks are part of the Peninsular terrane ("upper plate") or accretionary wedge ("lower plate") is debatable. (4) The Seldovia metamorphic belt (Seldovia schist terrane of Cowan and Boss, 1978) is a narrow zone, metamorphosed to blueschist facies, along the inboard margin of the accretionary wedge. Rock types include marble, quartzite (metachert), metapelite, and metabasite. Comparable protoliths all occur within the McHugh Complex (albeit in different proportions), which otherwise is metamorphosed to prehnite-pumpellyite facies. Recent work has shown that mélange of the McHugh Complex occurs in narrow bands on both sides of the metamorphic belt (D. Bradley and S. Karl, unpubl. field mapping, 1989). (5) The Kachemak "terrane" of Jones and others
(1987) consists of intensely faulted pillow and massive basalt, overlain by complexly folded and faulted radiolarian chert, now known to range in age from Middle Triassic to Early Jurassic (C. Blome, oral commun., 1991). Stratigraphic nomenclature for these rocks has yet to be formalized, and the structure is far more complex than it would seem from the simple map pattern on the compilation map of Magoon and others (1976). It is not clear that there are any compelling lithologic differences between chert and basalt within the area identified by Jones and others (1987) as the Kachemak "terrane", and chert and basalt within the outcrop belt of the McHugh Complex. The only mappable difference is that the McHugh Complex also includes abundant graywacke and argillite. On the basis of similar radiolarian age ranges in cherts of the McHugh Complex and Kachemak "terrane", Blome and others (1990) suggested that the Kachemak "terrane" may be merely a part of the McHugh (accretionary) Complex in which the basaltchert association dominates the outcrop. (6) In the Seldovia quadrangle, the Border Ranges ultramafic and mafic complex of Burns (1985) consists of at least seven separate bodies of mafic and ultramafic plutonic rocks that occur as fault-bounded slices within the outcrop belt of the McHugh Complex (fig. 2).

\section{STRATIGRAPHY OF THE MCHUGH COMPLEX}

Despite structural disruption, locally preserved stratigraphic relations and fossil ages within the McHugh Complex and Kachemak "terrane" permit a crude reconstruction of an original stratigraphy (fig. $3 A$ ) that is now repeated by numerous thrust faults. It is uncertain whether any ultramafic or mafic plutonic rocks of the lower part of this inferred stratigraphic succession are exposed within the McHugh Compex. The ultramafic body at Red Mountain (loc. 7 in fig. 2), which otherwise would seem a likely candidate, has magmatic-arc affinity and, according to one interpretation (Burns, 1985), is part of the original basement of the Peninsular terrane. Mafic volcanic rocks within both the McHugh Complex as mapped by Magoon and others (1976) and the Kachemak "terrane" of Jones and others (1987) include variably altered pillow basalt, hyaloclastic basalt, and massive basalt; the McHugh Complex, in addition, contains cataclastically microbrecciated basalt that in hand sample resembles a volcaniclastic rock (commonly designated "tuff" in the field). At several places in the Kachemak "terrane" (for example, loc. 4, fig. 2), radiolarian chert overlies pillow basalt. Chert in the McHugh Complex and Kachemak "terrane" includes gray, green, red, and black radiolarian-bearing ribbon chert, interbedded on a scale of a few centimeters with argillite; faulting and disharmonic folding are pervasive. Radiolarian ages in 
both the McHugh Complex (from Turnagain Arm and Seldovia) and the Kachemak "terrane" range from Late Triassic to Early Cretaceous (Nelson and others, 1987; Blome and others, 1990; C. Blome, oral commun., 1990). At locality 5 (fig. 2), graywacke conformably overlies ribbon chert that yielded Pliensbachian (Early Jurassic) radiolarians (C. Blome, oral commun., 1990). Graywacke in the McHugh Complex mainly occurs as amalgamated massive turbiditic sandstone (facies B of Mutti and Ricci-Lucchi, 1978) but also includes horizons of up to 50 percent interbedded argillite (facies $\mathrm{C}$ and
D). Conglomerate and associated graywacke occur in massive zones hundreds of meters thick (facies A of Mutti and Ricci-Lucchi, 1978). Weakly deformed, gently dipping interbedded argillite and siltstone is present at Jakolof Bay (loc. 8 in fig. 2). Outcrop-scale mélange also is abundant. We interpret its origin as structural, not stratigraphic, as described below.

Implicit in figure $3 A$ is the assumption that the basalt, chert, and graywacke each occur at a single relative position in the stratigraphic succession. Because some chert is younger than at least some graywacke, either

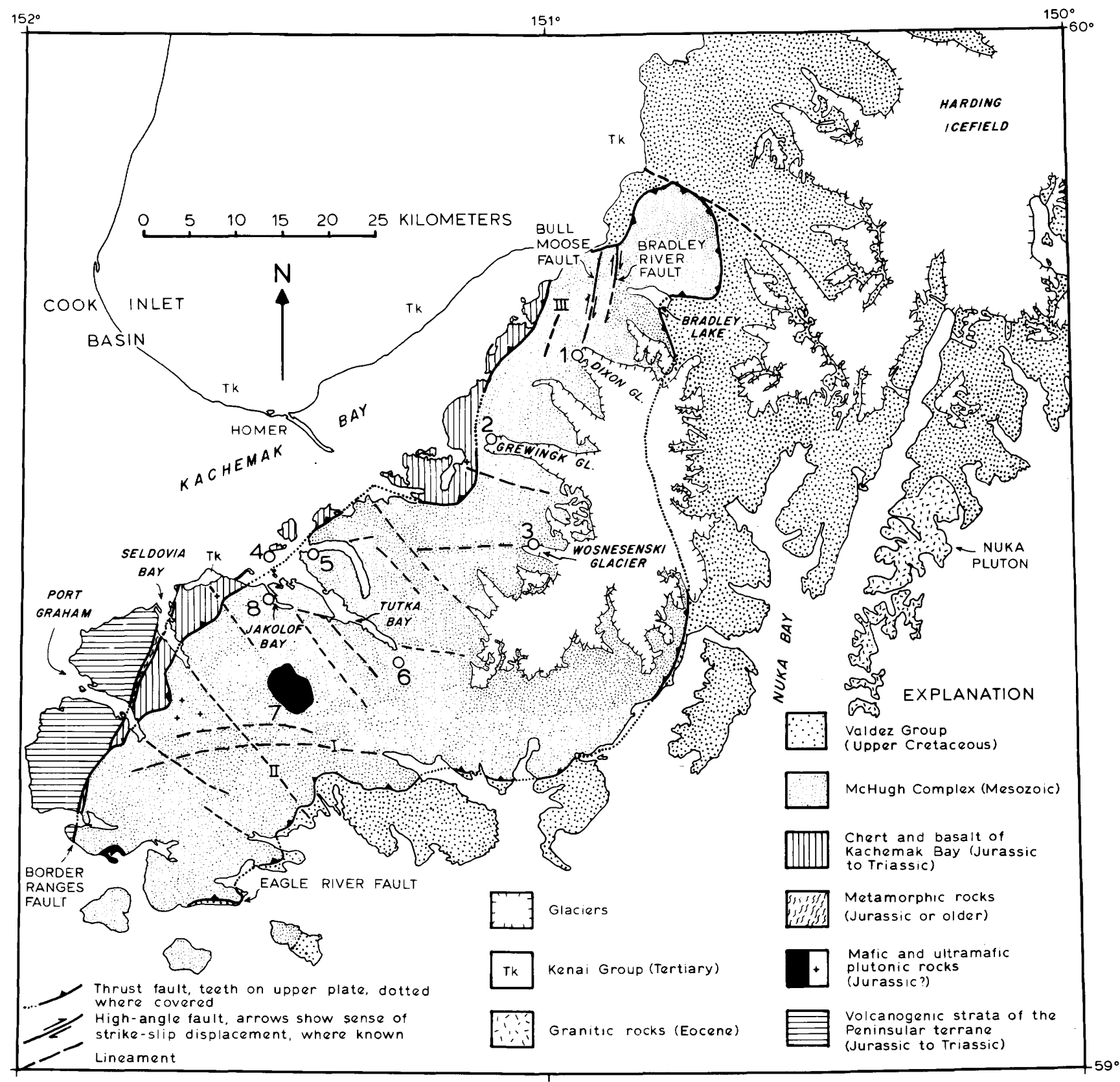

Figure 2. Generalized geologic map of eastern two-thirds of Seldovia quadrangle. Arabic numbers refer to localities mentioned in text; Roman numerals identify faults representative of fault sets I, II, and III. Modified from Magoon and others (1976). 
their mutual contact is strongly diachronous or a second chert unit overlies the graywacke.

Following an original suggestion by Connelly (1978) for the Uyak Complex (a McHugh correlative along strike on Kodiak Island; fig. 1), we illustrate in figure $3 B$ how the components of the McHugh Complex and Kachemak "terrane" might be related paleogeographically. According to this model, the basalts formed at a spreading center (or, perhaps equally likely, at an off-axis seamount), and the conformably overlying cherts were subsequently deposited as the oceanic plate was conveyed toward a convergent plate boundary. The argillite, graywacke, and conglomerate were deposited in the trench, mainly on the descending plate along the outer trench slope and trench axis. The mildly deformed argillite and siltstone at Jakolof Bay (fig. 2) may have been deposited on the inner trench slope, atop the accretionary prism. A key aspect of this general model (and a similar model for accreted rocks in Japan by Matsuda and Isozaki, 1991) is that deposition and subduction-ac-

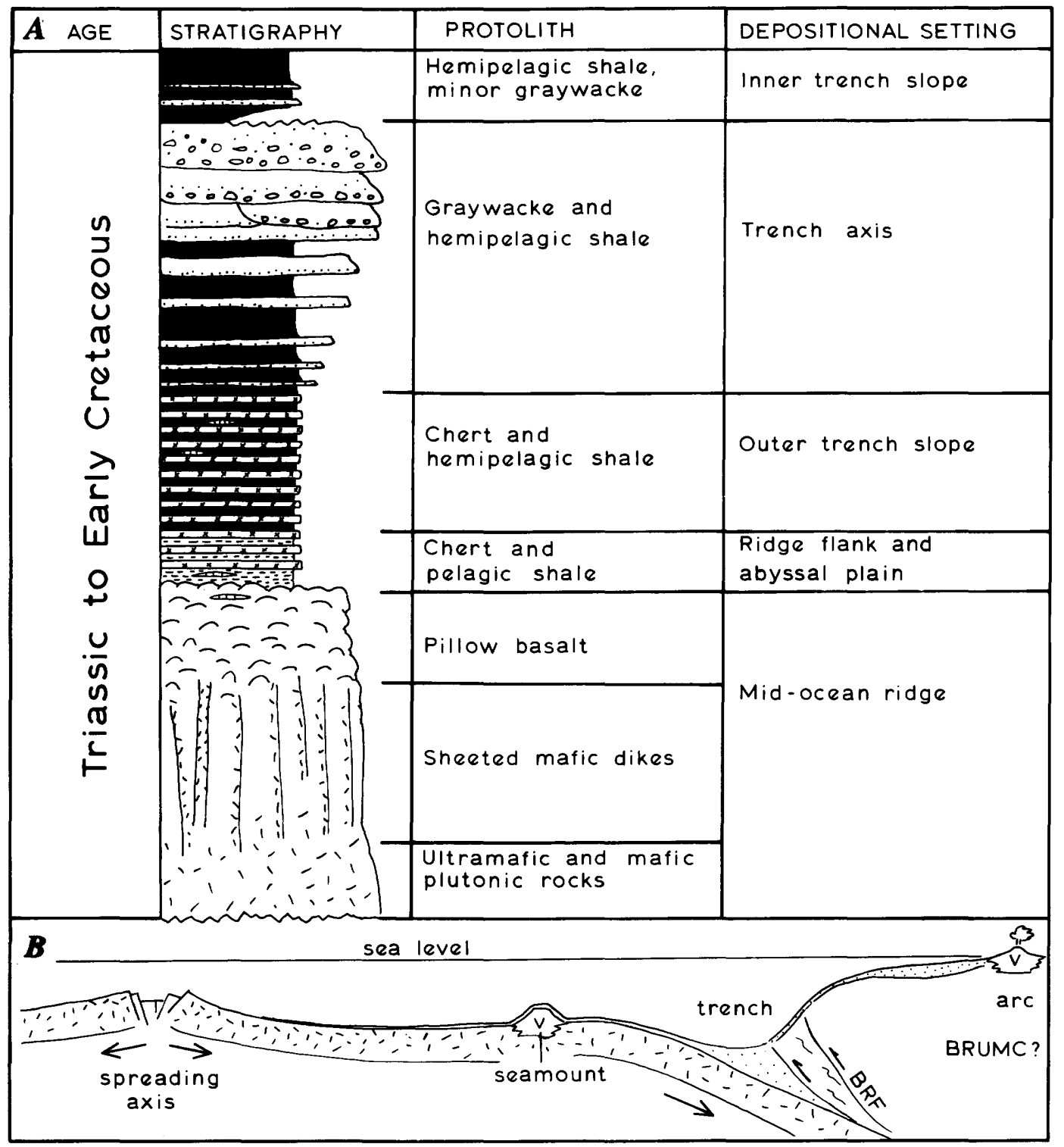

Figure 3. A, Generalized stratigraphy of McHugh Complex in Seldovia quadrangle, showing inferred relations among rock types prior to deformation within accretionary wedge. Specific radiolarian age ranges are not given, pending work in progress. $B$, Cross section from an oceanic spreading center to a subduction zone, modified from Connelly (1978). This conceptual model illustrates how varied rock types comparable to those within Kachemak "terrane" of Jones and others (1987) and McHugh Complex might have been conveyed into trench and either subducted or incorporated into accretionary wedge. BRF, Border Ranges fault zone; BRUMC, Border Ranges ultramafic-mafic complex of Burns (1985); V, seamount volcanics. 
cretion are steady-state, continuous, overlapping processes, not one-time events. This pattern inevitably leads to diachronous relations: contacts between basalt, chert, and graywacke in two different offscraped or underplated slices of the oceanic plate should differ in age; likewise, deformation of one part of the mélange might predate the existence of some or all protoliths in a different part of the mélange.

Our stratigraphic model accounts for basalt and cherts of the Kachemak "terrane" as the basement and pelagic cover of an oceanic plate that has largely vanished down a subduction zone. Jones and others (1987) regarded the basalt and cherts of Kachemak Bay as a tectonostratigraphic terrane that was distinct from the surrounding McHugh Complex. Alternatively, we suggest that the siliciclastic strata of the McHugh Complex were deposited on top of the chert and basalt of the Kachemak "terrane" and were subsequently offscraped and (or) underplated at the subduction zone. Detailed mapping at Grewingk Glacier (fig. $4 A$ ) provides structural evidence for thrust repetition that is consistent with this scenario.

\section{SEDIMENTARY AND EARLY TECTONIC STRUCTURES AT GREWINGK GLACIER}

\section{Bedding}

At Grewingk Glacier (fig. 4), graded beds, upright with tops toward the northwest, are locally preserved in the graywacke (fig. 5A). Well-preserved bedding in the ribbon cherts is roughly parallel with that in the graywacke, but tops are unknown. Bedding is rarely preserved in the greenstones. The pattern of bedding poles in figure $5 A$ is consistent with deformation by offscraping and (or) underplating in a subduction zone that was subparallel with the present one. If the Chugach terrane underwent coast-parallel strike-slip translation and oroclinal rotation during Tertiary time (see, for example, Plafker and others, 1989), then the McHugh Complex subduction zone more likely dipped to the northeast.

\section{Early Tectonic Contacts}

Most contacts between the map units at Grewingk Glacier are early tectonic contacts. These early faults or shear zones are typically uneven, deformed surfaces that contrast markedly with the late, straight faults described later. Some early faults are associated with thin (up to a few centimeters) veins of quartz-chlorite-calcite, commonly with thin selvages of wall rock. The early tectonic contacts locally truncate bedding (fig. $4 B$ ), but statistically the two fabric elements are essentially parallel (fig.
$5 A, B)$. We suggest that at least some early tectonic contacts initiated as bedding-parallel to low-angle thrust faults through subhorizontal strata; this interpretation is consistent with the repetition of rock types whose inferred stratigraphy is shown in figure 3 . Some early tectonic contacts probably underwent large displacements, whereas others probably are minor movement surfaces related only to rheological contrasts between units that remain in their original stratigraphic order.

\section{Mélange, Broken Formation, and Pebbly Mudstone}

The entire outcrop at Grewingk Glacier is mappable at 1:63,360 scale only as mélange. However, at $1: 1,140$ scale, it is possible to map individual belts of greenstone, chert, and graywacke that are a few meters to tens of meters wide. In some places, slices become so narrow and interfaulted that even at 1:1,140 scale, they can only be mapped as mélange (fig. $4 A$ ). We refer to these zones as "mesoscale mélanges." They contain blocks of greenstone, chert, graywacke, and rare limestone set in an argillite matrix; different mélange zones contain different block assemblages (see numbers along base of fig. $4 B$ ). The blocks typically are elongate lozenges up to a few meters long and lie either in fault contact with other blocks or within a matrix of less competent black argillite. Where blocks are smaller (up to a few tens of centimeters), we have mapped these as zones of "pebbly mudstone" (fig. 6A), a field term that we use without any implied genetic connotation. Pebbly mudstone grades into "broken formation" (another field term used without any genetic connotation), which consists of variably pulled-apart beds of graywacke and chert (fig. $6 A$ ) in argillite matrix. In zones of broken formation, one or more competent beds commonly can be traced across the outcrop essentially unbroken, whereas other beds are extended on small faults into rhomboidal bed fragments that are aligned parallel to throughgoing bedding. Bedding disruption during development of broken formation was accomplished by movement along an intricate network of cataclastic shear zones [web structure of Cowan (1985) and Byrne (1984)]. In thin section, these are seen to be zones of significant grain-size reduction. Broken formation and pebbly mudstone exhibit a prominent layering, which is defined by both phacoidal cleavage of argillaceous matrix and by $X Y$ planes of fragments (fig. $5 C$ ). This mélange foliation is essentially parallel to both bedding and early tectonic contacts.

\section{Early Bedding-Extensional Shear Bands}

Mélange foliation and early thrust faults are commonly offset across shear bands that, where present, are 

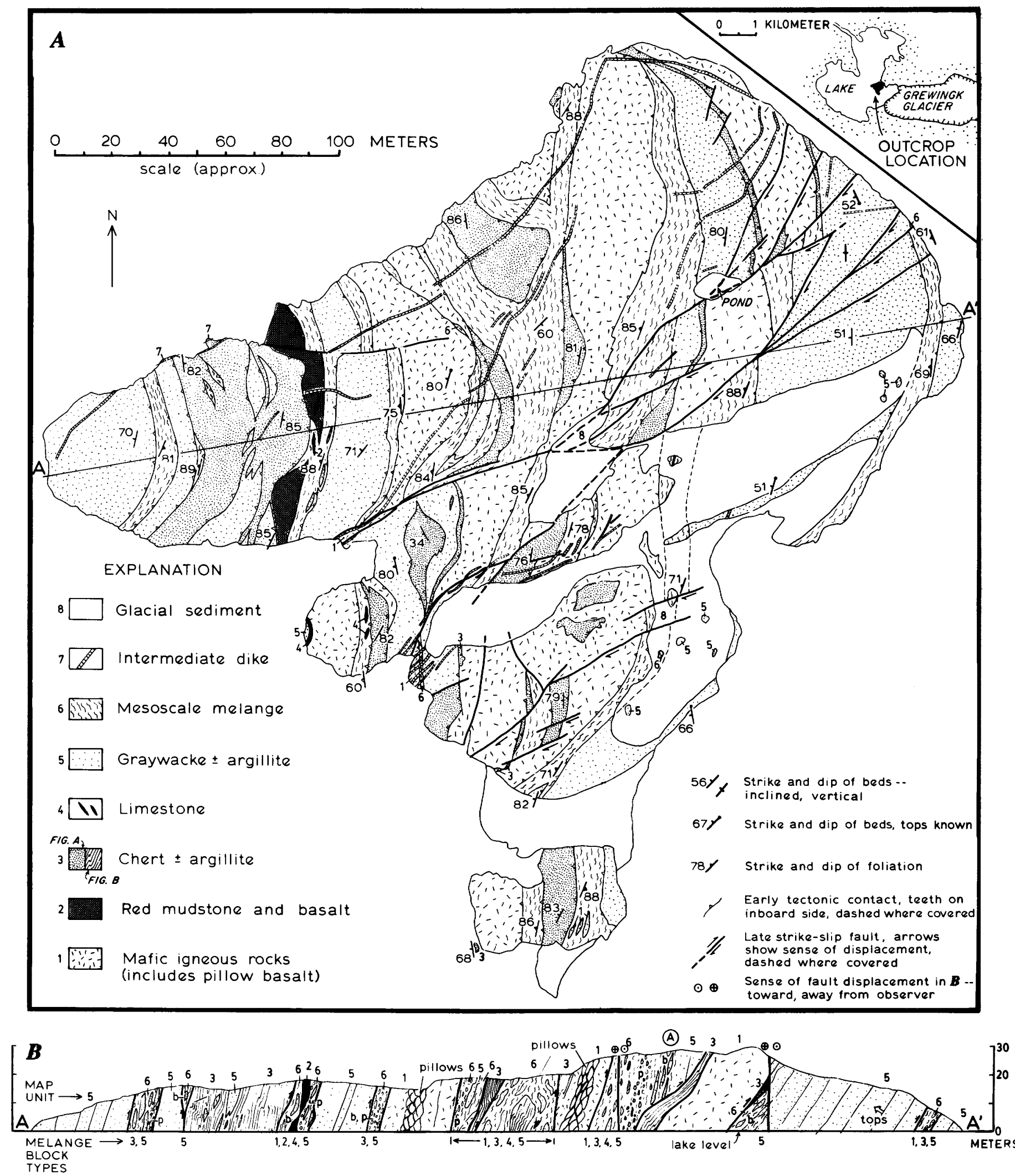

Figure 4. $A$, Geobgic map (original scale 1:1,140) of McHugh Complex near lower terminus of Grewingk Gacier. Numbers indicate rock units in explanation. Map area is at locality 2 in figure 2 . Inset shows location of ice front in late 1980's. B, Cross section A-A', showing repetition along early contractional faults of various ocean-floor rock types that comprise McHugh Complex. Numbers below cross section identify types of blocks in mesoscale mélange zones. $b$, broken formation; $p$, pebbly mudstone. No vertical exaggeration. 

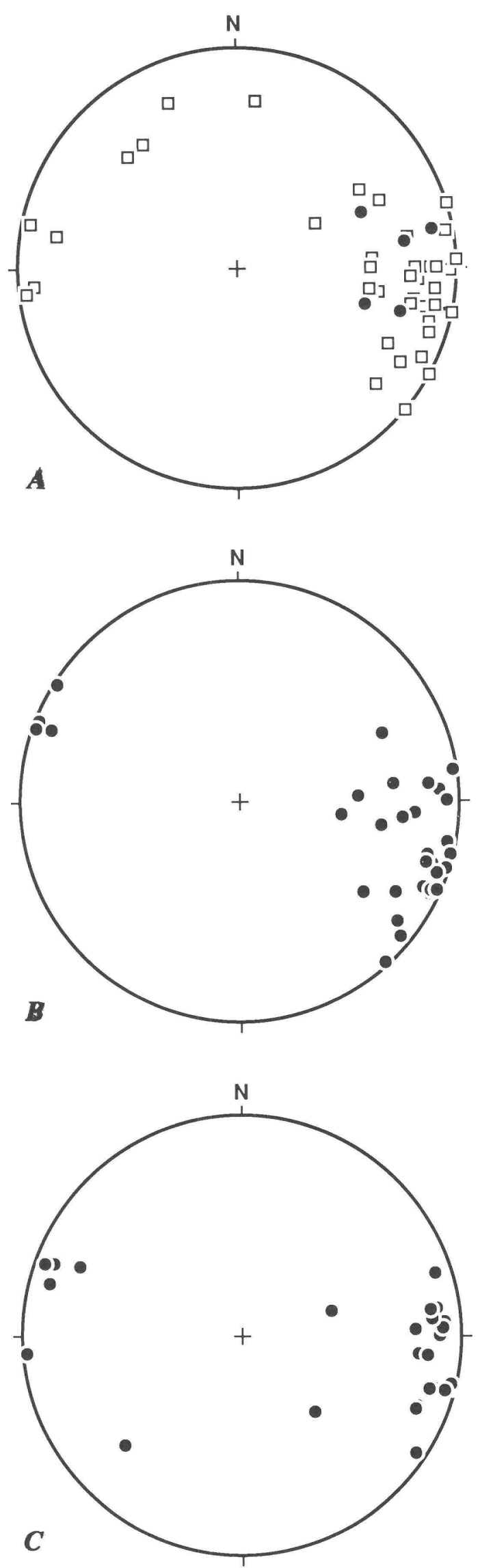

spaced a few tens of centimeters to several meters apart. The shear bands are mesoscopically ductile; layering shows conspicuous drag adjacent to the shear bands. In cross-sectional views, the shear bands cause offsets of up to a few meters (fig. $6 B, C$ ). A stereoplot of shear bands is shown in figure $7 A$; their significance is discussed below.

\section{LATE STRUCTURES AT GREWINGK, WOSNESENSKI, AND DIXON GLACIERS}

\section{Brittle Faults}

Late brittle faults occur throughout the area underlain by the McHugh Complex in the Seldovia quadrangle. We recognize three sets of late faults that are important on a regional scale (fig. 2): (I) older east-northeast-striking dextral faults; (II) northwest-striking lineaments that we interpret as conjugate sinistral faults related to set I; and (III) younger dextral faults that strike approximately north. In our detailed study areas (figs. 4,8 ), prominent late faults belonging to sets I and III cause mappable offsets of up to a few tens of meters. At the outcrop scale, very minor late faults, too small to cause mappable offsets, are abundant. These belong to sets I, II, and III, as well as to three additional fault sets: (IV) west-dipping thrust faults, and (V and VI) conjugate north- and south-dipping normal faults. Equal-area projections of fault planes and associated slickenlines at Grewingk Glacier are displayed in figure 9. In all cases, only crystal fibers with unambiguous stepping directions are plotted. For ease of comparison, the stereonets are displayed in the same order as those from comparable late brittle faults along Turnagain Arm (see Bradley and Kusky, 1990). The average attitudes of the fault sets are summarized in figure 9.

At Grewingk and Wosnesenski Glaciers (figs. $4 A$, $8 A$ ), the most prominent late faults belong to set I: dextral strike-slip faults that strike about $070^{\circ}$ (range about $060^{\circ}$ to $100^{\circ}$ ). The largest dextral map separation of subvertical mélange units at Grewingk Glacier is about $50 \mathrm{~m}$; subhorizontal fibrous slickensides with dextral steps confirm the shear sense (fig. 9E, $F$ ). At Wosnesenski Glacier, faults of set I cause dextral map separations of subvertical mélange units of up to about $20 \mathrm{~m}$. Elsewhere in the Seldovia quadrangle, prominent,

Figure 5. Lower-hemisphere equal-area projections from McHugh Complex at Grewingk Glacier. A, Poles to bedding. Filled circles, upright bedding; open squares, stratigraphic tops unknown. B, Poles to fragment foliation in mesoscale mélange. $C$, Poles to early faults and shear zones. Mean tectonic strike is about $020^{\circ}$. 

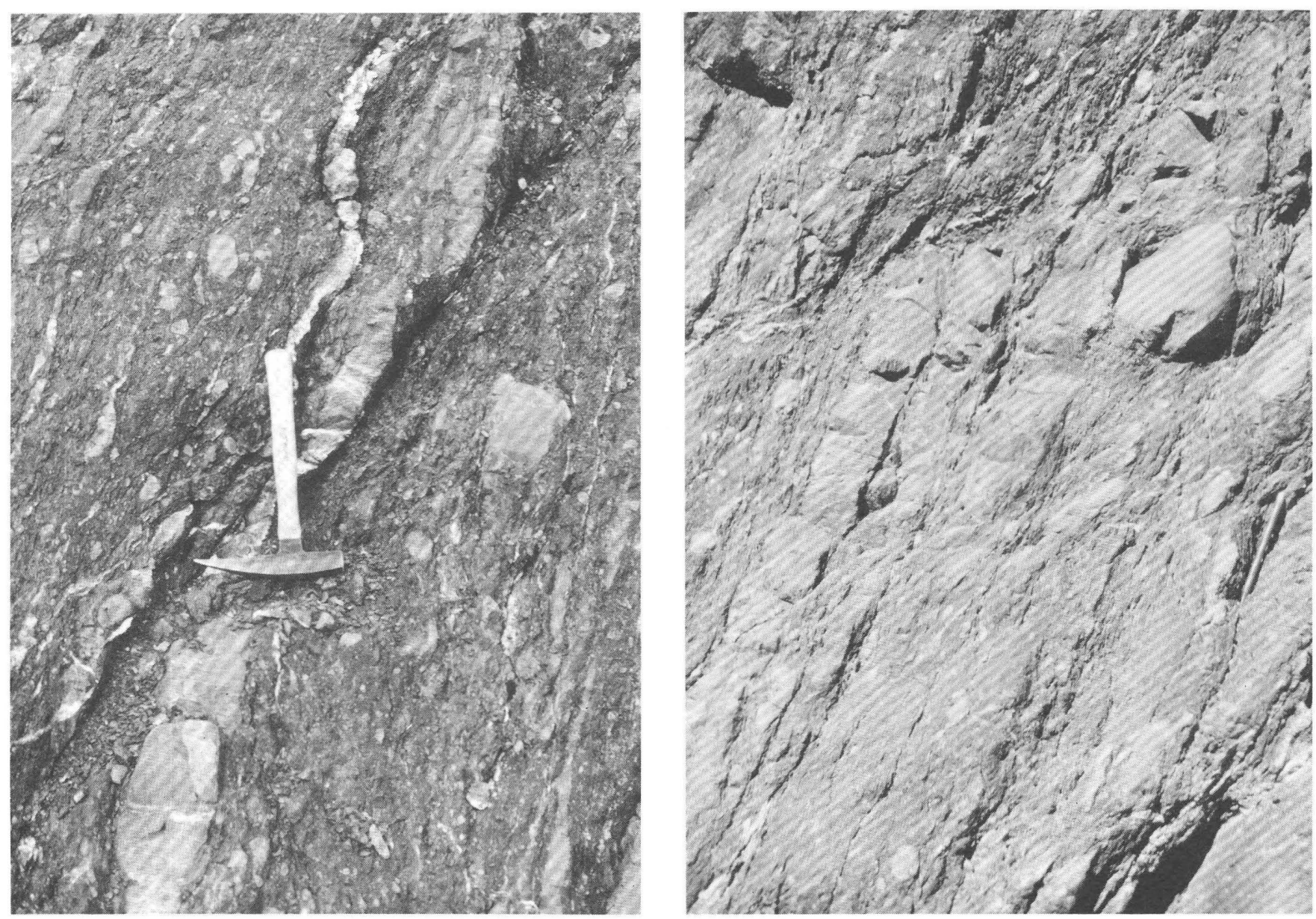

$\boldsymbol{A}$

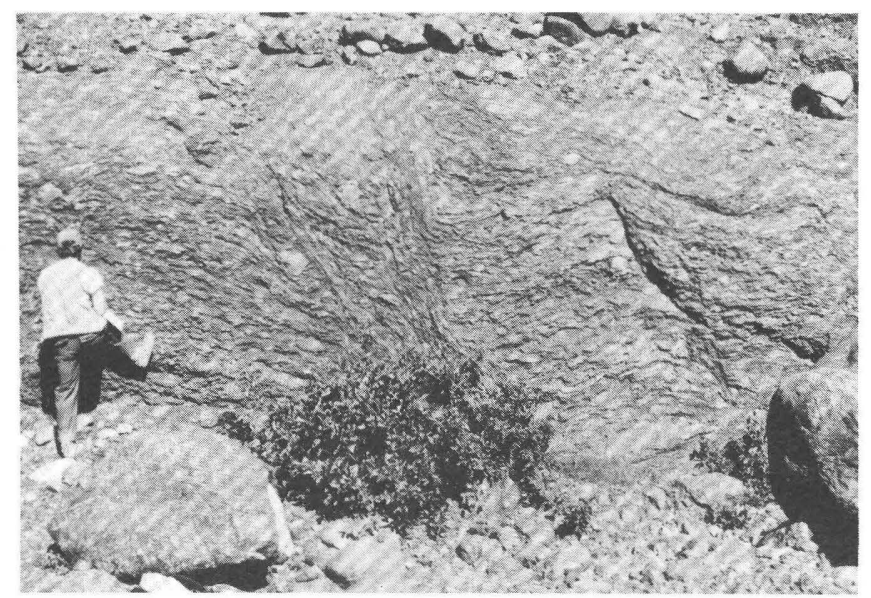

C

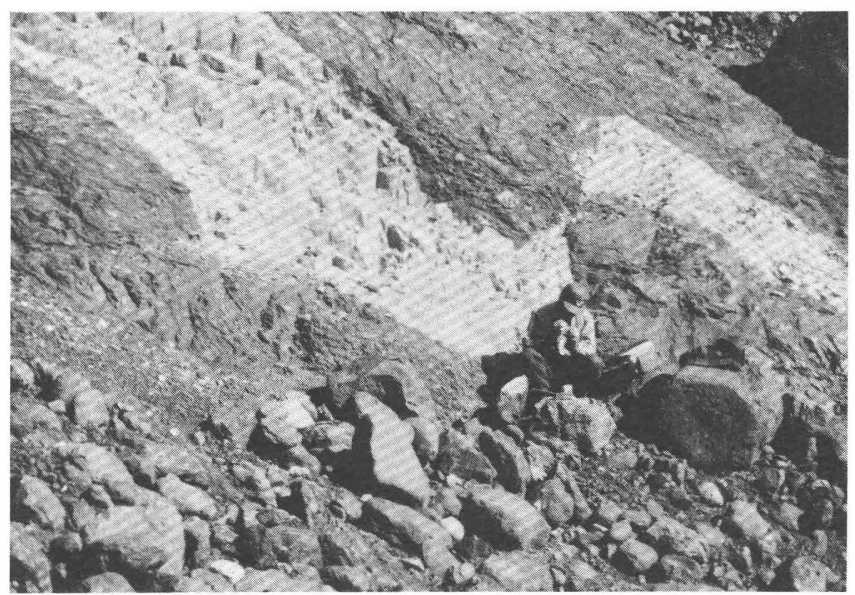

D

Figure 6. A, Pebbly mudstone grading into broken formation, McHugh Complex, Grewingk Glacier. Elongate bed fragments and equant "clasts" are mainly graywacke and black cherty argillite; matrix is phacoidally cleaved argillite. B, Early layer-extensional shear bands (moderately to steeply right-dipping) causing apparent normal offset of mélange foliation (gently dipping) in McHugh Complex at

Dixon Glacier. C, Early shear band that extends steeply dipping layers, causing apparent contractional offset of mélange foliation in McHugh Complex at Grewingk Glacier. If shear band formed before layering was rotated to its present steep dip, shear band would have had an initial normal offset, like those in $B$. D. Transform offset across an intermediate dike, McHugh Complex, Dixon Glacier. 
approximately east-trending lineaments can be traced for distances of several kilometers (fig. 2); most of these probably correspond to faults belonging to set I.

Although only one mappable sinistral fault was encountered in the three detailed map areas (at Grewingk Glacier; fig. 4A), northwest-trending lineaments (average trend about $320^{\circ}$ ) that we interpret as probable sinistral faults are conspicuous in the region (fig. 2). The best evidence that these are sinistral faults comes from the Bradley Lake area (fig. 2), where one such lineament, which trends about $310^{\circ}$, is responsible for 30 -m sinistral map separation of mélange units (Woodward-Clyde Consultants, 1979, p. 47); the fault is truncated by the Bradley River fault (see below). Northwest-striking sinistral faults are common in Kodiak and Turnagain Arm (Bradley and Kusky, 1990). Very minor sinistral faults at Grewingk Glacier, too small to be mappable, mainly strike about northwest, but there is considerable scatter of dips and dip directions (fig. $9 G, H$ ). We suggest that northwest-striking, high-angle sinistral faults constitute an important set of late faults in the McHugh Complex, which we assign to set II.

Approximately north-striking $\left(000^{\circ}\right.$ to $\left.025^{\circ}\right)$ dextral strike-slip faults, assigned to set III, cause mappable offsets at Wosnesenski and Dixon Glaciers (fig. 8). Elsewhere in the Seldovia quadrangle, north-trending lineaments were first recognized as dextral faults during engineering geology studies for the Bradley Lake Hydroelectric Project (fig. 2). The Bradley River fault dextrally offsets a vertical east-west dike by about 300

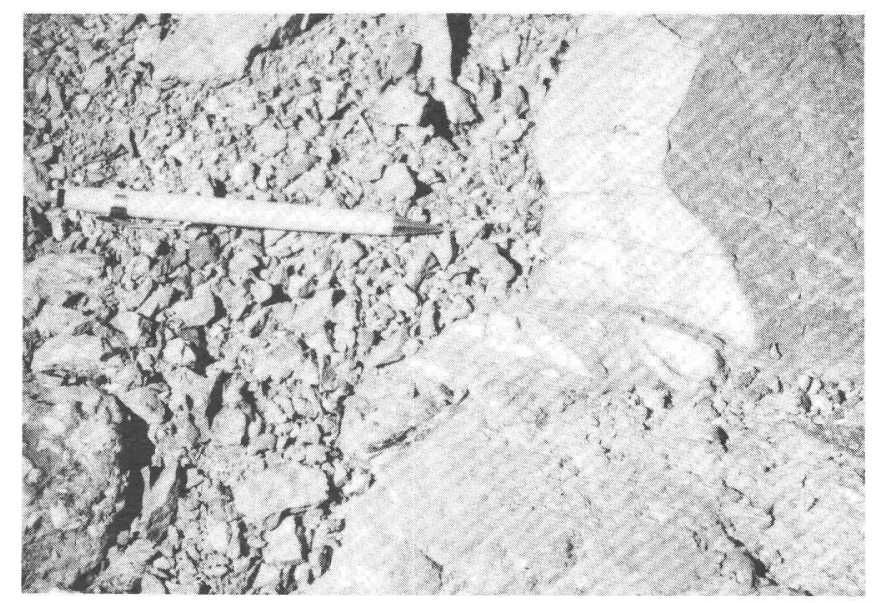

$\boldsymbol{E}$

The transform does not cut country rock beyond the dike and hence was only active during dike emplacement. $E$, Leucocratic dike truncated by late, east-northeast striking dextral fault zone (parallel to pencil in lower half of photograph), Grewingk Glacier near pond (fig. 4A). Fragments of dike are entrained in fault breccia and displaced dextrally. m (Woodward-Clyde Consultants, 1979, p. 19). A similar but smaller fault recognized in the Bradley Lake project, the Bull Moose fault (Woodward-Clyde Consult-
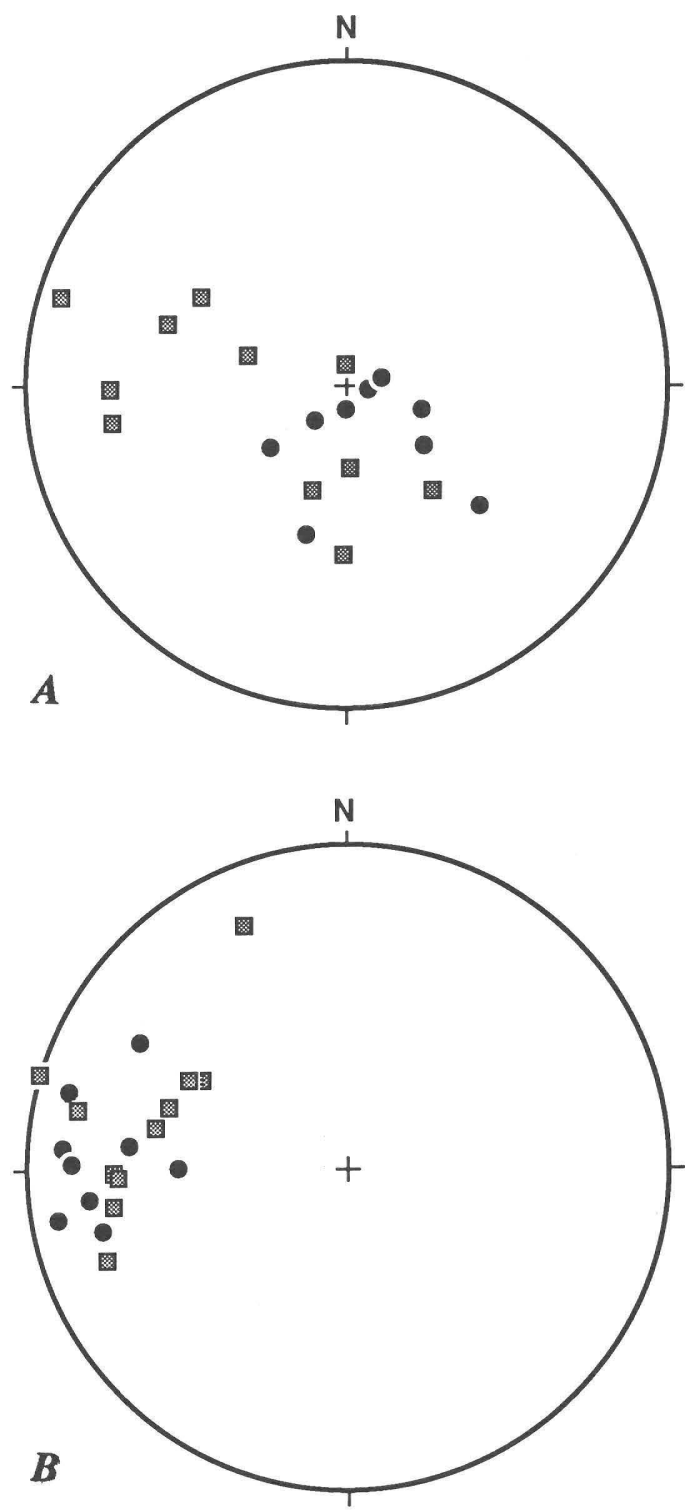

Figure 7. Lower-hemisphere equal-area projections from McHugh Complex at Grewingk Glacier. A, Poles to early layer-extensional shear bands. In all cases, apparent hanging wall moved to east, but some of shear bands are apparent thrust faults, whereas others are apparent normal faults. Filled circles are from Grewingk Glacier; shaded squares are from elsewhere in McHugh Complex in Seldovia quadrangle. $B$, Poles to same faults subject to tilt correction (by strike rotation) of bedding or fragment foliation; actual tilt-correction paths are different for each datum because of variable attitudes of layering. Resulting tighter clustering of poles supports interpretation that these structures all originated as early ductile normal faults and were then variably rotated into their present attitudes. 
ants, 1979 , p. 20), can be traced as a topographic lineament to the terminus of Dixon Glacier (fig. $8 B$ ), where we found that it dextrally offsets a subvertical east-striking dike by about $15 \mathrm{~m}$. At Wosnesenski Glacier, a minor north-northeast-striking fault offsets both an eaststriking dike and east-striking dextral faults by about 15 $\mathrm{m}$ (fig. 8A). Thus, fault set III is younger than both fault set I and the dikes. At Grewingk Glacier, minor dextral faults plot in two clusters, one corresponding to set I (mean strike and dip $240^{\circ}, 85^{\circ} \mathrm{N}$.), and the second corresponding to set III (mean strike and dip $173^{\circ}, 43^{\circ} \mathrm{W}$.). Fault set IV consists of minor late thrusts with considerable scatter, which, on average, strike about north and dip west (mean strike and dip $181^{\circ}, 52^{\circ} \mathrm{W}$.)(fig. $9 A, B$ ). Fault sets V and VI form a conjugate pair of minor late normal faults that strike east and dip moderately north and south (mean strike and dip $268^{\circ}, 62^{\circ} \mathrm{N}$. and $093^{\circ}$, $31^{\circ} \mathrm{S}$., respectively). These faults are poorly developed structures of minor significance at Grewingk Glacier.
To summarize observed cross-cutting relations, fault sets I and II are cut by fault set III; relative ages of the other fault sets are unknown.

\section{Dikes}

Northeast-striking intermediate to silicic dikes (fig. $6 D)$ cut mélange fabric and extensional shearbands throughout the Chugach terrane in the Seldovia quadrangle. In the detailed study areas, dike widths vary from a few centimeters to $2.5 \mathrm{~m}$. Dike margins are commonly chilled. Chert xenoliths are common, as is dike-parallel flow banding. In places, the margins are irregular; elsewhere, they are sharp and it is possible to match opposite sides. An apparent opening direction of about $345^{\circ}$ is revealed by the attitude of dike normals and transform offsets (fig. 10). Transform offsets like that in figure $6 D$ are exactly analogous to transform offsets of mid-ocean

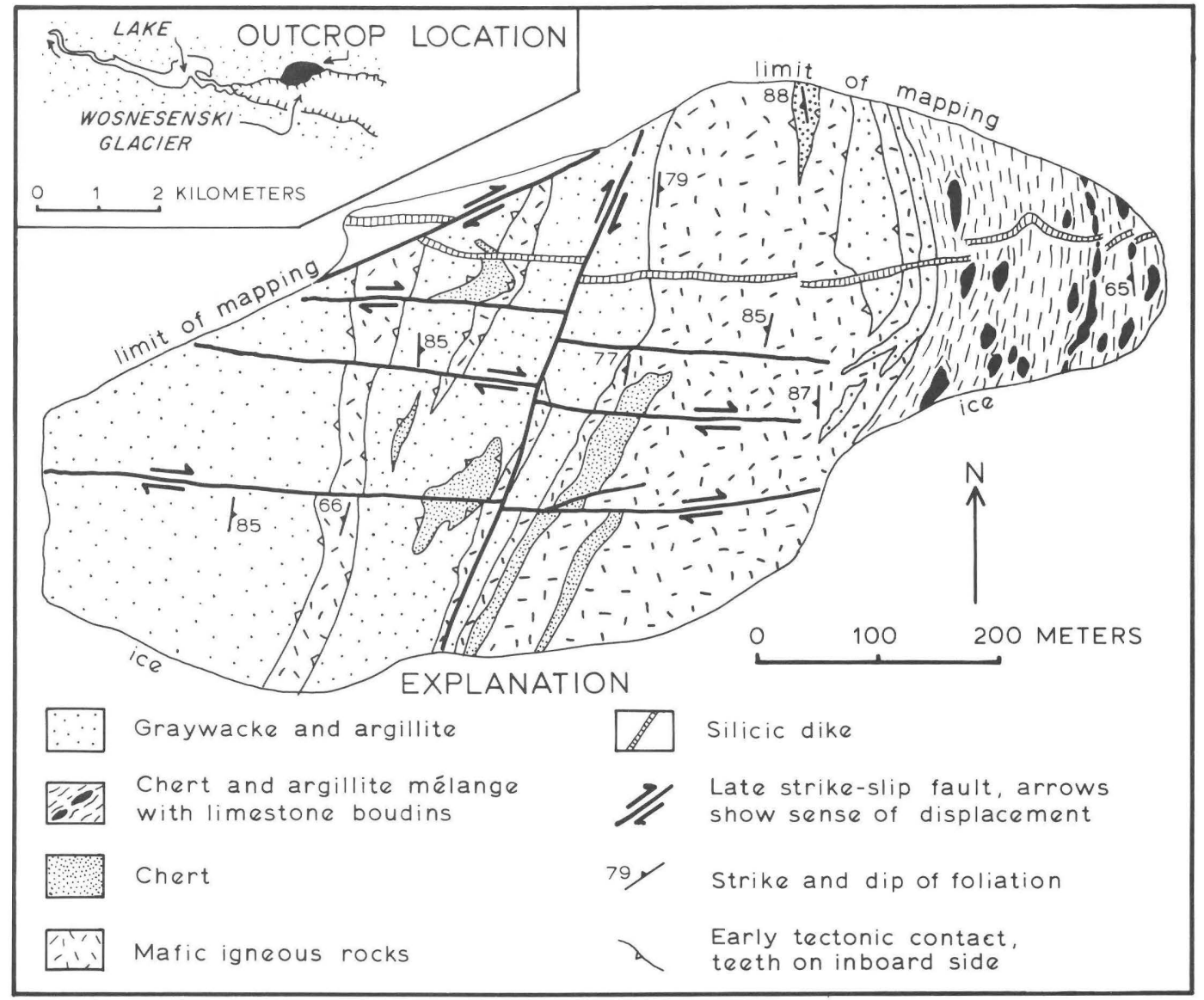

$\boldsymbol{A}$

Figure 8. A, Detailed geologic map (original scale 1:6,000) of McHugh Complex at lower terminus of Wosnesenski Glacier. Inset shows position of ice front in late 1980's. Map area is at locality 3 in figure 2. B, Detailed geologic map (original scale $1: 6,000$ ) of McHugh Complex at lower terminus of Dixon Glacier. McHugh Complex here is not readily divisible into mappable units. Map area is at locality 1 in figure 2. 
ridges (Wilson, 1965). The fault in figure $6 D$ connecting the two dike segments moved only during dike intrusion and does not cut country rock beyond the dike; the sense of motion in figure $6 D$ was left-side-up, not right-sideup. On the basis of mutually cross-cutting relationships, dike emplacement appears to have been coeval with movement on fault set I. Some of the dikes are offset by fault set I (fig. $6 E$ ), whereas elsewhere, dikes intrude along fault traces (for example, near both small bays on the southwestern side of the island in fig. $4 A$ ). Protoclastic textures in some dike margins near the fault zones indicate that deformation occurred while the dikes were still hot.

Although none of the dikes mapped in the present study have been dated, we believe that they are probably early Eocene on the basis of isotopic ages of compositionally similar intrusive rocks elsewhere in the Seldovia quadrangle. Biotites from the Nuka pluton (biotite granite; fig. 2) yielded a ${ }^{40} \mathrm{Ar} /{ }^{39} \mathrm{Ar}$ plateau age of $54.2 \pm 0.08$ $\mathrm{Ma}$; monazite from the same sample yielded a U-Pb age of $56.0 \pm 0.5 \mathrm{Ma}$. Amphiboles from an intermediate dike at the head of Seldovia Bay yielded $\mathrm{a}^{40} \mathrm{Ar} /{ }^{39} \mathrm{Ar}$ isochron age of $57.0 \pm 0.22 \mathrm{Ma}$ (W. Clendenen, written commun., 1989).

\section{INTERPRETATION}

\section{Early Structures}

Whereas the map pattern at Grewingk Glacier is complicated by offsets on late cross-faults, we interpret the primary repetition of elongate belts of greenstone, chert, graywacke, and mesoscale mélange as the product of motion on myriad early seaward-directed thrust faults (fig. 4A). This interpretation is consistent with the map pattern, the inferred oceanic-plate stratigraphy (fig. $3 A$ ), and the few available way-up indicators. Both insequence and out-of-sequence thrusting would seem to be necessary to account for the thinness of fault-bounded map units that are likely to have been many times thicker originally. In the McHugh Complex in the TransAlaska Crustal Transect transect area, about $450 \mathrm{~km}$ along strike to the northeast, Nokleberg and others (1989) attributed the earliest generation of structures to subduction-accretion. Similarly, we suggest that previously subhorizontal rocks of a downgoing oceanic plate were imbricated along subduction-zone thrusts.

A less compelling explanation for the repetition of rock types is by contractional soft-sediment deformation

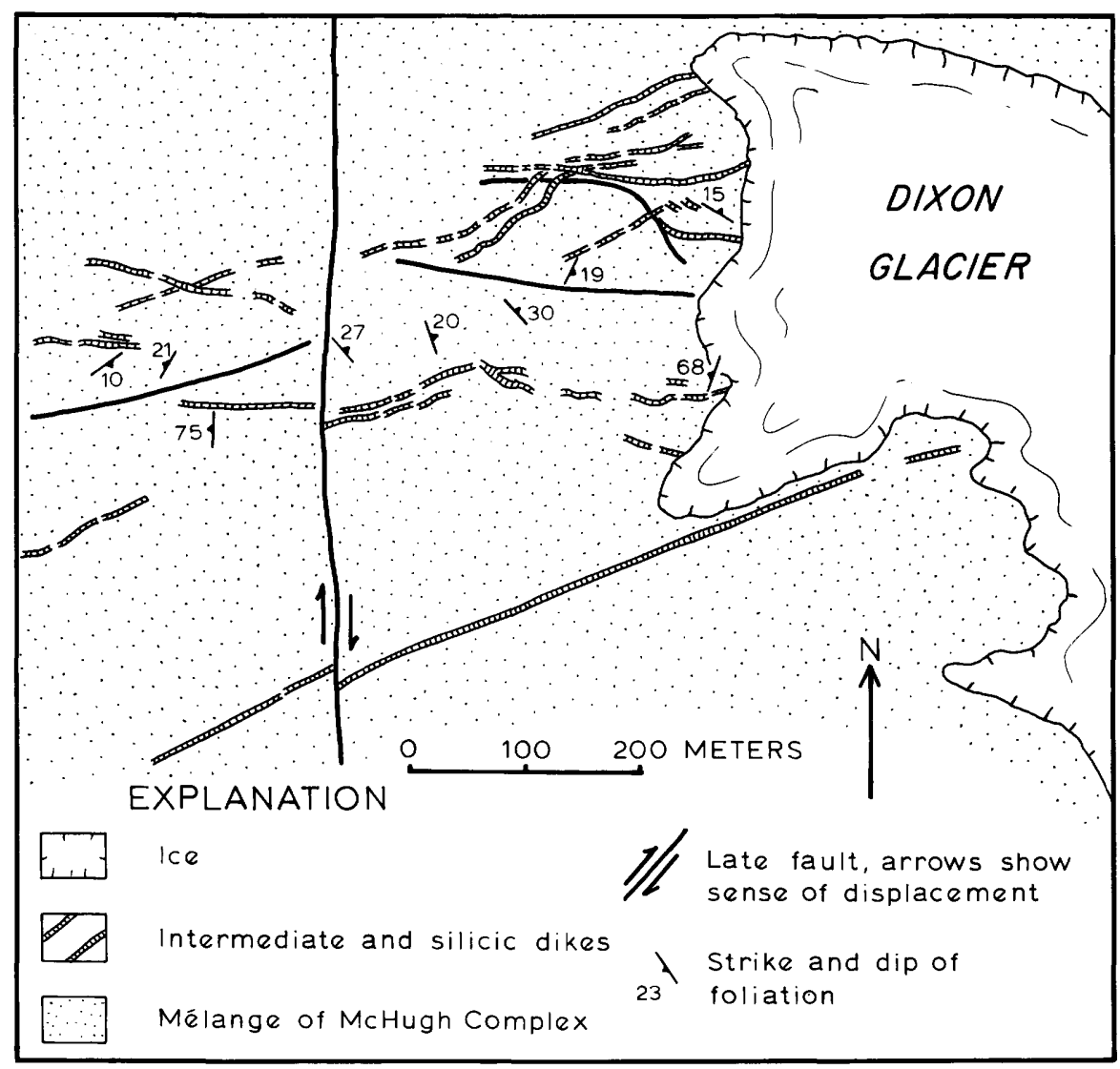

$\boldsymbol{B}$

Figure 8. Continued. 
(for example, at the base of a slope where slump sheets accumulate). However, some of the imbricated rocks at Grewingk Glacier, such as pillow basalt, could not conceivably have been soft when deformed. A similar argument applies to the origin of the pebbly mudstone. Two key relations are that the pebbly mudstone grades into broken formation consisting of pulled apart beds of graywacke and argillite, and that broken formation grades into coherently bedded turbidites (fig. $6 A$; fig. $4 B$, loc. A). Thin-section evidence of cataclastic grain-size reduction during disruption of bedding, mentioned previously, requires that disruption occurred in already lithified graywacke. Accordingly, we suggest that both broken formation and pebbly mudstone formed in zones of particularly intense tectonic disruption of already lithified rocks, rather than as a result of soft-sediment deformation. Clear evidence for soft-sediment deformation is lacking at Grewingk Glacier.

Early ductile shear bands are widespread but enigmatic structures in the McHugh Complex. The sense of motion presents an interesting problem in structural analysis. Some shear bands offset steeply dipping markers in
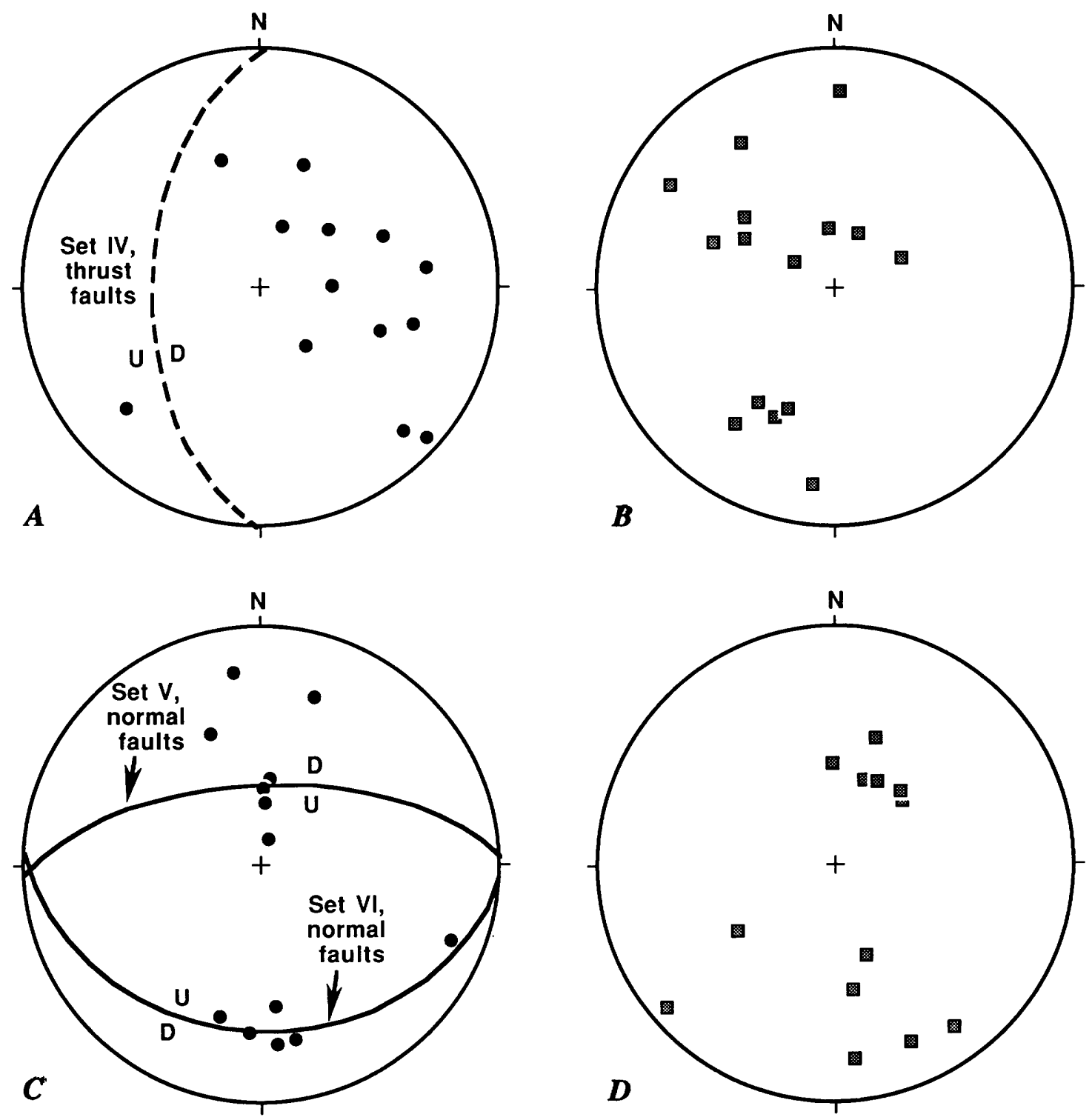

Figure 9. Lower-hemisphere equal-area projections from McHugh Complex at Grewingk Glacier. $A$, Poles to thrust-fault surfaces. $B$, Thrust-fault slickenlines. $C$, Poles to normal-fault surfaces. $D$, Normalfault slickenlines. E, Poles to dextral-fault surfaces. $F$, Dextral-fault slickenlines. $G$, Poles to sinistralfault surfaces. $H$, Sinistral slickenlines. Solid great circles represent average fault attitudes from tightly clustered poles to faults; dashed great circles are rough approximate averages from poorly clustered poles to faults. 
an apparent thrust sense (in the present reference frame), whereas a number of otherwise identical shear bands offset moderately dipping markers in an apparent normal sense (fig. $6 B, C$ ). In all cases, however, the shear bands cause extension of layering. This is clearly seen by comparing stereoplots of the shear bands in their present orientation (fig. 7A) with the same data subject to simple strike rotation of host layering to correct for tilt [fig. $7 B$; see Bradley (1989) for methodology and rationale]. After tilt correction, data that had been scattered and inconsistent all plot as down-to-east normal faults. Accordingly, we suggest a simple scenario wherein the shear bands formed in a single tectonic regime at a time when layering (bedding, early tectonic contacts, and mélange folia- tion) were still subhorizontal. Subsequent, mainly landward rotation of layering also affected the shear bands, and in some cases rotation was sufficient to transform the normal faults into apparent thrust faults (Bradley, 1989). Fisher and Byrne (1987, p. 778) recognized comparable early faults on Afognak Island, which cut accreted trench deposits of the Kodiak Formation. The faults on Afognak Island occur in a variety of orientations, but all extend bedding and, subject to restoration of bedding to horizontal, most have a seaside-down sense of displacement. Because their effect is opposite that commonly thought to be associated with subduction (that is, extension in the inferred direction of plate convergence), the significance of the early extension faults is unclear.
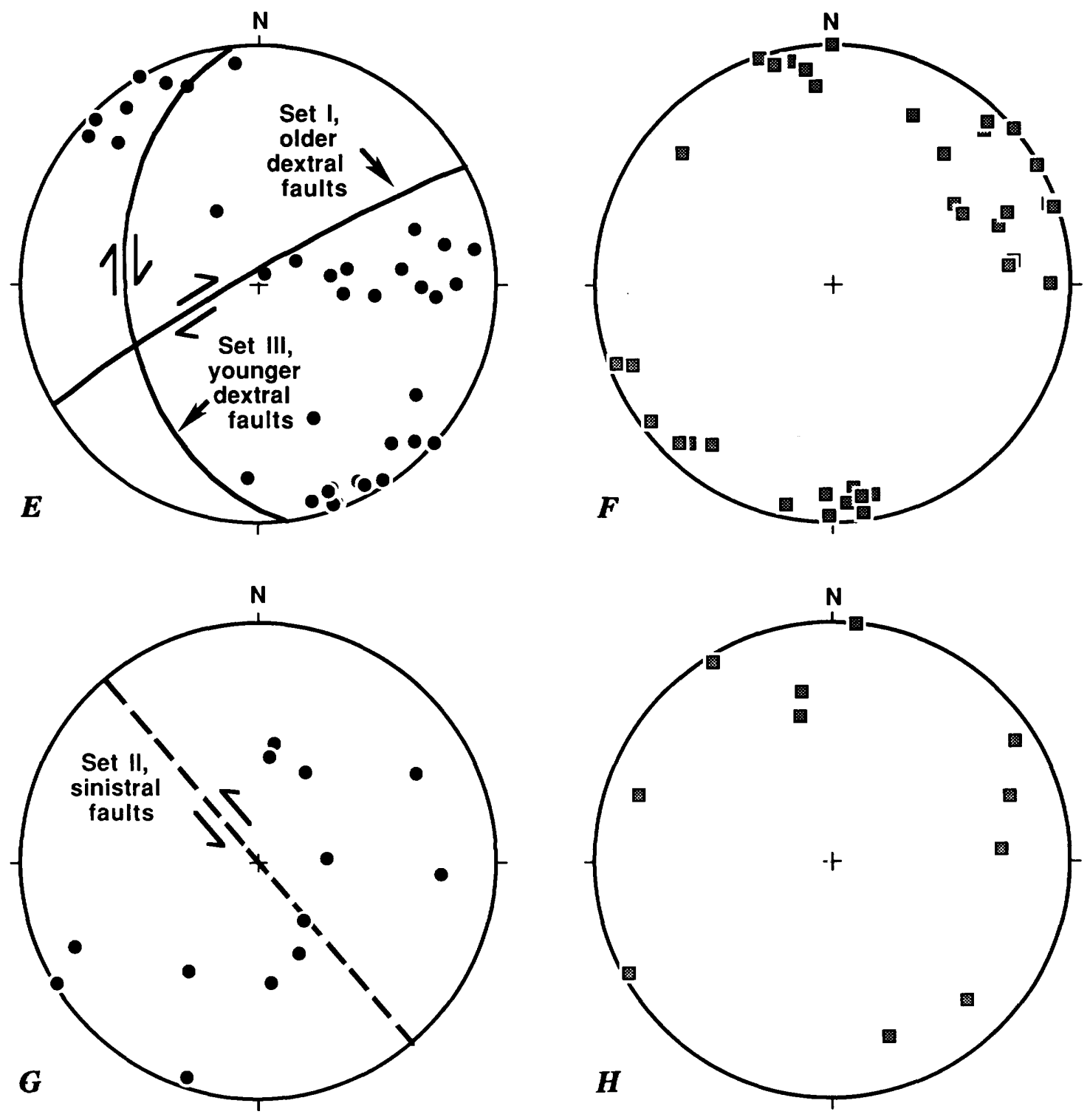

Figure 9. Continued. 


\section{Late Faults and Dikes}

Of the various late structures in the study area, the dikes and apparently coeval dextral faults are most readily interpreted in terms of regional tectonic events. Intermediate to silicic dikes pervade the Chugach terrane in the Seldovia quadrangle and are part of the Sanak-Bara-
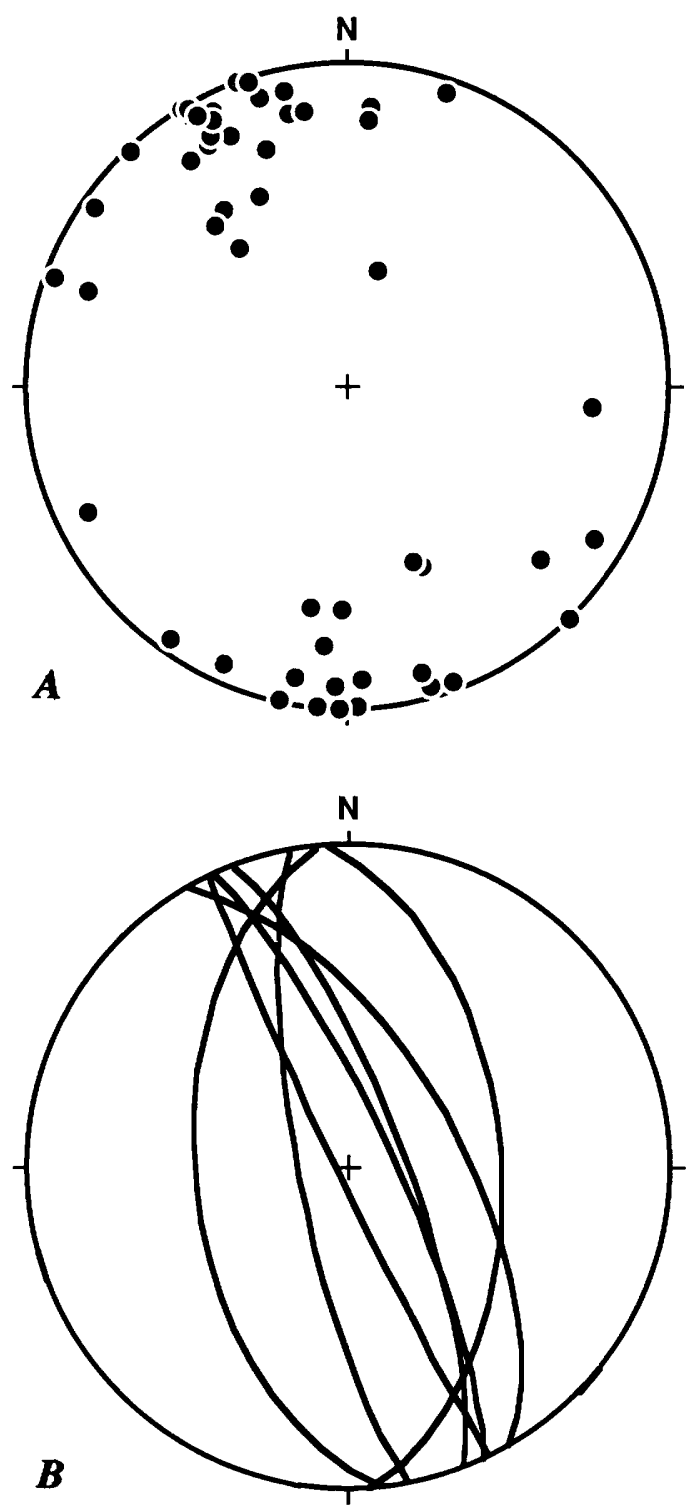

Figure 10. Lower-hemisphere equal-area projections from McHugh Complex and Valdez Group in Seldovia quadrangle. $A$, Poles to dike margins, which plunge in approximate direction of dike opening. $B$, Dike-opening transform faults, plotted as great circles rather than as poles because true opening direction is constrained to lie on transform plane but could have any orientation on it. Taken together with population of poles to dike margins, mean dike opening direction is about $345^{\circ}$. nof magmatic belt (Hudson, 1983; also called the Gulf of Alaska belt by Wallace and Engebretson, 1984), which intrudes the Chugach terrane along a strike length of more than $2,000 \mathrm{~km}$. Intrusions lie anomalously close to the trench, far from the coeval axis of the magmatic arc (Hill and others, 1981). Existing isotopic ages tend to progress systematically along strike around the southern Alaska orocline, being older at Sanak (62 Ma) and younger at Baranof (47 Ma). Isotopic ages of 57-54 Ma from the Seldovia quadrangle fit this overall pattern.

Two findings from the present study bear on conditions within the accretionary wedge during near-trench magmatism. Dike injection was accompanied by extension at a high angle to tectonic strike (dike opening direction was about $345^{\circ}$ and tectonic strike at Grewingk Glacier is about $020^{\circ}$ ). Dike injection at Grewingk Glacier was coeval with motion on $070^{\circ}$ dextral faults. Bradley and Kusky (1990) showed that dextral faults of comparable orientation are widespread from Kodiak Island to Turnagain Arm, and that motion on these and conjugate sinistral faults resulted in orogen-parallel extension.

We interpret the near-trench magmatism and associated orogen-parallel extension as the products of subduction of an oceanic spreading center: either the KulaFarallon ridge (Marshak and Karig, 1977; Hill and others, 1981; Plafker and others, 1989, p. 4287) or, conceivably, another ridge farther to the north. The former existence of a Kula-Farallon ridge during the Late Cretaceous and Paleogene is a fundamental, irrefutable feature of all modern plate reconstructions of the Pacific realm (for example, Engebretson and others, 1985). Because the Kula and Farallon plates have all but disappeared, most details of the plate-motion history are limited to what can be reconstructed from the half-spreading history of the Pacific plate (Atwater, 1989). One unknown parameter is the location, through time, of the Kula-Farallon-North America triple junction; a related unknown is the position along the continental margin of the Chugach terrane (Moore and others, 1983; Plafker and others, 1989). The along-strike progression of igneous ages along the Sanak-Baranof belt implies that the triple junction migrated west to east along the continental margin. This would mean that, for the part of the Chugach terrane now in the Seldovia quadrangle, the Farallon plate was subducted prior to about 57-54 Ma, and that the Kula plate was subducted between about 54 and $42 \mathrm{Ma}$. After about $42 \mathrm{Ma}$, the Kula-Pacific ridge became extinct and the two plates became one (Lonsdale, 1988); presumably, the Pacific plate has been subducted since then.

An important, unknown parameter that geologic data may ultimately yield is the Kula-Farallon spreading direction. This might simply be the dike opening direction, but it seems unlikely that there is such a close relationship between spreading direction in the two under- 
riding plates and any structures produced in the overriding plate. Foremost among the possible complications is that subduction of a high-standing spreading axis is likely to upset the critical taper of the accretionary wedge, creating compressional or tensional body forces of unknown orientations [a qualitative solution will require that the critical taper equations of Platt (1986) be recast in three dimensions].

Late structures in the three detailed map areas do not bear conclusively on the long-standing hypothesis that the Chugach terrane slid northward to its present location along one or more coast-parallel strike-slip faults (for example, Plumey and others, 1983). Strike of early contractional structures is about the same as would be produced at the Benioff Zone today. We are led to conclude that if the McHugh Complex did undergo major coastwise strike-slip, it must have done so without experiencing any of the internal block rotations that are so prevalent in active strike-slip settings, and without being cut by major splays such as typify the San Andreas fault system.

Late structures in the three detailed map areas also have little bearing on Carey's (1955) hypothesis that the southern Alaska orocline formed by bending of belts, such as the Chugach terrane, that were originally straight (see, for example, Coe and others, 1985; Plafker and others, 1989). If such bending did occur, it would have been accompanied by shortening parallel to strike on the inner side of the arc. Instead, we observe three structural elements (conjugate fault sets I and II, dikes, and conjugate fault sets V and VI) that had the opposite effect: extension parallel or nearly parallel with the orogen. The only late structures in the study areas of suitable orientation are north-striking dextral faults of set III, which might be related either to the southward escape of material being squeezed out of the tightening hinge of the orocline or to coastwise motion around an existing bend. Whatever the case, cross-cutting relations require that events related to fault set III followed those related to the dikes and fault sets I and II.

\section{SUMMARY}

At Grewingk Glacier, the McHugh Complex consists of multiple fault slices of relatively coherent basalt, chert, and graywacke, each up to a few tens of meters thick, bounded by zones of mesoscale mélange. We interpret the mesoscale mélanges as having formed in thrust zones, and the map pattern as the result of thrust repetition of an originally simple oceanic-plate stratigraphy, the lower part of which constitutes the Kachemak "terrane" of Jones and others (1987). Throughout the Seldovia quadrangle, intermediate to silicic dikes were injected into already deformed rocks of the McHugh
Complex and Valdez Group during early Eocene time. Dike emplacement was coeval with motion on dextral strike-slip faults, which are prominent at Grewingk, Dixon, and Wosnesenski Glaciers, and are part of a conjugate pair whose acute bisector trends about east-west. Diking and conjugate strike-slip faulting together resulted in approximately orogen-parallel extension. We interpret both phenomena as the consequence of subduction of the Kula-Farallon Ridge. A younger set of north-striking dextral faults offsets the older strike-slip faults and dikes; these may be related to formation of the southern Alaska orocline and (or) to movement of the Chugach terrane around the oroclinal bend.

\section{REFERENCES CITED}

Atwater, T., 1989, Plate tectonic history of the northeast Pacific and western North America, in Winterer, E.L., Hussong, D.M., and Decker, R.W., eds., The eastern Pacific Ocean and Hawaii: Boulder, Colorado, Geological Society of America, The Geology of North America, DNAG Series, v. N, p. 21-72.

Blome, C.D., Nelson, S.W., and Karl, S.M., 1990, Accretionary history of the chert-rich McHugh Complex [abs.]: Geological Society of America Abstracts with Programs, v. 22, p. A321-A322.

Bradley, D.C., 1989, Description and analysis of early faults based on the geometry of fault-bed intersections: Journal of Structural Geology, v. 11, p. 1011-1019.

Bradley, D.C., and Kusky, T.M., 1990, Kinematics of late faults along Turnagain Arm, Mesozoic accretionary complex, south-central Alaska, in Dover, J.H., and Galloway, J.P., eds., Geologic studies in Alaska by the U.S. Geological Survey, 1989: U.S. Geological Survey Bulletin 1946, p. 3-10.

Burns, L.E., 1985, The Border Ranges ultramafic and mafic complex, south-central Alaska: cumulate fractionates of island arc volcanics: Canadian Journal of Earth Science, $v$. 22, p. $1020-1038$.

Byrne, T., 1984, Early deformation in mélange terranes of the Ghost Rocks Formation, Kodiak Islands, Alaska, in Raymond, L.A., ed., Melanges: Their nature, origin, and significance: Geological Society of America Special Paper 198 , p. $21-51$.

Carey, S.W., 1955, The orocline hypothesis in geotectonics: Proceedings of the Royal Society of Tasmania, v. 89, p. 255-288.

Clark, S.H.B., 1973, The McHugh Complex of south-central Alaska: U.S. Geological Survey Bulletin 1372-D, p. D1D11.

Coe, R.S., Globerman, B.R., Plumley, P.R., and Thrupp, G.A., 1985, Paleomagnetic results from Alaska and their tectonic implications, in Howell, D.G., ed., Tectonostratigraphic terranes of the circum-Pacific region: Houston, Texas, Circum-Pacific Council for Energy and Mineral Resources, Earth Science Series, v. 1, p. 85-108.

Connelly, W., 1978, Uyak Complex, Kodiak Islands, Alaska: A 
Cretaceous subduction complex: Geological Society of America Bulletin, v. 89, p. 755-769.

Cowan, D.S., 1985, Structural styles in Mesozoic and Cenozoic mélanges in the western Cordillera of North America: Geological Society of America Bulletin, v. 96, p. 451462.

Cowan, D.S., and Boss, R.F., 1978, Tectonic framework of the southwestern Kenai Peninsula, Alaska: Geological Society of America Bulletin, v. 89, p. 155-158.

Engebretson, D.C., Cox, A., and Gordon, R.G., 1985, Relative motions between oceanic and continental plates in the $\mathrm{Pa}$ cific Basin: Geological Society of America Special Paper 206, $59 \mathrm{p}$.

Fisher, D., and Byrne, T., 1987, Structural evolution of underthrusted sediments, Kodiak Islands, Alaska: Tectonics, v. 6, p. 775-793.

Hill, M., Morris, J., and Whelan, J., 1981, Hybrid granodiorites intruding the accretionary prism, Kodiak, Shumagin, and Sanak Islands, southwest Alaska: Journal of Geophysical Research, v. 86, p. 10,569-10,590.

Hudson, T., 1983, Calc-alkaline plutonism along the Pacific rim of southern Alaska, in Roddick, J.A., ed., Circum-Pacific plutonic terranes: Geological Society of America Memoir 159, p. 159-169.

Jacob, K.H., 1986, Seismicity, tectonics, and geohazards of the Gulf of Alaska regions, in Hood, D.W., and Zimmerman, S.T., eds., The Gulf of Alaska, physical environment and biological resources: U.S. Department of Interior, Minerals Management Service, p. 145-184.

Jones, D.L., Silberling, N.J., Coney, P.J., and Plafker, G.W., 1987, Lithotectonic terrane map of Alaska (west of the 141st meridian): U.S. Geological Survey, Miscellaneous Field Studies Map MF-1874, scale 1:250,000.

Kelley, J.S., 1980, Environments of deposition and petrography of Lower Jurassic volcaniclastic rocks, southwestern Kenai Peninsula, Alaska: Davis, California, University of California, Ph.D. dissertation, 304 p.

Kusky, T.M., and Bradley, D.C., 1990, Kinematics of late structures in mélange of the McHugh Complex, Kenai Peninsula, Alaska [abs.]: Eos (American Geophysical Union, Transactions), v. 71, p. 1590.

Lonsdale, P., 1988, Paleogene history of the Kula plate: Offshore evidence and onshore implications: Geological Society of America Bulletin, v. 99, p. 733-754.

Magoon, L.B., Adkison, W.L., and Egbert, R.M., 1976, Map showing geology, wildcat wells, Tertiary plant fossil localities, K-Ar age dates, and petroleum operations, Cook Inlet area, Alaska: U. S. Geological Survey Miscellaneous Investigations Series Map I-1019, scale 1:250,000.

Marshak, R.S., and Karig, D.E., 1977, Triple junctions as a cause for anomalously near-trench igneous activity between the trench and volcanic arc: Geology, v. 5, p. 233236.

Matsuda, T., and Isozaki, Y., 1991, Well-documented travel history of Mesozoic pelagic chert in Japan: From remote ocean to subduction zone: Tectonics, v. 10, p. 475-499.

Moore, J.C., Byrne, T., Plumley, P.W., Reid, M., Gibbons, H., and Coe, R.S., 1983, Paleogene evolution of the Kodiak Islands, Alaska: consequences of ridge-trench interaction in a more southerly latitude: Tectonics, v. 2, p. 265-293.

Mutti, E., and Ricci-Lucchi, F., 1978, Turbidites of the northern Appenines - introduction to facies analysis: International Geology Review, v. 20, p. 125-166.

Nelson, S.E., Blome, C.D., and Karl, S.M., 1987, Late Triassic and Early Cretaceous fossil ages from the McHugh Complex, southern Alaska, in Hamilton, T.D., and Galloway, J.P., eds., Geologic studies in Alaska by the U.S. Geological Survey during 1986: U.S. Geological Survey Circular 998, p. 96-98.

Nokleberg, W.J., Plafker, G., Lull, J.S., Wallace, W.K., and Winkler, G.R., 1989, Structural analysis of the southern Peninsular, southern Wrangellia, and northern Chugach terranes along the Trans-Alaska Crustal Transect, northern Chugach Mountains, Alaska: Journal of Geophysical Research, v. 94, p. 4297-4320.

Plafker, G., Nokleberg, W.J., and Lull, J.S., 1989, Bedrock geology and tectonic evolution of the Wrangellia, Peninsular, and Chugach terranes along the Trans-Alaska Crustal Transect in the Chugach Mountains and southern Copper River basin: Joumal of Geophysical Research, v. 94, p. 4255-4295.

Platt, J.P., 1986, Dynamics of orogenic wedges and the uplift of high-pressure metamorphic rocks: Geological Society of America Bulletin, v. 97, p. 1037-1053.

Plumley, P.W., Coe, R.S., and Byrne, T., 1983, Paleomagnetism of the Paleocene Ghost Rocks Formation, Prince William Terrane, Alaska: Tectonics, v. 2, p. 295-314.

Wallace, W.K., and Engebretson, D.C., 1984, Relationships between plate motions and Late Cretaceous to Paleogene magmatism in southwestern Alaska: Tectonics, v. 3, p. 295-315.

Wilson, J.T., 1965, A new class of faults and their bearing on continental drift: Nature, v. 207, p. 343-347.

Woodward-Clyde Consultants, 1979, Reconnaissance geology of the Bradley Lake hydroelectric project: U.S. Army Corps of Engineers, Contract No. DACW 85-79C-0045, 65 p., 2 app., 3 pls.

Reviewers: George Plafker and James H. Dover 


\title{
Occurrence of Platinum-Group Elements in Some Gold-Mining Districts of Alaska
}

\author{
By John B. Cathrall and John C. Antweiler
}

\begin{abstract}
Platinum-group elements (PGE) have been detected in several Alaskan gold districts by (1) emission spectrographic analyses of samples of native gold, and (or) (2) fire-assay analyses of sluice concentrates or pan concentrates, and (or) (3) fire-assay analyses of mineralized rock samples. The districts for which PGE elements are reported upon here are (1) Koyukuk-Chandalar, (2) Hot Springs, (3) Rampart, (4) Tolovana, (5) Circle, (6) Fortymile, (7) Bonnifield, (8) Fairbanks, and (9) Nome. Also, PGE occurrences are reported for selected mines in the Anchorage, Bendeleben, Candle, Healy, Juneau, Mt. Hayes, Mt. McKinley, Ruby, Solomon, and Teller quadrangles. Native-gold samples were obtained from 322 localities: 34 are lode sites, and the remaining 288 are placer sites. A total of 3,250 emission spectrographic analyses were performed on grains of native gold from the 322 localities; PGE were detected in 100 of these analyses. PGE were also detected in 234 of 564 concentrates from the localities using a fireassay inductively coupled plasma-mass spectrometric technique capable of detecting PGE concentrations in the low parts-per-billion range. In several districts, especially Rampart, Hot Springs, Tolovana, Bonnifield, and Fortymile, the distribution and concentration levels of PGE warrant further exploratory studies aimed at determining the sources of PGE and the possibility of locating recoverable resources. In the Fairbanks district, numerous PGE detections in lode samples suggest the desirability both of research on the mode of occurrence and distribution of PGE and of inquiry into applicable recovery methods should future large-scale mining operations be undertaken.
\end{abstract}

\section{INTRODUCTION}

Occurrences of the scarce platinum-group elements (platinum, palladium, rhodium, ruthenium, osmium, and iridium) were identified in native-gold samples and in heavy-mineral concentrates from many of the larger placer-mining districts of central and northern Alaska. Despite increasing demand for PGE, particularly for use in catalytic converters to control emissions from automobiles, domestic production has accounted for less than 5 percent of demand in the United States for the last 25 years (U.S. Department of the Interior, Bureau of Mines, 1988; see also previous Minerals Yearbooks from 1963 through 1987). The occurrences described in this report suggest that PGE resources may exist in and near these and other mines in Alaska.

PGE have occasionally been reported in several mining districts in Alaska based on analyses of sluice concentrates from placer mining, bullion, native gold, and byproducts from mining of other metals. Detections of these elements, however, are unknown or unreported in the majority of mining operations. Reasons are (1) the difficulty of obtaining reliable analyses for PGE, and (2) minerals that carry PGE (for example, natural alloys of PGE, such as platinum and osmiridium; alloys of platinum with iron, chromium, and nickel; and compounds of platinum with arsenic or sulfur, such as sperrylite, cooperite, and froodite) are often very difficult to see in concentrates because of their small particle size and their similarity in appearance to other minerals such as magnetite. Moreover, some PGE alloys and minerals that contain PGE are ferro- and paramagnetic (Mertie, 1969) and thus may accompany magnetite in magnetic separation methods.

A study of gold-producing districts in Alaska was begun by the U.S. Geological Survey (USGS) in 1982 and continued with participation of the Alaska Division of Geological and Geophysical Surveys (ADGGS) beginning in 1983. One aim of the study was to chemically characterize samples of native gold from active mines. Another objective was to determine whether concentrates from mining operations contain valuable commodities in addition to gold. Before the project was suspended for lack of funds (1986), samples were obtained from most of the active mines in the following districts: (1) Koyukuk-Chandalar, (2) Hot Springs (including the Manley, Eureka, and Tofty areas), (3) Rampart, (4) Tolovana (Livengood), (5) Circle (Central), (6) Fortymile, (7) Bonnifield, (8) Fairbanks, and (9) Nome. In addition, 177 gold samples, and 38 heavy-mineral-concentrate samples were obtained from a total of 50 other localities in the Anchorage, Bendeleben, Candle, Healy, Juneau, Mt. Hayes, Mt. McKinley, Ruby, Solomon, and Teller 
quadrangles. A number of data releases and interpretive reports, including a report on identification by emission spectrographic analyses of platinum and palladium in gold samples from the Hot Springs, Rampart, and Tolovana districts, have been published (Cathrall and others, 1987; Mosier and others, 1989). However, fireassay PGE analyses in concentrates were not completed until September 1990. Analyses of some native-gold samples from the Seward Peninsula are in progress.

\section{SAMPLING AND ANALYTICAL METHODS}

Two types of samples were analyzed: (1) native gold, and (2) concentrates of alluvium or mineralized rock from lode mines or prospects. Native gold was usually obtained from concentrates by further panning and hand-picking with the aid of a binocular microscope; in some instances, however, miners donated native gold (which they had hand-picked from their concentrates). Most of the concentrates from alluvium were from sluices, and most of the concentrates from mineralized rock were obtained by hand-panning.

\section{Emission Spectrographic Analysis}

Emission spectrographic analyses (Mosier, 1975) were made on 5-mg samples of native gold (or, in a few cases, on other heavy metallic grains, such as platinum or silver). The trace-element content of gold varies greatly both among deposits and from grain to grain, which creates a problem in determining the precision of the analytical technique. However, studies using artificial melts have shown that the variance of the method is smaller than the natural variance of trace elements in native gold (Mosier, 1975). The previously reported platinum and palladium identifications in the Rampart and Tolovana districts were made by use of the emission spectrographic method (Cathrall and others, 1987); this method was used in the present paper for identifications of platinum and palladium in several other districts.

\section{Fire Assay}

Fire-assay analyses for PGE were performed on 564 concentrates from 322 localities. These samples were chiefly of sluice concentrates from placer mining. They also included pulverized and panned samples of mineralized rock from lode mines or prospects, especially from the Fairbanks district. The fire-assay procedure consists of a nickel-sulfide fusion and an inductively coupled plasma-mass spectrometric (ICP-MS) analysis of the resulting PGE sulfide's melt. The lower detection limit of the PGE ranges from 0.5 to $1.0 \mathrm{ppb}$ on a $10-\mathrm{g}$ sample (R.R. Carlson, oral commun., October 1990). Determinations of PGE in standards have shown that the method yields reproducible results. However, erratically and sparsely distributed, discrete metallic PGE particles make it difficult to determine the precision of results. When available, several $10-\mathrm{g}$ splits were analyzed as replicates from the same sample, and the results inspire considerable confidence in the method. Less than $10 \mathrm{~g}$ was available for some samples, and in such instances all the available material was assayed. The assays were performed by R.R. Carlson in the Denver laboratories of the USGS.

\section{RESULTS}

Summaries of analyses for (1) platinum and palladium in gold samples by emission spectrography and (2) all PGE in concentrates by fire assay are presented for several districts in tables 1 and 2 . The districts discussed are Hot Springs, Rampart, Tolovana, Fortymile, Bonnifield, Fairbanks, and Nome. Although PGE were detected in several samples from the Koyukuk-Chandalar and Circle districts, the detected values of platinum and palladium were very low and are therefore omitted from discussion in this report. Most of the emission spectrographic analyses have appeared in other reports (Mosier and Lewis, 1986; Cathrall and others, 1987, 1988a, b, 1989a, b, c, 1990; McDanal and others, 1988). The locations of districts and quadrangles where samples containing PGE were collected are shown on figure 1.

The analytical data reported here are best used as indicators of potential sources of PGE. They cannot be used to determine the content of PGE in a placer or lode deposit, but they might indicate a potential byproduct of gold mining. Although the sluice concentrates generally were obtained directly from miners, they were grab samples rather than representative samples. The fire-assay determinations on the concentrates are reasonably accurate for the six PGE (Pt, Pd, Rh, Ru, Os, and Ir) in the assayed sample, but much more detailed sampling is required to know the PGE content in any deposit being mined. The emission spectrographic analyses were made on 5-mg samples of metal grains hand-picked from gold recovered by mining operations; they show only the presence of platinum or palladium or both in the deposit from which they came.

\section{Hot Springs District}

The Hot Springs district is about $160 \mathrm{~km}$ west of Fairbanks and about $50 \mathrm{~km}$ south of the Yukon River. Gold-bearing gravels were discovered in 1898 (Mertie, 
Table 1. Summary of localities in some gold-mining districts and quadrangles in Alaska where platinum-group elements (PGE) were identified by fire-assay ICP-mass spectrometric analyses of concentrates

[Analyst: R.R. Carlson; results are expressed in parts per million; nd, not detected]

\begin{tabular}{|c|c|c|c|c|c|c|c|c|}
\hline \multirow{2}{*}{ District } & \multirow{2}{*}{$\begin{array}{l}\text { Number } \\
\text { of sites }\end{array}$} & \multirow{2}{*}{$\begin{array}{l}\text { Number of } \\
\text { sites with } \\
\text { PGE }\end{array}$} & \multicolumn{6}{|c|}{ Maximum Concentration } \\
\hline & & & Pt & Pd & Rh & Ru & Os & Ir \\
\hline $\begin{array}{l}\text { Koyukuk- } \\
\text { Chandalar }\end{array}$ & 52 & 10 & 0.060 & 0.025 & 0.001 & 0.095 & $<0.003$ & 0.001 \\
\hline Hot Springs --.---.-. & 35 & 18 & 1.500 & .250 & .002 & .200 & 2.500 & 4.000 \\
\hline Rampart -.---.-- & 10 & 7 & 1.000 & .007 & .008 & .010 & nd & .300 \\
\hline Tolovana --.---.-- & 22 & 15 & 150.000 & .800 & .600 & 4.000 & 1.000 & 5.000 \\
\hline 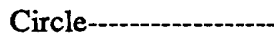 & 51 & 7 & .005 & .004 & .001 & .003 & $<.100$ & $<.035$ \\
\hline 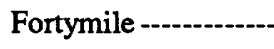 & 31 & 26 & .350 & .007 & .003 & .060 & .010 & .006 \\
\hline Bonnifield --------. & 29 & 19 & 30.000 & .450 & .400 & .150 & 1.500 & 2.000 \\
\hline Fairbanks -........... & 56 & 27 & .250 & .040 & .015 & .045 & $<.001$ & $<.003$ \\
\hline 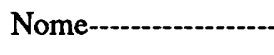 & 47 & 43 & .350 & .025 & .003 & .040 & .070 & .035 \\
\hline \multicolumn{9}{|l|}{ Quadrangles: } \\
\hline Teller-----------.. & 2 & 2 & .100 & .001 & .040 & .850 & 3.000 & 1.500 \\
\hline Others & 48 & 21 & .040 & .035 & .040 & .004 & .070 & .004 \\
\hline
\end{tabular}

Table 2. Summary of emission spectrographic analyses of gold from some gold-mining districts and quadrangles in which platinum or palladium was detected

[Analyst: E.L. Mosier; results are in percent; nd, not detected]

\begin{tabular}{|c|c|c|c|c|c|}
\hline \multirow{2}{*}{ District } & \multirow{2}{*}{$\begin{array}{c}\text { Number of } \\
\text { sites sampled }\end{array}$} & \multirow{2}{*}{$\begin{array}{l}\text { Number of } \\
\text { sites with } \\
\text { Pt or Pd }\end{array}$} & \multirow{2}{*}{$\begin{array}{l}\text { Number of } \\
\text { samples with } \\
\text { Pt or Pd }\end{array}$} & \multicolumn{2}{|c|}{ Maximum value } \\
\hline & & & & Pt & Pd \\
\hline $\begin{array}{l}\text { Koyukuk- } \\
\text { Chandalar }\end{array}$ & 52 & 3 & 5 & 0.0500 & 0.0015 \\
\hline Hot Springs - - & 35 & 5 & 9 & .0037 & .0021 \\
\hline Rampart------------- & 10 & 2 & 4 & 1.0000 & .0234 \\
\hline Tolovana & 22 & 5 & 7 & 73.5294 & 2.0588 \\
\hline 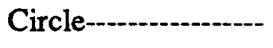 & 51 & 4 & 5 & nd & .0017 \\
\hline Fortymile --------- & 31 & 9 & 20 & .2137 & .0150 \\
\hline Bonnifield ----_-_-- & 29 & 11 & 37 & 82.9460 & 1.2500 \\
\hline Fairbanks & 56 & 0 & 0 & nd & nd \\
\hline $\begin{array}{l}\text { Nome (analyses --- } \\
\text { incomplete) }\end{array}$ & 36 & 4 & 6 & .0150 & .0007 \\
\hline Quadrangles: & & & & & \\
\hline Mt. Hayes --.-- & 5 & 1 & 1 & 62.4000 & 26.3138 \\
\hline Others - & 45 & 5 & 4 & nd & .0033 \\
\hline
\end{tabular}


1934, p. 165-166). The district has produced probably more than $500,000 \mathrm{oz}$ of gold more or less continuously since 1904. The district is in the Yukon-Tanana Upland, which consists of Devonian through late Paleozoic schists (Chapman and others, 1971). Three units of metamorphosed clastic sedimentary rocks and a metamorphosed carbonate chert unit are separated by an eastward-trending belt of serpentinite and associated mafic and ultramafic rocks. These units are intruded by granitic rocks at several localities (Chapman and others, 1971; Cathrall and others, 1987). The Hot Springs district lies north of the Beaver Creek fault and overlies part of the east-west Tintina fault system. The serpentinite belt includes mafic and ultramafic dike rocks; tectonic inclusions derived from igneous, sedimentary, and metamorphic rocks; and rodingite. Both the serpentinite and the mafic and ultramafic units are of pre-Upper Devonian age (Chapman and others, 1971).

Identification of PGE in gold samples from the Hot Springs district was reported previously (Cathrall and others, 1987). Fire-assay data for PGE in concentrates showed the presence of PGE in 18 of 35 concentrate sites, including 5 sites where platinum or palladium was also identified in gold samples. The fire-assay data show PGE at 13 localities where they were not found by spec- trographic analyses of gold grains and thus reiterate the potential importance of exploration for PGE.

\section{Rampart District}

The Rampart district, immediately north of the Hot Springs district, extends northward to the Yukon River. Gold was discovered in the district in 1882 , and the district production to 1990 is estimated to exceed 100,000 ounces on the basis of 86,800 ounces through 1959 (Koschmann and Bergendahl, 1968) and rather steady production through 1990. The geology of the district is similar to that of the Hot Springs district (Chapman and others, 1971). Fire-assay determinations of PGE in concentrates show the presence of PGE at 7 of 10 sites where concentrates were obtained. At two of these sites, platinum or palladium were also identified in native-gold samples (Cathrall and others, 1987).

\section{Tolovana District}

The Tolovana district is located near the town of Livengood, about $110 \mathrm{~km}$ northwest of Fairbanks. Gold-

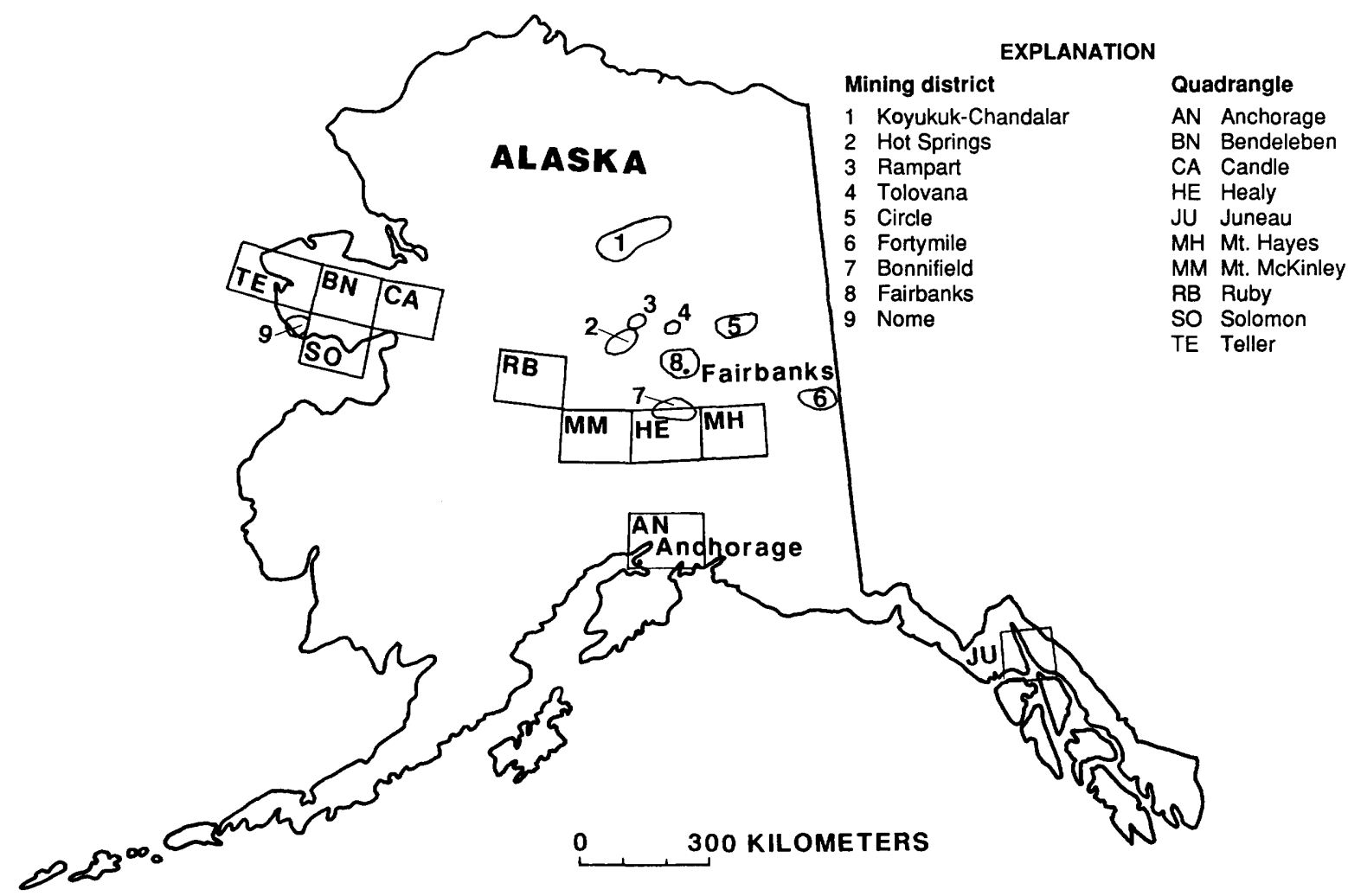

Figure 1. Map showing some gold-mining districts and quadrangles in which platinum-group elements are found. 
bearing placer deposits were discovered in 1914, and the district is still active. Total gold produced from the district probably exceeds $400,000 \mathrm{oz}$ on the basis of $375,000 \mathrm{oz}$ produced through 1959 (Koschmann and Bergendahl, 1968). Geologically, the district is similar to the Hot Springs and Rampart districts (Chapman and others, 1971). Like those districts, it is in the northwestern part of the Yukon-Tanana Upland, and it is bordered on the south by the Beaver Creek fault (Chapman and others, 1971; Cathrall and others, 1987). The Tolovana district is bordered on the north by two major east-west faults, which may be an extension of the east-west Tintina fault system (Chapman and others, 1971). The same serpentinite belt that was briefly described in the discussion of the Hot Springs district occurs in the Tolovana district, as do the mafic and ultramafic rocks that parallel the serpentinite belt. Fire-assay analyses show that 15 of the 22 mines sampled contained PGE (table 1); one of these showed a concentration of $150-p p m$ platinum. Platinum or palladium were also identified in five of these mines (table 2) by analyses of gold grains (Cathrall and others, 1987).

\section{Fortymile District}

The Fortymile district lies just west of the Canadian boundary (fig. 1). It has had almost continuous production since 1883 and is thus perhaps the oldest goldproducing region of the Yukon country (Koschmann and Bergendahl, 1968). Recorded gold production through 1959 was about 400,000 oz (Koschmann and Bergendahl, 1968), and large-scale dredging has continued since that time. Gold has been recovered by placer mining of gravels of Pleistocene and Holocene age. In some of these gravels, gold has been reconcentrated from much older Tertiary gravels (Mertie, 1938, p. 154).

The most abundant rocks of the district are schists (the Birch Creek Schist of former usage; Mertie, 1938) of the Yukon-Tanana Upland. These metasediments are similar to those in many areas that occur in gold-producing districts of the Yukon-Tanana Upland, including Circle, Fairbanks, and Tolovana. Local outcrops of (1) Tertiary conglomerate, shale, and sandstone, (2) early Paleozoic greenstone and limestone, and (3) igneous rocks that include granite, basalt, gabbro, and diabase are also present (Mertie, 1938).

PGE were detected by fire-assay analyses at 26 of the 31 sites where concentrates were obtained (table 1), and platinum or palladium were also found in 20 samples from 9 localities by emission spectrographic analyses of gold samples (table 2). The highest platinum value $(0.35 \mathrm{ppm})$ was obtained on a concentrate from Fortymile River. Mertie (1938) believed the ultimate source of the gold to be quartz veins related to the granite intru- sives. PGE are quite probably alloyed with gold particles (as indicated by emission spectrographic analyses of gold grains) and also occur as tiny mineral grains in the placer deposits (as indicated by the fire-assay analyses).

\section{Bonnifield District}

The Bonnifield district extends from the Tanana flats on the north to the northern slope of the Alaska Range on the south. It is bounded on the east by the Delta River and on the west by the Nenana River. The first gold mined came from the gravels of Gold King Creek in 1903 (Koschmann and Bergendahl, 1968), and some mines in the district were active at the time of our visit in 1986. Although the district is geographically large, its total production is probably less than 50,000 oz. Total production through 1959 was 36,600 oz (Koschmann and Bergendahl, 1968, p. 24), and several intermediate to large placer-mining enterprises, whose production is unknown, became active after increases in the price of gold in the 1970's.

Concentrates from 19 of 29 sites in the Bonnifield district (table 1) were found by fire-assay analysis to contain PGE, and one site had a concentration of $30 \mathrm{ppm}$ of platinum. Tiny gray-white grains isolated from concentrates were evidently native platinum, as indicated by emission spectrographic analysis in two instances that showed platinum was a major constituent. In addition, 37 samples from 11 sites were found to contain platinum or palladium (table 2 ).

Nearly all the mining enterprises are in alluvium derived from the Tertiary Nenana Gravel. The deposition of the Nenana Gravel is interpreted to mark a still ongoing late Cenozoic orogenic uplift in south-central Alaska (Csejtey and others, 1986). The present topographic relief of south-central Alaska, including the Alaska Range, results from this orogenic activity (Capps, 1940; Wahrhaftig, 1970, 1975). The Nenana Gravel largely rests uncomformably on rocks as old as the Precambrian and (or) early Paleozoic pelitic and quartzose schist, but locally it is conformable with underlying Tertiary coalbearing rocks (Csejtey and others, 1986, p. 2). The areal extent of the Nenana Gravel exceeds $1,536 \mathrm{~km}^{2}$, reaches a maximum thickness of over $1,220 \mathrm{~m}$ (Csejtey and others, 1986), and has a volume of $2,870 \mathrm{~km}^{3}$. Most of the Nenana is thought to be of Pliocene age, but its basal part may be as old as late Miocene (Csejtey and others, 1986).

The placer deposits are unusual in that they contain silver, platinum, and gold nuggets. The drainage basins of some streams (for example, Gagnon, Bonnifield, and St. George Creeks) whose alluvium has been mined for gold are entirely within the Tertiary Nenana Gravel. In addition, a gold sample was panned from an outcrop of 
the Nenana Gravel west of the source of St. George Creek; a small gold nugget from this source was found by emission spectrographic analysis to contain 11-ppm palladium. In the Bonnifield district, PGE are quite probably alloyed with gold and also occur as nuggets. Gold can be found by panning the Nenana Gravel at many localities, but most of the placer deposits that have been mined are in alluvium of present streams that have reconcentrated and redeposited the detrital minerals of older alluvium from the Nenana.

Coal constitutes the bedrock where gold has been concentrated in some placer mines (for example, on California Creek). Samples of coal fly ash obtained (by courtesy of the Usibelli Mining Company) from coal mined from this underlying formation (Suntrana Formation) was found to contain $0.12-0.87 \mathrm{ppm}$ gold in seven samples, and also it contains 1-2 ppb platinum and 2.5$3.1 \mathrm{ppb}$ palladium (J.B. Cathrall, unpubl. data, 1990). The authors are not aware, however, of any placer-mining enterprises that have recovered gold from the Suntrana Formation, except where alluvium derived from the Nenana has penetrated it.

Primary lode sources in older rocks that could account for gold and platinum in the Nenana Gravel have not been identified, but a few lode mines in the district (for example, the Liberty Bell, which produced bismuth and gold) have been located. Fire-assay analyses of two concentrates from the Liberty Bell mine showed low levels of all PGE (up to $0.02 \mathrm{ppm}$ ). Older rock units that might be investigated as a lode source for platinum include (1) Triassic diabase and gabbro intrusive rocks north of the McKinley fault of the Denali fault system (Wahrhaftig, 1968; Csejtey and others, 1982); (2) mafic units of the Middle Devonian to Early Mississippian Totatlanika Schist (Wahrhaftig, 1968); (3) ultramafic intrusive rocks of Early Cretaceous or Jurassic age just north of the McKinley fault (Csejtey and others, 1986); (4) Late Devonian serpentinite, basalt, chert, and gabbro (Jones and others, 1987); and (5) other mafic or ultramafic rock units.

\section{Fairbanks District}

The Fairbanks district, located west, north, and northeast of Fairbanks, has produced more gold than other districts in Alaska and ranks seventh in the United States (Koschmann and Bergendahl, 1968). The district produced nearly $7,500,000 \mathrm{oz}$ through 1959 . All of the gold was produced from placers (except about 300,000 oz from lodes), and the district has had substantial production since 1959. At least one lode mine was active in the late 1980 's.
The geology of the district has been intensively studied because of its economic importance. A possible source of gold is the 152-m-thick Cleary sequence (Smith and others, 1981), which is a subdivision of the Late Devonian Fairbanks schist unit (Aleinikoff and Nokleberg, 1989). Gold lodes of the district are generally spatially related to intrusive rocks at three areas: (1) vicinity of Ester dome, about $4.8 \mathrm{~km}$ west of Fairbanks; (2) Cleary Hill, 19-24 km northeast of Fairbanks; and (3) Gilmore dome, $9.5-12.8 \mathrm{~km}$ northeast of Fairbanks.

Fire-assay analysis of concentrates from the district resulted in the detection of PGE for 27 of the 56 sites (table 1). Twenty-one of the sample sites were lode deposits. All but 2 of these 21 sites yielded detectable PGE. The maximum platinum content found $(0.25 \mathrm{ppm}$; table 1) was in a sample from the Grant mine.

The mode of occurrence of PGE is unknown. However, emission spectrographic analyses of the concentrates from lodes show that most of those with detectable PGE have a high arsenic content. One possibility, therefore, is that PGE occur in sperrylite-an arsenide of platinum. Another possibility is that PGE occur in sulfides of iron, arsenic, antimony, lead, and copper, which are present in many gold lodes. The fire-assay data show PGE in concentrates of alluvium from Ready Bullion Creek, which drains Ester dome; from Cleary Creek, Fish Creek, and a small tributary of Fish Creek-all of which drain Cleary Hill; and from Hill Creek and Goldstream Creek, which drain Gilmore dome. The highest concentration of platinum found in a placer deposit $(0.035 \mathrm{ppm})$ was from Cleary Creek alluvium. Fire-assay analyses of 45 concentrates from other placer deposits in the district failed to detect PGE. Neither platinum nor palladium were detected in any of the emission spectrographic analyses.

\section{Nome District}

The Nome district is located on the western tip of the Seward Peninsula. By 1959, it had produced a minimum of 3,600,000 oz of gold (Koschmann and Bergendahl, 1968, p. 18), and it has been active every year since then. The district is renowned for the variety and richness of its placer gold deposits. Among the types of placer deposits are hillside placers from former streams, placers in alluvium of modern streams and alluvial fans, eluvial placers, and placers on modern, submerged, and elevated beaches. In 1987, a large dredge was brought to Nome to recover gold from the floor of the Bering Sea.

Nearly all the gold produced in the Nome district has been from placers. Several lode-gold mines and prospects in the district occur along limestone-schist 
contacts (Collier and others, 1908), but their production has been small. All the placer areas, including the eluvial placers and others on the floor of the Bering Sea, are underlain by low- to medium-grade metamorphic rocks divisible into several mappable lithostratigraphic units (Kaufman and Hopkins, 1989). Exposures of the mixed unit of Till and others (1986), dominated by quartzgraphite schist and marble, are common to all areas and are now thought to be the most likely source of gold in placers (Kaufman and Hopkins, 1989).

Fire-assay data show that concentrates from 43 of 47 localities contain PGE. The highest platinum concentration $(0.35 \mathrm{ppm}$; table 1$)$ was found in a sample panned from Dexter Gulch. This locality is near bedrock exposures of marble and graphite schist on the divide between Anvil Creek and Nome River. Incomplete data show that only 4 of 36 sites were also found to contain detectable platinum or palladium by emission spectrographic analysis of gold grains (table 2). These samples came from a tributary of Rock Creek north of Nome, the Cooper Gulch alluvial fan, the Monroeville beach, and the floor of the Bering Sea. Fire-assay analysis on concentrates also showed the presence of PGE in the samples from Rock Creek and the Cooper Gulch alluvial fan.

\section{INTERPRETATIONS AND CONCLUSIONS}

Average values for PGE by fire-assay analysis are given in table 3, together with average concentrations of other elements obtained by emission spectrography analysis. The highest concentrations of PGE were found in the Tolovana and Bonnifield districts, followed by the Hot Springs, Rampart, and Fortymile districts. The Fairbanks district is next, with the majority of the PGE identifications in concentrates from lode mines and prospects. Some of the gold samples from the Nome district have not yet been analyzed, but the available data from concentrates suggest the desirability of further assays for PGE there because of the high percentage of assays in which PGE were detected. Moreover, high assays for PGE were obtained on two concentrates from the Teller quadrangle (table 1). Elsewhere on the Seward Peninsula, PGE were found at all of the nine sampled sites in the Solomon quadrangle, at six of nine sites in the Bendeleben quadrangle, and at one of two sites in the Candle quadrangle (fig. 1). Only a few of the concentrates from the Circle and Koyukuk-Chandalar districts had detectable concentrations of PGE, and those levels were relatively low.

Interelement correlations for the data from the concentrates show the strongest positive correlations of platinum with the following elements (correlation coeffi- cients after the element symbol): $\mathrm{Pd}, 0.85 ; \mathrm{Rh}, 0.91 ; \mathrm{Ru}$, 0.93 ; Ir, 0.56; Ni, 0.49; Cr, 0.28; Fe, 0.28; and As, 0.19. Positive correlations were also obtained with $\mathrm{Mn}, \mathrm{Bi}$, $\mathrm{Co}, \mathrm{Sn}, \mathrm{V}, \mathrm{Os}$, and $\mathrm{Zr}$. The correlation coefficient of $\mathrm{Pt}$ with Os was quite low (0.29), which partly reflects the difficulty of obtaining satisfactory data on osmium in a number of samples, and partly the somewhat different geochemical behavior for the two elements.

On the basis of individual districts, some groupings are obtained by plotting average concentrations of platinum against several other non-PGE elements (figs. 2-9). Samples with high platinum content were excluded from averaging because of the strong bias such values create in the averages. In the plot of arsenic vs. platinum (fig. 3 ), the Fairbanks district stands alone with very high concentrations of arsenic. This association may suggest the possibility that platinum occurs as sperrylite (an arsenide of platinum) or in sulfides of iron, arsenic, antimony, lead, and copper (table 3). The Tolovana and Nome districts follow Fairbanks in arsenic concentrations. Similarities in arsenic concentrations vs. platinum concentrations are shown in the Rampart, Bonnifield, and Hot Springs districts. In the plot of platinum vs. nickel (fig. 5), Fairbanks once again stands alone, but close to the Circle district, which (like Fairbanks) has a low nickel content. The Rampart, Bonnifield, and Hot Springs districts have intermediate contents of both platinum and nickel, and the Koyukuk and Tolovana districts have a high nickel but low platinum content. Examination of the other plots (figs. 2, 4, 6-9) shows that the districts with highest concentrations of platinum show similarities in their concentrations of other elements.

The districts with highest platinum content are characterized by areas of known mafic and ultramafic rocks with the possible exception of the Bonnifield district, where known bodies of such rocks are generally appreciably distant from placer deposits that have been mined. Correlations with most elements for these districts are also similar.

The frequent detections of PGE in the Hot Springs, Rampart, Tolovana, Fortymile, and Bonnifield districts, taken together with associations of other elements and possible source rocks for PGE, suggest the desirability of further exploration in these districts. The occurrence of PGE in many lode samples from the Fairbanks district indicates that if future large-scale hard-rock mining in the district develops, detailed studies on the occurrence and possible recovery of PGE are warranted.

Acknowledgments.-We gratefully acknowledge the help and generosity of Alaskan miners who provided numerous samples for the subsequent analyses that form the basis of this report. They permitted us to observe their mining operations and allowed us to study the geology of the areas in which they were working. 
Table 3. Average analytical values of samples containing PGE

[Element followed by FA = Fire-Assay analysis; all other values by emission-spectrographic analyses; $\mathrm{Fe}, \mathrm{Mg}, \mathrm{Ca}, \mathrm{Ti}$, and $\mathrm{Na}$ in percent; all others in parts per million; nd = no data, or analyses showed no measurable values. Analysts: R.R. Carlson and E.L. Mosier]

\begin{tabular}{|c|c|c|c|c|c|c|c|c|c|}
\hline District & $\begin{array}{c}\text { Koyukuk- } \\
\text { Chandalar } \\
1\end{array}$ & $\begin{array}{c}\begin{array}{c}\text { Hot } \\
\text { Springs }\end{array} \\
2\end{array}$ & $\begin{array}{c}\text { Rampart } \\
3\end{array}$ & $\begin{array}{c}\text { Tolovana } \\
4\end{array}$ & $\begin{array}{c}\text { Circle } \\
5\end{array}$ & $\begin{array}{c}\text { Fortymile } \\
6\end{array}$ & $\begin{array}{c}\text { Bonnifield } \\
7\end{array}$ & $\begin{array}{c}\text { Fairbanks } \\
8\end{array}$ & $\begin{array}{c}\text { Nome } \\
9\end{array}$ \\
\hline Pt-FA-_-_-_- & 0.010 & 0.266 & 0.175 & 0.024 & 0.004 & 0.058 & 0.231 & 0.035 & 0.013 \\
\hline Pd-FA -......--- & .005 & .045 & .020 & .056 & .021 & .032 & .044 & .007 & .003 \\
\hline Rh-FA-------- & .001 & .002 & .068 & .001 & .001 & .046 & .011 & .002 & .002 \\
\hline Ru-FA-------- & .001 & .026 & .054 & .198 & .002 & .009 & .016 & .016 & .037 \\
\hline Os-FA-------- & .002 & .704 & nd & .265 & nd & .035 & .217 & nd & .346 \\
\hline Ir-FA & .001 & .271 & .466 & .226 & nd & .239 & .161 & nd & .067 \\
\hline $\mathrm{Fe}$ & 35.9 & 51.5 & 35.2 & 39.5 & 17.1 & 57.7 & 38.5 & 14.1 & 35.6 \\
\hline Mg---_-_-_-_-- & .63 & 1.32 & .70 & 1.98 & .68 & 1.29 & .55 & .20 & .93 \\
\hline $\mathrm{Ca}$ & .48 & .72 & .25 & .49 & 1.26 & .50 & .40 & .26 & .79 \\
\hline Ti -.............. & .57 & .81 & .46 & .46 & 1.78 & 1.02 & 1.79 & .45 & .74 \\
\hline Mn-..-- & 4495 & 1023 & 1798 & 677 & 4500 & 2869 & 2828 & 867 & 1149 \\
\hline Ag - & 29.7 & 1065.6 & 419.7 & 639.3 & 1.1 & 970.6 & 129.2 & 1809.2 & 49.1 \\
\hline As-- & 1909 & 440 & 2008 & 6962 & 363 & 1535 & 2024 & 13256 & 6718 \\
\hline $\mathrm{Au}$ & 34 & 688 & 158 & 378 & 12 & 207 & 142 & 423 & 132 \\
\hline В & 27 & 35 & 29 & 17 & 83 & 22 & 283 & 277 & 123 \\
\hline $\mathrm{Ba}-$ & 517 & 2198 & 4365 & 2338 & 154 & 3054 & 2023 & 226 & 150 \\
\hline Be------------- & 1.0 & 1.0 & 1.7 & 2.0 & 1.3 & 1.0 & 1.2 & 1.4 & 1.1 \\
\hline $\mathrm{Bi}$ & 56 & 23 & 46 & 19 & 10 & 33 & 51 & 66 & 12 \\
\hline Cd - & 32 & 20 & 20 & 20 & 20 & 20 & 79 & 35 & 20 \\
\hline Co & 170 & 98 & 34 & 71 & 33 & 110 & 91 & 22 & 54 \\
\hline Cr --.-- & 223 & 3027 & 1642 & 9240 & 934 & 2645 & 4356 & 42 & 161 \\
\hline $\mathrm{Cu}$ & 385 & 153 & 90 & 121 & 96 & 65 & 202 & 2030 & 151 \\
\hline La-_.............. & 56 & 733 & 131 & 222 & 443 & 58 & 547 & 108 & 63 \\
\hline Mo-........... & 5 & 5 & 9 & 6 & 5 & 9 & 11 & 9 & 6 \\
\hline $\mathrm{Nb}$ & 22 & 119 & 35 & 32 & 44 & 30 & 30 & 53 & 27 \\
\hline $\mathrm{Ni}$ & 204 & 176 & 108 & 250 & 64 & 169 & 165 & 47 & 108 \\
\hline $\mathrm{Pb}$ & 7596 & 2671 & 6175 & 2241 & 44 & 2439 & 3181 & 12758 & 373 \\
\hline Sb-....-.-.-.-. & 545 & 193 & 533 & 2308 & 100 & 135 & 1572 & 10548 & 137 \\
\hline Sc - - & 22 & 10 & 6 & 5 & 34 & 8 & 10 & 11 & 6 \\
\hline Sn-......-- & 241 & 621 & 1026 & 343 & 1135 & 194 & 595 & 252 & 113 \\
\hline Sr - & 100 & 100 & 158 & 131 & 100 & 108 & 196 & 103 & 104 \\
\hline V & 248 & 147 & 150 & 296 & 93 & 330 & 168 & 43 & 119 \\
\hline W - & 99 & 32 & 688 & 3045 & 100 & 1077 & 124 & 782 & 1866 \\
\hline Y & 65 & 212 & 38 & 37 & 334 & 35 & 165 & 264 & 43 \\
\hline Zn--.--.--..- & 373 & 267 & 225 & 827 & 213 & 392 & 1064 & 1934 & 338 \\
\hline$Z_{r}^{1}-\ldots$ & 80 & 1544 & 211 & 199 & 1209 & 144 & 1413 & 439 & 83 \\
\hline Th------------.- & 95 & 140 & 100 & 100 & 175 & 100 & 124 & 100 & 100 \\
\hline 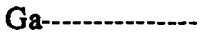 & 13 & 10 & 6 & 24 & 13 & 48 & 37 & 11 & 24 \\
\hline $\mathrm{Na}$ & .2 & .2 & .4 & .5 & .2 & .4 & .3 & .2 & .4 \\
\hline
\end{tabular}




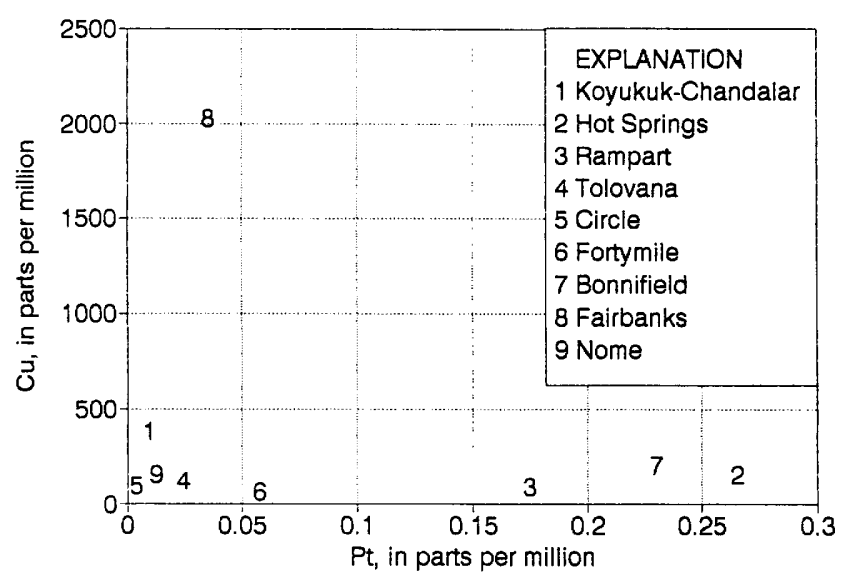

Figure 2. Correlation of district averages of $\mathrm{Pt}$ (platinum) and $\mathrm{Cu}$ (copper).

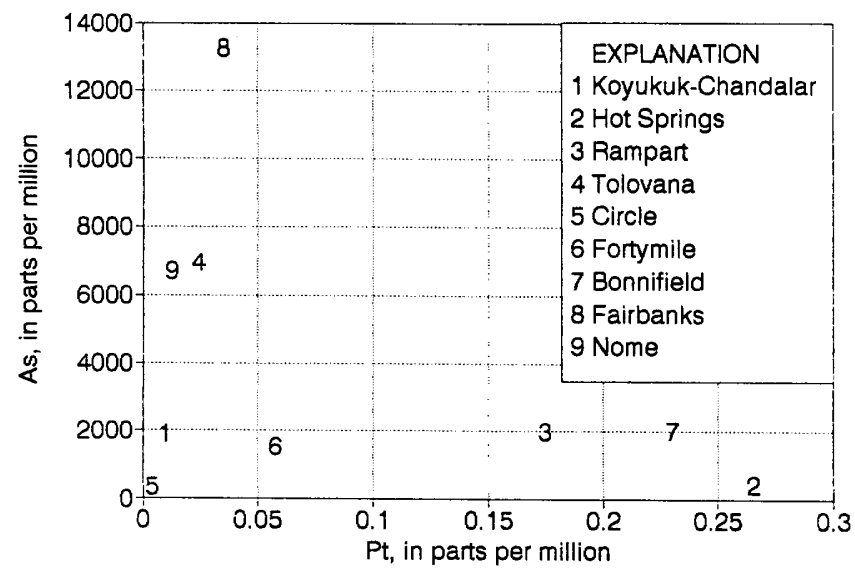

Figure 3. Correlation of district averages of $\mathrm{Pt}$ (platinum) and As (arsenic).

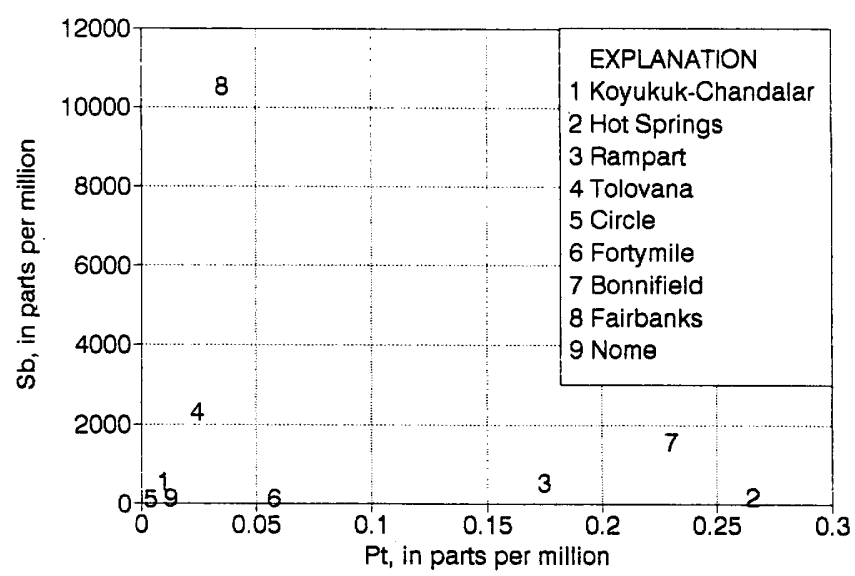

Figure 4. Correlation of district averages of $\mathrm{Pt}$ (platinum) and $\mathrm{Sb}$ (antimony).

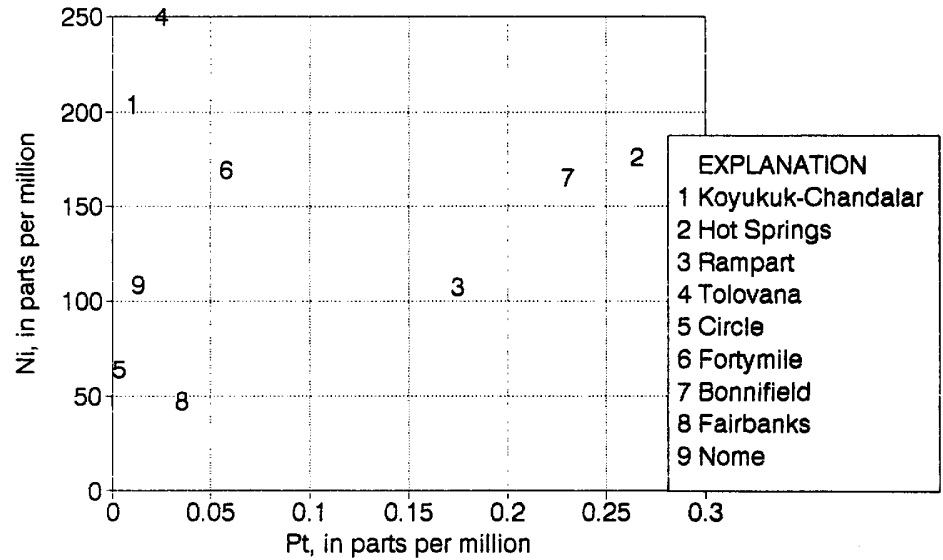

Figure 5. Correlation of district averages of $\mathrm{Pt}$ (platinum) and $\mathrm{Ni}$ (nickel).

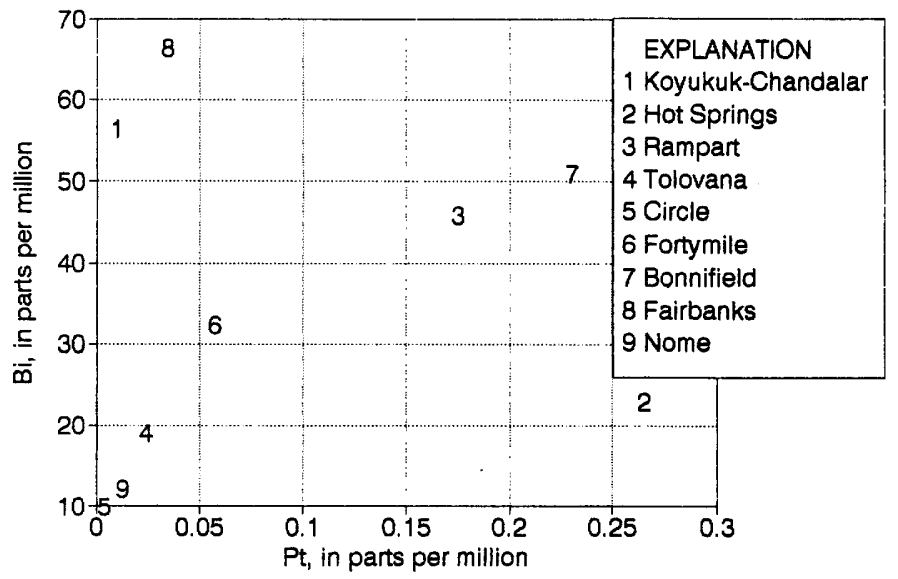

Figure 6. Correlation of district averages of $\mathrm{Pt}$ (platinum) and $\mathrm{Bi}$ (bismuth).

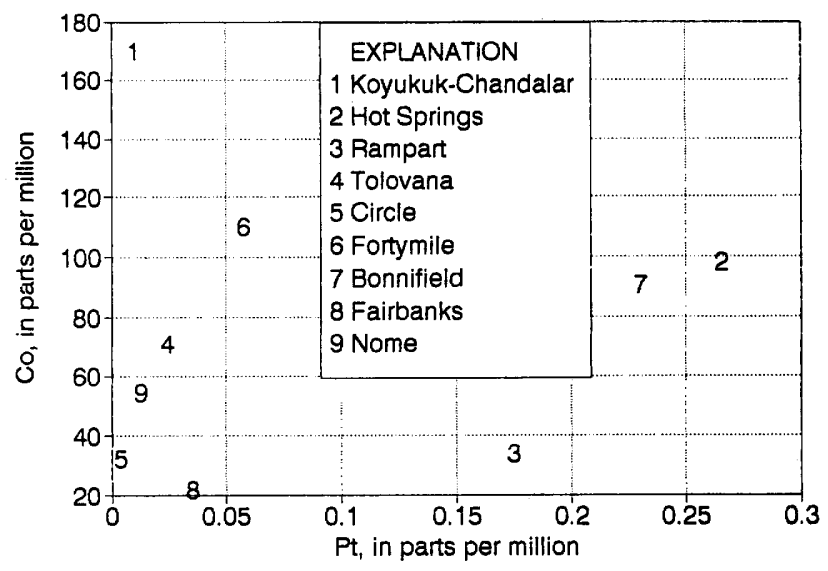

Figure 7. Correlation of district averages of $\mathrm{Pt}$ (platinum) and $\mathrm{Co}$ (cobalt). 


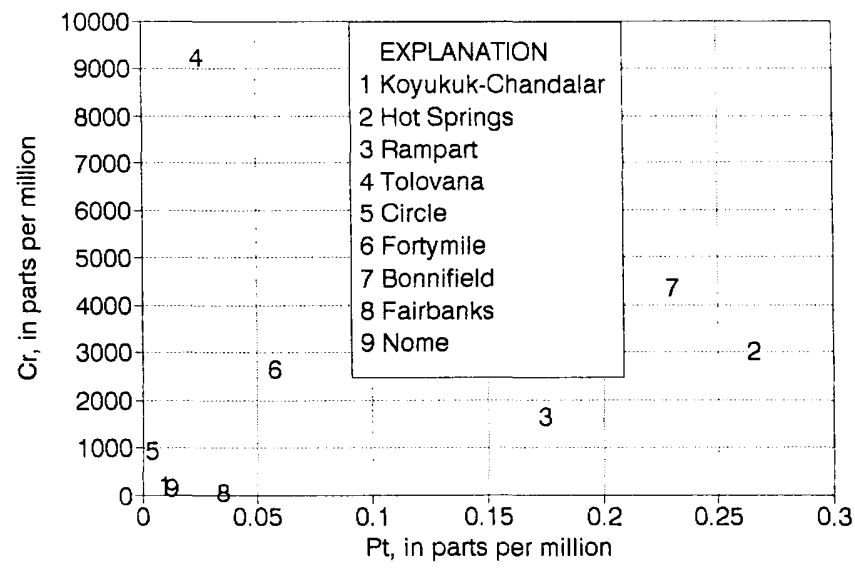

Figure 8. Correlation of district averages of $\mathrm{Pt}$ (platinum) and $\mathrm{Cr}$ (chromium).

\section{REFERENCES CITED}

Aleinikoff, J.N., and Nokleberg, W.J., 1989, Age of deposition and provenance of the Cleary sequence of the Fairbanks schist unit, Yukon-Tanana terrane, east-central Alaska, in Geologic studies in Alaska by the U.S. Geological Survey, 1988: U.S. Geological Survey Bulletin 1903, p. 75-83.

Capps, S.R., 1940, Geology of the Alaska Railroad region: U.S. Geological Survey Bulletin 909, 201 p.

Cathrall, J.B., Albanese, M., VanTrump. George, and Mosier, E.L., 1989a, Geochemical signatures, analytical results, mineralogical data, and sample locality map of placer and lode gold, and heavy-mineral concentrates from the Fortymile mining district, Eagle quadrangle, Alaska: U.S. Geological Survey Open-File Report 89-451, 32 p.

Cathrall, J.B., Antweiler, J.C., and Mosier, E.L., 1987, Occurrence of platinum in gold samples from the Tolovana and Rampart mining districts, Livengood quadrangle, Alaska: U.S. Geological Survey Open-File Report 87-330, 12 p., 1 $\mathrm{pl}$.

Cathrall, J.B., Antweiler, J.C., VanTrump, George, and Mosier, E.L., 1989b, Gold, platinum, and silver analytical results and gold signatures from the Bonnifield mining district, Fairbanks and Healy quadrangles, Alaska: U.S. Geological Survey Open-File Report 89-461, 23 p.

$-1989 \mathrm{c}$, Gold analytical results and gold signatures from the Fairbanks mining district, Fairbanks and Livengood quadrangles, Alaska: U.S. Geological Survey Open-File Report 89-490, 32 p.

1990, Gold analytical results and gold signatures from the Anchorage, Charley River, Healy, Iditarod, Juneau, Mt. Hayes, Mt. McKinley, Ophir, Ruby, and Talkeetna quadrangles, Alaska: U.S. Geological Survey Open-File Report 90-210, 25 p.

Cathrall, J.B., McDanal, S.K., VanTrump, George, Mosier, E.L., and Tripp, R.B., 1988b, Analytical results, geochemical signatures, mineralogical data, and sample locality map of lode gold, placer gold, and heavy-mineral concentrates from the Tolovana mining district, Livengood quadrangle, Alaska: U.S. Geological Survey Open-File Report 88-578, 32 p.

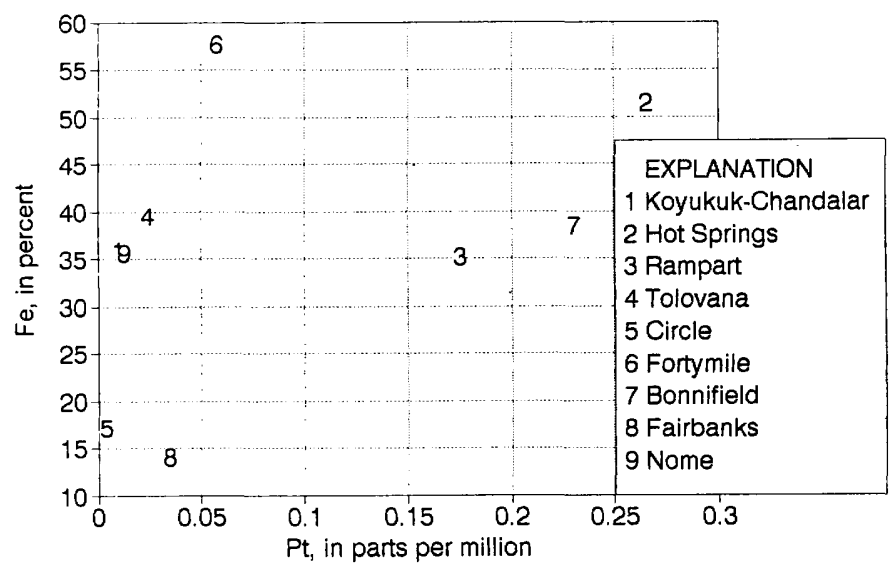

Figure 9. Correlation of district averages of $\mathrm{Pt}$ (platinum) and $\mathrm{Fe}$ (iron).

Cathrall, J.B., Tripp, R.B., McDanal, S.K., Mosier, E.L., and VanTrump, George, 1988a, Analytical results, geochemical signatures, mineralogical data, and sample locality map of placer gold and heavy-mineral concentrates from the Circle mining district, Circle quadrangle, Alaska: U.S. Geological Survey Open-File Report 88-676, 48 p., scale 1:250,000, $1 \mathrm{pl}$.

Chapman, R.M., Weber, F.R., and Taber, Bond, 1971, Preliminary geologic map of the Livengood quadrangle, Alaska: U.S. Geological Survey Open-File Report 71-66, scale $1: 250,000,2$ pls.

Collier, A.J., Hess, F.L., Smith, P.S., and Brooks, A.H., 1908, The gold placers of parts of Seward Peninsula, Alaska: U.S. Geological Bulletin 328, 343 p.

Csejtey, Béla, Jr., Cox, D.P., Evarts, R.C., Stricker, G.D., and Foster, H.L., 1982, The Cenozoic Denali fault system and the Cretaceous accretionary development of southern Alaska: Journal of Geophysical Research, v. 87, no. B5, p. 3541-3754.

Csejtey, Béla, Jr., Mullen, M.W., Cox, D.P., Gilbert, W.G., Yeend, W.E., Smith, T.E., Wahrhaftig, C., Craddock, C., Brewer, W.M., Sherwood, K.W., Hickman, R.G., Stricker, G.D., St. Aubin, D.R., and Goerz, D.J., III, 1986, Geology and geochronology of the Healy quadrangle, Alaska: U.S. Geological Survey Open-File Report 86-396, 92 p., 4 pls.

Jones, D.L., Silberling, N.J., Coney, P.J., and Pflaker, George, 1987, Lithotectonic terrane map of Alaska (west of 141st meridian): U.S. Geological Survey Miscellaneous Field Studies Map MF-1874-A, scale 1:2,500,000.

Kaufman, D.S., and Hopkins, D.M., 1989, Late Cenozoic geologic controls on placer-gold distribution in the Nome nearshore area, in Dover, D.H., and Galloway, J.P., eds., Geologic studies in Alaska by the U.S. Geological Survey, 1988: U.S. Geological Survey Bulletin 1903, p. 26-45.

Koschmann, A.H., and Bergendahl, M.H., 1968, Principal gold-producing districts of the United States: U.S. Geological Survey Professional Paper 610, 283 p.

McDanal, S.K., Cathrall, J.B., Mosier, E.L., Antweiler, J.C., and Tripp, R.B., 1988, Analytical results, geochemical signatures, mineralogical data, and sample locality map of placer gold and heavy-mineral occurrences from the 
Manley Hot Springs, Tofty, Eureka, and Rampart mining districts, Tanana and Livengood quadrangles, Alaska: U.S. Geological Survey Open-File Report 88-443, 54 p.

Mertie, J.B., Jr., 1934, Mineral deposits of the Rampart and Hot Springs district, Alaska: U.S. Geological Survey Bulletin 844-D, p. 163-226.

1938, Gold placers of the Fortymile, Eagle, and Circle districts, Alaska: U.S. Geological Survey Bulletin 897-C, p. 133-261.

1969, Ecomomic geology of the platinum metals: U.S. Geological Survey Professional Paper 630, 120 p., 1 pl.

Mosier, E.L., 1975, Use of emission spectroscopy for the semiquantitative analysis of trace elements and silver in native gold, in Ward, F.N., ed., New and refined methods of trace analysis useful in geochemical exploration: U.S. Geological Survey Bulletin 1408, p. 97-105.

Mosier, E.L., Cathrall, J.B., Antweiler, J.C., and Tripp, R.B., 1989, Geochemistry of placer gold, Koyukuk-Chandalar mining district, Alaska: Journal of Geochemical Exploration, v. 31, no. 3, p. 97-115.

Mosier, E.L., and Lewis, J.S., 1986, Analytical results, geochemical signatures, and sample locality map of lode gold, placer gold, and heavy-mineral concentrates from the Koyukuk-Chandalar mining district, Alaska: U.S. Geologi- cal Survey Open-File Report 86-345, 172 p., 1 pl.

Smith, T.E., Robinson, M.S., Buntzen, T.K., and Metz, P.A., 1981, Fairbanks mining district in 1981: New look at an old mineral province [abs.]: Alaska Miners Association Convention Program with Abstracts, p. 12.

Till, A.D. Dumoulin, J.A., Gamble. B.M., Kaufman, D.S., and Carrol, P.I., 1986, Preliminary geologic map and fossil data from Solomon, Bendeleben, and southern Kotzebue quadrangles, Alaska: U.S. Geological Survey Open-File Report 86-276, 59 p., scale 1:250,000, 3 pls.

U.S. Department of the Interior, Bureau of Mines, 1988, Metals and Minerals, v. 1 of Minerals Yearbook: Washington, D.C., Government Printing Office, 1076 p.

Wahrhaftig, Clyde, 1968, Schists of the central Alaska Range: U.S. Geological Survey Bulletin 1254-E, p. E1-E22. 1970, Late Cenozoic orogeny in the Alaska Range [abs.]: Geological Society of America Abstracts with Programs, v. 2, no. 7, p. 713-714.

1975, Late Cenozoic orogeny in the Alaska Range [abs.], in Forbes, R.B., ed., Contributions to the geology of the Bering Sea Basin and adjacent regions: Geological Society of America Special Paper 151, p. 189-190.

Reviewers: Robert R. Carlson and George A. Desborough 


\title{
Age of the Late Cenozoic Bigbendian Marine Transgression of the Alaskan Arctic Coastal Plain: Significance for Permafrost History and Paleoclimate
}

\author{
By L. David Carter and John W. Hillhouse
}

\begin{abstract}
A magnetic-polarity reversal has been identified within sediment of the informally named Bigbendian marine transgression of the Alaskan Arctic Coastal Plain. This transgression was the second oldest of the presently recognized eustatic high-sea-level events in northern Alaska that have occurred since the opening of the Bering Strait shortly before $3.0 \mathrm{Ma}$. Stratigraphic evidence and the groundtemperature history indicated by measurements of aminoacid diagenesis in fossil mollusks suggest that this polarity reversal is the Gauss-Matuyama boundary. The Bigbendian transgression exidently occurred $2.48 \mathrm{Ma}$, shortly before the first major late Cenozoic glaciation of the Northern Hemisphere at about $2.4 \mathrm{Ma}$. Climate during the Bigbendian transgression was significantly warmer than at present. Sea ice was absent from the Beaufort and Chukchi seas, and the adjacent North Slope supported an open sprucebirch woodland or parkland. The succeeding Fishcreekian transgression occurred sometime between 2.48 and 2.14 $\mathrm{Ma}$, either immediately before or shortly after the first major glaciation. Climate during the later part of the Fishcreekian transgression was warmer than now but cooler than during Bigbendian time. Sea ice was absent, and vegetation was wetland herbaceous tundra. The extent of amino-acid diagenesis in fossil mollusks allows the effective diagenetic temperature (EDT), or generalized ground-temperature history, to be calculated for the period between these two transgressions. This EDT is in the range of from $-10.0_{-5.4}^{+2.6}{ }^{\circ} \mathrm{C}$ to $-2.2_{-5.7}^{+28}{ }^{\circ} \mathrm{C}$, which shows that climate cooled and permafrost formed during this interval, regardless of the precise age of the Fishcreekian transgression. If the EDT was in the colder part of this range, then perennial 'sea ice was probably present during at least part of this period. The EDT for the period since the Fishcreekian transgression was between -15.8 and $-17.6^{\circ} \mathrm{C}$, which suggests that permafrost has been continuously present on the North Slope throughout this period, and that perennial sea ice was present except perhaps for brief intervals at the peaks of the warmest interglacial episodes.
\end{abstract}

\section{INTRODUCTION}

The informally named Bigbendian marine transgression was the second oldest of the presently recognized eustatic high-sea-level events in northern Alaska that have occurred since the opening of the Bering Strait shortly before 3.0 Ma (Carter and others, 1986a; Dinter and others, 1990; Brigham-Grette and Carter, 1991). Deposits of the three oldest transgressions record interglacial climates that were warmer than the present climate, and dating these marine incursions is important if we are to understand the late Cenozoic cooling of global climate and the evolution of the biota of the Arctic. However, determining the precise ages of these high-sea-level events has been difficult. Age estimates for the Bigbendian transgression have included middle Pleistocene based on fossil mollusks (Carter and others, 1977), between 2.2 and $2.0 \mathrm{Ma}$ based on fossil sea otter remains (Repenning, 1983), >2.4 Ma (Carter and Galloway, 1985) and 2.7 Ma (Repenning and others, 1987) based on paleoclimatic arguments, and between 4.7 and 1.9 Ma based on strontium isotopes (Kaufman and others, 1990). We present paleomagnetic data that, together with stratigraphic constraints and the ground-temperature history indicated by measurements of amino-acid diagenesis in fossil mollusks, suggest a probable age of $2.48 \mathrm{Ma}$. We then discuss the paleoclimate during the Bigbendian and succeeding Fishcreekian transgressions, and estimate generalized ground temperatures for the periods between and since these two high-sea-level events.

Deposits of these transgressions are assigned to the Gubik Formation (Dinter and others, 1990) and are correlated and differentiated across northern Alaska using the technique of amino-acid geochronology, which compares the extent of racemization of L-isoleucine (Ile) to D-alloisoleucine (aIle) in fossil mollusks (Brigham, 
Table 1. Amino-acid ratios for Hiatella arctica, Portlandia arctica, and Mya truncata

\begin{tabular}{|c|c|c|c|}
\hline Taxon & Locality' & alle/lle ${ }^{2}$ & $\begin{array}{c}\text { Number of } \\
\text { analyses }\end{array}$ \\
\hline \multirow[t]{2}{*}{ Hiatella arctic --- } & Bigbendian beds at site 1 & $126 \pm 0.016$ & 23 \\
\hline & Bigbendian beds at site 3 & $120 \pm 0.012$ & 3 \\
\hline Mya truncata----_-_-_-_--- & Bigbendian beds at site 1 & $121 \pm 0.021$ & 4 \\
\hline \multirow[t]{3}{*}{ Portlandia arctica } & Bigbendian beds at site 1 & $136 \pm 0.015$ & 5 \\
\hline & Bigbendian beds at site 2 & $155 \pm 0.007$ & 5 \\
\hline & Bigbendian beds at site 3 & $165 \pm 0.009$ & 4 \\
\hline Hiatella arctica--.-..-- & Fishcreekian beds at site 2 & $085 \pm 0.010$ & 10 \\
\hline Hiatella arctica & Colvillian beds at site 3 & $227 \pm 0.026$ & 19 \\
\hline
\end{tabular}

${ }^{1}$ Sample localities shown on fig. 1.

${ }^{2}$ Total acid hydrolysate.

1985). L-isoleucine is the only form present at the death of the mollusk, and provides the starting point for the amino-acid racemization "clock." After the death of the mollusk, Ile racemizes to alle at a rate that is dependent upon time and temperature. For the Arctic Coastal Plain, which has relatively uniform modern climate and ground temperatures, mollusks from deposits of the same age that have been affected by the same sequence of climatic changes and ground temperatures will yield similar alle/ Ile ratios [see Miller and Brigham-Grette (1989) for a review of the geologic application of this method]. The Bigbendian transgression is based on deposits containing Hiatella arctica with alle/Ile ratios of $0.126 \pm 0.016$ (table 1) that are exposed in bluffs along the big bend of the Colville River from near Ocean Point and the Big Bend benchmark upstream for about $10 \mathrm{~km}$ (fig. 1). These deposits in places rest unconformably on Cretaceous and possibly slightly younger strata, but elsewhere they are separated from these strata by a few meters of sediment formed during the Colvillian transgression, which is the oldest late Cenozoic marine transgression recognized for the Alaskan Arctic Coastal Plain.

\section{PALEOMAGNETIC DATA}

Sediment of the Gubik Formation is weakly magnetized, and analyses commonly have not allowed unequivocal determination of depositional remanent magnetism. Three sites (figs. 1,2), however, have yielded paleomagnetic data that indicate magnetic polarity during the Bigbendian transgression. Data from site 1 and some data from site 2 were previously reported (Carter and others, 1986b), but correlation between these two sites could not be made at that time. Furthermore, the significance of a normal magnetic polarity determination for the basal sample at site 2 in terms of polarity at the time of deposition was uncertain. We report additional analyses from site 2 that clarify this uncertainty and analyses from another site (site 3 ) that document a magnetic polarity reversal during the Bigbendian transgression (table 2).

Bigbendian beds at site 1 consist of $1 \mathrm{~m}$ of transgressive gravelly sand overlain by $4 \mathrm{~m}$ of silt to pebbly

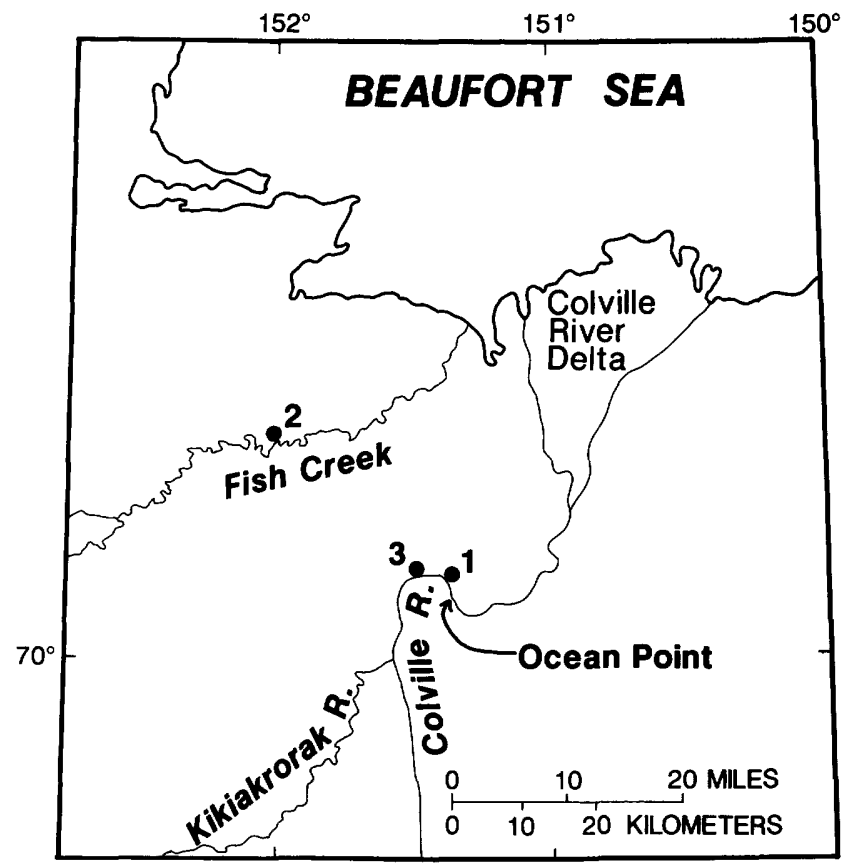

Figure 1. Location of sites described in text. Entire land area shown is within Arctic Coastal Plain physiographic province (Wahrhaftig, 1965). 
silt (Nelson and Carter, 1985). The silt exhibits normal magnetic polarity throughout its thickness (Carter and others, 1986b). Reversed polarity during part of the Bigbendian transgression is documented by measurements on marine silt that forms the basal unit at site 2 , and that is overlain by reversely magnetized sediment formed during the succeeding Fishcreekian transgression (Carter and others, 1986b). This basal unit was initially inter- preted as Fishcreekian in age (Carter and Galloway, 1985) and later as Colvillian (Brouwers, 1987), but recent measurements of amino-acid diagenesis in shells of the mollusk Portlandia arctica collected from this unit show that it formed during the Bigbendian transgression (table 1). Repenning and others (1987) concluded that a magnetic-polarity boundary is present near the base of this unit on the basis of a single determination of normal

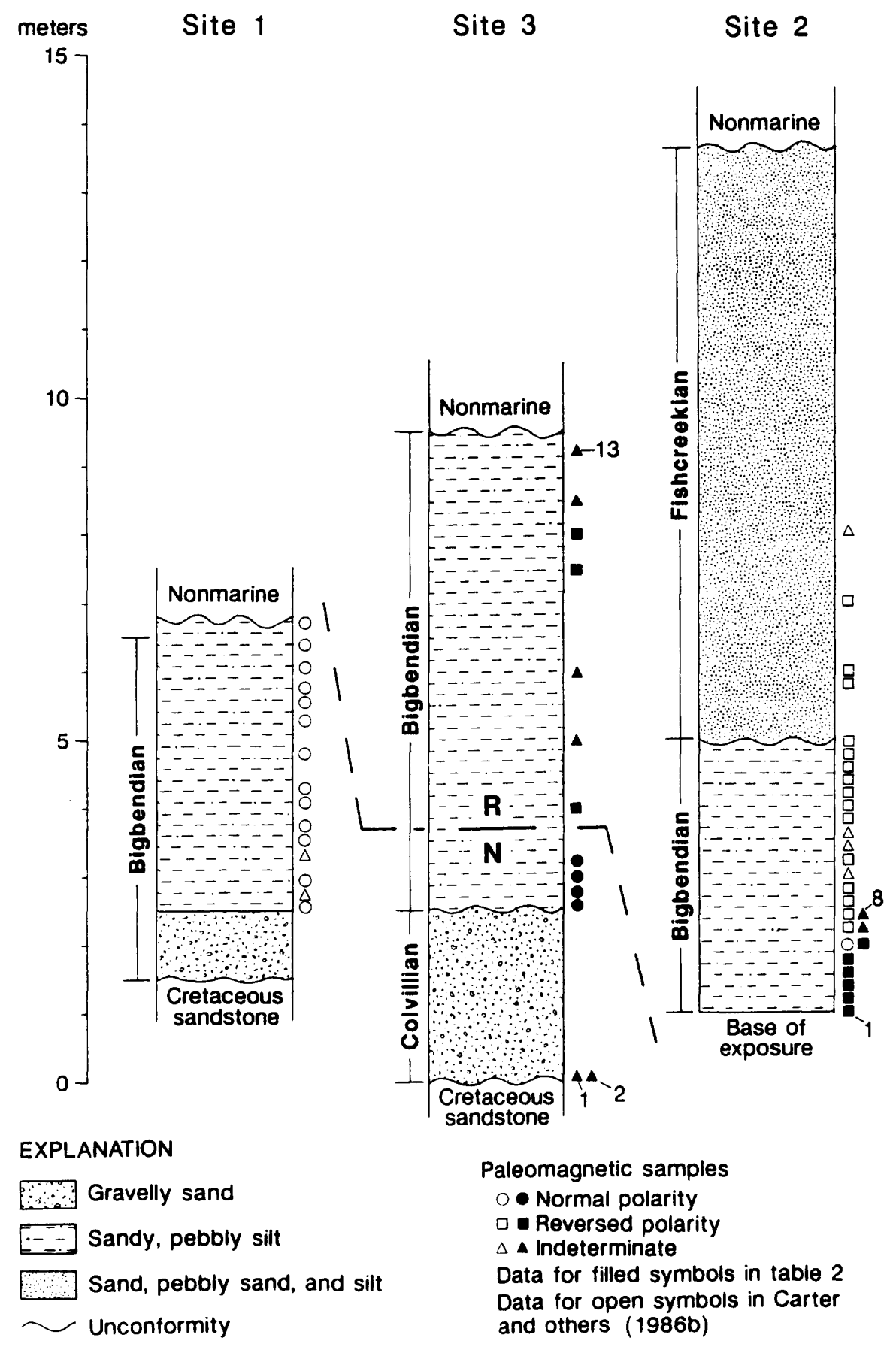

Figure 2. Stratigraphic sections for sites described in text, showing positions of paleomagnetic samples. $N$, normal; $R$, reversed polarity. 


\section{Table 2. Paleomagnetic analyses}

[Sample localites shown in fig. 1. Stratigraphic position of samples shown in fig. 2. Samples were progressively demagnetized in 50 oersted (Oe) increments to 500 oe, using a Schoenstedt alternatingfield demagnetizer. $N$, normal; $R$, reversed; I, indeterminate; $(R)$, reversed natural-remanent magnetism, but demagnetized at $700 \mathrm{Oe}$ and not at lower magnetic fields]

\begin{tabular}{|c|c|c|c|c|}
\hline Site & Sample & Polarity & $\begin{array}{l}\text { Inclination } \\
\text { (in degrees) }\end{array}$ & $\begin{array}{l}\text { Declination } \\
\text { (in degrees) }\end{array}$ \\
\hline \multirow[t]{8}{*}{ 2--.--.--..- } & 1 & $\mathbf{R}$ & -62.5 & 116.4 \\
\hline & 2 & $\mathbf{R}$ & -71.3 & 135.5 \\
\hline & 3 & $\mathbf{R}$ & -80.6 & 187.1 \\
\hline & 4 & $(\mathrm{R})$ & 0 & 0 \\
\hline & 5 & $\mathbf{R}$ & -76.7 & 174.6 \\
\hline & 6 & $\mathbf{R}$ & -81.6 & 189.8 \\
\hline & 7 & I & 17.0 & 121.9 \\
\hline & 8 & I & 26.9 & 180.4 \\
\hline \multirow[t]{13}{*}{ 3-......... } & 1 & I & 32.4 & 50.5 \\
\hline & 2 & I & 59.6 & 5.0 \\
\hline & 3 & $\mathbf{N}$ & 9.0 & 210.1 \\
\hline & 4 & $\mathbf{N}$ & 44.9 & 177.9 \\
\hline & 5 & $\mathbf{N}$ & 49.9 & 228.2 \\
\hline & 6 & $\mathrm{~N}$ & 58.0 & 177.3 \\
\hline & 7 & $\mathbf{R}$ & -66.0 & 62.2 \\
\hline & 8 & I & 27.7 & 333.6 \\
\hline & 9 & I & 46.5 & 135.3 \\
\hline & 10 & $\mathbf{R}$ & -86.2 & 177.4 \\
\hline & 11 & $\mathbf{R}$ & -31.9 & 213.6 \\
\hline & 12 & I & -18.6 & 116.6 \\
\hline & 13 & I & -34.4 & 13.5 \\
\hline
\end{tabular}

polarity for the lowest sample that had been measured at that time. More recent measurements (table 2) show that the determination of normal polarity was spurious, and that a magnetic-polarity boundary is not present in this exposure.

A normal to reversed magnetic-polarity boundary is present at site 3 , however, where $7 \mathrm{~m}$ of sandy, pebbly silt overlies $2.5 \mathrm{~m}$ of gravelly sand (fig. 2). Amino-acid ratios (table 1) for Hiatella arctica collected from the silt at site 3 show that it is correlative with the Bigbendian beds at site 1, whereas the much higher ratios for $H$. arctica from the gravelly sand show that it was deposited during the preceding Colvillian transgression. Samples from the lower $1.0 \mathrm{~m}$ of Bigbendian sediment are normally magnetized, whereas some samples more than
$1.5 \mathrm{~m}$ above the base exhibit reversed magnetic polarity, and the polarities of other samples in this interval are indeterminate (table 2).

\section{AGE}

Strontium isotope analyses of mollusk shells from site 1 suggest a minimum age of $1.9 \mathrm{Ma}$ for the Bigbendian transgression (Kaufman and others, 1990). This is in close agreement with the minimum age of $1.7 \mathrm{Ma}$ suggested by Repenning (1983) on the basis of the stage of evolution exhibited by the partial mandibular ramus of a sea otter from this site. These ages bracket the 1.87Ma change from reversed to normal polarity that marks the lower boundary of the Olduvai Normal-Polarity Subchron, according to the geomagnetic polarity time scale of Mankinen and Dalrymple (1979). The polarity change recorded by Bigbendian sediment is normal to reversed, so the Bigbendian transgression occurred before the Olduvai event and after the opening of the Bering Strait. During this period, changes from normal to reversed polarity (fig. 3) occurred at the ends of both parts of the Reunion Normal-Polarity Subchron (2.01 and 2.12 Ma), at the Gauss Normal-Matuyama Reversed-Polarity Chron boundary $(2.48 \mathrm{Ma})$, at the beginning of the

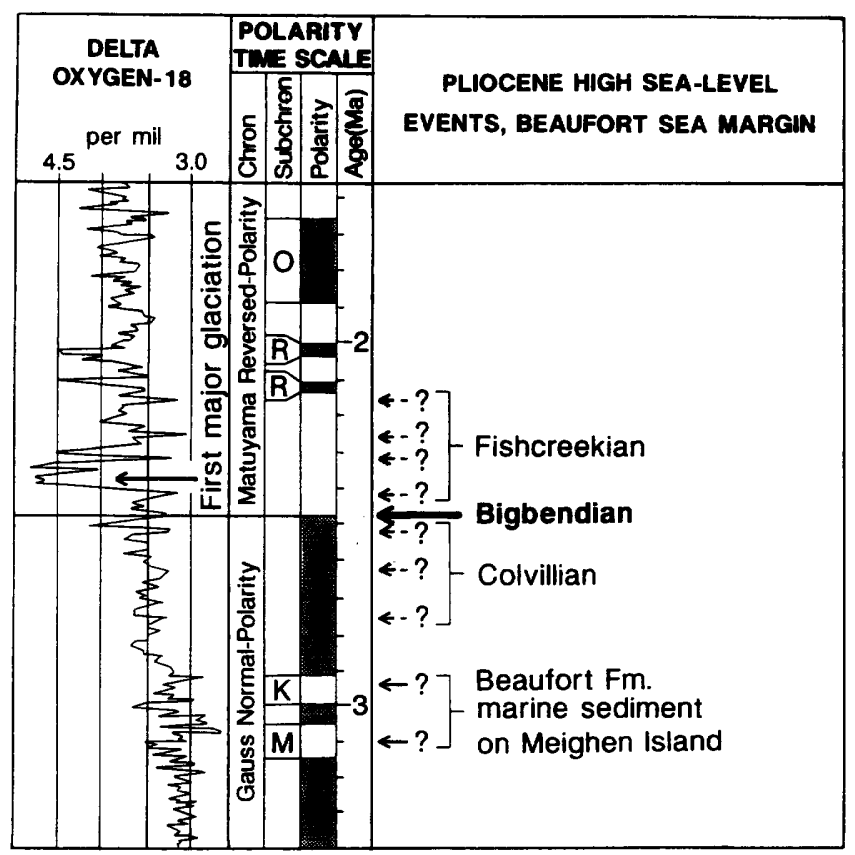

Figure 3. Oxygen-isotope record from North Atlantic site 552A (Shackleton and others, 1984), the geomagnetic polarity time scale of Mankinen and Dalrymple (1979), and suggested correlations with high-sea-level events around the Beaufort Sea margin. Subchron symbols: O, Olduvai; R, Reunion; K, Kaena; M, Mammoth. Shading indicates normal magnetic polarity. ? indicates uncertainty in age of sediment or high-sea-level event. 
Kaena Reversed-Polarity Subchron (3.01 Ma), and at the beginning of the Mammoth Reversed-Polarity Subchron (3.15 Ma). Stratigraphic constraints discussed below indicate that the Bigbendian transgression occurred either at the Gauss-Matuyama boundary or at the beginning of the Kaena event. Consideration of the temperature history of Bigbendian sediment in the light of our present knowledge of the history of permafrost (ground that remains at or below $0{ }^{\circ} \mathrm{C}$ for at least two years) suggests that the Bigbendian transgression probably occurred 2.48 Ma, during the Gauss-Matuyama polarity reversal.

\section{Stratigraphic Constraints}

A minimum age for the Bigbendian transgression is provided by the age of the next younger Fishcreekian transgression. An age of $2.41 \mathrm{Ma}$, in the early part of the Matuyama Reversed-Polarity Chron and immediately prior to the first major glaciation of the Northen Hemisphere, was proposed based on paleomagnetic measurements, paleontological constraints, and paleoclimatic arguments (Carter and others, 1986b; Repenning and others, 1987), but ages younger than the Olduvai event also have been proposed (Brigham, 1985; Kaufman and others, 1990; Matthews and Ovendon, 1990). We doubt these young age assignments and instead favor an early Matuyama, pre-Reunion age of greater than $2.14 \mathrm{Ma}$ for the Fishcreekian transgression because of microtine rodent fossils collected from the Fishcreekian beds at site 2 , and because of the stage of evolution exhibited by the tooth of a primitive sea otter collected from the same locality. Repenning and others (1987) state that the tooth does not resemble that of the living sea otter, Enhydra lutris, and is more like the ancestor Enhydriodon than is the single known tooth of Enhydriodon? reevi from the Norwich Crag in East Anglia, which was deposited during Olduvai time (Zalasiewicz and Gibbard, 1988). Teeth of the microtine Plioctomys mimomiformis occur in the Fishcreekian beds at site 2, and the youngest occurrence of this genus elsewhere is in beds that are older than the oldest part of the Reunion event (C.A. Repenning, U.S. Geological Survey, written commun., 1990), which began 2.14 Ma. The Fishcreekian transgression evidently occurred between 2.14 and $2.48 \mathrm{Ma}$, either immediately before or shortly after the first major glaciation of the Northern Hemisphere.

A maximum age for the Bigbendian transgression is suggested by recent studies of marine sediment of the Beaufort Formation on Meighen Island in the Canadian Arctic Archipelago. This deposit closely postdates the opening of the Bering Strait and records upward transitions from normal to reversed to normal magnetic polarity (Fyles and others, 1991). The interval of reversed polarity is believed to represent either the Mammoth or
Kaena event (Fyles and others, 1991). These deposits are thought to be older than both the Bigbendian and Colvillian transgressions based on amino-acid geochronology (Brigham-Grette and Carter, 1991), and therefore the Bigbendian transgression is younger than the Mammoth event. The Bigbendian transgression must have occurred either at the beginning of the Kaena event or at the Gauss-Matuyama boundary.

\section{Ground-Temperature History}

These two possible ages can be evaluated by considering the ground-temperature history suggested by measurements of amino-acid diagenesis in fossil marine mollusk shells of Bigbendian age. The degree of aminoacid epimerization of L-isoleucine (Ile) to D-alloisoleucine (alle) in fossil mollusks is primarily dependent upon time and temperature; for the bivalve genus Mya, it is specified by the empirical equation given by Miller (1985):

$$
\begin{gathered}
T=6141 /(16.45-\log (((\ln (1+\text { aIle } / \mathrm{Ile}) / 1-0.77(\text { alle } / \\
\text { Ile }))-0.0194) / 1.77 t),
\end{gathered}
$$

where temperature $(T)$, time $(t)$, and the ratio alle/Ile are the only unknowns. Bigbendian sediment has undergone a complex thermal history since deposition, and $T$ can be considered only as an effective diagenetic temperature (EDT), or generalized ground temperature, for this entire period. Despite this limitation, the EDT can be used to evaluate the past presence of permafrost and the occurrence of significant intervals of warmer ground temperatures. This is because there is an exponential relationship between $T$ and the forward rate constant of isoleucine epimerization (not shown directly in the above equation) that makes the EDT especially sensitive to increases in temperature, which accelerate the reaction rate more than a decrease in temperature of the same magnitude would slow the reaction rate. Any EDT of less than $0^{\circ} \mathrm{C}$ indicates that permafrost was present at some time during the interval considered $(t)$, and the more negative the EDT, the more likely it becomes that permafrost was present during the entire interval. Because ground temperature is controlled by air temperature, modulated by snow cover, vegetation, surface moisture, and proximity to water bodies, the EDT provides information regarding paleoclimate. Generally, mean annual ground temperatures from the top of permafrost to the level of zeroannual-temperature amplitude at depths of about 20 to $30 \mathrm{~m}$ are from $1{ }^{\circ} \mathrm{C}$ to several degrees warmer than mean annual air temperature, depending on the modulating factors (Brewer, 1958).

Using the alle/Ile ratio of $0.121 \pm .021$ for Bigbendian Mya truncata in the above equation and solving for $T$ 
using the possible ages of 2.48 and $3.01 \mathrm{Ma}$ results in an EDT of $-15.2_{-1.0}^{+0.8}$ for the past $2.48 \mathrm{~m} . \mathrm{y}$. and $-16.1_{-1.0}^{+0.8}$ for the past $3.01 \mathrm{~m} . y$. This can be compared with modern permafrost temperatures of -8 to $-10^{\circ} \mathrm{C}$ at a depth of 10 $\mathrm{m}$ at Barrow, where the mean annual air temperature is about $-12.2{ }^{\circ} \mathrm{C}$ (Brewer, 1958), and with permafrost temperatures 2 to $4{ }^{\circ} \mathrm{C}$ colder than now about a century ago (Lachenbruch and Marshall, 1986).

Brigham and Miller (1983) calculated an EDT of $-13.8^{\circ} \mathrm{C}$ for the past $125,000 \mathrm{yr}$, which includes the latest glacial-interglacial cycle, and discussed possible temperature regimes that could account for this EDT. Their EDT must be revised to $-15.2 \pm 0.4^{\circ} \mathrm{C}$ because the equation used for their calculation has since been modified to the equation used in this paper on the basis of additional empirical data (Miller, 1985), but their conclusions apply even more strongly to the slightly colder EDT that results from recalculation. They concluded that even a slight warming of as much as $3^{\circ} \mathrm{C}$ for as little as 15 percent of this period would require that the remainder of the period average at least $8{ }^{\circ} \mathrm{C}$ colder than now, which is similar to the modern mean annual air temperature in the Dry Valleys of Antarctica (Decker and Bucher, 1982). Any increase in the temperature or length of the warm intervals would require even greater temperature depressions throughout the remainder of the period to produce such a cold EDT, and a temperature depression of greater than $8^{\circ} \mathrm{C}$ seems unreasonable.

This argument also applies to the cold EDT for the period since the Bigbendian transgression, which is essentially the same as for the latest glacial-interglacial cycle. The constraints on the length and temperature of warm intervals provided by an EDT in the range of -15 to $-16{ }^{\circ} \mathrm{C}$ make it unlikely that mean annual ground temperature in Bigbendian sediment could have risen above $0{ }^{\circ} \mathrm{C}$ for any appreciable period since this highsea-level event. Permafrost must therefore have been nearly continuously present since the Bigbendian transgression. The earliest known unequivocal evidence of permafrost in lowland continental areas of the Northern Hemisphere is in the upper part of the Kutuyakh beds of Siberia, which span the Gauss-Matuyama boundary (Sher and others, 1979). This suggests either that the Bigbendian transgression occurred $2.48 \mathrm{Ma}$, or that permafrost developed more than $0.5 \mathrm{~m}$.y. earlier than previously believed and that there has been a similar ratio of glacial to interglacial time over the past $3 \mathrm{~m}$.y. as over the past $125 \mathrm{k}$.y. The latter possibility does not seem likely, because climate did not cool sufficiently to produce ice sheets about half the size of late Pleistocene ones until about $2.6 \mathrm{Ma}$, and ice sheets did not become large enough to produce significant ice rafting in the North Atlantic until 2.4 Ma (Raymo and others, 1989), which is commonly considered the time of the first major late Cenozoic glaciation. The most probable age for the Bigbendian transgression is $2.48 \mathrm{Ma}$, the age of the Gauss-Matuyama boundary. Supporting this conclusion is the presence of an $\delta^{18} \mathrm{O}$ minimum, which represents low ice volume and high eustatic sea level, at the GaussMatuyama boundary in North Atlantic deep-sea core 552A (fig. 3; Shackleton and others, 1984). This interglacial interval is designated as oxygen-isotope stage 103 by Raymo and others (1989).

\section{DISCUSSION}

Determining a probable age for the Bigbendian transgression and correlating Bigbendian sediment between sites 1 and 2 places past paleoenvironmental interpretations in a firmer stratigraphic and temporal context, and provides some new conclusions regarding paleoclimate, permafrost, and the presence or absence of sea ice for the past 2.48 m.y. Paleoenvironmental conditions during the older Colvillian transgression (fig. 3) are discussed by Nelson and Carter (1991), and Brigham-Grette and Carter (in press) present possible circum-Arctic correlations of Colvillian, Bigbendian, and Fishcreekian deposits.

Faunal and palynological evidence from Bigbendian sediment indicates a relatively mild marine and terrestrial climate during the early part of the Bigbendian transgression. Faunal evidence for a mild climate includes the presence of sea otter remains at site 1 (Repenning, 1983), and a mollusk fauna that contains the gastropod Littorina squalida and the bivalve Clinocardium californiense (Deshayes) (Repenning and others, 1987). The modern northern limit of these mollusk taxa is the Bering Strait. Moreover, modern sea otters cannot tolerate severe seasonal sea-ice conditions (Schneider and Faro, 1975); hence, the presence of sea otter remains suggests that the limit of seasonal sea ice during the Bigbendian transgression was north of site 1 and more than $1,600 \mathrm{~km}$ north of the present limit (Carter and others, 1986b). Palynological evidence consists of a pollen suite from site 1 that indicates that during the early part of this high-sea-level event nearby land areas supported an open spruce-birch woodland with rare pine, fir, and larch (Nelson and Carter, 1985, 1991). Mean annual air temperatures on the North Slope during the Bigbendian transgression may have been as warm as those of the modern Anchorage area $\left(1.5^{\circ} \mathrm{C}\right)$, which is north of the modern limit of pine and fir. Permafrost beneath the coastal area adjacent to the Beaufort and Chukchi Seas must have been either limited to favorable microclimates or not present at all.

Climate cooled somewhat during the later part of this transgression, as shown by palynological analyses of samples from the upper part of the Bigbendian beds at site 2 . The fossil pollen from these beds includes an as- 
semblage of conifers similar to that at site 1 , but it contains a smaller percentage of conifer pollen. The overall pollen flora suggests that nearby vegetation was similar to present-day shrub tundra, such as occurs in the foothills of the Brooks Range, perhaps with conifers in river valleys (Repenning and others, 1987).

The EDT calculated for the past 2.48 m.y. shows that climate became cooler and permafrost formed shortly after the Bigbendian transgression. A better idea of how ground temperatures changed between the Bigbendian and Fishcreekian transgressions can be obtained by calculating the EDT that would produce the degree of amino-acid diagenesis that occurred between the two transgressions. This can be done using the technique described by Brigham and Miller (1983), which determines the rate constant of epimerization for an interval of unknown temperature. The EDT can then be calculated from the rate constant.

The Fishcreekian transgression occurred sometime between 2.48 and $2.14 \mathrm{Ma}$; it may correlate with the $\delta^{18} \mathrm{O}$ minimum that occurred about $2.41 \mathrm{Ma}$ (Carter and others, 1986b), but other possible correlations are with minima that occurred between about 2.41 and $2.15 \mathrm{Ma}$ (fig. 3). For the youngest possibility, the time span between the two high-sea-level events would be 330,000 $\mathrm{yr}$, and for the oldest possibility 70,000 yr. Using Brigham and Miller's (1983) technique yields EDT's ranging from $-10.0_{-5.4}^{+26}{ }^{\circ} \mathrm{C}$ to $-2.2_{-5.7}^{+2.8}{ }^{\circ} \mathrm{C}$. If the youngest age for the Fishcreekian transgression is correct, then perennial sea ice was probably present during at least part of the interval between the Bigbendian and Fishcreekian transgressions. An EDT of about $-12{ }^{\circ} \mathrm{C}$ is slightly colder than permafrost temperatures of the present and similar to those of the recent past. This suggests that climatic conditions were at least as cold as those of the present, in which perennial sea ice is maintained. This would be consistent with recent interpretations of Arctic Ocean deep-sea cores that propose a brief interval of perennial sea ice between 2.48 and $2.15 \mathrm{Ma}$ (Scott and others, 1989).

There is little evidence bearing on climatic conditions during the height of the Fishcreekian transgression. However, climate during the later part of the Fishcreekian transgression, which is represented by the upper marine beds at site 2 (figs. 1,2), was warmer than now but cooler than during the later part of the Bigbendian transgression. Pollen analyses indicate that the terrestrial climate was cooler than during the Bigbendian transgression because vegetation was wetland herbaceous tundra, possibly with scattered larch trees (Repenning and others, 1987), rather than the shrub tundra that characterized the later part of Bigbendian time. The presence of $\mathrm{Nu}$ phar (water lily) pollen in Fishcreekian beds suggests that the climate then was somewhat warmer than now because Nuphar is not known today north of the Brooks Range (Repenning and others, 1987). A climate warmer than now is also suggested by the Fishcreekian mollusk fauna, which is similar to the Bigbendian one, and the presence of sea otter remains that indicate relatively warm conditions and an absence of even severe seasonal sea ice (Carter and others, 1986b; Repenning and others, 1987).

Paleoclimate, permafrost, and sea-ice conditions for the period since the Fishcreekian transgression were discussed by Carter and others (1986b). Their discussion was based on an EDT of -15.8 to $-16.3^{\circ} \mathrm{C}$ for this period, and the fact that this EDT is colder than the EDT calculated by Brigham and Miller (1983) for the past 125 k.y. The EDT for the period since the Fishcreekian transgression must be revised to -15.8 to $-17.6{ }^{\circ} \mathrm{C}$, based on the modified equation given above, but their conclusions regarding permafrost and sea ice still seem valid. This cold EDT for the past 2.15 to 2.41 m.y. suggests that permafrost has been continually present north of the Brooks Range throughout this period. It also suggests that there have been no ice-free intervals on the Beaufort and Chukchi Seas since the Fishcreekian transgression, except perhaps for brief intervals at the peaks of the warmest interglacial episodes; this conclusion, however, conflicts with recent interpretations of Arctic Ocean sediment cores, which place the beginning of the permanent occurrence of perennial sea ice at just above the Pliocene-Pleistocene boundary (Scott and others, 1989).

\section{REFERENCES CITED}

Brewer, M.C., 1958, Some results of geothermal investigations of permafrost in northern Alaska: Eos (American Geophysical Union, Transactions), v. 39, p. 19-26.

Brigham, J.K., 1985, Marine stratigraphy and amino-acid geochronology of the Gubik Formation, western Arctic Coastal Plain, Alaska: U.S. Geological Survey Open-File Report 85-381, $218 \mathrm{p}$.

Brigham, J.K., and Miller, G.H., 1983, Paleotemperature estimates of the Alaskan Arctic Coastal Plain during the last 125,000 years, in International Conference on Permafrost, 4th, Fairbanks, Alaska, 1983, Proceedings: Washington, D.C., National Academy Press, p. 80-85.

Brigham-Grette, Julie, and Carter, L.D., in press, Pliocene marine transgressions of northern Alaska: Circumarctic correlations and paleoclimatic interpretations: Arctic.

Brouwers, E.M., 1987, On Pterygocythereis vannieuwenhuisei Brouwers sp. nov., in Bate, R.H., Horne, D.J., Neale, J.W., and Siveter, D.J., eds., A stereo atlas of ostrocode shells: London, British Micropaleontological Society, v. 14, part 1, p. 17-20.

Carter, L.D., Brigham-Grette, Julie, and Hopkins, D.M., 1986a, Late Cenozoic marine transgressions of the Alaskan Arctic 
Coastal Plain, in Heginbottom, J.A., and Vincent, J.S., eds., Correlation of Quaternary deposits and events in the area around the Beaufort Sea, abstracts of the Joint Canadian-American Workshop: Geological Survey of Canada Open-File Report 1237, p. 21-26.

Carter, L.D., Brigham-Grette, Julie, Marincovich, Louie, Jr., Pease, V.L., and Hillhouse, J.W., 1986b, Late Cenozoic Arctic Ocean sea ice and terrestrial paleoclimate: Geology, v. 14 , p. 675-678.

Carter, L.D., and Galloway, J.P., 1985, Engineering-geologic maps of northern Alaska, Harrison Bay quadrangle: U.S. Geological Survey Open-File Report 85-256, 48 p., scale $1: 250,000,2$ sheets.

Carter, L.D., Repenning, C.A., Marincovich, L.N., Hazel, J.E., Hopkins, D.M., McDougall, Kristin, and Naeser, C.W., 1977, Gubik and pre-Gubik Cenozoic deposits along the Colville River near Ocean Point, North Slope, Alaska, in Blean, K.M., ed., The United States Geological Survey in Alaska-Accomplishments during 1976: U.S. Geological Survey Circular 751-B, p. B12-B14.

Decker, E.R., and Bucher, G.J., 1982, Geothermal studies in the Ross Island-Dry Valley region, in Craddock, C., ed., Antarctic geoscience: Madison, University of Wisconsin Press, p. 887-894.

Dinter, D.A., Carter, L.D., and Brigham-Grette, Julie, 1990, Late Cenozoic geologic evolution of the Alaskan North Slope and adjacent continental shelves, in Grantz, A., Johnson, L., and Sweeney, J.F., eds., The Arctic Ocean region: Boulder, Colorado, Geological Society of America, The Geology of North America, DNAG Series, v. L, p. 459-490.

Fyles, J.G., Marincovich, Louie, Jr., Matthews, J.V., Jr., and Barendregt, R., 1991, Unique mollusc find in the Beaufort Formation (Pliocene), Meighen Island, Arctic Canada, in Current Research, Part B: Geological Survey of Canada Paper 91-B, p. 105-112.

Kaufman, D.S., Farmer, G.L., Miller, G.H., Carter, L.D., and Brigham-Grette, Julie, 1990, Strontium isotopic dating of upper Cenozoic marine deposits, northwestern Alaska, in Gosnell, L.B., and Poore, R.Z., eds., Pliocene climates: Scenario for global warming, abstracts from a USGS workshop, Denver, Colorado, October 23-25, 1989: U.S. Geological Survey Open-File Report 90-64, p. 17-21.

Lachenbruch, A.H., and Marshall, B.V., 1986, Changing climate: Geothermal evidence from permafrost in the Alaskan Arctic: Science, v. 234, no. 4777, p. 689-696.

Mankinen, E.A., and Dalrymple, G.B., 1979, Revised geomagnetic polarity time scale for the interval $0-5$ m.y. B.P.: Journal of Geophysical Research, v. 84, no. B2, p. 615626.

Matthews, J.V., Jr., and Ovendon, L.E., 1990, Late Tertiary plant macrofossils from localities in Arctic/Subarctic North America (Alaska, Yukon, and Northwest Territories): a review of the data: Arctic, v. 43, p. 364-392.
Miller, G.H., 1985, Aminostratigraphy of Baffin Island shellbearing deposits, in Andrews, J.T., ed., Quaternary environments-Baffin Island, Baffin Bay and West Greenland: United Kingdom, George Allen and Unwin, p. 394-427.

Miller, G.H., and Brigham-Grette, Julie, 1989, Amino acid geochronology: Resolution and precision in carbonate fossils, in Rutter, N.W., Brigham-Grette, Julie, and Catto, N., guest eds., Applied Quaternary geology: Quaternary International, v. 1, p. 111-128.

Nelson, R. E., and Carter, L. D., 1985, Pollen analysis of a part of the Gubik Formation, Arctic Coastal Plain, Alaska: Quaternary Research, v. 24, no. 3, p. 295-306.

-1991, Preliminary interpretation of vegetation and paleoclimate in northern Alaska during the late Pliocene Colvillian marine transgression, in Bradley, D.C., and Ford, A.B., eds., Geologic studies in Alaska by the U.S. Geological Survey, 1990: U.S. Geological Survey Bulletin [this volume].

Raymo, M.E., Ruddiman, W.F., Backman, J., Clement, B.M., and Martinson, D.G., 1989, Late Pliocene variation in northern hemisphere ice sheets and North Atlantic deep water circulation: Paleoceanography, v. 4, p. 413-446.

Repenning, C.A., 1983, New evidence for the age of the Gubik Formation, Alaskan North Slope: Quaternary Research, v. 19 , no. 3, p. 356-372.

Repenning, C.A., Brouwers, E.M., Carter, L.D., Marincovich, Louie, Jr., and Ager, T.A., 1987, The Beringian ancestry of Phenacomys (Rodentia: Cricetidae) and the beginning of the modern Arctic Ocean borderland biota: U.S. Geological Survey Bulletin 1687, 31 p.

Schneider, K.B., and Faro, J.B., 1975, Effects of sea ice on sea otters (Enhydra lutris): Journal of Mammology, v. 56, p. 91-101.

Scott, D.B., Mudie, P.J., Baki, V., MacKinnon, K.D., and Cole, F.E., 1989, Biostratigraphy and late Cenozoic paleoceanography of the Arctic Ocean: Foraminiferal, lithostratigraphic, and isotopic evidence: Geological Society of America Bulletin, v. 101, p. 260-277.

Shackleton, N.J., and others, 1984, Oxygen isotope calibration of the onset of ice-rafting and history of glaciation in the North Atlantic region: Nature, v. 307, p. 620-623.

Sher, A.V., and others, 1979, Late Cenozoic of the Kolyma Lowland, Pacific Science Congress, 14th, Tour Guide XI: Moscow, USSR Academy of Sciences, 115 p.

Wahrhaftig, Clyde, 1965, Physiographic divisions of Alaska: U.S. Geological Survey Professional Paper 482, 52 p., 6 pls.

Zalasiewicz, J.A., and Gibbard, P.L., 1988, The Pliocene to early middle Pleistocene of East Anglia: an overview, in Gibbard, P.L., and Zalasiewicz, eds., Pliocene-middle Pleistocene of East Anglia, field guide: Cambridge, England, Quaternary Research Association, p. 1-31.

Reviewers: Max C. Brewer and Oscar J. Ferrians, Jr. 


\title{
Tectonic Implications of the Albatross Sedimentary Sequence, Sitkinak Island, Alaska
}

\author{
By William S. Clendenen, William V. Sliter, and Tim Byrne
}

\begin{abstract}
We present stratigraphic and lithologic data from a newly recognized sedimentary sequence on Sitkinak Island, Alaska. This new sequence contains diamictite, sandstone, and siltstone and probably correlates with late Miocene to Pliocene sediments documented offshore. Conglomerate horizons in this sequence contain clasts of granite, chert, mélange, and slate that were probably derived from the emergent accretionary prism to the north; in addition, the conglomerate horizons display a suite of distinctive calcareous-shale clasts that are unlike any of the presently exposed units nearby. These clasts of calcareous shale contain a late early Miocene fauna that was probably deposited originally on the accretionary prism under deep water and subsequently uplifted along what is now the shelf break. Relatively rapid uplift of the shelf break may have been driven by an increase in accretion due in part to an increase in glacially derived sediment during the late Cenozoic. The newly recognized sedimentary sequence therefore documents the role of erosion and sedimentation in transporting mass in an active accretionary prism and emphasizes the importance of these processes in maintaining the taper of the prism.
\end{abstract}

\section{INTRODUCTION}

Accretionary prisms have been modeled in recent years as deforming wedges of material overlying a subducting slab (see, for example, Davis and others, 1983). The models assume a homogeneously deforming wedge and predict patterns of uplift that are relatively simple and uniform. The convergent margin in southern Alaska, however, displays a complex pattern of uplift and includes extensive shelf basins that record considerable subsidence (Clendenen, 1991). This pattern suggests that the deformation related to plate convergence is inhomogeneous.

In this paper we present new information from a sedimentary sequence heretofore considered to be part of the Oligocene Sitkinak Formation. This sequence, informally called the Albatross sedimentary sequence, probably correlates with strata within the intraprism shelf ba- sins and appears to record the transition from glaciomarine to fluvial deposition. The composition and paleontology of conglomerate clasts contained within the Albatross sedimentary sequence record significant uplift and erosion of the accretionary prism both landward and seaward of the subsiding shelf basins. In particular, the presence of deep-water calcareous-shale clasts within these conglomerates suggests that the seaward margin of the accretionary prism underwent about $4 \mathrm{~km}$ of uplift during the Neogene.

\section{GEOLOGIC SETTING}

The modern convergent margin along southern Alaska can be divided into several elements (fig. 1). The Alaska Peninsula and the Alaska Range are underlain by plutonic and volcanic rocks of a long-lived volcanic arc. Immediately seaward of the active volcanic arc is an extensive forearc basin that contains sedimentary rocks of Mesozoic and Cenozoic age (see, for example, Fisher and others, 1987). To the southeast, the accretionary prism encompasses variably metamorphosed and highly deformed rocks that progressively decrease in age from Late Triassic on the northwest (Roeske and others, 1989) to Holocene at the trench (Kulm and others, 1973). Kodiak and adjacent islands represent uplifted parts of the accretionary prism (von Huene and others, 1985), while farther to the southeast, the prism is submerged beneath a broad, shallow shelf, the site of a series of subsiding shelf basins (Fisher and von Huene, 1980; Pavlis and Bruhn, 1983; Turner, 1987; Clendenen, 1991). Finally, a relatively steep slope extends from the shelf break to the Aleutian trench, where a large volume of clastic sediment is being accreted today (Kulm and others, 1973; Davis and von Huene, 1987).

The shelf basins that overlie the accretionary prism contain interbedded shale, siltstone, sandstone, and conglomerate of late(?) and middle Miocene through Holocene age (Turner, 1987). The basin fill is glacially influenced (Turner, 1987) and correlates with the largely 


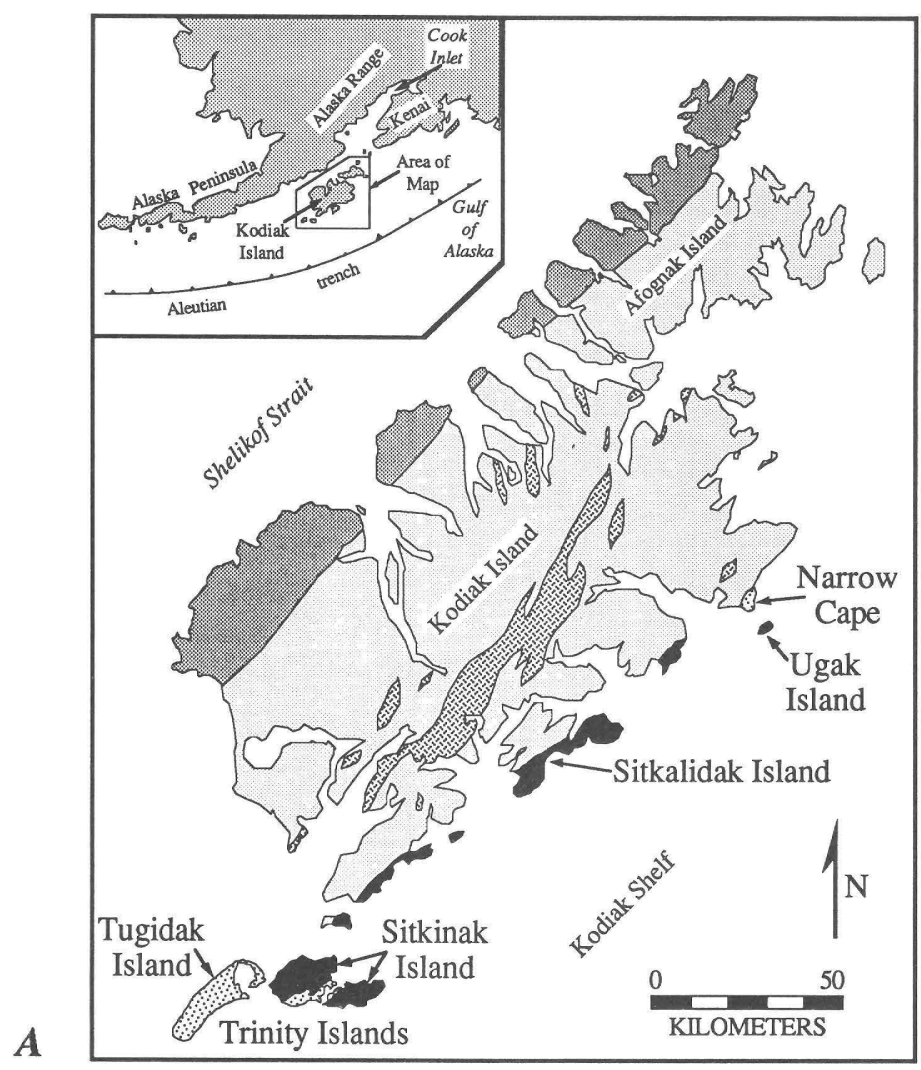

NW

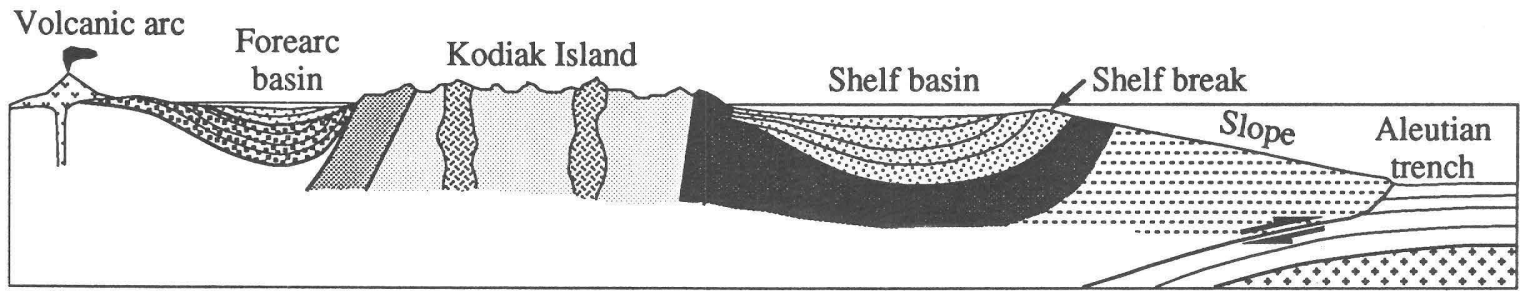

$\boldsymbol{B}$

\section{EXPLANATION}

ACCRETED ROCKS

Earlier Mesozoic

Maestrichtian to Paleocene

Eocene

Neogene to Holocene

\section{BASIN SEDIMENTS}

Tesozoic

Cenozoic

Contact

Fault - Arrows indicate direction of relative movement

Figure 1. Regional geology of Kodiak Island region. A, Generalized geologic map of Kodiak Island region. Geology from Moore (1967), Connelly and Moore (1979), Moore and Allwardt (1980), and Moore and others (1983). See $B$ for explanation of symbols. B, Schematic cross section through southern Alaska convergent margin. Basin geometries from Fisher and von Huene (1980) and Fisher and others (1987). Geology of shelf break and slope from Fisher and von Huene (1980), von Huene and others (1987), and Moore and others (1991). 
glaciomarine Yakataga Formation of similar age found along the northeastern margin of the Gulf of Alaska (Plafker and Addicott, 1976; Marincovich, 1990). The bottom of the basins is marked by an angular unconformity where the basin sediments overlie more deformed Eocene turbidites (Turner, 1987). The regional configuration of the shelf basins is shown in figure 2 by contours of depth below sea level to the basal angular unconformity, which has been traced on seismic-reflection lines throughout the region (seismic horizon $\mathrm{C}$ of Fisher and von Huene, 1980).

The seaward boundary of the shelf basins is a major anticlinal or homoclinal flexure underlying the shelf break (figs. $1 B, 2$; Fisher and von Huene, 1980; von Huene and others, 1987). The shelf break is the site of rapid late Cenozoic uplift, has been locally truncated by erosion (Fisher and von Huene, 1980), and has provided a sediment dam behind which the basins have been filled. Uplift of the shelf break resulted from the growth of the seaward part of the accretionary prism; this growth was probably driven by the accretion of sediment at the trench (Clendenen, 1991).

\section{GEOLOGY OF SITKINAK ISLAND AND VICINITY}

The rocks exposed on and near Sitkinak Island (fig. $1 A$ ) represent the most extensive onland exposure of sedimentary rocks that are otherwise submerged beneath the shelf. Sitkinak Island actually consists of two islands separated by a shallow lagoon (fig. 3 ), which together with neighboring Tugidak Island comprise the Trinity Islands (fig. 1A). Rocks exposed on Sitkinak and nearby islands include Paleogene turbidites, Oligocene conglomerates, and Neogene and Quaternary sedimentary units (fig. 3 ) that are probably the lateral equivalents of strata of similar age submerged offshore.

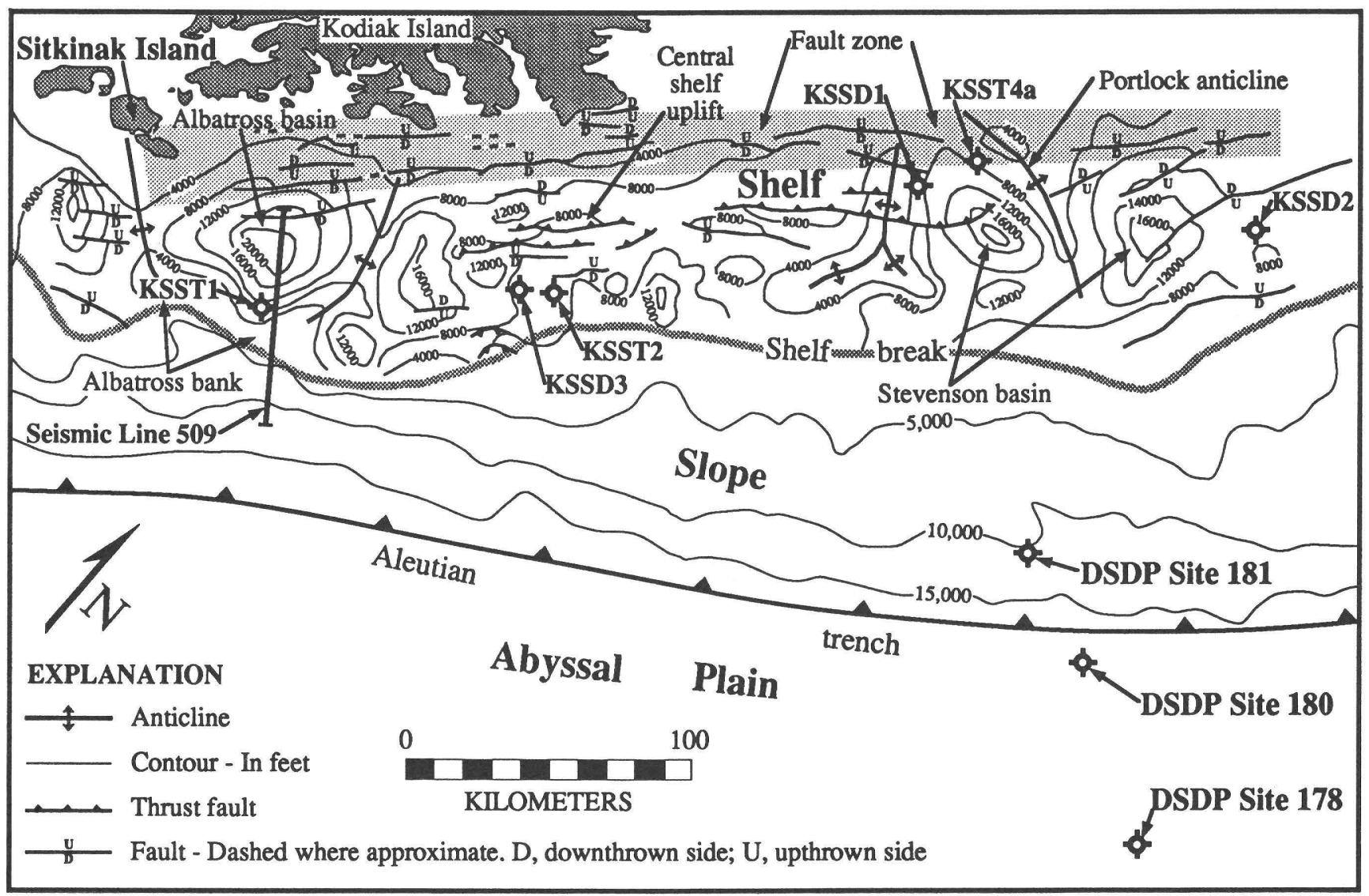

Figure 2. Physiography, shelf basins, structure, and well locations near Kodiak Island. Shelf basins defined by contours of seismic horizon C (Fisher and von Huene, 1980; Turner, 1987, fig. 58), which mark base of basins and top of acoustic basement across most of shelf. Water is shallow across shelf, so thickness of basin sediment is only slightly less than contour values. Fault zone located between subsiding shelf basins and uplifting Kodiak Island is shown by light shading (von Huene and others, 1972). Locations of six Deep Stratigraphic Test (DST) wells drilled on shelf and nearby Deep Sea Drilling Project (DSDP) sites are shown. Structure of shelf is from Turner $(1987$, fig. 58) and von Huene and others (1980). Bathymetry of the slope seaward of shelf break is from von Huene and Shor (1969) and von Huene (1979) and was converted to feet to be consistent with basin bottom contours. 


\section{Sitkalidak Formation}

The oldest unit found on Sitkinak Island is the Sitkalidak Formation, which was divided by Moore and Allwardt (1980) into two structural units: a more deformed unit and a less deformed unit (fig. 3). It is composed of interbedded sandstone and siltstone, mudstone, and conglomerate, representative of deep-sea fan deposition (Nilsen and Moore, 1979). Micropaleontological samples previously collected on east Sitkinak Island were barren (J.M. Armentrout, cited in Moore and Allwardt, 1980).

We collected four shale samples on Sitkinak Island for micropaleontologic analysis (table 1; fig. 3, locs. 14). These samples contain a poorly preserved, predominately agglutinated benthic foraminiferal assemblage (table 2). Most of these species are long-ranging in age. However, the presence of Praeglobobulimina ovata cowlitzensis constrains the depositional age of the Sitkal- idak Formation to be Eocene, while the species Haplophragmoides obliquicameratus indicates a longer ranging, Eocene through Miocene age. The assemblage indicates bathyal water depths, and the presence of calcareous benthic foraminifers as rare, small, pyrite casts associated with large, agglutinated species implies that deposition took place below the carbonate compensation depth (CCD). Previous regional correlations (Moore and Allwardt, 1980) and the observed foraminiferal assemblage indicate that the Sitkalidak Formation on Sitkinak Island is most probably Eocene in age.

Lithologically and structurally similar rocks have been penetrated beneath the shelf basins to the southeast by three Deep Stratigraphic Test (DST) wells (KSSD series, fig. 2; Turner, 1987). These rocks are Eocene in age (Turner, 1987), but no species of foraminifers were found in common with the few that we collected from the Sitkalidak Formation. Like the Sitkalidak Formation, the deformed turbidites beneath the shelf basins are deep

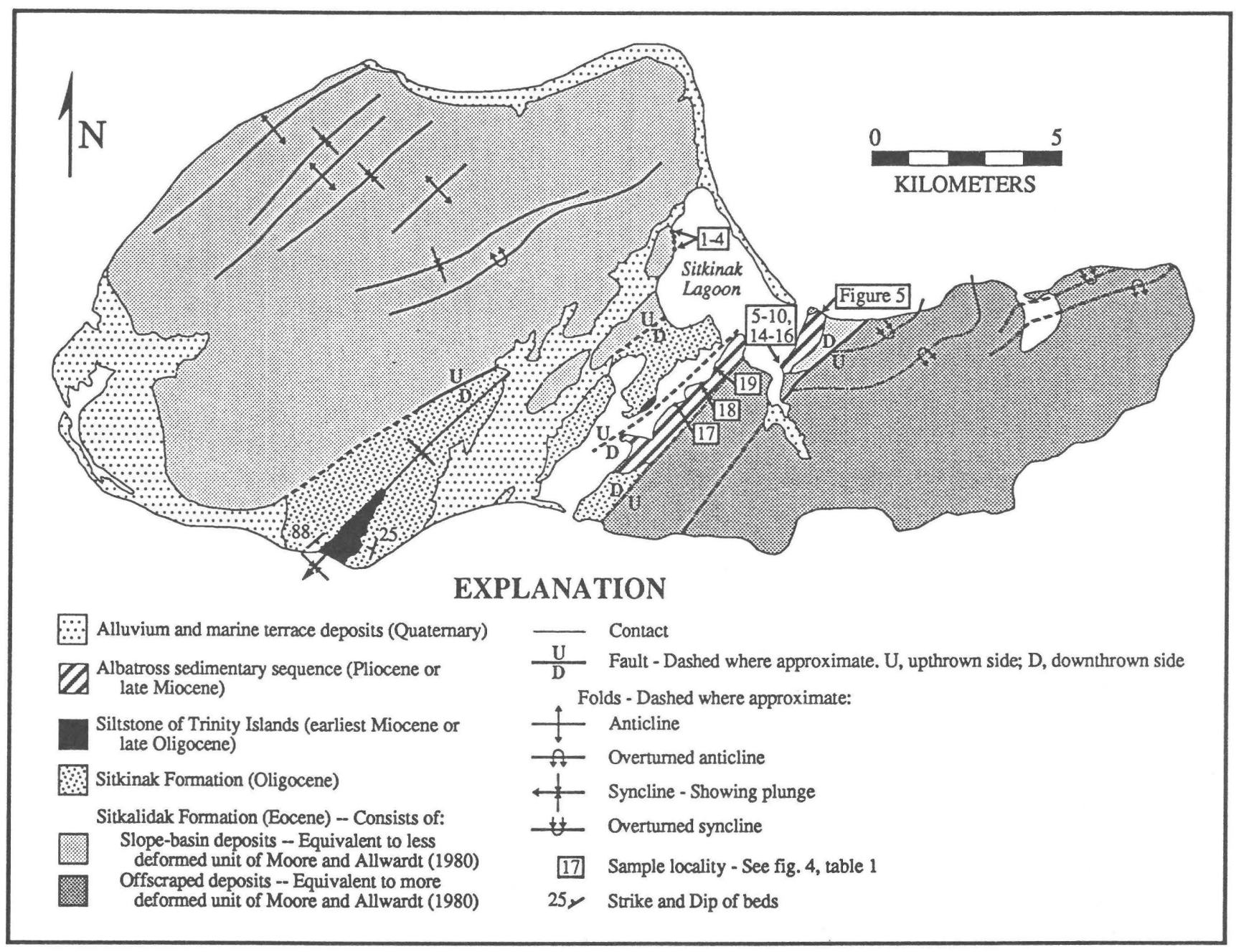

Figure 3. Generalized geologic map of Sitkinak Island. Information comes primarily from Moore and Allwardt (1980; unpubl. map, 1980). 
Table 1. Samples used for micropaleontology and pebble counting

\begin{tabular}{|c|c|c|c|c|c|}
\hline Map No. & $\begin{array}{l}\text { Sample } \\
\text { identifier }\end{array}$ & Latitude & Longitude & $\begin{array}{l}\text { Elevation } \\
(\mathrm{m})\end{array}$ & Description \\
\hline \multicolumn{6}{|c|}{ Micropaleontology: } \\
\hline 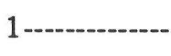 & SL-2-88 & N56 $34.48^{\prime}$ & $\mathrm{W} 154^{\circ} 05.49^{\prime}$ & 1 & Shale sample-Sitkalidak Formation \\
\hline 2------------ & SL-3-88 & $\mathrm{N} 56^{\circ} 34.44^{\prime}$ & $\mathrm{W} 154^{\circ} 05.48^{\prime}$ & 1 & Shale sample-Sitkalidak Formation \\
\hline 3----------- & SL-4-88 & N56 $34.36^{\prime}$ & $\mathrm{W} 154^{\circ} 05.44^{\prime}$ & 1 & Shale sample_-Sitkalidak Formation \\
\hline 4------------- & SL-5-88 & N5 $56^{\circ} 34.25^{\prime}$ & $\mathrm{W} 154^{\circ} 05.42^{\prime}$ & 1 & Shale sample-Sitkalidak Formation \\
\hline 5------------- & N-1a-88 & N56 $32.59^{\prime}$ & $\mathrm{W} 154^{\circ} 02.51^{\prime}$ & 0 & Shale rip-up_-Albatross sedimentary sequence \\
\hline 6------------ & $\mathrm{K}-10-87$ & N56 $32.59^{\prime}$ & $\mathrm{W} 154^{\circ} 02.51^{\prime}$ & 0 & Calcareous-shale clasts_-Albatross sedimentary sequence \\
\hline 7------------- & SK-2-87 & $\mathrm{N} 56^{\circ} 32.41^{\prime}$ & $\mathrm{W} 154^{\circ} 02.55^{\prime}$ & 0 & Calcareous-shale cobble-Albatross sedimentary sequence \\
\hline 8----------- & $\mathrm{N}-1 \mathrm{~b}-88$ & $\mathrm{~N} 56^{\circ} 32.41^{\prime}$ & $\mathrm{W} 154^{\circ} 02.55^{\prime}$ & 0 & Calcareous-shale clasts_-Albatross sedimentary sequence \\
\hline 9----------- & $\mathrm{N}-3-88$ & $\mathrm{~N} 56^{\circ} 32.53^{\prime}$ & $\mathrm{W} 154^{\circ} 02.54^{\prime}$ & 0 & Calcareous-shale clasts_-Albatross sedimentary sequence \\
\hline 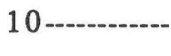 & N-4-88 & N5632.59' & $\mathrm{W} 154^{\circ} 02.51^{\prime}$ & 0 & Calcareous-shale clasts-Albatross sedimentary sequence \\
\hline \multicolumn{6}{|c|}{ Pebble Counts: } \\
\hline $14----------$ & PC-14 & $\mathrm{N} 56^{\circ} 32.41^{\prime}$ & $\mathrm{W} 154^{\circ} 02.55^{\prime}$ & 0 & Basal conglomerate-Albatross sedimentary sequence \\
\hline 15 ------------ & PC-15 & N56 $32.59^{\prime}$ & $\mathrm{W} 154^{\circ} 02.51^{\prime}$ & 0 & Conglomerate-Albatross sedimentary sequence \\
\hline 16 ---------- & PC-16 & N5632.59' & $\mathrm{W} 154^{\circ} 02.51^{\prime}$ & 0 & Gravel-lag deposit-Albatross sedimentary sequence \\
\hline 17 --:----- & PC-17 & $\mathrm{N} 56^{\circ} 31.97^{\prime}$ & $\mathrm{W} 154^{\circ} 05.48^{\prime}$ & 0 & Conglomerat-Albatross sedimentary sequence \\
\hline 18 ----------- & PC-18 & N5 $56^{\circ} 32.28^{\prime}$ & $\mathrm{W} 154^{\circ} 04.71^{\prime}$ & 0 & Conglomerate-Albatross sedimentary sequence \\
\hline 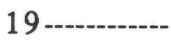 & PC-19 & N5 $56^{\circ} 32.45^{\prime}$ & $\mathrm{W} 154^{\circ} 04.41^{\prime}$ & 0 & Conglomerate-Albatross sedimentary sequence \\
\hline
\end{tabular}

water (probably bathyal) and may have been deposited below the CCD (Turner, 1987). These observations support the interpretation that the Eocene Sitkalidak Formation is an onland exposure of the deformed turbidites found beneath the shelf basins offshore. If so, then a large tract of Eocene rocks extends from Sitkinak Island and the southeast shore of Kodiak Island beneath the shelf basins and probably all the way to the shelf edge (fig. 1B; Turner, 1987; Moore and others, 1991).

\section{Middle Tertiary Deposits}

The Oligocene Sitkinak Formation and the overlying siltstone of Trinity Islands are present in a downfaulted block flanking Sitkinak Lagoon (fig. 3). The Sitkinak Formation consists of conglomerate and sandstone alternating with fine-grained sandstone, siltstone, coal, and carbonaceous shale (Nilsen and Moore, 1979). These strata are primarily terrestrial and were deposited as channelized, braided-stream gravels interbedded with interchannel, lagoonal, and interdistributary bay deposits (Nilsen and Moore, 1979). Although not exposed, an angular unconformity most probably lies between the Sitkinak Formation and the underlying Sitkalidak Formation. Conglomerates of the Sitkinak Formation probably record the uplift and unroofing of the accretionary prism during the middle Tertiary (Clendenen, 1991).

Conformably overlying the Sitkinak Formation at two locations on west Sitkinak Island is the siltstone of Trinity Islands (fig. 3; J.M. Armentrout, cited in Moore and Allwardt, 1980). This unit, whose rocks were included by Moore (1969) in the Narrow Cape Formation, is late Oligocene or earliest Miocene in age on the basis of a well-characterized molluscan fauna and benthic foraminifers (Allison, 1978; Allison and Marincovich, 1981). It was deposited under outer neritic water depths (100-186 $\mathrm{m}$ ) and in cool-temperate climatic conditions. The siltstone of Trinity Islands is especially important for this study because it constrains the age of the underlying Sitkinak Formation to be no younger than late Oligocene. Units correlative with the Sitkinak Formation or the siltstone of Trinity Islands are not found nearby (Armentrout, 1979; Moore and Allwardt, 1980) and were not penetrated by any of the DST wells offshore (Turner, 1987), suggesting that these units were never regionally extensive.

\section{Neogene and Quaternary Sediments}

The Tugidak and Narrow Cape Formations are the only recognized onland equivalents of strata occurring 
Table 2. Microfossils identified in shale samples from the Sitkalidak Formation

$[-$, not present; $x$, present $]$

\begin{tabular}{|c|c|c|c|c|}
\hline \multirow[b]{2}{*}{ Species } & \multicolumn{4}{|c|}{ Samples } \\
\hline & $\mathrm{SL-2-88}$ & SL-3-88 & SL-4-88 & SL-5-88 \\
\hline Bathysiphon eocenica Cushman and Hanna & $\mathbf{x}$ & $\mathbf{x}$ & $\mathbf{x}$ & $\mathbf{x}$ \\
\hline Haplophragmoides obliquicameratus Marks & $\mathbf{x}$ & $\mathbf{x}$ & & $\mathbf{x}$ \\
\hline Nodosarella atlantisae hispidula (Cushman) & - & $\mathbf{x}$ & - & - \\
\hline Nodosaria arundinea Schwager & - & $\mathbf{x}$ & 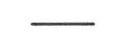 & - \\
\hline Praeglobobulimina ovata cowlitzensis (Beck) & $\longrightarrow$ & - & $\mathbf{x}$ & $\longrightarrow$ \\
\hline Rhabdammina eocenica Cushman and Hanna & $\longrightarrow$ & $\mathbf{x}$ & - & $\mathbf{x}$ \\
\hline Trochammina globigeriniformis (Parker and Jones) & $\mathrm{x}$ & $\mathbf{x}$ & - & $\mathbf{x}$ \\
\hline
\end{tabular}

within the shelf basins offshore (Turner, 1987). The Narrow Cape Formation is exposed on Kodiak Island at Narrow Cape, $150 \mathrm{~km}$ northeast of Sitkinak Island (fig. $1 A$ ), where it lies unconformably above the Sitkalidak Formation. It is early middle Miocene in age and was deposited under shallow-marine conditions (about $50 \mathrm{~m}$ ) on the basis of its abundant and diagnostic molluscan fauna (Allison, 1978; Marincovich and Moriya, 1991). Sandstones of the Narrow Cape Formation appear to be similar in composition to those penetrated by the DST wells offshore (for example, Turner, 1987). This similarity suggests that the Narrow Cape Formation correlates with part of the basin sediments offshore, and that the angular unconformity beneath it is the same as the basal unconformity underlying the shelf basins (fig. 2; seismic horizon C of Fisher and von Huene, 1980).

The strata comprising the siltstone of Trinity Islands on Sitkinak Island (fig. 3) were originally included in the Narrow Cape Formation (Moore, 1969), but the Narrow Cape Formation contains a distinct molluscan fauna and is clearly younger (Allison, 1978; Marincovich and Moriya, 1991). In addition, the siltstone of Trinity Islands is probably older than the regional unconformity offshore, whereas the Narrow Cape Formation is most likely younger. Therefore, we propose that separate designations for these two rock sequences should be adopted as more geologically realistic.

The youngest sedimentary unit exposed on land is the late(?) Pliocene and Pleistocene Tugidak Formation found on Tugidak Island (fig. 1A) (Moore, 1969; Allison, 1978). It consists of compacted but unlithified silt and clay with floating pebbles and minor amounts of channel gravels and sands (Armentrout, 1979), suggesting deposition under glaciomarine conditions. The Tugidak Formation contains a diverse, cold-water molluscan fauna indicative of an upper outer-neritic environment (Allison, 1978). Like the lower middle Miocene
Narrow Cape Formation, the Tugidak Formation probably correlates with strata of similar age within the shelf basins offshore (Turner, 1987).

Prior to our work, no other units were recognized on Sitkinak Island. However, evidence presented in this paper requires the existence of another distinct and separate unit whose strata have heretofore been considered to be part of the Oligocene Sitkinak Formation, but which must be significantly younger. This new unit, like the Narrow Cape and Tugidak Formations, is probably an onland exposure of correlative strata occurring within the neighboring Albatross basin and may have important ties to the emergent Albatross bank to the southeast (fig. 2). Therefore, we here informally designate this new unit as the Albatross sedimentary sequence. This unit provides evidence concerning the evolution of the intraprism shelf basins and the late Cenozoic growth of the accretionary prism.

\section{ALBATROSS SEDIMENTARY SEQUENCE}

The Albatross sedimentary sequence crops out in two separate areas on Sitkinak Island (fig. 3) and includes many of the strata on east Sitkinak Island that have been heretofore mapped as the Sitkinak Formation by Moore (1969) and Moore and Allwardt (1980). Evidence presented here indicates that the Albatross sedimentary sequence is younger than late early Miocene in age and is perhaps even as young as Pliocene in age. The Albatross sedimentary sequence is probably an onland exposure of strata within the shelf basins offshore and may eventually prove to be an older part of the Pliocene and Pleistocene Tugidak Formation.

The Albatross sedimentary sequence is moderately deformed by folding (see Moore and Allwardt, 1980, fig. 3 and pl. 1) and is commonly faulted. It is present along 
the east shore of Sitkinak Lagoon (fig. 3) and as a small fault sliver between the two units of the Sitkalidak Formation. (This fault sliver is too small to be shown on fig. 3, but the fault involved is approximately $2 \mathrm{~km}$ east of the northern entrance to Sitkinak Lagoon.) The poorly indurated Albatross sedimentary sequence can be divided stratigraphically into upper and lower parts. The lower part is best exposed in the smaller, northeastern outcrop of the Albatross sedimentary sequence (fig. 3, locs. 516). Here, it lies unconformably above both the more and less deformed units of the Eocene Sitkalidak Formation and includes Sitkalidak sandstone boulders in its basal conglomerate. The lower part contains a thick, distinctive layer of diamictite (fig. 4) that is crudely stratified and contains scattered lenses of sandstone and pebble conglomerate (fig. 5). This section of the Albatross sedimentary sequence also contains calcareous-shalebearing conglomerates, which typically form the fill of prominent channels cutting finer grained deposits (fig. $4 B$ ). The presence of calcareous shale is anomalous, as very few carbonate rocks of any type are found within the Kodiak accretionary complex.

Both the lower and upper parts are exposed in the larger outcrop area of the Albatross sedimentary sequence, which is located along the southeast shore of the narrow, central part of Sitkinak Lagoon (fig. 3). At the southeast end of this outcrop area, the Albatross sedimentary sequence may unconformably overlie the Sitkinak Formation, although this pattern was not directly observed in the field. In the lower part of this section, diamictite is again exposed and scattered calcareousshale clasts are present locally (fig. 4A). A distinctive, thin layer of pebble-supported conglomerate marks the base of the upper part of the Albatross sedimentary sequence (just above $100 \mathrm{~m}$; fig. $4 A$ ) and is directly overlain by the first coalbed. The upper part of the Albatross sedimentary sequence is lithologically very much like the Sitkinak Formation in most aspects, consisting of conglomerate and sandstone interbedded with finer grained sandstone, siltstone, and coal. Overall, the Albatross sedimentary sequence appears to represent a prograding sequence, with the lower part representing shallow-marine deposition and the pebble-supported conglomerate marking the transition to terrestrial conditions similar to those recorded by the Sitkinak Formation.

Six pebble counts from conglomerates throughout the Albatross sedimentary sequence (tables 1, 3; fig. 4, locs. 14-19) identify important trends that help in identifying the provenance of its sediment. From the bottom to the top of the Albatross sedimentary sequence, the fraction of clasts that are chert decreases while the fraction that are sandstone increases. These trends may reflect the gradual reduction in the input of chert from erosion of the underlying chert-rich conglomerates of the Sitkinak Formation and its replacement by sandstone from an emerging Kodiak Island. The presence of granite, mélange, and slate clasts only in conglomerates of the upper part of the Albatross sedimentary sequence (table 3) is significant because these rock types are prominent constituents of the emergent accretionary prism to the north. This evidence further supports the view that the upper part represents deposition from an uplifting and eroding Kodiak Island. The calcareous-shale clasts in the lower part of the Albatross sedimentary sequence are problematic because no rocks of this type are known anywhere within the exposed accretionary prism. The concentration of calcareous-shale clasts in the basal part of the Albatross sedimentary sequence and their total absence in the upper part (table 3; fig. 4) suggest that, after deposition of the lower part, either the source of the calcareous shale was removed or the transport path of the calcareous shale from its source was interrupted.

Some features of the diamictite are suggestive of deposition under glaciomarine conditions. The diamictite is several meters thick, poorly sorted, and only crudely bedded (figs. 4,5 ), all representative traits of glaciomarine deposition (see, for example, Eyles and others, 1985). The presence of stringers of sandstone and apparent lag gravels may represent later sorting of the material by current action (see, for example, Eyles and others, 1985). However, macrofossils were not observed in the diamictite. With the exception of the apparent absence of macrofossils, the diamictite within the Albatross sedimentary sequence is similar to that found within the glaciomarine Yakataga Formation exposed along the continental margin to the northeast (see, for example, Plafker and Addicott, 1976).

The presence of calcareous-shale clasts and diamictite makes the Albatross sedimentary sequence lithologically distinctive relative to the Sitkinak Formation. Diamictite lithologically similar to that found in the Albatross sedimentary sequence has not been recognized in the Sitkinak Formation, and of 2,776 pebbles counted at 13 sites throughout the stratigraphic extent of the hereinrestricted Sitkinak Formation, not one calcareous-shale clast was found (table 3). We now discuss the micropaleontology, environment of deposition, and probable source of the calcareous-shale clasts.

\section{Clasts of Calcareous Shale}

Ninety-three separate calcareous-shale clasts were collected from conglomerates of the lower part of the Albatross sedimentary sequence. Individual clasts are rounded and range in size from a few to tens of centimeters in diameter. They may have originally formed as concretions in an otherwise clastic sequence. In thin section, the matrix of the calcareous-shale clasts shows an almost complete transition from a poorly defined, finely 


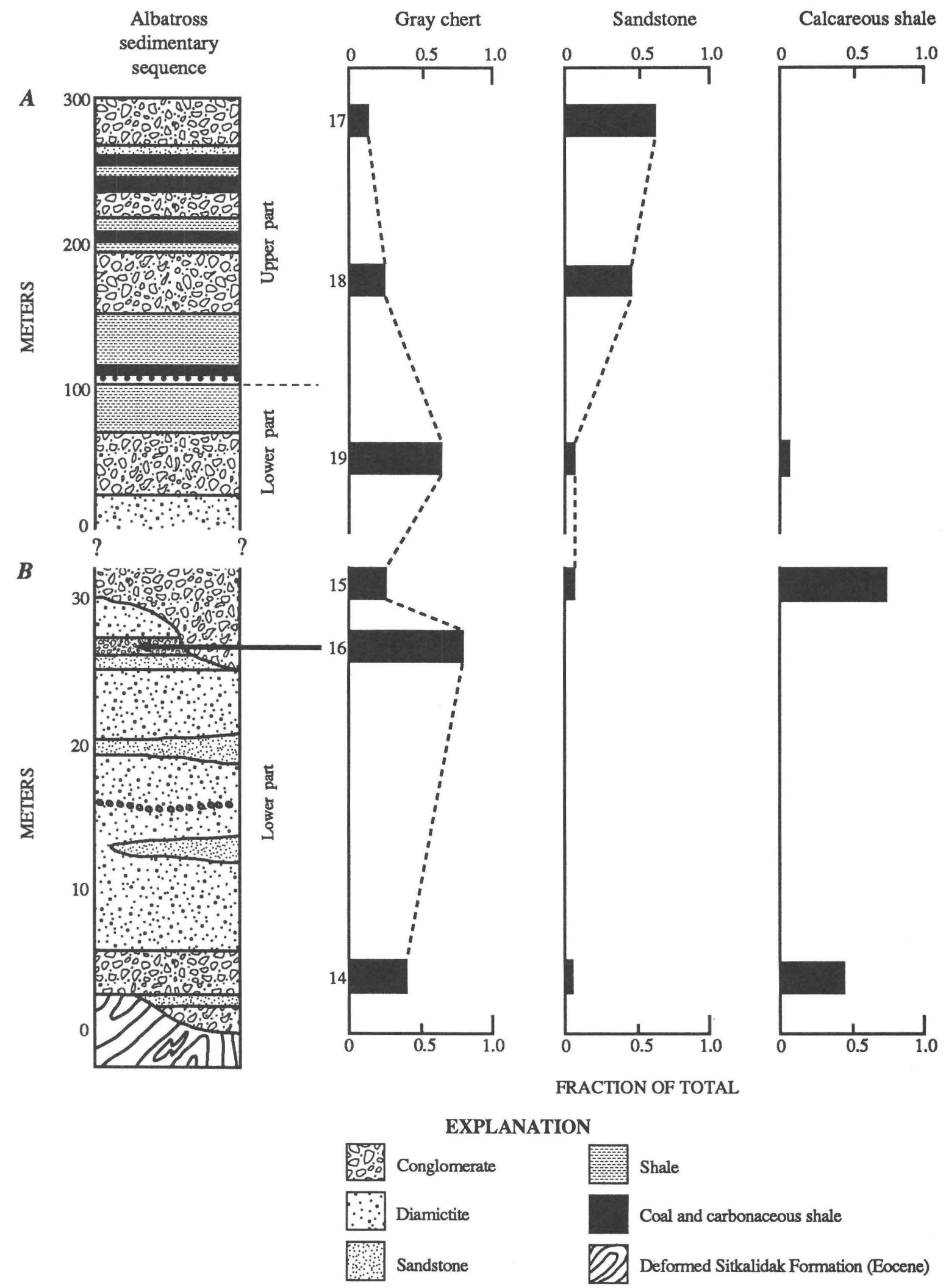

Figure 4. Generalized stratigraphic sections of Albatross sedimentary sequence and results from pebble counts of conglomerates. $A$, Stratigraphic section of largest exposure area of Albatross sedimentary sequence located along central part of Sitkinak Lagoon (fig. 3). B, Stratigraphic section of sedimentary sequence exposed near north entrance to Sitkinak Lagoon (fig. 3). Positions of samples are shown next to stratigraphic sections. The pebble-count data are provided in table 3. Note that vertical scales of two sections are only approximate and differ by an order of magnitude. 
laminated diatomaceous matrix on one hand, to a thoroughly bioturbated and homogenized matrix on the other. Of the 143 thin sections made, 60 contained microfossils that were used to establish the age and environment of deposition of the calcareous-shale lithology. All of the micropaleontologic identifications reported here were made from material collected from the smaller, northeastern exposure area of the Albatross sedimentary sequence. These samples are from three separate conglomerate layers contained in the basal lower part (fig. 4B). Only seven calcareous-shale clasts were collected from the lower part exposed in the larger, southwestern exposure area of the Albatross sedimentary sequence, and none of these contained microfossils, although they are sedimentologically identical to the clasts from the smaller outcrop area.

\section{Micropaleontology}

Identifiable planktic foraminifers occur in 19 of the 60 thin sections (table 4). The planktic foraminifers are sparse and vary from one to a few specimens per thin section. All the thin sections contain elements of a similar fauna that yield a late early Miocene age [N7 to N8 of Blow (1969)], or approximately 17.5 to $15.2 \mathrm{Ma}$ after Berggren and others (1985). This biostratigraphic interval is defined by the total range of Globigerinoides diminutus Bolli, and by the first appearance of Praeorbulina $\mathrm{cf}$. $P$. transitoria (Blow) and the last appearance of Globorotaloides suteri Bolli. The more common elements of the fauna give a somewhat broader age range of late early to early middle Miocene, or from N6 to N9. This result is based on the stratigraphic ranges of Globorotalia archaeomenardii Bolli, G. peripheroronda Blow, and G. praescitula Blow. This planktic assemblage indicates warm-temperate paleoceanographic conditions, which correlate with the Neogene thermal maximum during the late early Miocene (N8).
Benthic foraminifers occur in two-thirds of the samples. The most persistent group includes very small, elongate, thin-walled calcareous specimens attributed to Bolivina, Coryphostoma, Dentalina, and possibly Nodogenerina. A second group of larger, more robust calcareous benthic foraminifers includes rare specimens of spinose Ehrenbergina that resemble E. spinosissima Cushman and Jarvis, spinose forms of Bulimina similar to $B$. spinifera Cushman, and large Globobulimina sp. The ehrenberginids are especially interesting from two aspects. First, although the genus ranges from the Eocene to the Holocene, distinctly spinose forms did not appear until the Miocene. And, second, the genus indicates deep-water or bathyal to abyssal water depths. Finally, a third group consists of rare, very poorly preserved large benthic foraminifers that include specimens of Lenticulina, Gyroidina, and possibly Trochulina. Members of this group indicate a shallower depositional environment of outer neritic to upper-slope water depths.

Diatoms occur in many of the thin sections. Large circular diatoms, up to $0.23 \mathrm{~mm}$ in diameter, are identified as Coscinodiscus and occur together with smaller Stephanopyxis (identifications by John Barron, U.S. Geological Survey). The dominance of Coscinodiscus in the samples suggests a late Oligocene to younger, or most likely Miocene, age according to J. Barron (oral commun., 1989). Based on the similarity in bio- and lithogenic constituents in the thin sections, all the clasts are considered to be late early Miocene in age.

\section{Environment of Deposition}

Deposition of the calcareous shale probably took place at lower-bathyal to abyssal water depths on a continental slope or in a basin. The persistence of Ehrenbergina together with spinose globobuliminids indicates that deposition took place in deep water $(2,000$ to $4,000 \mathrm{~m}$ or more) and yet above the CCD. In fact, in the narrowest

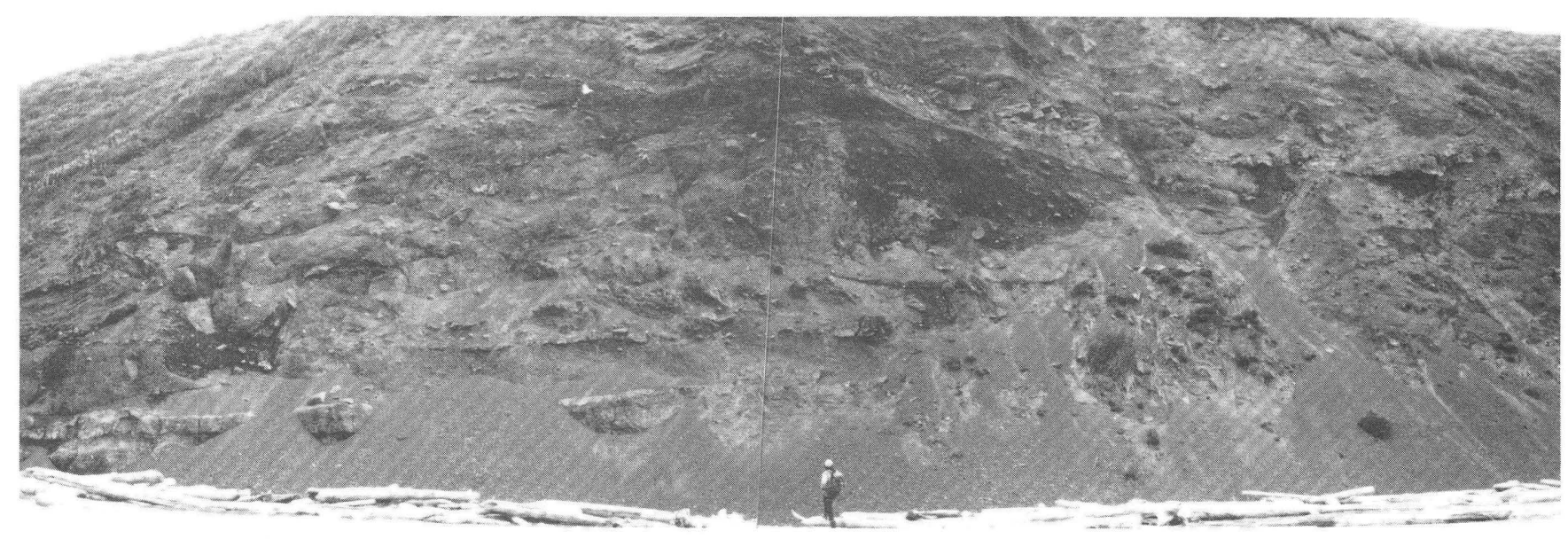

Figure 5. Thick section of diamictite within Albatross sedimentary sequence exposed in seacliff. Location shown in figure 3. 
Table 3. Pebble-count data from conglomerates of the Albatross sedimentary sequence

[tr, trace. All values in percent]

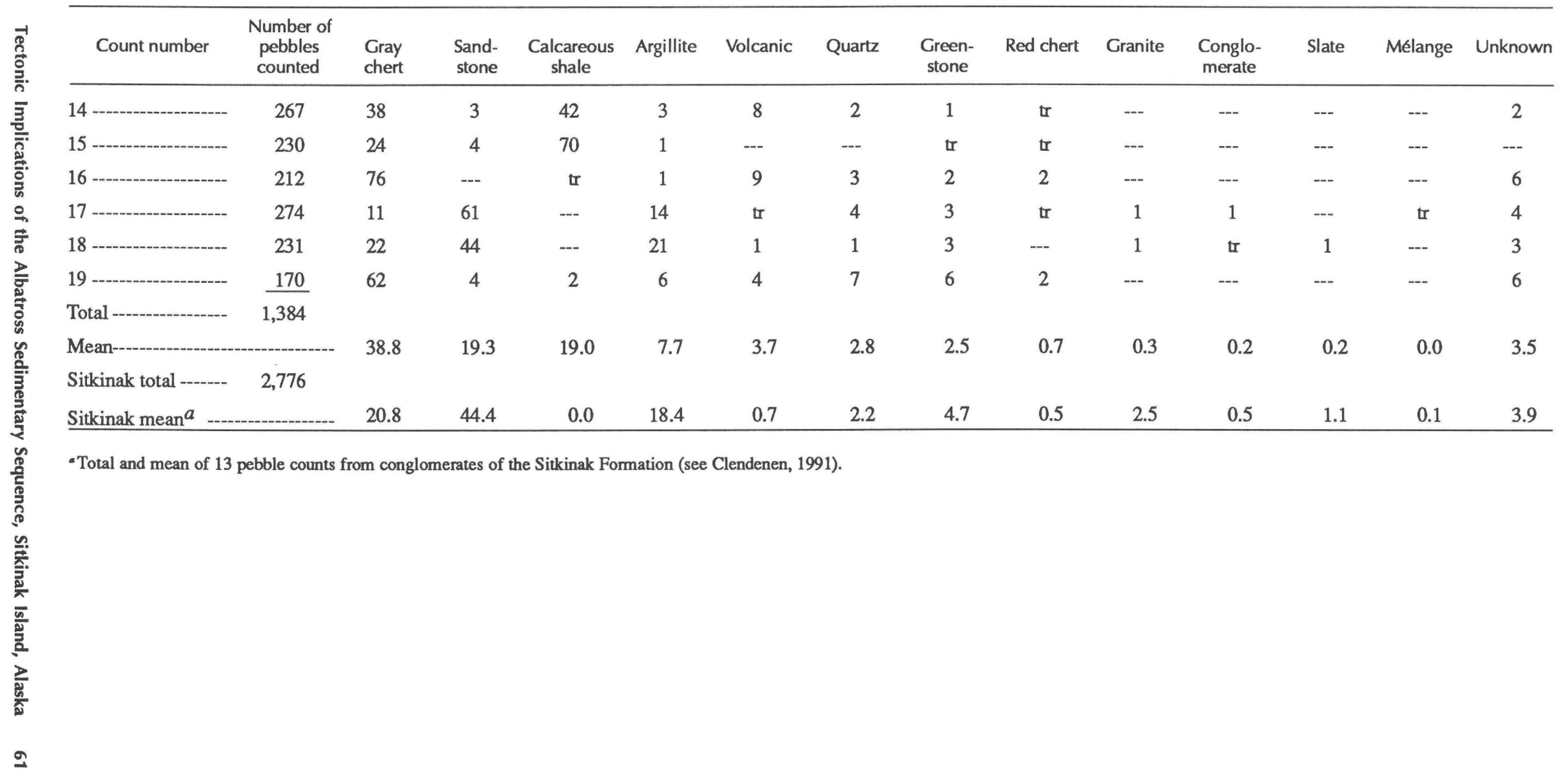


Table 4. Microfossils identified in calcareous-shale clasts from the Albatross sedimentary sequence [-, not present; $x$, present; ?, questionable identification]

\begin{tabular}{|c|c|c|c|c|c|c|c|c|c|c|c|c|c|c|c|}
\hline \multirow[b]{2}{*}{ Species } & \multicolumn{15}{|c|}{ Samples } \\
\hline & 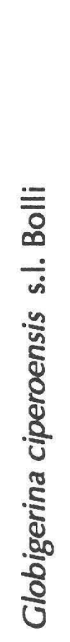 & 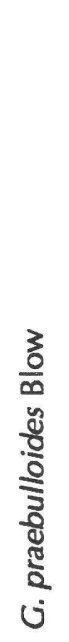 & 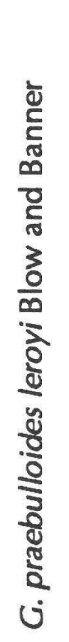 & 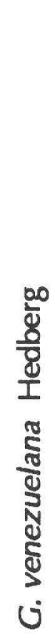 & 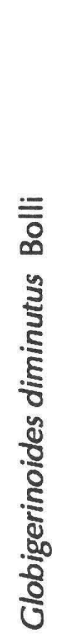 & 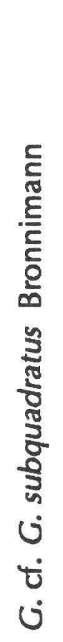 & 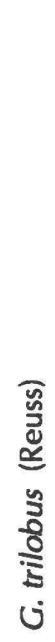 & 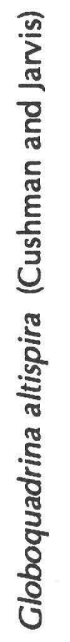 & 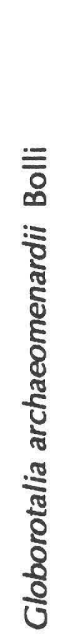 & 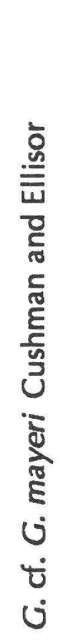 & 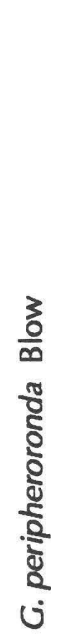 & 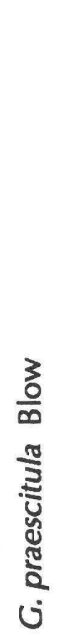 & 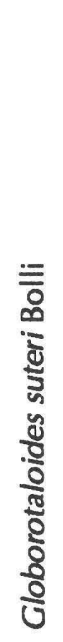 & 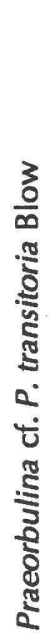 & 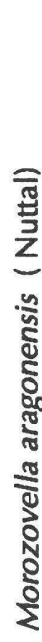 \\
\hline SK-10D-87 & $\mathrm{x}$ & - & $\mathrm{x}$ & $\mathrm{x}$ & - & - & $\mathbf{x}$ & $\mathbf{x}$ & $\mathrm{x}$ & - & $\mathrm{x}$ & - & - & - & - \\
\hline SK-10G-87 & $\mathbf{x}$ & - & $\mathrm{x}$ & - & - & - & - & - & - & - & - & - & - & - & - \\
\hline SK-2-87 & $\mathrm{x}$ & $\mathbf{x}$ & $\mathbf{x}$ & - & - & - & $?$ & - & - & $?$ & $\mathbf{x}$ & - & $\mathbf{x}$ & - & - \\
\hline N-1b-88-C & - & - & - & - & - & $?$ & $?$ & - & - & - & $\mathbf{x}$ & - & - & - & - \\
\hline N-1b-88-E & $\mathrm{x}$ & - & $\mathrm{x}$ & - & - & - & - & $\mathrm{x}$ & - & - & $\mathbf{x}$ & - & - & $\mathrm{x}$ & - \\
\hline N-1b-88-F & - & $\mathrm{x}$ & - & - & - & - & $\mathbf{x}$ & - & - & $?$ & - & - & - & - & - \\
\hline N-1b-88-G & - & - & - & - & $\mathrm{x}$ & - & - & - & - & - & - & - & - & - & - \\
\hline N-1b-88-J & - & - & $\mathrm{x}$ & - & - & - & - & - & - & - & $\mathbf{x}$ & - & - & - & $\mathrm{x}$ \\
\hline N-1b-88-L & $\mathrm{x}$ & - & $\mathrm{x}$ & - & - & - & - & - & - & - & - & - & - & - & - \\
\hline N-1b-88-U & $\mathbf{x}$ & - & - & - & - & - & - & - & - & - & - & - & - & - & - \\
\hline N-3-88-A & $\mathrm{x}$ & - & - & - & - & - & - & - & - & - & - & - & - & - & - \\
\hline N-3-88-E & $\mathrm{x}$ & - & $\mathbf{x}$ & - & - & - & - & - & - & - & $\mathrm{x}$ & - & - & - & - \\
\hline N-3-88-W & $\mathbf{x}$ & - & $\mathrm{x}$ & - & - & - & - & - & - & - & - & - & - & - & - \\
\hline N-3-88-Z & $\mathrm{x}$ & - & - & - & - & - & - & - & - & $\mathrm{x}$ & - & - & - & - & - \\
\hline N-4-88-L & - & - & $\mathrm{x}$ & - & - & $\mathrm{x}$ & $?$ & - & - & - & $\mathrm{x}$ & $x$ & - & - & - \\
\hline $\mathrm{N}-4-88-\mathrm{N}$ & $\mathrm{x}$ & - & $\mathrm{x}$ & - & - & - & $?$ & - & - & - & - & - & - & - & - \\
\hline N-4-88-O & $\mathrm{x}$ & - & $\mathrm{x}$ & - & $?$ & - & - & $\mathbf{x}$ & - & $?$ & $\mathbf{x}$ & $\mathrm{x}$ & $?$ & - & - \\
\hline N-4-88-AA & $\mathrm{x}$ & - & $\mathrm{x}$ & - & - & - & - & $\mathrm{x}$ & $\mathrm{x}$ & - & $\mathrm{x}$ & - & - & - & - \\
\hline N-4-88-CC & - & - & - & - & - & - & - & - & $\mathbf{x}$ & - & - & - & - & - & - \\
\hline
\end{tabular}


sense the abundance of this fauna would suggest that water depths approached the deeper end of the range, near 4,000 m. Van Andel and others (1975) estimated that the equatorial Pacific CCD was near $4,500 \mathrm{~m}$ water depth during most of the Miocene. A northward rise in the CCD would be expected; however, the rise should have been less than at present owing to the warmer paleotemperatures of the early Miocene.

An intriguing similarity in foraminiferal faunas is found at Deep Sea Drilling Project (DSDP) Site 178 located on the western Alaskan Abyssal Plain (fig. 2) at a water depth of $4,218 \mathrm{~m}$. Core 54 recovered a multicolored chalk that contains a planktic fauna dated as early Miocene (N5 to N7). The abundant and well-preserved fauna includes several species in common with the present samples, such as Globorotalia praescitula Blow and Globorotaloides suteri Bolli. Further, the benthic fauna, although different than that of the present samples, is dominated by well-preserved, calcareous species of the lower bathyal-abyssal biofacies (Ingle, 1973, p. 554). The presence of the carbonate material at that depth and latitude was considered puzzling. Subsequently, hiatuses at Site 178 were backtracked by Keller and Barron (1987) and shown to range from $4,200 \mathrm{~m}$ at $18 \mathrm{Ma}$ to 4,260 $\mathrm{m}$ at $15 \mathrm{Ma}$. Thus, several lines of evidence suggest that the depositional site was situated near $4,000 \mathrm{~m}$ and yet above the CCD.

In summary, all the clast data indicate that the calcareous shale was originally deposited during the late early Miocene in deep, relatively warm water. The presence of these deep-water calcareous-shale clasts within the Albatross sedimentary sequence implies that after deposition at a $4 \mathrm{~km}$ water depth, the calcareous shale was uplifted, eroded, and deposited on top of the accretionary prism. After deposition, the Albatross sedimentary sequence was buried and deformed before being uplifted and exposed at the surface today. It must be emphasized that all of this sequence of events took place during the past 15-17 m.y., highlighting the rapidity of tectonism at this convergent margin during the late Cenozoic.

From the perspective of Sitkinak Island stratigraphy, these results are important because they constrain the age of the Albatross sedimentary sequence to be younger than early Miocene, indicating that it is indeed distinct from the Sitkinak Formation. In fact, the large amount of uplift that must have taken place between the time of original deposition of the calcareous shale and its erosion and redeposition as clasts in the Albatross sedimentary sequence indicates that the age of the Albatross sedimentary sequence may be significantly younger than early Miocene. Unfortunately, the only sample we analyzed from the Albatross sedimentary sequence that would have given its age directly, shale sample N-1a-88 (table 1), was barren of microfossils. In any case, the geologically permissible age of the Albatross sedimenta- ry sequence (middle Miocene to present) is the same as the range in age of the sediments filling the offshore shelf basins (Turner, 1987), indicating that the Albatross sedimentary sequence is probably an onland exposure of some part of them. All of this still leaves the question of provenance of the calcareous-shale clasts unanswered, although their deposition in deep water indicates that one might look to the continental margin for their source.

\section{Uplifted Shelf Break as a Possible Source}

A migrated line drawing from seismic-reflection line 509 (fig. 2) across Albatross bank (Fisher and von Huene, 1980, fig. 5) clearly shows the homoclinal flexure that has accommodated a large amount of uplift and has led to the exposure and erosion of the basin sediments (fig. 6A). The seismic horizons recognized throughout the shelf basins (Fisher and von Huene, 1980) are also shown in figure 6. Horizon A represents the Pliocene-Pleistocene boundary (Fisher and von Huene, 1980; Turner, 1987), while the sediments immediately above horizon $\mathrm{C}$ are middle Miocene in age in the nearest DST well (KSSD3; fig. 2) (Turner, 1987). Horizon $\mathrm{C}$ also represents the base of the shelf basins nearly everywhere (fig. 2), except in the area of Albatross bank, where there is another, older package of layered strata below horizon $\mathrm{C}$ and floored by horizon $\mathrm{D}$ (fig. 6A). Dredging across Albatross bank between the surface traces of seismic horizons C and D retrieved samples as old as late early Miocene in age (McClellan and others, 1982), indicating that rocks that are the same age as the calcareous shale are present there. Although not described in detail, carbonate samples (particularly concretions) were also collected from the same region (McClellan and others, 1982), indicating that rocks that are lithologically similar to the calcareous shale are present on Albatross bank.

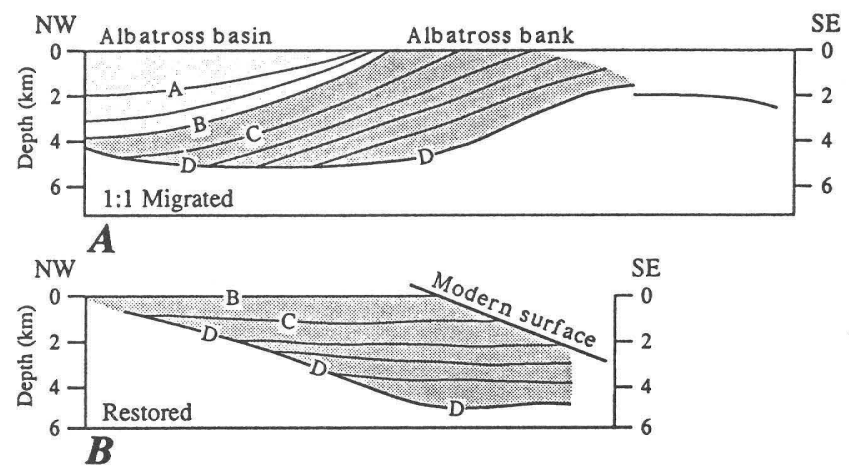

Figure 6. Migrated part of seismic line 509 across Albatross bank (location shown in fig. 2). $A$, Depth section without vertical exaggeration. $B$, Section with horizon $B$ restored to horizontal, showing approximate configuration of basin sediments before Albatross bank began to grow. From Fisher and von Huene (1980, fig. 5); reprinted by permission of the author and publisher. 
Horizon B marks the boundary between seawardthickening strata below and landward-thickening units above (fig. 6A) and therefore records the time that this part of the shelf break began to be uplifted (Fisher and von Huene, 1980). The strata are shown in figure $6 B$ as they would have been at the time horizon $B$ was deposited, assuming that it was originally horizontal and deposited at sea level. However, horizon B probably sloped offshore and was certainly deposited below sea level, indicating that the actual depths of deposition were probably deeper than those shown on figure $6 B$. The important point to note is that the layered sequence between horizons $\mathrm{C}$ and $\mathrm{D}$ was deposited in water depths similar to conditions indicated for the calcareous shale. Together, the similarity in age, environment of deposition, and lithology between the calcareous-shale clasts and rocks present across Albatross bank indicate that the uplifted shelf break could be the source of the calcareous-shale clasts found within the Albatross sedimentary sequence.

The age of horizon B, and thus the time of uplift of the shelf break, can be inferred using paleocurrent data from the nearby DST well KSSD3 (fig. 2), although age control is poor owing to the relatively sparse fauna (Turner, 1987). Currents during the Miocene were directed offshore (fig. 7A), indicating deposition across a broad slope. In marked contrast, currents during the Pliocene and early Pleistocene were predominantly to the southwest (fig. $7 B$ ), parallel to the trend of the continental margin. This pattern suggests that significant uplift of the shelf break began in the late Miocene or early Pliocene as a result of the rapid accretion of sediment underlying the slope. Thereafter, the shelf break may have formed a sediment dam behind which the shelf basins were filled. Currents during the later part of the Pleistocene have no preferred direction (fig. $7 C$ ), probably indicative of glaciomarine deposition across the shelf (Turner, 1987).

Information from offshore and the local stratigraphy can be used to constrain the age of the Albatross sedimentary sequence. If the shelf break is the source of the calcareous shale, and if the dramatic change in paleocurrents at DST well KSSD3 records its growth, then the calcareous shale could not have been supplied to the Albatross sedimentary sequence before the late Miocene, and thus the Albatross sedimentary sequence is late Miocene or younger in age. A further constraint comes from the local stratigraphy. It is probable that the Albatross sedimentary sequence belongs to the same stratigraphic sequence as the nearby late Pliocene and Pleistocene Tugidak Formation. However, the base of the Albatross sedimentary sequence is exposed, whereas the bottom of the Tugidak Formation is not seen, strongly suggesting that the Albatross sedimentary sequence is stratigraphically lower than the Tugidak Formation and therefore older than Pleistocene. Together, these data suggest that
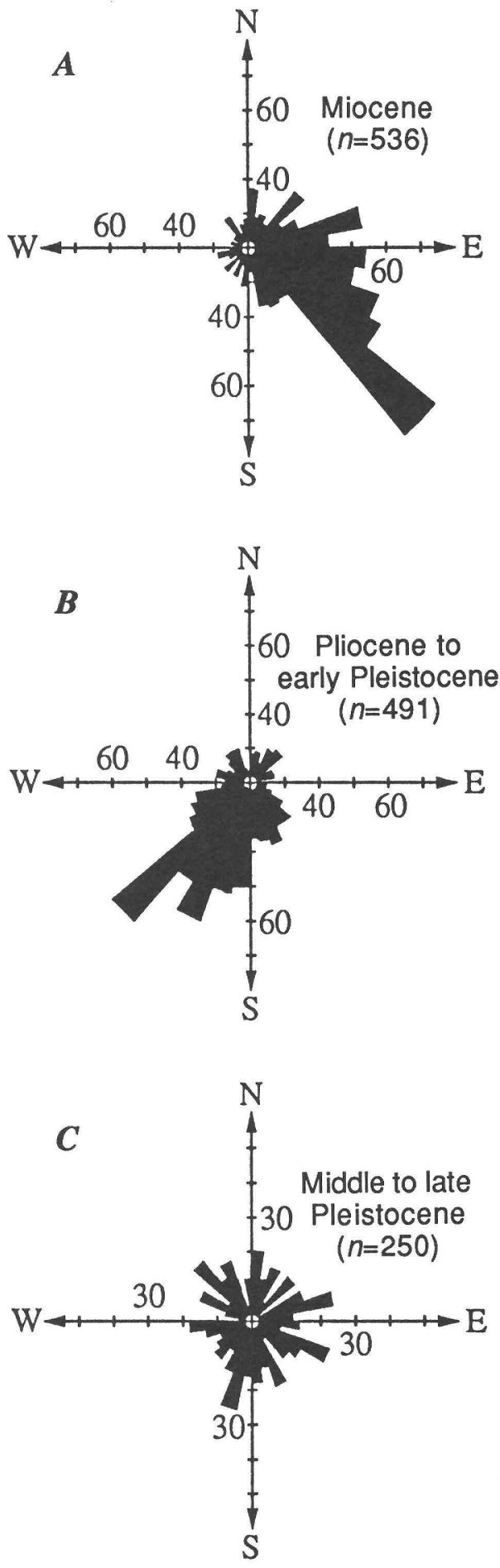

Figure 7. Rose diagrams of dip azimuth frequency from shelf-basin sediments penetrated by DST well KSSD3 (fig. 2). Change in preferred azimuth from southeast to southwest near end of Miocene probably reflects shift in paleocurrent direction caused by growth of Albatross bank (fig. 2), which channeled flow parallel to margin. $n$, sample size. From Turner (1987, pl. 7). 
the Albatross sedimentary sequence is late Miocene or Pliocene in age.

\section{Implications of the Albatross Sedimentary Sequence}

Our interpretation of the Neogene history of the accretionary prism (fig. 8) illustrates the differences between the two basinal sequences exposed on Sitkinak Island. The Oligocene Sitkinak Formation (fig. 8A) was probably never extensive, and the underlying angular unconformity is only of local importance. The angular unconformity between the Sitkinak Formation and the overlying Albatross sedimentary sequence, however, is more significant and most probably correlates with the region- ally extensive seismic horizon C (and, locally, horizon D) offshore (figs. 8,9). The modern shelf basins were initially formed in the early Miocene when the sediment between horizons $\mathrm{C}$ and $\mathrm{D}$ (fig. 6) was deposited locally behind a slowly growing accreting wedge (fig. $8 B$ ). As discussed earlier, these sediments may include the calcareous shale that is presently found as clasts within conglomerates of the Albatross sedimentary sequence. Sedimentation within the shelf basins increased rapidly after the late Miocene as the accretionary wedge beneath the slope grew rapidly (fig. 8C; Clendenen, 1991).

Our correlation between the Eocene and younger rock units exposed on land and the sediments filling the shelf basins offshore is shown in figure 9. It shows the limited extent of the Sitkinak Formation, the siltstone of Trinity Islands, and the underlying angular unconformi-
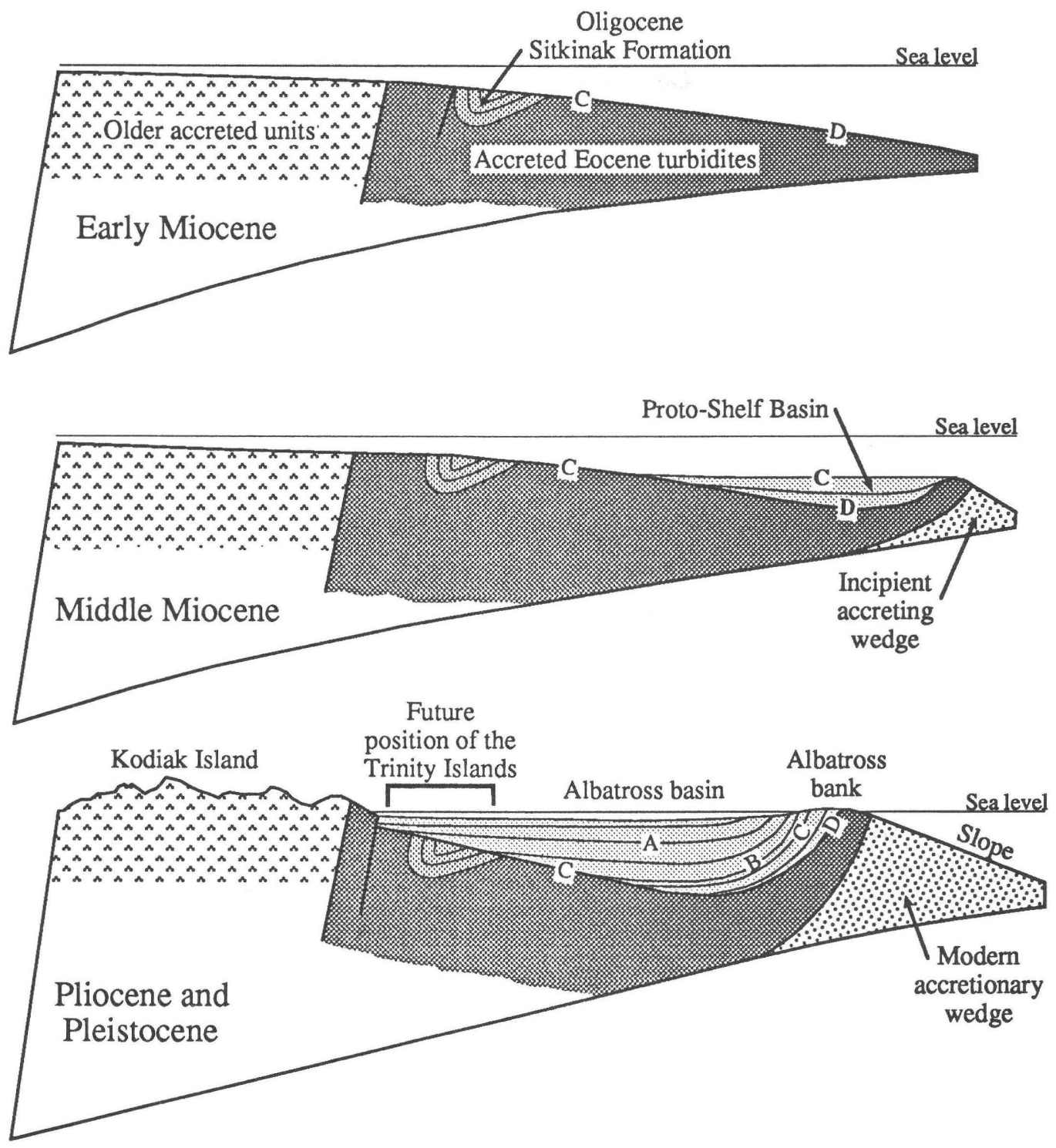

Figure 8. Schematic interpretation of late Cenozoic evolution of accretionary prism. Letters refer to features discussed in text. 
ty. In contrast, the angular unconformity beneath the Albatross sedimentary sequence is regionally extensive and correlates with the unconformity beneath the shelf basins offshore. Sediments directly above this unconformity are time transgressive, ranging in age from at least as old as the late early Miocene in the Albatross basin to presumably late Miocene or Pliocene on Sitkinak Island (fig. 9). Basin strata above the unconformity lap onto it from seaward to landward. In addition, basin strata thin appreciably across and lap onto the anticline that extends from the shelf break to Sitkinak Island (fig. 2), explaining why the Albatross sedimentary sequence is younger than other units above the unconformity.

The Albatross sedimentary sequence is important from the perspective of the shelf basins themselves because it provides information about the provenance of sediments filling them. During deposition of the Albatross sedimentary sequence, the basins received sediment primarily from the emergent accretionary prism to the northwest and also probably from an emergent and actively eroding shelf break. Therefore, much of the material within the intraprism shelf basins came directly from erosion of the accretionary prism itself.

\section{DISCUSSION}

The pattern of uplift across the modern, partially submerged accretionary prism is complex. Both the Kodiak area and the shelf break have undergone uplift and erosion, whereas the forearc and shelf basins have been sites of subsidence and sedimentation. Analysis of rocks from the Albatross sedimentary sequence shows that the extensive shelf basins contain material that was eroded from both the Kodiak area and the uplifted shelf break. However, it is not clear what mechanism was responsi-

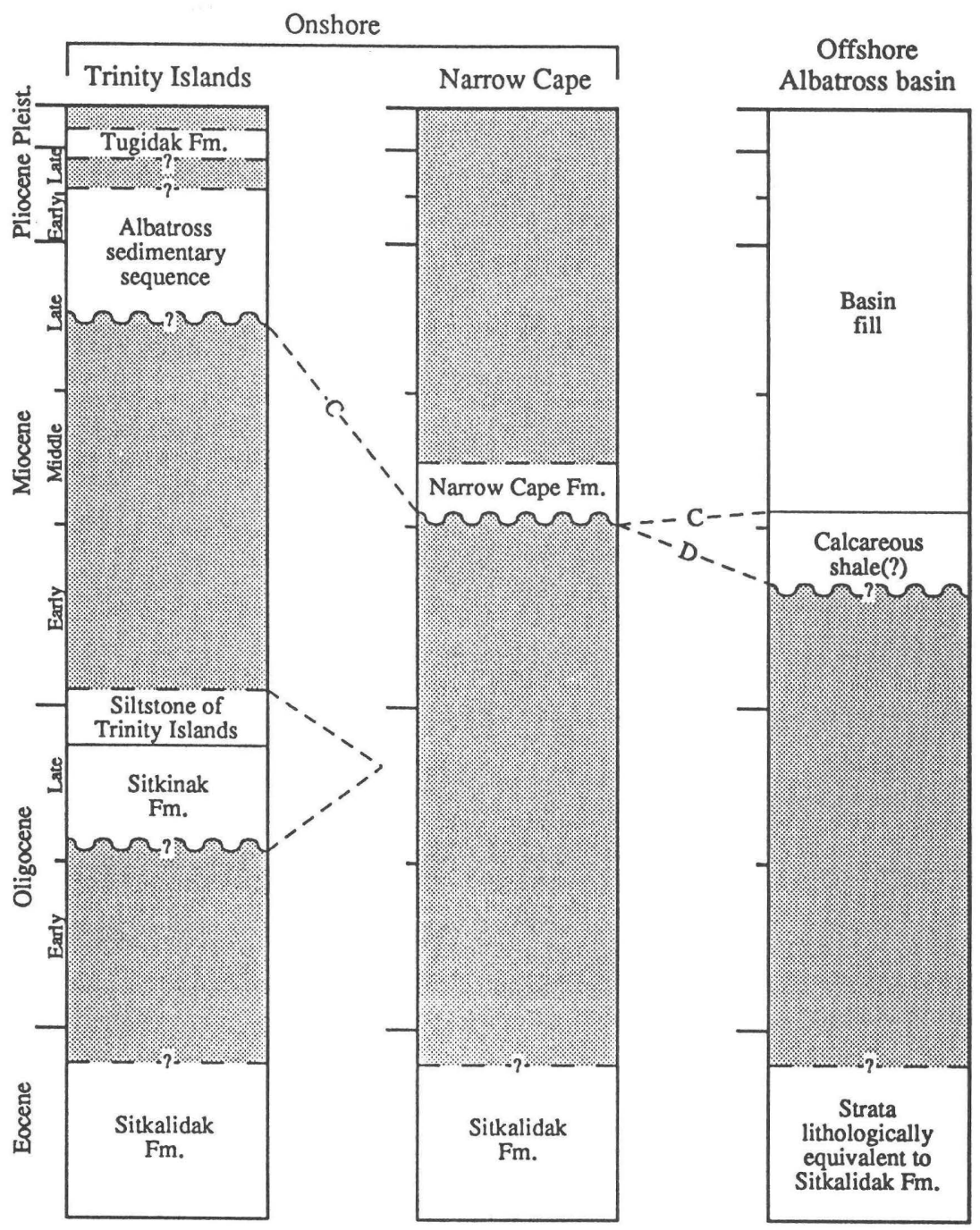

Figure 9. Correlation diagram for Eocene and younger rock units, and angular unconformities exposed onshore and within shelf basins offshore. Letters refer to seismic horizons discussed in text and shown in figure 6. 
ble for the large amount of intraprism subsidence recorded by these basins.

\section{The Role of Glacially Derived Sediment}

Sedimentation increased rapidly throughout the region during the late Cenozoic. This voluminous sediment supply has been important both for the late Cenozoic growth of the accretionary prism and for the recent evolution of the shelf basins. Prior to the late Cenozoic, only a thin layer of pelagic material covered the Pacific plate beneath the Gulf of Alaska (Kulm and others, 1973; Stevenson and Embley, 1987). However, during the late Miocene, voluminous terrigenous turbidite sedimentation began in the area and increased markedly throughout the Pliocene and Pleistocene (Stevenson and Embley, 1987). This great increase in sedimentation was due to the glaciation of tectonically formed mountains around the Gulf of Alaska (Stevenson and Embley, 1987; Marincovich, 1990). Today, the entire Gulf of Alaska abyssal plain is underlain by up to several kilometers of clastic sediment that is being carried on the Pacific plate to the Aleutian trench, where much of it will eventually be accreted.

The glacially caused increase in clastic sedimentation recorded throughout the region during the late $\mathrm{Ce}$ nozoic is probably the principal factor ultimately responsible for the rapid recent growth of the accretionary prism, uplift of the shelf break and slope, and growth of the shelf basins. The late Cenozoic influx of terrigenous sediments onto the Pacific plate and down the Aleutian Trench led directly to a dramatic increase in the amount of material accreted to the accretionary prism. The wedge of clastic material beneath the slope of the accretionary prism grew in step with sedimentation on the subducting oceanic plate and caused uplift of the shelf break. The uplifting shelf break provided an effective sill, behind which the shelf basins were filled (fig. 8). The increase in glacially derived sediment supplied directly to the shelf basins was also crucial, because it kept the basins full and led to additional subsidence driven by sediment loading (Clendenen, 1991).

\section{Mechanisms of Accretion and the Pattern of Secular Uplift and Subsidence Across the Accretionary Prism}

The presence within the accretionary prism of extensive, subsiding shelf basins between two areas undergoing active uplift is puzzling. It is also unclear why the shelf basins are not more deformed themselves. Recent compressional deformation seems to be largely confined to the wedge of material beneath the slope. The contrast in the degree of recent deformation across the shelf break may be explained by a difference in the mechanical strength of the Eocene rocks beneath the shelf relative to the young, accreted sediments between the shelf break and trench. The Eocene rocks are highly compacted and lithified (Turner, 1987), whereas the newly accreted material is probably only partly consolidated and lithified. The shelf-basin sediments also probably played an important role by buttressing the shelf break as it was uplifted. The total effect may have been for the relatively strong accretionary prism underlying the shelf to act as a local "backstop," against which the weaker material beneath the slope was accreted.

At the Aleutian trench, about half of the total sediment accumulation of 2 to $5 \mathrm{~km}$ is being offscraped and added to the margin at the toe of the accretionary prism (Kvenvolden and von Huene, 1985). The lower half of the sediment cover is being underthrust beneath the prism, remaining undeformed and attached to the subducting plate for the approximately $30 \mathrm{~km}$ that it can be observed seismically (von Huene, 1989). This material may be carried on the subducting plate and eventually underplated beneath the uplifting Kodiak area. Prominent seismic reflectors observed beneath the Kodiak Island area probably represent material that was underplated during a middle Tertiary episode of accretion (Byrne, 1986; Clendenen, 1991; Moore and others, 1991). Perhaps the bottom part of these reflectors is material that was underplated during the late Cenozoic, causing uplift of the Kodiak area.

Our preferred model for accretion during the late Cenozoic is shown in figure 10. In this model the accretionary prism is thickened vertically both by offscraping at the toe and by underplating at depth. Between the zone of underplating and the zone of offscraping is an area where sediment on top of the subducting plate is underthrust beneath the prism. Underthrusting of this undeformed sediment on top of the oceanic plate implies the presence of a weak décollement above it (Davis and von Huene, 1987). The weak décollement is probably caused by very high pore pressures, resulting from the progressive dewatering of these rapidly deposited, submarine sediments (Byrne and Fisher, 1990). The décollement may progressively gain strength with depth, and at some point slip is transferred downward to the top of the igneous oceanic crust. The end result is that the underthrusted sediment pile is underplated at depth beneath the accretionary prism (see, for example, Byrne and Fisher, 1990). Vertical thickening of the accretionary prism by underplating at the base and offscraping at the toe results in the loading and downward flexure of the underlying oceanic lithosphere (Karig and others, 1976). This downward flexure leads to subsidence of the shelf basins.

An important part of our model is the coupling of erosion and sedimentation within the accretionary prism. 
The combined effect has been to remove material from emergent areas overlying the zones of underplating and offscraping and to transport it to the subsiding shelf basins. This effect is recorded well by the Albatross sedimentary sequence, which shows that sediment filling the shelf basins came from both the emergent Kodiak area and the emergent shelf break. In fact, erosion and sedimentation may be just as important as internal deformation in transporting mass within the accreting system (compare with Platt, 1986). The coupling of erosion and sedimentation thus provides an effective means of maintaining the taper of the accretionary prism, in spite of the complex pattern of uplift and subsidence across it.

The long-term uplift pattern shown in figure 10 is reversed relative to that observed during present-day coseismic deformation (Plafker, 1972). This suggests that interseismic vertical deformation exceeds coseismic uplift. In fact, Savage and Plafker (1991) document uplift rates along southern Alaska during the past 20 years that are also opposite in sense compared with 1964 coseismic deformation. If interseismic vertical deformation exceeds coseismic uplift, then the relatively rapid uplift rates recorded by Savage and Plafker (1991) reflect the secular uplift trend. We believe that secular uplift across the southern Alaska convergent margin is dominated by interseismic deformation and is driven primarily by the growth of the accretionary prism.

Acknowledgments.-This work was supported by NSF grant EAR-8707993 to Byrne and by grants to
Clendenen from the Geological Society of America and Sigma Xi. We wish to express our appreciation to Casey Moore for providing unpublished information from Sitkinak Island and the Minerals Management Service for data from the Kodiak Shelf wells. We also thank the U.S. Coast Guard, B. Heine, J. P. Dick, and D. Fisher for assistance in the field. Clendenen and Byrne thank Bob and Rosella Godfrey for providing superb accommodations on Sitkinak Island.

\section{REFERENCES CITED}

Allison, R.C., 1978, Late Oligocene through Pleistocene molluscan faunas in the Gulf of Alaska region: Veliger, v. 21, p. 171-188.

Allison, R.C., and Marincovich, L., Jr., 1981, A late Oligocene or earliest Miocene molluscan fauna from Sitkinak Island, Alaska: U.S. Geological Survey Professional Paper 1233, $11 \mathrm{p}$.

Armentrout, J.M., 1979, Cenozoic stratigraphy, Kodiak Island Archipelago, Alaska [abs.]: Geological Society of America Abstracts with Programs, v. 11, p. 66.

Berggren, W.A., Kent, D.V., Flynn, J.J., and van Couvering, J.A., 1985, Cenozoic geochronology: Geological Society of America Bulletin, v. 96, p. 1407-1418.

Blow, W.H., 1969, Late middle Eocene to Recent planktonic foraminiferal bio-stratigraphy, in First International Conference on Planktic Microfossils: Leiden, The Netherlands, E. J. Brill, p. 199-421.
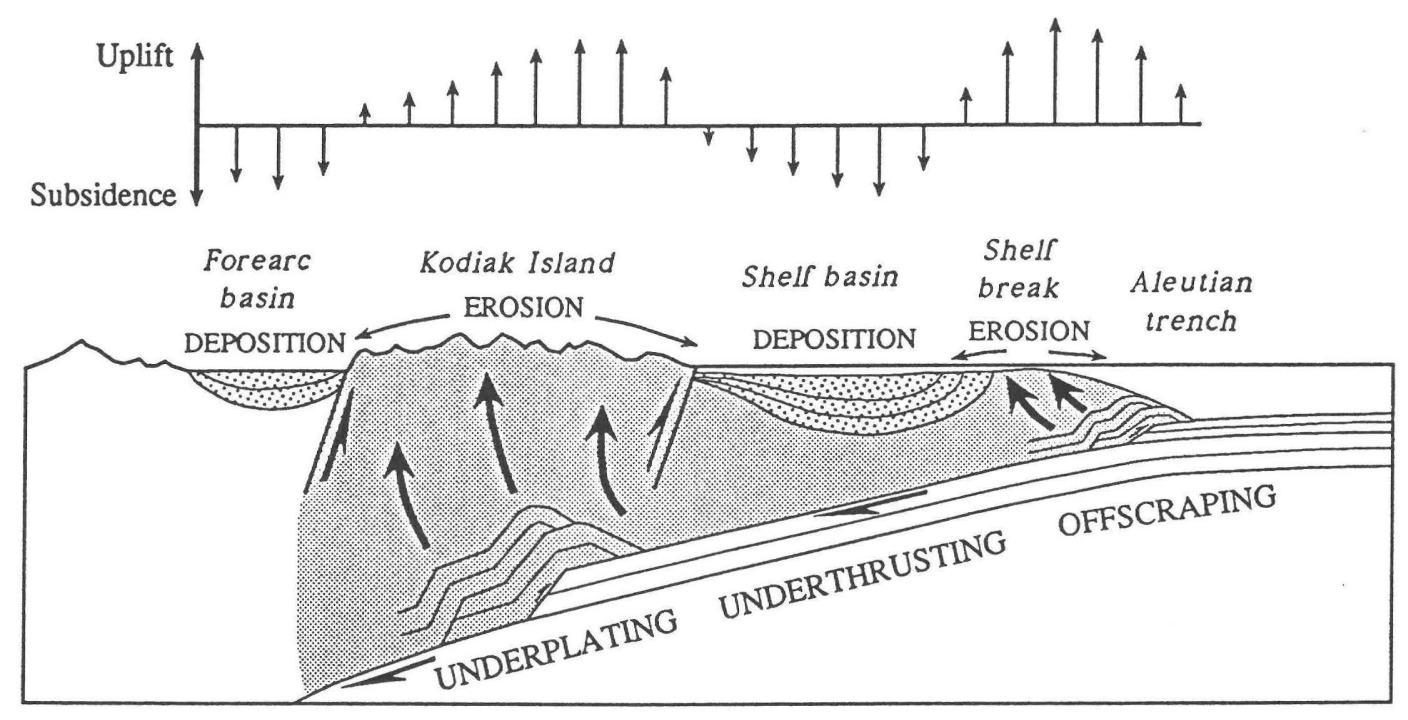

Figure 10. Pattern of uplift and subsidence across modern southern Alaska convergent margin and mechanisms of accretion, which may be driving it. Toe of accretionary prism is thickening by offscraping that has driven uplift of slope and shelf break. Underplating may be causing vertical growth of prism below emergent Kodiak area, leading to uplift and erosion. In contrast, area of accretionary prism beneath shelf basins has not been appreciably thickened by accretion or deformation. Resultant effect has been to isostatically depress the underlying, subducting oceanic lithosphere, causing subsidence of shelf basins. Heavy arrows show predicted material flow lines through accretionary prism; half-arrow indicates direction of relative movement. 
Byrne, T., 1986, Eocene underplating along the Kodiak shelf, Alaska: Implications and regional correlations: Tectonics, v. 5 , p. $403-421$.

Byme, T., and Fisher, D., 1990, Evidence for a weak and overpressured décollement beneath sediment-dominated accretionary prisms: Journal of Geophysical Research, v. 95, p. 9081-9097.

Clendenen, W.S., 1991, Thermal history and vertical tectonics of the southern Alaska convergent margin: Providence, R.I., Brown University, Ph.D. dissertation, 177 p.

Connelly, W., and Moore, J.C., 1979, Geologic map of the northwest side of the Kodiak and adjacent islands, Alaska: U.S. Geological Survey Miscellaneous Field Studies Map MF-1057, scale 1:250,000, 2 sheets.

Davis, D.M., and von Huene, R., 1987, Inferences on sediment strength and fault friction from structures at the Aleutian Trench: Geology, v. 15, p. 517-522.

Davis, D., Suppe, J., and Dahlen, F.A., 1983, Mechanisms of fold-and-thrust belts and accretionary wedges: Journal of Geophysical Research, v. 88, p. 1153-1172.

Eyles, C.H., Eyles, J., and Miall, A.D., 1985, Models of glaciomarine sedimentation and their application to the interpretation of ancient glacial sequences: Palaeogeography, Palaeoclimatology, Palaeoecology, v. 51, p. 15-84.

Fisher, M.A., Detterman, R.L., and Magoon, L.B., 1987, Tectonics and petroleum geology of the Cook-Shelikof Basin, southern Alaska, in Scholl, D.W., Grantz, A., and Vedder, J.G., eds., Geology and resource potential of the continental margin of western North America and adjacent ocean basins-Beaufort Sea to Baja California: Houston, Texas, Circum-Pacific Council for Energy and Mineral Resources, Earth Science Series, v. 6, p. 213-228.

Fisher, M.A., and von Huene, R., 1980, Structure of upper Cenozoic strata beneath Kodiak Shelf, Alaska: American Association of Petroleum Geologists Bulletin, v. 64, p. $1014-1033$.

Ingle, J.C., Jr., 1973, Neogene Foraminifera from the northeastern Pacific Ocean, Leg 18, Deep Sea Drilling Project, in Kulm, L.D., von Huene, R.E., and others, Initial Reports, Deep Sea Drilling Project: Washington, D.C., Government Printing Office, v. 18, p. 517-567.

Karig, D.E., Caldwell, J.G., and Parmentier, E.M., 1976, Effects of accretion on the geometry of the descending lithosphere: Journal of Geophysical Research, v. 81, p. 62816291.

Keller, G., and Barron, J.A., 1987, Paleodepth distribution of Neogene deep-sea hiatuses: Paleoceanography, v. 2, p. 697-713.

Kulm, L.D., von Huene, R., Duncan, J.R., Ingle, J.C., Kling, S.A., Musich, L.F., Piper, D.J. W., Pratt, R.M., Schroder, H.J., Weser, O., and Wise, S.W., 1973, Initial Reports, Deep Sea Drilling Project: Washington, D.C., Government Printing Office, v. 18, 1077 p.

Kvenvolden, K.A., and von Huene, R., 1985, Natural gas generation in sediments of the convergent margin of the eastern Aleutian Trench area, in Howell, D.G., ed., Tectonostratigraphic terranes of the circum-Pacific Region: Houston, Texas, Circum-Pacific Council for Energy and Mineral Resources, Earth Science Series, v. 1, p. 31-49.

Marincovich, L., Jr., 1990, Molluscan evidence for early middle Miocene marine glaciation in southern Alaska: Geological Society of America Bulletin, v. 102, p. 15911599.

Marincovich, L., Jr., and Moriya, S., 1991, Early middle Miocene mollusks and benthic foraminifers from Kodiak Island, Alaska, in Bradley, D.C., and Ford, A.B., eds., Geologic studies in Alaska by the U.S. Geological Survey, 1990: U.S. Geological Survey Bulletin [this volume].

McClellan, P.H., Fisher, M.A., von Huene, R., and Moore, G.W., 1982, Summary and discussion of microfossil biostratigraphy in the western Gulf of Alaska, in Coonrad, W.L., ed., The U.S. Geological Survey in Alaska: Accomplishments during 1980: U.S. Geological Survey Circular 844 , p. $148-151$.

Moore, G.W., 1967, Preliminary geologic map of Kodiak Island and vicinity, Alaska: U.S. Geological Survey openfile map 271 , scale $1: 250,000,1$ sheet.

1969, New formations on Kodiak and adjacent islands, Alaska: U.S. Geological Survey Bulletin 1274A, p. A27A35.

Moore, J.C. and Allwardt, A., 1980, Progressive deformation of a Tertiary trench slope, Kodiak Islands, Alaska: Journal of Geophysical Research, v. 85, p. 4741-4756.

Moore, J.C., Byrne, T., Plumley, P.W., Reid, M., Gibbons, H., and Coe, R.S., 1983, Paleogene evolution of the Kodiak Islands, Alaska: Consequences of ridge-trench interaction in a more southerly latitude: Tectonics, v. 2, p. 265-293.

Moore, J.C., Diebold, J., Fisher, M.A., Sample, J., Brocher, T., Talwani, M., Ewing, J., von Huene, R., Rowe, C., Stone, D., Stevens, C., and Sawyer, D., 1991, Edge deep seismic reflection transect of the eastern Aleutian arc-trench layered lower crust reveals underplating and continental growth: Geology, v. 19, p. 420-424.

Nilsen, T.H., and Moore, G.W., 1979, Reconnaissance study of Upper Cretaceous to Miocene stratigraphic units and sedimentary facies, Kodiak and adjacent islands, Alaska: U.S. Geological Survey Professional Paper 1093, 34 p.

Pavlis, T.L., and Bruhn, R.L., 1983, Deep-seated flow as a mechanism for the uplift of broad forearc ridges and its role in the exposure of high P/T metamorphic terranes: Tectonics, v. 2, p. 473-497.

Plafker, G., 1972, Tectonics, in Krauskopf, K.B., ed., The great Alaska earthquake of 1964: Seismology and geodesy: Washington, D.C., National Academy of Sciences, p. 112188.

Plafker, G., and Addicott, W.O., 1976, Glaciomarine deposits of Miocene through Holocene age in the Yakataga Formation along the Gulf of Alaska margin, Alaska, in Miller, T.P., ed., Recent and ancient sedimentary environments in Alaska: Anchorage, Alaska Geological Society Symposium Proceedings, p. Q1-Q23.

Platt, J.P., 1986, Dynamics of orogenic wedges and the uplift of high-pressure metamorphic rocks: Geological Society of America Bulletin, v. 97, p. 1037-1053.

Roeske, S.M., Mattison, J.M., and Armstrong, R.L., 1989, Isotopic ages of glaucophane schists on the Kodiak Islands, southern Alaska, and their implications for the Mesozoic tectonic history of the Border Ranges fault system: Geological Society of America Bulletin, v. 101, p. 1021-1037.

Savage, J.C., and Plafker, G., 1991, Tide gage measurements 
of uplift along the south coast of Alaska: Journal of Geophysical Research, v. 96 , p. $4325-4335$.

Stevenson, A.J., and Embley, R., 1987, Deep-sea fan bodies, terrigenous turbidite sedimentation, and petroleum geology, Gulf of Alaska, in Scholl, D.W., Grantz, A., and Vedder, J.G., eds., Geology and resource potential of the continental margin of western North America and adjacent ocean basins-Beaufort Sea to Baja California: Houston, Texas, Circum-Pacific Council for Energy and Mineral Resources, Earth Science Series, v. 6, p. 503-522.

Turner, R.F., ed., 1987, Geological and operational summary, Kodiak Shelf stratigraphic test wells, western Gulf of Alaska: Anchorage, Alaska, U.S. Department of the Interior, Minerals Management Service, $341 \mathrm{p}$.

van Andel, T.H., Heath, G.R., and Moore, T.C., 1975, Cenozoic history and paleoceanography of the central Equatorial Pacific: Geological Society of America Memoir 143, $134 \mathrm{p}$.

von Huene, R., 1979, Structure of the outer continental margin off Kodiak Island, Alaska, from multichannel seismic records: American Association of Petroleum Geologists Memoir 29, p. 261-272.

1989, Continental margins around the Gulf of Alaska, in Winterer, E.L., Hussong, D.M., and Decker, R.W., eds., The eastern Pacific Ocean and Hawaii: Boulder, Colorado, Geological Society of America, The Geology of North America, DNAG Series, v. N, p. 383-401.

von Huene, R., Fisher, M.A., and Bruns, T.R., 1987, Geology and evolution of the Kodiak margin, Gulf of Alaska, in Scholl, D.W., Grantz, A., and Vedder, J.G., eds., Geology and resource potential of the continental margin of western North America and adjacent ocean basins-Beaufort Sea to Baja California: Houston, Texas, Circum-Pacific Council for Energy and Mineral Resources, Earth Science Series, v. 6, p. 191-212.

von Huene, R., Hampton, M.A., Fisher, M.A., Varchol, D.J., and Cochrane, G.R., 1980, Near-surface geologic structures, Kodiak Shelf, Alaska: U.S. Geological Survey Miscellaneous Field Studies Map MF-1200, scale 1:500,000, 1 sheet.

von Huene, R., Keller, G., Bruns, T.R., and McDougall, K., 1985, Cenozoic migration of Alaskan terranes indicated by paleontologic study, in Howell, D.G., ed., Tectonostratigraphic terranes of the circum-Pacific Region: Houston, Texas, Circum-Pacific Council for Energy and Mineral Resources, Earth Science Series, v. 1, p. 121-136.

von Huene, R., and Shor, G.G., Jr., 1969, Structure and tectonic history of the eastern Aleutian Trench: Geological Society of America Bulletin, v. 80, p. 1889-1902.

von Huene, R., Shor, G.G., Jr., and Malloy, R.J., 1972, Offshore features in the affected region, in The great Alaska earthquake of 1964, oceanography and coastal engineering: Washington, D.C., National Academy of Sciences, p. 266-289.

Reviewers: Louie N. Marincovich and George Plafker 


\title{
Discrepancies Between Geologic Evidence and Rotational Models-Talkeetna Mountains and Adjacent Areas of South-Central Alaska
}

\author{
By Béla Csejtey, Jr.
}

\begin{abstract}
Paleomagnetists have recently concluded that western and central Alaska underwent approximately $40^{\circ}$ of counterclockwise rotation since early Tertiary time. The hinge zones of all mechanisms proposed so far to accomplish this rotation are located near or within the Talkeetna Mountains of south-central Alaska. Thus, the Talkeetna Mountains are in such a geographic location that if any of the proposed mechanisms did operate in the way postulated, the Talkeetnas should display structural features attributable to such a major crustal disturbance. Paradoxically, no such structural features were disclosed by geologic mapping. This contradiction should be resolved before any of the proposed mechanisms, or even the concept of differential rotation between various regions of Alaska, become widely accepted in attempts to decipher the tectonic history of southern Alaska.
\end{abstract}

\section{INTRODUCTION}

In recent years a number of paleomagnetic investigations on Cenozoic volcanogenic rocks from western and south-central Alaska, including the Talkeetna Mountains, have concluded that these parts of Alaska underwent an approximately $40^{\circ}$ counterclockwise rotation within the last 50 m.y. (for instance, Coe and others, 1985, 1989; Panuska, 1987; Panuska and others, 1990; fig. 1). Three mechanisms have been proposed to accomplish the paleomagnetically suggested rotation: (1) oroclinal bending (for instance, Coe and others, 1985), (2) rotation caused by movements along curved strike-slip faults (Panuska, 1987), and (3) rotation by megakinking (Coe and others, 1989). The first two of the proposed mechanisms should have involved the shortening of large crustal segments between the rotating and the nonrotating, buttressing parts of Alaska. The amount of crust that should have been disposed of in order to make room for the rotating crustal blocks is quite large. Hence, in and near the zone of maximal crustal shortening, as in the Talkeetna Mountains, considerable numbers and types of compressional structures, directly attributable to such a major crustal shortening, should be present if the proposed mechanisms indeed have operated in the postulated way. In the case of the third proposed mechanism, that of megakinking, there should be at least one large pull-apart basin, with accompanying discontinuity between correlative rocks on either side of the basin, within and (or) near the hinge zone of the postulated megakink. Tensional faults would also be expected on both sides of such a pull-apart basin(s).

The areally extensive Talkeetna Mountains of south-central Alaska are located near and partly within the hinge zone of the proposed orocline and of the proposed megakinking structure. The Talkeetna Mountains also lie just south of a sharp bend in the surface trace of the Denali fault system. With such a critical geographic setting, the Talkeetna Mountains would be expected to display at least some geologic features resulting from an operation of the proposed mechanisms of oroclinal bending, strike-slip motions, or regional megakinking, or some combination of such activities.

A generalized geologic sketch map of the Talkeetna Mountains and adjacent central Alaska Range of south-central Alaska (after Csejtey and others, 1978, 1986 , in press) is given in figure 2 . The map shows the major rock units and all of the significant faults of the region. Much of the geology of the map area, and indeed that of south-central Alaska, is the result of the accretion of the Talkeetna superterrane to the ancient North American continent in about mid- and (or) Late Cretaceous time (for instance, Csejtey and others, 1982). For detailed lithologic descriptions and an interpretive overview of the geologic history of the map area, the reader is referred to the above-mentioned publications.

The overall lithologic character of Cenozoic sedimentary and volcanic rocks scattered throughout the Talkeetna Mountains indicates that in the Cenozoic the Talkeetna Mountains and adjacent central Alaska Range were never deeply buried, and hence that these regions 
in essence underwent only rigid-state (that is, brittle) deformation (Csejtey and others, 1978, 1986). Accordingly, the crustal shortening inherent in the proposed oroclinal bending and strike-slip mechanisms should be accomplished primarily by folding, thrust faulting, highangle reverse faulting, and strike-slip faulting. The crustal extension inherent in the megakinking mechanism should be manifested by rotational pull-apart basins and by a swarm of extensional normal faults, trending roughly between north and northwest. This paper summarizes these rotational mechanisms in terms of their proposed structural consequences and lack of corresponding geologic features in the critically located Talkeetna Mountains region.

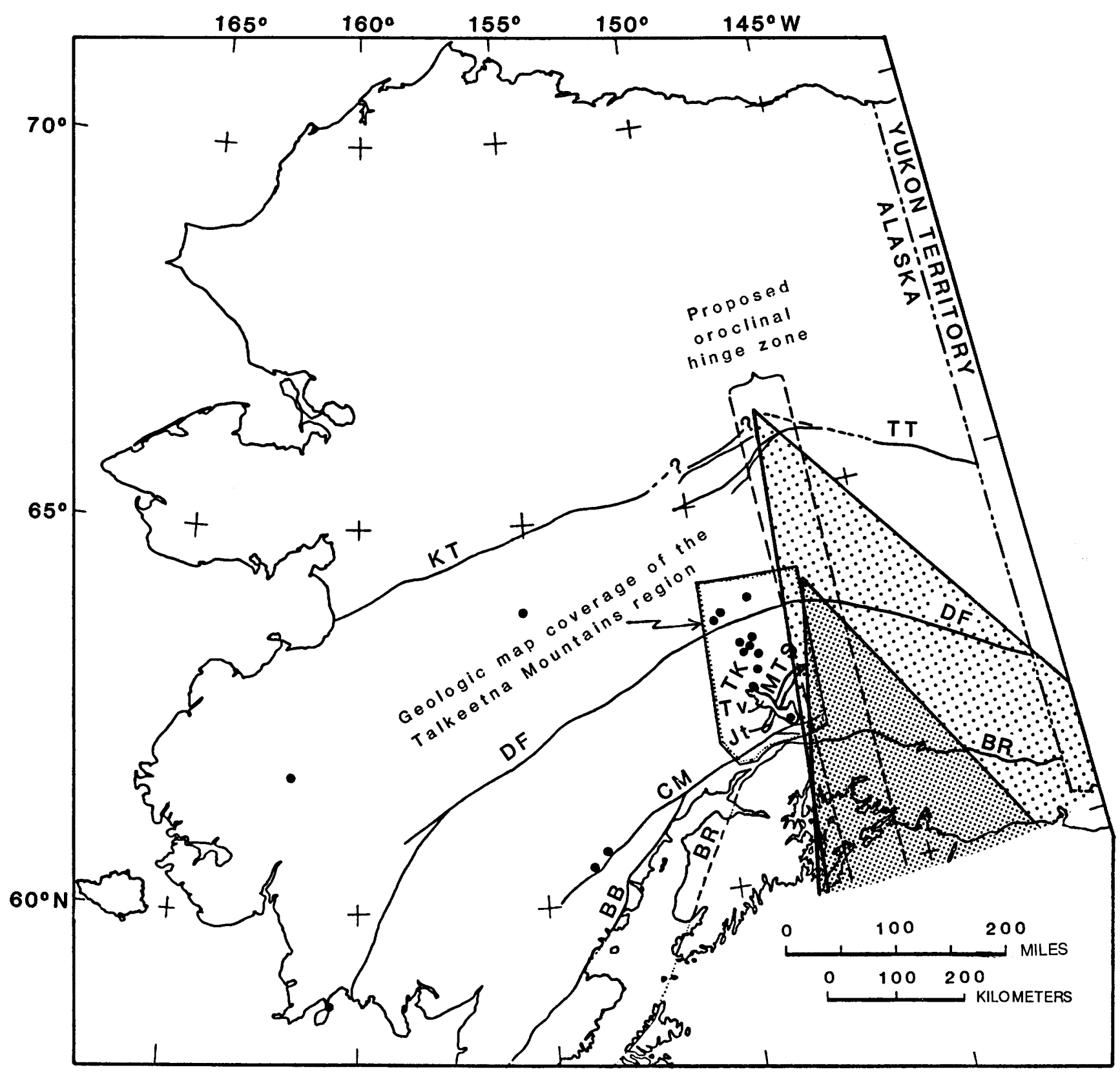

Figure 1. Locations of paleomagnetic study sites (large dots) that suggest approximately $40^{\circ}$ of Cenozoic counterclockwise rotation for western and central Alaska. Map also shows approximate hinge zone of proposed Cenozoic oroclinal rotation and pie-shaped slices of excessive crust, discussed in text, if actual axis of rotation within hinge zone is located near Denali fault system (densely stippled area) or near Tintina fault (lightly stippled area). Map-unit symbols: Tv, exposure area of Tertiary volcanic rocks in Talkeetna Mountains; Jt, Late Jurassic trondhjemite pluton in Talkeetna Mountains. Other symbols used: TK MTS, Talkeetna Mountains; KT, Kaltag fault; TT, Tintina fault; DF, Denali fault system; CM, Castle Mountain fault; BB, Bruin Bay fault; BR, Border Ranges fault system. Faults dashed where approximate, dotted where covered, and queried where uncertain. Geologic map coverage of Talkeetna Mountains region by Csejtey and others (1978, 1986). 


\section{OROCLINAL BENDING}

The oroclinal-bending hypothesis proposes that the north-trending hinge zone of the rotation of western and south-central Alaska is located in eastern Alaska near longitude $146^{\circ} \mathrm{W}$., just east of the Talkeetna Mountains (Carey, 1958; Grantz, 1966; Coe and others, 1985). The implied approximately vertical rotational axis somewhere within this hinge zone (fig. 1) must thereby have formed the apex of a southward-widening crustal block that became successively narrower as oroclinal bending progressed. The implicit compression within the pieshaped slice south of the axis would have to have occurred within and near the eastern Talkeetna Mountains (fig. 1). Tightening of such an orocline requires elimination of intervening crust, unless accommodated by global expansion (Carey, 1976), a controversial mechanism that even if operative and in keeping with extreme versions of expansion (Carey, 1976), could not have accommodated the amount of crust required. The width of the crustal wedge requiring elimination increases the farther north the rotational axis is located within the hinge zone (fig. 1). The paleomagnetic data and regional geologic considerations essentially require that the postulated rotational axis within the hinge zone be located at least as far north as the Denali fault system, but most probably the axis should have been located even farther to the north-that is, north of the postulated Kaltag-Tintina fault system. Thus, the amount of crust to be disposed of in front of the rotating Talkeetna Mountains, especially the southern Talkeetnas, is quite considerable. If a large mass of crust had been disposed of or displaced by this mechanism, one would expect to find major compressional features in this region. Strong evidence for the lack of such structural features is provided by a large and well-exposed northwest-trending outcrop area, about $80 \mathrm{~km}$ by $20 \mathrm{~km}$ in surface dimensions, of a more than 1,500-m-thick sequence of early to middle Cenozoic volcanogenic rocks in the southern and central parts of the Talkeetna Mountains (figs. 1, 2). The lower two-thirds of the volcanic sequence predates the proposed rotation, as shown by two paleomagnetic study sites (Hillhouse and others, 1985; Panuska and others, 1990), and should have been involved in the proposed rotation. Paradoxically, this volcanic sequence is essentially undeformed; its layering only varies from horizontal to subhorizontal, and intravolcanic regional unconformities are lacking. East of this volcanic sequence, and thus closer to the proposed hinge zone, detailed geologic mapping in the southeastern Talkeetna Mountains (Grantz, 1960a, b, 1961a, b, 1965) does not indicate the presence of significant compressional structural features. Still farther to the east, in the southern Copper River basin, and thus within the proposed hinge zone, available drill-hole correlation data and seismic-refraction profiles do not indicate, or even suggest, the presence of major compressional structural features (Alaska Geological Society, 1971a, b; Gary S. Fuis, U.S. Geological Survey, oral commun., 1989). The northwest-elongated exposure area of the Cenozoic volcanic rocks (Csejtey and others, 1978) and a Late Jurassic trondhjemite pluton (Csejtey and Nelson, 1979; figs. 1, 2), trending northeastward across the Talkeetna Mountains, preclude the presence of northeastward- or northwestward-trending strike-slip faults within the Talkeetna Mountains.

\section{STRIKE-SLIP MECHANISM}

The strike-slip mechanism hypothesis (Panuska, 1987) postulates that the rotation of western and southcentral Alaska occurred as a result of right-lateral strikeslip offset in the Cenozoic along curved faults with small-circle geometries, such as the proposed TintinaKaltag fault system and the Denali fault system (Stout and Chase, 1980). According to this hypothesis, because the movements occur along curving strike-slip faults of uniform radii, the moving and (or) rotating blocks should undergo only insignificant internal deformation. However, neither the postulated Tintina-Kaltag fault system nor the Denali fault system is a strike-slip fault of small-circle geometry (Csejtey and others, 1982, 1986; Coe and others, 1989). The surface traces of both fault systems comprise long and straight segments separated by sharply curving and short segments (for instance, Beikman, 1980). Thus, the curvatures of both fault systems have nonuniform radii. Furthermore, the postulated Tintina-Kaltag fault system may not be a single fault system; its component Tintina and Kaltag faults may not join, but might each form a fault system independent of the other (W.W. Patton, Jr., U.S. Geological Survey, oral commun., 1989). Consequently, only the Denali fault system is discussed in this paper, but with the proviso that if the Tintina and Kaltag faults do form a single fault system, the general conclusions derived for the Denali system would also be applicable for the postulated Tintina-Kaltag system.

A sharp, southward-concave curvature occurs in the Denali fault system just north of the Talkeetna Mountains between two long and straight segments (Beikman, 1980; fig. 3). Assuming $200 \mathrm{~km}$ of dextral offset along the Denali system within the last 50 m.y. (after Nokleberg and others, 1985), the actively moving wide southern fault block, while passing the sharp curve, should rotate counterclockwise. This rotation should have resulted in a southward-widening, pie-shaped slice of excessive crust overlapping the eastern part of the Talkeetna Mountains. The central angle of the pie slice should be about the same as the angle of curvature of the Denali fault system, that is between $30^{\circ}$ and $40^{\circ}$. The 


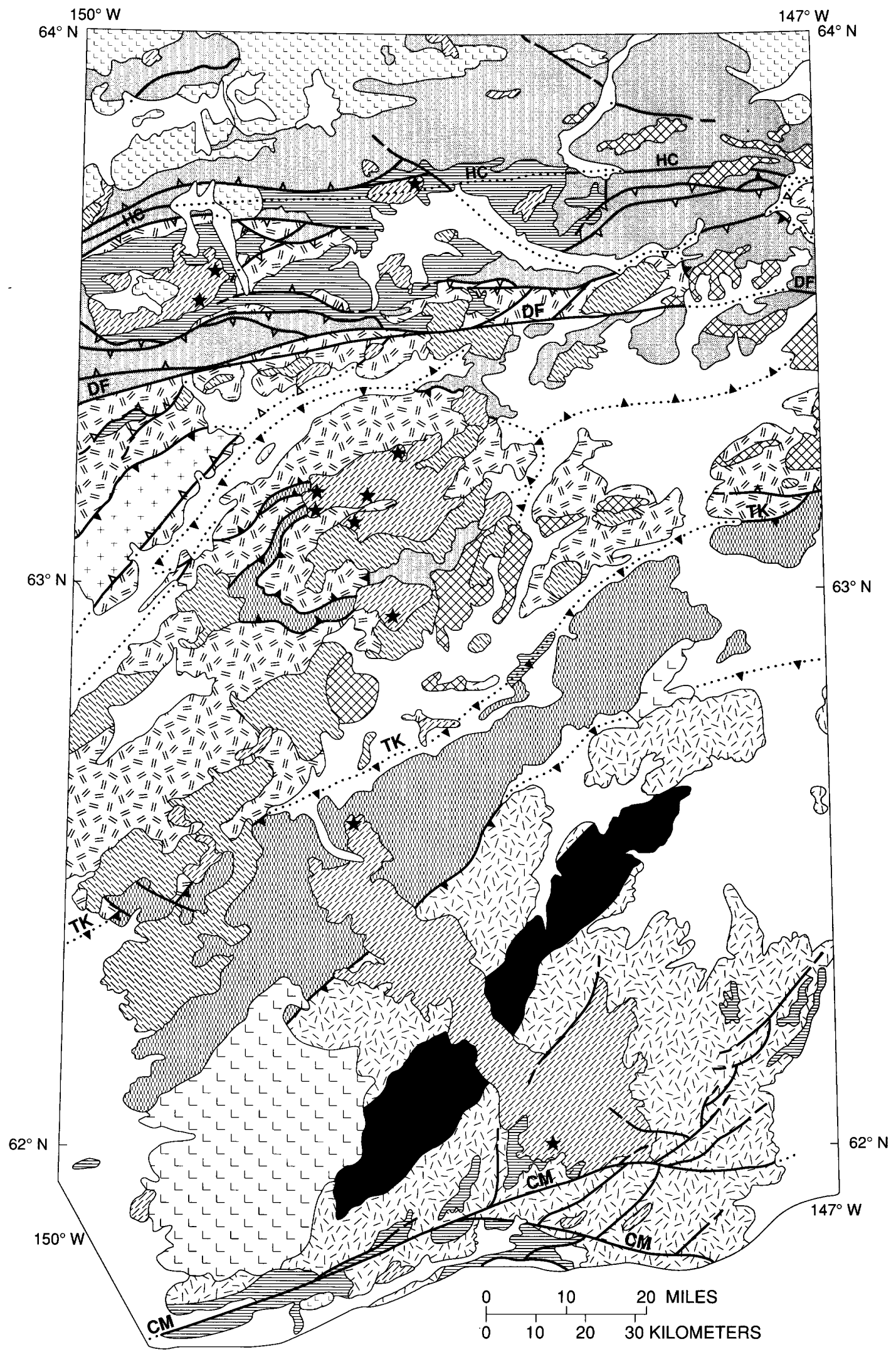

Figure 2. Generalized geologic map of Talkeetna Mountains and central Alaska Range of southcentral Alaska (from Csejtey and others, 1978, 1986, in press). 
structures resulting from this rotation should be most prevalent in the southeastern Talkeetna Mountains. As mentioned in conjunction with the oroclinal-bending mechanism, no such structures were mapped in that region. The counterclockwise rotation of such a moving

\section{EXPLANATION}

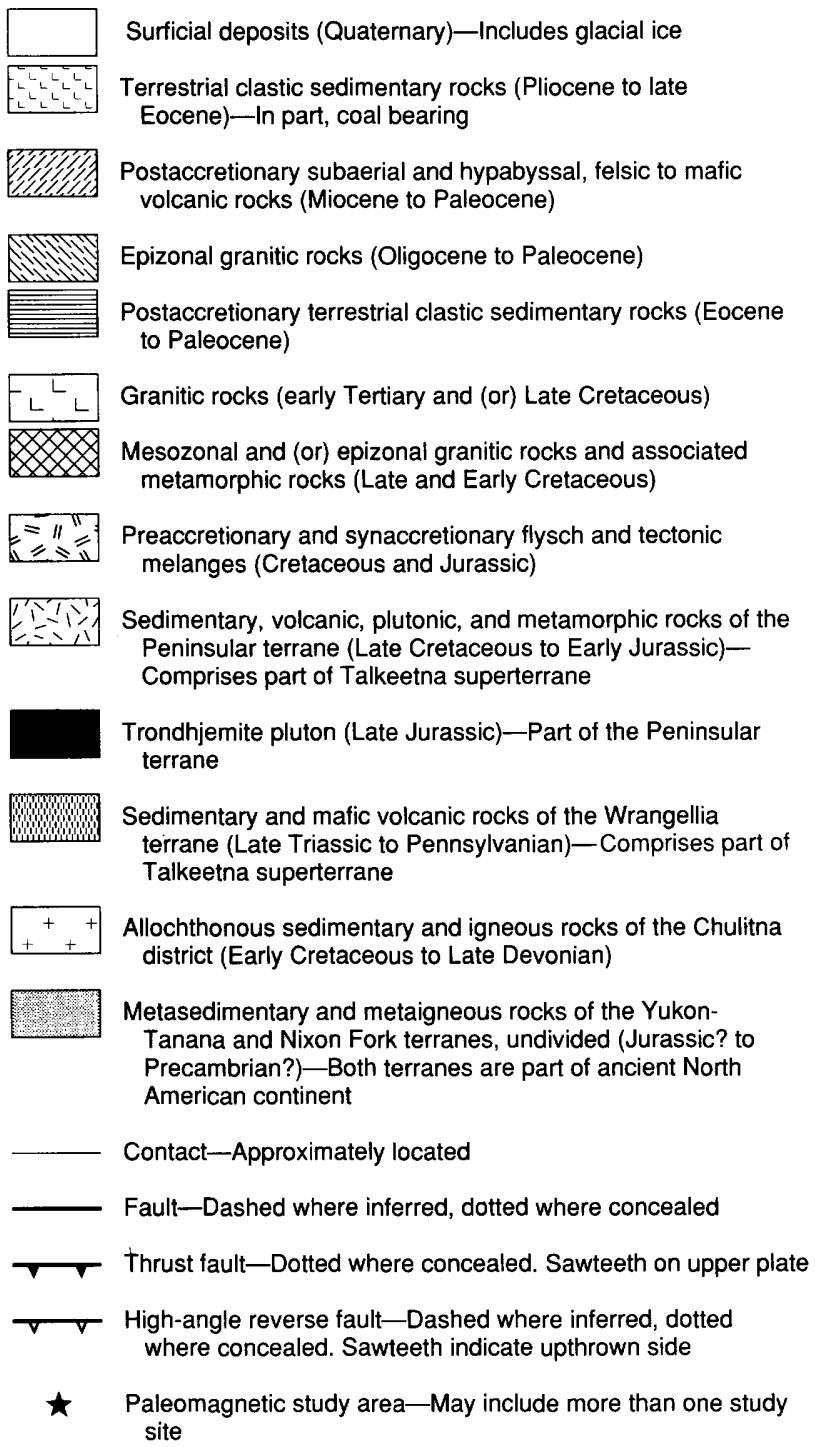

Note: TK, Talkeetna thrust fault; HC, Hines Creek fault; DF, McKinley fault of Denali fault system; CM, Castle Mountain-Caribou fault systems

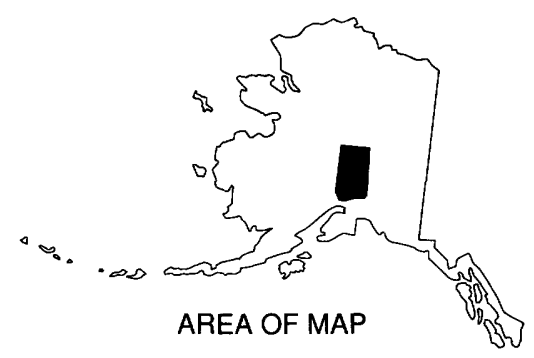

Figure 2. Continued. fault block near the Talkeetna Mountains should have been accompanied by compensatory clockwise rotation within the block not far from, but west of, the Talkeetna Mountains. Without this compensatory clockwise rotation, a gap would have developed along the fault west of the Talkeetna Mountains, between the stationary northern block and the actively moving southern block. The most likely area for this compensatory rotation is the Talkeetna quadrangle, just west of the Talkeetna Mountains (fig. 3). However, compressional structures of the type expected from such rotation were not mapped in that region (Reed and Nelson, 1980). Moreover, such rotations within the moving fault block should be shown by time-progressive deformations of additional portions of the block. In other words, all portions of the moving fault block that already had passed the stationary curve in the fault should display at least some evidence for these rotational deformations. Again, no such evidence was found anywhere within the moving fault block west of the Talkeetna Mountains.

The lack of such rotational structures in the moving fault block is considered here to be supportive evidence for minimal movement along the Denali fault system in Cenozoic time (Csejtey and others, 1982, 1986, in press).

\section{MEGAKINKING HYPOTHESIS}

The megakinking hypothesis (Coe and others, 1989) explains the rotation of western and central Alaska in two steps. First, a set of elongate and parallel fault blocks are crosscut at a high angle into two segments. Then, individually but simultaneously, the fault blocks of one of the segments are pushed and rotated away from corresponding fault blocks in the other segment by northwesterly regional compressional forces (fig. 4). Applying the megakinking hypothesis to this part of Alas$\mathrm{ka}$, the hinge zone, where the set of elongate fault blocks have been cut into two segments, has been proposed to coincide roughly with longitude $148^{\circ} \mathrm{W}$., which runs through the middle of the Talkeetna Mountains (fig. 5). The curved fault systems of Alaska, such as the Denali and the proposed Tintina-Kaltag system, are assumed to be part of the set of originally straight faults that outlined the elongate and parallel fault blocks. According to the megakinking hypothesis (Coe and others, 1989), large parts of the area of the Talkeetna Mountains should be underlain by at least one rotational pull-apart basin (figs. 4, 5). Geologic investigations to date in the Talkeetna Mountains and adjacent regions (Csejtey and others, 1978, 1986, in press) do not support this contention.

From the viewpoint of the geology of the Talkeetna Mountains, it would be more appropriate to locate the position of the hinge zone of the postulated megakink somewhere east of the Talkeetnas, perhaps across the 
Copper River basin near longitude $146^{\circ} \mathrm{W}$. In this case, the lack of known northeast-trending dextral strike-slip faults in the Talkeetna Mountains requires that the region between the Denali and Border Ranges fault systems be composed of one fault block. Consequently, the postulated rotational pull-apart basin should fully extend between the two fault systems, underlying a large part of the Copper River basin (fig. 5). The presence of such a northward-widening basin under the surficial deposits in the Copper River basin region is precluded by the wide and continuous belt of Paleozoic and Mesozoic rocks flanking the Copper River basin to the north (Beikman, 1980; Nokleberg and others, 1982; Warren J. Nokleberg, U.S. Geological Survey, oral commun., 1989), and in the basin itself by exploratory drill-hole data (Alaska Geological Society, 1971a, b), and by seismic-refraction profiles (Gary Fuis, U.S. Geological Survey, oral commun., 1989). Furthermore, if such a rotational pull-apart basin

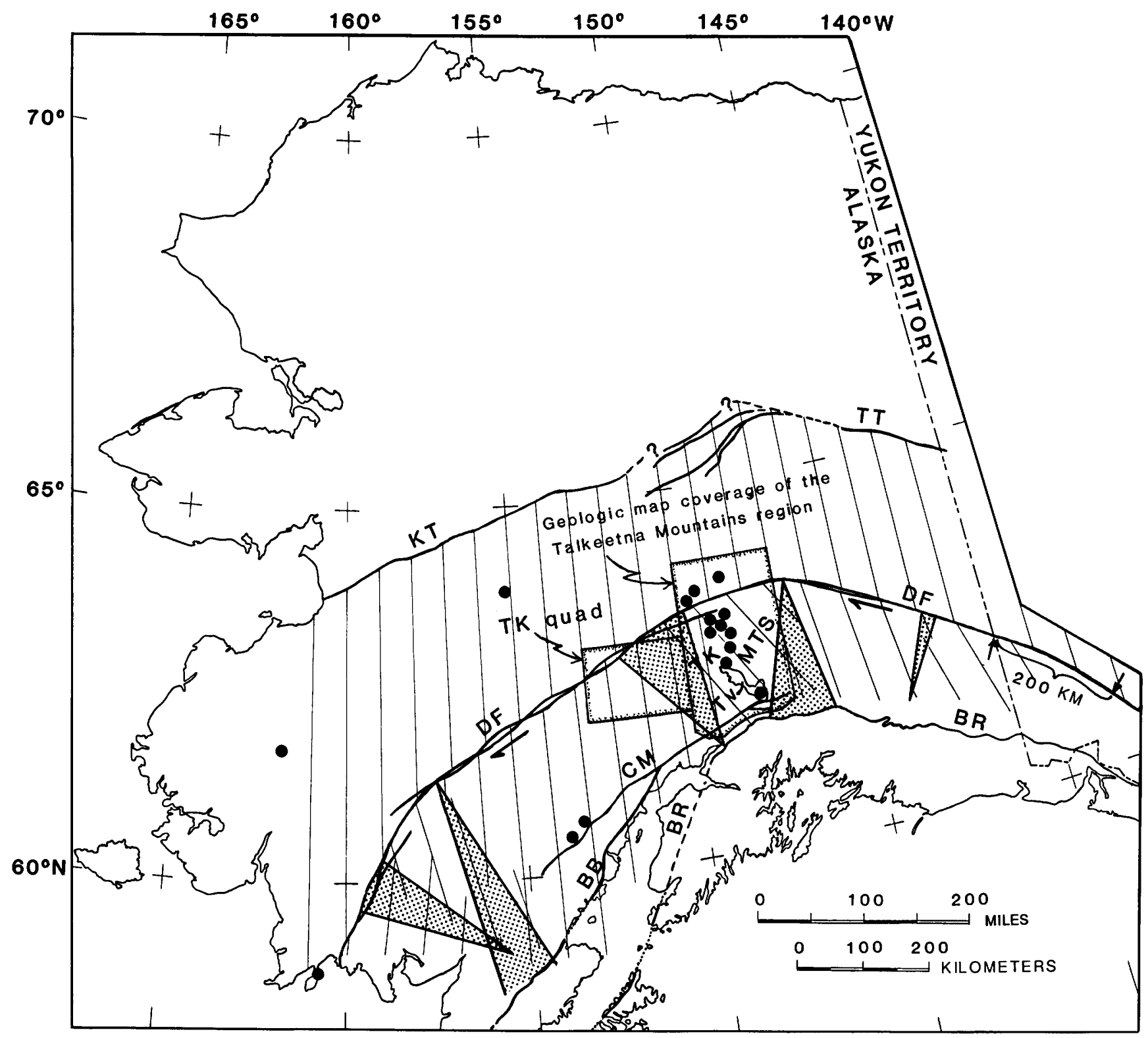

Figure 3. Relative rotational positions (black lines) and approximate locations and amounts of crustal shortening (stippled areas) due to counterclockwise and compensatory clockwise rotations within entire southern fault block of Denali fault system after $200 \mathrm{~km}$ of postulated Cenozoic movement of the block. Large dots indicate paleomagnetic study sites in western and south-central Alaska. Map-unit symbol: Tv, elongate exposure area of Tertiary volcanic rocks referred to in text. Other symbols used: TK quad, Talkeetna quadrangle; TK MTS, Talkeetna Mountains; KT, Kaltag fault; TT, Tintina fault; DF, Denali fault system; CM, Castle Mountain fault; BB, Bruin Bay fault; BR, Border Ranges fault system. Faults dashed where approximate, dotted where covered, and queried where uncertain. Geologic map coverage of Talkeetna Mountains region by Csejtey and others $(1978,1986)$. 
did develop just east of the Talkeetna Mountains, then there also should be a number of roughly north- to northwestward-trending extensional faults in the Talkeetna Mountains. None are known to be present.

In addition to the foregoing discussion, it is important to point out that the schematic model of megakinking, as presented by Coe and others (1989) and reproduced in figure 4 , is in fact geometrically incorrect. If rotation took place with each of the rotated fault slivers remaining connected to their nonrotated counterpart at their individual rotational axis, then at a $40^{\circ}-50^{\circ}$ rotation there should be gaps between the rotated fault slivers (fig. $6 \mathrm{~A}$ ). If one closes the gaps, and stacks the rotated fault slivers against the southernmost sliver, in response to the speculated northwesterly regional compression, then there should be left-lateral displacement along the fault that initially crosscut the original set of fault slivers (fig. $6 B$ ). In case of $45^{\circ}$ rotation, the displacement of any point along this left-lateral fault or fault zone is a little over 7 percent of the original distance of that point from the rotational axis of the southernmost fault sliver. In case of $40^{\circ}$ rotation, the displacement is nearly 10 percent.

Applying the above considerations to Alaska, it appears that if the megakinking mechanism did operate, then in addition to rotational pull-apart basins and related structures, there also should be a roughly north-southtrending, left-lateral fault or fault zone, or at least an Sshaped regional bend across southern and central Alaska somewhere near or between longitudes $146^{\circ} \mathrm{W}$. and $148^{\circ}$ W. Near the apex of the postulated Kaltag-Tintina fault system, left-lateral displacement along this hypothetical fault zone or regional bend should be about $45 \mathrm{~km}$ - that is, 7 percent of the approximately $640 \mathrm{~km}$ distance of the apex from the southern margin of conti-

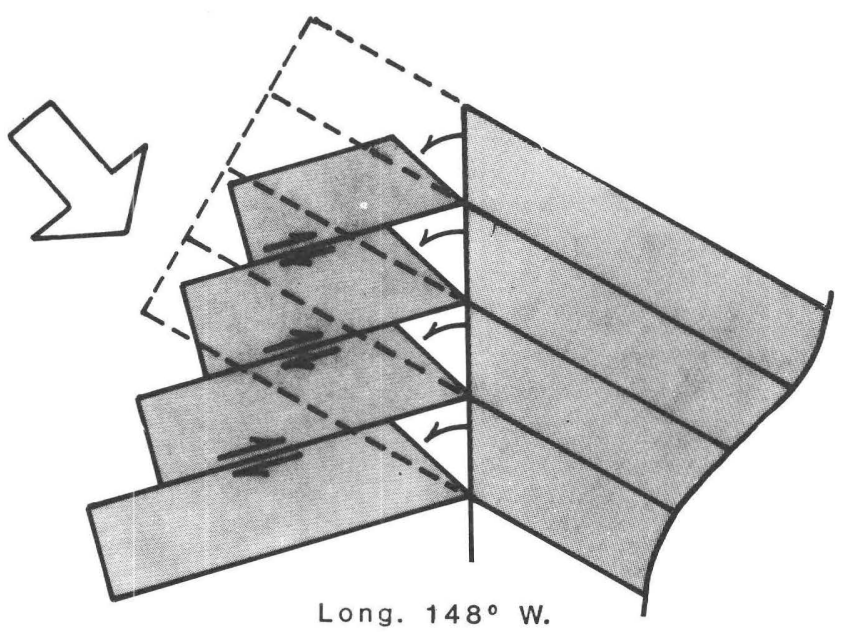

Figure 4. Schematic model of megakinking mechanism of Coe and others (1989). Model is geometrically incorrect because widths of rotated fault slivers should equal widths of nonrotated slivers. See figure $6 A$ and text for discussion. nental Alaska. Near the apex of the Denali fault system, left-lateral offset should be about $23 \mathrm{~km}$. Both distances are of sufficient magnitude to be disclosed even by 1:250,000-scale reconnaissance geologic mapping. No evidence for such left-lateral offsets was disclosed by reconnaissance geologic mapping near the Tintina and Kaltag faults (Chapman and others, 1971; Foster and others, 1983; Weber and others, 1978; Péwé and others, 1966) or along the apex of the Denali fault system (Csejtey, and others, 1978, 1986, in press).

\section{"DRAG" BETWEEN CONCURRENT STRIKE-SLIP FAULTS}

Several U.S. Geological Survey colleagues (for instance, H.L. Foster, oral commun., 1989) discussed the possibility that the counterclockwise rotation of the Talkeetna Mountains region might be the result of concurrent dextral movements along the Denali fault system to the north and the Castle Mountain fault and (or) the Border Ranges fault system to the south. Accordingly, the Talkeetna Mountains region should be a tectonically independent block that is bounded by faults not only on the north and south, but on the east and west as well. However, eastern or western boundary faults were not observed in the field (Csejtey and others, 1978; Reed and Nelson, 1980). Furthermore, tectonic forces in south-central and southern Alaska, having been generated by generally northward plate motions during the Cenozoic, should have been strongest at the margin of the continent. Accordingly, dextral displacement along the Castle Mountain fault and (or) the Border Ranges fault system should have been concomitant with but greater than that along the Denali fault system. Thus, the resulting "drag" should have caused clockwise rotation in the Talkeetna Mountains.

\section{CONCLUSIONS}

The Talkeetna Mountains are critically located for testing the proposed Cenozoic counterclockwise rotations of western and south-central Alaska based on paleomagnetic data. Geological mapping of the Talkeetna Mountains, however, shows a lack of structural features required by such rotations and related movements. Thus, a contradiction exists between the geologic and paleomagnetic data. A resolution of these discrepancies is needed to assess the credibility of the proposed Cenozoic rotations between various regions of this part of Alaska, particularly before any of the various proposed mechanisms to explain such inferred rotations gains general acceptance in the deciphering of western and south-central Alaska's tectonic history. 


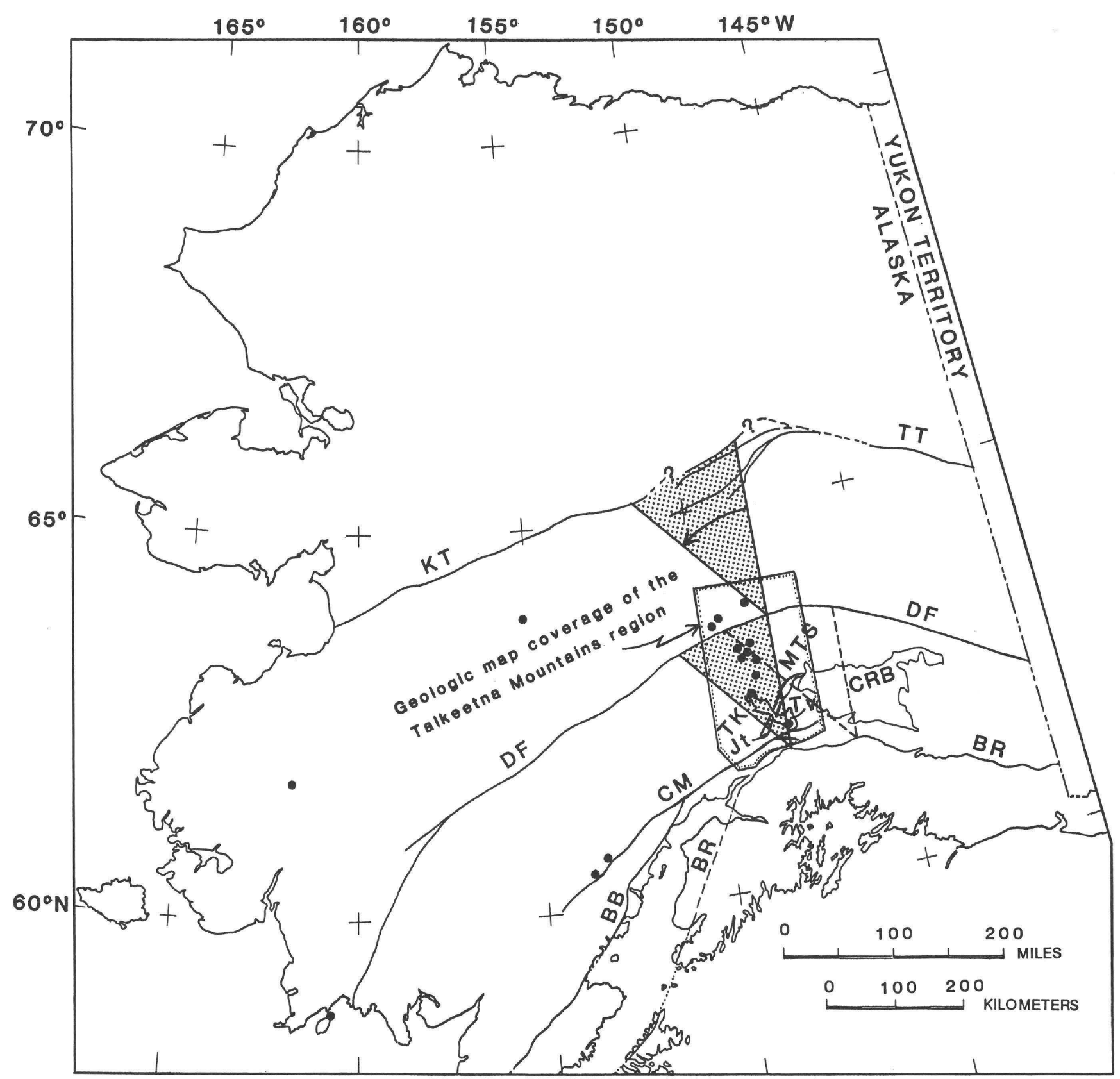

Figure 5. Approximate locations of rotational pull-apart basins in central Alaska from megakinking mechanism proposed by Coe and others (1989). Stippled triangularshaped areas indicate locations of rotational pull-apart basins as originally postulated by Coe and his co-workers. Triangular area outlined by dashed lines between Denali and Border Ranges fault systems shows more likely location of at least one of rotational pull-apart basins in view of geology of Talkeetna Mountains. Large dots indicate locations of paleomagnetic studies. Map-unit symbols: Tv, elongate exposure area of Tertiary volcanic rocks discussed in text; Jt, Late Jurassic trondhjemite pluton discussed in text. Other symbols used: TK MTS, Talkeetna Mountains; CRB, Copper River basin; KT, Kaltag fault, TT, Tintina fault; DF, Denali fault system; CM, Castle Mountain fault; BB, Bruin Bay fault; BR, Border Ranges fault system. Faults dashed where approximate, dotted where covered, and queried where uncertain. Geologic map coverage of Talkeetna Mountains region by Csejtey and others (1978, 1986). 

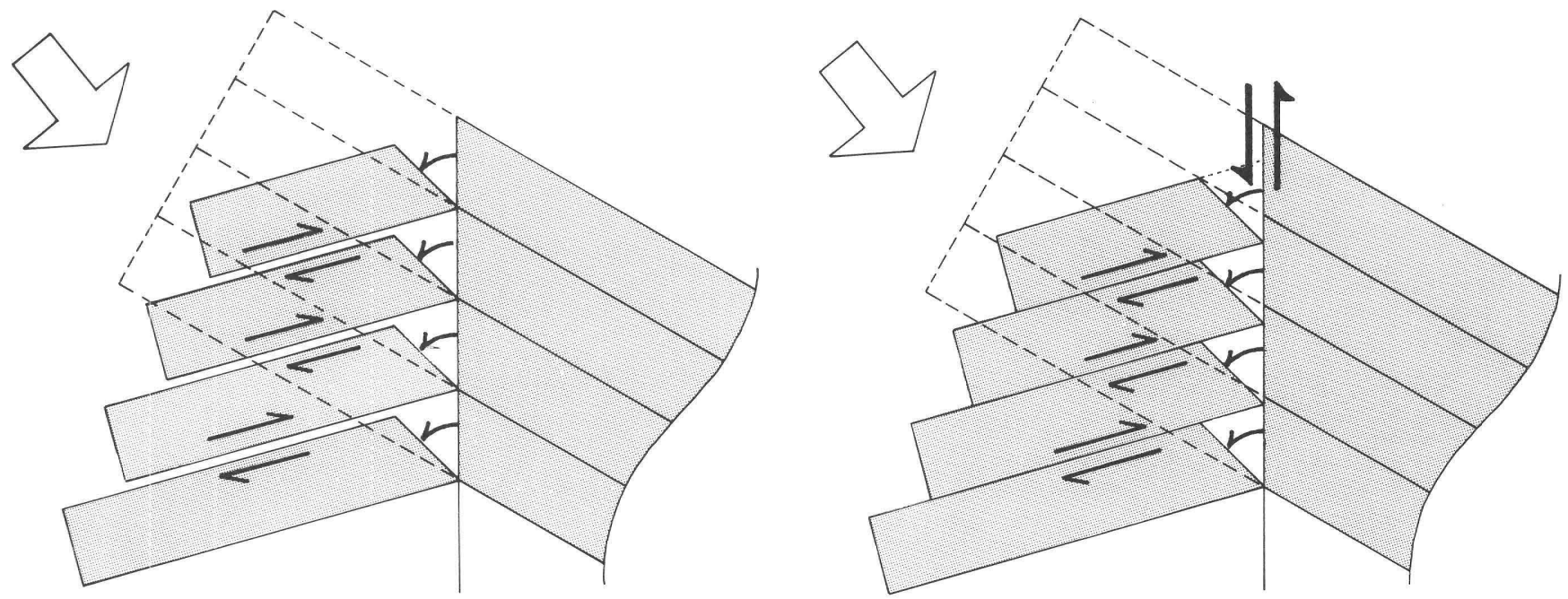

$A$

$B$

Figure 6. Reconstructed model of megakinking mechanism of Coe and others (1989). A, With gaps between rotated fault slivers. $B$, With gaps closed and rotated fault slivers stacked against southernmost sliver. Note left-lateral offset along initial crosscutting fault.

\section{REFERENCES CITED}

Alaska Geological Society, Stratigraphic Committee, 1971a, Southwest to northeast stratigraphic correlation section, Eureka to Rainbow, Copper River basin, Alaska: Anchorage, Alaska, vertical scale 1:4,800, no horizontal scale.

- 1971b, West to east stratigraphic correlation section, Tazlina unit to Moose Creek, Copper River basin, Alaska: Anchorage, Alaska, vertical scale 1:4,800, no horizontal scale.

Beikman, H.M., 1980, Geologic map of Alaska: Reston, Va., U.S. Geological Survey, scale 1:2,500,000, 2 sheets.

Carey, S.W., 1958, The tectonic approach to continental drift, in Carey, S.W. ed., Continental drift: A symposium: Hobart, University of Tasmania, p. 177-363.

- 1976, The expanding earth, v. 10 of Developments in Geotectonics: New York, Elsevier, 488 p.

Chapman, R.M., Weber, F.R., and Taber, Bond, 1971, Preliminary geologic map of the Livengood quadrangle, Alaska: U.S. Geological Survey Open-File Report 71-66, scale $1: 250,000,2$ sheets.

Coe, R.S., Globerman, B.R., Plumley, P.W., and Thrupp, G. A., 1985, Paleomagnetic results from Alaska and their tectonic implications, in Howell, D.G., ed., Tectonostratigraphic terranes of the Circum-Pacific region: Houston, Texas, Circum-Pacific Council for Energy and Mineral Resources, Earth Science Series, v. 1, p. 85-108.

Coe, R.S., Globerman, B.R., and Thrupp, G.A., 1989, Rotation of central and southern Alaska in the early Tertiary: oroclinal bending by megakinking, in Kissel, Catherine, and Laj, Carlo, eds., Paleomagnetic rotations and continental deformation: Boston, Kluwer Academic Publishers, NATO-ASI series, p. 327-339.

Csejtey, Béla, Jr., Cox, D.P., Evarts, R.C., Stricker, G.D., and Foster, H.L., 1982, The Cenozoic Denali fault system and the Cretaceous accretionary development of southern Alaska: Journal of Geophysical Research, v. 87, no. B5, p. 3741-3754.

Csejtey, Béla, Jr., Mullen, M.W., Cox, D.P., Gilbert, W.G., Yeend, W.E., Smith, T.E., Wahrhaftig, Clyde, Craddock, Campbell, Brewer, W.M., Sherwood, K.W., Hickman, R.G., Stricker, G.D., St. Aubin, D.R., and Goertz, D.J., III, 1986, Geology and geochronology of the Healy quadrangle, Alaska: U.S. Geological Survey Open-File Report 86-396, 92 p., scale 1:250,000, 4 map sheets.

Csejtey, Béla, Jr., Mullen, M.W., Cox, D.P., and Stricker, D.G., in press, Geology and geochronology of the Healy quadrangle, south-central Alaska : U.S. Geological Survey Miscellaneous Investigations Series Map I-1961, 80(?) p., scales $1: 250,000$ and 1:360,000, 2 map sheets.

Csejtey, Béla, Jr., and Nelson, W.H., 1979, Trondhjemite in the Talkeetna Mountains, south-central Alaska, in Johnson, K.M., and Williams, J.R., eds., The United States Geological Survey in Alaska-Accomplishments during 1978: U.S. Geological Survey Circular 804-B, p. B93-B96.

Csejtey, Béla, Jr., Nelson, W.H., Jones, D.L., Silberling, N.J., Dean, R.M., Morris, M.S., Lanphere, M.A., Smith, J.G., and Silberman, M.L., 1978, Reconnaissance geologic map and geochronology, Talkeetna Mountains quadrangle, northern part of Anchorage quadrangle, and southwest corner of Healy quadrangle, Alaska: U.S. Geological Survey Open-File Report 78-558-A, scale 1:250,000, 62 p.

Foster, H.L., Laird, Jo, Keith, T.E.C., Cushing, G.W., and Menzie, W.D., 1983, Preliminary geologic map of the Circle quadrangle, Alaska: U.S. Geological Survey OpenFile Report 83-170A, scale 1:250,000, 30 p.

Grantz, Arthur, 1960a, Geologic map of the Talkeetna Mountains A-1 quadrangle and the south third of the Talkeetna Mountains B-1 quadrangle, Alaska: U.S. Geological Survey Miscellaneous Geologic Investigations Map I-314, scale $1: 48,000$. 
1960b, Geologic map of the Talkeetna Mountains A-2 quadrangle, Alaska and the contiguous area to the north and northwest: U.S. Geological Survey Miscellaneous Geologic Investigations Map I-313, scale 1:48,000.

1961a, Geologic map of the north two-thirds of Anchorage D-1 quadrangle, Alaska: U.S. Geological Survey Miscellaneous Geologic Investigations Map I-343, scale $1: 48,000$.

1961b, Geologic map and cross sections of the Anchorage D-2 quadrangle and northernmost part of the Anchorage D-3 quadrangle, Alaska: U.S. Geological Survey Miscellaneous Geologic Investigations Map I-342, scale 1:48,000.

-1965, Geologic map and cross sections of the Nelchina area, south-central Alaska: U.S. Geological Survey OpenFile Report 255, scale 1:63,360, 4 sheets.

1966, Strike-slip faults in Alaska: U.S. Geological Survey Open-File Report 66-53, 82 p.

Hillhouse, J.W., Grommé, C.S., and Csejtey, Béla, Jr., 1985, Tectonic implications of paleomagnetic poles from lower Tertiary rocks, south-central Alaska: Journal of Geophysical Research, v. 90, no. B14, p. 12,523-12,535.

Nokleberg, W.J., Albert, N.R.D., Bond, G.C., Herzon, P.L., Miyaoka, R.T., Nelson, W.H., Richter, D.H., Smith, T.E., Stout, J.H., Yeend, Warren, and Zehner, R.E., 1982, Geologic map of the southern part of the Mount Hayes quadrangle, Alaska: U.S. Geological Survey Open-File Report $82-52,26$ p., scale 1:250,000, 1 sheet.

Nokleberg, W.J., Jones, D.L., and Silberling, N.J., 1985, Origin and tectonic evolution of the Maclaren and Wrangellia terranes, eastern Alaska Range, Alaska: Geological Society of America Bulletin, v. 96, no. 10, p. 1251-1270.

Panuska, B.C., 1987, Is there an orocline in south-central Alaska? [abs.]: Geological Society of America Abstracts with Programs, v. 19, no. 6, p. 438-439.

Panuska, B.C., Stone, D.B., and Turner, D.L., 1990, Paleomagnetism of Eocene volcanic rocks, Talkeetna Mountains, Alaska: Journal of Geophysical Research, v. 95, no. B5, p. 6737-6750.

Péwé, T.L., Wahrhaftig, Clyde, and Weber, Florence, 1966, Geologic map of the Fairbanks quadrangle, Alaska: U.S. Geological Survey Miscellaneous Geologic Investigations Map I-455, scale 1:250,000.

Reed, B.L., and Nelson, S.W., 1980, Geologic map of the Talkeetna quadrangle, Alaska: U.S. Geological Survey Miscellaneous Investigations Series Map I-1174, 15 p., scale $1: 250,000,1$ sheet.

Stout, J.H., and Chase, C.G., 1980, Plate kinematics of the Denali fault system: Canadian Journal of Earth Sciences, v. 17 , no. 11 , p. $1527-1537$.

Weber, F.R., Foster, H.L., Keith, T.E.C., and Dusel-Bacon, Cynthia, 1978, Preliminary geologic map of the Big Delta quadrangle, Alaska: U.S. Geological Survey Open-File Report 78-529A, scale 1:250,000.

Reviewers: John P. Galloway, William Glen, and Robert A. Loney 


\title{
Clay Mineral Depositional Facies and Uranium Resource Potential in Part of the Tertiary Kenai Group, Kenai
} Peninsula, Alaska

\author{
By Kendell A. Dickinson and Gary L. Skipp
}

\section{Abstract}

Thick sections of the Tertiary Beluga and Sterling Formations of the Kenai Group crop out along the east coast of Cook Inlet on the Kenai Peninsula in south-central Alaska. Parts of these sections, which consist mostly of sandstone, mudstone, and coal, were measured and sampled during 1976 and 1977 in an effort to determine uranium resource potential. Statistical analyses of chemical and mineralogical data from this study suggest several interesting associations.

Three suites of clay minerals from at least two different source terrains were recognized. One suite, consisting mostly of illite and chlorite, was apparently derived from the Kenai-Chugach Ranges to the east, and one suite, consisting mostly of smectite, was apparently derived from the Aleutian-Alaska Ranges to the west. A third assemblage probably represents a mixture of these sources and perhaps other areas to the north as well. The data presented here do not support the previously held view that the itlite-chlorite suite is limited to the Beluga Formation and the smectite suite is limited to the Sterling Formation.

A correlation-coefficient matrix and an r-mode factor analysis using a five-factor model are presented for a mineralogical and chemical data base of 41 samples. Factor one contains geochemically related $U$ and Th, together with $\mathrm{Mg}, \mathrm{Cr}, \mathrm{Sc}$, and $\mathrm{V}$ at one pole and feldspar (which appears to represent the detrital grains in the sandstones) at the other pole. Factor two, which contains $\mathrm{Ba}, \mathrm{Ti}, \mathrm{Na}$, $\mathrm{Zr}, \mathrm{Ga}, \mathrm{Sr}$, and $\mathrm{Yt}$, appears to represent the heavy-mineral concentrates. Factor three contains $\mathrm{Fe}, \mathrm{Mn}$, and $\mathrm{Co}$, which may be related to the sulfide minerals. Factor four contains the large cations $\mathrm{K}$ and $\mathrm{Ca}$ at a negative pole and smectite at a positive pole. Factor five contains chlorite, illite, quartz, and $\mathrm{Cu}$. Chlorite and illite appear to represent the fine-grained sediment fraction derived primarily from the Kenai-Chugach Ranges.

\section{INTRODUCTION}

Dall and Harris (1892) published the first discussion of the Kenai Group. Early interest in the group was motivated by its coal content. Coal resources of the southwestern part of the Kenai Peninsula were described by Barnes and Cobb (1959), and those of the northwestern part of the Cook Inlet area were described by Barnes (1966). Oil was discovered at Swanson River in 1957 (Parkinson, 1962), and much of the later interest in the Kenai Group was stimulated by the search for petroleum (Calderwood and Fackler, 1966, 1972; Crick, 1971; Kirschner and Lyon, 1973; Hayes and others, 1976). Interest in uranium during the late 1970's resulted in further reevaluation of the Kenai Group (Croff and others, 1977; Dickinson and Campbell, 1978).

In the present report, a reconnaissance study of the uranium resource potential of the Tertiary Kenai Group on the Kenai Peninsula (fig. 1) was carried out, and partial sections of the Miocene Beluga Formation and the Miocene and Pliocene Sterling Formation were described and sampled. The data provide new insight into the stratigraphy and sedimentation of the Beluga and Sterling Formations, as well as on the potential for uranium mineralization in these units in the Kenai Peninsula area.

\section{METHODS}

The study area includes partial measured sections of the formations exposed in various areas at the upper McNiel Canyon about $17 \mathrm{~km}$ northeast of Homer, at Homer Bluff about $9 \mathrm{~km}$ west of Homer, and at Diamond Gulch about $12 \mathrm{~km}$ west of Homer (figs. 1-6). Samples were also collected from the Cook Inlet beach at and north of Ninilchik (fig. 1).

The data used to compute the statistics in this report include analyses of 19 elements and 5 minerals for 41 samples (table 4). Beryllium, boron, and lead (also given in table 4) were not included in the statistical calculations because of the large number of qualified values in these results. The amount of iron for sample number $2-4$ (table 4) was reported as $>10$ percent. In order to include this sample in the calculations, this value was arbitrarily changed to 15 percent. Uranium and thorium 
contents were determined by the delayed-neutron method (Millard, 1976). Elemental values were determined by six-step semiquantitative spectroscopy (SSQ) (Myers and others, 1961). Mineralogical determinations were made by X-ray diffraction (XRD) of whole-rock cell mounts and oriented clay mineral mounts. Oriented mounts of the $<2$-micron clay fractions were X-rayed after air-drying, glycolation, and heating to 325 and $550{ }^{\circ} \mathrm{C}$. The whole-rock XRD data were obtained under conditions made as uniform as possible for all of the XRD runs.
The same preparation procedures, the same instrument, and the same instrument settings were used for all samples. All the runs were made continuously, and a standard sample was X-rayed before and after each daily run. All analyses were made from splits of the same sample.

The data set in table 4 contains the chemical and mineralogical content of the samples. The values for quartz, feldspar and calcite were determined by measuring the areas of the XRD peaks in square inches from the whole-rock diffractograms. The values for chlorite,

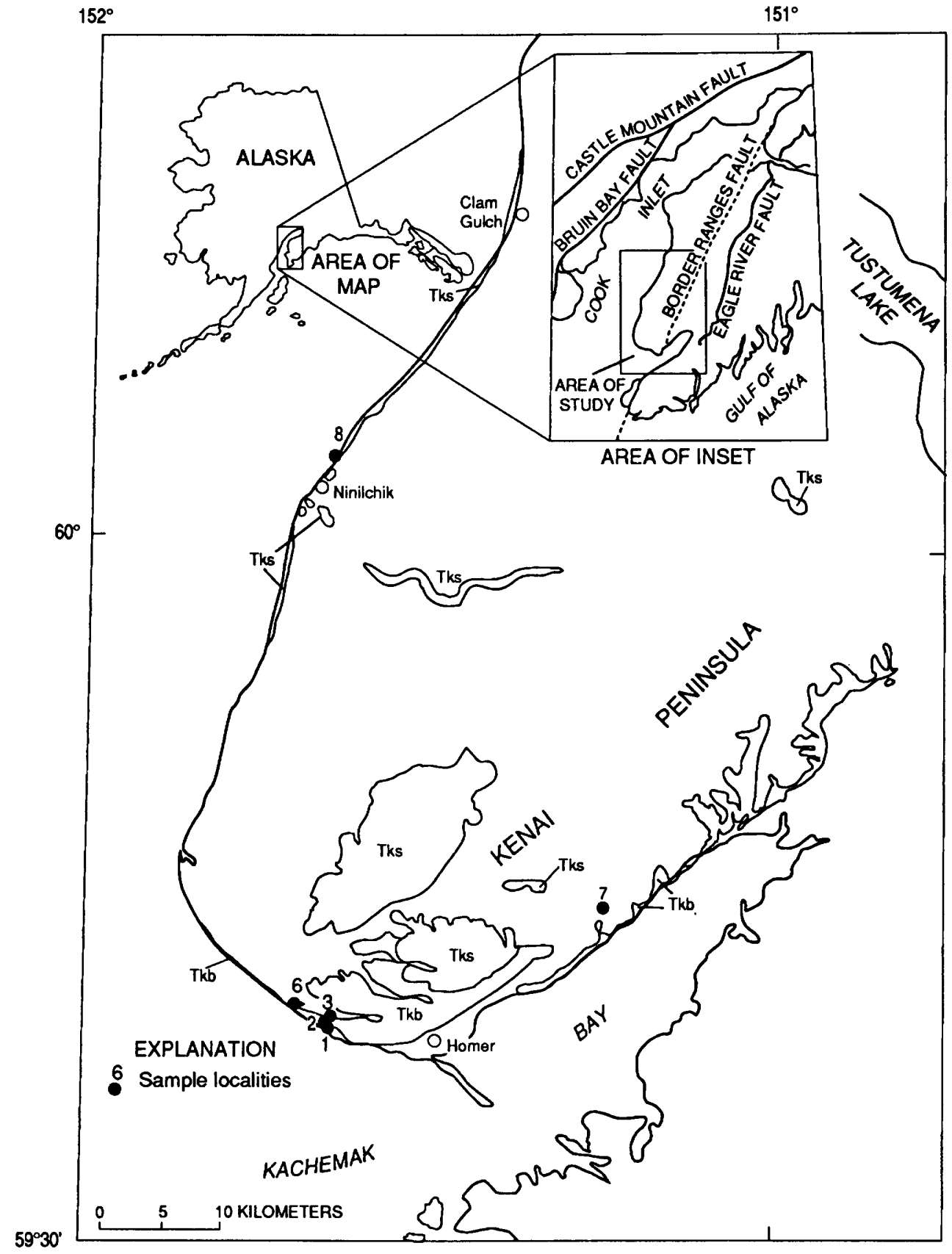

Figure 1. Geologic map of Cook Inlet basin study area showing sample localities (numbered dots). Map units: Tks, Sterling Formation; Tkb, Beluga Formation. 
smectite and illite were determined by the number of XRD counts from each peak on the glycolated, oriented clay mounts. The peaks measured for each mineral are listed in table 1. The amplitudes of the XRD peaks, whether in counts or square inches, cannot be considered as depicting actual quantities of minerals present, but they do indicate relative amounts.

\section{GEOLOGY}

The Cook Inlet basin, in the coastal area of southcentral Alaska, separates the Alaska Range to the northwest from the Kenai-Chagach Mountains to the southeast. The Talkeetna Mountains and the Copper River basin lie to the northeast. The basin measures about 100

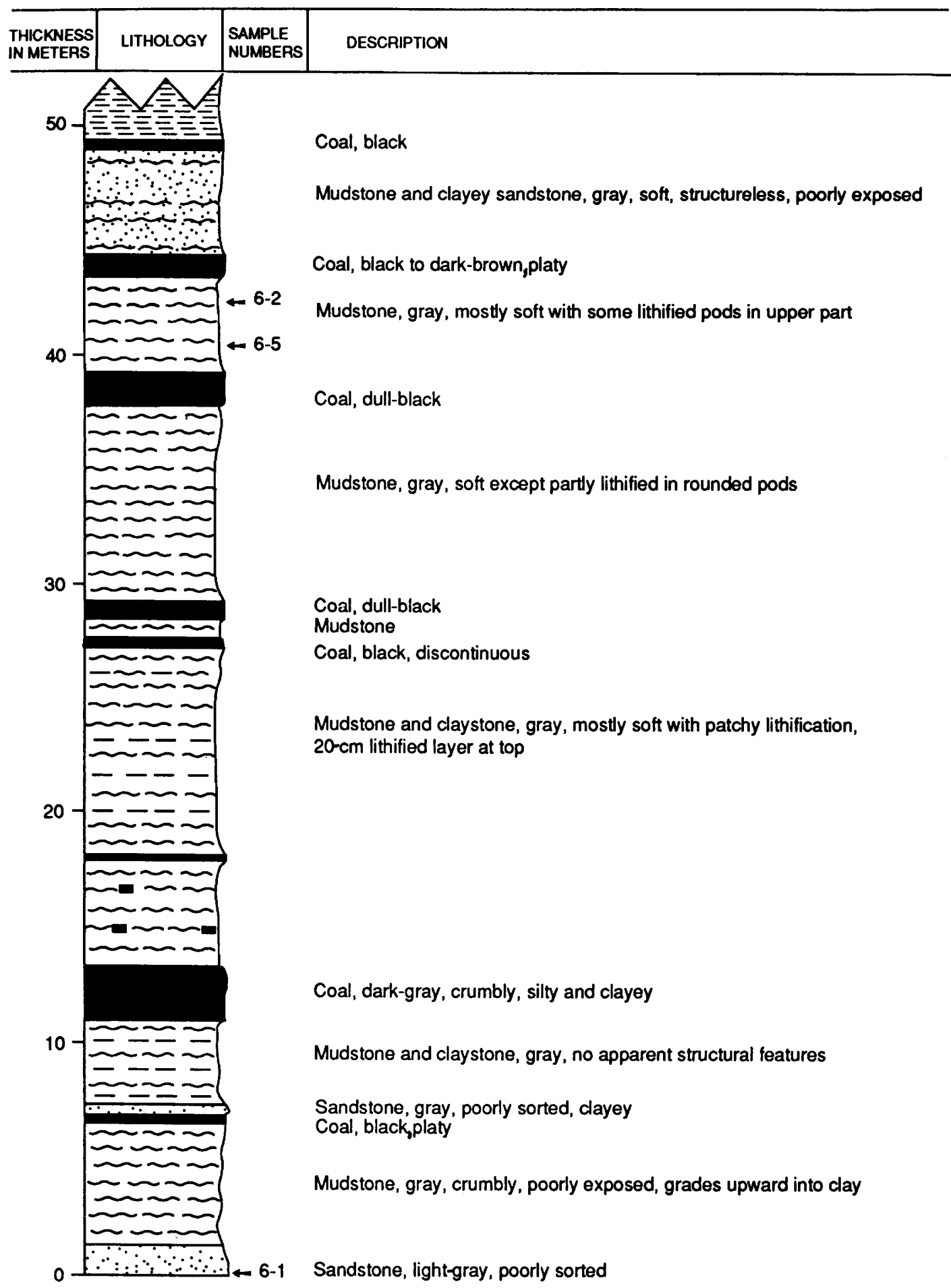

Figure 2. Measured section of part of Beluga Formation at Diamond Gulch (loc. 6, fig. 1). 
$\mathrm{km}$ by $300 \mathrm{~km}$; its axis is oriented about N. $25^{\circ} \mathrm{E}$. It contains about $8,500 \mathrm{~m}$ of mostly nonmarine Tertiary sedimentary rock that comprise the Kenai Group. The Kenai Group overlies Jurassic, Cretaceous, and older
Tertiary rocks (Kremer and Stadnicky, 1985) and underlies Quaternary alluvium and glacial deposits.

The Cook Inlet basin is generally bounded on the east by the Border Ranges fault (Knik fault of Magoon

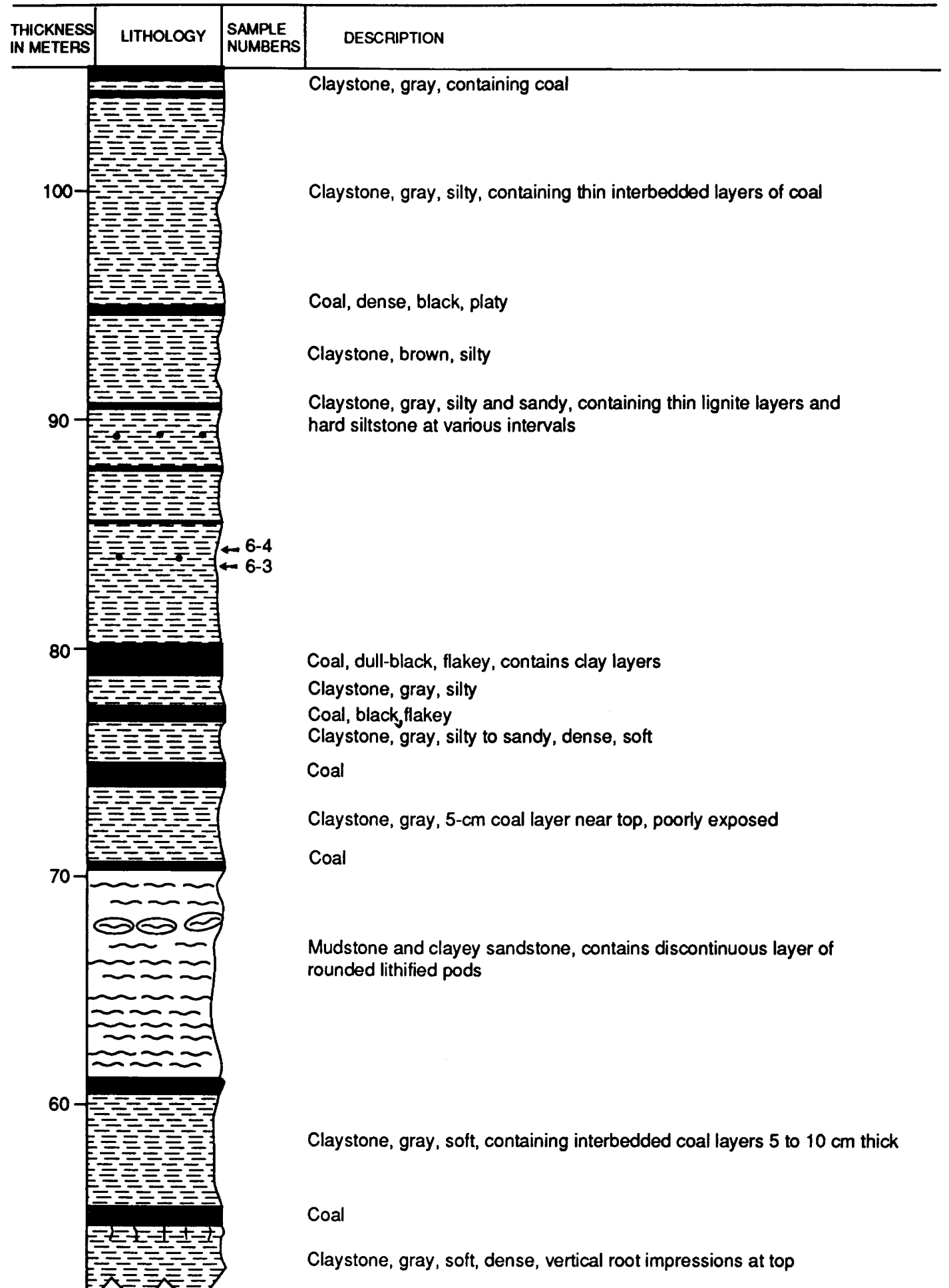

Figure 2. Continued. 
and others, 1976). This fault strikes about N. $30^{\circ} \mathrm{E}$. The Bruin Bay fault, which generally forms the western margin of the basin, extends northward about N. $45^{\circ} \mathrm{E}$. It intersects the Castle Mountain fault in the northern part of the basin. The Castle Mountain fault trends about N. $60^{\circ} \mathrm{E}$. and generally forms the northwestern boundary of the basin (fig. 1). Thinner, undifferentiated equivalents of the Kenai Group rocks extend north of the Castle Mountain fault into the Susitna lowlands. Other minor faults or lineaments have been mapped on the Kenai Peninsula. Several gentle anticlines and synclines, whose axes generally parallel the long axis of the basin, were mapped by Magoon and others (1976) in the eastern half of the Cook Inlet basin (fig. 1). Water of Cook Inlet covers most of the northwest half of the basin.

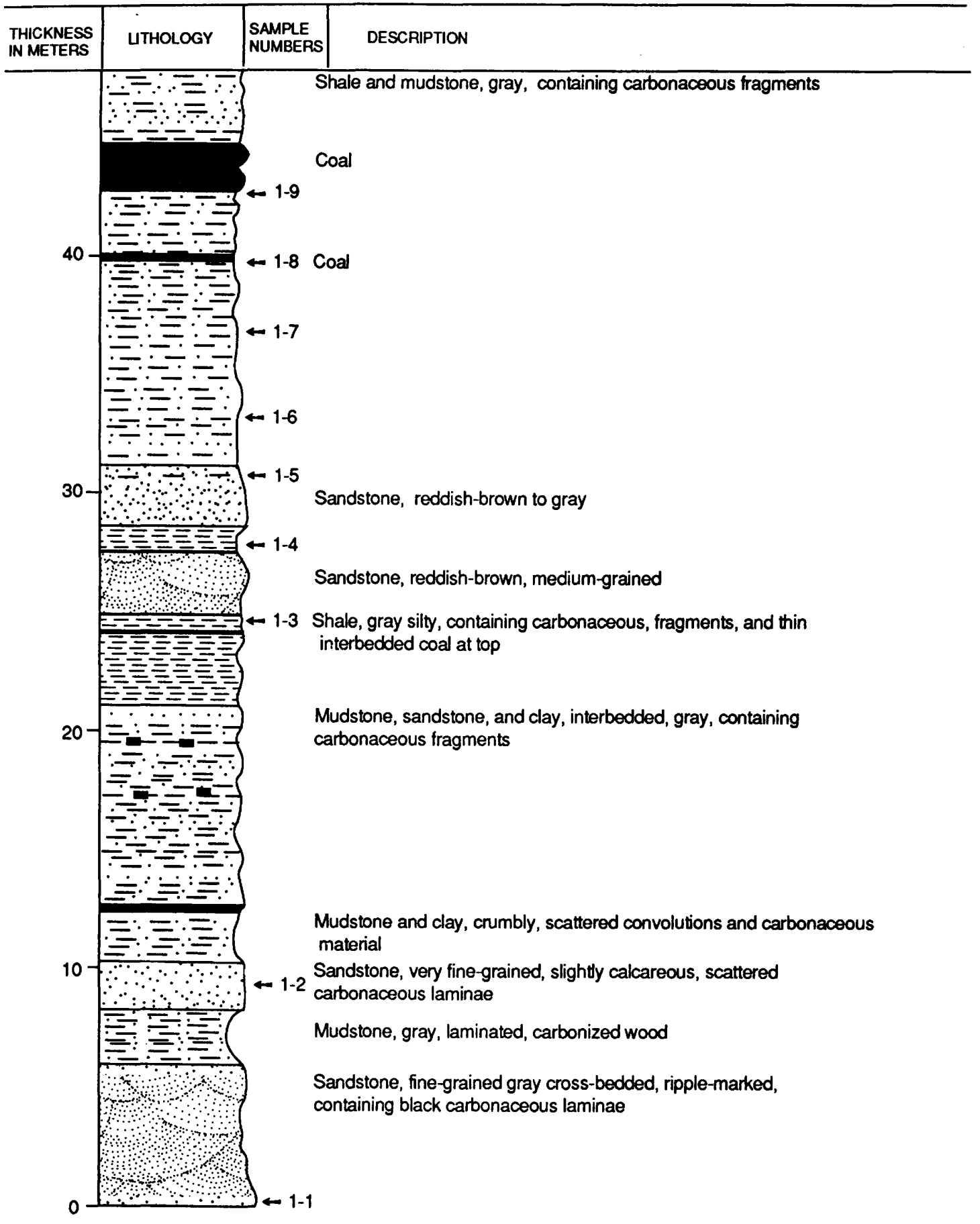

Figure 3. Measured section of part of Beluga Formation exposed near beach at Homer Bluff (loc. 1, fig. 1) 


\section{Tertiary Sedimentary Rocks}

The Tertiary sedimentary rocks of the Kenai basin were first referred to as the "Kenai Group" by Dall and
Harris (1892). They assigned the Group to the Miocene. Barnes and Cobb, (1959) and Parkinson (1962) later referred to the same rocks as the Kenai Formation. The Kenai Group was later divided into five named forma-

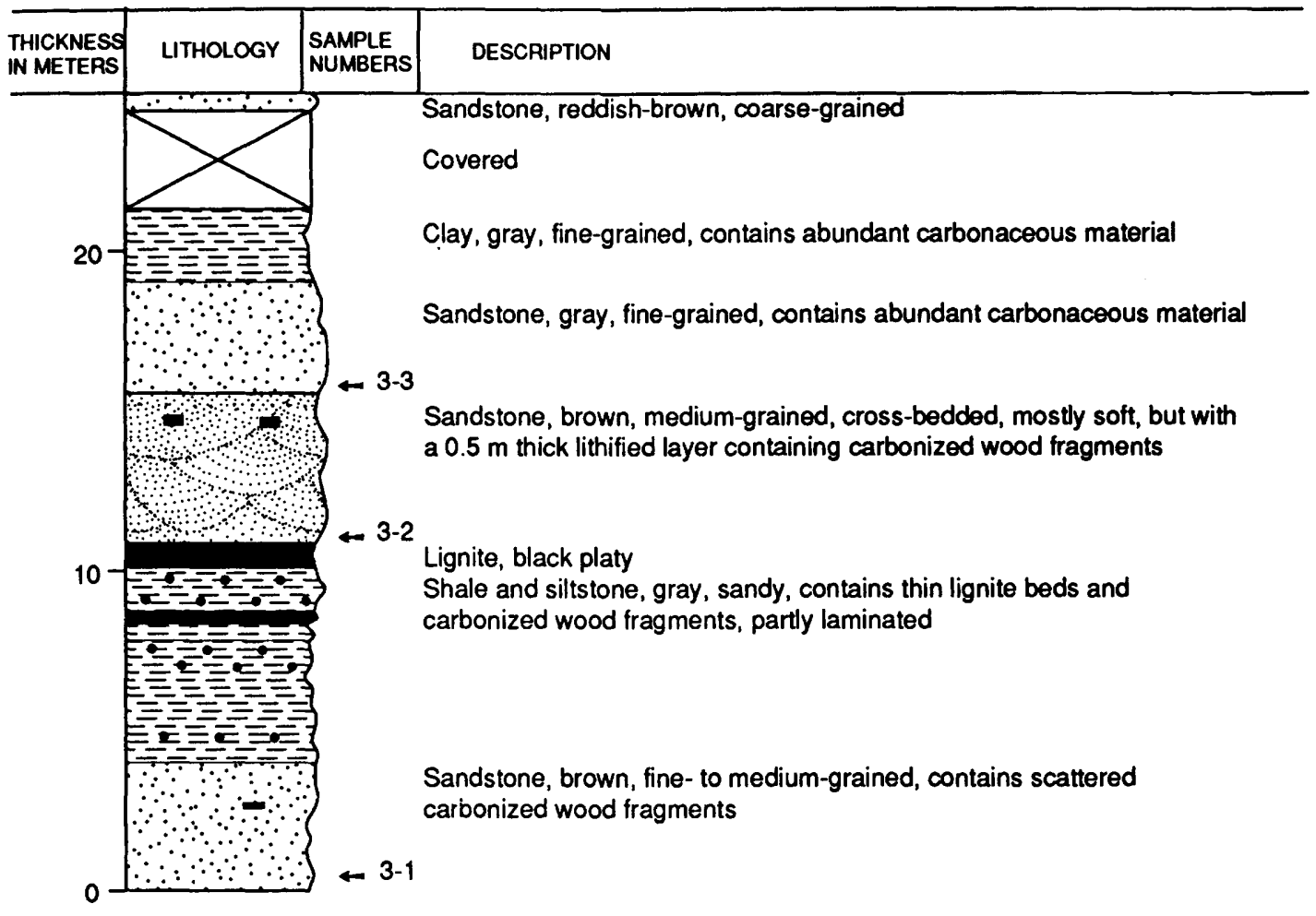

Figure 4. Measured section of part of Beluga formation exposed below highway at Homer Bluff (loc. 3, fig. 1).

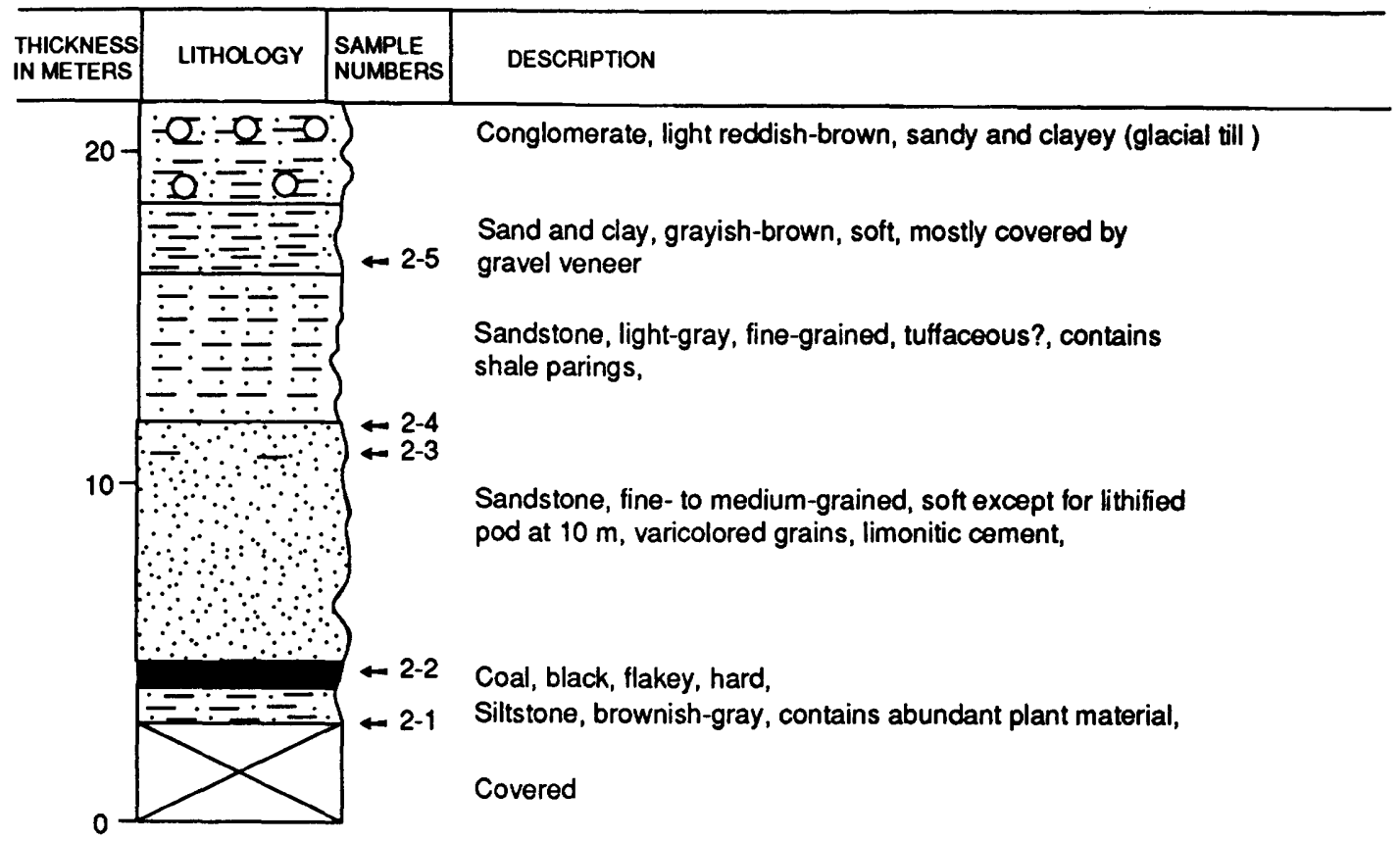

Figure 5. Measured section of part of Beluga Formation exposed above highway at Homer Bluff (loc. 2, fig. 1). 
tions (Crick, 1971; Calderwood and Fackler 1966, 1972): the West Foreland, Hemlock Conglomerate, Tyonek, Beluga, and Sterling, in ascending order. Later, Magoon and others (1976) dropped the West Foreland Formation from the Kenai Group. The Beluga and Sterling Formations were also described by Kremer and Stadnicky (1985) and by Magoon and Egbert (1986).

This study involves mainly the upper part of the Beluga Formation and the lower part of the Sterling Formation, which crop out along the Kenai Peninsula on the east shore of Cook Inlet.

\section{Beluga Formation}

The type section of the Beluga Formation consists of $1,265 \mathrm{~m}$ of thin interbedded sandstone, siltstone, claystone, and lignitic to subbituminous coal. The type section is the Beluga River No. 1 (212-35) well drilled in

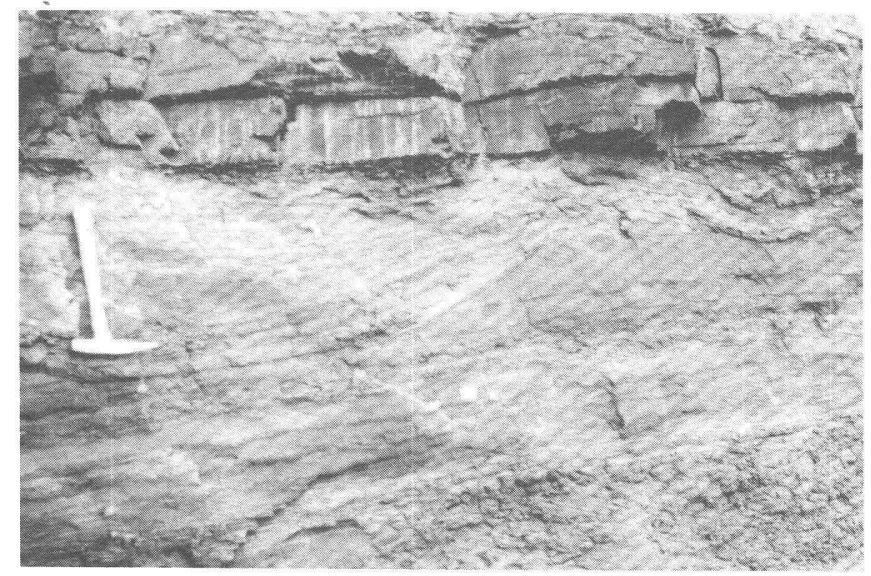

$\boldsymbol{A}$

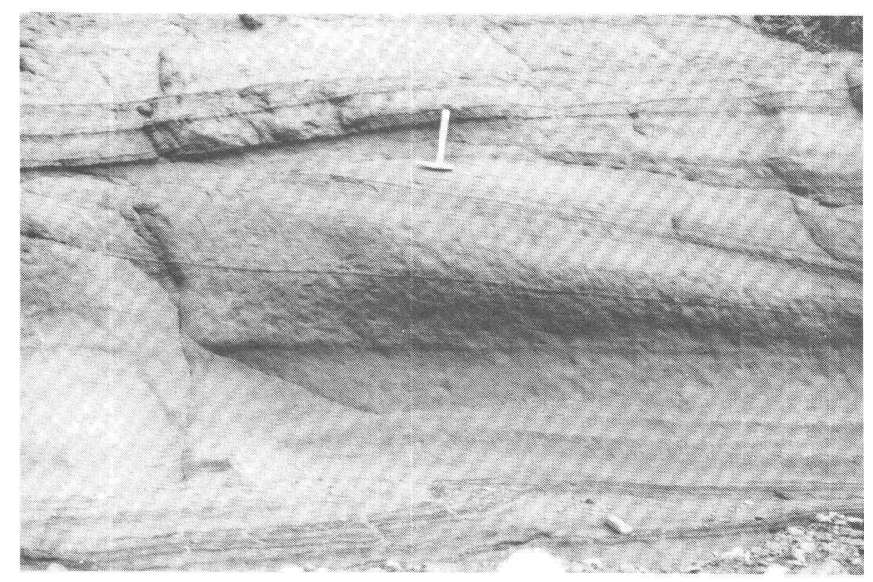

$B$

Figure 6. Beluga Formation along beach 1 to $5 \mathrm{~km}$ west of Homer. A, Trough crossbedding in fine-grained brown sandstone underlying lignite beds. $B$, Large-scale crossbedding in fine- to medium-grained brown sandstone. $C$, Contorted bedding and rip-up of thin-bedded
Table 1. X-ray diffractogram peaks ( $\mathrm{Cu}, \mathrm{K}$-alpha radiation) measured for the Kenai Group samples

\begin{tabular}{|c|c|c|}
\hline Mineral & $\begin{array}{l}\text { X-ray diffraction peak } \\
\text { (degrees 2-theta) }\end{array}$ & $\begin{array}{l}\text { Crystallographic } \\
\text { indices }\end{array}$ \\
\hline Calcite--.-- & 29.4 & 104 \\
\hline Feldspar-- & $26.9-27.9$ & 002 \\
\hline Quartz - & 20.8 & 100 \\
\hline 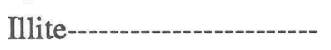 & 8.8 & 001 \\
\hline Smectite----_-_-_----- & 10.2 & 002 \\
\hline 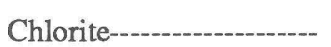 & 12.5 & 002 \\
\hline
\end{tabular}

The statistical analyses were calculated using a commercial program called "Number-Cruncher Statistical System" (Hintze, 1987). The results of these studies are used to interpret sedimentologic and diagenetic processes. Some of the results, however, defy interpretation, which probably reflects inadequacies in the methods, inaccuracies in the data, or various degrees of departure from normality of data distribution.

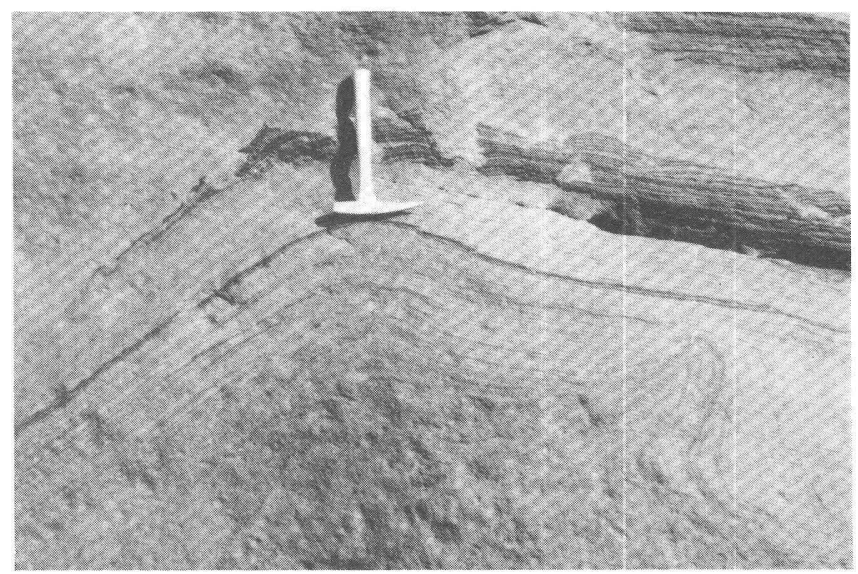

C

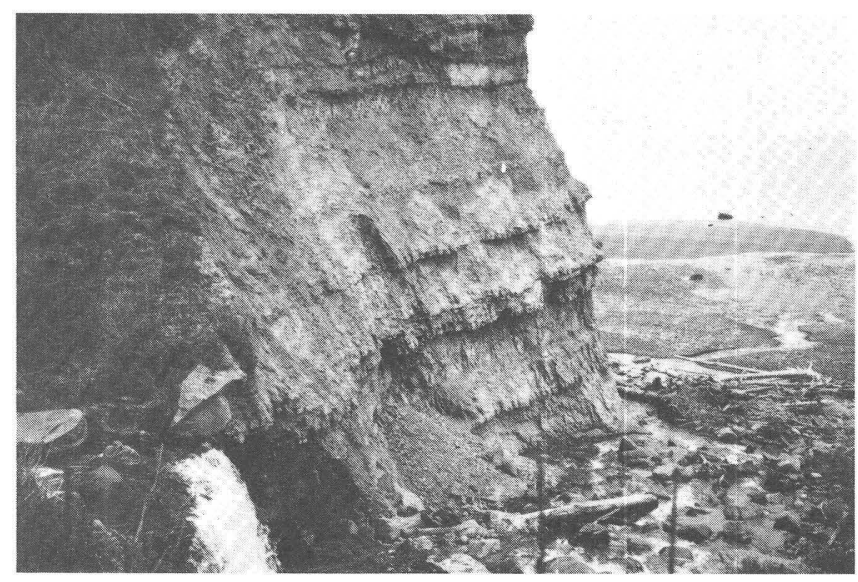

$D$

lacustrine(?) layer in fine- to medium-grained brown sandstone along beach at Homer Bluff. D, Gray carbonaceous mudstone and coal sequence at beach at Diamond Gulch (exposed section is about $4 \mathrm{~m}$ thick). 


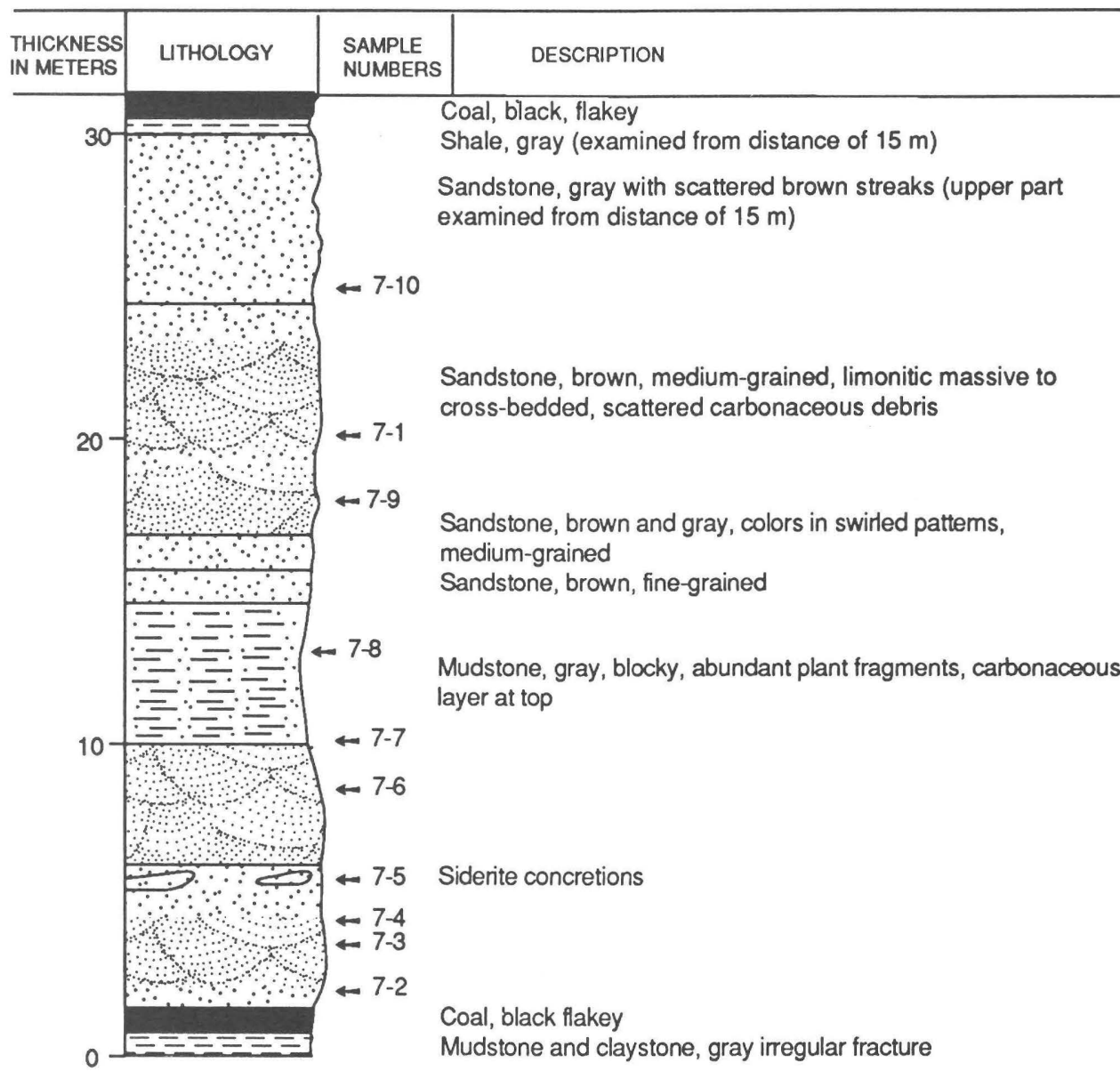

Figure 7. Measured section of exposed part of Sterling Formation at McNiel Canyon (loc. 7, fig. 1).

1962 by Standard Oil Company of California at the village of Beluga on the northwest shore of Cook Inlet, about $100 \mathrm{~km}$ north of Lake Tustumena (Crick, 1971; Calderwood and Fackler, 1972). The composition of the Beluga at the type section is similar to the exposures in Kachemak Bay and near Homer (Adkison and others, 1975). Adkison and Newman (1973) reported rock types similar to the type section in the Deep Creek Unit well on the Kenai Peninsula.

The Beluga Formation outcrops near Homer Bluff studied for this report consist mostly of gray carbonaceous mudstone, siltstone, and claystone, together with beds of coal and gray to light-reddish-brown arkosic sandstone (figs. 2-6). They were assigned to the Homerian Provincial Stage by Wolfe and others (1966). Wolfe and Toshimasa (1980) determined, based mainly on plant fossils, that these rocks are upper Miocene.

\section{Sterling Formation}

At its type section, the Sterling Formation consists of approximately $1,369 \mathrm{~m}$ of massive and conglomeratic sandstone with interbeds of claystone. The type section is the Sterling Unit No. 23-15 well drilled in 1961 by Union Oil Company of California about $14 \mathrm{~km}$ east of Kenai. The formation may reach a total thickness of more than 3,350 $\mathrm{m}$ in the East Foreland area of Cook Inlet, about 75 km north of Ninilchik (Calderwood and Fackler, 1972). Similar lithologies, together with coalbeds, are found in the Sterling on the Kenai Peninsula along the east shore of Cook Inlet (Adkison and others, 1975; figs. 7, 8).

For this study the Sterling Formation was sampled both at the uppermost section exposed in McNiel Can-

Figure 8. Outcrops of Sterling Formation. A, Massive fine- to medium-grained light-brown sandstone along beach north of Ninilchik (exposed section is about $9 \mathrm{~m}$ thick; note rock hammer near base). B, Upper part of exposed section at McNiel Canyon, consisting mostly of medium-grained gray and brown sandstone; contains lignite layer in upper third. C, Irregularly bedded light-brown fine- to medium-grained sandstone overlying coalbed along beach north of Ninilchik (note fossil stump at rock hammer). $D$, Alternating coalbeds and brown fine- to medium-grained sandstone beds along beach north of Ninilchik (exposed section is about $10 \mathrm{~m}$ thick). 


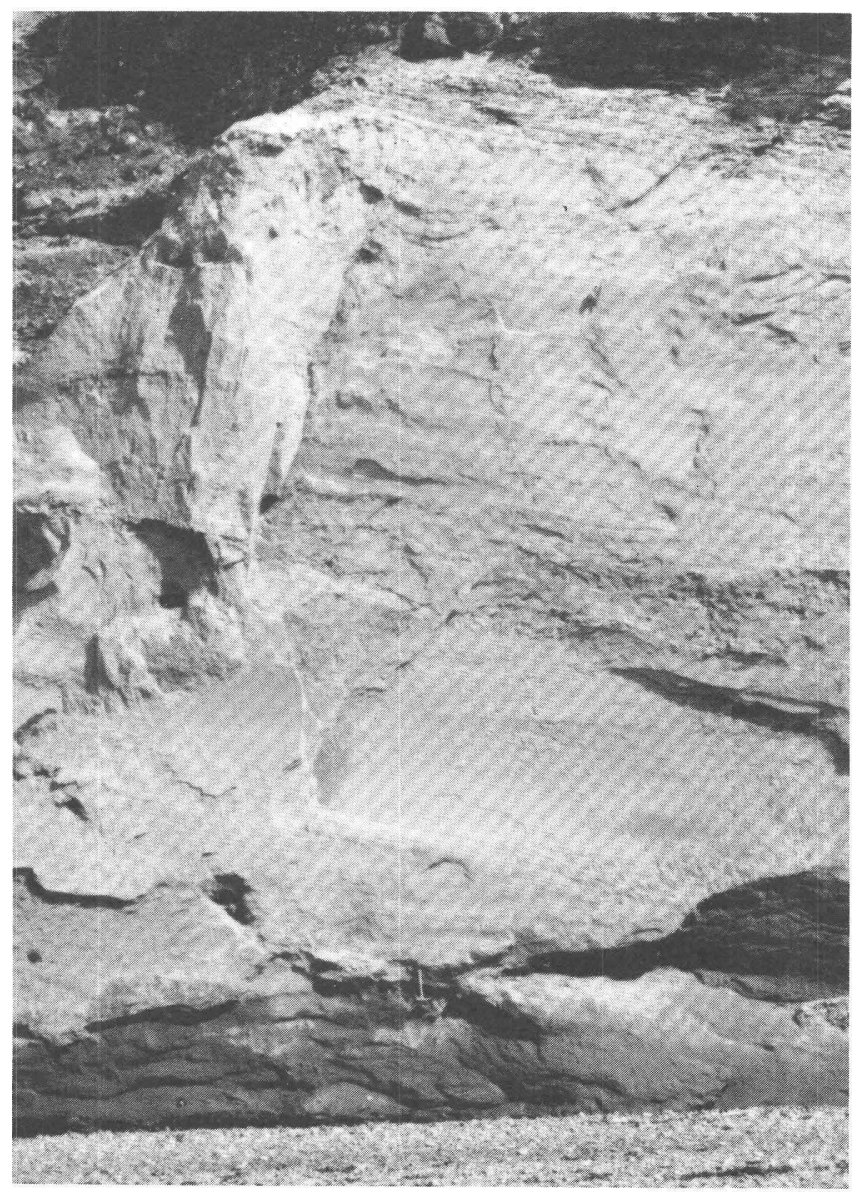

A

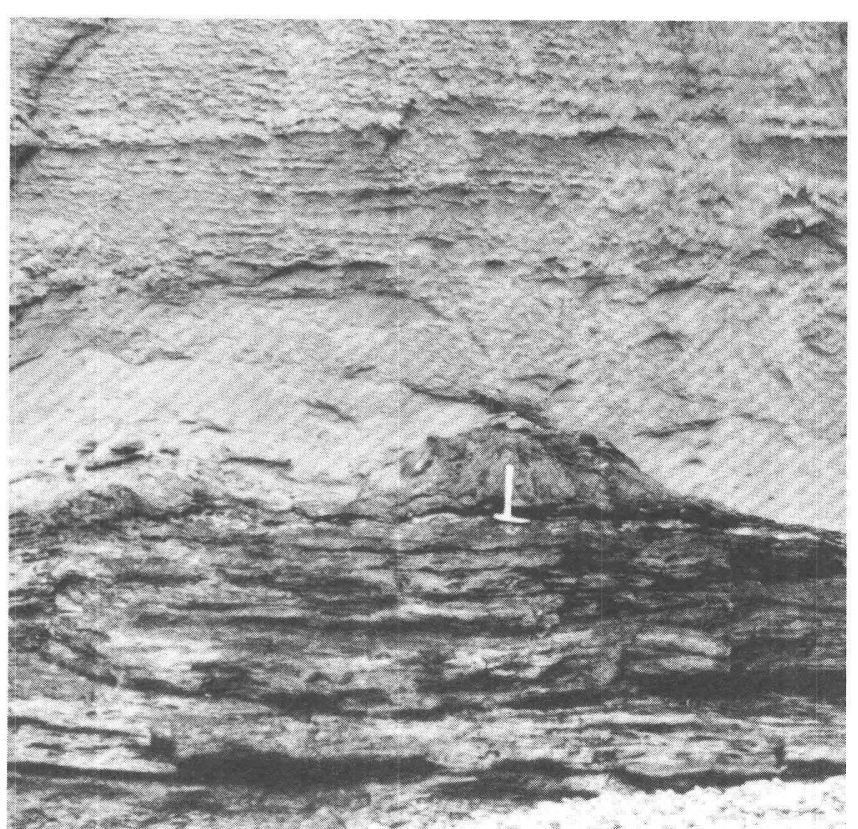

C

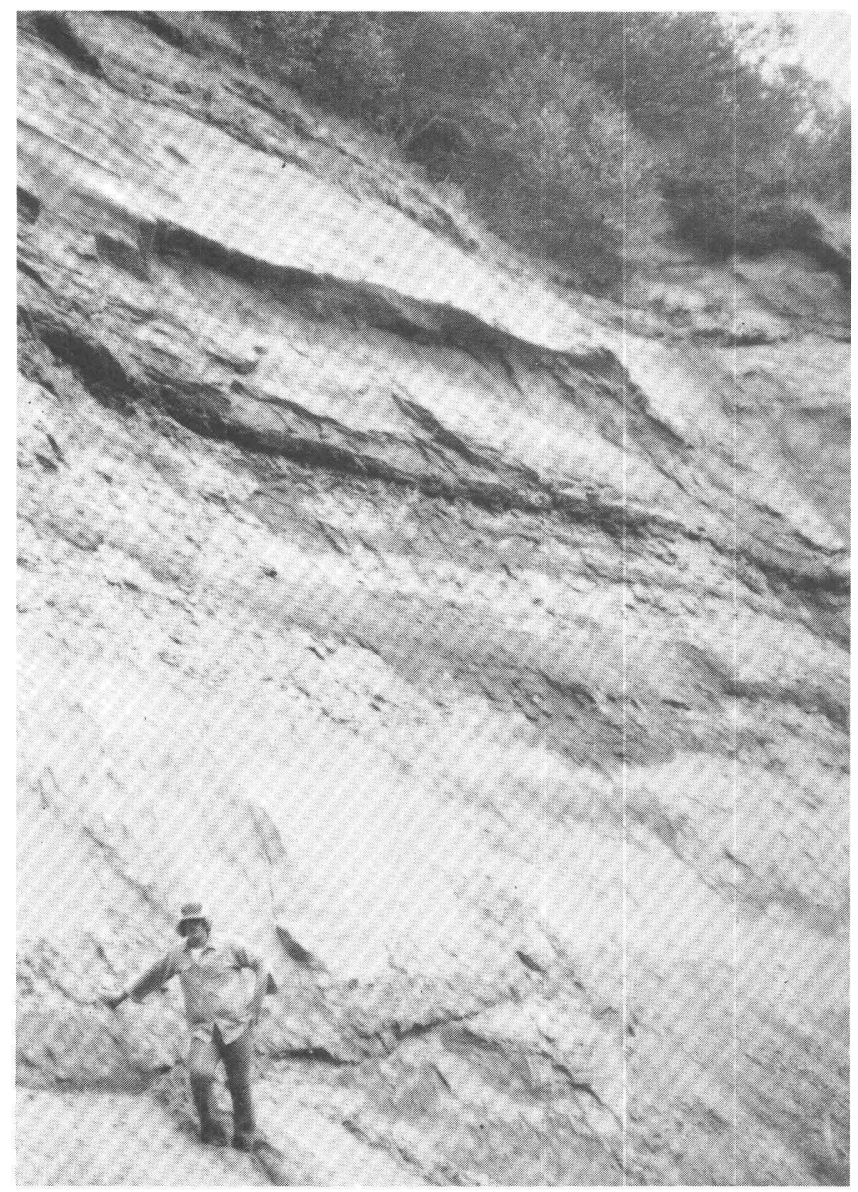

B

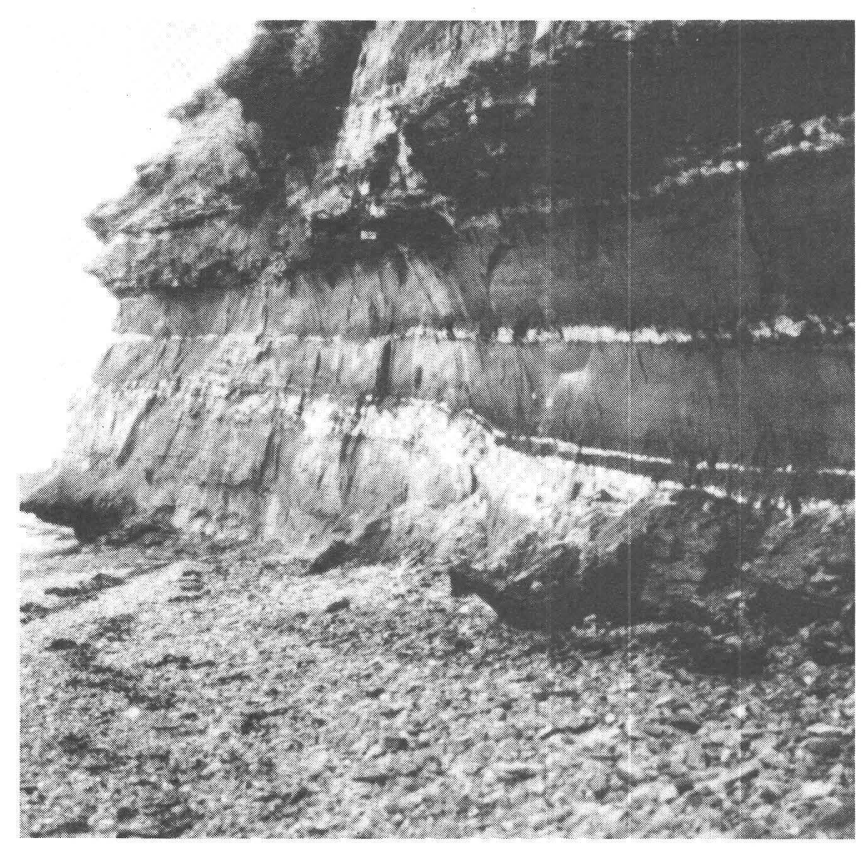

D 
yon about $19 \mathrm{~km}$ east of Homer and along the beach north of Ninilchik. At McNiel Canyon, the formation consists of light-brown and gray, fine- and mediumgrained feldspathic partly crossbedded sandstone, gray blocky carbonaceous mudstone containing plant fossils, and thin coalbeds (figs. 7, 8B).

The Sterling Formation in the vicinity of Ninilchik northward along the coast to Clam Gulch was assigned to the Clamgulchian Provincial Stage by Wolfe and others (1966). It was determined to be late Miocene and Pliocene based on plant fossils (Wolfe and Toshimasa, 1980).

\section{Sediment Source Areas for the Beluga and Sterling Formations}

Calderwood and Fackler (1972) proposed two general sediment sources for the late Tertiary Beluga and Sterling Formations in the Cook Inlet basin. These are the Aleutian-Alaska Ranges rocks to the north and west and the Kenai-Chugach Ranges rocks to the east. According to Calderwood and Fackler (1972) sediments derived from the Aleutian-Alaska Ranges are primarily granitic, and the sediments derived from the Kenai-Chugach Ranges are primarily metamorphic. Hayes and others (1976) showed that sandstones of the Sterling Formation are composed of quartz, plagioclase, and volcanic rock fragments that were derived from the AleutianAlaska Ranges west and north of Cook Inlet (see also Kremer and Stadnicky, 1985). These sediments were deposited by moderately large meandering streams. Hayes and others (1976) also suggest that the Beluga was deposited by high-gradient, braided streams, and that the sediment, which was derived from the Kenai-Chugach Ranges to the east, consists mostly of metasedimentary rock fragments. In addition, Hayes and others (1976) suggested that the two formations can be differentiated on the basis of their clay-mineral suites. The Sterling clays are predominantly smectite formed by alteration of volcanic material in sediment that was derived from the westerly source, whereas the Beluga clays are high in illite [mica] and chlorite that was derived from metamorphic rocks having an easterly source. The different sediment sources are probably also reflected in the heavy minerals, as is discussed below.

The data presented in this report do not support all the ideas of previous authors. The chlorite-illite clays (Kenai-Chugach Ranges source sediments) are not confined to the Beluga Formation, and the smectite (Aleutian-Alaska Ranges source sediments) is not the predominant clay in the Sterling Formation, as claimed by Hayes and others (1976). The ratio of chlorite to smectite, as indicated by $\mathrm{XRD}$ responses, for the Beluga (2.17) is nearly identical to that for the Sterling (2.13). Samples that show strong illite and chlorite peaks combined with no smectite may characterize Kenai-Chugach sources, but in this study they oc- curred in samples from both formations (fig. 9). Samples with strong smectite responses and scant chlorite-illite are also present in samples from both formations. The scatterplot in figure 9A shows three groups of samples based on chlorite and smectite XRD responses. One group is mostly smectite and probably represents Aleutian-Alaska Ranges source sediments, and another group is mostly chlorite and probably represents Kenai-Chugach Ranges source sediments. A third group, the largest, is from a mixture of sources and may include sediments from both the AleutianAlaska Ranges and the Kenai-Chugach Ranges, together with more distant sources north and northeast of the Cook Inlet basin area. A good correlation is apparent between chlorite and smectite within the group of mixed-source sediments, whereas the overall correlation is nearly zero (table 2). A similar distribution can be found and similar conclusions can be made comparing illite with smectite (fig. $9 B$ ).

Several authors (Kirschner and Lyon, 1973; Hite, 1976; Biddle, 1977) have shown two different heavymineral suites exist in the Beluga-Sterling sequence. A stratigraphically lower suite is dominated by epidote and garnet, and an upper one is dominated by hypersthene and hornblende. Hite (1976) attempted to attribute the lower heavy mineral suite to the Beluga Formation and the upper one to the Sterling, but Biddle (1977) placed the change from lower to upper in the Homer Bluff section, which is entirely within the Beluga Formation as mapped by Magoon and others (1976). Furthermore, Biddle (1977) states that the change occurs at a stratigraphically lower point in the Homer Bluff section than in the Kachemak Bay sections, although exact correlation between the two areas is difficult. These heavy-mineral suites suggest a cleaner separation between sediments from the proposed two sources than is indicated in the clay minerals, but considerable scatter occurs in the heavy-mineral contents as well.

Either quartz is slightly more abundant in the XRD responses from the Beluga Formation than from the Sterling Formation, or, considering possible analytical errors, they are indistinguishable. If the Aleutian-Alaska Ranges source of sediments is granitic terrain, considerable quartz would be expected in these sediments. In addition, both thorium and uranium are slightly higher in the Beluga than in the Sterling. If the Sterling sediments were derived from a granitic source, one would expect these sediments to be higher in $U$ and $T h$ because granitic rocks are generally high in these elements.

\section{STATISTICAL ANALYSIS}

Correlation coefficients and results of an $r$-mode factor analysis (Harmon, 1960) are presented for part of the data listed in tables $2-4$. The choice of a five-factor model was based on a compromise between striving for 
the lowest number of factors and higher communalities (proportions of each variable potentially explained by the factor score).

\section{Factor One}

The primary factor one loadings are for $\mathrm{U}, \mathrm{Mg}, \mathrm{Th}$, $\mathrm{Cr}, \mathrm{Sc}$, and $\mathrm{V}$, which are negative, and for feldspar, which is positive. Uranium and thorium have a well- known geochemical relationship in igneous rocks and their occurrence in the same factor is expected in sedimentary rocks if the sediments have not undergone oxidizing alteration before or after deposition. The loadings for $\mathrm{Cr}, \mathrm{Sc}$, and $\mathrm{V}$, although primary, are not high in this factor. The secondary loading for all three are nearly as strong. Vanadium occurs with uranium in many of the epigenetic uranium deposits in the western conterminous United States and is moderately related to the uranium in this analysis. The vanadium, however, has a very low
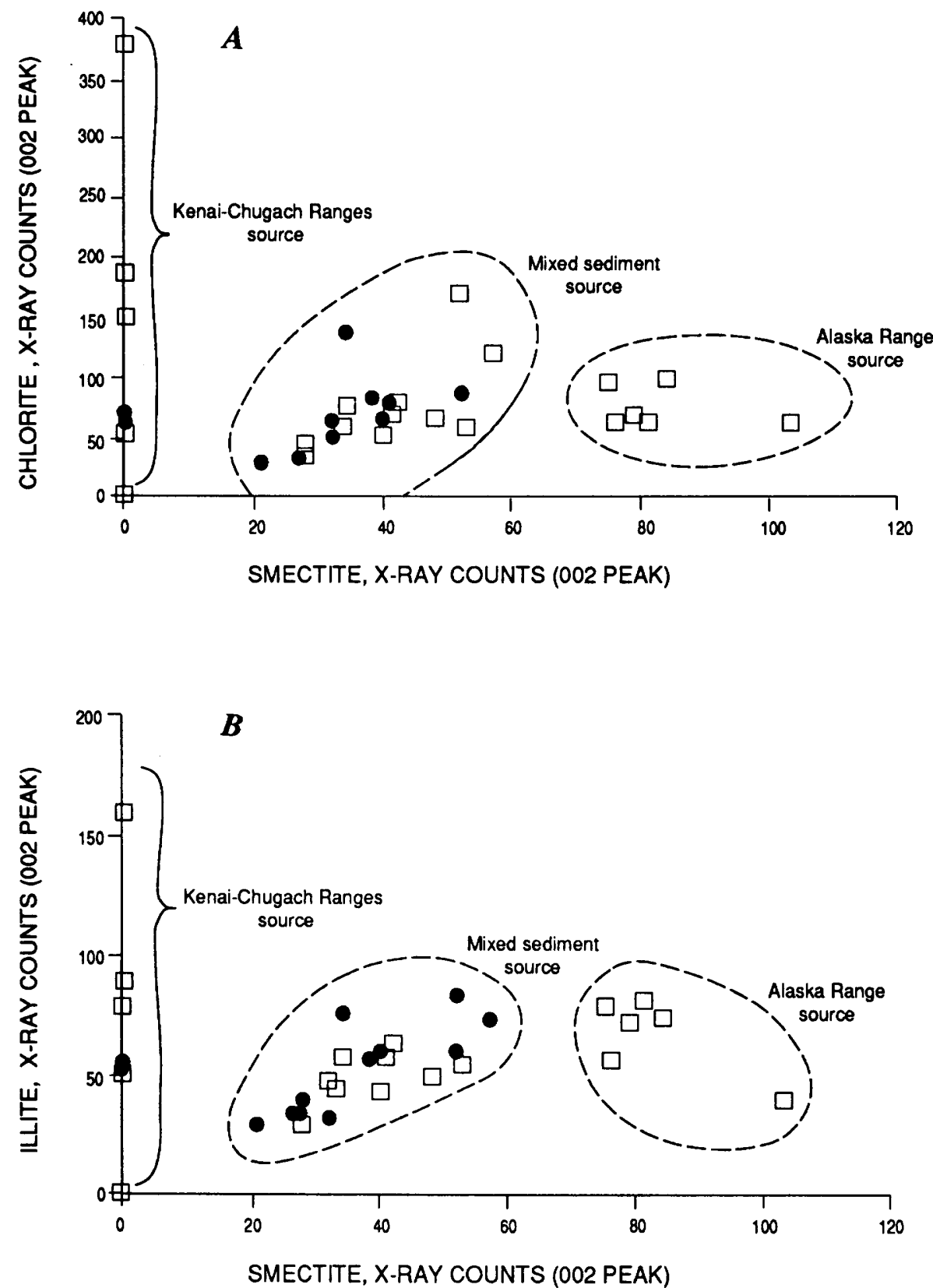

Figure 9. Scatterplots of $X$-ray diffraction counts for clay minerals for samples of Beluga (squares) and Sterling (circles) Formations, Kenai Peninsula, showing possible source areas for different clay ratios. $A$, Chlorite versus smectite. $B$, lllite versus smectite. 
communality $(0.37)$, indicating that much of its distribution is not accounted for. Feldspar is at the negative pole of factor one and probably represents the most common detrital grains in the sandstone. It may represent sandsized material from all the sediment sources.

\section{Factor Two}

Factor two consists, in order of decreasing loading strength, of $\mathrm{Ba}, \mathrm{Ti}, \mathrm{Na}, \mathrm{Zr}, \mathrm{Ga}, \mathrm{Sr}$, and $\mathrm{Y}$. The occurrence of $\mathrm{Ti}$ and $\mathrm{Zr}$ in this factor suggests that this group generally represents the heavy minerals. Both titanite and zircon are reported in the heavy-mineral suites for the Sterling and Beluga Formations (Hite, 1976). The Beluga reportedly contains more of both minerals than does the Sterling. How $\mathrm{Ba}, \mathrm{Yt}, \mathrm{Ga}$, and $\mathrm{Na}$ are incorporated in this factor is not known.

\section{Factor Three}

Iron, manganese, and cobalt form factor three. These elements are commonly associated in the geologic environment. All three elements may be deposited as sulfides in a reducing sedimentary environment, which could explain their association here.

\section{Factor Four}

Factor four contains $\mathrm{Ca}$ and $\mathrm{K}$ at a negative pole and smectite at a positive pole. $\mathrm{Ca}$ and $\mathrm{K}$ both form large cations that probably mostly reside in silicates, considering that few or no carbonates were included in the data set. It is apparent that neither $\mathrm{Ca}$ nor $\mathrm{K}$ resides in smectite, which has the opposite loading. The occurrence of smectite in this factor suggests a relation to Aleutian-Alaska Ranges source sediments.

Table 2. Correlation coefficient matrix

\begin{tabular}{|c|c|c|c|c|c|c|c|c|c|c|c|}
\hline Feldspar & Quartz & Illite & Smectite & Chlorite & Uranium & Thorium & Iron & Magnesium & Calcium & Titanium & Manganese \\
\hline \multicolumn{12}{|l|}{ Feldspar-ar----- 1.00} \\
\hline Quartz --..- .15 & 1.00 & & & & & & & & & & \\
\hline 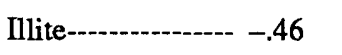 & .25 & 1.00 & & & & & & & & & \\
\hline Smectite-- & -.04 & .34 & 1.00 & & & & & & & & \\
\hline Chlorite---------- -.46 & .32 & .90 & .06 & 1.00 & & & & & & & \\
\hline Uranium------.- -.70 & -.14 & .49 & .15 & .38 & 1.00 & & & & & & \\
\hline Thorium--------- -.39 & .03 & .51 & .20 & .38 & .54 & 1.00 & & & & & \\
\hline Iron - & .22 & .29 & .04 & .27 & .35 & -.01 & 1.00 & & & & \\
\hline Magnesium --.--- -.39 & -.02 & .33 & -.03 & .29 & .44 & .54 & .07 & 1.00 & & & \\
\hline Calcium --------- -.06 & -.09 & -.23 & .20 & -.10 & -.30 & -.12 & .04 & -.04 & 1.00 & & \\
\hline Titanium --------- -.08 & .06 & .01 & -.01 & -.04 & .27 & .35 & .09 & .41 & -.18 & 1.00 & \\
\hline Manganese ----- -.23 & -.28 & -.05 & .09 & -.10 & -.03 & -.27 & .74 & -.20 & .21 & -.14 & 1.00 \\
\hline Barium -------- $\quad .07$ & .33 & .16 & .12 & .07 & .11 & .16 & .09 & .16 & -.19 & .42 & -.08 \\
\hline Cobalt --:-'---17 & -.06 & .12 & -.18 & .18 & .03 & -.04 & .54 & .15 & -.11 & .17 & .50 \\
\hline Chromium ------- -.41 & .06 & .24 & -.04 & .22 & .67 & .48 & .30 & .58 & -.17 & .66 & -.12 \\
\hline Copper--.4- -.44 & .14 & .46 & -.05 & .46 & .31 & .36 & .23 & .51 & -.10 & .27 & -.14 \\
\hline Scandium ------ -.27 & .09 & .26 & -.15 & .23 & .38 & .41 & .05 & .52 & -.18 & .57 & -.20 \\
\hline Strontium ---.-- .50 & .07 & -.37 & -.19 & -.38 & -.32 & -.27 & -.29 & -.00 & -.04 & .39 & -.10 \\
\hline Vanadium-------- -.33 & .02 & .15 & -.04 & .11 & .44 & .23 & .06 & .39 & -.13 & .09 & .04 \\
\hline Yttrium--------.-- -.35 & .07 & .22 & -.12 & .23 & .42 & .10 & .37 & .36 & -.11 & .31 & .03 \\
\hline Żrconium -.-.- -.14 & -.12 & .08 & -.06 & .08 & .33 & .23 & .19 & .14 & -.16 & .58 & -.09 \\
\hline Sodium-16 & .13 & -.17 & -.06 & -.14 & -.01 & -.06 & .02 & -.09 & .04 & .26 & -.09 \\
\hline Potassium -------- -.24 & .01 & .12 & -.15 & .17 & .16 & .18 & -.04 & .40 & .15 & .19 & -.15 \\
\hline Gallium- & .07 & -.02 & -.00 & -.05 & -.02 & .16 & -.00 & .15 & -.20 & .59 & -.20 \\
\hline
\end{tabular}




\section{Factor Five}

Factor five, in order of decreasing strength, consists of chlorite, illite, quartz, and $\mathrm{Cu}$. The minerals probably owe their association to their occurrence as detrital grains in the finer grained mudstones and shales. The lack of smectite and the strong illite and chlorite loadings suggest that this group is also related to sources in the Chugach and Kenai Ranges. The quartz loading is not strong, and the communality $(0.61)$ suggests that only a little over half of the quartz distribution is explained by this analysis. The analysis suggests that copper is also weakly associated with these sediments. The secondary factor loading for copper in factor one is nearly as high, however (table 3 ).

\section{DIAGENESIS}

The only known diagenetic minerals in the Sterling and Beluga Formations are carbonates. Calcite occurs in scattered concretions. Siderite concretions were found at one locality (fig. 7). Small siderite spherulites were found in the heavy-mineral suites (Biddle, 1977).

Hayes and others (1976) believed that porosity in the Sterling Formation was derived from the solution of detrital grains of volcanic glass, trachytic rock, biotite, hornblende, and hypersthene. According to them, the solution of these grains from the Sterling sandstone produced the porosities (as much as 35 percent) that greatly increased the favorability of the Sterling for petroleum accumulation. They failed to find a depositional site for the dissolved material. Solution of the volcanic grains would have released uranium in an oxidizing solution, but no evidence was found for uranium mobilization in these rocks. With the abundance of carbonaceous material and a resulting abundance of rock that is chemically reducing in both the Sterling and Beluga Formations, the uranium would not have moved far.

\section{URANIUM RESOURCE POTENTIAL}

The Beluga and Sterling Formations on the Kenai Peninsula have been given a low favorability rating for uranium ore deposits by Dickinson and Campbell (1978) and by Croff and others (1977). Dickinson and Campbell (1978) rated the uranium favorability of the Beluga and Sterling Formations on the Kenai Peninsula below that of Kenai Group rocks or rocks of similar age in the Susitna lowlands, northwest Cook inlet, and the Matanuska Valley and above that of Tertiary sedimentary rocks of the Copper River basin. They found low-grade epigenetic mineralization (as high as $13 \mathrm{ppm} \mathrm{U}$, or about four times background, for a few samples) for Kenai Group rocks in the Susitna lowlands north of Cook Inlet, but the correlative formation on the Kenai Peninsula is not known.

Croff and others (1977), while giving a low rating for uranium potential to both the Sterling and Beluga Formations, rated the Sterling higher, based on granitic source sediments and better porosity in the sandstone as reported by Hayes and others (1976). The data presented in this report do not support this conclusion. The uranium is associated with the chlorite-illite clay fraction, which, in turn, is related to the Kenai-Chugach Ranges metamorphic sediment sources to the east.

Despite the low favorability ratings for the Beluga and Sterling Formations on the Kenai Peninsula, both units exhibit several generally favorable characteristics for uranium mineralization. Uranium was derived from a variety

Table 2. Continued.

\begin{tabular}{|c|c|c|c|c|c|c|c|c|c|c|c|c|}
\hline & Barium & Cobalt & Chromium & Copper & Scandium & Strontium & Vanadium & Ytrium & Zirconium & Sodium & Potassium & Gallium \\
\hline \multicolumn{13}{|c|}{ Barium ----------- 1.00} \\
\hline Cobalt --.-..-- & -.05 & 1.00 & & & & & & & & & & \\
\hline Chromium -------- & -.42 & .19 & 1.00 & & & & & & & & & \\
\hline Copper-------......- & -.08 & .09 & .41 & 1.00 & & & & & & & & \\
\hline Scandium -.....--- & -.33 & .21 & .66 & .49 & 1.00 & & & & & & & \\
\hline Strontium --.....-- & -.47 & .06 & .03 & -.25 & .25 & 1.00 & & & & & & \\
\hline Vanadium--------- & -.08 & .03 & .29 & .06 & .33 & .00 & 1.00 & & & & & \\
\hline Yttrium------------- & -.47 & .27 & .63 & .43 & .61 & .05 & .07 & 1.00 & & & & \\
\hline Zirconium -------- & -.29 & .27 & .58 & .17 & .51 & .11 & .06 & .58 & 1.00 & & & \\
\hline Sodium--.--------- & .57 & -.04 & .28 & -.05 & .21 & .46 & -.04 & .34 & .31 & 1.00 & & \\
\hline Potassium --------- & .15 & .10 & .24 & .39 & .64 & .13 & .21 & .36 & .19 & .24 & 1.00 & \\
\hline Gallium---------.-- & .32 & .05 & .36 & .18 & .31 & .22 & .07 & .27 & .47 & .33 & -.05 & 1.00 \\
\hline
\end{tabular}


Table 3. Varimax factor analysis for five factors: rotated factor loadings

\begin{tabular}{|c|c|c|c|c|c|c|}
\hline Variable & Factor 1 & Factor 2 & Factor 3 & Factor 4 & Factor 5 & Communality \\
\hline Feldspar------_-_--- & 0.68 & -0.19 & 0.19 & 0.07 & -0.23 & 0.75 \\
\hline Quartz--............... & .26 & -.19 & .29 & -.04 & .64 & .61 \\
\hline Illite --------------- & -.37 & .09 & -.14 & .30 & .79 & .89 \\
\hline Smectite---------- & -.00 & .04 & .03 & .67 & .13 & .47 \\
\hline Chlorite -......-- & -.30 & .13 & -.15 & .08 & .83 & .83 \\
\hline Uranium --.---.-- & -.78 & -.08 & -.21 & .26 & .15 & .75 \\
\hline Thorium---'--- & -.68 & -.09 & .19 & .25 & .27 & .64 \\
\hline Iron -...-- & -.15 & -.03 & -.92 & .08 & .12 & .90 \\
\hline Magnesium---------- & -.73 & -.17 & .08 & -.19 & .18 & .63 \\
\hline Calcium----.--- & .14 & .26 & -.10 & -.53 & -.10 & .40 \\
\hline Titanium ------------- & -.38 & -.74 & .03 & .07 & -.12 & .71 \\
\hline Manganese -------- & .17 & .17 & -.85 & .01 & -.18 & .81 \\
\hline Bariium ------------- & .13 & -.76 & -.02 & .08 & .33 & .70 \\
\hline Cobalt - & -.02 & -.19 & -.68 & -.14 & .06 & .52 \\
\hline Chromium ---'--- & -.64 & -.59 & -.16 & .03 & .12 & .80 \\
\hline Copper ---------- & -.49 & -.10 & -.06 & -.19 & .51 & .55 \\
\hline Scandium ----------- & -.57 & -.55 & .03 & -.33 & .20 & .79 \\
\hline Strontium --.--.--.- & .32 & -.62 & .22 & -.27 & -.24 & .67 \\
\hline Vanadium ---------- & -.56 & .02 & .03 & -.07 & -.11 & .37 \\
\hline Yttrium--------------- & -.31 & -.56 & -.36 & -.22 & .29 & .67 \\
\hline Zirconium ---------- & -.33 & -.65 & -.21 & .07 & -.08 & .59 \\
\hline Sodium--------------- & .22 & -.67 & .00 & -.16 & .03 & .53 \\
\hline Potassium ---------- & -.37 & -.19 & .07 & -.66 & .23 & .66 \\
\hline Gallium ------------ & -.13 & -.65 & .08 & .21 & -.10 & .50 \\
\hline
\end{tabular}

of sediment source areas; these areas included easily altered volcanic material, which (according to Hayes and others, 1976) was dissolved, a process that should have put uranium in solution. Many permeable sandstone beds that could have served as conduits for transport of U-pregnant solutions are found in both the Sterling and the Beluga Formations, and, as mentioned above, abundant carbonaceous material to act as a reductant-precipitant is also found in these units. The occurrence of siderite in the rocks suggests a history of reducing conditions.

Several aspects of the mode of occurrence of uranium in the Beluga and Sterling Formations suggest that the present distribution of uranium does not result from epigenetic enrichment or alteration. Uranium correlates with thorium ( $r=+0.54$, table 2$)$, with the chlorite-illite clays (factor 1, table 3), and, although somewhat less strongly, with the heavy minerals (factor 2 , table 3 ). Uranium is soluble in oxidizing solutions and thorium is not because uranium has a plus 6 valence and thorium does not. Mobilization of uranium in sedimentary rocks by dissolution in oxidizing water segregates uranium and thorium and destroys a strong U-Th correlation. Furthermore, the coefficient of variation for $U(0.28)$ is less than for Th (0.33), a condition hardly expected if the $U$ is mobile. In typical epigenetic mineralization, uranium is concentrated in sandstone (because of its permeability), not in mudstone or shale. Many of the reported uranium anomalies in Alaska are associated with modern placer deposits (Eakins, 1969), and the occurrence of $U$ in the heavy-mineral fractions of fluvially deposited Tertiary sediments is to be expected.

\section{SUMMARY}

1. Clay-mineral facies may represent sediment sources but cannot be used to distinguish between the Beluga and Sterling Formations as mapped by Magoon and others (1976).

2. The distribution of quartz is poorly explained by the factor analysis and appears to be unrelated to grain size or sediment source. 
3. Uranium and thorium in the Beluga and Sterling Formations are associated with clay minerals, especially the chlorite-illite suite, more than with the feldspathic sandstone.

4. Uranium and thorium, because of their association with the chlorite-illite clay facies, relate more closely to a sediment source in the Kenai-Chugach Ranges than to one in the Aleutian-Alaska Ranges.

5. Uranium and thorium are secondarily associated with the heavy minerals.

6. Little diagenesis has occurred in the Beluga and Sterling Formations.

7. The Beluga and Sterling Formations are unfavorable for significant uranium mineralization, despite having many characteristics generally considered favorable. The unfavorable rating is due mainly to lack of evidence of uranium mobilization or epigenetic mineralization.

\section{REFERENCES CITED}

Adkison, W.L., and Newman, K.R., 1973, Lithologic characteristics and palynology of Upper Cretaceous and Tertiary rocks in the Deep Creek Unit well, Kenai Peninsula, Alaska: U.S. Geological Survey Open-File Report, 271 p.

Adkison, W.L., Kelley, J.S., and Newman, K.R., 1975, Lithology and palynology of the Beluga and Sterling Formations exposed near Homer, Kenai Peninsula, Alaska: U.S. Geological Survey Open-File Report 75-383, 239 p.

Barnes, F.F., 1966, Geology and coal resources of the BelugaYentna region, Alaska: U.S. Geological Survey Bulletin 1202-C, 54 p.

Barnes, F.F., and Cobb, E.H., 1959, Geology and coal resources of the Homer district, Kenai coal field, Alaska: U.S. Geological Survey Bulletin 1058-F, p. 217-260.

Biddle, K.T., 1977, Preliminary study of heavy minerals from the Beluga and Sterling Formations exposed near Homer, Kenai Peninsula, Alaska: U.S. Geological Survey Open-File Report 77-874, 12 p.

Calderwood, K.W., and Fackler, W.C., 1966, Significant oil and gas developments in Alaska, 1965-1966 [abs.]: American Association of Petroleum Geologists Bulletin, v. 50, no. 9, p. 2029-2030.

1972, Proposed stratigraphic nomenclature for Kenai Group, Cook Inlet basin, Alaska: American Association of Petroleum Geologists Bulletin, v. 56, no. 4, p. 739-754.

Crick, R.W., 1971, Potential petroleum reserves, Cook Inlet, Alaska: American Associaton of Petroleum Geologists Memoir 15, v. 1, p. 109-119.

Croff, C., Lessman, J., Bigelow, C., and Ruzicka, J., 1977, Uranium favorability of the Cook Inlet basin, Alaska: prepared by WGM Inc., Anchorage, Alaska, for the U.S. Department of Energy, Grand Junction Office, v. 1, 163 p., v. 2, 138 p, v. 3, 56 maps.

Dall, W.H., and Harris, G.D., 1892, Correlation papers, Neocene: U.S. Geological Survey Bulletin 84, p. 234-236.

Dickinson, K.A., and Campbell, J.A., 1978, Epigenetic mineralization and areas favorable for uranium exploration in Ter- tiary continental sedimentary rock in south-central Alaska, a preliminary report: U.S. Geological Survey Open-File Report $78-757,14 \mathrm{p}$.

Eakins, G.R., 1969, Uranium in Alaska: Division of Mines and Geology, Department of Natural Resources, State of Alaska Geologic Report No. 38, 50 p.

Harmon, H.H., 1960, Modern factor analysis (2nd rev. ed.): Chicago, Ill., University of Chicago Press, 471 p.

Hayes, J.B., Harms, J.C., and Wilson, T., Jr., 1976, Contrasts between braided and meandering stream deposits, Beluga and Sterling Formations (Tertiary), Cook Inlet, Alaska, in Miller, T.P. ed., Recent and ancient sedimentary environments of Alaska, Proceedings of the Alaska Geological Society Symposium: Anchorage, Alaska Geological Society, p. J1-J26.

Hintze, J.L., 1987, Number Cruncher Statistical System, version 5.01, reference manual: Kaysville, Utah, J. L. Hintze, 286 p.

Hite, D.M., 1976, Some sedimentary aspects of the Kenai Group, Cook Inlet, Alaska, in Miller, T.P., ed., Recent and ancient sedimentary environments in Alaska, Proceedings of the Alaska Geological Society Symposium, : Anchorage, Alaska Geological Society, p.I1-I22.

Kirschner, C.E., and Lyon, C.A., 1973, Stratigraphic and tectonic development of Cook Inlet Petroleum Province, in Pitcher, M.G., ed. Arctic geology: American Association of Petroleum Geologists Memoir 19, p. 396-407.

Kremer, Meg C., and Stadnicky, George, 1985, Tertiary stratigraphy of the Kenai Peninsula - Cook Inlet region, in Sisson, Alexandra, ed., Guide to the geology of the Kenai Peninsula, Alaska: Anchorage, Alaska Geological Society, p. $24-42$.

Magoon, L.B. , Adkison, W.L., and Egbert, R.M., 1976, Map showing geology, wildcat wells, Tertiary plant fossil localities, $\mathrm{K}-\mathrm{Ar}$ age dates, and petroleum operations, Cook Inlet area, Alaska: U.S. Geological Survey Miscellaneous Investigations Series Map I-1019, scale 1:250,000, 3 sheets.

Magoon, L.B., and Egbert, R.M., 1986, Framework geology and sandstone composition, in Geologic studies of the lower Cook Inlet COST No. 1 well, Alaska outer continental shelf: U.S. Geological Survey Bulletin 1596, p. 65-90.

Millard, D.J., Jr., 1976, Determinations of uranium and thorium in USGS Standard rocks by the delayed neutron technique: U.S. Geological Survey Professional Paper 840, p. 61-65.

Myers, A.T., Havens, R.G., and Dunton, P.J., 1961, A spetrochemical method for the analysis of rocks, minerals and ores: U.S. Geological Survey Bulletin 1084-I, p. 12071229.

Parkinson, L.J., 1962, One field, one giant-the story of Swanson River: Oil and Gas Joumal, v. 60 , no. 13 , p. 180 183.

Wolfe, J.A., Hopkins, D.M., and Leopold, E.R., 1966, Tertiary stratigraphy and paleobotany of the Cook Inlet region, Alaska: U.S. Geological Survey Professional Paper 398-A, $32 \mathrm{p}$.

Wolfe, J.A.. and Toshimasa, Tanai, 1980, The Miocene Seldovia Point flora from the Kenai Group, Alaska: U.S. Geological Survey Professional Paper 1105, 52 p., 25 pl.

Reviewers: Henry W. Roehler and C. Gene Whitney 
Table 4. Chemical and mineralogical data for samples of the Beluga and Sterling Formations, Kenai Peninsula

[Chemicals are given in parts per million (ppm) or percent as indicated at top of column. Quartz (Qtz.) and feldspar (Fldsp.) are given in peak areas in square inches; illite (III.), smectite (Smect.), and chlorite (Chl.) are given in number of XRD counts. The miller indices of XRD peaks measured for each mineral are given at top of column. Chemicals are given in percent or parts per million (ppm), as indicated at top of each column. Abbreviations: L, detected but not determined; N, not detected; S.D., standard deviation; Mdst, mudstone; Slst, siltstone; SS, sandstone; Cgl, conglomerate; H.B., Homer Bluff; H, Highway; CG, campground. Samples were chemically analyzed in analytical laboratories of the U.S. Geological Survey at Denver, Colorado. D.M. McKown supervised radiochemical analyses, J.E. Taggart supervised X-ray spectroscopy, and D.E. Detra and L.R. Layman supervised optical spectroscopy]

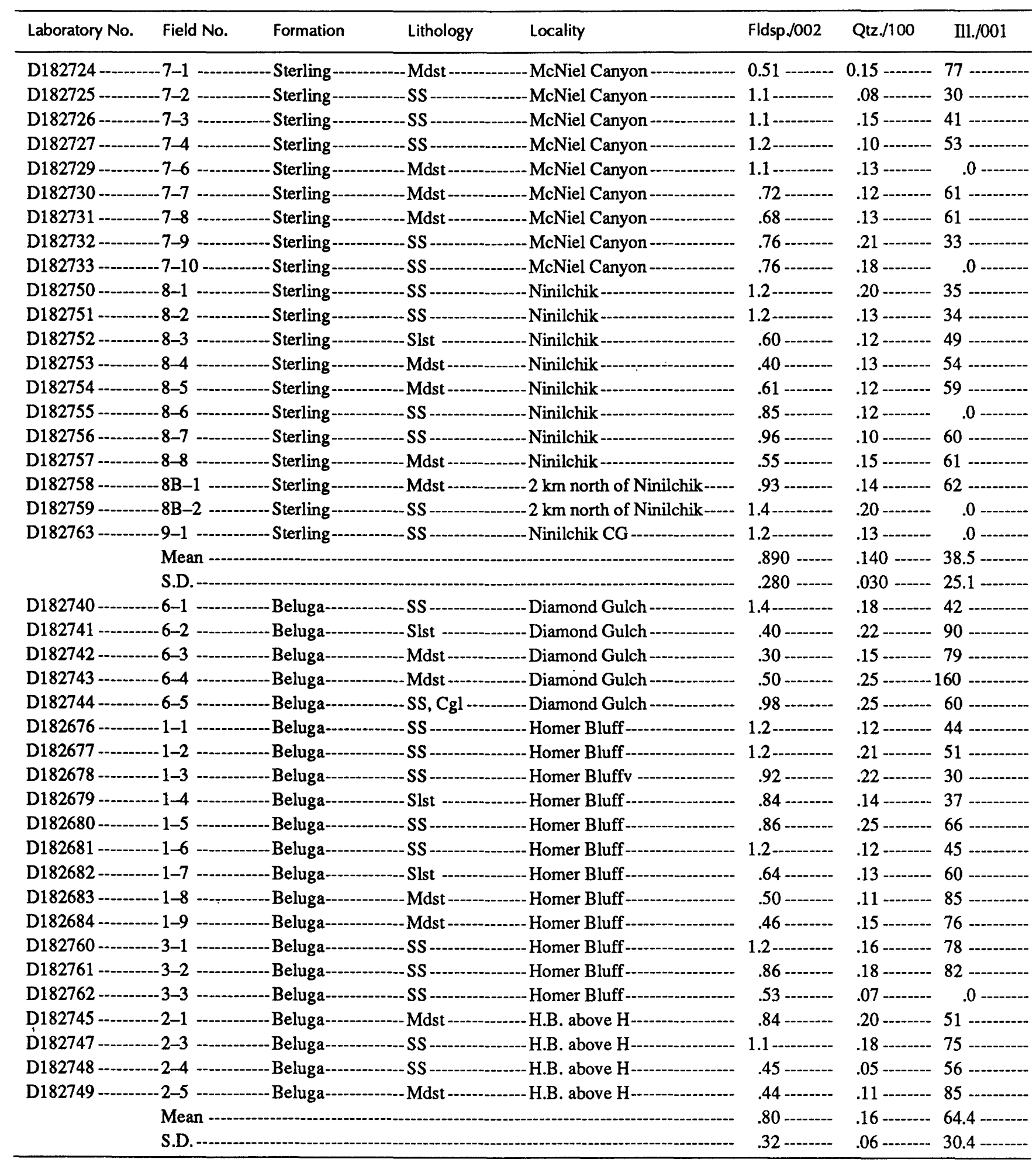


Table 4. Chemical and mineralogical data for samples of the Beluga and Sterling Formations, Kenai Peninsula-Continued

[Chemicals are given in parts per million (ppm) or percent as indicated at top of column. Quartz (Qtz.) and feldspar (Fldsp.) are given in peak areas in square inches; illite (III.), smectite (Smect.), and chlorite (Chl.) are given in number of XRD counts. The miller indices of XRD peaks measured for each mineral are given at top of column. Chemicals are given in percent or parts per million (ppm), as indicated at top of each column. Abbreviations: L, detected but not determined; N, not detected; S.D., standard deviation; Mdst, mudstone; Slst, siltstone; SS, sandstone; Cgl, conglomerate; H.B., Homer Bluff; H, Highway; CG, campground. Samples were chemically analyzed in analytical laboratories of the U.S. Geological Survey at Denver, Colorado. D.M. McKown supervised radiochemical analyses, J.E. Taggart supervised X-ray spectroscopy, and D.E. Detra and L.R. Layman supervised optical spectroscopy]

\begin{tabular}{|c|c|c|c|c|c|c|c|c|c|}
\hline Field No. & Smect./002 & Ch!/.002 & $\underset{(\mathrm{ppm})}{U}$ & $\begin{array}{c}\text { Th } \\
\text { (percent) }\end{array}$ & $\begin{array}{c}\mathrm{Fe} \\
\text { (percent) }\end{array}$ & $\begin{array}{c}\mathrm{Mg} \\
\text { (percent) }\end{array}$ & $\begin{array}{c}\mathrm{Ca} \\
\text { (percent) }\end{array}$ & $\begin{array}{c}\mathrm{Ti} \\
\text { (percent) }\end{array}$ & $\begin{array}{c}\mathrm{Mn} \\
\text { (ppm) }\end{array}$ \\
\hline - & 34 & - & 4.0 & (5.2- & - 7.0 & 1.5 - & 2.0 --------- & - 30 & 700 \\
\hline 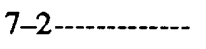 & 21 & 27 -...- & 1.8 & 4.3 & 3.0 & 1.0 & 3.0 & 30 & 500 \\
\hline 7-3 & 28 & 33 -..--- & 1.7 & 3.8 & 3.0 & 1.0 & 3.0 & - 30 & 500 \\
\hline 7-4-4-י-י & .0 & 57 ......... & 2.9 & 4.4 & 7.0 ------ & . 70 & 3.0 & 30 & 500 \\
\hline 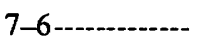 & .0 & 0 & 1.7 & 4.3 & 3.0 & 1.5 & 5.0 & 30 & 700 \\
\hline 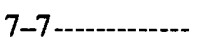 & 40 & 68 - & 2.6 & 6.5 & 7.0 ------ & 1.5 -------- & 3.0 & -...-. & 700 \\
\hline 7-8 & 41 -------- & 80 - & 2.3 & 5.3 & 7.0 & 1.5 & 3.0 & .50 & $1000 \ldots$ \\
\hline 7-9----------.-. & 27 & 30 -.......... & 2.0 & 2.3 & 7.0 & .70 & 3.0 & 30 & 1500 \\
\hline 7-10 ----- & .0 & .0 & 2.0 & 2.8 & 5.0 & . 70 & 3.0 & . 50 - & 700 \\
\hline & 28 & 42 & 1.9 & 4.8 & 3.0 & 1.5 & 3.0 & 70 & $300-$ \\
\hline & 32 & 48 - & .94 & 2.2 & 3.0 & .70 & 1.5 & 15 & 500 \\
\hline & 32 & 65 - & 2.7 & 5.6 & 3.0 & 1.0 & 1.5 & .30 & 300 \\
\hline-- & .0 & 72 - & 2.8 & 3.6--..-- & 5.0 & 1.5-------- & 1.0 & 30 & 300 \\
\hline- & 38 & 81 - & 2.9 & 7.4--.-- & 3.0 & 1.0 & 1.0 & .30 & 150 \\
\hline - & .0 & .0 & 2.0 & 3.9 & 2.0 & .70 & 1.5 & 30 & 300 \\
\hline - & 41 -..--- & 70 & 2.2 & 6.2 & 3.0 & 1.0------ & 2.0 & 30 & 700 \\
\hline 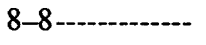 & 41 -.....-..- & 70 & 3.4 & 5.8 & 3.0 & 2.0 & 2.0 & 30 & 500 \\
\hline 8B-1---------- & 52 & 87 - & 2.1 & 6.9 & 5.0 & 1.5 & 70 & 30 & ----- \\
\hline 2--..------- & .0 & .0 & .54 & 1.2 & 3.0 & 1.5 & 3.0 & 30 & -----.- \\
\hline 9-1 & .0 & . 0 & 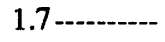 & 3.5 & - 5.0 & 1.0 & 3.0 & - 30 . & 300 \\
\hline Mean---------- & 22.8 & 48.6 & 2.15 & 4.49 & 4.35 & 1.20 & $2.41 \ldots \ldots$ & . & 543 \\
\hline S.D. & 17.9 & 36.8 & .750 & 1.61 & 1.74 & .380 & 1.00 & - 140 & 30 \\
\hline 6-1 & 100 & 63 & 1.4 & 4.1 & 3.0 & 70 & 7.0 & 15 & 700 \\
\hline 6-2-- & . 0 & 190 --.-.-.... & 1.9 & 6.8 & 5.0 & 1.5 & 7.0 & 30 & $\cdots$ \\
\hline 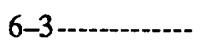 & - 0 & 150 & 2.3 & 6.4 & 7.0 & 2.0 & 10 -------.- & 30 & 100 \\
\hline 6-4 & .0 & 380 - & 2.6 & 4.9- & 7.0 & 1.5 & .50 & 30 & \\
\hline 6-5 & 34 & 75 & 2.0 & 4.6- & 5.0 & .70 & 2.0 & . 30 & \\
\hline 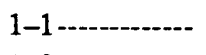 & 40 & 52 & 2.1 -..... & 4.2 & 5.0 & 1.0 & 3.0 & 30 & 500 \\
\hline -..--... & 48 - & 67 & 2.1 & 4.9 & 5.0 & 1.0 & 3.0 & 30 & \\
\hline 3-..-.-.-... & 28 & 36 & 2.1 & 5.0 & 5.0 & 1.0 & 3.0 & . & \\
\hline 1-4-- & 28 & 41 & 2.6 & 6.8 & 7.0 & 1.5 & 3.0 & .50 & 700 \\
\hline 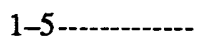 & 42 -------- & 80 - 80 & 2.1 - & $6.2-\ldots$ & - 5.0 & 1.0 & 2.0 & 30 & 700 \\
\hline 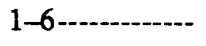 & 33 & 57 -י-י-י-יני & 2.2- & 4.0--- & --י--יב 5.0 & - & 3.0 & . 50 & גב-..... \\
\hline $1-7$ & 76 & $64 \ldots$ & $3.0 \ldots$ & 4.7- & --י--- & 1.0--י--י- & 2.0 & .50 & 300 \\
\hline $1-8-$ & 52 & 170 & 2.8 & 7.6------ & 7.0 & 2.0- & 2.0 & - & 500 \\
\hline 1-9---------- & 57 - & 120 & 3.3 & 3.7 & 10 - & 1.5 & 1.5 ------- & . 30 & 700 \\
\hline 3-1 -..--_- & 84 & 100 & 1.9 & 4.6 & 2.0 & .70 & 3.0 & -.-- 15 . & 300 \\
\hline 3-2--- & 75 & 96 & 1.9 & 5.3 & 3.0 & 70 & 2.0 & 30 & 300 \\
\hline 3-3-- & . 0 & .0 & 1.9 & 2.6 & 5.0 & 70 & 10 & 15 & 700 \\
\hline 2-1- & .0 & 51 & 2.7------- & 7.0 & 3.0 & 1.5 & 1.5 & 30 & 300 \\
\hline 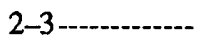 & 79 & 71 & 2.0 & 3.9 & 3.0 & 1.0 & 2.0 & 30 & 500 \\
\hline - & 53 & 58 & $2.1 \ldots$ & 2.9 & 10 & 30 ------ & 3.0 & 15 & \\
\hline 2-5- & 81 -.----- & 63 & 3.0 & 7.3 & 7.0 & 3.0 & 1.5 & .50 & \\
\hline Mean--.--_--- & 43.5 & 94.0 & 2.28 & 5.10 & $4.95 \ldots$ & 1.20 & 3.43 & 33 & $652-$ \\
\hline S.D. & 31.2 & 77.40 & .470 & 1.41 & 2.13 & .590 & 2.63 & 120 & 558 \\
\hline
\end{tabular}


Table 4. Chemical and mineralogical data for samples of the Beluga and Sterling Formations, Kenai Peninsula—Continued

[Chemicals are given in parts per million (ppm) or percent as indicated at top of column. Quartz (Qtz.) and feldspar (Fldsp.) are given in peak areas in square inches; illite (III.), smectite (Smect.), and chlorite (Chl.) are given in number of XRD counts. The miller indices of XRD peaks measured for each mineral are given at top of column. Chemicals are given in percent or parts per million (ppm), as indicated at top of each column. Abbreviations: L, detected but not determined; N, not detected; S.D., standard deviation; Mdst, mudstone; Slst, siltstone; SS, sandstone; $\mathrm{Cgl}$, conglomerate; H.B., Homer Bluff; H, Highway; CG, campground. Samples were chemically analyzed in analytical laboratories of the U.S. Geological Survey at Denver, Colorado. D.M. McKown supervised radiochemical analyses, J.E. Taggart supervised X-ray spectroscopy, and D.E. Detra and L.R. Layman supervised optical spectroscopy]

\begin{tabular}{|c|c|c|c|c|c|c|c|c|c|}
\hline Field No. & $\begin{array}{c}\text { B } \\
(\mathrm{ppm})\end{array}$ & $\begin{array}{c}\mathrm{Ba} \\
(\mathrm{ppm})\end{array}$ & $\begin{array}{c}\text { Be } \\
(\mathrm{ppm})\end{array}$ & $\begin{array}{c}\text { Co } \\
\text { (ppm) }\end{array}$ & $\begin{array}{c}\mathrm{Cr} \\
(\mathrm{ppm})\end{array}$ & $\begin{array}{c}\mathrm{Cu} \\
(\mathrm{ppm})\end{array}$ & $\begin{array}{c}\mathrm{Pb} \\
(\mathrm{ppm})\end{array}$ & $\begin{array}{c}\text { Sc } \\
(\mathbf{p p m})\end{array}$ & $\begin{array}{c}\mathrm{Sr} \\
(\mathrm{ppm})\end{array}$ \\
\hline 7-1 & 70 & 700 & 2.0 & 15 --------- & 100 ---.--.-- & 50 & 15 -..-. & 15 -.---.---.- & 200 \\
\hline & L-_......... & 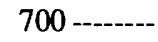 & 1.5 & 500 -...--.-- & 70 & 15 & 0 & 15 & 300 \\
\hline - & L-------- & 1000 & 1.5 & 15 & 50 & 15 & 10 & 15 & 500 \\
\hline$-\cdots$ & L-----.-- & 1000 & 1.5 & 15 --.--.-- & 50 - & 30 & 15 --י----. & 15 & 500 \\
\hline ....... & L-.-.--.--- & 700 & N-_--.-- & $30 \ldots$ & 70 & 15 & 15 -......-- & 15 & 500 \\
\hline .-.-... & 30 & 700 & 1.5 & 20 & 100 -...-.-. & 70 & 15 -..--.-...... & 20 & 300 \\
\hline 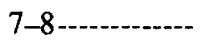 & 20 & 700 & 1.5 & 20 & 70 & 70 & 15 -.-.-.- & 15 & 300 \\
\hline 7-9--בי--- & 20 & 1000 & 1.5 & 20 & 70 & 15 ------- & 10 & 15 & 500 \\
\hline -י--10 & L- & 700 & N-_- & 15 -.--ני-ני- & 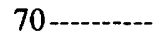 & 30 & 10 -..-- & 15 - 15 & 300 \\
\hline 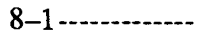 & L-_-_...... & 1000 & 1.5 & 10 -.--.-- & 70 - & 15 & 15 & 15 & 700 \\
\hline 8-2-.-.--- & L & 500 & 1.5 & 10 & 15 & 30 & L --.--- & 7.0 & 00 \\
\hline $8-3-$ & L--.-..... & 700 & 1.5 & 10 & 70 & 70 & 10 -.......- & 15 & 0 -...... \\
\hline $8-4$ & L--.----- & 700 --.---.- & 1.5 & 15 & 70 & 50 & 10 -...-...-... & $15 \cdots$ & -..... \\
\hline $8-5$ & L-........... & 70 & N- & 7.0 & 70 & 50 & - & - & (-..-. \\
\hline $8-6$ & L & 700 & L--------- & 7.0 & 30 & 10 & 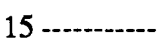 & 1.0 & ב.-.-. \\
\hline $8-7$ & L-.-- & 700 & L-. & 15 & 30 & 15 & 10 - & 15 & 300 \\
\hline 8-8------. & L........... & 500 & L---. & 10 ------- & 70--------- & 10 & 0 & --.---.--_. & 300 \\
\hline 8B-1-.--.. & L-------- & 700 & 1.5 & 15 ------- & 70 & 50 & 0 & ; - & 200 \\
\hline $8 \mathrm{~B}-2$ & L-------- & 700 & L & 15 -------. & 30 & 70 & 10 & 15 & 500 \\
\hline- & L-............ & 500 & & 15 & 50 & 15 & 10 & 10 & 300 \\
\hline Mean--- & - & 30 & - & 14.7 & 61.3 & 34.8 & - & 14.2 & 60 - 60 \\
\hline $\mathrm{S}$ & - & 152 & - & 5.13 & 21.6 & 22.3 & --..-- & 2.87 & 4 -------- \\
\hline 6-1 - & L_- & 700 & L-.---.-- & ------ & 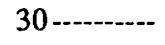 & 15 & L & 10 & 200 \\
\hline 6-2-- & 30 & 700 & L & 7.0 & 70--- & 70--.---. & 10 & 15 & 50 -.---.. \\
\hline 6-3-...- & 20 & 700 & 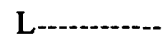 & 15 & 70 & 70 & L & 15 & 300 \\
\hline $6-4-\ldots$ & 30 & 700 & L-- & 30 & 70 & 70 & 15 -------. & 15 - & 200 \\
\hline 6-5 & 20 & 1000 & 1.5 & 15 --.---- & 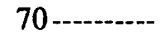 & 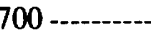 & L --.-. & 15 - 15 & - 300 - \\
\hline - & 20 & 700 & 1.5 & 20 & 70 & 15 & 10 & 10 & 300 \\
\hline $1-2$ & 20 & 700 & 1.5 & 10 & 70 & 15 & 10 & 10 & - 300 \\
\hline 1-3 & 20 & 1000 & 1.5 & 20 & 70 & 15 & 10 & 10 & 300 \\
\hline 1-4-4- & 30 & 700 & 2.0 & 20 -.-.--. & 100 -.--.-- & 50 & 15 - & 15 & 300 \\
\hline 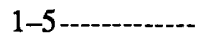 & 20 & 1000 & 2.0 & 15 -----.-- & 70 & 20 & 10 - & 10 & 300 \\
\hline 1-6------.-- & 20 & 1000 & 2.0 & 10 & 100 & 15 -....- & 10 & 15 & 500 \\
\hline $1-7$ & 30 & 700 & 1.5 & 10 & 100 & 50 & 10 & -.--- & $\ldots$ \\
\hline -8------ & 30 & 1000 & 2.0 & 15 --.--... & 100 & $70 \ldots$ & 15 & ------ & ----- \\
\hline 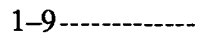 & 30 & 1000 & 2.0 & 10 & 100 & 50 & 10 - 10 & -...---. & -..... \\
\hline ------.- & L--------- & 700 & L-.-- & 5.0 & 7.0 & 10 & L -....... & 7.0 & -........ \\
\hline - & L-........- & 700 & L--------- & 15 & 30 & 7.0 & 10 - 10 & 15 & 300 \\
\hline - & L-_-_--- & 500 & N-.......... & 7.0 & 30 & 15 & L - & 7.0 & 200 \\
\hline 2-1-..-..-- & 30 & 700 & 1.5 & 7.0 & 70 & 50 & 15 & 15 & 200 \\
\hline 2-3- & L------- & 700 & L-........... & 7.0 & - 30 & - 70 & 10 - & 10 - 10 & - 300 - \\
\hline 2-4-------- & L-............ & 500 & L----------- & 30 & 20 & 15 & L - & 7.0 & 150 \\
\hline 2-5- & 30 & 1000 & 1.5 & 20 & 100 - & 70 & 15 - & 15 & 300 \\
\hline Mean-......-... & 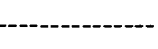 & 781 & . & $14.1-$ & 65.6 & 39.6 & 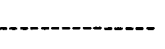 & 12.4 & 271 \\
\hline S.D. & ----------- & 5.1 --.--. & - & 7.07 & 29.2 & 25.3------ & - & 3.11 & . 74.91 \\
\hline
\end{tabular}


Table 4. Chemical and mineralogical data for samples of the Beluga and Sterling Formations, Kenai Peninsula—Continued

[Chemicals are given in parts per million (ppm) or percent as indicated at top of column. Quartz (Qtz.) and feldspar (Fldsp.) are given in peak areas in square inches; illite (III.), smectite (Smect.), and chlorite (Chl.) are given in number of XRD counts. The miller indices of XRD peaks measured for each mineral are given at top of column. Chemicals are given in percent or parts per million (ppm), as indicated at top of each column. Abbreviations: L, detected but not determined; N, not detected; S.D., standard deviation; Mdst, mudstone; Sist, siltstone; SS, sandstone; $\mathrm{Cgl}$, conglomerate; H.B., Homer Bluff; H. Highway; CG, campground. Samples were chemically analyzed in analytical laboratories of the U.S. Geological Survey at Denver, Colorado. D.M. McKown supervised radiochemical analyses, J.E. Taggart supervised X-ray spectroscopy, and D.E. Detra and L.R. Layman supervised optical spectroscopy]

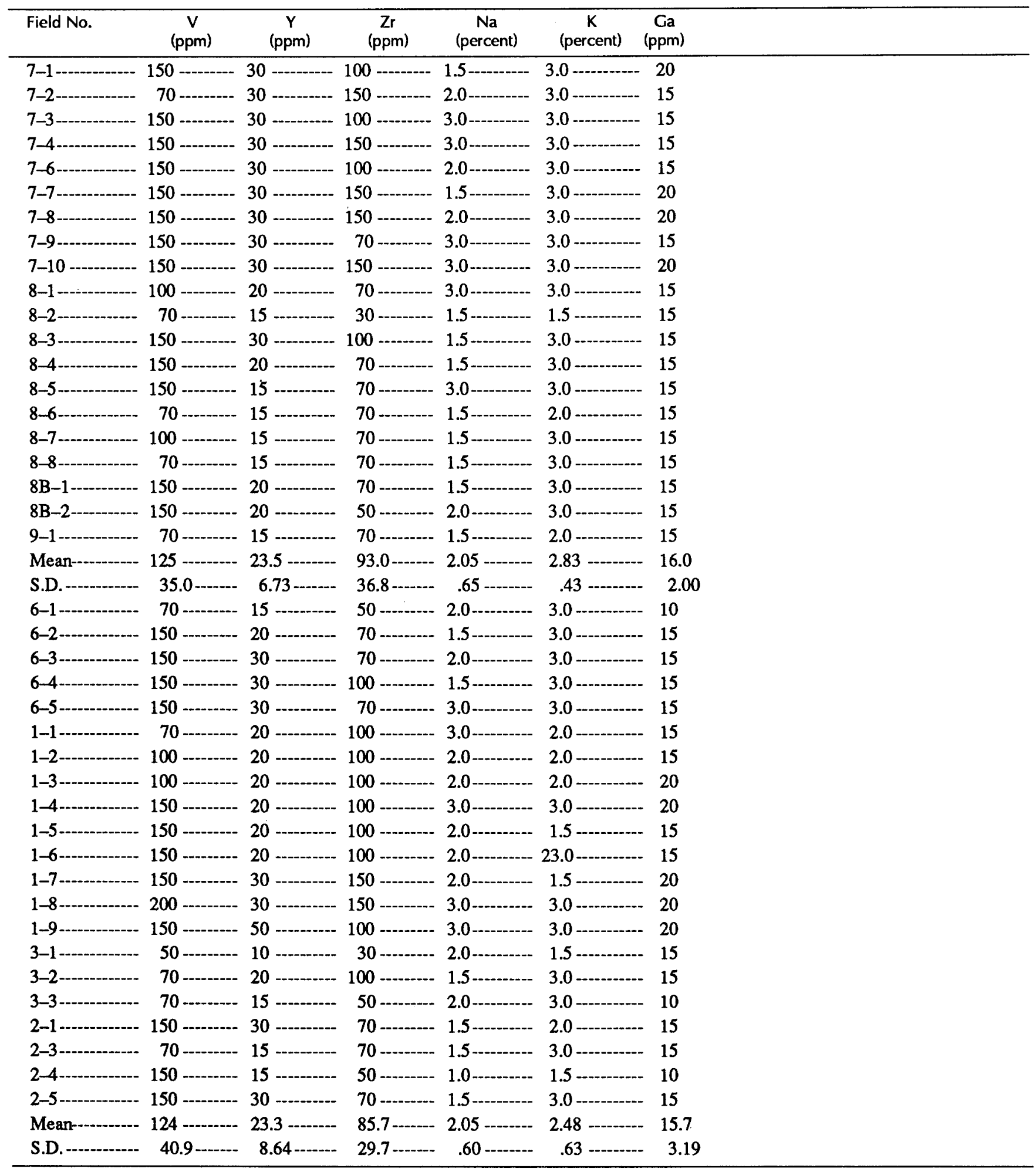




\title{
Early Holocene Calcretes from the Subarctic Active Nogahabara Sand Dune Field, Northern Alaska
}

\author{
By John P. Galloway, Mark Huebner, Robert Lipkin, and Jos W.A. Dijkmans
}

\begin{abstract}
Calcretes are widespread in the interdunes of the Nogahabara Sand Dunes. A radiocarbon age on a calcrete collected from the Nogahabara Sand Dune field is $8.28 \mathrm{ka}$ (early Holocene). This age falls at the younger end of the range (10.5 to $8.1 \mathrm{ka}$ ) for four radiocarbon age determinations of calcretes from the Great Kobuk Sand Dunes, northern Alaska. The formation of these calcretes in eolian environments in northern Alaska may have been caused by climatic changes during the late Wisconsin and early Holocene.
\end{abstract}

\section{NOGAHABARA SAND DUNES}

The Nogahabara Sand Dunes are approximately 45 $\mathrm{km}$ west of the village of Huslia in the Koyukuk Lowland, west-central Alaska (fig. 1). The active dunes lie within an area of about $3,200 \mathrm{~km}^{2}$ of stabilized dunes in the lower Koyukuk Valley (Péwé, 1975).

A preliminary photointerpretation map of this dune area was prepared in 1984 as part of an international study on eolian deposits in periglacial environments (Koster and others, 1984). Five eolian sand units were

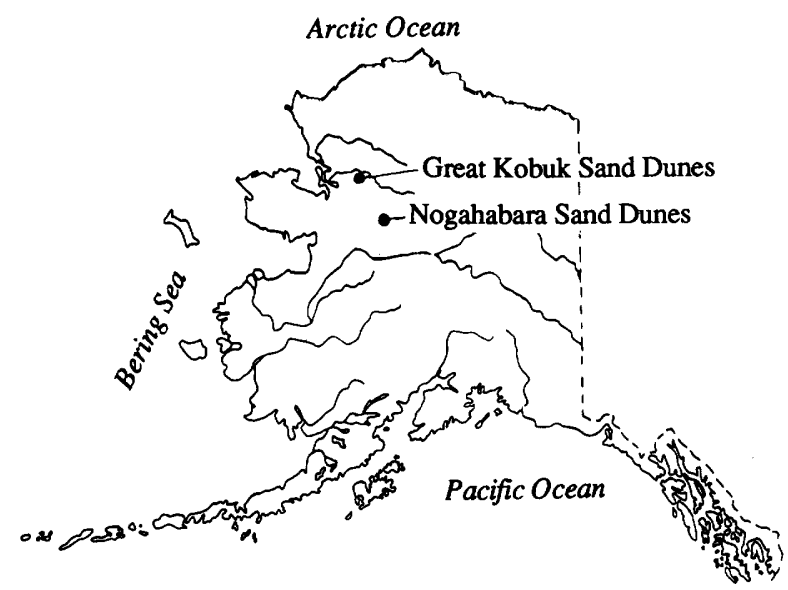

Figure 1. Location map of Nogahabara Sand Dunes and the Great Kobuk Sand Dunes, central Alaska. recognized based on topographic expression. The active part of the dune field forms a circular body of sand having a diameter of approximately $7 \mathrm{~km}$ (fig. 2). The edge of the field is sharply defined by a distinct escarpment. The active dune fields cover an area of $44.5 \mathrm{~km}^{2}$ and are 100 to $170 \mathrm{~m}$ above sea level. Case (1957) described the active dune field as consisting of quartz-rich sand, coarse grained on the western edge and decreasing in grain size toward the eastern edge. A single grain-size analysis of a sand sample was reported by Weber and Péwé (1970). The midpoint on the cumulative frequency curve is 2.75 phi $(0.149 \mathrm{~mm}$, fine-grained sand).

The active dune field (unit Q $s_{5}$ of Koster and others, 1984) consists of drifting sand, with sparse vegetation that appears white to light-blue on the false-color infrared aerial photographs. Dunes with relatively low height and even spacing, as measured from the photographs, are clearly visible and appear to be transverse or barchanoid in form. Dune height (trough to crest) is estimated to be generally less than $10 \mathrm{~m}$, with crest-line spacing being 50 to $200 \mathrm{~m}$. Preliminary measurements by Lipkin suggest a crest height of approximately $20 \mathrm{~m}$ for a dune in the southwest corner of the dune field. Dune forms are surprisingly uniform in spacing, height, and crest-line orientation (fig. 3). Most dune crests are continuous for a few kilometers. The low dune height is probably caused by shallow sediment thickness, as seen from the many areas of deflation in the central part of the dune field. Deflation areas (red on infrared photographs) show a west to east to west-northwest to southsoutheast linear pattern. This direction deviates slightly from the inferred transport direction of the dunes based on dune morphology.

\section{Vegetation}

The Nogahabara Sand Dunes are one of the few examples of active inland sand dunes in the circumboreal region; only the Great Kobuk Sand Dunes $(150 \mathrm{~km}$ north) and the Lake Athabasca Sand Dunes in Saskatchewan are comparable. The vegetation and flora of these 


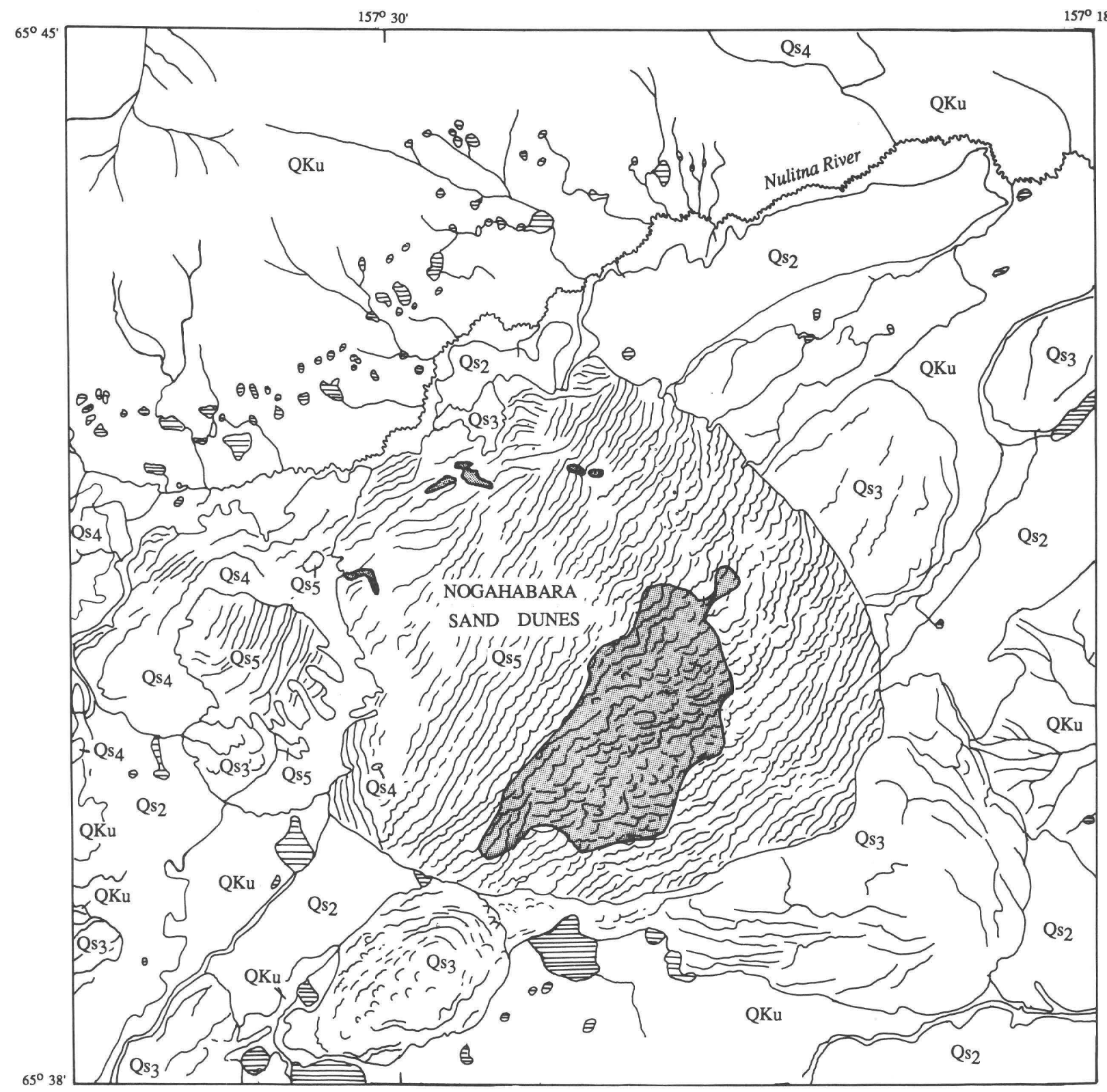

$0 \quad 1 \quad 2$ KILOMETERS

EXPLANATION

Qs5 Active dunes (Quaternary)

Qs4 Younger stabilized dunes (Quaternary)

Qs3 Older stabilized dunes (Quaternary)

Qs2 Relatively flat lowlands, partly sand covered (Quaternary)

$\mathrm{QKu}$ Slope deposits and bedrock, undivided (Quaternary and Cretaceous)

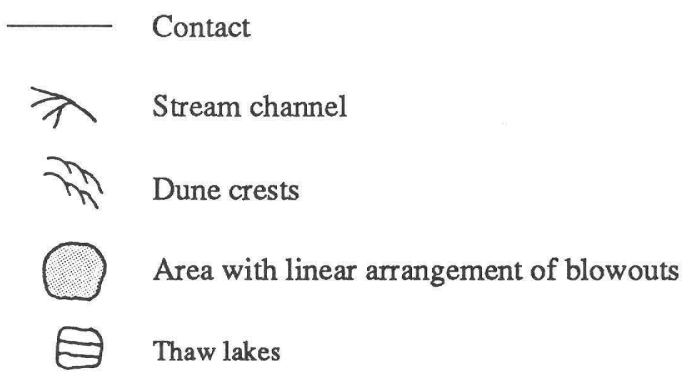

Figure 2. Geologic map of Nogahabra Sand Dunes (modified from Koster and others, 1984). Map-unit terminology and map-unit symbols are primarily those of Koster and others (1984). 
other areas are known from several studies (Hermesh, 1972; Racine, 1976; Young, 1977; Raup and Argus, 1982), but virtually nothing is known about the vegetation or flora of the Nogahabara Sand Dunes.

The Nogahabara Sand Dunes lie within the borealforest region of Alaska and are mainly surrounded by closed and open needle-leaf forests of Picea glauca (white spruce) and $P$. mariana (black spruce), intermixed with aquatic and wetland communities. This region of the Koyukuk River basin has an active history of fire, which has eventually resulted in initiating blowouts in previously stabilized dunes. Recently stabilized portions of the dunes typically have a lichen woodland vegetation (table 1). Older portions have open spruce forests of $P$. glauca and Betula papyrifera (paper birch) with an understory of dry-site shrubs and herbs (table 1).

The active-sand-dune habitats range from exposed dune crests and slip faces, to interdune areas and wet dune slacks, to ventifact slopes and pebble-covered deflation surfaces. Species are most plentiful in protected, moist habitats such as dune slacks and margins.

The most exposed areas, such as large dune crests and slopes, are typically barren or have less than 5 percent vegetation cover (table 1). Artemisia borealis (bore- al wormwood) also occurs, especially on leeward slopes and slip faces. Areas of low, rolling topography often have sufficient stability for willows to survive on the dune crests and slopes (table 1).

Along the western and eastern portions of the dunes are deflation surfaces with a thin veneer of coarser sand and a variety of plants (table 1).

Interdune areas may remain stable long enough to develop a rich lichen cover with scattered spruce having diameter breast heights of up to $25 \mathrm{~cm}$. Species found here are largely derived from the surrounding flora (table 1).

\section{CALCRETES}

Large numbers of fragmented calcretes [following Goudie's (1971) definition] were observed in the central flat or slightly undulating interdune areas of the dune field. This is the same area as the linear arrangement of blowouts mapped by Koster and others (1984). In all locations, surficial calcretes are shattered into fragments varying from a few millimeters to several decimeters in thickness (fig. 4). A radiocarbon age of 8.28 ka was

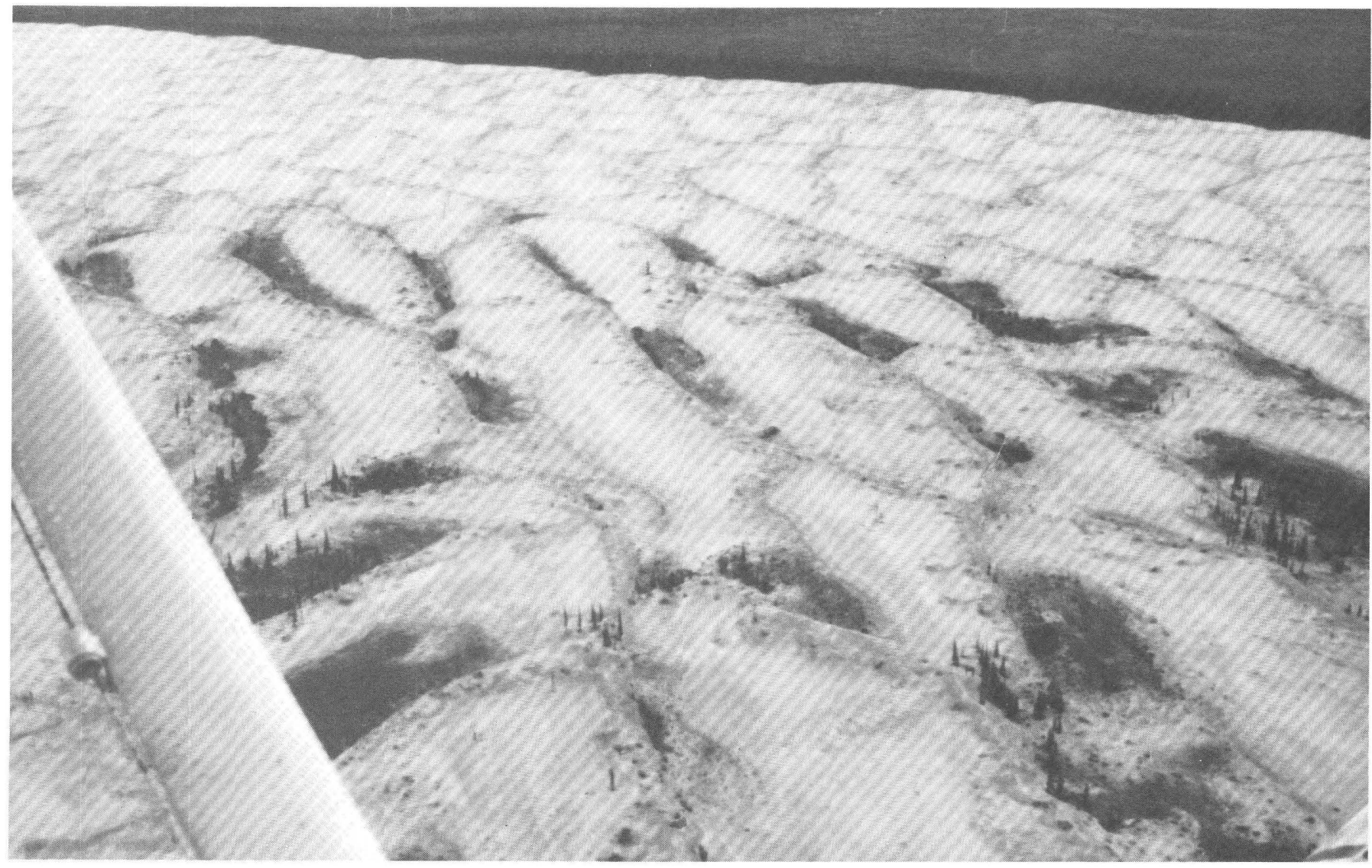

Figure 3. Aerial photograph of Nogahabara Sand Dunes. 
Table 1. Plant communities found in the Nogahabara Sand Dunes

\begin{tabular}{ll}
\hline \multicolumn{1}{c}{ Plant } & \multicolumn{1}{c}{ Common name } \\
\hline Recently stabilized dunes-lichen woodland vegetation \\
Populus tremulaides $-\mathrm{-}$ -
\end{tabular}

Older stabilized dunes_-open spruce forests with an understory of dry site shrubs and herbs

\begin{tabular}{|c|c|}
\hline \multicolumn{2}{|l|}{ P. glauca - } \\
\hline Betula papyrifera & paper birch \\
\hline Juniperus communis --.-- & common juniper \\
\hline Rosa acicularis - & prickly rose \\
\hline Vaccinium vitis-idaea------------ & lingonberry \\
\hline Festuca altaica - & rough fescue \\
\hline
\end{tabular}

Large dune crests and slopes

Leymus mollis

Bromopsis pumpelliana

Chrysanthemum bipinnatum

Artemisia borealis ---_-_-_-_-_-_-_--- boreal wormwood

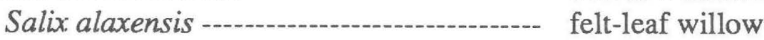

S. hastata --.-- willow

S. brachycarpa ssp. niphoclada --..--..--- willow

Western and eastern portions of the dunes-deflation surfaces

Bromopsis pumpelliana

Artemisia borealis

boreal wormwood

Astragalus adsurgens ssp. viciifolius ------ standing milk-vetch

Festuca rubra

Solidago multiradiata

Calamagrostis purpurascens -

Dianthus repens -

Cnidium cnidiifoliu

Lupinus kuschei -

red fescue

northern goldenrod

purple reedgrass

northern pink

Jakutsk snow parsley

Yukon lupine

\section{Interdune areas}

Picea glauca -

Shepherdia canadensis

Arctostaphylos uva-ursi

Empetrum nigrum

Geocaulon lividum

Pyrola chlorantha -

Aster sibiricus -

Stereocaulon spp.

Cladina spp. obtained from a fragment of calcrete collected from the interdune area (table 2).

A sample of the Nogahabara calcretes was treated with 100 percent phosphoric acid (McCrea, 1950), liberating $\mathrm{CO}_{2}$ which was then purified and analyzed on a Finnigan MAT 251 mass spectrometer for carbon and oxygen isotopes. The $\delta^{13} \mathrm{C}$ and $\delta^{18} \mathrm{O}$ values reported in table 2 are relative to PDB (Peedee Belemnite). Major oxides and trace elements are reported in table 3.

Examination of samples of the relic calcrete with the scanning electron microscope (SEM) reveals that voids between grains are filled with an amorphous calcium carbonate cement. Sand grains in the calcrete are dominantly subround and exhibit primarily fluvial microfeatures with some secondary chemical features. SEM photomicrographs show grains with edge modification and exhibit some mechanical $\mathrm{V}$-shaped patterns (fig. $5 \mathrm{~A}$, $B)$. The degree of grain-edge modification suggests transport in a high-energy subaqueous environment before cementation. Classic eolian and glacial microfeatures, such as well-rounded to subrounded frosted grains or conchoidal fractures, are absent.

\section{GREAT KOBUK SAND DUNES CALCRETES}

The Great and Little Kobuk Sand Dunes (78 $\left.\mathrm{km}^{2}\right)$ are a small part of a larger area $\left(700 \mathrm{~km}^{2}\right)$ of stabilized eolian sand (Kuhry-Helmens and others, 1985, fig. 6). The extensive relic carbonate crust in the relatively stable eastern and central parts of the Great Kobuk Sand Dunes is described by Cox and Lawrence (1983), Galloway and others (1984, 1985), Cox (1985), and Dijkmans and others (1986). SEM photomicrographs of calcretes show well-developed secondary calcite grains that were probably formed from the reprecipitation of calcium-rich ground water (fig. $7 \mathrm{~A}$ ). Voids between the sand grains are filled with amorphous carbonate. Quartz grains in the relic calcrete exhibit glaciofluvial and eolian features such as well-preserved conchoidal fractures, shatter lines, large dish-shaped depressions, and rounding of grain edges (fig. $7 B$ ). The same microfeatures are observed on SEM photomicrographs of quartz sand from the active dune field. The microfeatures on the quartz grains from both the active dune sands and the relic calcrete suggest a glaciofluvial, rather than eolian, history.

Three early Holocene radiocarbon ages on calcretes from the Great Kobuk Sand Dunes have been reported by Dijkmans and others (1986). An additional age was obtained as a check on sample GrN-11141. The two ages are concordant and overlap at one sigma.

The calcretes in the Great Kobuk Sand Dunes originate in the interdune areas and in the depressions in front of the dunes. Infiltration of water from a topographic high through the carbonate-bearing dune sands 
resulted in the dissolution and reprecipitation of carbonate (Dijkmans and others, 1986).

\section{DISCUSSION}

The Yukon-Koyukuk Lowland was not subjected to glaciation during the Quaternary but was influenced by glacial activity to the north (Fernald, 1962). Aggradation of streams in the Koyukuk River flood plain and upper Kuskokwim River regions provided a large source of sediment favorable to the formation of dunes. Thus, microfeatures on the eolian sand grains from the Nogahabara dune field should reflect the transport history of the grains. Microfeatures observed on the sand grains in the calcretes suggest that they were subjected to greater fluvial than eolian or glacial conditions before formation of the calcretes. Microfeatures of the sand grains from the Great Kobuk

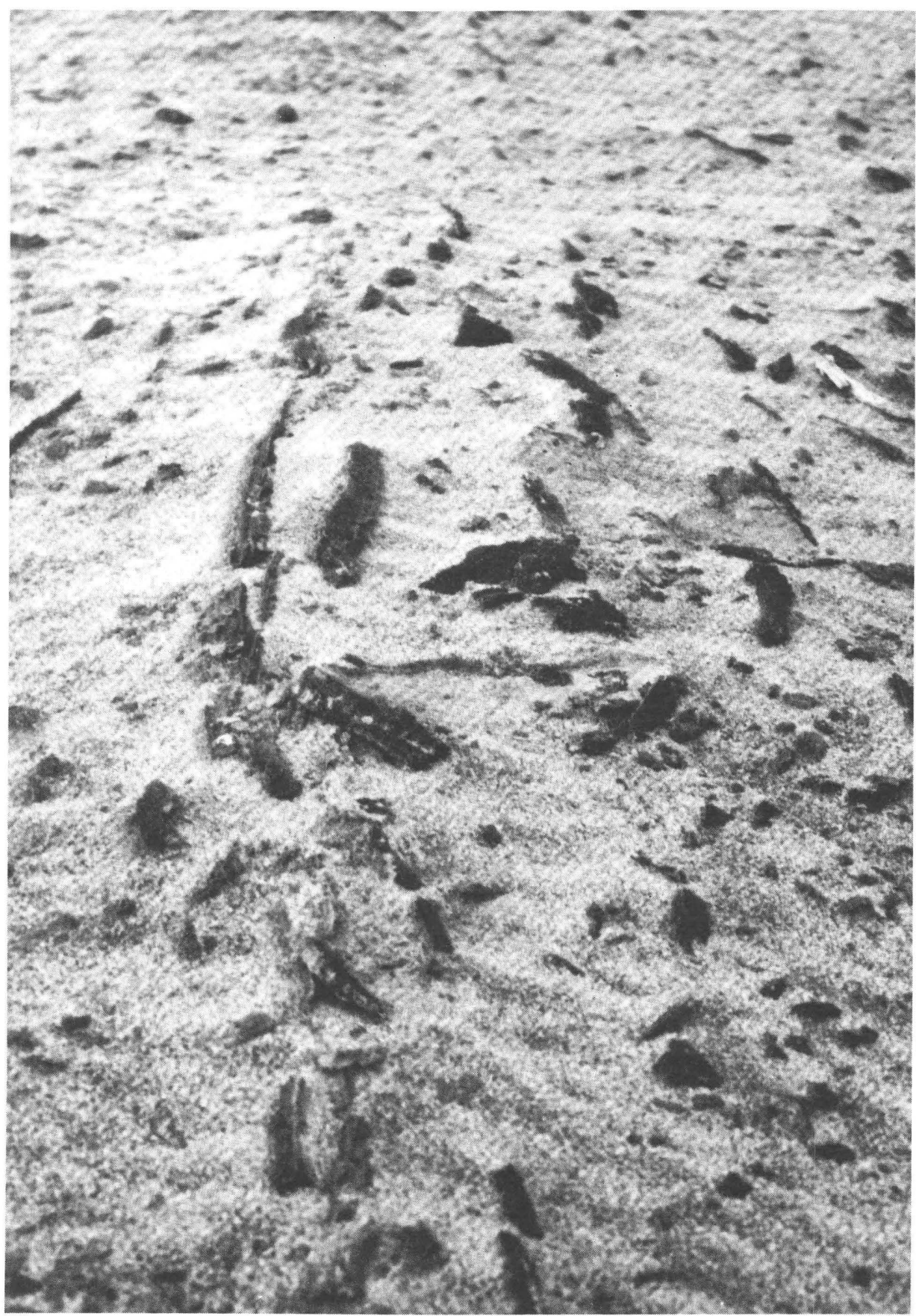

Figure 4. Calcretes from the Nogahabara Sand Dunes. Calcretes are several decimeters in length. 
Table 2. Radiocarbon age determinations and stable isotopic analysis of calcrete crusts

[*, check on GrN-11141 relative to PDB -2.7, normalized age using Libby half-life 5568 is $10,670 \pm 150$ yr B.P.; see table 3 for majoroxide and trace-element analyses]

\begin{tabular}{|c|c|c|c|}
\hline $\begin{array}{l}\text { Radiocarbon } \\
\text { laboratory No. }\end{array}$ & $\begin{array}{l}{ }^{14} \text { C age } \\
\text { (yr B.P.) }\end{array}$ & $\delta^{13} \mathrm{C}$ & $\delta^{18} \mathrm{O}$ \\
\hline \multicolumn{4}{|c|}{ Nogahabara Sand Dunes } \\
\hline (USGS-2765) -.-- & $8,280 \pm 60$ & +1.9 & -13.5 \\
\hline \multicolumn{4}{|c|}{ Great Kobuk Sand Dunes } \\
\hline (GrN-11139) :--.-- & $8,100 \pm 80$ & +1.32 & -14.11 \\
\hline (GrN-11140) --.-. & $10,070 \pm 110$ & +1.80 & -13.45 \\
\hline$(\mathrm{GrN}-11141)$ & $10,530 \pm 110$ & +0.05 & -14.38 \\
\hline$(\mathrm{I}-13545)^{*}$ & $10,310 \pm 150$ & & \\
\hline
\end{tabular}

Sand Dunes calcretes reflect a history of glaciofluvial transport with minor eolian modification before cementation. The source area and the distance that the grains were transported clearly influenced grain modification. Regardless of the sand-grain transportation history before deposition as calcretes, the formation of calcretes during the late Wisconsin and early Holocene in both dune fields reflects an environmental change. Late Wisconsin glaciation and increased wind intensity may have provided enough sediment to bury the shallow interdune and foredune depressions, resulting in precipitation of the calcretes. Dijkmans and others (1986) have described a model for the Great Kobuk Sand Dunes in which infiltration of water from a topographic high filtering through carbonate-bearing sands causes dissolution of carbonate, followed by precipitation; the calcretes in the Nogahabara Sand Dunes may have formed similarly. Tentative evidence described by Bigelow and others (1990) suggests high-latitude climatic change in

Table 3. Major-oxide composition and trace-element content of calcrete crusts

[Oxide analysis on samples 81-KO-13-Al, 21, and 28 performed by Jos Dijkmans; oxide analysis (ED-XRF) and trace element contents (WD-XRF) on samples 81-AGy-017A and 90-AGy-001 performed by J. Kent, U.S. Geological Survey, Menlo Park. LOI, loss on ignition]

\begin{tabular}{|c|c|c|c|c|}
\hline \multicolumn{4}{|c|}{ Great Kobuk Sand Dunes } & \multirow{2}{*}{$\begin{array}{l}\text { Nogahabara } \\
\text { Sand Dunes } \\
90 \text {-AGy-001 }\end{array}$} \\
\hline Sample number -..--.--81-KO-13-Al & 81-KO-21-Al & 81-KO-28-Al & 81-AGy-017A & \\
\hline $\begin{array}{l}\text { Radiocarbon } \\
\text { laboratory number } \\
\text { (see table 2)-.-- GrN-11139 }\end{array}$ & GrN-11140 & GrN-11141 & $\mathrm{I}-13,545$ & USGS-2765 \\
\hline \multicolumn{5}{|c|}{ Major-oxide composition (dry wt \%) } \\
\hline $\mathrm{SiO}_{2}$ & 50.7 & 52.6 & 55.8 & 38.5 \\
\hline $\mathrm{Al}_{2} \mathrm{O}_{3}$ & 3.75 & 3.81 & 3.92 & 3.66 \\
\hline $\mathrm{Fe}_{2} \mathrm{O}_{3}$ & .51 & .51 & & \\
\hline $\mathrm{FeO}$ & .49 & .48 & & \\
\hline $\mathrm{Fe}_{\mathrm{T}} \mathrm{O}$ & & & 1.78 & 1.58 \\
\hline $\mathrm{MnO}$ & .05 & .03 & .03 & .05 \\
\hline $\mathrm{MgO}$ & .60 & .44 & .5 & .5 \\
\hline $\mathrm{CaO}$ & 22.50 & 20.40 & 20.3 & 31.4 \\
\hline $\mathrm{Na}_{2} \mathrm{O}$ & 1.19 & 1.27 & .8 & .9 \\
\hline $\mathrm{K}_{2} \mathrm{O}$ & .90 & .66 & .5 & .62 \\
\hline $\mathrm{TiO}_{2}$ & .20 & .42 & .32 & .38 \\
\hline $\mathrm{P}_{2} \mathrm{O}_{5}$ & .07 & .07 & .04 & .04 \\
\hline LOI 17.4 & 19.9 & 18.3 & 16.4 & 23.5 \\
\hline \multicolumn{5}{|c|}{ Trace elements (ppm) } \\
\hline $\mathrm{Nb}$ & 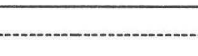 & (2) & $<10$ & $<10$ \\
\hline $\mathrm{Rb}$ & & & 20 & 20 \\
\hline Sr-- & & -1..-...- & 104 & 68 \\
\hline $\mathrm{Zr}$ & & & 90 & 78 \\
\hline Y-1- & & & 16 & 16 \\
\hline
\end{tabular}


the northwest Pacific Ocean during the early Holocene, resulting in increased wind intensity in central Alaska. Flora and fauna of deposits contemporaneous with a phase of eolian sand movement lasting from 11 to $8 \mathrm{ka}$ in northern Alaska indicate that summer temperatures were relatively warm and may have peaked at this time (Carter and others, $1984 \mathrm{a}, \mathrm{b})$. The 10.5- to 8.1-ka radiocarbon ages for the calcretes suggest that the calcretes may be contemporaneous with this period of eolian sand movement and climatic change.

Changes in flora and fauna as well as geomorphic processes known in other northern Alaska areas suggest that an environmental change occurred between 12 and 8 $\mathrm{ka}$. The present dune flora includes many species from the surrounding woods, hills, and river bars (for example, Salix alaxensis, Aster sibiricus, Solidago multiradiata, Arctostaphylos uva-ursi). A smaller group of taxa, Lupinus kuschei and Carex sabulosa, that are disjunct and as many as hundreds of kilometers away from other areas may represent relicts of a vegetation type found on a once widespread semiarid landscape. These taxa are otherwise known in North America only from southwest
Yukon Territory and eastern Alaska, and they are associated on the small dune field near Carcross, Yukon Territory (Monty Woods, Canadian Department of Agriculture, oral commun., 1989).

Young (1977) suggested that the flora of the Great Kobuk Sand Dunes represents a relict of the steppe-tundra vegetation that is presumed to have been widespread in Beringia during the Pleistocene. The Nogahabara Sand Dunes share many of the same floristic characteristics with the Great Kobuk Sand Dunes, especially the prominence of Artemisia (A. borealis) and grass (Leymus, Bromopsis, Calamagrostis and Festuca) that match pollen profiles from this period. Specific differences between the floras of the Great Kobuk and Nogahabara Sand Dunes may be due in part to differences between the floras of the areas now. surrounding these dune fields. In northwestern Alaska, Populus pollen accumulation rates dropped 50 percent about $11 \mathrm{ka}$ (Anderson, 1985, 1988). Populus pollen is especially sensitive to summer warmth. Evidence for a decrease in pollen influx at about $10.5 \mathrm{ka}$ in the central Brooks Range was reported by Brubaker and others (1983). The present

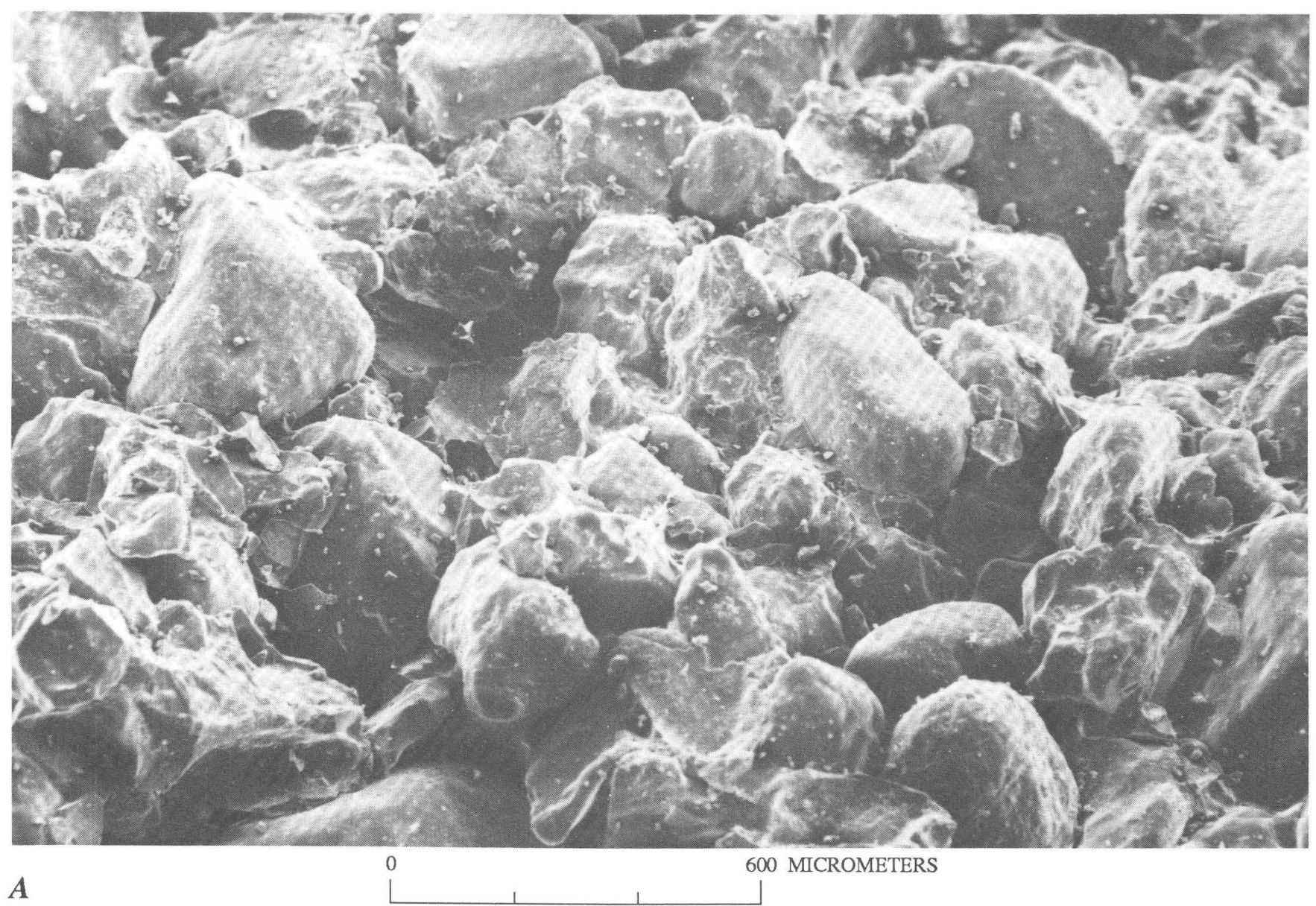

Figure 5. Scanning electron microscope photomicrographs of calcrete from Nogahabara Sand Dunes. A, Overview of sand grains that comprise the crust. B, Amorphous calcium carbonate crust. 
vegetation of the dunes may represent the relict steppetundra vegetation as seen in the pollen profiles.

The calcretes of the Great Kobuk Sand Dunes have stable isotope values showing that the crusts formed in shallow surface water and were isotopically and physically equilibrated with atmospheric $\mathrm{CO}_{2}$ (Dijkmans and others, 1986). Similarly, stable isotopic data from the Nogahabara Sand Dunes calcretes are consistent with those of Dijkmans and others (1986) and indicate that these calcretes also formed from shallow surface waters isotopically and physically equilibrated with atmospheric $\mathrm{CO}_{2}$. Isotopic measurements of soil carbonates, including calcretes, have been suggested as having paleoclimatic significance (Cerling, 1984). Cerling (1984) stated that ${ }^{18} \mathrm{O}$ of soil carbonates can reflect local meteoric water during deposition and that ${ }^{13} \mathrm{C}$ can give information on the biomass present if overprinting and diagenesis of the carbonate are minimal. Samples from the Nogahabara Sand Dunes and the Great Kobuk Sand Dunes (Dijkmans and others, 1986) show similar carbon and oxygen iso- topic ratios (table 2). These have been interpreted as indicating a formation from shallow surface water that has been isotopically and physically equilibrated with atmospheric $\mathrm{CO}_{2}$. Whereas ${ }^{18} \mathrm{O}$ seems to be related to local meteoric waters, ${ }^{13} \mathrm{C}$ values do not discriminate biomass changes that have been suggested from other types of data in northwestern Alaska. Although low plant respiration rates and freezing conditions to the depth of carbonate formation may explain equilibration with atmospheric $\mathrm{CO}_{2}$ (Cerling, 1984), the permeable nature of sand dunes must also facilitate this isotopic exchange, which would erase any original biomass contribution.

The formation of these two well-developed calcretes in dune fields $150 \mathrm{~km}$ apart probably correlates with climatic changes and eolian sand movement in northern Alaska during the late Wisconsin to early Holocene $(11$ to $8 \mathrm{ka})$. The distribution and isotopic composition of calcrete deposits in northern Alaska remain poorly studied, however, and firm conclusions are not yet possible.

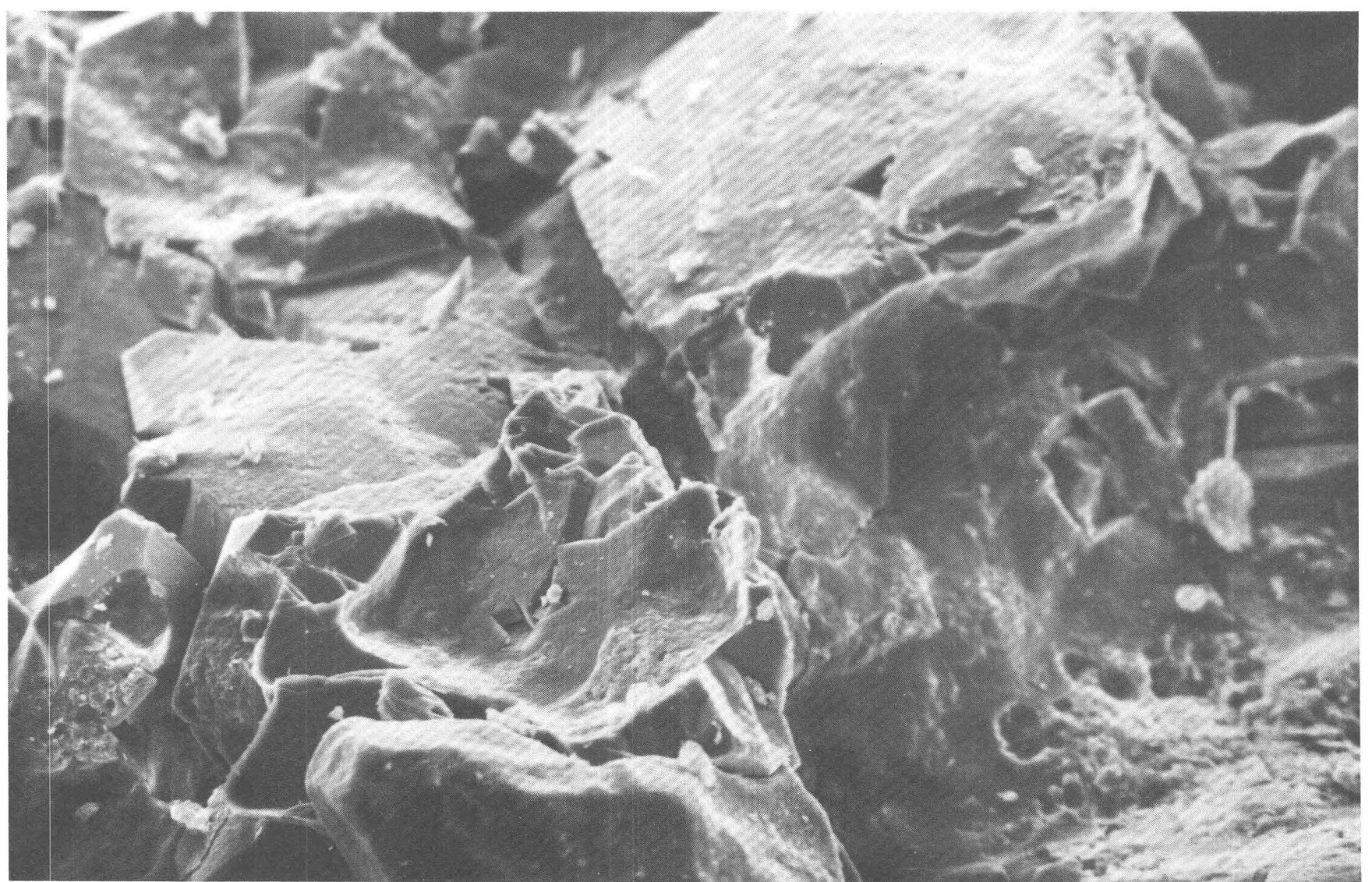

Figure 5. Continued. 


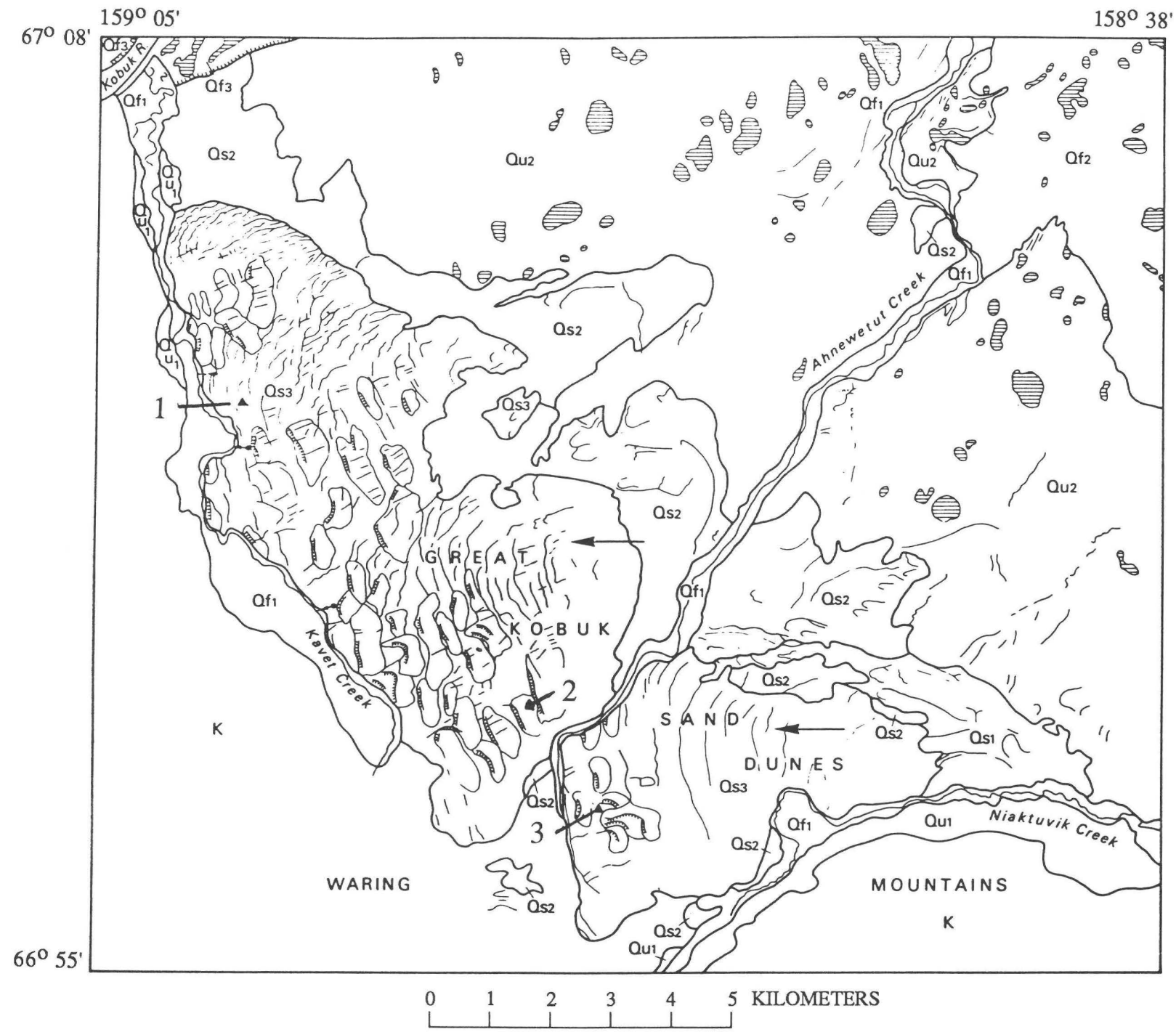

EXPLANATION

\begin{tabular}{|c|c|c|c|c|}
\hline$\underline{\text { LITHOLOGICAL UNITS }}$ & GEC & MORPHOLOGICAL UNITS & & $\underline{\text { SYMBOLS }}$ \\
\hline \multirow[t]{3}{*}{ Eolian sand deposits } & Qs3 & Active dune fields & & Unit boundary based on aerial \\
\hline & Qs2 & Stabilized sandsheets & & proto-mierpretaton \\
\hline & Qs1 & $\begin{array}{l}\text { Complex, moderately stabilized } \\
\text { canoe-shaped blowouts }\end{array}$ & $\cdots$ & $\begin{array}{l}\text { Meandenng stream } \\
\text { Spring with small watercourse }\end{array}$ \\
\hline \multirow[t]{4}{*}{ Fluvial deposits } & Qf3 & Point bar systems & & Thaw lake \\
\hline & $\mathrm{Qf}_{2}$ & Fluvial terraces & & Terrace scarp \\
\hline & $\mathrm{Qf}_{1}$ & Fluvial plains & $=$ & Longitudinal dunes \\
\hline & & & $K /$ & Parabolic dunes \\
\hline \multirow[t]{2}{*}{$\begin{array}{l}\text { Undifferentiated } \\
\text { surficial deposits }\end{array}$} & Qu2 & $\begin{array}{l}\text { Flat to gently sloping areas, } \\
\text { locally with dune morphology }\end{array}$ & 10 & $\begin{array}{l}\text { Transverse, simple respectively } \\
\text { complex dune ridge }\end{array}$ \\
\hline & val & Comuvial Iootsiopes & 8 & Barchanoid, complex dune ridge \\
\hline Bedrock & $\mathrm{K}$ & Mountainous areas & $\longleftarrow$ & $\begin{array}{l}\text { (Paleo)wind direction responsible } \\
\text { for dune formation }\end{array}$ \\
\hline
\end{tabular}

Figure 6. Simplified geomorphologic photointerpretation map of Great Kobuk Sand Dunes and adjacent areas. Locations of calcretes: (1) 81-KO-13-Al, (2) 81-KO-21-Al, (3) 81-KO-28-Al and 81-AGy-017A. Slightly modified from Dijkmans and others (1986). 


\section{REFERENCES CITED}

Anderson, P.M., 1985, Late Quaternary vegetational change in the Kotzebue Sound, northwestern Alaska: Quaternary Research, v. 24, no. 3 , p. 307-321.

-1988, Late Quaternary pollen records from the Kobuk and Noatak Drainages, northwestern Alaska: Quaternary Research, v. 29, no. 3, p. 263-276.

Bigelow, Nancy, Begét, Jim, and Powers, Rodger, 1990, Latest Pleistocene increase in wind intensity recorded in eolian sediments from central Alaska: Quaternary Research, v. 34 , no. 2 , p. $160-168$.

Brubaker, L.B., Garfinkel, H.L., and Edwards, M.E., 1983, A late Wisconsin and Holocene vegetation history from the central Brooks Range: Implications for Alaska paleoecology: Quaternary Research, v. 20, no. 2, p. 194-214.

Carter, L.D., Forester, R.M., and Nelson, R.E., 1984a, Mid Wisconsin through early Holocene changes in seasonal climate in northern Alaska: American Quaternary Association, Biennial Meeting, 8th, Boulder, University of Colorado, p. 20-22.

Carter, L.D., Nelson, R.E., and Galloway, J.P., 1984b, Evidence for latest Wisconsin - early Holocene increased precipitation and summer warmth in Arctic Alaska: Geological Society of America Abstracts with Program, v. 16, no. 5 , p. 274.

Case, J.T., 1957, Reconnaissance geologic map of the Kateel River quadrangle, Alaska: U.S. Geological Survey Miscellaneous Geologic Investigations Map I-243, scale $1: 250,000,1$ sheet.

Cerling, T.E., 1984, The stable isotopic composition of modern soil carbonate and its relationship to climate: Earth and Planetary Science Letters, v. 71, p. 229-240.

Cox, G.W., 1985, Reply - Comments on cemented horizon in subarctic Alaskan sand dunes: American Journal of Science, v. 285, p. 190-191.

Cox, G.W., and Lawrence, W.T., 1983, Cemented horizons in subarctic Alaskan sand dunes: American Joumal of Science, v. 283, p. 369-373.

Dijkmans, J.W.A., Koster, E.A., Galloway, J.P., and Mook, W.G., 1986, Characteristics and origin of calcretes in a subarctic environment, Great Kobuk Sand Dunes, northwestern Alaska: Arctic and Alpine Research, v. 18, no. 4, p. 377-387.

Fernald, A.T., 1962, Geomorphology of the upper Kuskokwim region, Alaska: U.S. Geological Survey Bulletin 1071-G, p. 191-279.

Galloway, J.P., Koster, E.A., and Hamilton, T.D., 1985, Comments on cemented horizon in subarctic Alaskan sand dunes: American Journal of Science, v. 285, p. 186-190.

Galloway, J.P., Oscarson, R., and Koster, E.A., 1984, Scanning electron microscope microfeatures on sand grains and carbonate crusts from the Great Kobuk Sand Dunes, Kobuk River valley, northwestern Alaska: Geological Society of America Abstracts with Programs, v. 16, p. 285.

Goudie, A., 1971, A regional bibliography of calcrete, in McGinnies, W.G., Goldman, B.J., and Paylore, P., eds., Food, fiber and the arid lands, Tucson, University of Arizona Press, p. 421-437.

Hermesh, R., 1972, A study of the ecology of the Athabasca Sand Dunes with emphasis on the phytogenic aspects of dune formation: Saskatoon, Saskatchewan, Canada, University of Saskatoon, Ph.D. dissertation.

Koster, E.A., Galloway, J.P., and Pronk, T., 1984, Photo-interpretation map of surficial deposits and landforms of the Nogahabara Sand Dunes and part of the Koyukuk Lowland, Alaska: U.S. Geological Survey Open-File Report 84-10.

Kuhry-Helmens, K.F., Koster, E.A., and Galloway, J.P., 1985, Photo-interpretation map of surficial deposits and landforms of the Kobuk Sand Dunes and part of the Kobuk Lowland, Alaska: U.S. Geological Survey Open-File Report 85-242.

McCrea, J.M., 1950, The isotopic chemistry of carbonates and a paleotemperature scale: Journal of Chemical Physics, v. 18 , p. 849-857.

Péwé, T.L., 1975, Quaternary geology of Alaska: U.S. Geological Survey Professional Paper 835, 145 p.

Racine, C.H., 1976, Flora and vegetation, in Melchior, H.R., ed., Biological survey of the proposed Kobuk Valley National Monument: Fairbanks, Alaska, National Park Service, and University of Alaska, Alaska Cooperative Park Studies Unit, Biological and Resource Management Program, Final Report, p. 39-139.

Raup, H.M., and Argus, G.W., 1982, The Lake Athabasca Sand Dunes of northern Saskatchewan and Alberta, Canada: I. The land and vegetation: Ottawa, National Museum of Canada, National Museum of Natural Science Publication in Botany no. 12.

Weber, F.R., and Péwé, T.L., 1970, Surficial and engineering geology of the central part of the Yukon-Koyukuk Lowland, Alaska: U.S. Geological Survey Miscellaneous Geologic Investigations Map I-590, scale 1:125,000, 2 sheets.

Young, S.B., 1977, Special features of the Kobuk Valley which are potentially significant in reconstructiong the climatic and vegetational history of the Beringian Region, in Young, S.B., and Racine, C.H., eds., Vegetational anf floristic analysis and discussion of the Quaternary environment of the Kobuk Valley: Wolcott, Vermont, Center for Northern Studies, 47 p.

Reviewers: Oscar J. Ferrians, Jr. and Warren E. Yeend 


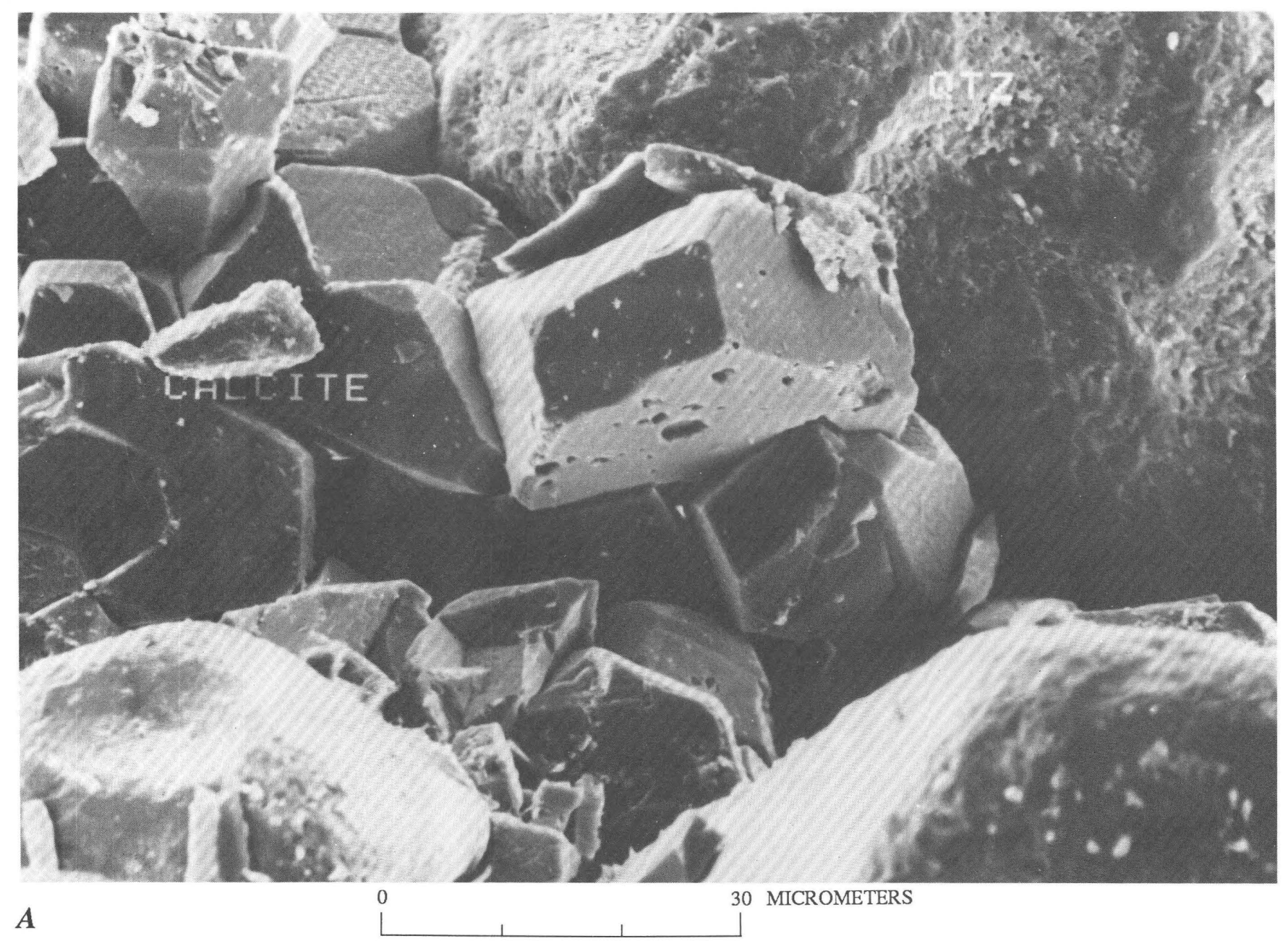

Figure 7. Scanning electron microscope photomicrographs of calcrete from Great Kobuk Sand Dunes. A, Well-developed secondary calcite grains. B, Typical glaciofluvial features. Qtz, quartz. 


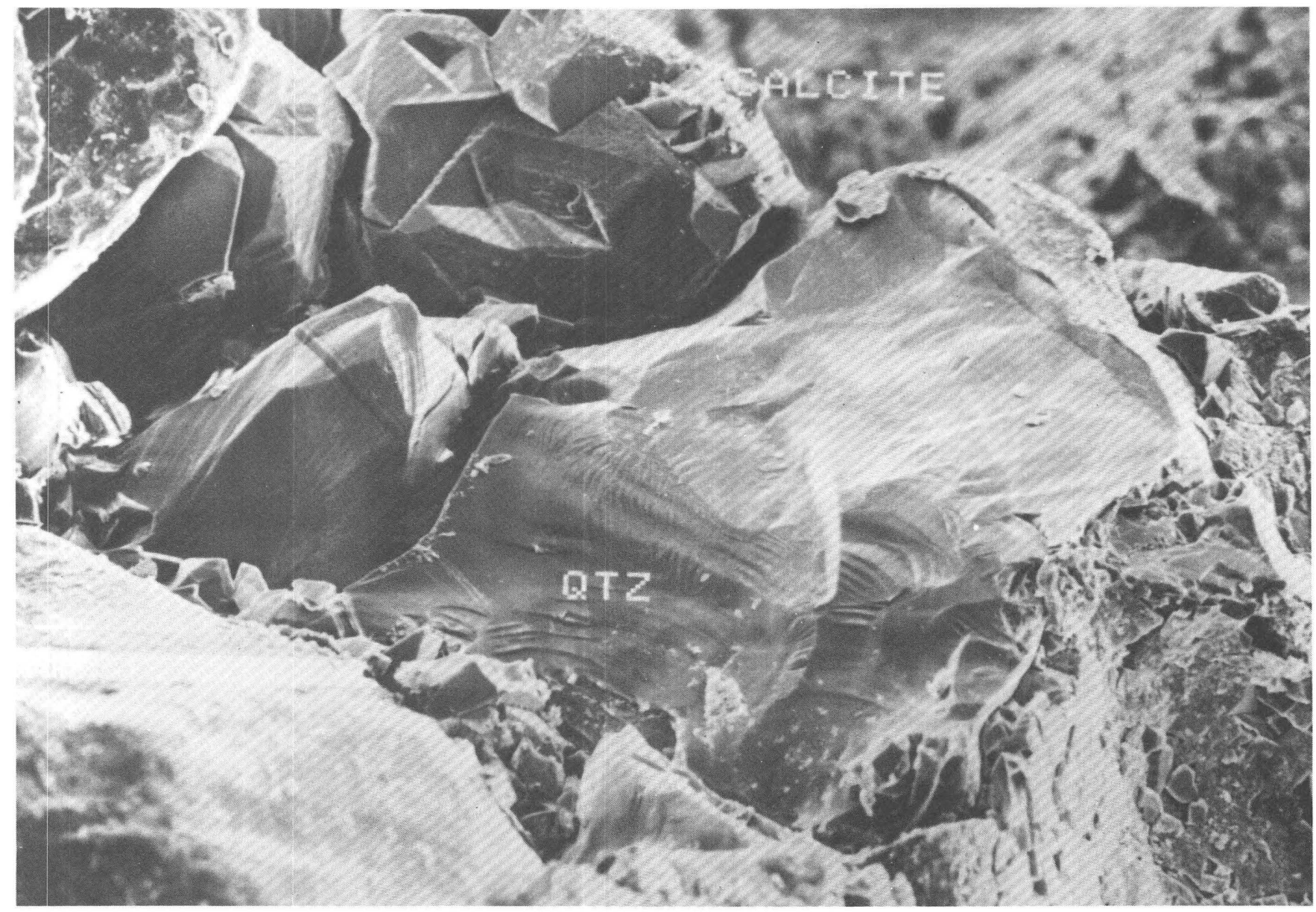

B

$0 \quad 60$ MICROMETERS

Figure 7. Continued. 


\title{
Tectonics and Petroleum Potential of the Brooks Range Fold and Thrust Belt —A Progress Report
}

\author{
By David G. Howell, Kenneth J. Bird, Lu Huafu, and Mark J. Johnsson.
}

\begin{abstract}
An analysis has been made of the structure and paleothermal data along the Dalton Highway across the northern Brooks Range and southern Colville basin to evaluate the petroleum potential of the Brooks Range fold-and-thrust belt. Preliminary structural interpretations show a minimum of about $145 \mathrm{~km}$ of crustal shortening along this traverse; unlike previous interpretations, this crustal shortening involves basement in thrusting well north of the Brooks Range front. Vitrinite-reflectance data indicate that the 0.6 to 2.0 percent $R_{\mathrm{o}}$ isograds lie between 2,000 and 4,600 $\mathrm{m}$ depth at the north end of our section. These limits to the oil and condensate window rise in elevation southward, suggesting postorogenic uplift ranging from of 3 to $5 \mathrm{~km}$ at the range front to as much as $10 \mathrm{~km}$ at the south end of the section, in the core of the range. The vitrinite isograds are folded along the Atigun and Marmot synclines, indicating compressional tectonics associated with uplift. Near the range front, sedimentologic and published apatite fission-track analyses constrain the time of uplift to be between the mid-Cretaceous and the early Tertiary. Maturation and migration of oil and gas most likely occurred at the time of maximum burial and heating, estimated from apatite fission-track analyses at about $60 \mathrm{Ma}$.

Based on the stratigraphy, structural geology, and thermal maturity data, we propose a thermo-tectonic model that includes a preorogenic phase of platformal sedimentation involving the accumulation of organic-rich petroleum source rocks; an orogenic phase of convergence that produced a crustal load and a consequent foreland basin where sediments formed a thermal blanket generating oil and gas from preorogenic source rocks; and, finally, a late orogenic phase where thermal equilibration and erosion resulted in the uplift of the crust and lithosphere associated with a small component of N.-S. shortening.
\end{abstract}

\section{INTRODUCTION}

The North Slope, like most foreland basins of the world, is a composite sedimentary basin made up of a relatively thin ( 2 to $3 \mathrm{~km}$ ) preorogenic continental margin sequence and a thick ( 7 to $10 \mathrm{~km}$ ) orogenic sequence of sedimentary rocks. The Brooks Range orogen is a continental, or A-type, subduction zone (Bally and Snelson, 1980). It is generally interpreted to be the result of $400-600 \mathrm{~km}$ of crustal shortening, most of which was accomplished from Late Jurassic to Late Cretaceous time (Tailleur, 1969; Mull, 1982; Mayfield and others, 1988; Moore and others, 1991). We interpret three fundamental episodes of crustal uplift: two are associated with folding and thrusting in the internal zone (hinterland); the third is principally a postconvergent phase of uplift involving the internal zone and the southern part of the foreland as a response to heating of the previously subducted part of the lithosphere and isostatic adjustment as erosion denuded the range.

The large body of literature on North Slope oil and gas, summarized recently by Bird (1991), shows that the preponderance of discovered North Slope oil and gas (larger than 90 percent) is located along the north side of the foreland basin (near Prudhoe Bay). A relatively small amount of oil and gas is known to occur within the southern, deformed part of the foreland basin, such as the Umiat oil field (fig. 1). Geochemical signatures indicate that the main source of North Slope oil is marine shale of the preorogenic sedimentary package. Sedimentary and tectonic loading produced the necessary burial and heating of these rocks to generate oil and gas. Paleothermal indicators show that, as a first approximation, the present configuration of the oil and condensate window rises southward into the fold-and-thrust belt, where it intersects the ground surface in the foothills and northern part of the Brooks Range. The occurrence of the hydrocarbon preservation window, at relatively shallow depth in the foothills, suggests that this part of the basin remains a potentially prospective area for both oil and gas. The relation of the present-day hydrocarbon preservation window to structure and petroleum source-rock distribution is displayed here as figure 2 .

We have posed the questions, do commercial oil accumulations exist in the foothills of the Brooks Range, and if so, what are the limits of the oil-prospective region in terms of area and depth? An unknown factor in 
this exercise is the congifuration of liquid and gaseous hydrocarbon migration pathways. Because of the abundance of oil and gas in the Prudhoe Bay area, one of the primary directions of migration must have been northward away from the orogen, through or beneath the fore- land basin, and up the south-dipping flank of the lithospheric bulge. The occurrence of solid bitumen in thrust panels (Patton and Tailleur, 1964; Molenaar and others, 1988; Howell and others, 1991) seems to confirm the existence of some pathways within the duplex structures of
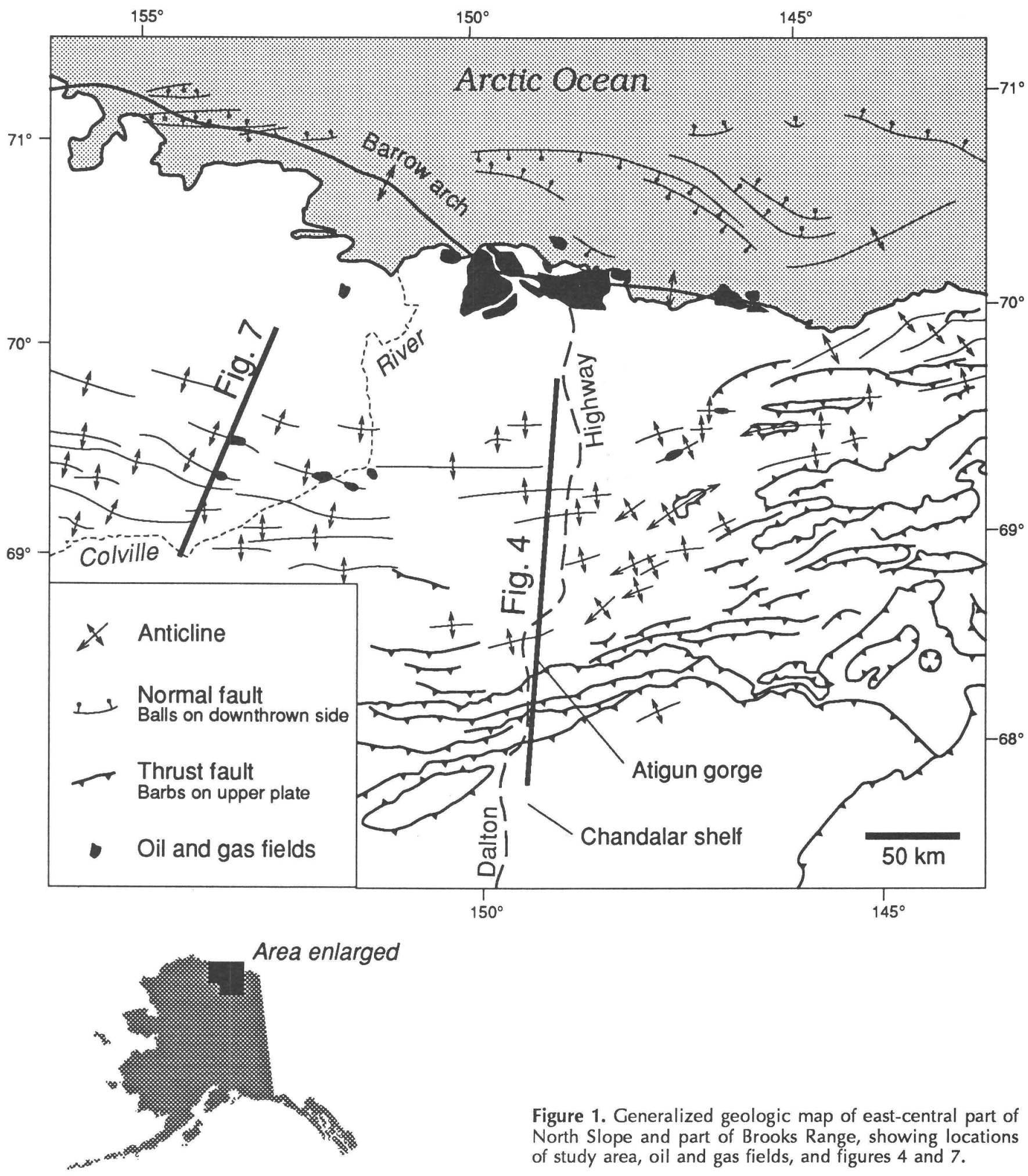

Figure 1. Generalized geologic map of east-central part of North Slope and part of Brooks Range, showing locations of study area, oil and gas fields, and figures 4 and 7. 
the foothills and Brooks Range front. The existence of adequate traps is another factor of critical importance. Where hydrocarbons may now reside in the fold-andthrust belt depends not only on old pathways but also on the occurrence of reservoir seals and the preservation of the structural integrity of traps. In an effort to evaluate the hydrocarbon potential of the foothills region, we have spent the last two field seasons gathering stratigraphic, structural, and paleothermal data (vitrinite reflectance) along a transect of the Brooks Range and foothills belt that parallels the Dalton Highway (fig. 1).

Our approach is to model the development of the foreland basin that formed in response to loading of the lithosphere by thrust faulting in the Brooks Range. The basic premise is that the stratigraphy and sedimentology of the foreland-basin deposits provide a record from which one can read the time and extent of crustal thickening in the orogen. The thermal signature of the foreland deposits not only indicates the amount of sediment burial, but also provides information regarding the amount of postdepositional uplift.

In this report we provide a preliminary structural interpretation combined with thermal maturity data along a transect of the northern part of the Brooks Range and adjacent foreland basin that parallels the Dalton Highway. Thermal maturity data provide an estimate of total thicknesses of foreland sediments. The age of the foreland sedimentation is a reflection of the timing of thrusting in the hinterland, and this information bears directly on the time of maturation of petroleum source rocks in the foreland-basin area as well as on the timing and direction of oil migration. The present configuration of isograds indicates the amount of crustal uplift and the nature of deformation since the establishment of those isograds. Fission-track analyses help constrain the timing of uplift (O'Sullivan and others, 1990; Blythe and others, 1990).

\section{STUDY AREA AND AVAILABLE DATA}

Our study section along the Dalton Highway encompasses the Brooks Range, north of the Continental Divide, northward across the Colville basin to within 40 $\mathrm{km}$ of Prudhoe Bay and the Arctic Ocean. The point at which our section crosses the front of the Brooks Range, at Atigun Gorge (fig. 1), is the area where the range front changes trend from east-west to northeast-southwest. This area marks the juncture of two structural provinces: the main Brooks Range province, and the subsidiary northeastern Brooks Range province. The main Brooks Range province is characterized by eaststriking, multiple thrust sheets believed by some to record as much as $600 \mathrm{~km}$ of crustal shortening (Tailleur, 1969; Oldow and others, 1987; Mayfield and others, 1988); the northeastern Brooks Range is characterized by a series of northeast-trending anticlinoria, with subsidiary upright detachment folds recording less than $100 \mathrm{~km}$ of shortening (Leiggi, 1987; Mull and Adams, 1989; Wallace and Hanks, 1990). Exposed structures in the northern part of the main Brooks Range generally involve Upper Devonian and younger strata, whereas structures in the northeastern Brooks Range cut to deeper structural levels and involve considerable

\section{North}

South

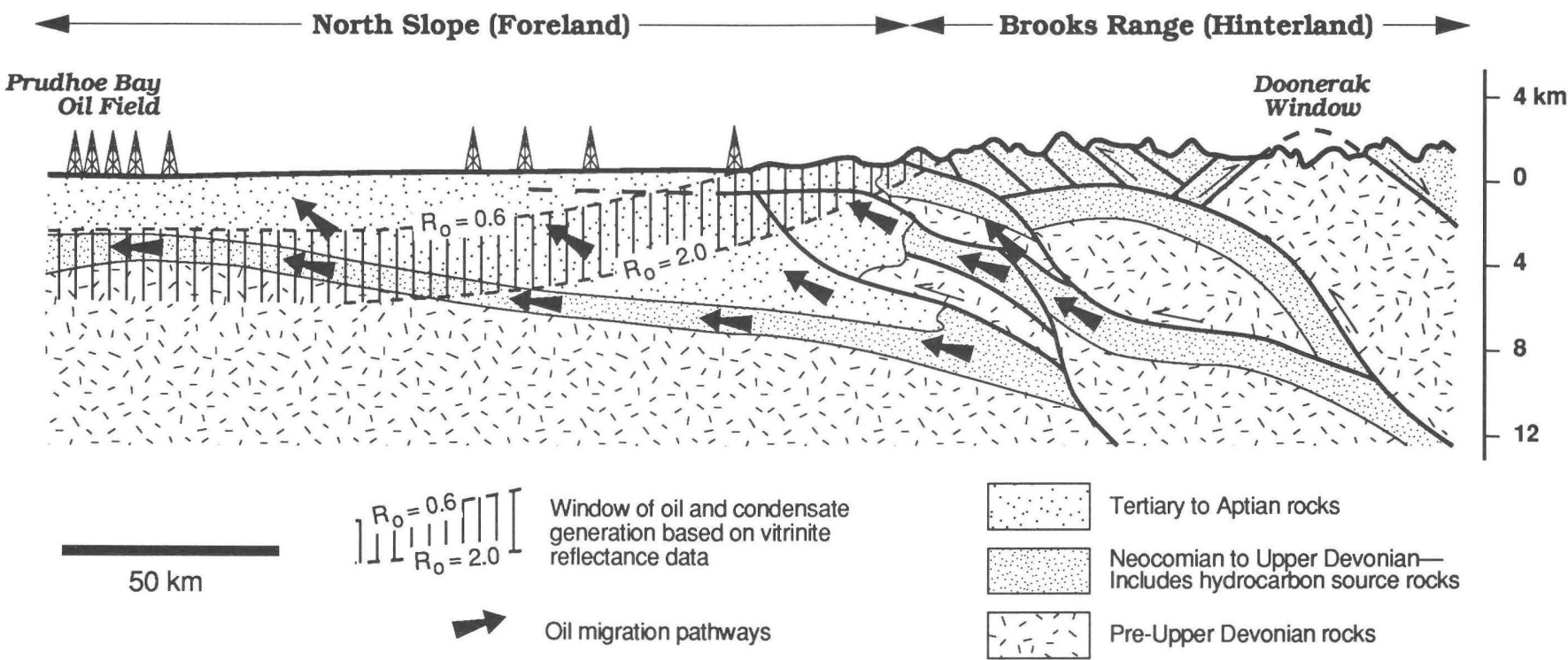

Figure 2. Diagrammatic cross section of northern part of Brooks Range and North Slope, showing disposition of oil preservation window (from Howell and others, 1990). 
thicknesses of pre-Upper Devonian strata. The Brooks Range part of our traverse lies entirely within the main Brooks Range structural province.

We have chosen to begin our work in this area because of the ease of access and the abundance of data. These data include a seismic-reflection line (AS-2) (Mull and Adams, 1989, fig. 45), geologic mapping (summarized in Mull and Adams, 1989), well data (Bird, 1982), published and newly acquired thermal maturity data (Brosgé and others, 1981), apatite fission-track analyses (O'Sullivan, 1990a, b; O'Sullivan and others, 1990; Blythe and others, 1990), and numerous measured sections (Huffman and others, 1981; Molenaar and others, 1984; Bodnar, 1989; Adams and Siok, 1989; Crowder, 1989; Moore and others, 1989; Armstrong and Mamet, 1989). Important descriptions of North Slope orogenic deposits along our section include reports by Crowder (1989) and Huffman (1989). More regional treatment of the stratigraphy is provided in Molenaar $(1983,1988)$, Molenaar and others (1987, 1988), and Moore and others (1991).

\section{STRATIGRAPHY}

Virtually all of the rocks exposed along our traverse are sedimentary and range in age from early Paleozoic to early Tertiary (fig. 3). Rocks exposed in the Brooks Range are allochthonous, Late Devonian to earliest Cretaceous (Valanginian) in age, and about $8 \mathrm{~km}$ in stratigraphic thickness. The uppermost $1 \mathrm{~km}$ of this section represents a Lower Cretaceous foreland-basin deposit related to the initial phase of Brooks Range orogenesis. In contrast, the North Slope section is primarily autochthonous. The Carboniferous to lower Tertiary sequence, with a cumulative thickness of about $12 \mathrm{~km}$, rests unconformably in the subsurface on deformed metasedimentary rocks. Foreland-basin deposits make up nearly three-quarters of this sequence and reflect the second phase of Brooks Range convergent tectonics.

The basal part of the Brooks Range stratigraphic section is composed of a 5,000-m-thick Upper Devonian southwestward-prograding clastic wedge (Moore and Nilsen, 1984), the product of uplift and erosion related to the Ellesmerian orogeny of Lerand (1973). Carboniferous marine shelfal or platformal carbonate rocks and shale about $1,000 \mathrm{~m}$ thick conformably overly these deposits. The Permian through Jurassic rocks, about $250 \mathrm{~m}$ thick, are shale and siltstone, representing distal, condensed continental-margin deposits. The uppermost part of the Brooks Range section is primarily Early Cretaceous (Valanginian) in age and is made up of two contrasting rock units: one is a marine shale and turbidite sandstone deposit (Okpikruak Formation) about 1,000 m thick (Siok, 1989), and the other is a 15-m-thick unnamed sequence of gray and brown shale with beds of coquinoid limestone formed from the shells of the bivalve Buchia (Bodnar, 1989). The depositional relationship of these units is obscured by faulting. In the western Brooks Range, Mayfield and others (1988) show that the coquinoid limestone, a part of the Ipewik unit of Crane and Wiggins (1976), is depositionally overlain by the Okpikruak Formation. They note that the coquinoid limestone is present only in a few of the structurally lowest (and least far travelled) thrust sheets, whereas in structurally higher and farther travelled thrust sheets, the Ipewik unit is missing and only the Okpikruak Formation is present. Furthermore, sparse fossil control suggests that the base of the Okpikruak Formation is time transgressive, older in farther travelled allochthons and younger in less far travelled allochthons.

The North Slope section rests with angular unconformity on deformed and metamorphosed sedimentary rocks that range in age from Proterozoic(?) to Devonian. Above the "basement" unconformity, the lower 2,600 m of this section represents marine-shelf deposition predating the Brookian orogeny. These deposits include Carboniferous sandstone, shale, and carbonate rocks $(\sim 1,000$ $\mathrm{m})$; Permian and Triassic deltaic sandstone and shale $(600 \mathrm{~m})$; and Jurassic to Lower Cretaceous shale with minor amounts of sandstone $(\sim 1,000 \mathrm{~m})$. The Lower Cretaceous regional unconformity, which lies near the top of this section, seems to reflect an episode of uplift that presaged the opening of the Canadian basin (Embry and Dixon, 1990; Fehri, 1990). The upper $9,000 \mathrm{~m}$ of the North Slope section is made up of foreland-basin deposits. Although this section (fig. 3 ) is a composite of thicknesses measured in different areas, we estimate a vertical thickness of at least 7,000 m of foreland-basin fill along our traverse based on the thermal-maturity data. The foreland-basin fill is represented by Lower Cretaceous (Aptian?) to lower Tertiary (Eocene) deposits organized into three progading, coarsening-upward cycles: (1) Aptian(?) to Albian Torok and Fortress Mountain Formations, (2) the Albian to Cenomanian Torok Formation and Nanushuk Group, and (3) the Turonian to Eocene part of the Canning and Sagavanirktok Formations. The lower part of each cycle, $1,000 \mathrm{~m}$ or more in thickness, is marine shale and interbedded turbidite sandstone that grades upward into shelf sandstone and shale. These units, in turn, grade to nonmarine (often coalbearing) sandstone, shale, and conglomerate. Each cycle thins and fines to the east-northeast, indicating the direction of basin filling (Molenaar, 1983, 1988; Molenaar and others, 1987). Details of the relations between cycles in the fold-and-thrust belt are not well known because of structural complexity, poor exposures, few well penetrations, and limited age control. Nonetheless, we infer that the first two cycles relate to Brookian thrust tectonism, while the latter cycle reflects lithospheric rebound following the principal phases of thrusting. 


\section{North Slope}

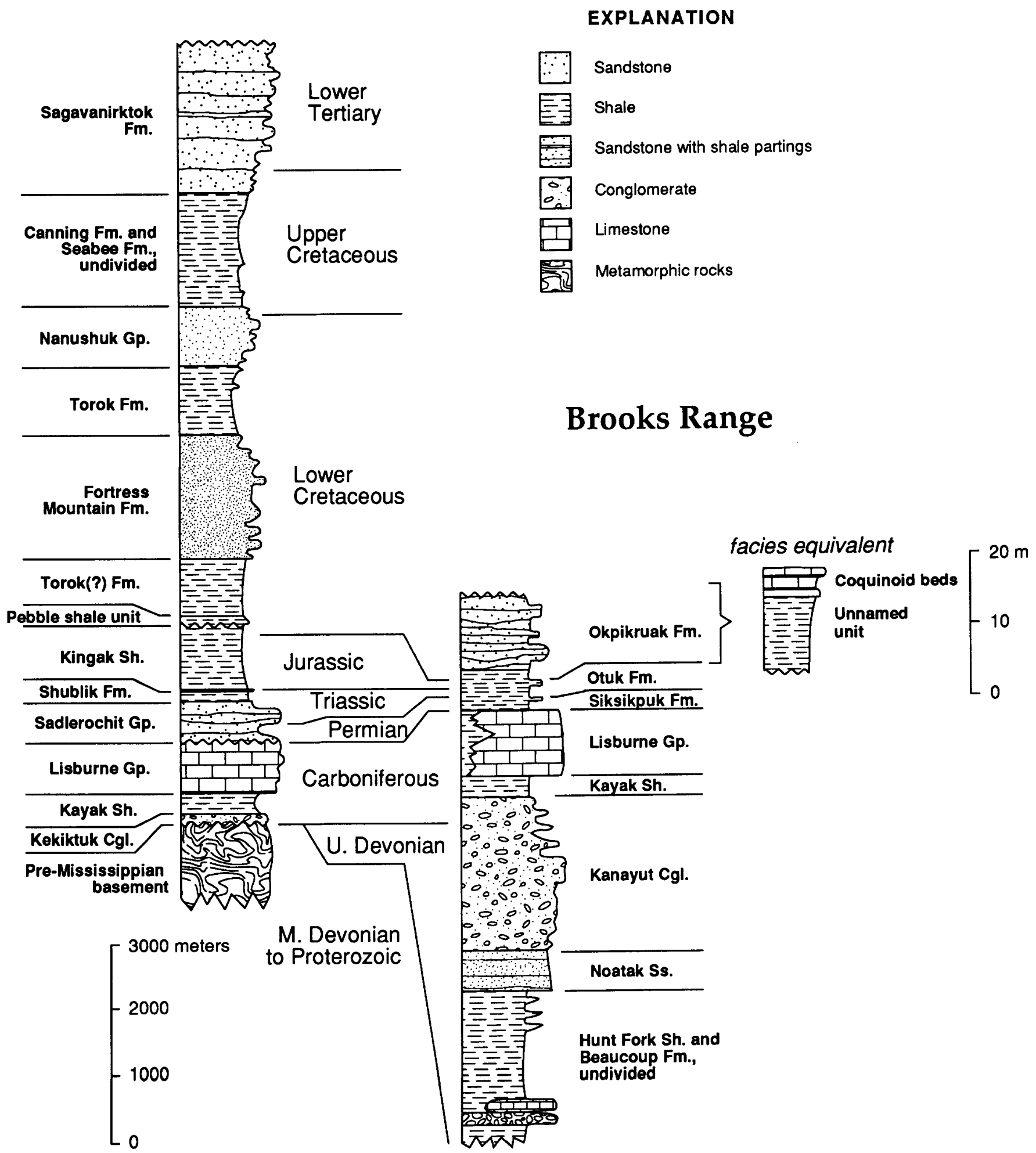

Figure 3. Summary of stratigraphy along our traverse. Brooks Range columns modified from Bodnar (1989) and Moore and others (1991). 


\section{STRUCTURE}

In our area of interest, four regional north-south cross sections have been published to date (Mull and others, 1987; Oldow and others, 1987; Mull, 1989; Grantz and others, 1990). None of these structure sections, however, have shown deformation within the foreland basin to the extent proposed in this paper. Even though our surveys have been of a more spatially restricted nature, some of our findings do bear on the question of shortening in the orogen as a whole, as well as on the extent of basement-involved thrusting. Successively more detailed renderings of the structure across the northern Brooks Range front generally paralleling the Dalton Highway are shown in figures $4-6$. The structures are inferred from seismic-reflection data in the north, well information, mapped structural and bedding features along the line of section, and down-plunge extensions of exposed structural relations east and west of the section.

Our section portrays our interpretation of the deformational character of the foreland-basin fill, Ellsmerian strata, and basement rocks well north of the range front (fig. 4). The basement-involved thrusting is based on two observations: (1) exposed structures in the Sadlerochit-Shublik-Franklin Mountains to the east (Brosgé and others, 1979; Wallace and Hanks, 1990) in the up-plunge direction (fig. 1), include both basementcored uplifts and numerous tight folds indicative of blind ramps and basement-cored propagating folds (Leiggi, 1987; Rattey, 1987; Kelley and Foland, 1987; Wallace and Hanks, 1990); and (2) well and seismic data show a gently south-dipping basement surface, as imaged on seismic line RCS-8 in the National Petroleum Reserve in Alaska (fig. 7), that would be too deep in the area of the frontal fold belt to be accounted for by the available overlying stratigraphy. For example, if the aforementioned unaccounted-for volume in the foreland is filled by thin-skinned duplexes of upper Paleozoic and (or) Mesozoic units, the required amount of structural shortening seemingly becomes too great; more than $190 \mathrm{~km}$ of shortening would be required in the foreland area alone, and this exacerbates the perennial problem of disposing of continental basement. Alternatively, we suggest a shortening of about $30 \mathrm{~km}$ involving the emplacement of panels of basement. Broad synclines and anticlines in the foothills region characterize the style of structure extending for nearly $100 \mathrm{~km}$ north of the front of the range. The seismic line RCS-8 (fig. 7), which, despite lying northwest of the Atigun Gorge, is emblematic of the structures along strike in the foothills. A gap in seismic coverage of nearly $80 \mathrm{~km}$ exists from the southern end of line RCS-8 to the range front, but the surface expression of folding in this intervening area could be explained by means of linking thrusts in the orogen with the thrusts such as those imaged on the southernmost part of line RCS-8.

The apparent westward termination of northeastern Brooks Range structures has been postulated to result from a major NE.-SW.-oriented tear fault-the Canning fault zone (Grantz and others, 1990). If, however, the northeastern Brooks Range structures extend by plunging to the west in the subsurface, there would be no need for such a fault zone to explain the northward protuberance of this structural province. We note that this part of the Brooks Range has experienced relatively small amounts of northward displacement $(<100 \mathrm{~km})$ and a large amount of differential uplift that is displayed in both the level of exposed structures and the elevated thermal maturity of the rocks (Johnsson and others, 1990).

Elsewhere, map and field relations in the area of Atigun Gorge (Brosgé and others, 1979; Mull and Adams, 1989) indicate a duplexing of the upper Paleozoic and Mesozoic strata involving at least five thrust sheets of Lisburne Group limestones and associated strata, which includes a recumbent fault-bend fold as depicted in figure 5. The northward propagation of this fold and the enclosing thrust faults are apparently balanced, in part, by a south-verging back thrust that creates a small triangle zone beneath Atigun Gorge (figs. 5, 6). A palinspastic reconstruction of the faults in this part of the section (fig. 5) indicates at least $75 \mathrm{~km}$ of shortening. The age of faulting is probably post-Albian because rocks of this age (Fortress Mountain and Torok Formations) make up the hanging wall of the back thrust. By looking at the wider zone of the thrust system from Atigun Gorge southward to the northern part of the Chandalar shelf, we estimate additional shortening amounting to at least $40 \mathrm{~km}$. Thus, the amount of shortening across the section shown on figure 4 is not less than $145 \mathrm{~km}$. These values are preliminary determinations based on an approximate balancing of line lengths in our section ${ }^{1}$.

The juxtaposition of two distinct Valanginian lithofacies at Atigun Gorge - the stratigraphically condensed coquinoid limestone and the flysch of the Okpikruak Formation-may provide additional constraints for reconstructing paleogeographic relations during early Brookian orogenesis. We infer that the coquinoid limestone unit, postulated by Jones and Grantz (1964) and Brosgé and Tailleur (1971) to represent deposition on a midbasin high, marks the position of the lithospheric bulge in Valanginian time, and that the aforementioned outcrops of Okpikruak flysch were deposited south of the bulge at or near the northern limit of the associated

\footnotetext{
${ }^{1}$ To date, we have not rigorously balanced the section to ensure conservation of line length or area of section. We are currently collaborating with the Institut Francais du Pétrole, where balanced sections will be developed using their LOCASE software.
} 
Cross Section along the Dalton Highway
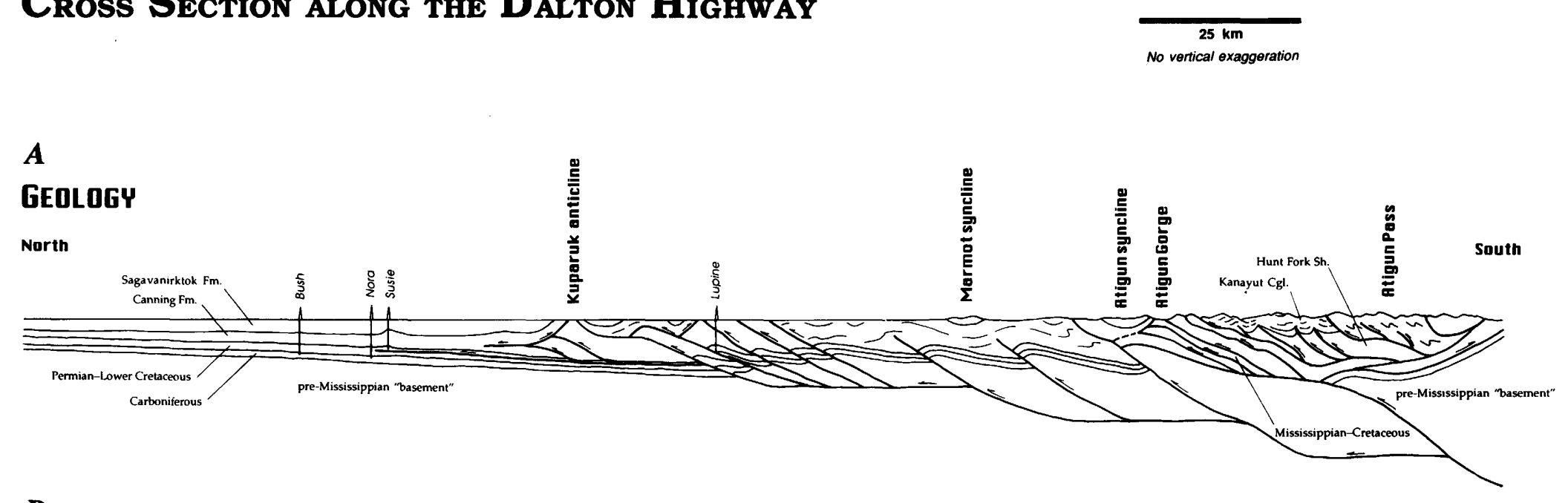

$\boldsymbol{B}$

\section{THERMAL MATURITY}

(Uitrinite Reflectance, mean $\mathbf{H}_{0}$ )

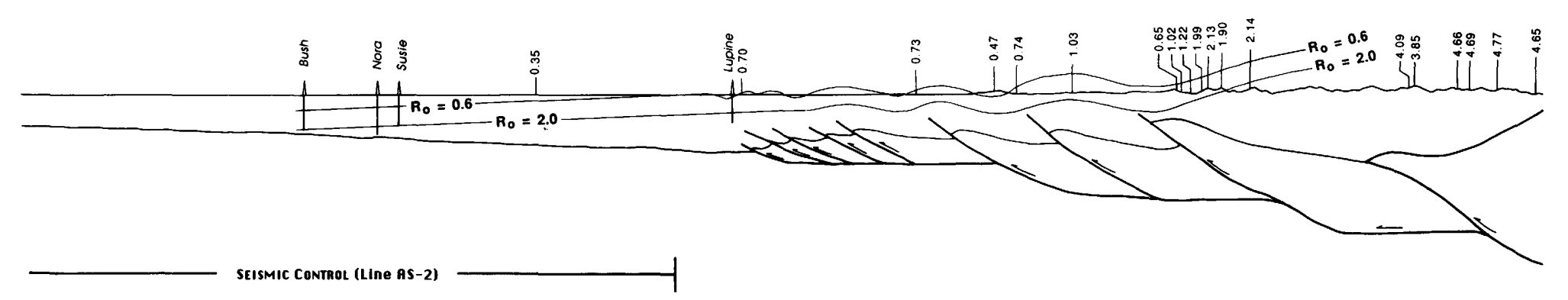

Figure 4. Structure section and paleothermal isograds across northern Brooks Range and southern part of Colville basin. A, Structure section. B, Simplified section showing vitrinite-reflectance data and warping of straight-line projections of vitrinite isograds in area of Atigun and Marmot synclines. Arrows on faults indicate direction of relative movement. See figure 1 for location of section. 
Early Cretaceous foreland. These relations were diagrammed by Molenaar (1988, fig. 25.3a).

The strength of continental lithosphere is such that the bulge in a viscoelastic slab is generally 200 to 300 $\mathrm{km}$ external or forward of the axis of the main crustal load (Beaumont and others, 1982). Based on gravity data across the range (Barnes, 1977), it can be inferred that the present location of the axis of load is at or near the end of our traverse in the Doonerak Window area, approximately $60 \mathrm{~km}$ south of Atigun Gorge. The modern position of the bulge-which presumably corresponds to its position at the end of thrusting in the Late Cretaceous-is at Prudhoe Bay, $260 \mathrm{~km}$ north of the present load axis and $\sim 200 \mathrm{~km}$ north of Atigun Gorge (Hubbard and others, 1987). These relations seem to indicate a post-Valanginian northward advance of the axis of the Brookian load of at least $200 \mathrm{~km}$. However, because we are unable at this time to characterize the nature of thrusting between the pre- and post-Valanginian episodes of crustal shortening, and because we cannot partition the amounts of thin- versus deep (midcrust and lower) thick-skin thrusting since the Valanginian, we cannot relate this northward advance in the crustal load to any specific amount of crustal shortening. What does seem certain, however, is that crustal thickening in the core of the range (for example, Doonerak Window) involves some amount of thick-skinned shortening. A variety of
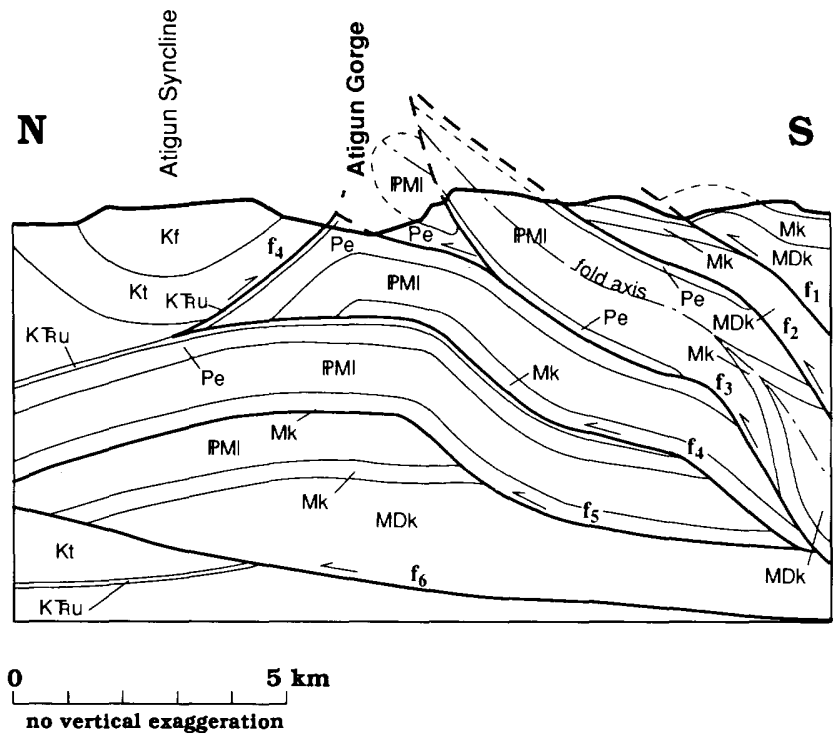

Figure 5. Structural interpretation of greater Atigun Gorge area. Map-unit symbols: Kf, Fortress Mountain Formation (Cretaceous); Kt, Torok Formation (Cretaceous); Kku, Okpikruak and Otuk Formations, undivided (Cretaceous to Triassic); Pe, Echooka Formation (Permian); PMI, Lisburne Group (Pennsylvanian and Mississippian); Mk, Kayak Shale (Mississippian); MDk, Kanayut Conglomerate (Mississippian? and Devonian); $f_{1}, f_{2}$, etc., faults with number indicating relative time of development ( 1 is oldest, 6 is youngest). See figures 1 and 4 for location. kinematic solutions have been proposed, most employing several superposed north-verging thrust packages (see, for example, Dutro and others, 1976; Mull, 1982, 1989; Oldow and others, 1987). Alternatively, we favor a thick-skinned solution that incorporates an out-of-sequence, north-verging basement wedge that is balanced by a south-verging roof thrust (an idea proposed to Howell by D.L. Jones, oral commun., 1985). A schematic diagram of this type of basement wedging is illustrated in figure 8 .

In summary, even though we are unable to constrain the amount of latest Jurassic to earliest Cretaceous shortening, the absence of a thick lowermost Cretaceous foreland sequence (save the approximately 1-km-thick erosional remnants of the Okpikruak Formation) leads us to suggest that the crustal load was relatively small, and that this earlier phase of thrusting was thin skinned in nature and (or) limited in the amount of shortening. Post-Valanginian shortening created a larger load, which stimulated the crustal subsidence of the Colville foreland basin. The axis of the mid-Cretaceous load was located approximately $200 \mathrm{~km}$ farther north than the earlier load axis. The total amount of mid- and Late Cretaceous shortening, for the rocks now north of the Doonerak Window, was at least $145 \mathrm{~km}$. This shortening reflects both thin-skinned structural duplexes and thick-skinned basement-cored thrust panels.

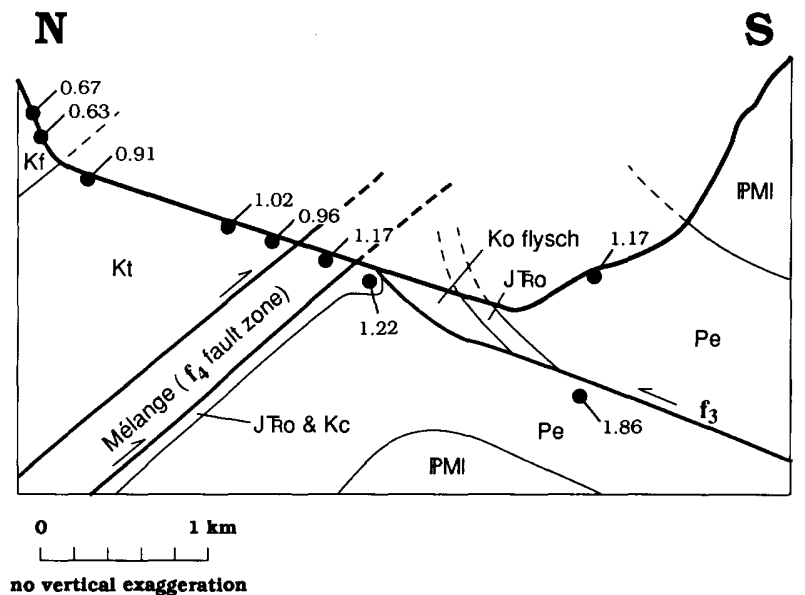

Figure 6. Cross section of Atigun Gorge showing details of paleothermal (vitrinite-reflectance) determinations and structural relations between contrasting Valanginian (Lower Cretaceous) lithofacies, the Okpikruak Formation (Ko), and the coquinoid limestone unit (Kc). Map-unit symbols: Kf, Fortress Mountain Formation (Cretaceous); Kt, Torok Formation (Cretaceous); J ko, Otuk Formation (Jurassic and Triassic); Pe, Echooka Formation (Permian); PMI, Lisburne Group (Pennsylvanian and Mississippian). $f_{3}$, fault. Arrows on faults indicate direction of relative movement. Contacts and faults dashed where projected. See figures 1,4 , and 5 for general location; this section traverses Atigun Gorge approximately $3 \mathrm{~km}$ to east, down-plunge of section shown on figure 5 . 


\section{DEFORMATION AND OIL MATURATION AND MIGRATION}

Organic-rich Triassic, Jurassic, and Lower Cretaceous rocks are the recognized source beds for the giant oil fields of the North Slope (Seifert and others, 1980; Claypool and Magoon, 1985; Sedivy and others, 1987). This geometry, whereby a giant oil field lies external to a major intracontinental orogenic belt and is fed by preorogenic strata that underwent maturation at the time of orogenesis, is in fact a common global theme [for example, the Laramide Rocky Mountains and Alberta basin sourced by Devonian strata (Bally and others, 1966), the Zagros Mountains and Persian Gulf region sourced by Jurassic and Cretaceous strata (Murris, 1980), the Permian Ural Mountains and Timan-Pechora and Volga basins sourced by the Upper Devonian Domanik Formation (Ulmishek, 1982), and the Eocene northern Andes and Llano basin sourced by Upper Cretaceous La Luna strata (Morris and others, 1990)].

The reasons for this geometry, from a geodynamic point of view, are straightforward. The accumulation and preservation of organic-rich rock requires both a stable setting and a time of high organic productivity. A continental platform provides the former, and times such as the Late Devonian, Pennsylvanian, Permian and Triassic, Late Jurassic, mid-Cretaceous, and middle to late Tertiary seem to mark global episodes of the latter (Ulmishek and Klemme, 1990). Potential source rocks of anorogenic origin lie at shallow depths subsequent to their deposition until the occurrence of conditions amenable for maturation, migration, and entrapment. These conditions are

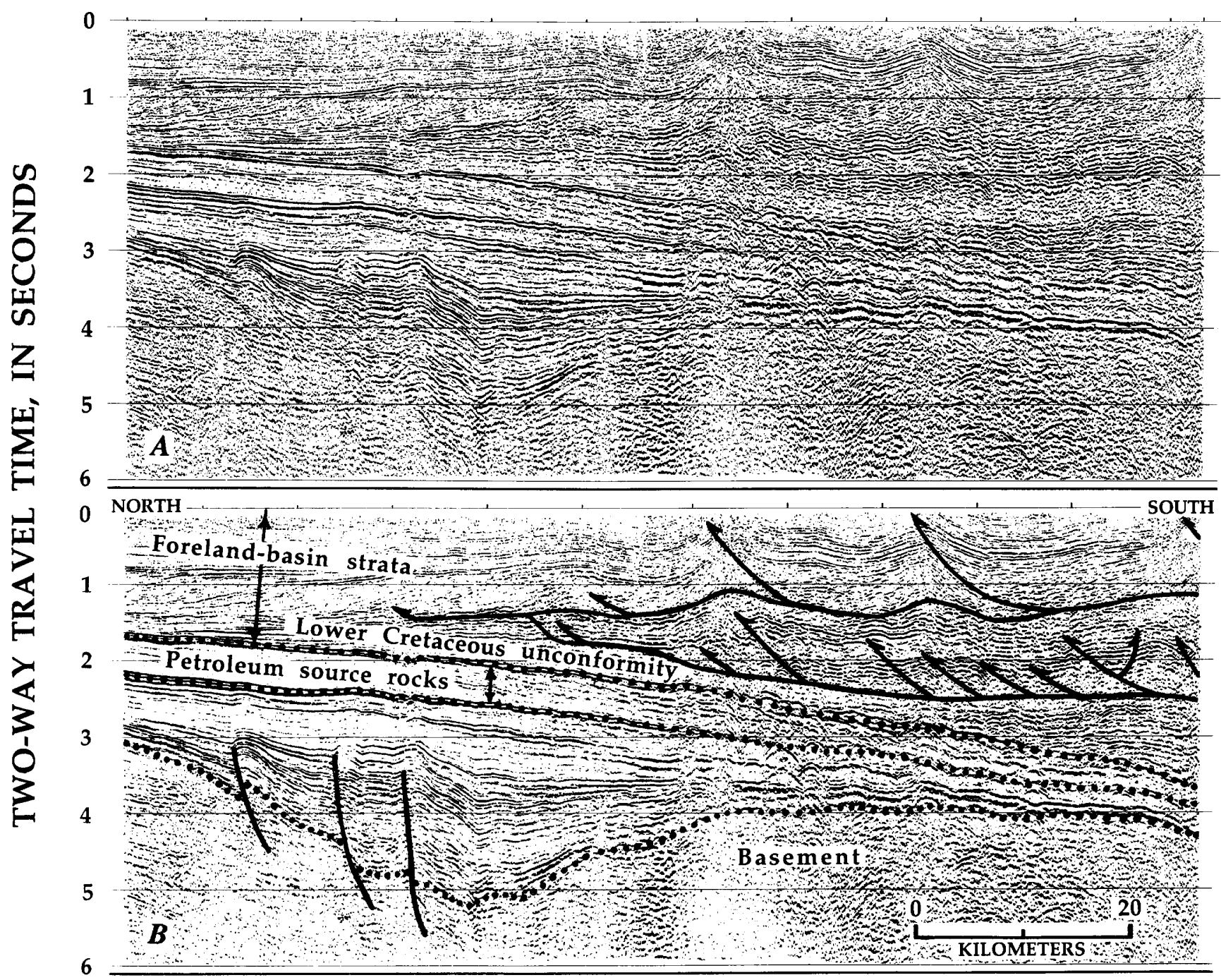

Figure 7. Southern part of U.S. Geological Survey regional compressed seismic line RCS-8 from southeastern part of the National Petroleum Reserve in Alaska. Note four stratigraphic packages (separated by dotted lines): (1) foreland-basin strata (Brookian sequence), (2) petroleum source rocks (Upper Triassic-lower Cretaceous), (3) continental-margin strata (Carboniferous-Triassic)_units 2 and 3 are Ellesmerian sequence, (4) "basement" (pre-Mississippian). See figure 1 for location. $A$, Data; $B$, Interpretation. 
provided by intracontinental convergence. Crustal shortening results in crustal thickening, which depresses the lithosphere and forms a foreland basin above the potential source rocks. The depositional fill in the foreland basin, along with the hot fluids expelled from the internal zones of the orogen, create the thermal regime for hydrocarbon maturation. The long run up to the lithospheric bulge provides a large fetch and the ultimate entrapment setting. As the orogen advances, the bulge and depocenter themselves will advance away from the orogen. The thermal effect of this process is like a hot wave moving across the source rocks. Liquid oil is expelled and swept frontally from a broad area of the source beds (Oliver, 1986).

Foreland basins, worldwide, are known to have enormous potential for hydrocarbons (Demaison, 1977). In the Alberta basin of Canada, in a setting generally comparable to the North Slope, as many as 2,500 billion barrels of heavy oil lie trapped in tar sands. In the North Slope petroleum province, about 70 billion barrels of inplace oil have been discovered (Bird, 1991). This amount is slightly less than one percent of the 10,000 billion barrels of oil estimated to have been generated (Hubbard and others, 1987; fig. 9). Most of the known oil indicates northward migration; however, some of the oil may have migrated vertically upward, closer to the range front itself. Evidence that lends credence to this premise is the presence of fracture-filling solid bitumen, which has been reported in numerous areas in the Brooks Range foothills (Molenaar and others, 1988, p. 271; Patton and Tailleur, 1964, p. 496) and most recently in the Atigun Gorge area (Howell and others, 1991; fig. 10). Analytical work on the latter occurrence is in progress in an attempt to "fingerprint" the oil and relate it to a specific source-rock unit.

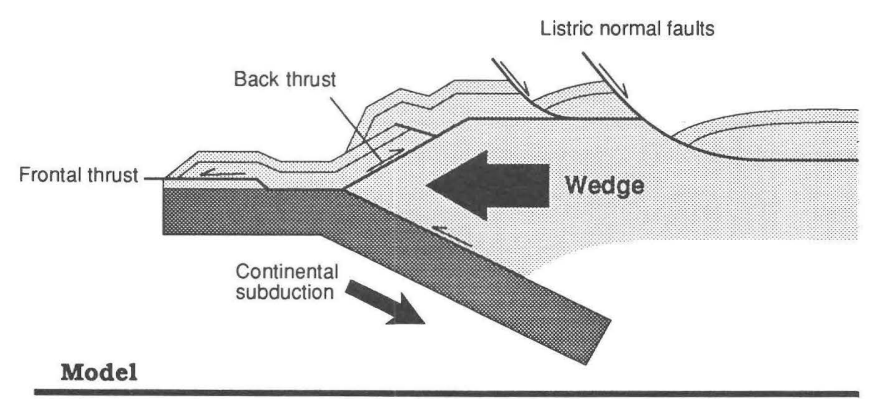

Application to Brooks Range/North Slope

Colville Basin/North Slope $\mid$ Brooks Range | Yukon-Koyukuk Basin

Figure 8. Generalized model of basement wedging and structural accommodation by back thrusting, listric normal faulting, and frontal thrusting (modified from Roure and others, 1990). Arrows on faults indicate direction of relative movement.

\section{THERMAL MATURITY}

Paleothermal indicators, mostly vitrinite-reflectance determinations, from the region of our cross section have been plotted on figures $4 B$ and 6 . We have extrapolated between widely spaced samples to produce 0.6 and 2.0 percent reflectance isograds. These isograds bracket the oil and condensate preservation window. At the northern end of our section, the oil and condensate preservation window lies between depths of 2,000 and $4,600 \mathrm{~m}$. These isograds rise in elevation southward; the 0.6 percent reflectance isotherm evidently reaches the surface somewhere near the Lupine well (fig. 4). The isograds indicate that progressively greater amounts of uplift have occurred southward along this section, from about 3 to $5 \mathrm{~km}$ at the range front to as much as $10 \mathrm{~km}$ in the core of the range near the southern end of our section. With the distribution of samples presently available, we are not able to demonstrate folding or fault-offset of the isograds in the range itself, as reported by Blythe and others (1990); however, we do see warping of isograds in the area of the Atigun and Marmot synclines, where the straight-line projections are downbowed by as much as $3,000 \mathrm{~m}$ (fig. $4 B$ ).

Apatite fission-track ages along the transect, from the southern end of the transect northward to the Marmot syncline, display ages that range from 90 to $40 \mathrm{Ma}$, with the greatest frequency at $60 \mathrm{Ma}\left(\mathrm{O}^{\prime}\right.$ Sullivan and others, 1990; Blythe and others, 1990). In order to compare the amount and timing of uplift across the transect, the fission-track ages must be normalized by factoring in vitrinite data. For example, if uplift is simply a vertical rise of the crust and lithosphere, with a null or pivot point near the paleobulge, then for any given isograd, the apatite fission-track ages should become progressively

$\mathbf{N}$

s

Generated: $10,000 \times 10^{9}$ barrels

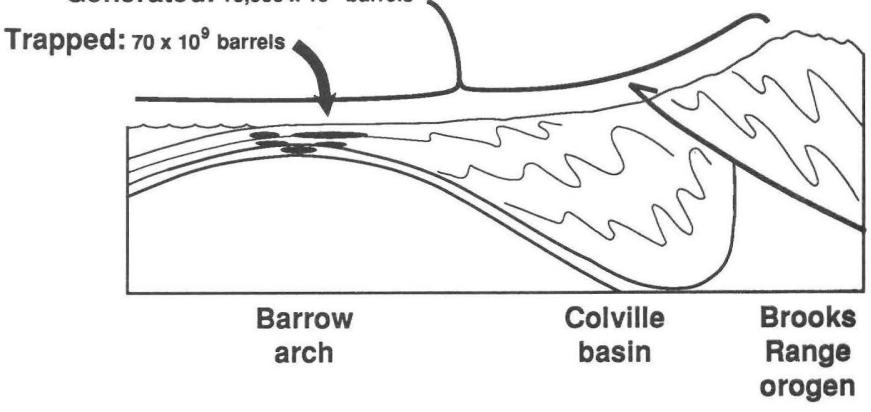

Figure 9. Comparison of total amount of oil estimated to have been generated in Arctic Alaska microplate (largely made up of North Slope petroleum province) according to Hubbard and others (1987) to total amount of oil (trapped in place) that has currently been discovered (from Bird, 1991). Arrows on faults indicate direction of relative movement. 

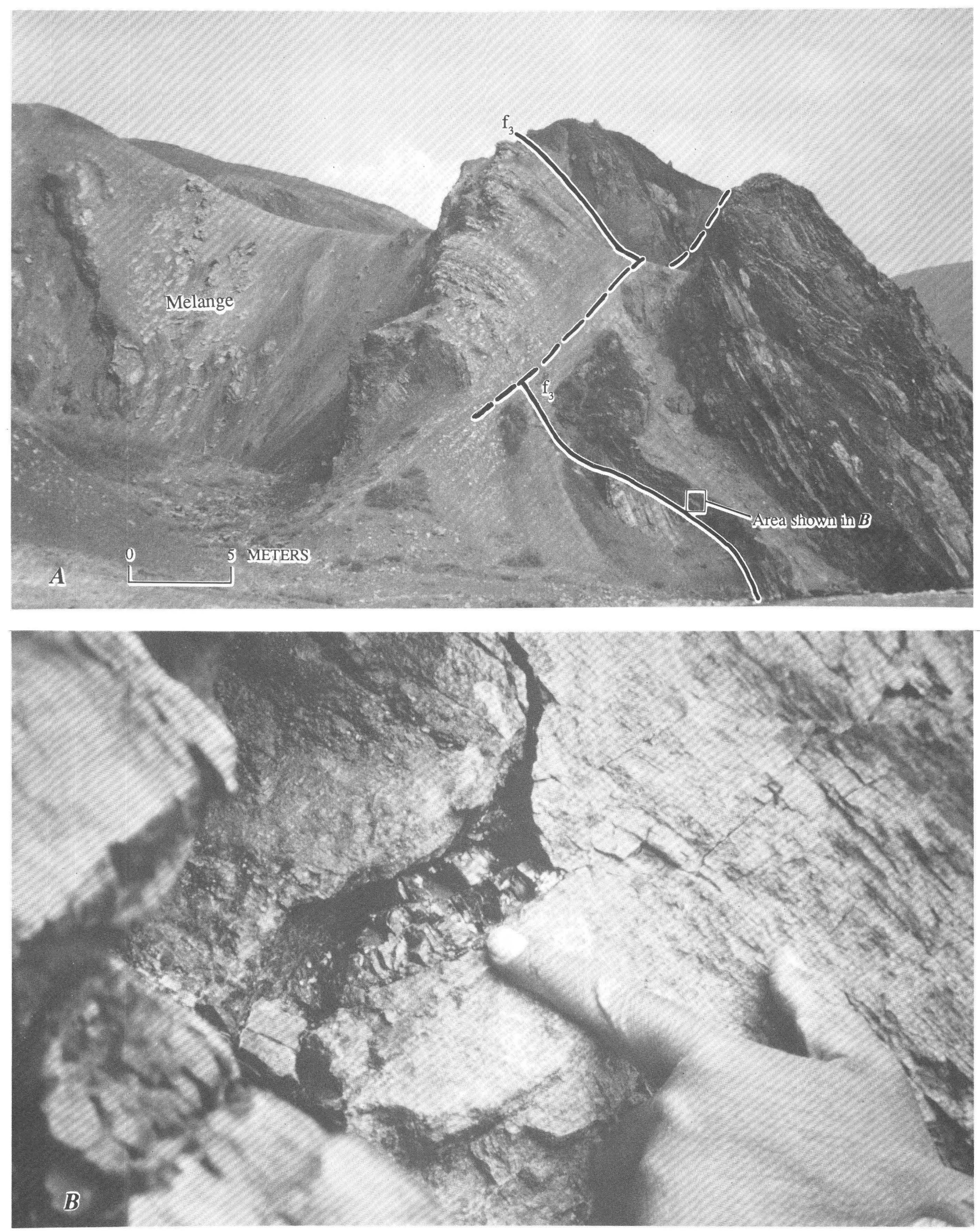

Figure 10. A, View looking toward the northeast along Atigun River, $5.5 \mathrm{~km}$ downriver from bridge, showing splay of fault f3 (fig. 5) and location of cracks filled with solid bitumen; scale is approximate. B, Solid bitumen filling fracture in Permian and Triassic strata; note hand for scale. 
younger toward the north, toward the null point in uplift. Unfortunately, there are not enough data at this time to effectively evaluate these relationships.

The timing of the maturation of oil and gas source rocks along our section is constrained to lie between the age of the youngest sedimentary strata at Atigun Gorge (mid-Cretaceous) and the approximate time of uplift and cooling (early Tertiary). Later folding and (or) faulting of the isograds could modify oil and gas accumulations by possibly destroying the integrity of the original petroleum traps.

\section{THE THERMO-TECTONIC MODEL}

We propose the following thermo-tectonic model for the part of the Brooks Range and Colville basin covered by our traverse. This model is based on structural, stratigraphic, and paleothermal data and could be applicable to continental foreland basins worldwide. We illustrate this model in figure 11.

\section{ANOROGENIC PHASE}

1. Deposition of petroleum source rocks (Siksikpuk, Otuk, and Shublik Formations, Kingak Shale, and pebble shale unit) prior to onset of orogeny.

\section{OROGENIC PHASE OF CONVERGENCE}

2. Early orogenic development of foredeep and forebulge in Valanginian time. Burial of source rocks by early foreland-basin deposits (Okpikruak Formation) insufficient to generate oil.

3. Younger orogenic development produces major foredeep (reflecting thin-skinned thrusting along the deformation front and more internal, out-of-sequence thrusting that emplaced thick crustal blocks). Foredeep sedimentary deposits (Torok and Fortress Mountain Formations and Nanushuk Group) accumulate sufficient thickness to mature source rocks (Aptian to Albian time); foreland bulge located just north of Atigun Gorge.

4. Continued northward advance of the thrust front results in deformation of Aptian to Albian foreland deposits (as well as of underlying older rocks seen in the Atigun triangle zone).

\section{POSTCONVERGENT OROGENIC PHASE}

5. After termination of the main phase of intracontinental subduction, the basal part of the lithosphere begins to equilibrate thermally, stimulating regional uplift and the deflexing of the lithosphere. Some folding and (or) faulting (formation of Marmot and Atigun synclines) accompanies this stage of the orogeny.

\section{SUMMARY AND CONCLUSIONS}

Analysis of the structure and thermal maturity along a section crossing the northern Brooks Range and southern Colville basin was undertaken to address the question of the petroleum potential of the fold-and-thrust belt. Our structural interpretation, unlike previous interpretations, includes involvement of the basement and preorogenic rocks in thrusting well north of the Brooks Range front. Preliminary estimates show a minimum of $145 \mathrm{~km}$ of crustal shortening along this section. The oil and condensate window, as defined by vitrinite-reflectance measurements, lies beneath the Colville basin at
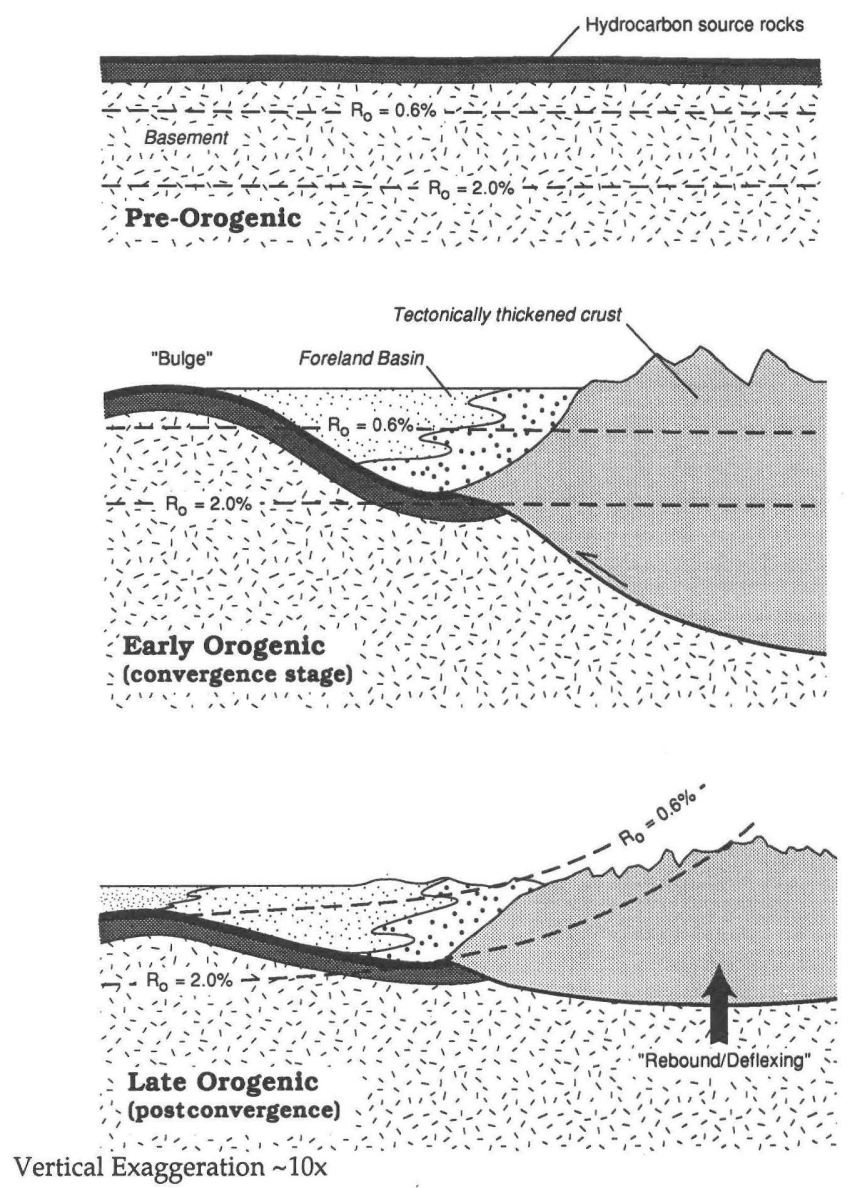

Figure 11. Thermo-tectonic model for North Slope, showing (in three stages) progression from continental platform, with organically rich undermature strata, to orogenic phase involving A-type subduction, to postconvergent phase involving principally uplift. Intermediate stage in this model provides conditions for oil maturation, migration, and entrapment. $R_{0}$, vitrinite reflectance in percent. Arrows on faults indicate direction of relative movement. 
the northern end of our section; it rises southward, an indication of postconvergent uplift. We estimate a total amount of uplift at the range front of 3 to $5 \mathrm{~km}$ and as much as $10 \mathrm{~km}$ at the southern end of the section. Thrust-related uplift occurred during mid- and Late Cretaceous time, and the postconvergence crustal rebound was underway by the early Tertiary. Maturation and migration of oil and gas occurred at the time of maximum burial and heating in the latest Cretaceous. Some compressive deformation continued after thermal maturity was achieved, so that rebound was not a simple vertical uplift; this may have compromised the integrity of earlier formed hydrocarbon traps.

Acknowledgments. - The newly acquired vitrinitereflectance data were prepared by Mark Pawlewicz of the Branch of Petroleum Geology, U.S. Geological Survey; we are certainly indebted to Mark's timely and careful analyses.

\section{REFERENCES CITED}

Adams, K.E., and Siok, J. P., 1989, Permian stratigraphy in the Atigun Gorge area: a transition between the Echooka and Siksikpuk Formations, in Mull, C.G., and Adams, K.E., eds., Dalton Highway, Yukon River to Prudhoe Bay, Alaska: Fairbanks, Alaska Division of Geological and Geophysical Surveys, Guidebook 7, v. 2, p. 267-276.

Armstrong, A.K., and Mamet, B.L., 1989, Stratigraphy of the Lisburne Group in the central Brooks Range, in Mull, C.G., and Adams, K.E., eds., Dalton Highway, Yukon River to Prudhoe Bay, Alaska: Fairbanks, Alaska Division of Geological and Geophysical Surveys, Guidebook 7, v. 2, p. 253-265.

Bally, A.W., Gordy, P.L., and Stewart, G.A., 1966, Structure, seismic data, and orogenic evolution of southern Canadian Rocky Mountains: Bulletin of Canadian Petroleum Geology, v. 14, no. 3, p. 337-381.

Bally, A.W., and Snelson, S., 1980, Realms of subsidence, in Miall, A.D., ed., Facts and principles of world petroleum occurrence: Canadian Society of Petroleum Geologists Memoir 6, p. 9-94.

Barnes, D.F., 1977, Bouguer gravity map of Alaska: U.S. Geological Survey Map GP-913, scale 1:2,500,000, 1 sheet.

Beaumont, C., Keen, C.E., and Boutilier, R., 1982, A comparison of foreland and rift margin sedimentary basins: Philosophical Transactions of the Royal Society of London, Series A, v. 305, p. 295-317.

Bird, K.J., 1982, Rock unit reports of 228 wells drilled on the North Slope, Alaska: U.S. Geological Survey Open-File Report 82-287, 106 p.

-1991, North Slope of Alaska, in Gluskoter, H.J., Rice, D.D., and Taylor, R.B., eds., Economic geology, U.S., Oil and Gas section, Part III., Regional synthesis of selected provinces, chapter 29: Boulder, Colorado, Geological Society of America, The Geology of North America, DNAG Series, v. P-2 [in press].

Blythe, A.E., Bird, J.M., and Omar, G.I., 1990, Brooks Range fission-track and ${ }^{40} \mathrm{Ar}{ }^{39} \mathrm{Ar}$ ages: implications for structural evolution [abs.]: Eos (American Geophysical Union, Transactions), v. 71, no. 43, p. 1617.

Bodnar, D.A., 1989, Stratigraphy of the Otuk Formation and a Cretaceous coquinoid limestone and shale unit, northcentral Brooks Range, in Mull, C.G., and Adams, K.E., eds., Dalton Highway, Yukon River to Prudhoe Bay, Alaska: Fairbanks, Alaska Division of Geological and Geophysical Surveys, Guidebook 7, v. 2, p. 277-284.

Brosgé, W.P., Reiser, H.N., and Dutro, J.T., Jr., 1979, Bedrock geologic map of the Philip Smith Mountains quadrangle, Alaska: U.S. Geological Survey Miscellaneous Field Studies Map MF-879-B, scale 1:250,000, 2 sheets.

Brosgé, W.P., Reiser, H.N., Dutro, J.T., Jr., and Detterman, R.L., 1981, Organic geochemical data for Mesozoic and Paleozoic shales, central and eastern Brooks Range, Alaska: U.S. Geological Survey Open-File Report 81-551, $17 \mathrm{p}$.

Brosgé, W.P, and Tailleur, I.L., 1971, Northern Alaska petroleum province, in Cram, I.H., ed., Future petroleum provinces of the United States; their geology and potential: American Association of Petroleum Geologists Memoir 15 , v. 1, p. 68-99.

Claypool, G.E., and Magoon, L.B., 1985, Comparison of oilsource rock correlation data for Alaskan North Slopetechniques, results, and conclusions, in Magoon, L.B., and Claypool, G.E., eds., Alaska North Slope oil/rock correlation study: American Association of Petroleum Geologists Studies in Geology No. 20, p. 49-81.

Crane, R.C., and Wiggins, V.D., 1976, Ipewick Formation, significant Jurassic-Neocomian map unit in northern Brooks Range foldbelt [abs.]: American Association of Petroleum Geologists Bulletin, v. 60, no. 12, p. 2177.

Crowder, R.K., 1989, Deposition of the Fortress Mountain Formation, in Mull, C.G., and Adams, K.E., eds., Dalton Highway, Yukon River to Prudhoe Bay, Alaska: Fairbanks, Alaska Division of Geological and Geophysical Surveys, Guidebook 7, v. 2, p. 293-301.

Demaison, G.J., 1977, Tar sands and supergiant oil fields: American Association of Petroleum Geologists Bulletin, v. 61 , no. 11, p. 1950-1961.

Dutro, J.T., Jr., Brosgé, W.P., Lanphere, M.A., and Reiser, H.N., 1976, Geologic significance of Doonerak structural high, central Brooks Range, Alaska: American Association of Petroleum Geologists Bulletin, v. 60, p. 952-961.

Embry, A., and Dixon, J., 1990, The breakup unconformity of the Amerasia basin, Arctic; evidence from Arctic Canada: Geological Society of America Bulletin, v. 102, p. 15261534.

Fehri, N., 1990, Histoire de la subsidence du bassin de Colville (North Slope, Alaska): Paris, France, Université Pierre et Marie Curie, unpublished thesis.

Grantz, A., Moore, T.E., and Roeske, S.M., 1990, North American Continent-Ocean transect A-3, Gulf of Alaska to Arctic Ocean: Boulder, Colorado, Geological Society of America Continental Continent/Ocean Transect, scale 1:500,000, 3 sheets, $49 \mathrm{p}$.

Howell, D.G., Johnsson, M.J., and Bird, K.J., 1990, Geodynamics and petroleum potential, Brooks Range, Alaska [abs.]: Annual meeting of the Geological Associa- 
tion of Canada and Mineralogical Association of Canada, Program with Abstracts, May 16-18, 1990, Vancouver, Canada, p. A61.

1991, Solid bitumen at Atigun Gorge, central Brooks Range front: implications for oil exploration in the North Slope fold and thrust belt [abs.]: American Association of Petroleum Geologists Bulletin, v. 75, p. 598.

Hubbard, R.J., Edrich, S.P., and Rattey, R.P., 1987, Geologic evolution and hydrocarbon habitat of the Arctic Alaska microplate, in Tailleur, I.L., and Weimer, Paul, eds., Alaskan North Slope geology: Bakersfield, California, Pacific Section, Society of Economic Paleontologists and Mineralogists, v. 50, p. 289-314.

Huffman, A.C., Jr., 1989, The Nanushuk Group, in Mull, C.G., and Adams, K.E., eds., Dalton Highway, Yukon River to Prudhoe Bay, Alaska: Fairbanks, Alaska Division of Geological and Geophysical Surveys, Guidebook 7, v. 2, p. 303-309.

Huffman, A.C., Ahlbrandt, T.S., Pasternak, I., Stricker, G.D., Bartsch-Winkler, S., Fox, J.E., May, F.E., Scott, R.A., and Materna, W.H., 1981, Measured sections in the Cretaceous Nanushuk and Colville Groups undivided, central North Slope, Alaska: U.S. Geological Survey Open-File Report OF-81-177.

Johnsson, M.J., Bird, K.J., Howell, D.G., Magoon, L.B., Stanley, R.G., Valin, Z.C., Harris, A.G., and Pawlewicz, M.J., 1990, Preliminary thermal maturity map of sedimentary rocks in Alaska [abs.]: Eos (American Geophysical Union, Transactions) v. 71, no. 43, p. 1617.

Jones, D.L., and Grantz, Arthur, 1964, Stratigraphic and structuralsignificance of Cretaceous fossils from Tiglukpuk Formation, northern Alaska: American Association of Petroleum Geologists Bulletin, v. 48, no. 9, p. 1462-1474.

Kelley, J.S., and Foland, R.L., 1987, Structural style and framework geology of the coastal plain and adjacent Brooks Range, in Bird, K.J., and Magoon, L.B., eds., Petroleum geology of the northern part of the Arctic National Wildlife Refuge, northeastern Alaska: U.S. Geological Survey Bulletin 1778, p. 255-270.

Leiggi, P.A., 1987, Style and age of tectonism of the Sadlerochit Mountains to Franklin Mountains, Arctic National Wildlife Refuge, Alaska, in Tailleur, I.L., and Weimer, Paul, eds., Alaskan North Slope geology: Bakersfield, California, Pacific Section, Society of Economic Paleontologists and Mineralogists, v. 50, p. 749-756.

Lerand, Monti, 1973, Beaufort Sea, in McCrossan, R.G., ed., The future petroleum provinces of Canada-their geology and potential: Canadian Society of Petroleum Geologists Memoir 1, p. 315-386.

Mayfield, C.F., Tailleur, I.L., and Ellersieck, I., 1988, Stratigraphy, structure, and palinspastic synthesis of the western Brooks Range, northwestern Alaska, in Gryc, G., ed., Geology and exploration of the National Petroleum Reserve in Alaska: U.S. Geological Survey Professional Paper 1399, p. 143-186.

Molenaar, C.M., 1983, Depositional relations of Cretaceous and lower Tertiary rocks, northeastern Alaska: American Association of Petroleum Geologists Bulletin, v. 67, no. 7, p. 1066-1080.

1988, Depositional history and seismic stratigraphy of
Lower Cretaceous rocks, National Petroleum Reserve in Alaska and adjacent areas, in Gryc, G., ed., Geology and exploration of the National Petroleum Reserve in Alaska: U.S. Geological Survey Professional Paper 1399, p. 593621.

Molenaar, C.M., Bird, K.J., and Kirk, A.R., 1987, Cretaceous and Tertiary stratigraphy of northeastern Alaska, in Tailleur, I.L., and Weimer, Paul, eds., Alaskan North Slope geology: Bakersfield, California, Pacific Section, Society of Economic Paleontologists and Mineralogists, v. 50, p. 513-528

Molenaar, C.M., Egbert, R.M., and Krystinik, L.F., 1988, Depositional facies, petrography, and reservoir potential of the Fortress Mountain Formation (Lower Cretaceous), central North Slope, Alaska, in Gryc, G., ed., Geology and exploration of the National Petroleum Reserve in Alaska: U.S. Geological Survey Professional Paper 1399, p. 257280.

Molenaar, C.M., Kirk, A.R., Magoon, L.B., and Huffman, A.C., Jr., 1984, Twenty-two measured sections of Cretaceous-Lower Tertiary rocks, eastern North Slope, Alaska: U.S. Geological Survey Open-File Report 84-695, 19 p.

Moore, T.E., and Nilsen, T.H., 1984, Regional sedimentological variations in the Upper Devonian and Lower Mississippian(?) Kanayut Conglomerate, Brooks Range, Alaska: Sedimentary Geology, v. 38, p. 464-498.

Moore, T.E., Nilsen, T.H., and Brosgé, W.P., 1989, Sedimentology of the Kanayut Conglomerate, in Mull, C.G., and Adams, K.E., eds., Dalton Highway, Yukon River to Prudhoe Bay, Alaska: Fairbanks, Alaska Division of Geological and Geophysical Surveys, Guidebook 7, v. 2, p. 219-252.

Moore, T.E., Wallace, W.K., Bird, K.J., Karl, S.M., Mull, C.G., and Dillon, J.T., (1991), Geology of northern Alaska, chapter 2B, in Plafker, G., Jones, D.L., and Berg, H.C., eds., The geology of the Cordilleran orogen, Alaska: Boulder, Colorado, Geological Society of America, The Geology of North America, DNAG Series.

Morris, A.E.L., Meyerhoff, A.A., Paner, Irfan, Bueno-Salazar, R., and Young, G.A., 1990, Energy resources of the Caribbean region, in Dengo, Gabriel, and Case, J.E., eds., The Caribbean region: Boulder, Colorado, Geological Society of America, The Geology of North American, DNAG Series, v. H, p. 483-510.

Mull, C.G., 1982, The tectonic evolution and structural style of the Brooks Range, Alaska: an illustrated summary, in Powers, R.B., ed., Geological studies of the Cordilleran thrust belt: Denver, Colorado, Rocky Mountain Association of Geologists, v. 1, p. 1-45.

-1989, Generalized geologic map of the Brooks Range and Arctic Slope, northern Alaska, in Mull, C.G., and Adams, K.E., eds., Dalton Highway, Yukon River to Prudhoe Bay, Alaska: Fairbanks, Alaska Division of Geological and Geophysical Surveys, Guidebook 7, v. 1, scale $1: 2,851,200,1$ sheet.

Mull, C.G., and Adams, K.E., eds., 1989, Dalton Highway, Yukon River to Prudhoe Bay, Alaska: Fairbanks, Alaska Division of Geological and Geophysical Surveys, Guidebook 7, 309 p. [2 vols.]

Mull, C.G., Roeder, D.H., Tailleur, I.L., Pessel, G.H., Grantz, 
A., and May, S.D., 1987, Geologic sections and maps across Brooks Range and Arctic Slope to Beaufort Sea, Alaska: Boulder, Colorado, Geological Society of America, MC-28S.

Murris, R.J., 1980, Middle East: stratigraphic evolution and oil habitat: American Association of Petroleum Geologists Bulletin, v. 64, no. 5, p. 597-618.

Oldow, J.S., Seidensticker, C.M., Phelps, J.C., Julian, F.E., Gottschalk, R.R., Boler, K.W., Handschy, J.W., and Ave Lallemant, H.G., 1987, Balanced cross sections through the central Brooks Range, and North Slope, Arctic Alaska: Tulsa, Oklahoma, American Association of Petroleum Geologists, eight pls. and text.

Oliver, J., 1986, Fluids expelled tectonically from orogenic belts: their role in hydrocarbon migration and other geologic phenomena: Geology, v. 14, p. 99-102.

O'Sullivan, P.B., 1990a, Preliminary results of 11 apatite fission-track analyses of samples from the Galbraith LakeToolik Lake region, North Slope, Alaska: Alaska Division of Geological and Geophysical Surveys Public-Data File 90-7a, 17 p.

-1990b, Preliminary results of seven apatite fission-track analyses of samples from the Cobblestone Creek region, Chandler Lake Quadrangle, North Slope, Alaska: Alaska Division of Geological and Geophysical Surveys PublicData File 90-7b, 13 p.

O'Sullivan, P.B., Decker, J., Bergman, S.C., and Wallace, W.K., 1990, Constraints by apatite fission track analysis on cooling times due to uplift in the northeastern Brooks Range, Alaska [abs.]: American Association of Petroleum Geologists Bulletin, v. 74, no. 5, p. 733.

Patton, W.W., Jr., and Tailleur, I.L., 1964, Geology of the Killik-Itkillik region, Alaska: U.S. Geological Survey Professional Paper 303-G, p. 409-500.

Rattey, R.P., 1987, Northeastern Brooks Range, Alaska: new evidence for complex thin-skinned thrusting [abs.], in Tailleur, I.L., and Weimer, Paul, eds., Alaskan North Slope geology: Bakersfield, California, Pacific Section, Society of Economic Paleontologists and Mineralogists, v.
50 , p. 757.

Roure, F., Howell, D.G., Guellec, S., and Casero, P., 1990, Shallow structures induced by deep-seated thrusting, in Letouzey, J., ed., Petroleum and tectonics in mobile belts: Paris, France, Editions Technip, 1988, p. 15-30.

Sedivy, R.A., Penfield, I.E., Halpern, H.I., Drozd, R.J., Cole, G.A., and Burwood, R., 1987, Investigation of source rock-crude oil relationships in the northern Alaska hydrocarbon habitat, in Tailleur, I.L., and Weimer, Paul, eds., Alaskan North Slope geology: Bakersfield, California, $\mathrm{Pa}-$ cific Section, Society of Economic Paleontologists and Mineralogists, v. 50, p. 169-179.

Seifert, W.K, Moldowan, J.M., and Jones, R.W., 1980, Application of biological marker geochemistry to petroleum exploration: World Petroleum Congress, 10th, Bucharest, Proceedings, p. 425-440.

Siok, J.P., 1989, Stratigraphy and petrology of the Okpikruak Formation at Cobblestone Creek, northcentral Brooks Range, in Mull, C.G., and Adams, K.E., eds., Dalton Highway, Yukon River to Prudhoe Bay, Alaska: Fairbanks, Alaska Division of Geological and Geophysical Surveys, Guidebook 7, v. 2, p. 285-292.

Tailleur, I.L., 1969, Speculations on North Slope geology: Oil and Gas Journal, September 22, 1969, p. 215-226.

Ulmishek, G.F., 1982, Petroleum geology and resource assessment of the Timan-Pechora basin, USSR, and the adjacent Barents-Northern Kara Shelf: Argonne National Laboratory Report ANL/EES-TM-199, 165 p.

Ulmishek, G.F., and Klemme, H.D., 1990, Depositional controls, distribution, and effectiveness of world's petroleum source rocks: U.S. Geological Survey Bulletin 1931, 59 p.

Wallace, W.K., and Hanks, C.L., 1990, Structural provinces of the northeastern Brooks Range, Arctic National Wildlife Refuge, Alaska: American Association of Petroleum Geologists Bulletin, v. 74, no. 7, p. 1100-1118.

Reviewers: John S. Kelley and Leslie B. Magoon, III 


\title{
Tectonic Evolution of the Kandik Region, East-Central Alaska: Preliminary Interpretations
}

\author{
By David G. Howell, Mark J. Johnsson, Michael B. Underwood, Lu Huafu, \\ and John W. Hillhouse
}

\begin{abstract}
Preliminary thermal, sedimentologic, structural, and paleomagnetic data indicate that the Kandik region of eastcentral Alaska represents a fold-and-thrust belt analogous to, and perhaps correlative with, the Brooks Range foldand-thrust belt. Anorogenic marine deposits, derived from continental sources, characterize Middle Triassic through earliest Cretaceous sedimentation. We interpret the remainder of the Lower Cretaceous sequence to represent orogenic, foreland-basin fill that commenced in the Valanginian. Quartzose, continentally derived sediments characterize the Valanginian and perhaps part of the Hauterivian. An influx of oceanic volcanic sediment occurred in Hauterivian or Barremian time, and this change in provenance may reflect the obduction of the Tozitna terrane. Aptian sandstones contain quartzose metasedimentary debris, suggesting erosional downcutting into the Paleozoic continental strata that lay below the obducted Tozitna terrane. The Cretaceous foreland-basin deposits buried Paleozoic strata of the Tatonduk terrane to the east, providing sufficient burial heat to drive these deposits into the oil-maturation window. The foreland-basin fill was in turn overridden by thick crustal nappes that advanced from the west. As thrusting continued, the foreland deposits were tectonically buried and injected with hot fluids, causing a high degree of thermal alteration. Upper Cretaceous through Tertiary foreland-basin sedimentary rocks, derived from the eastward-advancing thrust sheets provide a depositional record of the latest stages of thrusting preserved in the Kandik region.
\end{abstract}

\section{INTRODUCTION}

This report focuses on the regional tectonic framework of the Tatonduk and Kandik River terranes based on paleothermal, sedimentologic, structural, and paleomagnetic data collected during studies extending through November 1990. The principal objective of our study is to characterize the thermal setting of the Kandik area north of the Yukon fault. Two distinct thermal domains are displayed in this region-one within the hydrocarbon window and one that is thermally beyond this window. Our investigations are still underway, and this paper should be considered a progress report. Nonetheless, enough is now known to warrant constructive speculations that help define strategies for future research, and we conclude this report with a tentative working hypothesis regarding the tectonic development of the Kandik region.

The Kandik region straddles the Yukon-Alaska border between latitude $64.5^{\circ}$ and $66^{\circ} \mathrm{N}$. The region encompasses the drainage basins of the Kandik and Nation Rivers and is traversed by the Yukon River (fig. 1). The region is comprised of three tectonostratigraphic terranes-the Tatonduk, Kandik River, and Tozitna terranes-which are separated from the Yukon-Tanana and Seventymile terranes to the south by the Tintina fault (fig. 1). The three former terranes are not necessarily far-traveled, exotic entities. However, because their precise paleogeographic relations with the North American continent are not certain, they remain "suspect" at this time.

The Seventymile terrane, consisting of numerous discontinuous slivers of lower Mesozoic oceanic units, is largely surrounded by the Yukon-Tanana terrane, an amalgamated body made up of allochthonous crystalline rocks representing the remains of several Devonian volcanic arcs that were probably originally insular domains offshore from the North American continent (Foster, 1976; Jones and others, 1987; Stanley and others 1990; Hansen, 1990).

The Kandik region, north of the Tintina fault, is a fold-and-thrust belt; nappes involving both basement and cover strata partially overthrust foreland-basin strata (Brabb and Churkin, 1969; Dover and Miyoka, 1988). The Tatonduk terrane, lying east of the Glenn Creek fault, represents a displaced fragment of continental North America. The upper Precambrian through upper Paleozoic sequence exposed in this terrane records the breakup and subsidence of the western margin of North America (Payne and Allison, 1981; Howell and Wiley, 
1987). The Kandik River terrane, which lies north and west of the Glenn Creek fault, includes a Paleozoic sequence that differs stratigraphically and lithologically from the Paleozoic sequence of the Tatonduk terrane, suggesting that the Kandik River terrane is to some degree displaced relative to the Tatonduk terrane and to autochthonous North America. These Paleozoic rocks are overlain by Triassic to Lower Cretaceous shale, Lower Cretaceous shallow-marine quartz arenites, and a thick Lower Cretaceous sequence that we interpret to be foreland-basin fill. The northwesternmost and structurally highest terrane is the poorly exposed Tozitna terrane, which consists of volcanic rocks of oceanic affinity similar in many respects to rocks of the Angayucham terrane of the southern Brooks Range (Jones and others, 1987). The degree of allochthoneity of this terrane is not known.

The Kandik region has attracted geologic interest for some time, beginning in 1886 when gold was discovered in the Fortymile and Seventymile river drainages. Although later eclipsed by the discoveries in the Klondike, placer gold mining has been intermittently profitable in the Yukon-Tanana and Seventymile terranes throughout the 19th and 20th centuries. Currently, much interest is focused on locating mother-lode gold deposits responsible for the extensive historic placer accumulations. The thick sedimentary sequences and overthrust setting of the Kandik River and Tatonduk terranes drew the attention of the oil industry in the late 1960's and early 1970's (see, for example, Churkin and Brabb, 1969). Interest waned somewhat after three dry holes were drilled in east-central Alaska in the early 1970's. Recently, however, ARCO Alaska has resumed hydrocarbon exploration in the Tatonduk terrane. Finally, the area's magnificent scenic value, largely inherited from its geology and physiography, has led to the creation of the Yukon-Charley Rivers National Preserve and is attracting increasing numbers of visitors to the area.

\section{STRATIGRAPHY}

An understanding of the stratigraphy of the Kandik region is fundamental to the interpretation of the area's structure, tectonic evolution, and paleothermal configuration. The oldest rocks exposed in the Tatonduk terrane are those of the Tindir Group, a thick Precambrian and Lower Cambrian sequence consisting of a diverse group of sedimentary rocks including shale, nonmarine red beds with dropstones, limestone (occasionally bituminous), dolomite, and intercalated basalt (fig. 2A). The Tindir Group is overlain by a passive-margin sequence (bordering the North American continent), Cambrian through Devonian in age, consisting of the Funnel Creek Limestone, Adams Argillite, Hillard Limestone, Road

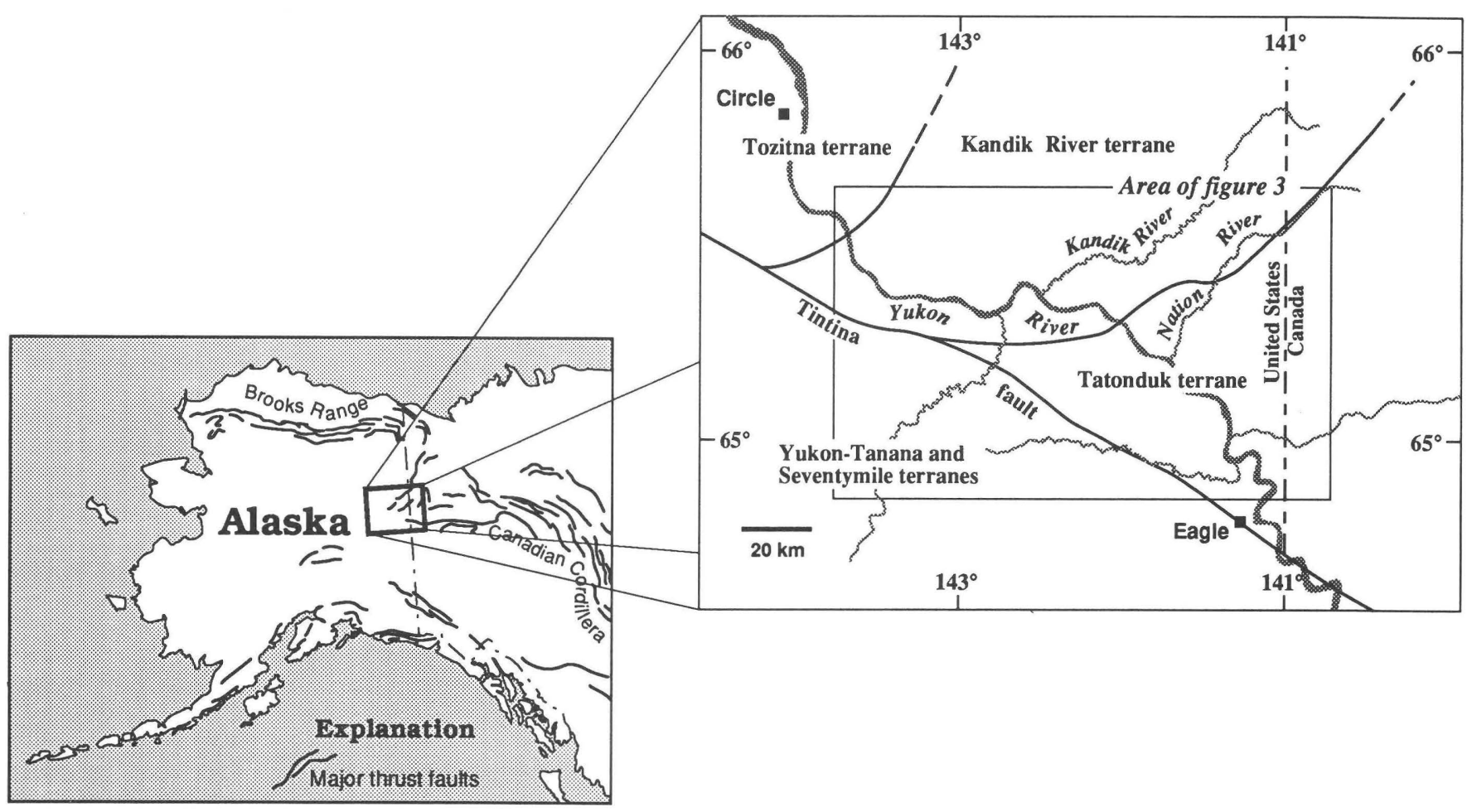

Figure 1. Location of study area in east-central Alaska. 


\section{A Tatonduk terrane}

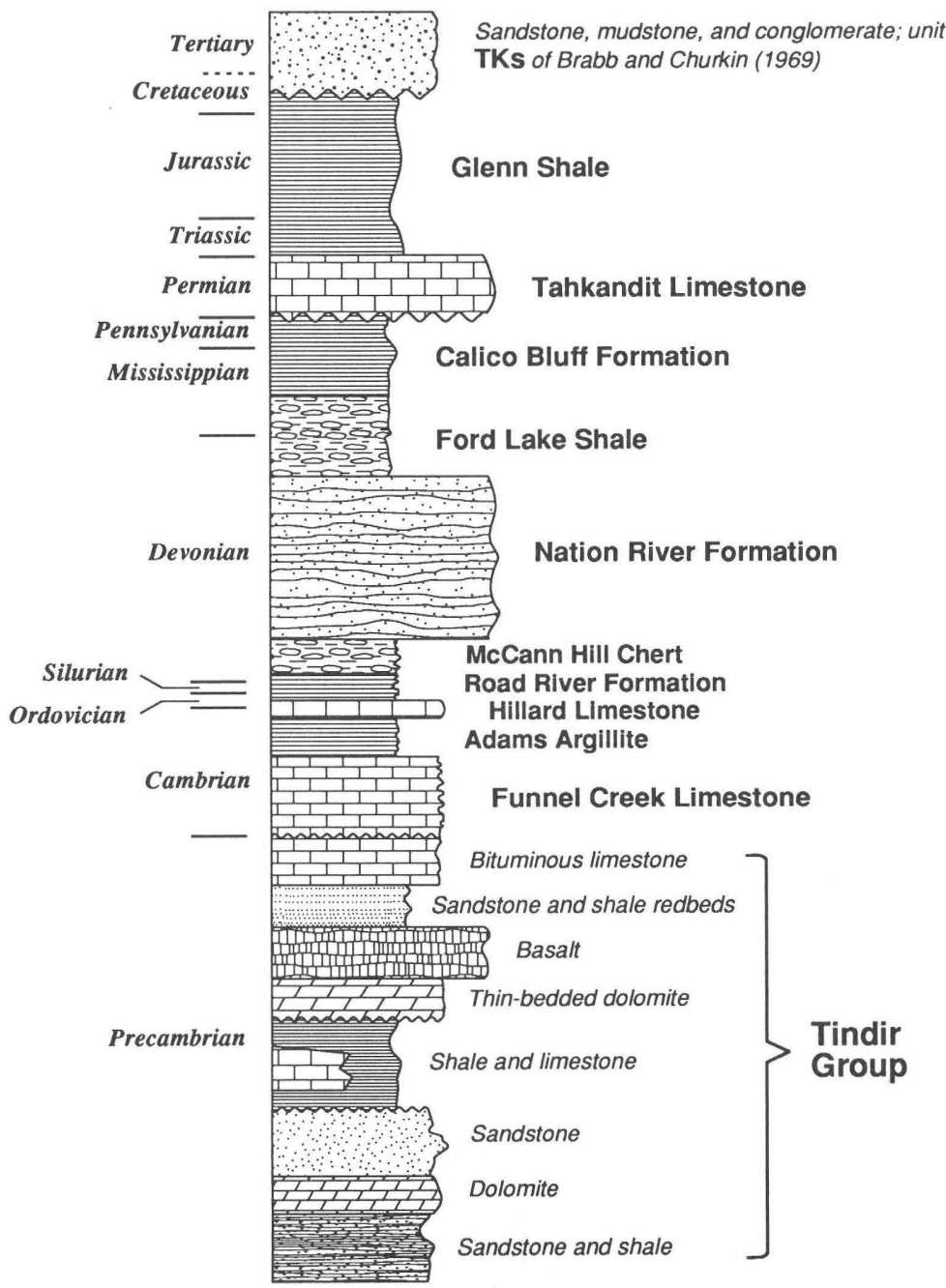

B Kandik River terrane

Figure 2. Schematic stratigraphic sections. A, Tatonduk terrane; B, Kandik River terrane. Modified from Brabb and Churkin (1969).

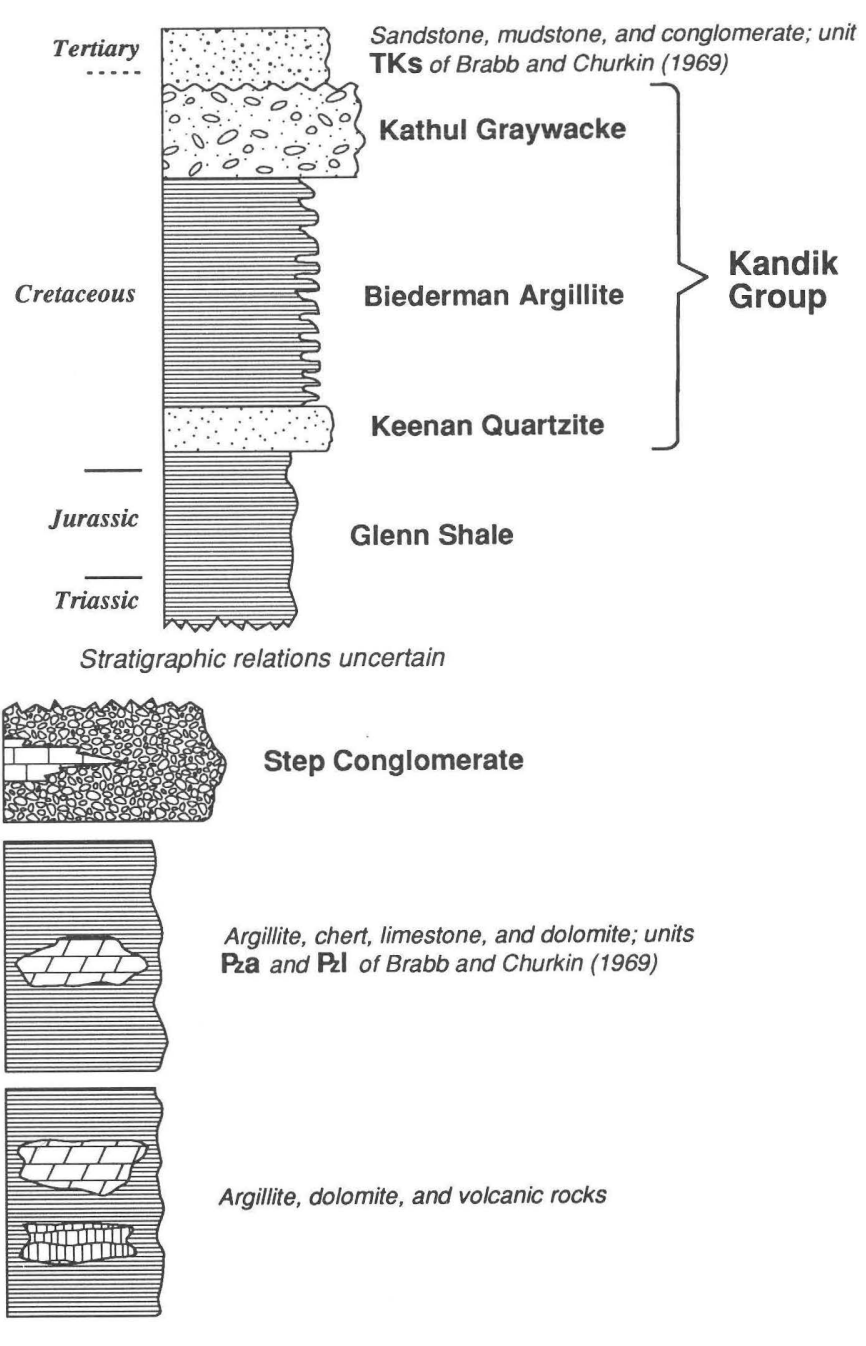

Precambrian

Paleozoic

ge relations uncertain 
River Formation, and McCann Hill Chert. Chert and shale characterize the lower and upper parts of the Devonian section, but cherty sedimentation was interrupted in the middle part of the Devonian section by a thick sequence of submarine-fan turbidities known as the Nation River Formation. Cherts and shales in the upper part of the Devonian section (Ford Lake Shale) give way to the calcareous turbidites of the Mississippian and Pennsylvanian Calico Bluff Formation. The Permian Tahkandit Limestone unconformably overlies the older units, recording tectonic uplift and a marked shallowing in water depth, as indicated by Zoophycos and large-scale crossbed structures. The Middle Triassic to Lower Cretaceous Glenn Shale conformably overlies the Tahkandit Limestone.

Although the Paleozoic section of the Kandik River terrane is poorly understood, it is different than the Tatonduk terrane in a number of ways (fig. $2 B$ ). First, the thick Precambrian red-bed sequence of the Tatonduk terrane appears to be entirely missing from the Kandik River terrane. Second, no Paleozoic subsiding continental-margin sequence analogous to that of the Tatonduk terrane has been demonstrated from the Kandik River terrane. Finally, the Permian of the Kandik River terrane is characterized by a thick quartz-pebble conglomerate (Step Conglomerate) rather than massive bioclastic limestones (Tahkandit Limestone) as in the Tatonduk terrane. The local presence of carbonate horizons within the Step Conglomerate indicates shallow-marine conditions and may, however, suggest some linkage to the Tahkandit Limestone.

The stratigraphic differences and the thrust contact between the Kandik River and Tatonduk terranes suggest that these two terranes are allochthonous with respect to each other, but the extent of slip between the two terranes is not known. The oldest unit common to both terranes is the Middle Triassic to Lower Cretaceous Glenn Shale; however, Lower Cretaceous shales lithologically similar to the Glenn Shale are common throughout the region (North Slope, Canadian Arctic Islands, Yukon Territory). These shales thus have regional paleoenvironmental significance in addition to being evidence of local outcrop relations. We suspect some post-Early Cretaceous horizontal shortening within the Glenn Shale because the Glenn Creek fault lies within this unit. In the Kandik River terrane, the Glenn Shale is overlain by the Kandik Group, a series of coarser clastic rocks consisting of the Valanginian Keenan Quartzite, the Lower Cretaceous Biederman Argillite, and the Aptian(?) Kathul Graywacke.

The youngest unit in the Kandik region is the Upper Cretaceous to Pliocene(?) sandstone, mudstone, and conglomerate unit of Brabb and Churkin (1969) (TKs). This unit unconformably overlies older sedimentary rocks in both the Kandik River and Tatonduk terranes.

\section{STRUCTURE}

The geologic map (scale 1:250,000) of the Charley River quadrangle by Brabb and Churkin (1969) accurately portrays the overall distribution of rock types over most of the Kandik area. A more recent interpretation by Dover and Miyoka (1988) portrays this area as a fold-and-thrust belt. Although we harbor some doubts regarding the number of thrust faults identified by these authors, we have relied heavily on this map, together with Foster's (1976) geologic map of the Eagle quadrangle, to establish a regional structural framework for our studies.

Across the Kandik region, thrusts and broad folds with shortening directions parallel to thrust vergence are well developed (Dover and Miyoka, 1988; figs. 3, 4). A major thrust, the Glenn Creek fault, separates the Paleozoic strata of the Kandik River and Tatonduk terranes. Because of the contrasts between the oceanic and continental rocks of the Tozitna and Kandik River terranes, we infer that a terrane-boundary thrust separates these two terranes as well. However, because of poor exposures in the northwestern portion of the study area, the location and nature of this thrust remain poorly understood. The Mardow Creek fault, another southeast-verging thrust, brings Paleozoic rocks of the Kandik River terrane to the surface in the west part of the Kandik region. Cretaceous rocks of the Kandik River terrane (Kandik Group) are folded into the Kandik Mountain syncline, a broad synclinorium with smaller anticlines and synclines developed on both limbs. A complementary antiform, the Michigan Creek anticline, similarly folds Precambrian and Paleozoic rocks of the Tatonduk terrane (figs. 3,4 ).

During our 1990 reconnaissance survey we located 12 sites that provided small-scale kinematic indicators, including $\mathrm{C}$ and $\mathrm{S}$ planes; conjugate planes with riedel shears; fault surfaces with calcite-filled tension cracks; and small-scale duplexes, locally with attendant faultbend folds. Kinematic indicators collected far from the Tintina fault yield two principal directions for $\sigma_{1}$ : either northeast-southwest or northwest-southeast. The latter direction is orthogonal to the strike of local faults and bedding and is, accordingly, the logical solution for thrusts and folds that verge toward the southeast. These data seem to be representative of the local stress field. The meaning of the northeast-southwest principal-stress orientation is less obvious. Norris (1985) and Dover (1985) both pointed out that the Kandik region is the possible site of an oroclinal bend in the northern Cordilleran fold-and-thrust belt, suggesting that the Brooks Range and the northwestern Canadian Cordillera may be structurally correlative and in some fashion linked kinematically. The northeast-southwest principal-stress orientation we observe in the Kandik region may, then, 
reflect the folding of the northwestern Cordillera into a regional Z-shaped pattern. The upper limb of the "Z," the northern Brooks Range, is linked to the lower limb, defined by the east-west-trending Dawson and related thrusts, by the southwest-northeast-trending thrusts in the Kandik region (fig. 1). This hypothesis suggests a large amount of clockwise rotation for the Kandik region. Halgedahl and Jarrard (1987) have demonstrated that the North Slope and Brooks Range underwent $66^{\circ}$ of counterclockwise rotation in the Cretaceous, but possible crustal rotations in the Kandik region are, at present, unconstrained.

On a more local scale, however, the northeastsouthwest-trending structures clearly are rotated $40-50^{\circ}$ clockwise as drag features along the north side of the Tintina fault (fig. 3). Many of the kinematic indicators collected just north of the Tintina fault yield north-south principal-stress orientations, thus maintaining $\sigma_{1}$ orthog- onal to the local structures and bedding. These relations seem to indicate that the latest phase of right-slip on the Tintina postdates the convergent tectonics of the Kandik area. Similarly, kinematic indicators within unit TKs of Brabb and Churkin (1969), show principal-stress orientations that cut the fault at $30-40^{\circ}$ angles. This observation, together with the occurrence of drag folds within unit TKs, indicates faulting on the Tintina that is younger than unit TKs.

An interesting exposure of Paleozoic rocks in the Step Mountain area (figs. 3,4) is critical to our interpretation of structural relations between the Tatonduk and Kandik River terranes. These rocks, exposed along the crest of a tight doubly plunging anticline, include two massive chert-pebble conglomerates separated by a black shale. Brabb and Churkin (1969) mapped the structure as a simple anticline that exposed the Nation River Formation, Ford Lake Shale, and Step Conglomerate (fig. 5A).

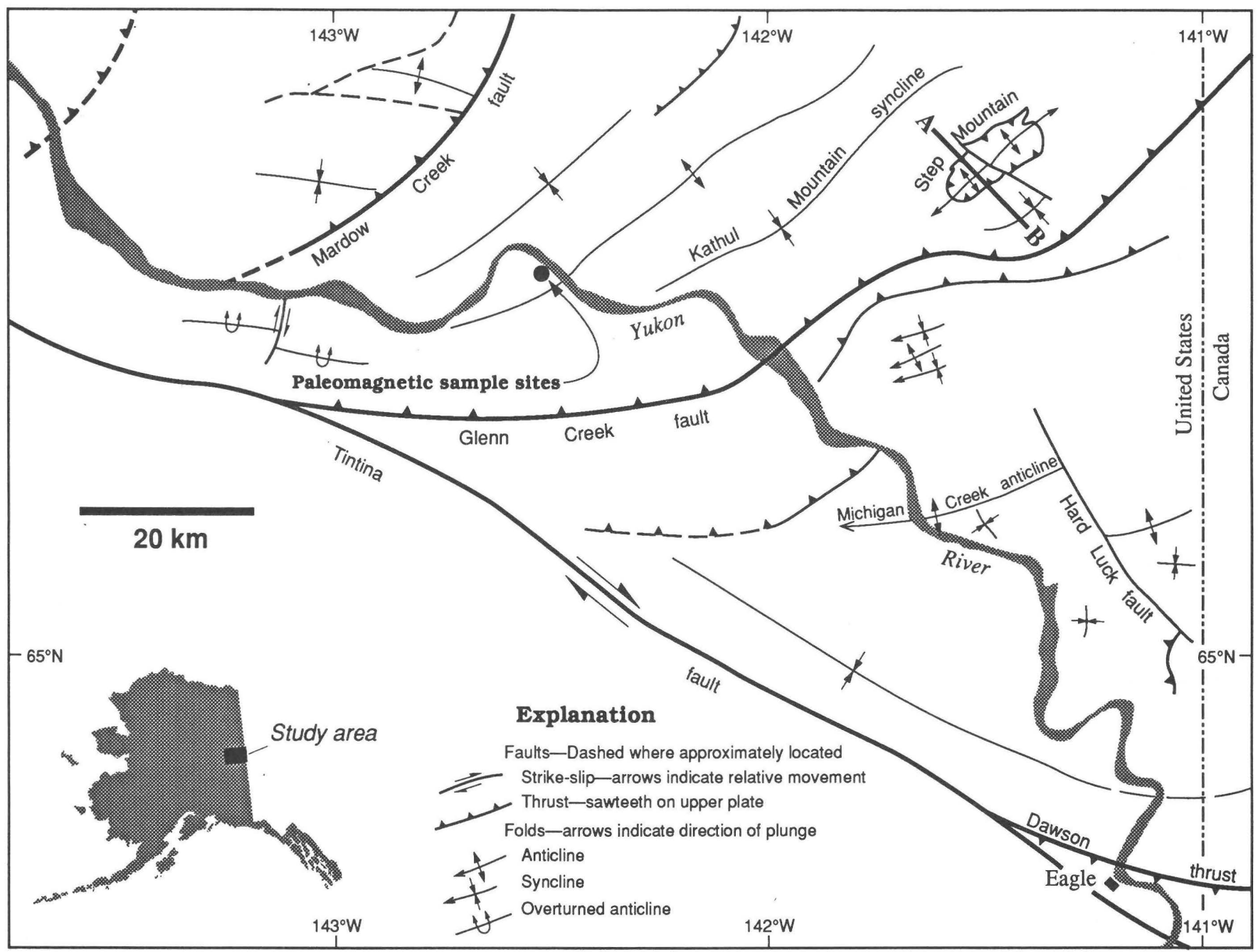

Figure 3. Generalized structural map for Kandik region. Two stratigraphic sections sampled for paleomagnetism are indicated. Location of structure section shown in figure 5 is indicated by line A-B. Map modified from Brabb and Churkin (1969). 
However, no facies of the Nation River Formation exposed in the Tatonduk terrane resembles the conglomeratic facies exposed at Step Mountain. Furthermore, the two conglomerates at Step Mountain are nearly indistinguishable, although no limestone interbeds were observed in the lower conglomerate. Nevertheless, the two conglomerates could well belong to the same depositional unit. We hypothesize that the two conglomerates both belong to the Step Conglomerate, that the intervening shale is unit Pza of Brabb and Churkin (1969), and that the unit Pza-Step Conglomerate section is repeated at Step Mountain by a duplex structure. Thus, we do not believe that the Step Mountain anticline represents a portion of the Tatonduk terrane, exposed in a structural window through the overlying Kandik River terrane, as suggested by Brabb and Churkin (1969) (fig. $5 A$ ). Two alternative structural configurations are possible (fig. $5 B, C$ ). First, the Step Mountain anticline may expose Paleozoic strata of the Kandik River terrane, repeated by a duplex structure, lying conformably beneath the Mesozoic turbidites exposed east and west of Step Mountain (fig. 5B). Alternatively, the Paleozoic rocks at Step Mountain may represent a klippe, itself containing a duplex structure, that happens to rest near the crest of an anticline in the Mesozoic rocks; the presence of conformably underlying Paleozoic strata is unsubstantiated (fig. 5C). The latter configuration (klippe) would suggest less tectonic burial for these strata than the former. Preliminary paleothermal data obtained from samples collected during the 1990 field season are equivocal; vitrinite-reflectance values of 2.7-3.9 percent are only slightly higher than those obtained from nearby Mesozoic rocks of the Kandik River terrane.

\section{SEDIMENTOLOGY AND SANDSTONE PETROLOGY}

Although age and stratigraphic controls in the Lower Cretaceous Kandik Group are sketchy, these rocks clearly record a major increase in sedimentation rate compared with that of the Glenn Shale. This increase in sedimentation rate, coupled with a concomitant increase in grain size, suggests that the Kandik Group records a major tectonic event. In order to understand the timing and nature of this event, we have examined the compositions of 23 sandstones in the Kandik Group. Although our results are reconnaissance in nature,

\section{$<$ terrane $\rightarrow$ Kandik River terrane $\longrightarrow<$ Tatonduk terrane $\rightarrow$}
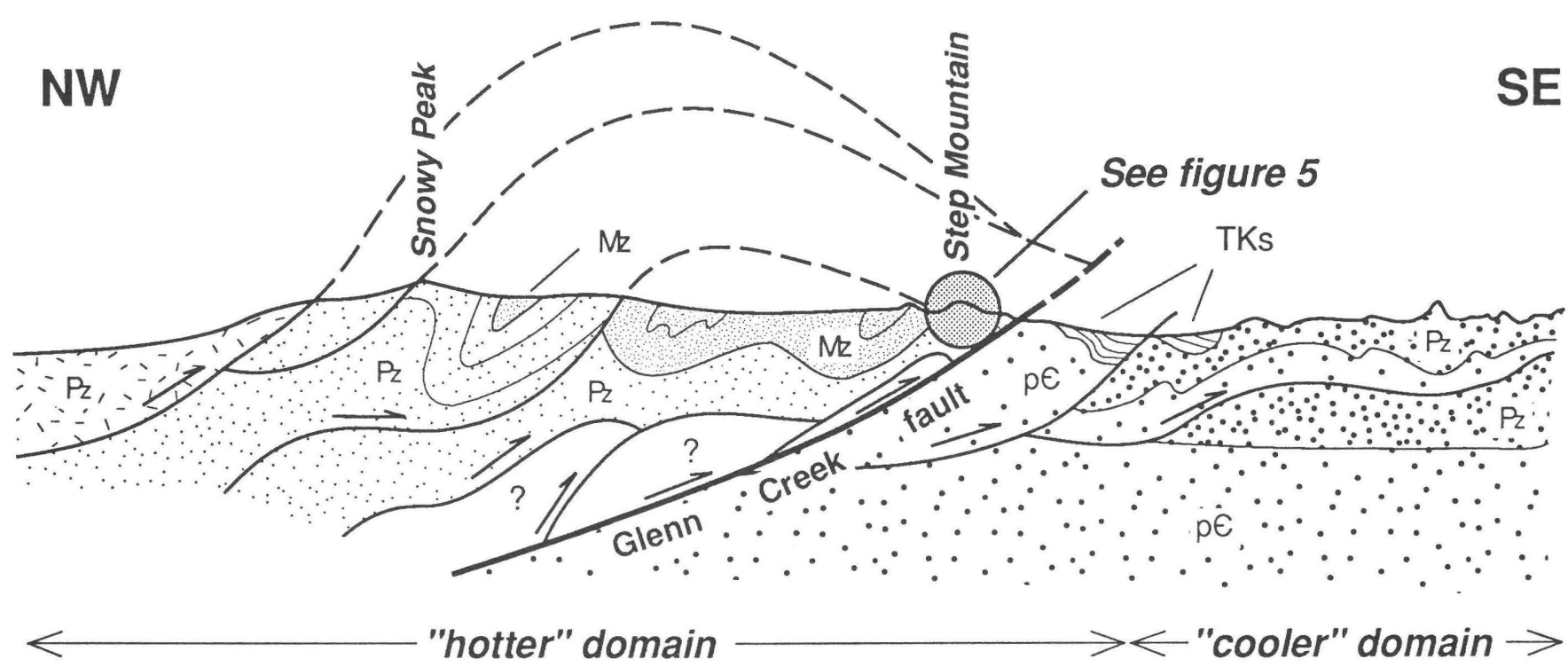

"cooler" domain $\rightarrow$

\section{$15 \mathrm{~km}$}

\section{Vertical exaggeration $\sim 3 x$}

Figure 4. Generalized structure section through Kandik region. Map unit symbols: TKs, Cretaceous and Tertiary sandstone, mudstone, and conglomerate unit of Brabb and Churkin (1969); p- , Precambrian rocks; Pz, Paleozoic rocks; Mz, Mesozoic rocks. Contact, thin line; fault, bold line, dashed where projected, arrows indicate direction of relative movement. 
enough is now known to reveal clear variations in provenance over time. Additional samples, collected in several measured sections, will be examined in the future to better constrain stratigraphic variations in sandstone composition.

Sandstones are abundant in the Kandik Group, although only in the Keenan Quartzite is sandstone the dominant lithology. Turbidites in the Biederman Argillite are generally fine grained and usually contain material no coarser than very fine or fine-grained sandstone. In contrast, the Kathul Graywacke dominantly consists of fineto medium-grained conglomerates and rarely contains lithologies finer than coarse-grained sandstone. Despite these interformational variations in grain size, an attempt was made to collect medium-grained sands wherever

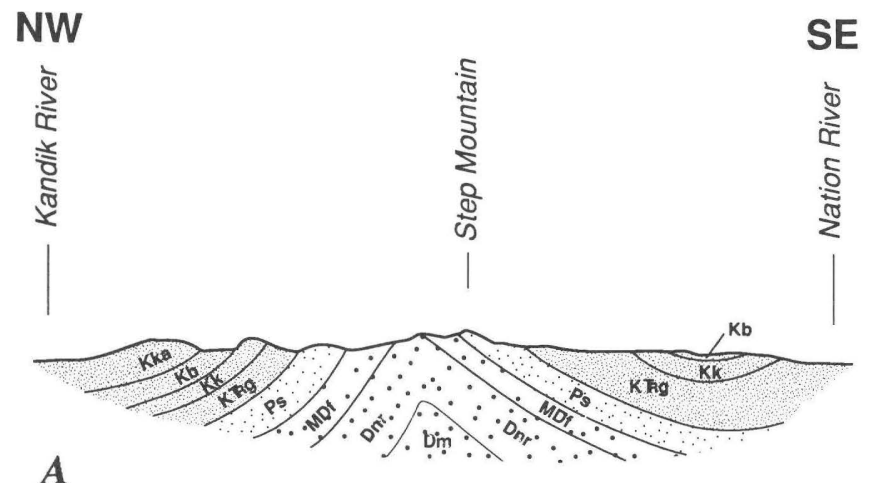

$\boldsymbol{A}$
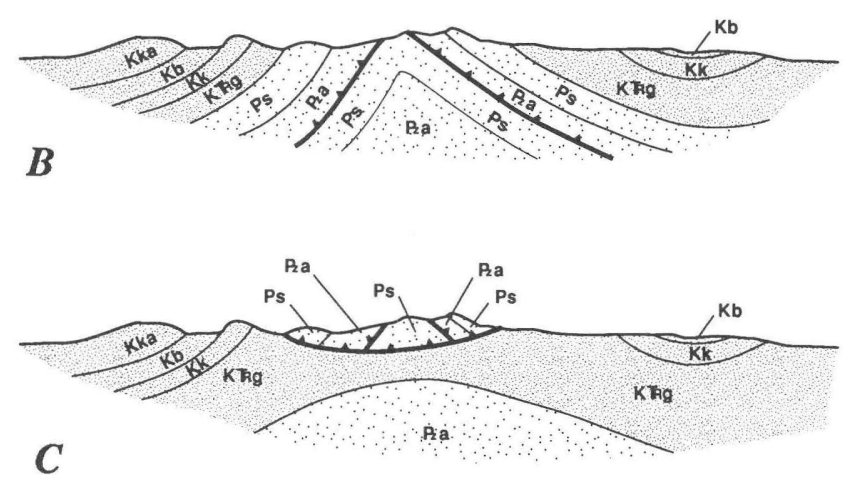

Explanation

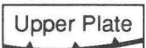

Lower Plate

Figure 5. Possible structure sections through Step Mountain region. A, From Brabb and Churkin (1969); $B$ and $C$, two possible configurations if Nation River Formation and Step Conglomerate are equivalent at this locality. Map-unit symbols: Dm, Devonian McCann Hill Chert; Dnr, Devonian Nation River Formation; MDf, Devonian and Mississippian Ford Lake Shale; Ps, Permian Step Conglomerate; KFg, Triassic to Cretaceous Glenn Shale; Kk, Cretaceous Keenan Quartzite; $\mathrm{Kb}$, Cretaceous Biederman Argillite; Kka, Cretaceous Kathul Graywacke; Pza, Paleozoic argillite of the Kandik River terrane. See figure 3 for location of section. possible in order to normalize for composition-grain-size dependency (Füchtbauer, 1964; Boggs, 1968; Ingersoll and others, 1984; Pettijohn and others, 1987) and to facilitate comparison of our data with those of other workers. While no point-counting technique can correct for actual variations of monomineralic grains with grain size (Ingersoll and others, 1984; Decker and Helmold, 1985), the Gazzi-Dickinson method of point-counting (Gazzi, 1966; Gazzi and Zuffa, 1970; Dickinson, 1970), by assuming that polycrystalline components will disaggregate into constituent grains, provides improved clustering of data obtained from sandstones of diverse grain size (Ingersoll and others, 1984). Accordingly, these techniques were followed in the classification of grain types. Sandstone thin sections were stained for both potassium feldspar and plagioclase, and the modal abundance of framework grains was determined by point counting at least 300 grains per sample. This was done "blind" (sample numbers covered). Forty-nine categories of framework grains were distinguished, and tallies were kept of matrix, cement, replacement minerals, and porosity.

The tranquil deposition that characterized Late Triassic to Early Cretaceous time in the Kandik region was interrupted in Valanginian time by a sudden pulse of coarse clastic material recorded by the deposition of the Keenan Quartzite. Compositionally, this unit is an exceptionally pure quartz arenite (fig. 6). The lack of polycyclic quartz overgrowths or sedimentary lithic fragments suggests a first-cycle origin. The unit is for the most part massive, but occasional meter-scale crossbedding and the occurrence of Buchia together suggest a shallow-marine origin.

The Keenan Quartzite is conformably and gradationally overlain by the Biederman Argillite. This unit, 1,500 to at least $2,500 \mathrm{~m}$ in thickness, consists almost entirely of fine-grained turbidites (mostly Bouma divisions $T_{\text {ce }}$ and $T_{\text {ace }}$ ) of Mutti/Ricci-Lucchi facies C and D. We interpret this sequence to represent submarine-fan or related mass-flow deposits, implying an increase both in water depth and in distance from the source regions as compared with the Keenan Quartzite. Fine-grained sandstones from the turbidites are quartz wackes near the base of the section but become more feldspathic upsection (fig. 7). The uppermost part of the Biederman, less than $100 \mathrm{~m}$ below the contact with the Kathul Graywacke, is a volcanic litharenite consisting primarily of basaltic material; this volcanic debris records a major change in provenance. Sedimentary lithic fragments, abundant in a few samples (fig. 7), probably represent an intrabasinal source. Scattered paleocurrent data from the Biederman Argillite are fairly consistent, indicating paleocurrents flowing toward the north-northeast (Howell and Wiley, 1987). Because of structural complexities, we are unable to define any variation in paleocurrent direction with stratigraphic position. 
The Kathul Graywacke conformably overlies the Biederman Argillite. The variation in composition is gradational, but increases in grain size and in the pro-
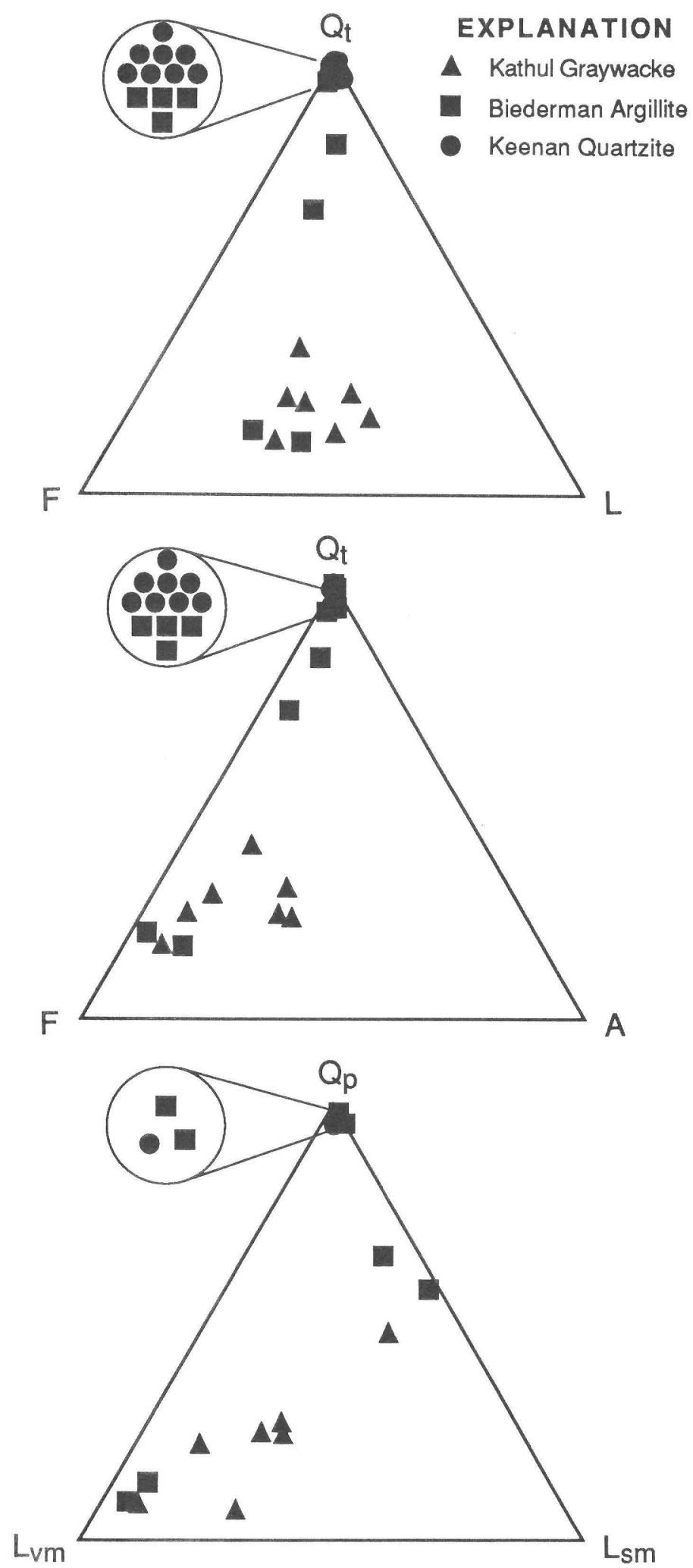

portion of channel facies are abrupt. The Kathul Graywacke is made up primarily of very coarse grained sandstone and fine-grained conglomerate. Paleocurrent directions are scattered but generally reflect flow toward the east (Howell and Wiley, 1987). The basal part of the Kathul Graywacke consists of volcanic litharenites containing basaltic detritus of probable oceanic affinity. Higher in the section, metasedimentary lithic fragments become abundant and the proportion of quartz increases (fig. 7). Polycrystalline quartz with metamorphic textures is abundant in the stratigraphically highest samples.

Thus, sandstones of the Kandik Group record major changes in provenance. These changes can be conveniently summarized by the feldspar/feldspar+quartz and volcanic lithic fragment/total lithic fragment ratios, both of which provide an index of "oceanic" to "continental" sources (fig. 7). The sands of the Keenan Quartzite and the basal part of the Biederman Argillite clearly were derived from a continental source. The compositional maturity and apparent first-cycle origin of these sandstones are consistent with their derivation from a tectonically quiescent continental setting in which pronounced chemical weathering and a high-energy mechanical breakdown have destroyed most unstable components. The upper part of the Biederman, however, records a shift to an oceanic volcanic source. Because our stratigraphic control is at present poor, it is unclear whether this shift was abrupt or gradual. The oceanic volcanic source remained important throughout the deposition of the Kathul Graywacke, but a continental orogenic source, reflected by metasedimentary and quartzose detritus, became important in the uppermost part of the section (fig. 7).

\section{THERMAL MATURITY}

The Mesozoic rocks of the Kandik River terrane display an intriguing paleothermal anomaly when compared with the older strata of the Tatonduk terrane (Underwood and others, 1989; Laughland and others, 1990). Samples collected in 1986 were analyzed for both vitrinite reflectance and illite crystallinity, and the results indicate a pronounced contrast in thermal history between these two terranes (fig. 8). Interestingly, the Lower Cre-

Figure 6. Ternary diagrams showing compositions of sandstones of Lower Cretaceous Kandik Group from preliminary point-counting data. $Q_{t}$, mono- and polycrystalline quartz; $Q_{p}$ polycrystalline quartz; $F$, feldspar; $A$, monomineralic "accessory minerals"; L, polymineralic (lithic fragments); $L_{v m}$, volcanic and metavolcanic lithic fragments; $\mathrm{L}_{\text {sm }}$, sedimentary and metasedimentary lithic fragments. Data collected under Gazzi-Dickinson conventions (Gazzi, 1966; Gazzi and Zuffa, 1970; Dickinson, 1970). 
taceous strata of the Kandik Group (exposed west of the Glenn Creek fault) are demonstrably more thermally altered than older strata of the Tatonduk terrare exposed to the east of the fault. The boundary between relatively unaltered rocks $\left(R_{\mathrm{o}}=0.3-1.6\right.$ percent $)$ and rocks that have been highly thermally altered $\left(R_{0}=1.6-5.0\right.$ percent) does not correspond precisely to the Glenn Creek fault but, rather, lies southeast of and parallel to the fault, approximately $10 \mathrm{~km}$ within the Tatonduk terrane. The presence of highly thermally altered rocks on either side of the Glenn Creek fault indicates that the thermal event responsible for the higher paleotemperatures was not restricted to the Kandik River terrane but occurred in both the Kandik River and Tatonduk terranes after their juxtaposition along the Glenn Creek fault.

An extensive suite of samples was collected during the 1990 field season to corroborate and refine the preliminary results. The samples, like those collected during the reconnaissance survey, are being analyzed for vitrinite reflectance and illite crystallinity. Mica rotational polymorphs and $b$-axis spacing will be determined as well. In addition, numerous quartz and calcite veins will be analyzed for fluid-inclusion homogenization temperatures and light-stable isotopic data in an effort to understand the role of circulating fluids in determining the distribution of paleotemperatures.

The difference in average paleotemperature between the rocks that lie east of and less than $10 \mathrm{~km}$ west of the Glenn Creek fault and those for the remainder of the Tatonduk terrane is as much as $130^{\circ} \mathrm{C}$ (Underwood and others, 1989; Laughland and others, 1990). The younger rocks (Kandik Group) display the highest levels of thermal alteration, as do Paleozoic rocks of the Tatonduk terrane that lie within $\sim 10 \mathrm{~km}$ of (and structurally below) the Glenn Creek fault. In the immediate vicinity of the Glenn Creek fault, Mesozoic rocks are highly altered. Well-developed slaty cleavage is restricted to the Kandik River terrane. Locally the rocks are schistose or have a pronounced slaty cleavage and are cut by numerous veins aligned roughly perpendicular to cleavage.

If one assumes an average thermal gradient of 30 ${ }^{\circ} \mathrm{C} / \mathrm{km}$, then the average thermal maturity of strata from the Tatonduk terrane $\left(R_{\mathrm{o}} \sim 1.0\right.$ percent) requires burial to a depth of 3-5 km, depending on which method is used to calculate paleotemperatures [see Laughland and others (1990) or Sweeney and Burnham (1990)]. This figure is roughly consistent with the thickness of Mesozoic strata in the Kandik River terrane. Thus, burial beneath foreland-basin deposits of the Kandik Group would account for the degree of thermal alteration of the Paleozoic strata of the Tatonduk terrane. The level of thermal alteration displayed by the Kandik Group itself is more difficult to explain. Assuming an average thermal gradient of $30^{\circ} \mathrm{C} / \mathrm{km}$, burial beneath as much as $10 \mathrm{~km}$ of strata is required to explain the vitrinite-reflectance $\left(R_{\mathrm{o}}=\right.$ 1.6 -4.2 percent) and illite-crystallinity data. Post-mid-
Kathul Graywacke

Biederman Argillite

Keenan Quartzite
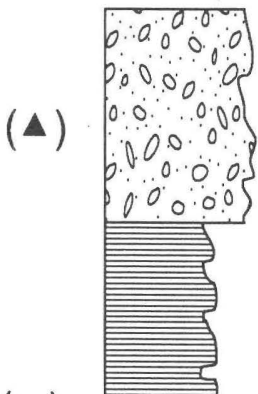

(घ)

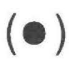

$F /(Q+F)$

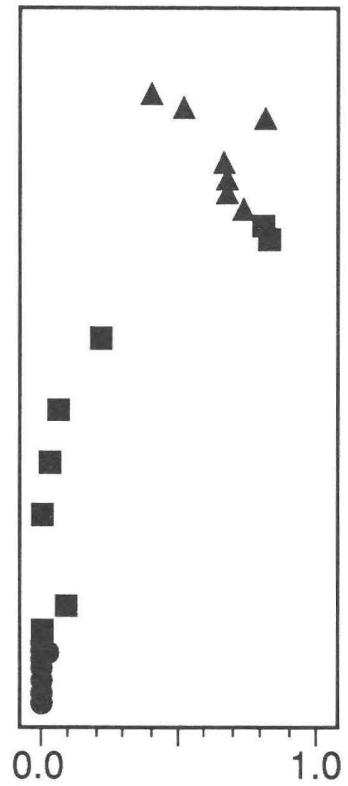

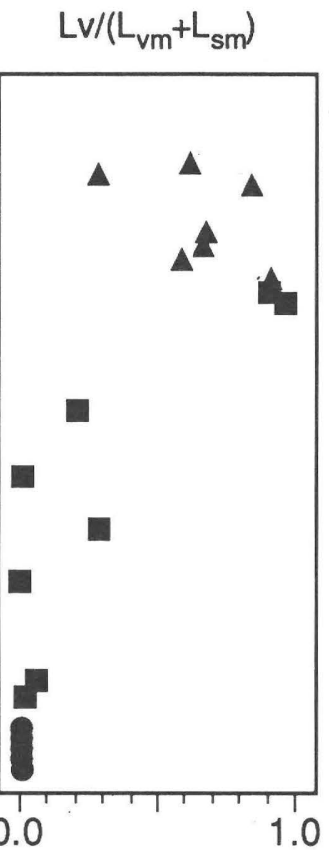

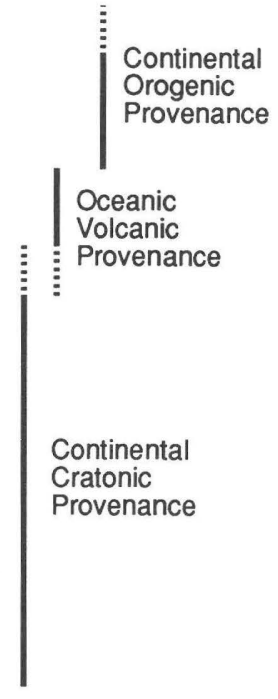

Continental

Cratonic

Provenance

Figure 7. Stratigraphic variation in ratios of (left) feldspar (F) to quartz+feldspar (Q+F) and of (right) volcanic lithic fragments (Lv) to volcanic+metavolcanic+sedimentary+metasedimentary lithic fragments $\left(\mathrm{L}_{\mathrm{vm}}+\mathrm{L}_{\mathrm{sm}}\right)$ in sandstones of Lower Cretaceous Kandik Group. Data collected under Gazzi-Dickinson conventions (Gazzi, 1966; Gazzi and Zuffa, 1970; Dickinson, 1970). 

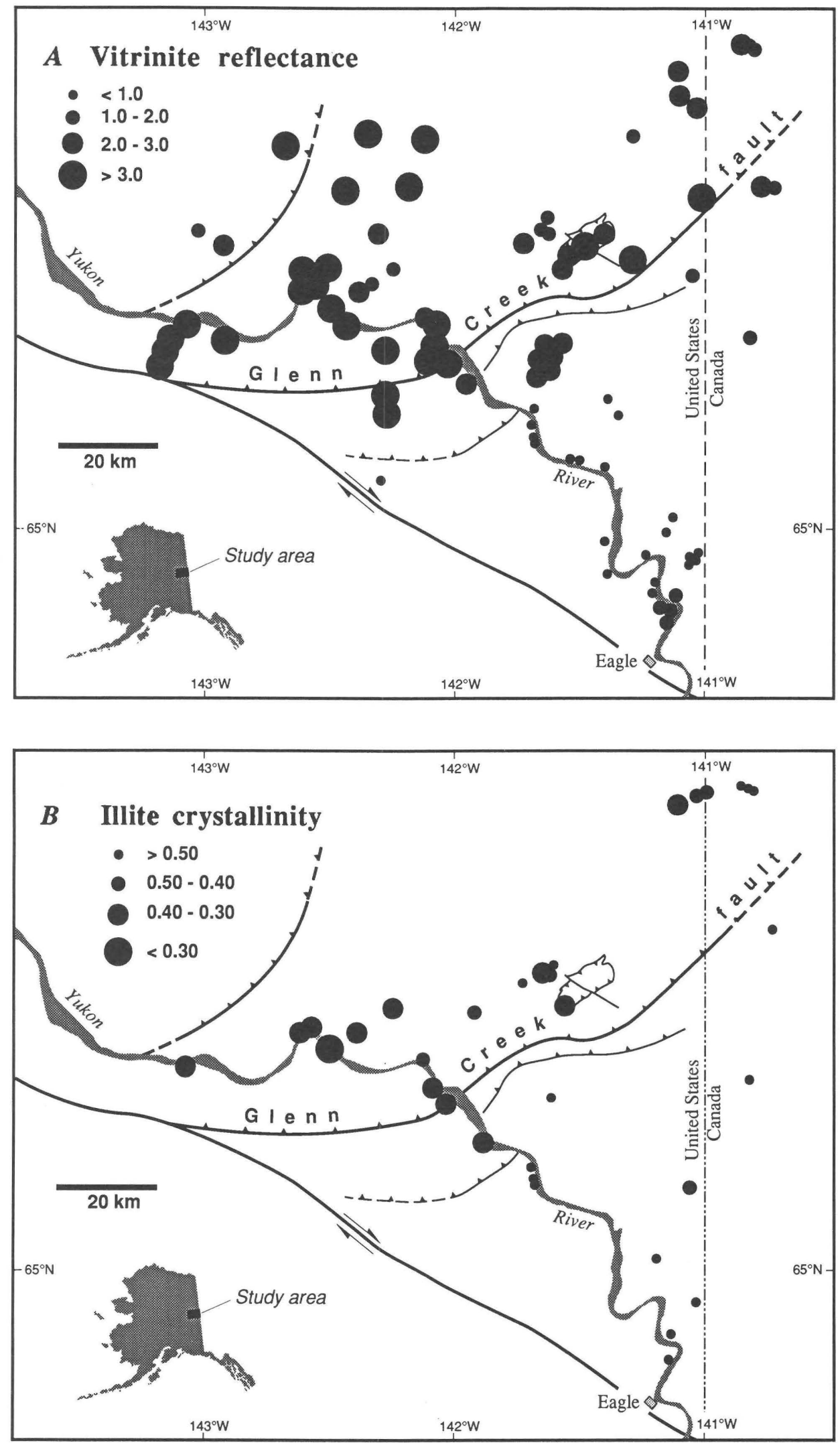

Figure 8. Thermal-maturity data from the Kandik region. $A$, Mean random vitrinite reflectance (percent $R_{\mathrm{m}}$ ); $B$, illite crystallinity index $\left(\Delta^{\circ} 2 \Theta\right)$. Size of symbol corresponds to level of thermal maturity at each sample locality. See figure 3 for explanation of geologic symbols. 
Cretaceous strata of this thickness, restricted to the Kandik River terrane, are possible but unlikely. Alternatively, some form of tectonic burial may be responsible for the thermal alteration of the Mesozoic strata of the Kandik River terrane. The depth of burial may be less than the putative $10 \mathrm{~km}$ if hot fluids, expunged from the thrust sheets, circulated through the Mesozoic foreland deposits and thereby raised the heat flux by means of advection. The pervasive regional alteration of these deposits (calcite replacement, sericitization, and veining) indicates that fluids have certainly permeated these rocks. Future research will quantify the role of fluids in affecting the thermal structure of the Kandik region.

\section{PALEOMAGNETISM}

The natural remanent magnetization (NRM) of sedimentary rocks can serve as a useful marker for determining rotations of large crustal blocks, provided that the magnetization was acquired during deposition. Throughout Alaska, however, the NRM of Mesozoic and older rocks is typically dominated by late-stage magnetizations acquired after deep burial and deformation of the strata. Our pilot paleomagnetic study of the Cretaceous Biederman Argillite in the Kandik region proved to be no exception. During 1986, samples for paleomagnetic study were collected from two well-exposed sections of the Biederman Argillite near the confluence of the Yukon and Kandik Rivers. The sampled unit consists of black shale and fine-grained sandstone with rhythmic interbedding typical of turbidites. The sampled stratigraphic sections, 130- and 35-m-thick, respectively, are located in the northeast-trending structural trough between the Kathul Mountain syncline and the Mardow Creek fault (fig. 3). Although the majority of samples in our preliminary study were not given standard demagnetization treatments to remove unstable components of magnetization, 12 specimens were treated in alternating fields to $1,000 \mathrm{G}$. In each case, the demagnetization experiments revealed a single component of magnetization with high coercivity of remanence. Analysis of the pilot demagnetizations suggests that the mean directions of NRM reported here for the Biederman Argillite would not be changed appreciably by extending demagnetization treatments to the entire collection. At both localities, the NRM was typically $2 \times 10^{-6} \mathrm{emu} / \mathrm{cm}^{3}$ and gave tightly clustered directions. Although the structural attitudes of the two sections differ by $7^{\circ}$ in dip and $27^{\circ}$ in strike, the mean directions of NRM (not corrected for bedding tilt) are nearly identical $\left(I=82.7^{\circ}, D=311.7^{\circ}\right.$, $\alpha_{95}=3.0^{\circ}, 25$ specimens; and $I=77.8^{\circ}, D=317.3^{\circ}, \alpha_{95}$ $=4.0^{\circ}, 25$ specimens). Applications of tilt corrections cause the mean directions of NRM from the two sites to diverge significantly, indicating that the magnetization was acquired after the strata were folded. Transforming the site-mean directions of NRM to paleomagnetic poles yields results of $71.7^{\circ} \mathrm{N} ., 180.9^{\circ} \mathrm{E}$. and $72.9^{\circ} \mathrm{N} ., 150.9^{\circ}$ E., respectively. These paleomagnetic poles lie within a few degrees of Late Cretaceous and Paleocene poles from cratonic North America. Of course, this age assignment for the overprinting magnetization of the Biederman Argillite is not valid if the strata have undergone any deformation after the magnetization was locked in.

\section{TECTONIC EVOLUTION OF THE KANDIK REGION-A WORKING MODEL}

The foregoing structural, paleothermal, and sedimentologic data provide sufficient constraints to construct a speculative geodynamic model for the Kandik region. The setting that we envision is analogous to the Brooks Range orogeny-that is, obduction of an ophiolite upon a continental margin followed by intracontinental shortening. Accordingly, the Cretaceous units of the Kandik River terrane may be grossly analogous to the Cretaceous foreland (Colville basin) of the North Slope.

The Glenn Shale, like the Shublik Formation and Kingak Shale of the North Slope, represents preorogenic, shallow-marine, passive-margin sedimentation along the northern margin of the North American continent. This setting experienced a sudden influx of quartzose sandstone in the Valanginian, represented by the Keenan Quartzite in the Kandik region and by the Tingmerkpuk subunit of the Ipewik unit, the Kuparuk Formation, and the slightly younger (Hauterivian) Kemik Sandstone in the North Slope. Paleomagnetic data from the North Slope, paleobathymetric data, and the age of oceanic crust in the Canada basin are consistent with the opening of the Canada basin through a $66^{\circ}$ counterclockwise rotation of the North Slope block away from the Canadian Arctic Islands some time during the interval 130-90 Ma (Eittreim and Grantz, 1979; Grantz and others, 1979; Halgedahl and Jarrard, 1987; Embry and Dixon, 1990). The Keenan Quartzite and turbidites of the lower part of the Biederman Argillite probably reflect the regional uplift of a deeply weathered continental source. The quartzose sandstones in northern Alaska may be erosional products of rift-margin uplift, whereas the quartzose sandstones from the Kandik region may represent shelf and slope facies of the same source. The exact paleogeographic relations of the Kandik region to the North Slope are, however, not known with certainty.

The upper part of the Biederman Argillite and the lower part of the Kathul Graywacke record a major shift in provenance to an oceanic volcanic source. Continuing the analogy with the Brookian orogeny, the Tozitna terrane may represent an obducted ophiolite analogous to the Angayucham terrane of central Alaska and the 
Brooks Range (Patton and others, 1989), and the Tozitna is the probable source for the mafic volcanic debris that characterizes these units of the Kandik Group. The timing of obduction and subsequent unroofing, however, was apparently somewhat later in the Kandik region than in the Brooks Range. With erosion of the thrust panels of the Tozitna terrane, we speculate that uplifted Paleozoic strata of the Kandik River terrane (unit Pza and the Step Conglomerate) were exposed, providing sedimentary and metasedimentary sources for the upper part of the Kathul Graywacke. The Kathul Graywacke would then be analogous to the Aptian to Albian Fortress Mountain Formation of the North Slope (see Howell and others, 1991). Hence, deposition of the upper part of the Biederman Argillite and the Kathul Graywacke records the time of continental intraplate thickening marginal to a foreland-basin setting (fig. 9A). Paleocurrent data from the Kathul Graywacke (flow toward the east-southeast in present coordinates) are consistent with a such an interpretation.

The thrust sheets advanced toward the southeast in the present reference frame. In order to account for the elevated temperatures that affected these foreland deposits, we suggest that eastward-advancing nappes tectonically buried the northwestern part of the recently deposited foreland basin (fig. 9B). These same nappes covered parts of the Tatonduk terrane proximal to the Glenn Creek fault, explaining the high thermal maturity of those rocks as compared with the rest of the Tatonduk terrane (Laughland and others, 1990). The Paleozoic

\section{A Valanginian}

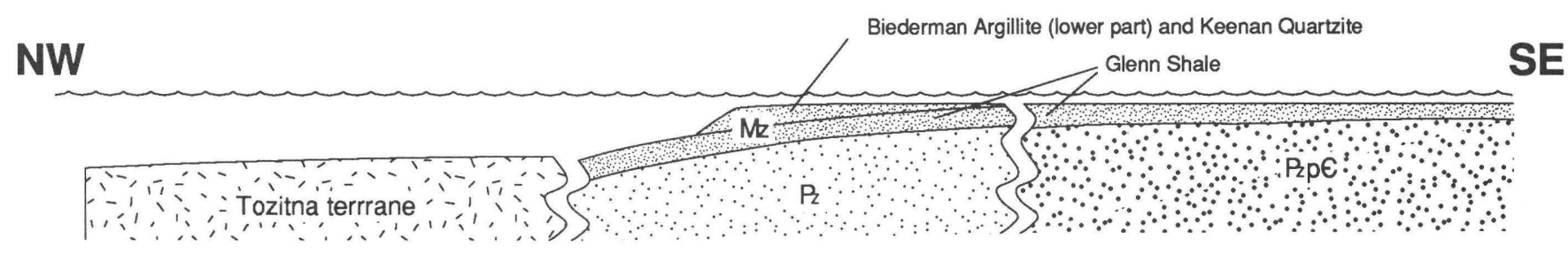

\section{$B$ Barremian to Aptian}

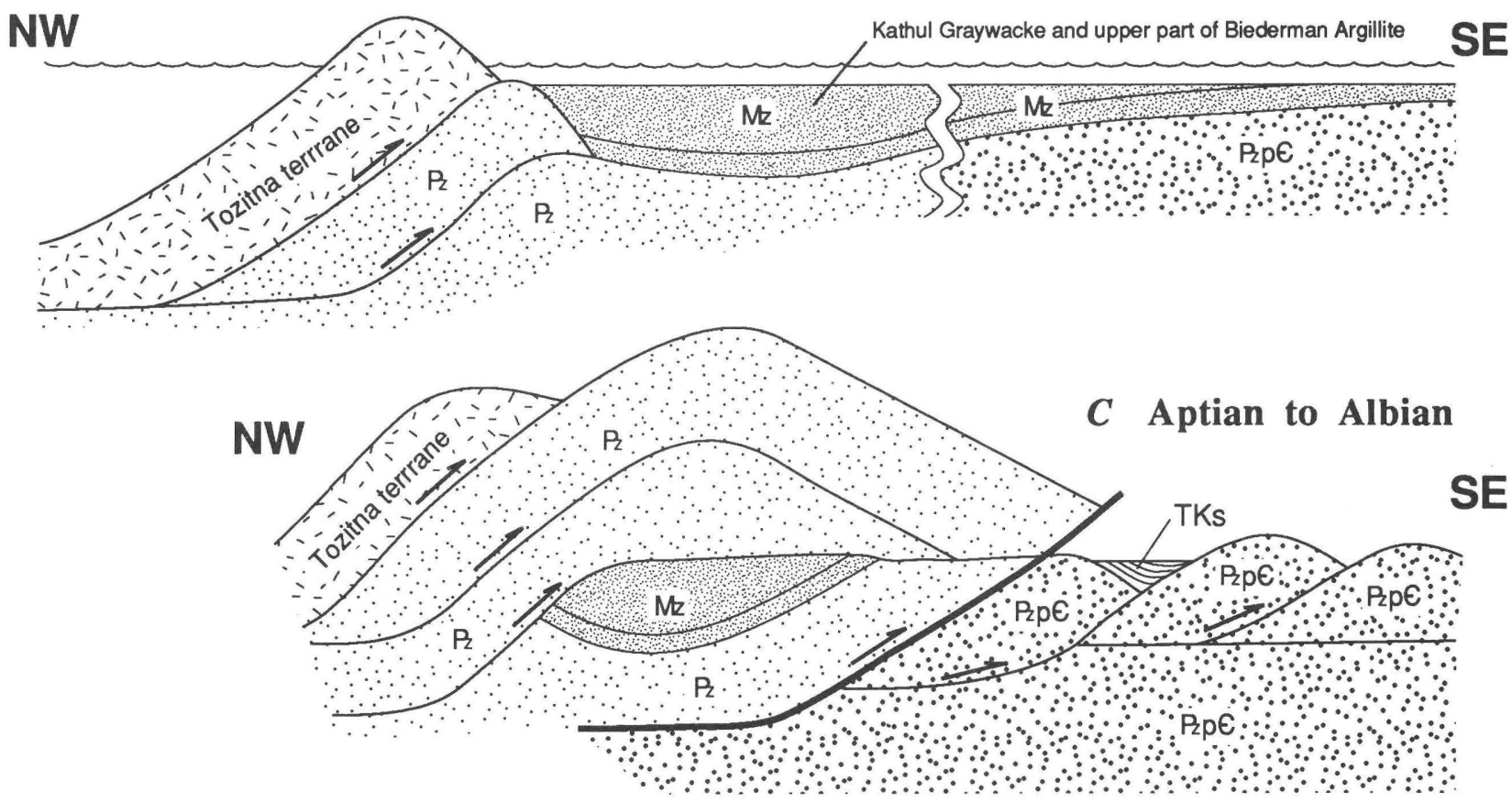

Figure 9. Schematic structure sections for Kandik region showing development of fold-and-thrust belt. $A$, Valanginian; $B$, Barremian to Aptian; C, Aptian to Albian. For present-day configuration, refer to figure 4. Map unit symbols: TKs, Cretaceous and Tertiary sandstone, mudstone, and conglomerate unit of Brabb and Churkin (1969); Pzpe, Precambrian to Paleozoic rocks; Pz, Paleozoic rocks; Mz, Mesozoic rocks. Arrows on faults indicate direction of relative movement. 
rocks at Step Mountain may be part of the nappes that root west of the Mesozoic outcrops (fig. 5C); alternatively, these rocks may represent a locally formed duplex structure within the Paleozoic "basement" of the Mesozoic strata (fig. 5B). In either case, unit TKs may represent nonmarine foreland-basin deposition resulting from further southeastward advance of the fold-and-thrust belt (fig. 9B). The magnetization overprinting the Biederman Argillite appears to have been acquired in the Late Cretaceous or Paleocene, making it approximately contemporaneous with deposition of unit TKs and near the time of maximum burial of the Biederman Argillite.

This model for the development of the Kandik region and northeastern Alaska is based on the structural, paleomagnetic, thermal, and sedimentologic data currently available. Refining the model as more such data become available and placing it in a regional framework relating to the opening of the Canada basin and the Brookian orogeny are the major goals of our continuing investigations in the region. Understanding the tectonic evolution of the Kandik region is key to developing an understanding of the relations between the Brooks Range/North Slope and the Canadian Cordillera and autochthonous North America.

Acknowledgments.-This project was supported, in part, by generous funding from ARCO Alaska and the Petroleum Research Fund. We thank all those who have accompanied us in the field, including S.Q. BoundySanders, T. Brocculeri, P.J. Coney, D.L. Jones, R.W. Murray, and T.J. Wiley. Much logistic assistance was provided in the field by the staff of the Yukon-Charley Rivers National Preserve and by ARCO Alaska. Vitrinite-reflectance data were provided by M.J. Pawlewicz and M.M. Laughland, and illite-crystallinity data were produced by M.M. Laughland. The ideas expressed here grew out of valuable discussions with K.J. Bird, M.M. Laughland, and T. Brocculeri.

\section{REFERENCES CITED}

Boggs, S., Jr., 1968, Experimental study of rock fragments: Journal of Sedimentary Petrology, v. 38, p. 1326-1339.

Brabb, E.E. and Churkin, M., Jr., 1969, Geologic map of the Charley River quadrangle, east-central Alaska, U.S. Geological Survey Miscellaneous Geologic Investigations Map I-573, scale $1: 250,000,1$ sheet.

Churkin, M., Jr., and Brabb, E.E., 1969, Prudhoe Bay discovery forces a look at other Alaskan petroliferous areas: Oil and Gas Journal, v. 67, p. 104-110.

Decker, J., and Helmold, K.P., 1985, The effect of grain size on detrital modes: A test of the Gazzi-Dickinson pointcounting method-Discussion: Journal of Sedimentary Petrology, v. 55, p. 618-620.

Dickinson, W.R., 1970, Interpreting detrital modes of graywacke and arkose: Journal of Sedimentary Petrology, v.
40, p. $695-707$.

Dover, J.H., 1985, Possible oroclinal bend in northern Cordilleran fold and thrust belt, east-central Alaska [abs.]: Geological Society of America Abstracts with Programs, v. 17 , p. 352.

Dover, J.H., and Miyoka, R.T., 1988, Reinterpreted geologic map and fossil data, Charley River quadrangle, east-central Alaska: U.S. Geological Survey Miscellaneous Field Studies Map MF-2004, scale 1:250,000, 2 sheets.

Eittreim, S., and Grantz, A., 1979, CDP seismic sections of the western Beaufort continental margin: Tectonophysics, v. 59 , p. $251-262$.

Embry, A.F., and Dixon, J., 1990, The breakup unconformity of the Amerasia Basin, Arctic Ocean: Evidence from Arctic Canada: Geological Society of America Bulletin, v. 102, p. 1526-1534.

Foster, H.L., 1976, Geologic map of the Eagle quadrangle, Alaska: U.S. Geological Survey Miscellaneous Geologic Investigations Map I-922, scale 1:250,000, 1 sheet.

Füchtbauer, H., 1964, Sedimentpetrographische Untersuchungen in der älteren Molasse nördlich der Alpen: Eclogae Geologicae Helvetiae, v. 57, p. 157-298.

Gazzi, P., 1966, Le arenarie del flysch sopracretaceo dell'Appennino modenese; correlazioni con il flysch di Monghidoro: Mineralogie et Petrographie Acta, v. 6, p. 69-97.

Gazzi, P., and Zuffa, G.G., 1970, Le arenarie paleogeniche dell'Appennino emiliano: Mineralogie et Petrographie Acta, v. 16, p. 97-137.

Grantz, A., Eittreim, S., and Dinter, D.A., 1979, Geology and tectonic development of the continental margin north of Alaska: Tectonophysics, v. 59, p. 262-291.

Halgedahl, S.L., and Jarrard, R.D., 1987, Paleomagnetism of the Kuparuk River Formation from oriented drill core: Evidence for rotation of the Arctic Alaska Plate, in Tailleur, I.L., and Weimer, P., eds., Alaskan North Slope geology: Bakersfield, California, Pacific Section, Society of Economic Paleontologists and Mineralogists, v. 50, p. 581-617.

Hansen, V.L., 1990, Evidence for deep-seated underplating, backflow, and margin-parallel shear within an ancient subduction complex, Teslin Suture Zone, Yukon [abs.]: Geological Society of America Abstracts with Programs, v. 22 , p. A325.

Howell, D.G., Bird, K.J., Lu, H., and Johnsson, M.J., 1991, Tectonics and petroleum potential of the Brooks Range fold-and-thrust belt-a progress report, in Bradley, D.C., and Ford, A.B., eds., Geologic studies in Alaska by the U.S. Geological Survey, 1990: U.S. Geological Survey Bulletin [this volume].

Howell, D.G. and Wiley, T.J., 1987, Crustal evolution of northern Alaska inferred from sedimentology and structural relations of the Kandik area: Tectonics, v. 6, p. 619631.

Ingersoll, R.V., Bullard, T.F., Ford, R.L., Grimm, J.P., Pickle, J.D., and Sares, S.W., 1984, The effect of grain size on detrital modes: a test of the Gazzi-Dickinson point-counting method: Journal of Sedimentary Petrology, v. 54, p. 103-116.

Jones, D.L., Silberling, N.J., Coney, P.J., and Plafker, G., 
1987, Lithotectonic terrane map of Alaska (west of the 141st meridian): U.S. Geological Survey Miscellaneous Field Studies Map MF-1874-A, scale 1:2,500,000, 1 sheet. Laughland, M.M., Underwood, M.B., and Wiley, T.J., 1990, Thermal maturity, tectonostratigraphic terranes, and regional tectonic history: An example from the Kandik area, east-central Alaska, in Nuccio, V.F. and Barker, C.E., eds., Applications of thermal maturity studies to energy exploration: Rocky Mountain Section, Society of Economic Paleontologists and Mineralogists, p. 97-111.

Norris, D. K., 1985, Eastern Cordilleran foldbelt of northern Canada: Its structural geometry and hydrocarbon potential: American Association of Petroleum Geologists Bulletin, v. 69 , p. $788-808$.

Patton, W.W., Jr., Box, S.E., Moll-Stalcup, E.J., and Miller, T.P., 1989, Geology of west-central Alaska: U.S. Geological Survey Open File Report 89-554, 51 p.

Payne, M.W. and Allison, C.W., 1981, Paleozoic continentalmargin sedimentation in east-central Alaska: Geology, v.
9, p. 274-279.

Pettijohn, F.J., Potter, P.E., and Siever, R., 1987, Sand and sandstone (2d ed.): New York, Springer-Verlag, 618 p.

Stanley, W.D., Labson, V.F., Nokleberg, W.J., Csejtey, B., Jr., and Fisher, M., 1990, The Denali fault system and Alaska Range of Alaska: Evidence for underplated Mesozoic flysch from magnetotelluric surveys: Geological Society of America Bulletin, v. 102, p. 160-173.

Sweeney, J.J., and Burnham, A.K., 1990, Evaluation of a simple model of vitrinite reflectance based on chemical kinetics: American Association of Petroleum Geologists Bulletin, v. 74, no. 10, p. 1559-1570.

Underwood, M.B., Laughland, M.M., Wiley, T.J., and Howell, D.G., 1989, Thermal maturity and organic geochemistry of the Kandik basin region, east-central Alaska: U.S. Geological Survey Open-File Report 89-353, 41 p.

Reviewers: Kenneth J. Bird and Hugh McLean 


\title{
Arc and Extensional Basin Geochemical and Tectonic Affinities for Maiyumerak Basalts in the Western Brooks Range
}

\author{
By Susan M. Karl
}

\begin{abstract}
Mafic igneous rocks in the Maiyumerak Mountains, northwestern Alaska, are part of a northeast-trending belt up to $50 \mathrm{~km}$ in width that extends discontinuously for 150 $\mathrm{km}$. The belt consists of a basal mélange, limestone, a thick series of basaltic flows, tectonized basalt and sedimentary rocks, and ubiquitous small gabbro and peridotite bodies. The mélange contains numerous diabase dikes and gabbros that syn- or post-deformationally intrude sedimentary rocks. The basalts have yielded no ages but are associated with Paleozoic, Triassic, and Jurassic sedimentary rocks. The basalt, diabase dikes, and gabbros intrude or are associated with continental-margin, shallow to moderately deep marine sedimentary rocks. These rocks are tholeiitic to slightly alkaline; have moderate $\mathrm{Ti}$, low $\mathrm{Ni}$, and low $\mathrm{Cr}$ contents; and are Ta depleted. The Mesozoic basalts have flat to slightly enriched rare-earth-element (REE) signatures at 10 to 20 times the chondrite ratio. The Paleozoic(?) basalt is more light rare earth element (LREE) enriched. The basalts are slightly enriched tholeiites, and their chemistry is compatible with oceanic arc, back-arc basin, rift, and extensional tectonic settings on various geochemical plots. Gravity and magnetic surveys indicate that the dense mafic rocks dip west under the Noatak River valley and south under the Igichuk Hills carbonate rocks, suggesting that the mafic rocks are not a klippe on a synformal stack of thrust sheets, as previously proposed. Previous workers assigned the basalts of the Maiyumerak Mountains to the Copter Peak allochthon, which is considered part of the Angayucham terrane. However, the Maiyumerak basalts differ from other Copter Peak basalts in chemistry and from the Angayucham basalts in age and stratigraphic association, petrography, and geochemistry. The Angayucham basalts display geologic and chemical characteristics typical of oceanic islands or plateaux. It is concluded that the Maiyumerak basalts may not be part of the Copter Peak allochthon, and that they should not be included in the Angayucham terrane because they do not resemble Angayucham basalts. A model is proposed in which some of the Maiyumerak basalts formed in an independent extensional basin on the Brookian continental margin in middle to late Paleozoic time. In the Mesozoic the basin was overridden by an advancing oceanic arc,
\end{abstract}

represented by most of the basalts in the Maiyumerak Mountains. Other mafic-ultramafic sequences of rocks in the northwestern Brooks Range may have formed in similar tectonic settings.

\section{INTRODUCTION}

Mafic and ultramafic igneous rocks in the Maiyumerak Mountains of the western Brooks Range are part of a discontinuously exposed belt approximately $150 \mathrm{~km}$ long that trends northeasterly and dips to the northwest. The width of this belt is uncertain owing to poor exposure but may be as much as $5 \mathrm{~km}$; the thickness of these mafic rocks may be up to $2 \mathrm{~km}$ at Maiyumerak Mountain.

Previous workers (Tailleur, 1973; Patton and others, 1977; Roeder and Mull, 1978) have interpreted these rocks as the upper part of a series of klippen comprising the highest thrust sheets involved in the Brookian orogeny. These klippen are exposed as large synformal erosional remnants that were thrust from the south, where a thick package of basalts comprises the Angayucham terrane (fig. 1). Mull (1982) assigned these klippen to the Copter Peak and Misheguk Mountain allochthons and correlated them with the basalts of the Angayucham terrane. The Copter Peak allochthon consists dominantly of basalt from which interpillow and interbedded limestone and chert have yielded Devonian and Triassic fossils. The Misheguk Mountain allochthon consists dominantly of partially serpentinized peridotite and gabbro and is always associated with the Copter Peak allochthon. Hornblende and biotite K-Ar ages from gabbro at Siniktanneyak and Misheguk Mountains range from 202 to 147 Ma (Patton and others, 1977; Boak and others, 1987; Harris, 1989; fig. 1). Dating using ${ }^{40} \mathrm{Ar} /{ }^{39} \mathrm{Ar}$ methods yielded crystallization ages of 182-172 Ma for Asik Mountain and Misheguk Mountain (Wirth and others, 1986; Harris, 1989). Variations in age ranges, chemistry, and associated lithologies, together with poorly understood tectonic histories of these klippen, have led some 
workers to question the relationship of these mafic and ultramafic rocks to the Angayucham terrane rocks (Harding and others, 1985; Karl and Dickey, 1987; Schmidt, 1987). This paper questions the relationship of the Maiyumerak basalts to the Angayucham basalts.

\section{MAIYUMERAK BASALTS}

The basalts of the Maiyumerak Mountains are tectonically disrupted and structurally interleaved with limestone, chert, quartz-wacke, and phyllite. In the northeastern Maiyumerak Mountains there are three basalt units and one gabbro unit that are mapped within three of four lithotectonic belts (fig. 2). The belts strike northeast, dip moderately to the northwest, and are complexly faulted.

The easternmost belt is as much as $2 \mathrm{~km}$ wide and is faulted against Paleozoic carbonate rocks to the east. This belt is composed of tectonic mélange (KJm) con- taining meter- to decameter-scale blocks of pillow basalt, dolostone, marble, chert, green phyllite, and gabbro in an argillite and quartz-wacke matrix. The quartz wacke is fine grained and well sorted, with up to 80 percent angular quartz clasts and minor feldspar, chert, detrital chlorite, volcanic rock fragments, and mudstone. The quartz wacke occurs in thin, centimeter-scale rhythmic beds suggesting turbidite deposition, and locally as thin layers in dominantly argillite sections. Blocks in the melange have yielded fossil ages ranging from Devonian to Jurassic (Karl and others, 1989). The age of the matrix is thus Jurassic or younger. Along strike $30 \mathrm{~km}$ to the north in the Misheguk Mountains quadrangle, similar mudstone and wacke contain Tithonian pelecypods (Curtis and others, 1984), suggesting a Late Jurassic (and younger?) protolith age for the mudstone and wacke matrix of the mélange in the Maiyumerak Mountains. The tectonic age of the mélange is considered to be Late Jurassic and Cretaceous, coincident with the development of the Brookian orogeny.

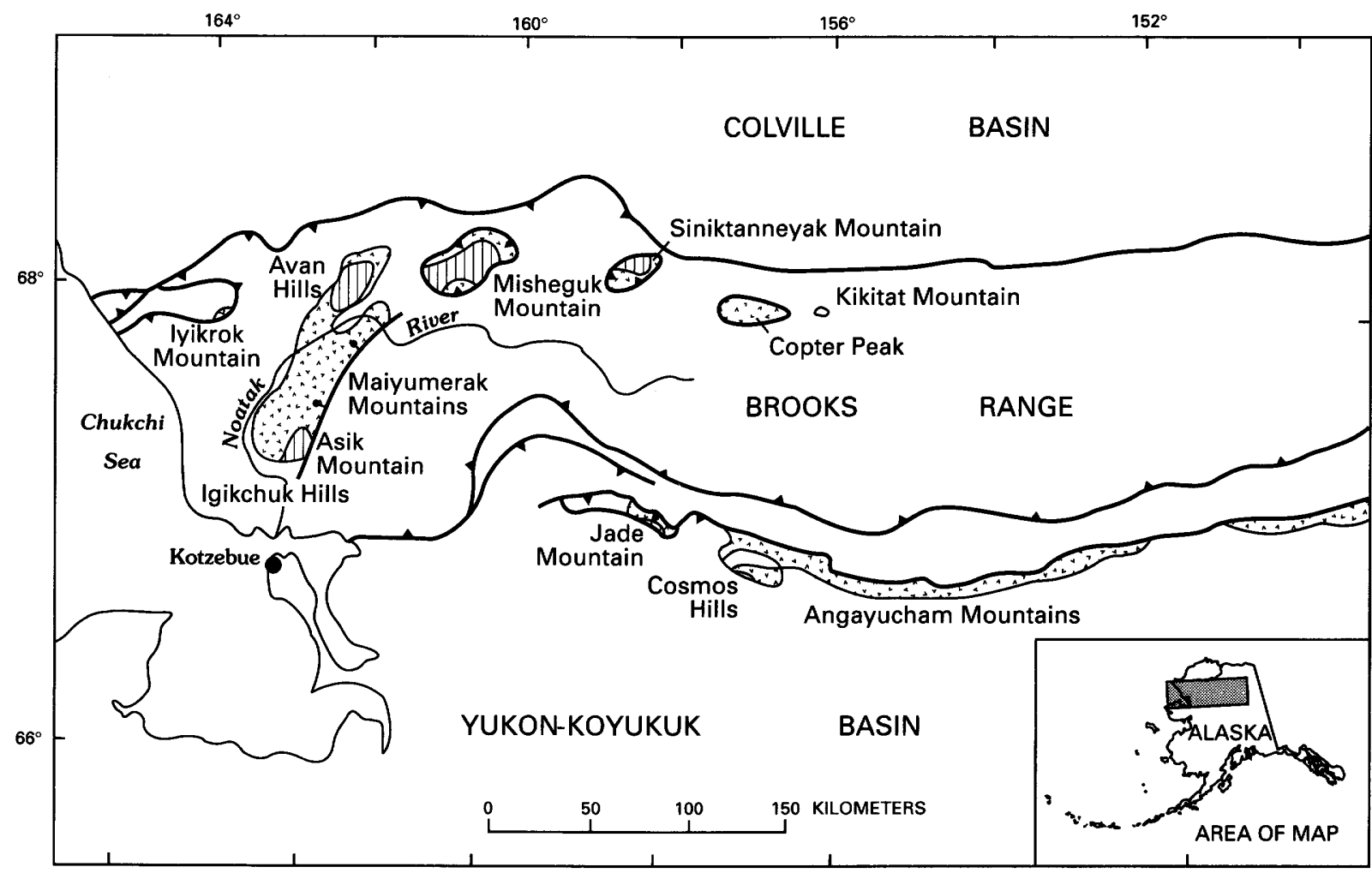

\section{EXPLANATION}

Ultramafic rocks

Mafic rocks

\section{Contact}

ـ Thrust fault-Sawteeth on upper plate

$\stackrel{\perp}{\perp}$ Normal fault-Ball and bar on footwall

Figure 1. Northwestern Brooks Range, showing location of mafic and ultramafic rocks. 

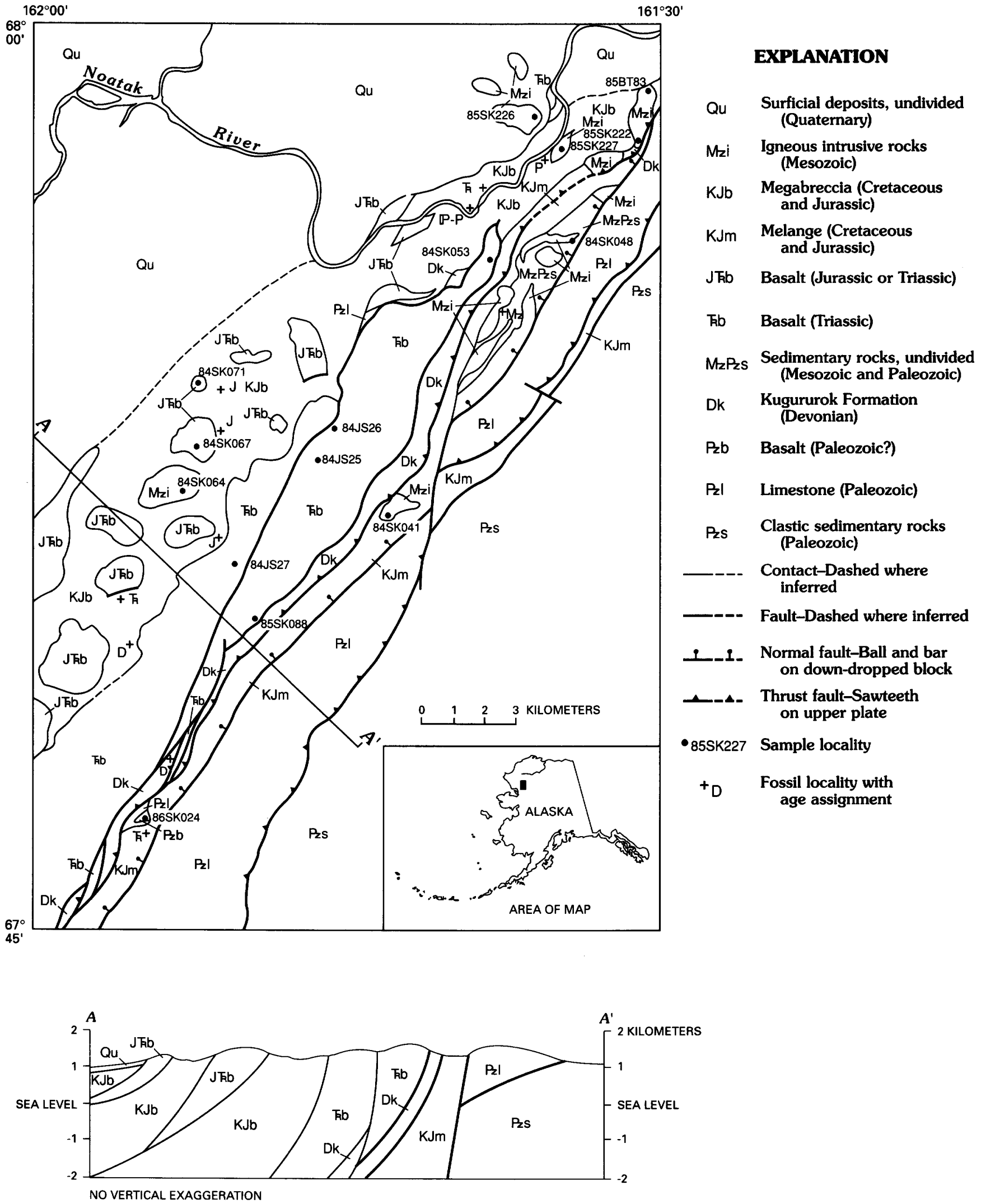

Figure 2. Map and cross-section of part of Maiyumerak Mountains in northwestern Baird Mountains quadrangle. Age abbreviations: D, Devonian; J, Jurassic; Mz, Mesozoic; P, Permian; P-P, Pennsylvanian to Permian; $K$, Triassic. 
Structurally overlying the mélange is a long thin belt of carbonate rocks with a maximum thickness of 1 $\mathrm{km}$ that does not contain any apparent structural repetitions. This carbonate unit is the Devonian Kugururok Formation, distinguished from all other Devonian limestones in the western Brooks Range by the presence of potassium feldspar clasts. It is recrystallized and technically a metalimestone. The metalimestone is light to medium gray, thin bedded, and locally contains quartz and feldspar clasts. It is continuously exposed for over 25 $\mathrm{km}$ in the map area, and it is discontinuously exposed in the same structural position to the northeast in the Misheguk Mountains quadrangle and to the southwest in the Noatak quadrangle.

The third belt of rocks is a layer of homogenous, massive to pillowed basalt with minor andesite, dacite, tuff, and volcanic breccia having a maximum structural thickness of $5 \mathrm{~km}$. These rocks are metamorphosed but retain most of their original mineralogy and textures. For the sake of simplicity they will be referred to as basalts in this report. The lower contact of the basalt with the Kugururok Formation is poorly exposed, but sharp, and may be a fault or a disconformity. Although there are numerous mafic dikes in the Kugururok Formation, they cannot unequivocally be linked to the overlying basalts. The basalts are fine grained with unzoned plagioclase laths $\left(A n_{70-80}\right)$ and rare interstitial augite grains. Secondary minerals include chlorite, epidote, chalcedony, calcite, pyrite, and magnetite. No interpillow sedimentary rocks or interbedded fossiliferous sedimentary rocks have been observed. However, $55 \mathrm{~km}$ on strike to the north in the Misheguk Mountains quadrangle, interpillow cherts in the same basalts have yielded Triassic radiolarians (Ellersieck and others, 1984), and $21 \mathrm{~km}$ to the north, in another fault slice, Triassic radiolarians from interpillow cherts are also reported (Curtis and others, 1984). Consequently, the basalts in the Maiyumerak Mountains are inferred to be Triassic as well. This unit corresponds to the eastern basalt unit of Wirth and others (1987), located to the southwest near Asik Mountain (fig. 1).

The fourth and northwesternmost belt exposed in the Maiyumerak Mountains consists of a pervasively faulted assemblage of quartz wacke, argillite, bedded chert, limestone, coarse volcaniclastic rocks, and basalt (JFb). It is not a blocks-and-matrix mélange; it is a collage of meter- to kilometer-scale blocks with no matrix between them, and it contains the same lithologies as the mélange to the southeast, described above. In some blocks chert grades upward into argillite, suggesting that the argillite and quartz wacke may depositionally overlie the Jurassic chert. Only fault contacts were observed between the basalts and the other lithologies, except for unfossiliferous interpillow limestone at one locality. In another place, coarse conglomeratic volcaniclastic rocks several meters thick are interbedded with basalt flows. The basalts are generally subophitic or diabasic, with augite and calcic plagioclase $\left(A n_{70-85}\right)$. Some of the basalts contain accessory magnetite and secondary calcite, quartz, chlorite, serpentine, epidote, or stilpnomelane. Fibrous amphibole was observed in one sample. The age of the basalts is unknown. One questionably depositional contact above dated Jurassic chert suggests some of the basalts may be as young as Jurassic. This unit corresponds to the western basalt unit of Wirth and others (1987), which contains thin layers of chert and tuff as well as vertical subparallel dikes in flat-lying flows (Wirth and others, 1989). The dikes and flows are inferred to represent the mafic section of an ophiolite, possibly the ophiolite represented by the overlying ultramafic rocks at Asik Mountain, which are Jurassic in age (Wirth and others, 1989). Bedded limestone blocks in this assemblage have yielded Devonian and Mississippian fossils; meter-scale chert sections have yielded Pennsylvanian, Permian, Triassic, and Jurassic radiolarians. As with the quartz wacke and argillite of the mélange belt $(\mathrm{KJm})$, the quartz wacke and argillite of the northwestern collage belt are considered to be Jurassic and (or) Cretaceous in age.

The mélange and the northwestern tectonic assemblage are both intruded by small isotropic gabbro bodies one to several kilometers in diameter. These gabbros are medium grained with subophitic to ophitic textures. Plagioclase is zoned in some samples and twinned in others, with common augite and rare olivine. Secondary minerals include chlorite, chalcedony, albite, epidote, and magnetite. There are no isotopic ages for the gabbros, but one body intrudes folded chert that yielded Mesozoic (Jurassic?) radiolarians (C.D. Blome, U.S. Geological Survey, written commun., 1986), which provides a maximum age of Mesozoic. In another place, gabbro dikes intrude quartz wacke in the northwestern tectonic assemblage, which suggests that the gabbro is Jurassic or younger in age. Prehnite veins in one gabbro sample indicate that these rocks have been metamorphosed and, assuming that they were metamorphosed during the Brookian orogeny, suggest a minimum Cretaceous age for the gabbros.

\section{ANGAYUCHAM TERRANE}

The Angayucham terrane (Jones and others, 1987) extends for more than $500 \mathrm{~km}$ along the south flank of the Brooks Range and consists of a package of southdipping imbricated fault slabs of pillow basalt with minor interpillow sedimentary rocks. The structural thickness of this package exceeds $10 \mathrm{~km}$ in the Angayucham Mountains (Pallister and Carlson, 1988). The basalts contain prehnite-pumpellyite to low-greenschist-facies 
mineral assemblages. The basalts overlie a tectonic mélange consisting of blocks of Paleozoic and Mesozoic basalt, chert, limestone, and phyllite in a metagraywacke and phyllite matrix. In a few places the basalts are overlain by fine-grained orthoamphibolite (metabasalt), tectonized harzburgite, or serpentinite (Loney and Himmelberg, 1985); the mafic and ultramafic rocks are structurally overlain by Cretaceous breccia and polymictic conglomerate.

In the Angayucham Mountains there are three basalt units. The structurally and stratigraphically lowest basalt unit consists of pillow basalt, hyaloclastic breccia, diabase and microgabbro (Pallister and Carlson, 1988; Pallister and others, 1989). The basalt is fine grained, vesicular to amygdaloidal, and aphyric. Chert and limestone occur between pillows and in sections up to $30 \mathrm{~m}$ thick. Conodonts from the limestones have yielded Devonian and Mississippian ages. Chemically, these basalts are tholeiitic and LREE enriched (Pallister and others, 1989).

The middle basalt unit is an imbricate stack of pillow basalt, breccia, tuff, diabase, and microgabbro (Pallister and others, 1989). The basalt is finegrained, sparsely vesicular, and aphyric to sparsely plagioclase phyric or plagioclase and clinopyroxene phyric, with intergranular, intersertal, or ophitic to subophitic textures (Pallister and others, 1989). Chert between pillows and in sections 5-50 m thick has yielded Middle and Late Triassic ages. Chemically, these basalts are tholeiitic with a flat REE pattern at about 10 times the chondrite ratio (Pallister and others, 1989).

The upper basalt unit is also imbricated pillow basalt, breccia, tuff, diabase and microgabbro with the same petrographic textures as the Triassic basalt; however, this upper basalt is distinguished by the presence of titaniferous augite, fibrous amphibole, and stilpnomelane (Pallister and others, 1989). Radiolarian ribbon chert and tuff sections up to $60 \mathrm{~m}$ thick have yielded Early Jurassic radiolarians. Chemically, these basalts are tholeiitic with enriched LREE up to about 100 times the chondrite ratio (Pallister and others, 1989).

The Triassic and Jurassic basalt units in the Angayucham Mountains and correlative units along strike to the east have been interpreted to represent oceanic plateaux or seamounts based on their mode of occurrence and their chemistry (Barker and others, 1988; Pallister and others, 1989). The Paleozoic basalts are also interpreted as oceanic (Pallister and others, 1989), with geochemical signatures that are compatible with rifting of continental crust at the initiation of, or the edge of, an ocean basin (Wilson, 1988). Late Devonian to Mississippian or Pennsylvanian rifting has been proposed for the Brooks Range paleo-continental margin by Hitzman and others $(1982,1986)$ and subsequent workers.

\section{CHEMISTRY}

Fresh basalt, with no calcite veins or blebs and no weathering rinds, were submitted as 1-kg samples for chemical analysis. Major and minor elements (table 1) were determined by X-ray fluorescence in the U.S. Geological Survey laboratories in Menlo Park. Rare-earth-element values (table 2) were determined by INAA in the U.S. Geological Survey laboratories in Denver.

The basalts and gabbros of the northeastern Maiyumerak Mountains fall into chemically defined groups that correspond to respective map units. These groups are (1) the Paleozoic(?) basalts ( $\left.P_{z b}\right)$ that are blocks in the mélange (KJm) (fig. 2), (2) the massive slab of Triassic basalt ( $\mathrm{kb}$ ) (fig. 2), (3) the fault slices of basalt in the northwestern tectonic assemblage $(\mathrm{JKb})$ (fig. 2), and (4) the gabbros (Mzi) (fig. 2). In general, all of the basalts are tholeiitic with normative olivine and hypersthene. Basalts of units $\mathrm{P}_{2 b}$ and $\mathrm{J}_{\mathrm{Bb}}$ have 48-50 percent silica, the gabbros have 50-51 percent silica, and the Triassic basalt unit includes andesites and dacites with silica contents of 53-61 percent. Alumina contents are low relative to silica for all the units. Titanium oxide is close to 2 percent for units $P_{z b}$ and $J T_{b}$, close to 1.5 percent for the gabbros, and close to 1 percent for unit $\mathrm{Fb}$. $\mathrm{Cr}$ and $\mathrm{Ni}$ are much lower for $\mathrm{Fb}$ than for the other units. Low $\mathrm{Ti}, \mathrm{Cr}$, and $\mathrm{Ni}$ are characteristic of arc tholeiites (Wilson, 1988.) The Paleozoic(?) basalt is distinctly more LREE enriched than the other basalts at 60 times the chondrite ratio (fig. 3, table 2). The Triassic basalts are flat to slightly LREE enriched at 25 times the chrondrite ratio (fig. 3; table 2) and the Triassic or Jurassic basalts and gabbros are flat at 10-20 times the chrondrite ratio. Slightly enriched LREE at about 20 times the chondrite ratio is considered typical of arc tholeiites (Holm, 1985; Wilson, 1988). Moderately to very LREE enriched basalts are typical of within-plate basalts (Holm, 1985; Wilson, 1988).

The REE signature of the Angayucham basalts is the reverse of the Maiyumerak basalts, except for the $\mathrm{Pa}$ leozoic(?) basalt from the mélange, which has a similar REE pattern to the Paleozoic Angayucham basalts (fig. $3 A, B$.) The Triassic Angayucham basalts have a flat REE pattern at about 10 times the chondrite ratio, like basalts of unit $\mathrm{JKBb}$ of the Maiyumerak Mountains. In contrast, the Jurassic Angayucham basalts are LREE enriched to 100 times the chondrite ratio (Pallister and others, 1989), which is significantly more enriched than basalts of unit J $\mathrm{Kb}$. None of the basalts from either data set has the signature of a midocean ridge basalt (MORB). Only the Paleozoic basalts are enriched similar to continental-rift basalts. Both data sets are within the range of ocean-island tholeiites, island-arc tholeiites, or back-arc basin basalts. 
Table 1. Major-element analyses, in weight percent, of mafic rocks from the Maiyumerak Mountains

[Unit designations as on figure 2. Symbols refer to diagrams in figures 3 through 8 . Element analyzed by X-ray fluorescence]

\begin{tabular}{|c|c|c|c|c|c|c|c|c|c|}
\hline $\begin{array}{l}\text { Field No. -...-.. } \\
\text { Map unit } \\
\text { symbol -.-....- }\end{array}$ & $\begin{array}{c}\text { 86SK024B } \\
\mathrm{Pzb}\end{array}$ & $\begin{array}{c}\text { 81EK202B } \\
\text { Kb }\end{array}$ & $\begin{array}{l}\text { 84JS25A } \\
\text { Kb }\end{array}$ & $\begin{array}{c}\text { 84JS25B } \\
\text { Kb }\end{array}$ & $\begin{array}{c}\text { 84JS26E } \\
\text { Kbb }\end{array}$ & $\begin{array}{l}\text { 84JS27A } \\
\text { Kb }\end{array}$ & $\begin{array}{l}\text { 84JS27D } \\
\text { Kb }\end{array}$ & $\begin{array}{c}\text { 84SK53A } \\
\text { Kb }\end{array}$ & $\begin{array}{c}\text { 85SK088A } \\
\text { Kb }\end{array}$ \\
\hline $\mathrm{SiO}_{2} \ldots$ & 49.08 & 55.27 & 54.91 & 54.32 & 55.18 & 53.12 & 55.61 & 53.95 & 60.81 \\
\hline $\mathrm{Al}_{2} \mathrm{O}_{3} \ldots$ & 15.62 & 15.67 & 16.21 & 14.46 & 15.46 & 15.59 & 16.10 & 15.81 & 14.86 \\
\hline $\mathrm{Fe}_{2} \mathrm{O}_{3} \ldots$ & 6.69 & 4.23 & 4.34 & 4.57 & 2.90 & 5.55 & 3.09 & 3.22 & 2.20 \\
\hline $\mathrm{FeO}$ & 7.46 & 8.07 & 7.76 & 6.12 & 9.30 & 5.85 & 7.93 & 7.81 & 7.21 \\
\hline MgO-_.-.-- & 7.64 & 4.51 & 5.98 & 4.84 & 5.13 & 4.66 & 5.80 & 5.14 & 4.05 \\
\hline $\mathrm{CaO}$ & 6.44 & 4.61 & 3.99 & 8.40 & 5.65 & 8.84 & 6.70 & 8.40 & 5.28 \\
\hline $\mathrm{Na}_{2} \mathrm{O}$ & 2.43 & 6.01 & 4.23 & 5.42 & 3.68 & 4.49 & 3.06 & 4.24 & 3.50 \\
\hline $\mathrm{K}_{2} \mathrm{O}$ & 2.22 & .26 & 1.19 & .10 & .17 & .18 & .39 & .11 & .68 \\
\hline $\mathrm{TiO}_{2} \ldots$ & 1.99 & 1.09 & 1.09 & 1.45 & 1.57 & 1.35 & 1.09 & 1.02 & 1.03 \\
\hline $\mathrm{P}_{2} \mathrm{O}_{5}$ & .28 & .11 & .12 & .16 & .17 & .19 & .11 & .14 & .19 \\
\hline $\mathrm{MnO}$ & .14 & .17 & .19 & .17 & .81 & .18 & .13 & .17 & .20 \\
\hline Total-......-.---- & 99.99 & 100.00 & 100.01 & 100.01 & 100.02 & 100.00 & 100.01 & 100.01 & 100.01 \\
\hline $\begin{array}{l}\text { Field No. -.....- } \\
\text { Map unit } \\
\text { symbol -.-.-... }\end{array}$ & $\begin{array}{c}84 S K 067 B \\
J \text { J b }\end{array}$ & $\begin{array}{c}84 \text { SK071A } \\
\text { JKb }\end{array}$ & $\begin{array}{c}\text { 84SK064A } \\
\text { Mzi }\end{array}$ & $\begin{array}{c}\text { 84SK41B } \\
\text { Mzi }\end{array}$ & $\begin{array}{c}\text { 84SK048A } \\
\text { Mzi }\end{array}$ & $\begin{array}{c}\text { 85BT83A } \\
\mathrm{Mzi}^{2}\end{array}$ & $\begin{array}{c}\text { 85SK222A } \\
\mathrm{Mzi}^{2}\end{array}$ & $\begin{array}{c}\text { 85SK226A } \\
\text { Mzi }\end{array}$ & $\begin{array}{c}\text { 85SK227A } \\
\mathrm{Mzi}\end{array}$ \\
\hline $\mathrm{SiO}_{2}$ & 48.82 & 49.86 & 49.98 & 50.01 & 50.01 & 50.31 & 50.65 & 50.25 & 51.13 \\
\hline $\mathrm{Al}_{2} \mathrm{O}_{3} \ldots$ & 14.02 & 14.77 & 14.81 & 13.23 & 14.27 & 15.52 & 14.40 & 17.10 & 13.28 \\
\hline $\mathrm{Fe}_{2} \mathrm{O}_{3} \ldots$ & 2.56 & 1.78 & 2.08 & 2.85 & 1.54 & 1.38 & 1.54 & 1.39 & 2.24 \\
\hline $\mathrm{FeO}$ & 9.94 & 9.52 & 9.98 & 11.30 & 9.80 & 9.07 & 8.68 & 6.60 & 9.65 \\
\hline MgO & 7.83 & 7.95 & 6.99 & 6.75 & 8.35 & 7.47 & 8.28 & 7.79 & 7.58 \\
\hline $\mathrm{CaO}$ & 11.53 & 11.00 & 11.72 & 10.24 & 10.47 & 11.25 & 12.02 & 12.72 & 10.30 \\
\hline $\mathrm{Na}_{2} \mathrm{O}$ & 2.85 & 3.13 & 2.08 & 3.00 & 2.74 & 2.81 & 2.59 & 2.43 & 3.35 \\
\hline $\mathrm{K}_{2} \mathrm{O}$ & .36 & .21 & .25 & .24 & .42 & .41 & .27 & .48 & .53 \\
\hline $\mathrm{TiO}_{2}$ & 1.76 & 1.46 & 1.82 & 1.97 & 1.54 & 1.50 & 1.33 & 1.03 & 1.61 \\
\hline $\mathrm{P}_{2} \mathrm{O}_{5}$ & .14 & .12 & .10 & .17 & .12 & .12 & .09 & .08 & .14 \\
\hline $\mathrm{MnO}$ & .21 & .20 & .19 & .24 & .73 & .17 & .17 & .15 & .21 \\
\hline Total & -100.02 & 100.03 & 100.00 & 100.00 & 99.99 & 100.01 & 100.02 & 100.02 & 100.02 \\
\hline
\end{tabular}

On major- and trace-element discriminant diagrams, the differences between the basalts are also apparent. The Triassic basalts are slightly than the other Maiyumerak basalts, more alkalic than the basalts from the western Angayucham terrane (Pallister and others, 1989), and more alkalic than the basalts from the eastern Angayucham terrane (Barker and others, 1988), as seen on an AFM plot (fig. $4 A, B$ ).

The $\mathrm{Y} / \mathrm{Cr}$ plot (fig. $5 A$ ) is considered useful for discriminating island-arc tholeiites from MORB tholeiites, because neither element is thought to participate in processes related to mantle heterogeneity (Pearce, 1982). Nevertheless, most of the Maiyumerak gabbros and basalts plot where fields overlap. The Triassic basalts plot as an independent cluster as a result of their lower $\mathrm{Cr}$ contents. In contrast, the Angayucham basalts plot more in the overlap zone of the MORB and within-plate fields (fig. $5 B$ ).

On the $\mathrm{Zr} / \mathrm{Y}$ diagram of Pearce and Norry (1979) (fig. $6 A, B$ ), most of the Maiyumerak basalts plot more distinctly in the MORB field than the Angayucham ba- 
Table 2. Trace-element analyses, in parts per million, of mafic rocks from the Maiyumerak Mountains

[Unit designations as on figure 2. Symbols refer to diagrams in figures 3 through 8. Elements analyzed by instrumental neutron activation analysis.

*: analyzed by X-ray fluorescence; NA: not analyzed; -: not detected]

\begin{tabular}{|c|c|c|c|c|c|c|c|c|c|c|}
\hline $\begin{array}{l}\text { Field No. ........ } \\
\text { MapUnit } \\
\text { Symbol .......... }\end{array}$ & $\begin{array}{c}\text { 86SK024B } \\
\text { Pb }\end{array}$ & $\begin{array}{c}84 J S 27 A \\
\text { kb }\end{array}$ & $\begin{array}{c}84 \text { SK53A } \\
\text { Kb }\end{array}$ & $\begin{array}{c}\text { 81EK202B } \\
\text { Kb }\end{array}$ & $\begin{array}{c}84 S K 071 A \\
J K b\end{array}$ & $\begin{array}{c}\text { 84SK064A } \\
\mathrm{Mzi}\end{array}$ & $\begin{array}{c}\text { 84SK048A } \\
\mathrm{Mzi}^{2}\end{array}$ & $\begin{array}{c}85 S K 226 \mathrm{~A} \\
\mathrm{Mzi}\end{array}$ & $85 S K 227 A$ & $85 S K 222 \mathrm{~A}$ \\
\hline Sc -............. & 39.3 & 34.0 & 36.5 & 35.5 & 45.5 & 43.5 & 41.7 & 38.5 & 47.9 & 44.3 \\
\hline $\mathrm{Cr}$ & 111 & 13.5 & 28.5 & 35.3 & 303. & 103. & 276. & 363. & 129. & 291. \\
\hline Co-.................. & 46.5 & 27.0 & 28.0 & 34.2 & 45.2 & 41.8 & 45.4 & 34.6 & 42.7 & 42.2 \\
\hline Ni -...........--. & 63.9 & 21. & -- & 16.8 & 89.8 & 72.5 & 85.3 & 94.90 & 70.10 & 74.90 \\
\hline $\mathrm{Cu}$ & 80. & 145. & 82. & 84. & 178. & 204. & 145. & 74. & 210. & 140. \\
\hline $\mathrm{Zn}$ & 88.8 & 110. & -- & 78. & 100. & 110. & 80.4 & 61.9 & 110. & 69. \\
\hline Rb-............... & 45.9 & -- & 4.6 & 10. & 3.35 & 11. & 8.3 & 10.9 & 11.4 & 6.71 \\
\hline *Sr & -110. & NA & NA & 112. & $\mathrm{NA}$ & NA & NA & 200. & 210. & 200. \\
\hline *Y & 23. & 22. & 18. & 22. & 20. & 28. & 22. & 20. & 25. & 20. \\
\hline Zr- & 160. & 64. & 47. & 56. & 80.8 & 97. & 91. & 60. & 109. & 47. \\
\hline *Nb - & 18.00 & $<10$ & $<10$. & $<10$ & $<10$ & $<10$. & $<10$ & $<10$ & $<10$. & $<10$ \\
\hline Sb -.................. & - & .13 & .24 & .205 & .46 & - & .18 & - & - & .12 \\
\hline Cs .................... & .593 & .049 & .24 & .169 & 1.14 & .109 & .488 & .484 & 1.28 & .396 \\
\hline Ba -............. & 2.41 & 118. & 110. & 97.3 & 1380. & 227. & 1130. & 256. & 1040. & 2610. \\
\hline La -................ & 17.1 & 6.67 & 3.05 & 3.66 & 4.02 & 3.80 & 4.14 & 2.60 & 4.62 & 3.35 \\
\hline $\mathrm{Ce}$ & 39.8 & 14.8 & 6.81 & 9.10 & 11.4 & 11.2 & 11.7 & 6.87 & 14.1 & 10.1 \\
\hline Nd-.-.... & 23.7 & 10.4 & 6.41 & 7.78 & 8.72 & 8.68 & 9.47 & 5.44 & 10.8 & 7.42 \\
\hline Sm - & 5.77 & 3.16 & 2.35 & 2.56 & 2.76 & 2.79 & 3.16 & 1.72 & 3.45 & 2.40 \\
\hline Eu -............... & 1.77 & 1.16 & .930 & 1.03 & 1.10 & 1.25 & 1.17 & .837 & 1.29 & 1.01 \\
\hline Gd--............-. & 5.21 & 3.92 & 3.28 & 3.61 & 3.82 & 3.54 & 4.30 & 2.30 & 4.42 & 3.19 \\
\hline Tb & .829 & .679 & .568 & .623 & .651 & .631 & .690 & .377 & .762 & .567 \\
\hline $\operatorname{Tm}$ & -- & .415 & .352 & .447 & .385 & .370 & .384 & .236 & .459 & .321 \\
\hline Yb-................ & 2.59 & 2.60 & 2.30 & 2.78 & 2.33 & 2.33 & 2.30 & 1.48 & 2.73 & 1.92 \\
\hline Lu & .377 & .383 & .34 & .411 & .333 & .35 & .32 & .211 & .412 & .276 \\
\hline Ta -.............. & 1.25 & .124 & .10 & .08 & .312 & .35 & .32 & .207 & .343 & .251 \\
\hline Th & 1.81 & .635 & .245 & .464 & .163 & .318 & .232 & .144 & .26 & .19 \\
\hline Hf --..........-- & 4.05 & 1.76 & 1.37 & 1.76 & 2.06 & 2.22 & 2.14 & 1.09 & 2.59 & 1.71 \\
\hline U & .538 & .326 & .290 & .341 & .0825 & .139 & .0942 & .0642 & .107 & - \\
\hline
\end{tabular}

salts. These diagrams show that there are small but consistent differences in the two data sets, but they do not define any difference in tectonic setting.

On Wood's (1980) Hf-Th-Ta diagram, the Triassic Maiyumerak basalts are quite depleted in tantalumtypical of convergent margin or arc basalts. Almost all of more than 25 analyses from both belts of Mesozoic Maiyumerak basalts in the Noatak quadrangle to the southwest plot in the convergent margin fields (Karl Wirth, unpub. data and written commun., 1987). One of the northwestern Triassic or Jurassic Maiyumerak basalts plots with all the Angayucham basalts in the transitional to enriched MORB field (fig. 7).

Pearce's (1982) Th-Ta plot is designed to discriminate between sources of basalt. Using $\mathrm{Yb}$ as a denominator eliminates variations due to partial melting and fractional crystallization in order to focus on source composition. In particular, this diagram allows discrimination between basalts contaminated by subduction processes and basalts derived from other sources (Pearce, 
1982). Uncontaminated within-plate basalts should plot in the enriched-mantle field, MORB in the depletedmantle field, and oceanic plateau or island basalts (typically slightly enriched) should plot someplace between. The northwestern Maiyumerak basalts $(\mathrm{JFb})$ and all of
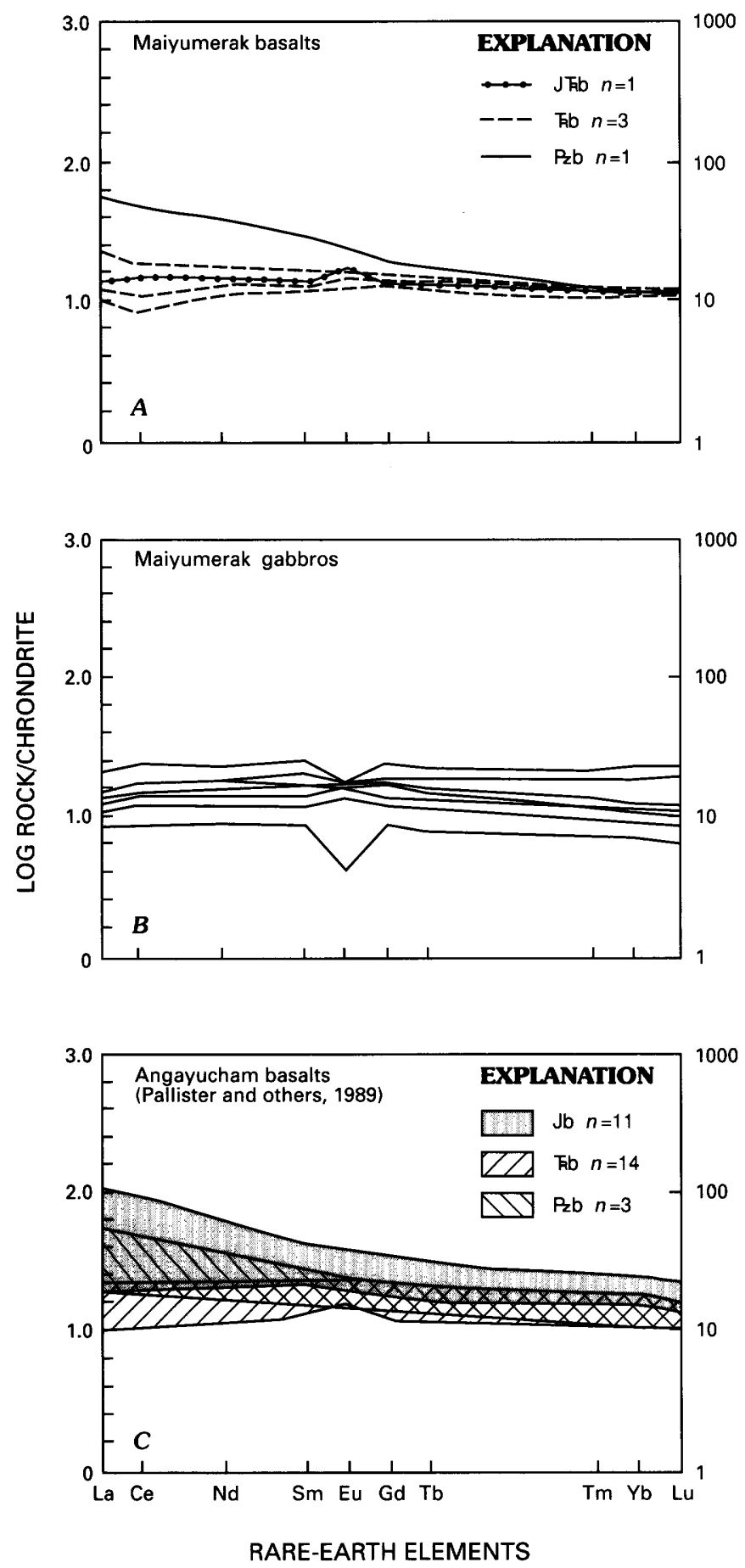

Figure 3. Chondrite-normalized rare-earth-element patterns for basaltic rocks. A, Basalt samples from Maiyumerak Mountains. B, Gabbro samples from Maiyumerak Mountains. C, Basalt samples from Angayucham Mountains. See figure 2 for description of map units. the Angayucham basalts fall in an uncontaminated, slightly enriched field (fig. 8). However, the Triassic Maiyumerak basalts ( $\mathrm{kb}$ ) fall distinctly in the enriched oceanic-arc tholeiite field.

Enrichment in Th and depletion in Ta are two hallmarks of arc basalts or contaminated basalts. This definitely distinguishes the Triassic Maiyumerak basalts from all of the other basalts. Pallister and others (1989) and Barker and others (1988) interpreted the chemistry of Angayucham basalts as indicative of an oceanic is-
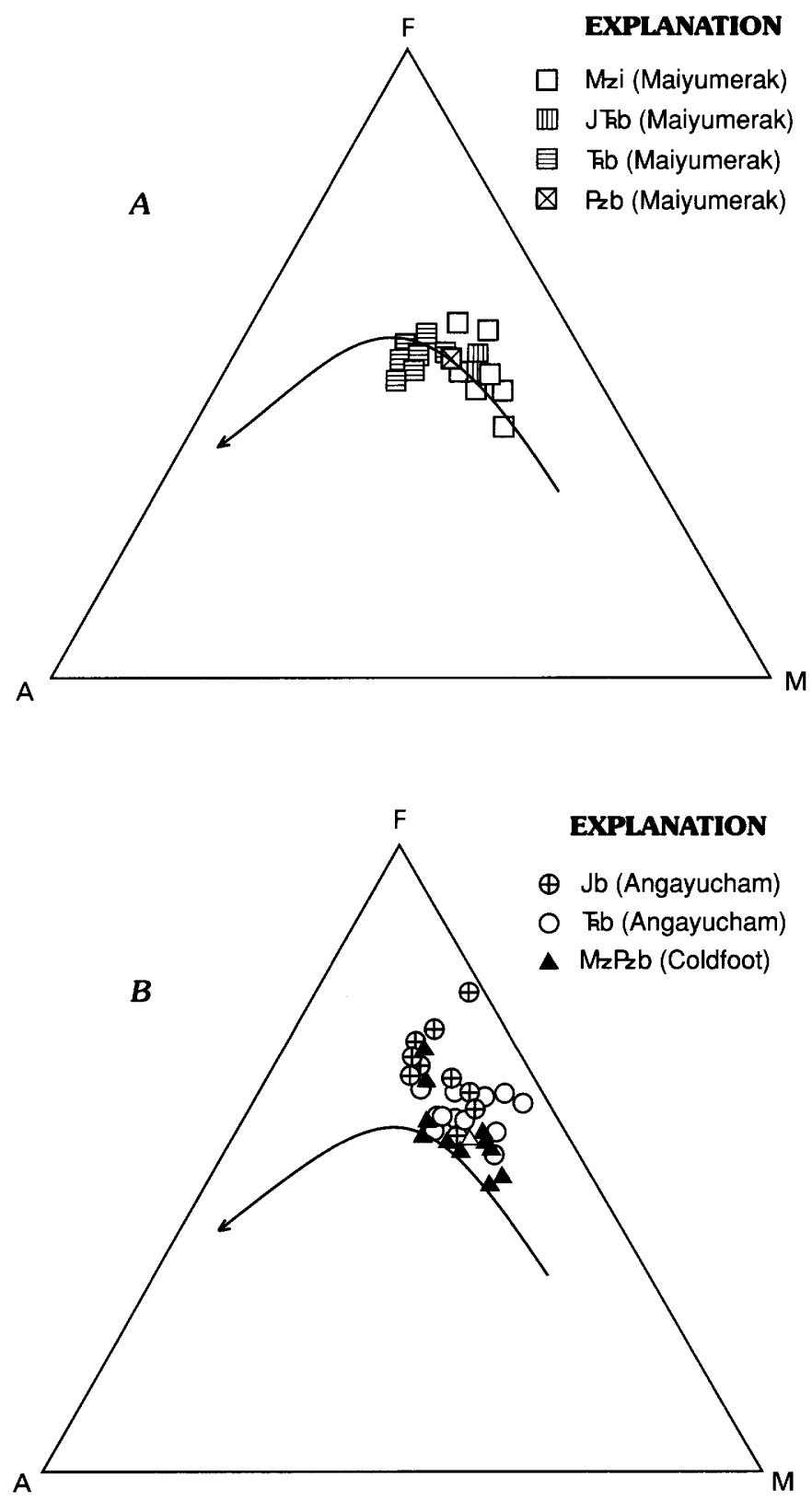

Figure 4. Alkalis- $\mathrm{FeO}+\mathrm{Fe}_{2} \mathrm{O}_{3}-\mathrm{MgO}$ (AFM) diagram. $A$, Values for Maiyumerak Mountains basalts and gabbros. $B$, Angayucham and Coldfoot basalts. See figure 2 for description of map units. Line separates tholeiitic and alkalic fields. 
land or plateau setting. This is supported by field relations-namely, the association of extensive basalt outcrops with only pelagic sedimentary rocks. The chemical signature is somewhat different for the northwestern Maiyumerak Triassic or Jurassic basalts (JKb), and the field relations are quite different-namely, the strong association with quartz wacke and argillite, and the gabbro plugs. A back-arc (fore-arc?) basin or some other extensional setting is permissible but not certain for the chemical signature of these Maiyumerak basalts because of overlap in REE values for various tectonic settings.

\section{GEOPHYSICS}

The Maiyumerak Mountains have complete gravitysurvey coverage (Barnes, 1967; Barnes and Tailleur, 1970;
D.F. Barnes, unpub. data, 1986). There are also local magnetic and audiomagnetotelluric (AMT) surveys and profiles for the area (Barnes and Tailleur, 1970; Karl and Long, 1990). A gravity and magnetic high follows the map pattern of the basalts and extends northwest under the Noatak River valley and southwest under the Igichuk Hills (fig 1). The Igichuk Hills are underlain by low-density carbonate rocks, which suggests either that the carbonate rocks must be underlain by dense (probably mafic) rocks or that the crust is thinned there. At the southern end of the Maiyumerak basalts is a Jurassic layered peridotite and gabbro body at Asik Mountain (Wirth and others, 1986), which is represented by one of the largest gravity anomalies in North America: $120 \mathrm{mgal}$ over $20 \mathrm{~km}$, indicating a depth on the order of $8 \mathrm{~km}$ (Barnes and Tailleur, 1970). Barnes and Tailleur pointed out that the regional southwest dip conflicts with the interpretation of a north-plunging

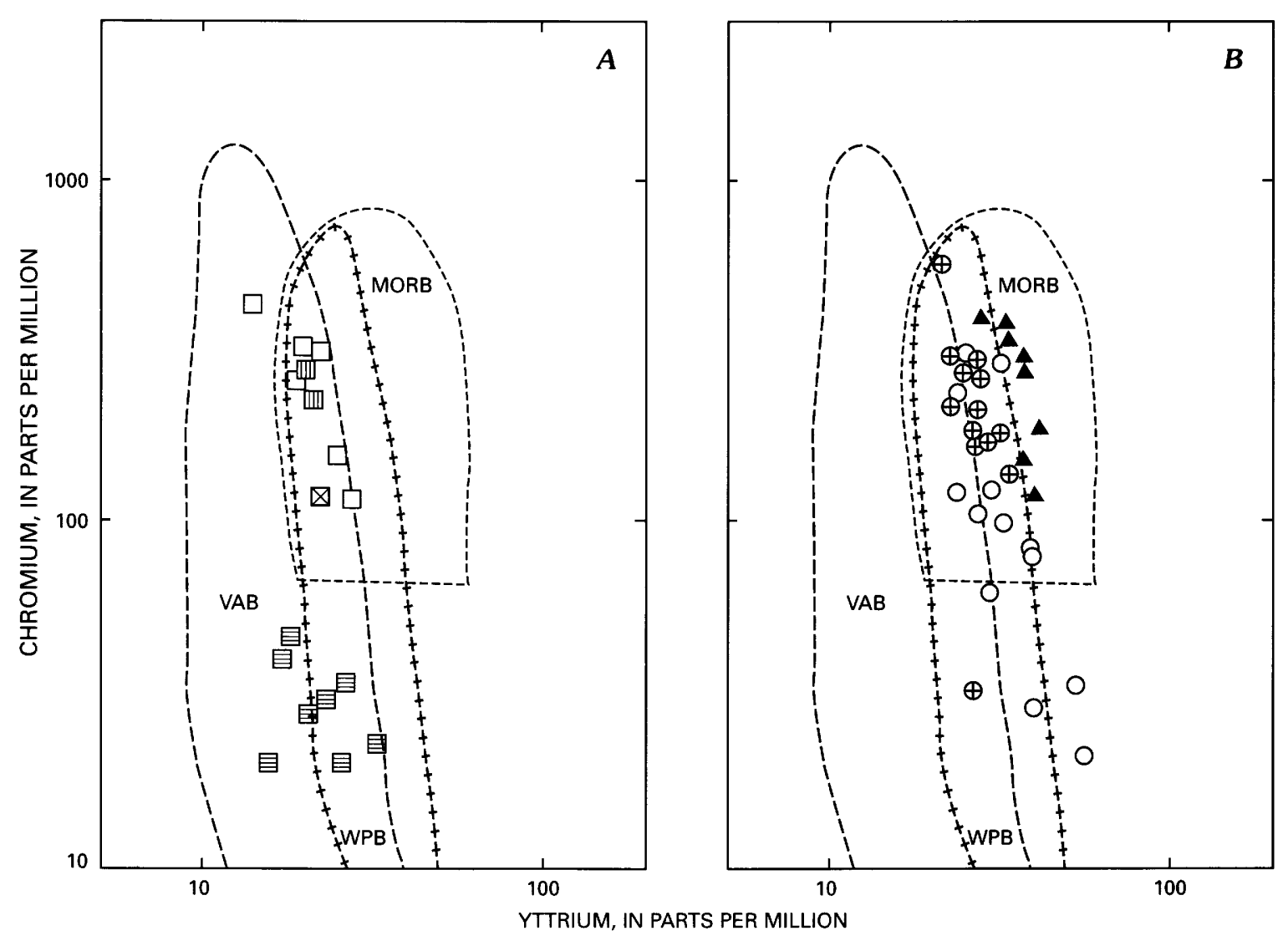

EXPLANATION

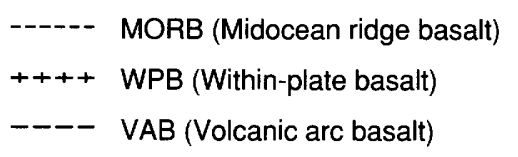

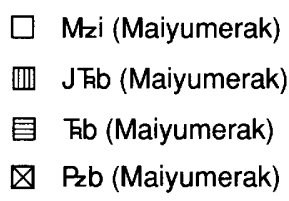

$\oplus \mathrm{Jb}$ (Angayucham)

O Kb (Angayucham)

- MzPzb (Coldfoot)

Figure 5. $\mathrm{Y} / \mathrm{Cr}$ diagram of Pearce (1982). A, Values for Maiyumerak basalts. B, Values for Angayucham and Coldfoot basalts. See figure 2 for description of map units. 
synform in the Noatak River valley. The magnetic-survey contours trend normal to the map pattern of the mafic rocks, and Barnes and Tailleur (1970) interpreted a steep eastern contact and moderately dipping western and southern contacts for the magnetic anomaly. Barnes argued that gravity and magnetic signatures suggest that Asik Mountain is rooted (Barnes and Tailleur, 1970). To the north and east, Misheguk Mountain, Siniktanneyak Mountain, and several other mafic-ultramafic bodies have discrete gravity anomalies and local magnetic anomalies that do not coincide exactly with mapped exposures of mafic or ultramafic rocks (D.F. Barnes, written commun., 1986), but that do suggest thick slabs of mafic rock.

\section{TECTONIC SETTING}

The Maiyumerak basalts are bounded by faults where contacts are exposed; basement to the basalts is

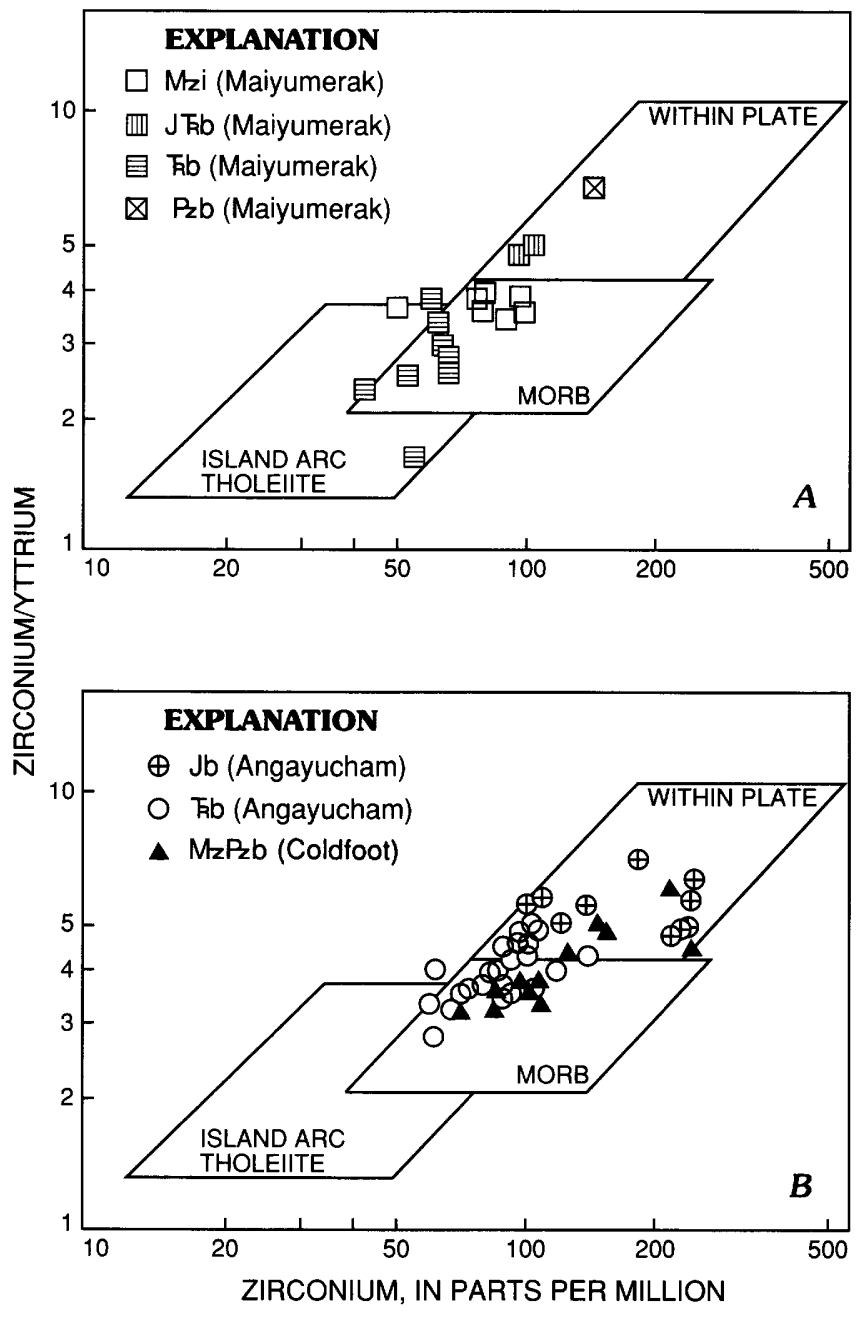

Figure 6. $\mathrm{Zr} N$ diagram of Pearce and Norry (1979). $A$, Values for Maiyumerak basalts. $B$, Values for Angayucham and Coldfoot basalts. See figure 2 for description of map units. MORB, Midocean-ridge basalt. undetermined. The basalts are structurally interleaved with limestone, chert, or argillite and wacke. The gabbro bodies and diabase dikes intrude quartzites, limestones, and cherts deposited in a continental-margin environment. Misheguk Mountain, Siniktanneyak Mountain, and other mafic-ultramafic occurrences in the northwestern Brooks Range are also floored by thrust faults and overlie continental-margin deposits of Paleozoic and Mesozoic age (Nelson and Nelson, 1982; Mayfield and others, 1988; Harris, 1989).

Available data suggest that the Maiyumerak basalts are dominantly Mesozoic in age, and the only older basalts occur as blocks in the mélange $(\mathrm{KJm})$. The Mesozoic basalts overlie Devonian limestone, indicating a missing section. At Siniktanneyak Mountain there is a fault contact between Devonian and Triassic basalts (S.W. Nelson, S.M. Karl, and B.L. Murchey, unpub. age data, 1989), a similar time gap. In the Angayucham Mountains, Paleozoic basalts overlie Paleozoic limestones, and there is no time gap in the section from the Devonian through the Jurassic (Murchey and Harris, 1985), although the section is faulted.

Most of the Brooks Range occurrences of ultramafic rocks lie in fault contact above basalt. It is unlikely that this association is fortuitous. All of the basalts lie in fault contact above continental-margin sedimentary rocks. In the Maiyumerak Mountains, basalts of unit JFb are faulted over chert, cherty limestone, limestone, tuff, argillite, and wacke. Basalts of unit Tb overlie feldsparbearing limestone. Although most contacts are faulted, the lithologic associations and field relations suggest that the two Mesozoic basalt units are independent packages. The feldspar-bearing limestones are spatially associated with other continental-margin sedimentary rocks elsewhere in the Brooks Range. In the Maiyumerak Mountains, they structurally overlie continental-margin limestone, quartzite, and chert intruded by gabbro plugs and diabase dikes. Thus, the gabbro and diabase have no apparent relation to the basalts. The gabbro and diabase are also Mesozoic or younger in age (Karl and others, 1989) and may be younger than some of the basalts.

The chemistry of the Maiyumerak basalts indicates that they are slightly enriched tholeiites, a finding that is compatible with mafic geochemical models for various types of extensional basins, rifted continental margins, or volcanic arcs (Basaltic Volcanism Study Project, 1981; Holm, 1985; Wilson, 1988). The chemical signatures of Paleozoic(?) Maiyumerak basalts, like the signatures for the Paleozoic Angayucham basalts, are contaminated and LREE enriched, which is more indicative of rift basalts.

The major-element, minor-element, and REE chemistry of the ultramafic rocks at Misheguk Mountain suggest an oceanic arc (Harris, 1988, 1989). The isotopic signature of the ultramafic rocks at Asik Mountain at the southern end of the Maiyumerak Mountains, Maiyumer- 
ak Mountain, and the Avan Hills also suggests an arc (Wirth and others, 1987, 1989). The chemistry of the basalts of unit $\mathrm{Kb}$ of this study is compatible with an arc interpretation. The chemical signature of the ultramafic rocks at Jade Mountain and the Cosmos Hills is undetermined owing to the poor condition of the rocks, but the composition and petrography of the rocks are compatible with an arc or back-arc basin setting (R.A. Loney, oral commun., 1990). This arc signature is in contrast with the ocean island/plateau signature of the Angayucham basalts (Barker and others, 1988; Pallister and others, 1989). Also, the basalts at Siniktanneyak Mountain and Copter Peak are moderately LREE enriched tholeiites with enriched-MORB to within-plate basalt affinities (Moore, 1987). Basalts at Kikitat Mountain have a flat REE pattern closer similar to normal-MORB (Moore, 1987).
There is abundant evidence for small local extensional (rift?) basins in the northwestern Brooks Range based on stratigraphy, sedimentology, volcanic compositions, and sedimentary-exhalative ore deposits in Upper Devonian to Pennsylvanian rocks (Schmidt, 1987). These sequences are characterized by deeper water sedimentary facies (carbonaceous shales and hemipelagic limestone and chert) and bimodal volcanic and volcaniclastic rocks (basaltic and rhyolitic), and they occur at even the lowest (more proximal) structural levels-for instance the sections that include the Red Dog and Drenchwater deposits. These sequences have lateral-facies associations with shallow-water carbonate and clastic rocks of the Lisburne Group, and they are overlain by deeper water pelagic cherts of the Etivluk Group. Taken as a whole, the sequences represent a subsiding continental margin.

\section{EXPLANATION}

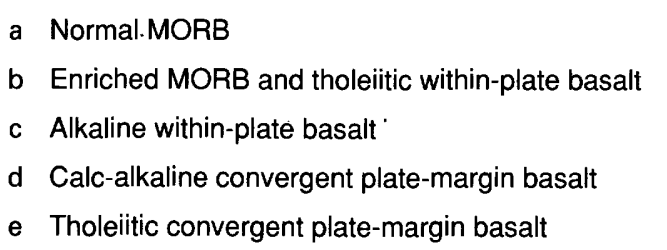

$\square$ Mzi (Maiyumerak)

四 J kb (Maiyumerak)

目 $\mathrm{kb}$ (Maiyumerak)

$\otimes$ Pzb (Maiyumerak)

$\oplus \mathrm{Jb}$ (Angayucham)

O Kb (Angayucham)

$\triangle \mathrm{MzP}_{2} b$ (Coldfoot)

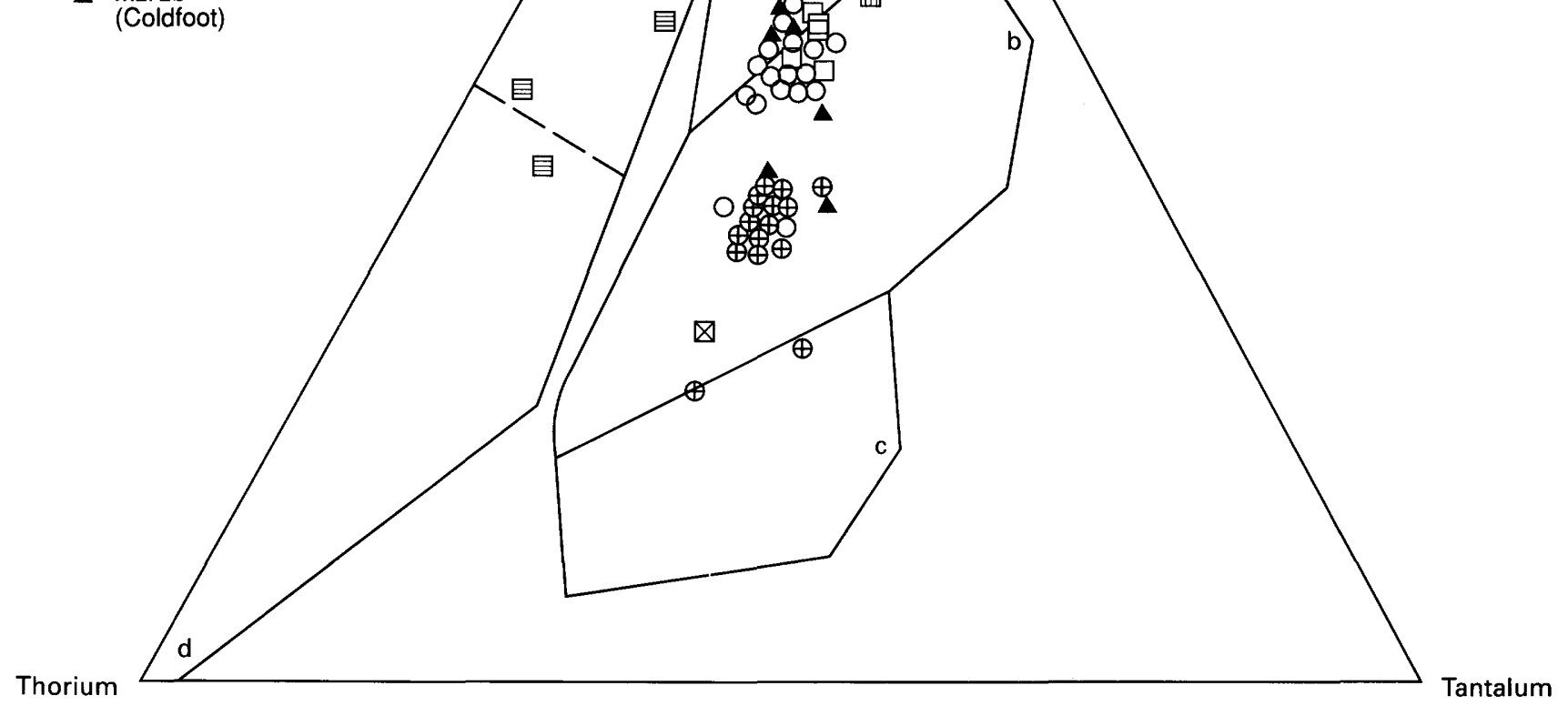

Figure 7. Hf-Th-Ta diagram of Wood (1980) for Maiyumerak, Angayucham, and Coldfoot basalts. MORB, Midoceanridge basalt 
In the allochthon model (Mayfield and others, $1983,1988)$, the mafic-ultramafic occurrences in the northwestern Brooks Range are interpreted to be fragments of the same ocean basin that is represented by the Angayucham terrane basalts (Roeder and Mull, 1978; Mull, 1982). The difficulty with this model is that there are numerous discrepancies in lithologic association, petrography, geochemistry, geophysics, and structural stacking order that make the correlation questionable, though not impossible. An alternative model, suggested here, requires neither contiguity of the Misheguk Mountain allochthon with the Angayucham terrane nor contiguity between the components of the Copter Peak and Misheguk Mountain allochtons. The mafic and ultramafic rocks of the Maiyumerak Mountains apparently represent a Mesozoic oceanic arc, as concluded by Wirth and others (1989), that overrode thinned "transitional" crust at the continental margin, which may have been composed of numerous small extensional basins of Late Devonian to Pennsylvanian age (fig. 9). Each basin had its own local sedimentary and volcanic history, resulting in slightly different chemistry and depositional sequences. The "Angayucham" basin was the largest of these basins, which is reflected by basalts containing Late Devonian, Mississippian, Pennsylvanian, Early Permian, Triassic, and Early Jurassic radioalarian assemblages
(Murchey and Harris, 1985; Jones and others, 1988) in the Angayucham terrane, whereas only Devonian and Mesozoic fossil assemblages are identified from the basalt occurrences in the northwestern Brooks Range.

The data from the Maiyumerak Mountains suggest that the Copter Peak allochthon, as defined and mapped by Mull (1982) and Mayfield and others (1988), includes basalts from more than one tectonic setting. In the Maiyumerak Mountains, the basalts mainly appear to represent a volcanic arc, with only minor remnants of overridden extensional basin basalts $\left(P_{z b}\right)$. The basalts at Avan Hills, Misheguk Mountain, Siniktanneyak Mountain, Kikitat Mountain, and Copter Peak may or may not include arc basalts in addition to the within-plate basalts reported by Moore (1987) and Harris (1989).

The gabbro plugs and diabase dikes in thrust sheets (part of the Ipnavik River allochthon of Mayfield and others, 1988) that lie below thrust sheets of the Maiyumerak basalts intrude Triassic or Jurassic and older sedimentary rocks (Karl and others, 1989). Mafic igneous activity during the Mesozoic at a consistent stratigraphic (and structural) horizon in the continentalmargin sequence may have been due to tension in the thinned and brittle continental margin that provided a plumbing system for mafic magma from below as subduction of the Angayucham basalts beneath a north-fac-

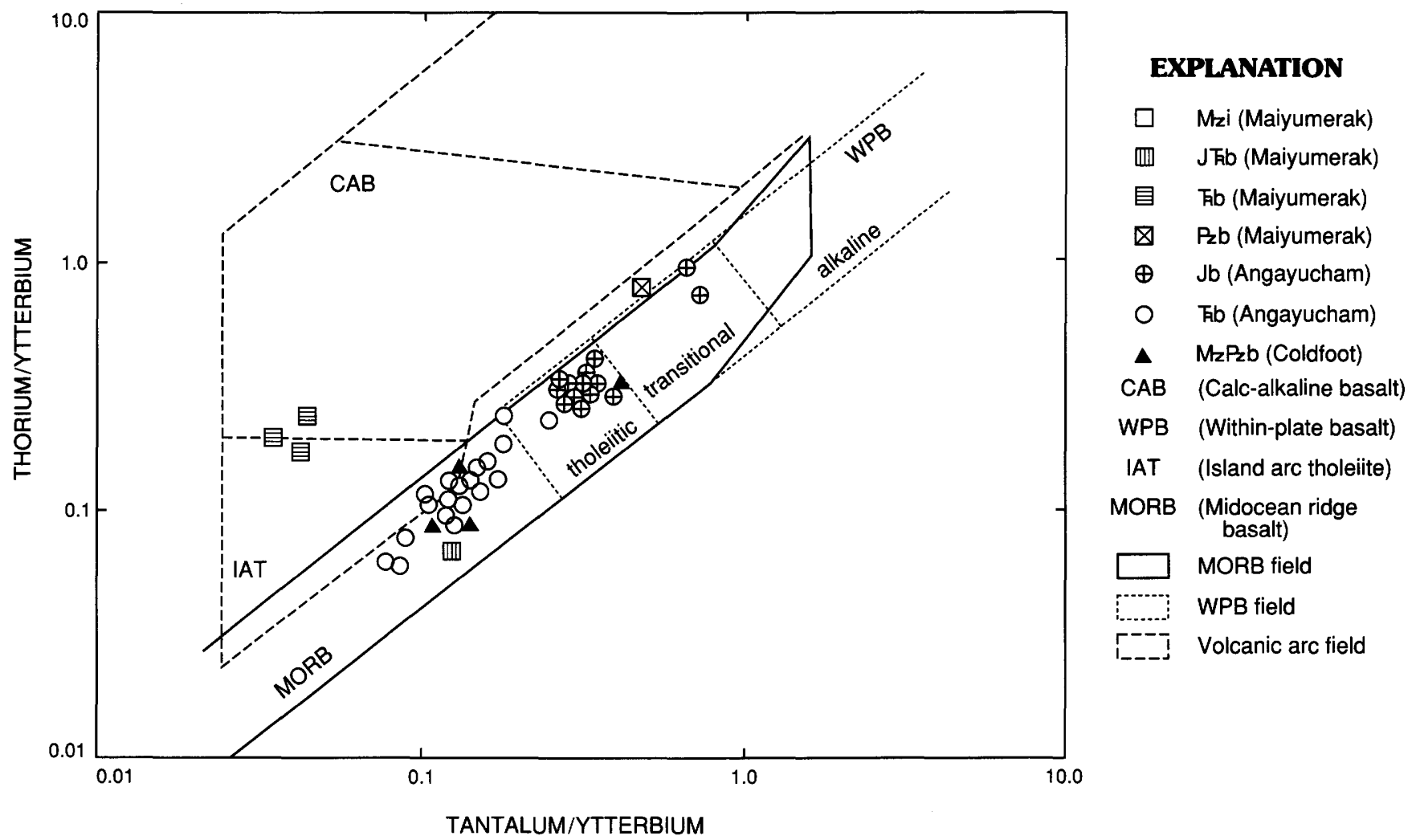

Figure 8. Th-Ta diagram of Pearce (1982) for Maiyumerak, Angayucham, and Coldfoot basalts. See figure 2 for description of map units. 
ing oceanic arc took place to the south of the continental margin (Roeder and Mull, 1978) (trench pull; see fig. 9). As subduction proceeded, the continental-margin collapsed and telescoped into the Brooks Range fold-andthrust belt in the Late Jurassic and Early Cretaceous. The Paleozoic (and Mesozoic?) basalts of the northern, independent extensional basins were imbricated with thrust sheets of continental margin sedimentary rocks at this time.

\section{CONCLUSIONS}

Triassic and Jurassic basalts of the Maiyumerak Mountains are massive to pillowed and locally contain interpillow, or interbedded, limestone, chert, volcanic breccia, conglomerate, or tuff. Their geochemical and isotopic signature suggests that they represent a volcanic arc according to Wirth and others (1989), and this interpretation is supported by the data from this report. Only a block of Paleozoic(?) basalt from the mélange structurally beneath the Triassic and Jurassic basalts has chemical affinity to within-plate or extensional basalts and some similarity to coeval basalts from the Angayucham
Mountains. The Mesozoic basalts from the Maiyumerak Mountains do not resemble the Mesozoic basalts from the Angayucham Mountains in either chemistry or lithologic association. The Angayucham basalts have withinplate and ocean-island chemistry and do not have interbedded volcaniclastic rocks. The basalts of the Maiyumerak Mountains also differ from other basalts in the northwestern Brooks range, which have been assigned to the Copter Peak allochthon by previous workers (Mull, 1982; Mayfield and others, 1988). Because the Maiyumerak basalts have more chemical affinity with the Misheguk Mountain allochthon, perhaps they should be associated with thrust sheets of that allochthon. Alternatively, the Copter Peak allochthon may include basalts from various different tectonic settings. If this is the case, "allochthon" may be an inappropriate term for the collective basalts in the northwestern Brooks Range. In addition, some of the basalts of the northwestern Brooks Range may be related to basalts of the Angayucham Mountains, whereas others are not. Until this problem can be resolved, it is suggested that the basalts of the Maiyumerak Mountains be considered separately and not assigned to either the Copter Peak allochthon or the Angayucham terrane.

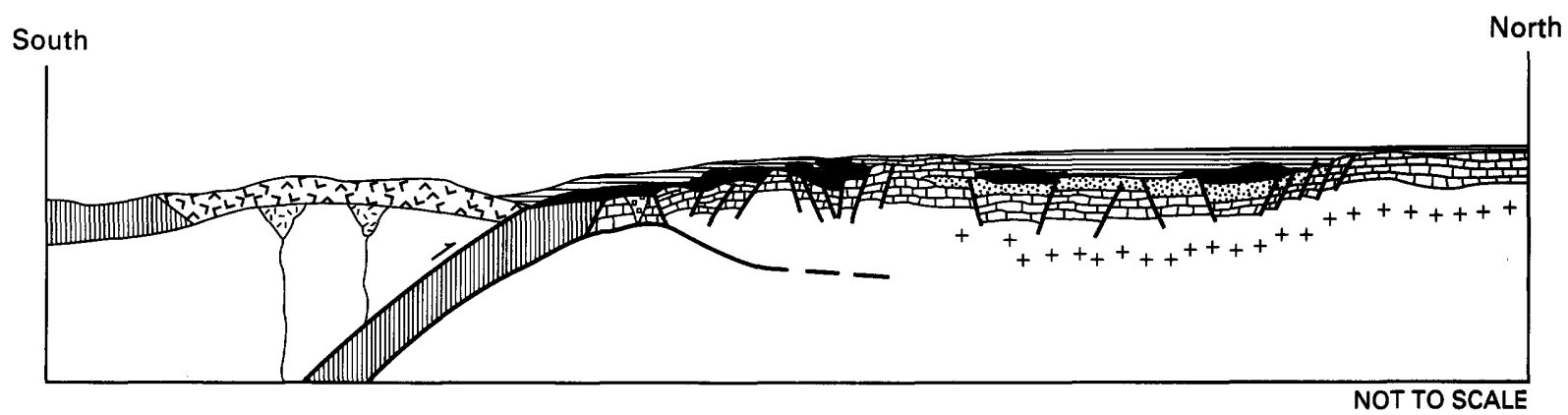

\section{EXPLANATION}
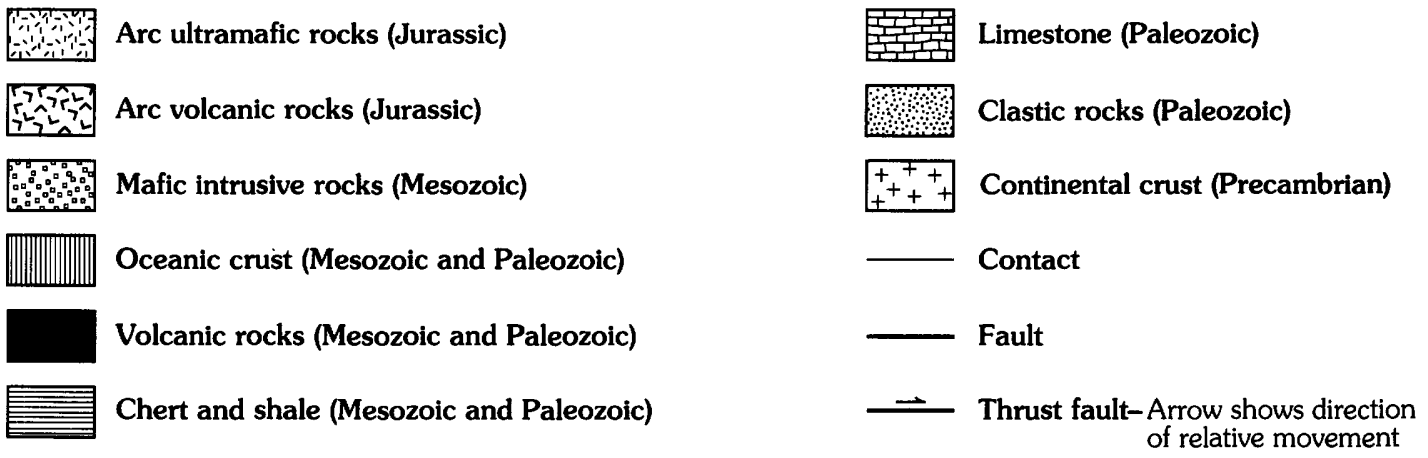

Figure 9. Hypothetical cross section depicting possible tectonic affinities of basalts from Maiyumerak Mountains during furassic. Diagram modified from Harris (1989.) 


\section{REFERENCES CITED}

Barker, Fred, Jones, D.L., Budahn, J.R., and Coney, P.J., 1988, Ocean plateau-seamount origin of basaltic rocks, Angayucham terrane, central Alaska: Journal of Geology, v. 96 , p. $368-374$.

Barnes, D.F., 1967, Four preliminary gravity maps of parts of Alaska: U.S. Geological Survey open-file report, 6 p.

Barnes, D.F., and Tailleur, I.L., 1970, Preliminary interpretation of geophysical data from the lower Noatak River basin, Alaska: U.S. Geological Survey open-file report, 15 p.

Basaltic Volcanism Study Project (Kaula, W.M., ed. chair.), 1981, Basaltic volcanism on the terrestrial planets: Pergamon Press, $469 \mathrm{p}$.

Boak, J.M., Turner, D.L., Henry, D.J., Moore, T.E., and Wallace, W.K., 1987, Petrology and K-Ar ages of the Misneguk igneous sequence-an allocthonous mafic and ultramafic complex and its metamorphic aureole, western Brooks Range, Alaska, in Tailleur, I.L., and Weimer, Paul, eds., Alaskan North Slope geology: Bakersfield, California, Pacific Section, Society of Economic Paleontologists and Mineralogists, v. 50, p. 737-745.

Curtis, S.M., Ellersieck, Inyo, Mayfield, C.F., and Tailleur, I.L., 1984, Reconnaissance geologic map of southwestern Misheguk Mountain quadrangle, Alaska: U.S. Geological Survey Miscellaneous Investigations Map I-1502, scale $1: 63,360$.

Ellersieck, Inyo, Curtis, S.M., Mayfield, C.F., and Tailleur, I.L., 1984, Reconnaissance geologic map of the south-central Misheguk Mountain quadrangle, Alaska: U.S. Geological Survey Miscellaneous Investigations Map I-1504, scale $1: 63,360$.

Harding, D.J., Wirth, K.R., Bird, J.M., and Shelton, D.H., 1985, Ophiolite emplacement, western Brooks Range, northern Alaska [abs.]: Eos (American Geophysical Union, Transactions), v. 46, no. 46, p. 1129.

Harris R.A., 1988, Origin, emplacement, and attenuation of the Misheguk Mountain allocthon, western Brooks Range, Alaska [abs.]: Geological Society of America Abstracts with Programs, v. 20, p. A112.

1989, The Brooks Range Ophiolite and its analogues: London, England, University College London, Ph.D. thesis, $460 \mathrm{p}$.

Hitzman, M.W., Profett, J.M., Jr., Schmidt, J.M., and Smith, T.E., 1986, Geology and mineralization of the Ambler district, northwestern Alaska: Economic Geology, v. 81, p. 1592-1618.

Hitzman, M.W., Smith, T.E., and Profett, J.M., Jr., 1982, Bedrock geology of the Ambler district, southwestern Brooks Range, Alaska: Alaska Division of Geological and Geophysical Surveys Geologic Report 75, scale 1:125,000, 2 sheets.

Holm, P.E., 1985, The geochemical fingerprints of different tectonomagmatic environments using hygromagmatophile element abundances of tholeiitic basalts and basaltic andesites: Chemical Geology, v. 51, p. 303-323.

Jones, D.L., Coney, P.J., Harms, T.A., and Dillon, J.T., 1988, Interpretive geologic map and supporting radiolarian data from the Angayucham terrane, Coldfoot area, southern
Brooks Range, Alaska: U.S. Geological Survey Miscellaneous Field Studies Map MF-1993, scale 1:63,360, 1 sheet.

Jones, D.L., Silberling, N.J., Coney, P.J., and Plafker, George, 1987, Lithotectonic terrane map of Alaska (west of the 141st meridian): U.S. Geological Survey Miscellaneous Field Studies Map MF-1874A, scale 1:2,500,000, 1 sheet.

Karl, S.M., and Dickey, C.F., 1987, Geology and geochemistry indicate belts of both ocean floor and arc basalt and gabbro in the Maiyumerak Mountains, northwestern Brooks Range, Alaska [abs.]: Geological Society of America Abstracts with Programs, v. 21, p. 100.

Karl, S.M., Dumoulin, J.A., Ellersieck, Inyo, Harris, A.G., and Schmidt, J.M., 1989, Preliminary geologic map of the Baird Mountains quadrangle, Alaska: U.S. Geological Survey Open-File Report 89-551, scale 1:250,000, 65 p.

Karl, S.M., and Long, D.L., 1990, Folded Brookian thrust faults: implications of three geologic/geophysical transects in the western Brooks Range: Journal of Geophysical Research, v. 95 , no. 86 , p. $8581-8592$.

Loney, R.A., and Himmelberg, G.R., 1985, Ophiolitic ultramafic rocks of the Jade Mountains-Cosmos Hills area, southwestern Brooks Range, in Bartsch-Winkler, Susan, ed., The U.S. Geological Survey in Alaska: Accomplishments during 1984: U.S. Geological Survey Circular 967, p. 13-15.

Mayfield, D.F., Tailleur, I.L., and Ellersieck, Inyo, Stratigraphy, structure and palinspastic synthesis of the western Brooks Range, northwestern Alaska: U.S. Geological Survey Open-File Report 83-779, 61 p.

1988, Stratigraphy, structure and palinspastic synthesis of the western Brooks Range, northwestern Alaska, in Gryc, George, ed., Geology and exploration of the National Petroleum Reserve in Alaska, 1974 to 1982: U.S. Geological Survey Professional Paper 1399, p. 143-186.

Moore, T.E., 1987, Geochemical and tectonic affinity of basalts from the Copter Peak and Ipnavik River allochthons, Brooks Range, Alaska [abs.]: Geological Society of America Abstracts with Programs, v. 19, p. 434.

Mull, C.G., 1982, The tectonic evolution and structural style of the Brooks Range, Alaska: an illustrated summary, in Powers, R.B., ed., Geologic studies in the Cordilleran thrust belt: Denver, Colorado, Rocky Mountain Association of Geologists, v. 1, p.1-45.

Murchey, B.L., and Harris, A.G., 1985, Devonian to Jurassic sedimentary rocks in the Angayucham Mountains of Alaska: possible seamount or oceanic plateau deposits [abs.]: Eos (American Geophysical Union, Transactions), v. 66, p. 1102 .

Nelson, S.W., and Nelson, W.H., 1982, Geology of the Siniktanneyak Mountain ophiolite, Howard Pass quadrangle, Alaska: U.S. Geological Survey Miscellaneous Field Studies Map MF-1441, scale 1:63,360.

Pallister, J.S., Budahn, J.R., and Murchey, B.L., 1989, Pillow basalts of the Angayucham terrane: oceanic plateau and island crust accreted to the Brooks Range: Journal of Geophysical Research, v. 94, p. 15,901-15,923.

Pallister, J.S., and Carlson, Christine, 1988, Bedrock geology map of the Angayucham Mountains, Alaska: U.S. Geological Survey Miscellaneous Field Studies Map MF-2024, 
scale $1: 63,360,1$ sheet.

Patton, W.W., Tailleur, I.L., Brosgé, W.P., and Lanphere, M.A., 1977, Preliminary report on the ophiolites of northern and western Alaska: Oregon Department of Geology and Mineral Industries, Bulletin 95, p. 51-57.

Pearce, J.A., 1982, Trace element characteristics of lavas from destructive plate boundries, in Thorpe, J.S., ed., Andesites: New York, John Wiley, p. 525-548.

Pearce, J.A., and Norry, M.J., 1979, Petrogenetic implications of $\mathrm{Ti}, \mathrm{Zr}, \mathrm{Y}$, and $\mathrm{Nb}$ variations in volcanic rocks; Contributions to Mineralogy and Petrology, v. 69, p. 33-47.

Roeder, Dietrich, and Mull, C.G., 1978, Tectonics of Brooks Range ophiolites, Alaska: American Association of Petroleum Geologists Bulletin, v. 62, p. 1696-1702.

Schmidt, J.M., 1987, Paleozoic extension of the western Brooks Range (WBR) continental margin-evidence from mineral deposits, igneous rocks and sedimentary facies [abs.]: Geological Society of America Abstracts with Programs, v. 19, p. 447.

Tailleur, I.L., 1973, Possible mantle-derived rocks in western Brooks Range, in Geological Survey research 1973: U.S. Geological Survey Professional Paper 850, p. 64-65.
Wilson, Marjorie, 1988, Igneous petrogenesis: Boston, Unwin Hyman, 734 p.

Wirth, K.R., Bird, J.M., and Cheatam, M.M., 1989, Geochemistry of western Brooks Range basalt, Alaska [abs.]: Geological Society of America Abstracts with Programs, v. 21 , no. 5 , p. 160-161.

Wirth, K.R., Harding, D.J., and Bird, J.M., 1987, Basalt geochemistry, Brooks Range, Alaska [abs.]: Geological Society of America Abstracts with Programs, v. 19, no. 6, p. 464.

Wirth, K.R., Harding, D.J., Blythe, A.E., and Bird, J.M., 1986, Brooks Range ophiolite crystallization and emplacement ages from ${ }^{40} \mathrm{Ar}{ }^{\beta 9} \mathrm{Ar}$ data [abs.]: Geological Society of America Abstracts with Programs, v. 18, no. 6, p. 792.

Wood, D.A., 1980, The application of a Th-Hf-Ta diagram to problems of tectonomagmatic classification and to establishing the nature of crustal contamination of basaltic lavas of the British Tertiary volcanic province; Earth and Planetary Science Letters, v. 50, p. 11-30.

Reviewers: Thomas E. Moore and Steven W. Nelson 


\title{
Geochemically Anomalous Areas in the Eastern Goodnews Bay $1^{\circ}$ by $3^{\circ}$ Quadrangle, Southwest Alaska
}

\author{
By James E. Kilburn, Stephen E. Box, Richard J. Goldfarb, and John E. Gray
}

\begin{abstract}
A followup lithogeochemical survey was carried out in the eastern Goodnews Bay quadrangle in areas targeted by an earlier stream-sediment reconnaissance survey. Significant new mineral occurrences were identified in four areas, all underlain by volcaniclastic sedimentary rocks of the Togiak terrane and spatially associated with granitic bodies. The sedimentary rocks at all four locations are strongly Fe stained, silicified, and contain abundant sulfides, both in veins and as disseminations. Arsenopyriterich quartz veins in the Rainbow basin area contain anomalous $\mathrm{Ag}, \mathrm{As}, \mathrm{Au}, \mathrm{B}, \mathrm{Bi}, \mathrm{Cu}$, and $\mathrm{Sb}$. Fe-carbonate-cemented breccia and altered argillite from Lone Mountain are anomalous in $\mathrm{Ag}, \mathrm{As}, \mathrm{Au}, \mathrm{Bi}, \mathrm{Cu}, \mathrm{Mn}$, and $\mathrm{Sb}$. In the Trail Creek area, a few kilometers north of the Kagati Lake epithermal $\mathrm{Hg}$-Sb prospect, silicified graywacke and associated quartz veins are enriched in $\mathrm{Ag}, \mathrm{As}, \mathrm{Au}, \mathrm{B}, \mathrm{Bi}$, and $\mathrm{Mn}$. Altered argillite from the Atshichlut Mountain area is anomalous in $\mathrm{Ag}, \mathrm{As}, \mathrm{Au}, \mathrm{Ba}, \mathrm{Hg}, \mathrm{Mo}, \mathrm{Pb}$, and $\mathrm{Zn}, \mathrm{a}$ slightly different element assemblage than is characteristic of the other hornfels zones. These newly discovered occurrences, as well as the few previously recognized mineral occurrences in the eastern Goodnews Bay quadrangle, are probably all small epigenetic base- and precious-metal vein systems that are genetically related to Late Cretaceous and early Tertiary igneous activity in southwest Alaska.
\end{abstract}

\section{INTRODUCTION}

Between 1975 and 1977, the U.S. Geological Survey conducted a reconnaissance geochemical survey of the Goodnews Bay quadrangle to aid in the mineral-resource appraisal of the region. Collected sample media included stream sediments and nonmagnetic heavy-mineral concentrates derived from stream sediments. A description of the sampling methods and analytical procedures, along with geochemical data and a site-locality map for these samples, is given in Cieutat and others (1988).

The reconnaissance survey delineated a number of formerly undocumented, geochemically anomalous tracts and provided new information pertinent to other known mineral occurrences (Kilburn and Jones, 1991; Jones and
Kilburn, 1991). Prominent elemental anomalies detected in the reconnaissance study collectively include $\mathrm{Ag}, \mathrm{As}$, $\mathrm{Au}, \mathrm{Bi}, \mathrm{Cr}, \mathrm{Cu}, \mathrm{Hg}, \mathrm{Mo}, \mathrm{Pb}, \mathrm{Sn}, \mathrm{W}$, and $\mathrm{Zn}$. Most anomalies except those near the well-studied Goodnews Bay and Bethel mining districts (Berg and Cobb, 1967) occur in the eastern part of the quadrangle, where only a few small $\mathrm{Hg}-, \mathrm{Cu}-$, and $\mathrm{Zn}$-bearing quartz veins and isolated $\mathrm{Au}$ placers have been reported (Eberlein and others, 1977).

During the summer of 1990 a followup study was undertaken in areas targeted by the reconnaissance in the eastern half of the Goodnews Bay quadrangle. Altered and mineralized rock samples were discovered in and collected from the most geochemically anomalous areas marked by the sediment survey (areas $1-4$; fig. 1, table 1). In addition, detailed sampling was carried out near two poorly studied known mineral occurrences. Mineralized vein samples were collected from a sphalerite-rich vein occurrence along the Togiak River (area 5; fig. 1, table 1) (Hoare and Cobb, 1977) and from $\mathrm{Hg}$-rich outcrops in the vicinity of the Ongivinuck River (area 6; fig. 1, table 1) (Coonrad and others, 1978). All rock samples taken in the 1990 study were analyzed for 35 elements using a semiquantitative emission spectrographic method described by Grimes and Marranzino (1968) and Motooka and Grimes (1976). In addition, the rocks were analyzed by more sensitive and precise techniques for specific elements of interest. These include analyses of $\mathrm{Ag}, \mathrm{As}, \mathrm{Bi}, \mathrm{Cd}, \mathrm{Cu}, \mathrm{Mo}, \mathrm{Pb}, \mathrm{Sb}$, and $\mathrm{Zn}$ using the inductively coupled plasma-atomic emission spectrographic (ICP-AES) method of Motooka (1988); $\mathrm{Hg}$ using the cold-vapor atomic absorption spectrometry (CVAAS) method of Kennedy and Crock (1987); and $\mathrm{Au}$ using the graphite furnace atomic absorption spectrometry (GFAAS) method of O'Leary and Meier (1986). The various analytical techniques used and a tabulation of the analytical results are given in Slaughter and Kilburn, (1991).

Only a few isolated lode occurrences are known in the eastern part of the Goodnews Bay quadrangle. These include (1) a base-metal (zinc-copper) occurrence in altered pillow lava just south of the Kashaiak Mountains along the 
Togiak River (Hoare and Cobb, 1977); (2) a mercury-antimony occurrence hosted in a granitoid stock of probable Tertiary age located several kilometers east of Kagati Lake near Mt. Oratia (Sainsbury and MacKevett, 1965); and (3) small copper-rich quartz veins in the Pistuk Peak-Togiak Lake region (Hoare and Cobb, 1977).

The eastern Goodnews Bay quadrangle is underlain by generally northeast-striking rocks of the Togiak tectonostratigraphic terrane (Hoare and Coonrad, 1978; Box, 1985). This terrane is characterized by a thick sequence of Lower Jurassic to Lower Cretaceous interbedded breccias, tuffs, lavas, and tuffaceous sandstones, siltstones, shales, and cherts (Hoare and Coonrad, 1978).
Intrusive rocks in the region vary considerably in age and composition. Jurassic ultramafic rocks and associated gabbros are known to the southwest of the study area (Hoare and Coonrad, 1978). Late Cretaceous to early Tertiary dioritic to granodioritic stocks are widespread. Structural features trend NE.-NNE., including the Togiak fault, a major Tertiary right-slip fault.

\section{GEOCHEMICAL RESULTS}

In this paper we discuss the most significant findings from the 1990 followup study. The discussed areas,

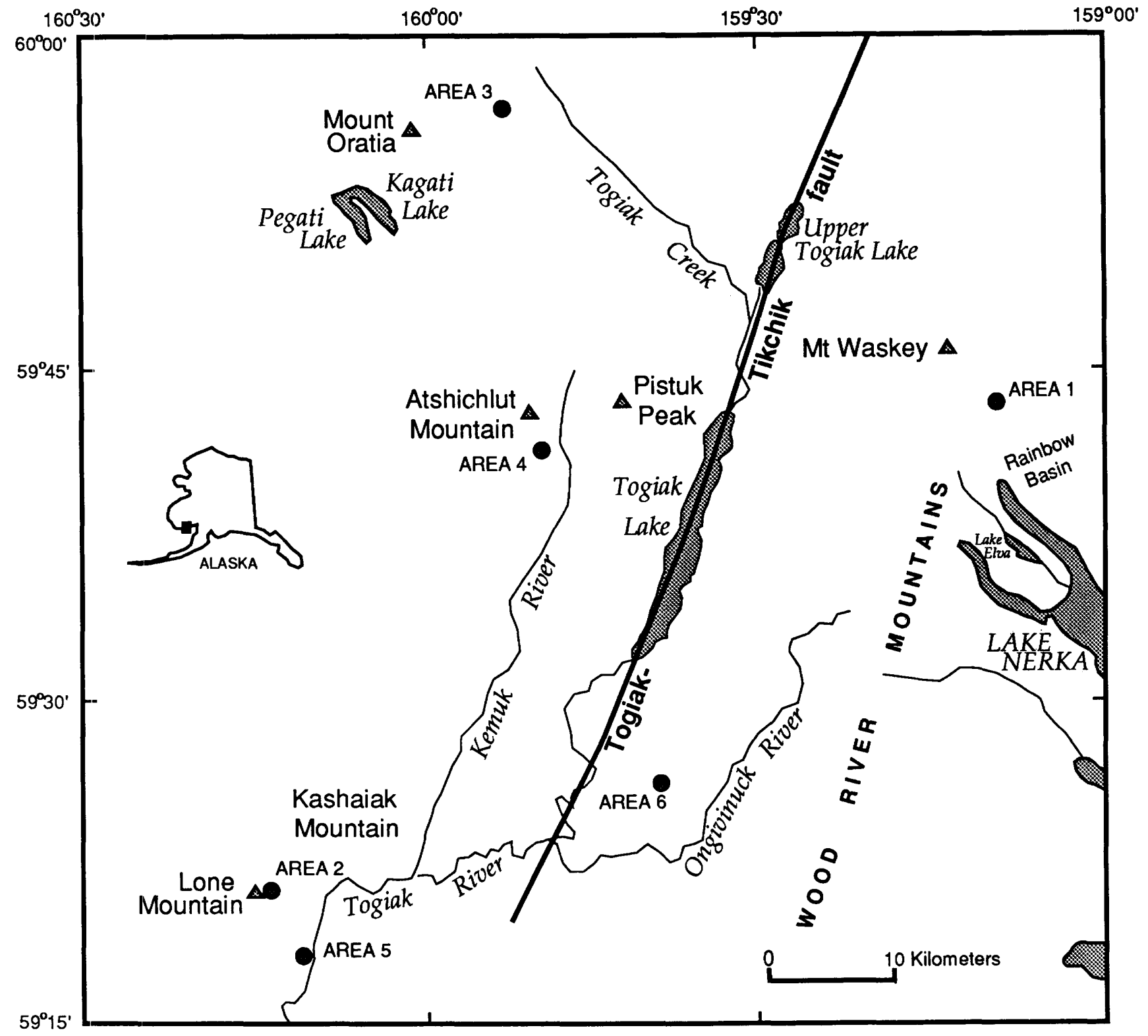

Figure 1. Geochemically anomalous area in eastern part of the Goodnews Bay quadrangle, Alaska. See table 1 for geochemical description of areas. 
Table 1. Analytical results for selected rock samples from the Goodnews quadrangle

[Analysis of $\mathrm{Ag}, \mathrm{As}, \mathrm{Bi}, \mathrm{Cd}, \mathrm{Cu}, \mathrm{Mo}, \mathrm{Pb}, \mathrm{Sb}$, and $\mathrm{Zn}$ by inductively coupled plasma-atomic emission spectrometry (ICP-AES); of $\mathrm{Au}$ and $\mathrm{Hg}$ by atomic absorption (AA); and of $\mathrm{BB}, \mathrm{Ba}, \mathrm{Cu}, \mathrm{Mn}, \mathrm{Ni}, \mathrm{Sn}$, and $\mathrm{W}$ by semiquantitative emission spectrography. All data in parts per million. $\mathrm{N}$, not detected at level shown; $L$, detected but not quantifiable; G, greater than value shown. Data source: U.S. Geological Survey Branch of.Geochemistry]

\begin{tabular}{|c|c|c|c|c|c|c|c|c|}
\hline Sample No. & Latitude & Longitude & $\mathrm{Ag}$ & As & $\mathrm{Au}$ & B & $\mathrm{Ba}$ & $\mathrm{Bi}$ \\
\hline \multicolumn{9}{|c|}{ (Area 1)-Rainbow basin region } \\
\hline 001 -...---hornfels & $59^{\circ} 43^{\prime} 05^{\prime \prime}$ & $159^{\circ} 09^{\prime} 39^{\prime \prime}$ & 0.74 & 1,000 & 0.75 & L10 & 700 & 41 \\
\hline 002------ quartz vein & $59^{\circ} 43^{\prime} 05^{\prime \prime}$ & $159^{\circ} 09^{\prime} 39^{\prime \prime}$ & 1.1 & 980 & 1.35 & 20 & 300 & 400 \\
\hline 003------.----argillite & $59^{\circ} 43^{\prime} 05^{\prime \prime}$ & $159^{\circ} 09^{\prime} 39^{\prime \prime}$ & .54 & 300 & .15 & 10 & 500 & 12 \\
\hline 101A-----punky, bleached rock & $59^{\circ} 43^{\prime} 08^{\prime \prime}$ & $159^{\circ} 09^{\prime} 29^{\prime \prime}$ & N.045 & $\mathrm{G} 3,800$ & .052 & 20 & 70 & 57 \\
\hline 101C-------argillite w/asp veinlets & $59^{\circ} 43^{\prime} 08^{\prime \prime}$ & $159^{\circ} 09^{\prime} 29^{\prime \prime}$ & N.045 & $\mathrm{G} 3,800$ & .050 & 20 & 100 & 75 \\
\hline 101D--------Fe-cemented talus & $59^{\circ} 43^{\prime} 08^{\prime \prime}$ & $159^{\circ} 09^{\prime} 29^{\prime \prime}$ & .21 & 340 & .004 & 100 & 500 & 4.3 \\
\hline 101F -------- asp veinlets & $59^{\circ} 43^{\prime} 08^{\prime \prime}$ & $159^{\circ} 09^{\prime} 29^{\prime \prime}$ & N.045 & $\mathrm{G} 3,800$ & .30 & 50 & 300 & 77 \\
\hline 300 -----.--oxidized hornfels & $59^{\circ} 43^{\prime} 46^{\prime \prime}$ & $159^{\circ} 09^{\prime} 48^{\prime \prime}$ & .39 & 2,000 & L.002 & 70 & 200 & 1.7 \\
\hline 302--.--silicified hornfels & $59^{\circ} 43^{\prime} 42^{\prime \prime}$ & $159^{\circ} 09^{\prime} 59^{\prime \prime}$ & .29 & 59 & N.002 & 200 & 1,000 & .72 \\
\hline $304--------$ qtz-asp veinlet & $59^{\circ} 43^{\prime} 43^{\prime \prime}$ & $159^{\circ} 09^{\prime} 44^{\prime \prime}$ & 1.8 & $\mathrm{G} 3,800$ & 1.40 & 1,500 & 50 & 81 \\
\hline \multicolumn{9}{|c|}{ (Area 2)-Lone Mountain } \\
\hline 026--oxidized hornfels & $59^{\circ} 21^{\prime} 49^{\prime \prime}$ & $160^{\circ} 13^{\prime} 16^{\prime \prime}$ & 1.0 & 8.8 & .008 & L10 & 70 & 26 \\
\hline 026A-------hornfels w/qtz veinlets & $59^{\circ} 21^{\prime} 49^{\prime \prime}$ & $160^{\circ} 13^{\prime} 16^{\prime \prime}$ & .14 & N.60 & .004 & N10 & 2,000 & 1.5 \\
\hline 026B-------- oxidized hornfels & $59^{\circ} 21^{\prime} 49^{\prime \prime}$ & $160^{\circ} 13^{\prime} 16^{\prime \prime}$ & .55 & 7.9 & .010 & 20 & 100 & 12 \\
\hline 026C---.-----qtz-pyrite veinlets & $59^{\circ} 21^{\prime} 49^{\prime \prime}$ & $160^{\circ} 13^{\prime} 16^{\prime \prime}$ & .19 & 11 & .008 & 15 & 200 & 1.4 \\
\hline 026D--a----oxidized hornfels & $59^{\circ} 21^{\prime} 49^{\prime \prime}$ & $160^{\circ} 13^{\prime} 16^{\prime \prime}$ & .092 & 1.2 & .004 & L10 & 1,500 & .90 \\
\hline 110A----..-Fe-carbonate breccia & $59^{\circ} 21^{\prime} 56^{\prime \prime}$ & $160^{\circ} 1436^{\prime \prime}$ & N.045 & 460 & .15 & L10 & 50 & N.60 \\
\hline 328 oxidized hornfels & $59^{\circ} 22^{\prime} 21^{\prime \prime}$ & $160^{\circ} 13^{\prime} 23^{\prime \prime}$ & .27 & N.60 & .002 & N10 & 300 & 1.8 \\
\hline 329-_.-.--Fe-stained granite & $59^{\circ} 22^{\prime} 20^{\prime \prime}$ & $160^{\circ} 13^{\prime} 38^{\prime \prime}$ & .13 & N.60 & N.002 & N10 & 1,000 & .62 \\
\hline 330--_------hornfels w/sulfide veins & $59^{\circ} 22^{\prime} 23^{\prime \prime}$ & $160^{\circ} 13^{\prime} 14^{\prime \prime}$ & .25 & N0.60 & .002 & L10 & 300 & 2.9 \\
\hline 331 -----o--oxidized hornfels & $59^{\circ} 22^{\prime} 22^{\prime \prime}$ & $160^{\circ} 13^{\prime} 05^{\prime \prime}$ & 1.2 & N.60 & .004 & L10 & 70 & 8.2 \\
\hline 332-_..--oxidized hornfels & $59^{\circ} 22^{\prime} 20^{\prime \prime}$ & $160^{\circ} 13^{\prime} 00^{\prime \prime}$ & .83 & N.60 & .008 & L10 & 20 & 9.6 \\
\hline \multicolumn{9}{|c|}{ (Area 3)-Trail Creek region } \\
\hline 319---------silicified breccia & $59^{\circ} 56^{\prime} 26^{\prime \prime}$ & $159^{\circ} 52^{\prime} 38^{\prime \prime}$ & .22 & $\mathrm{G} 3,800$ & .15 & 100 & 200 & N.60 \\
\hline 320 -----silicified hornfels & $59^{\circ} 56^{\prime} 26^{\prime \prime}$ & $159^{\circ} 52^{\prime} 38^{\prime \prime}$ & N.045 & 81 & N.002 & 150 & 500 & .88 \\
\hline 321 ---------silicified graywacke & $59^{\circ} 56^{\prime 26 "}$ & $159^{\circ} 52^{\prime} 38^{\prime \prime}$ & .13 & 56 & .002 & 50 & 300 & N.60 \\
\hline 322----------silicified homfels & $59^{\circ} 56^{\prime} 26^{\prime \prime}$ & $159^{\circ} 52^{\prime} 38^{\prime \prime}$ & N.045 & 870 & .008 & $\mathrm{G} 2,000$ & 20 & 11 \\
\hline 323 --_----.--silicified graywacke & $59^{\circ} 56^{\prime} 35^{\prime \prime}$ & $159^{\circ} 52^{\prime} 20^{\prime \prime}$ & .28 & 48 & .002 & 150 & 1,500 & N.60 \\
\hline \multicolumn{9}{|c|}{ (Area 4)-Atshichlut Mountain region } \\
\hline 333 -....----silicified argillite & $59^{\circ} 41^{\prime} 22^{\prime \prime}$ & $159^{\circ} 49^{\prime} 33^{\prime \prime}$ & 27 & 150 & .15 & N10 & G5,000 & N.60 \\
\hline 334--.------silicified argillite & $59^{\circ} 41^{\prime} 22^{\prime \prime}$ & $159^{\circ} 49^{\prime} 33^{\prime \prime}$ & 5.3 & 28 & L.002 & L10 & G5,000 & N.60 \\
\hline 335--..---silicified argillite & $59^{\circ} 41^{\prime} 22^{\prime \prime}$ & $159^{\circ} 49^{\prime} 33^{\prime \prime}$ & .39 & 1.8 & .002 & 20 & 1,000 & .63 \\
\hline 336-------Fe-stained argillite & $59^{\circ} 41^{\prime} 15^{\prime \prime}$ & $159^{\circ} 49^{\prime} 37^{\prime \prime}$ & 17 & 37 & .40 & N10 & G5,000 & N.60 \\
\hline \multicolumn{9}{|c|}{ (Area 5)-Togiak River } \\
\hline 024---------oxidized vein material & $59^{\circ} 18^{\prime} 37^{\prime \prime}$ & $160^{\circ} 09^{\prime} 56^{\prime \prime}$ & 3.0 & 13 & .35 & 20 & 300 & N.60 \\
\hline 024A----..--altered basalt & $59^{\circ} 18^{\prime} 37^{\prime \prime}$ & $160^{\circ} 09^{\prime} 56^{\prime \prime}$ & 1.3 & 110 & .20 & 50 & 200 & N.60 \\
\hline 024B--------oxidized vein material & $59^{\circ} 18^{\prime} 37^{\prime \prime}$ & $160^{\circ} 09^{\prime} 56^{\prime \prime}$ & .95 & 10 & L.002 & 20 & 500 & N.60 \\
\hline \multicolumn{9}{|c|}{ (Area 6)-Ongivinuck River } \\
\hline 338 ----------- altered diorite & $59^{\circ} 26^{\prime} 34^{\prime \prime}$ & $159^{\circ} 39^{\prime} 28^{\prime \prime}$ & .093 & 8.3 & L.002 & 50 & 500 & N.60 \\
\hline 029-_----mafic dike & $59^{\circ} 26^{\prime} 53^{\prime \prime}$ & $159^{\circ} 38^{\prime} 52^{\prime \prime}$ & N.045 & 4.9 & N.002 & 20 & 1,000 & N.60 \\
\hline 029A--------- quartz vein & $59^{\circ} 26^{\prime} 53^{\prime \prime}$ & $159^{\circ} 38^{\prime} 52^{\prime \prime}$ & .23 & 1,100 & .25 & 300 & 200 & N. 60 \\
\hline
\end{tabular}


Table 1. Analytical results for selected rock samples from the Goodnews quadrangle-Continued

[Analysis of $\mathrm{Ag}, \mathrm{As}, \mathrm{Bi}, \mathrm{Cd}, \mathrm{Cu}, \mathrm{Mo}, \mathrm{Pb}, \mathrm{Sb}$, and $\mathrm{Zn}$ by inductively coupled plasma-atomic emission spectrometry (ICP-AES); of $\mathrm{Au}$ and $\mathrm{Hg}$ by atomic absorption (AA); and of $\mathrm{BB}, \mathrm{Ba}, \mathrm{Cu}, \mathrm{Mn}, \mathrm{Ni}, \mathrm{Sn}$, and $\mathrm{W}$ by semiquantitative emission spectrography. All data in parts per million. $\mathrm{N}$, not detected at level shown; L, detected but not quantifiable; G, greater than value shown. Data source: U.S. Geological Survey Branch of Geochemistry]

\begin{tabular}{|c|c|c|c|c|c|c|c|c|c|c|c|c|}
\hline Sample No. & $C d$ & $\mathrm{Cr}$ & $\mathrm{Cu}$ & $\mathrm{Hg}$ & $M n$ & Mo & $\mathrm{Ni}$ & $\mathrm{Pb}$ & $\mathrm{Sb}$ & Sn & $w$ & $\mathrm{Zn}$ \\
\hline \multicolumn{13}{|c|}{ (Area 1)-Rainbow basin region } \\
\hline 001 -............ & 0.067 & 30 & 180 & N0.20 & 1,500 & 2.4 & 70 & 2.9 & 1.2 & L10 & $\mathrm{N} 20$ & 33 \\
\hline 002-------- & .063 & L10 & 56 & N.20 & 500 & 4.3 & 303 & 6.0 & 10 & $\mathrm{~N} 10$ & $\mathrm{~N} 20$ & 18 \\
\hline 003-- & .084 & 15 & 160 & .20 & 700 & 21.0 & 70 & 1.3 & 1.9 & N10 & $\mathrm{N} 20$ & 25 \\
\hline $101 \mathrm{~A}$ & N.030 & $\mathrm{N} 10$ & 780 & N.02 & 100 & .50 & L5 & 5.7 & 64 & N10 & $\mathrm{N} 20$ & N.030 \\
\hline 101C---.-..- & N.030 & L10 & 630 & N.02 & 1,000 & N.090 & 100 & 7.1 & 3.0 & 15 & $\mathrm{~N} 20$ & 4.9 \\
\hline 101D-_------ & .67 & 30 & 64 & N.02 & G5,000 & 1.4 & 20 & 3.6 & 1.7 & N10 & $\mathrm{N} 20$ & 87 \\
\hline 101F ------- & N.030 & N10 & 11 & $\mathrm{~N}: 02$ & 200 & 2.3 & L5 & 2.4 & N.60 & N10 & $\mathrm{N} 20$ & 4.0 \\
\hline 300--.-.-- & N.030 & $\mathrm{N} 10$ & 150 & N.02 & 500 & .65 & N5 & 14 & 10 & 20 & $\mathrm{~N} 20$ & 7.4 \\
\hline 302-..-.-.- & .53 & 20 & 61 & .02 & 3,000 & .37 & 100 & 4.5 & 6.3 & N10 & $\mathrm{N} 20$ & 91 \\
\hline 304--------- & 3.2 & N10 & 2.0 & N.02 & 1,000 & N.090 & 50 & 2.5 & 58 & N10 & $\mathrm{N} 20$ & N.030 \\
\hline \multicolumn{13}{|c|}{ (Area 2)-Lone Mountain } \\
\hline 026 & .13 & N10 & 900 & .02 & 700 & 7.2 & 10 & 5.4 & 1.8 & 30 & L20 & 16 \\
\hline 026A--.---.-- & .069 & 50 & 130 & N.02 & 1,000 & .41 & 50 & 2.4 & .78 & N10 & $\mathrm{N} 20$ & 48 \\
\hline 026B & .22 & N10 & 200 & .02 & 1,000 & 5.5 & 10 & 4.7 & 1.0 & 20 & 30 & 41 \\
\hline 026C & 1.2 & 50 & 160 & .02 & 1,000 & .44 & 30 & 3.1 & N.60 & N10 & $\mathrm{N} 20$ & 91 \\
\hline 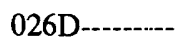 & .15 & 70 & 120 & N.02 & 1,500 & .32 & 20 & 2.0 & N.60 & N10 & $\mathrm{N} 20$ & 44 \\
\hline $110 \mathrm{~A}$ & N.030 & $\mathrm{N} 10$ & 16 & 1.9 & 1,500 & .17 & L5 & 3.8 & 11 & N10 & $\mathrm{N} 20$ & 25 \\
\hline 328 & .043 & 70 & 340 & N.02 & $\mathrm{G} 5,000$ & .16 & 30 & 2.2 & .77 & N10 & $\mathrm{N} 20$ & 44 \\
\hline 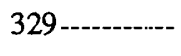 & .11 & 15 & 170 & N.02 & 150 & .48 & 5 & 9.0 & N.60 & N10 & $\mathrm{N} 20$ & 11 \\
\hline 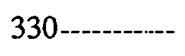 & .041 & 70 & 330 & N.02 & $\mathrm{G} 5,000$ & .29 & 20 & 1.8 & .86 & $\mathrm{~N} 10$ & $\mathrm{~N} 20$ & 31 \\
\hline 331 & .20 & 20 & 670 & N.02 & 1,000 & .13 & 50 & 7.3 & 2.3 & $\mathrm{~N} 10$ & $\mathrm{~N} 20$ & 17 \\
\hline 332 & .19 & L10 & 520 & N.02 & 500 & .16 & 70 & 3.0 & 1.4 & $\mathrm{~N} 10$ & 50 & 12 \\
\hline \multicolumn{13}{|c|}{ (Area 3)-Trail Creek region } \\
\hline 319--.----.--- & N.030 & N10 & 6.2 & .02 & 150 & .40 & 65 & 59 & 5.4 & N10 & $\mathrm{N} 20$ & 1.1 \\
\hline 320 & N.030 & 20 & 13 & N.02 & 100 & 4.3 & L5 & 7.8 & 3.9 & N10 & $\mathrm{N} 20$ & 1.8 \\
\hline 321 - & .13 & 20 & 130 & N.02 & $\mathrm{G} 5,000$ & .78 & 150 & 5.2 & 5.4 & N10 & $\mathrm{N} 20$ & 75 \\
\hline $322-----$ & .12 & 30 & 7.6 & .02 & 200 & 1.0 & 50 & 4.6 & 2.4 & $\mathrm{~N} 10$ & $\mathrm{~N} 20$ & 6.2 \\
\hline 323 & 2.0 & 30 & 65 & N.02 & 1,000 & .88 & 100 & 9.7 & 4.6 & $\mathrm{~N} 10$ & $\mathrm{~N} 20$ & 230 \\
\hline \multicolumn{13}{|c|}{ (Area 4)-Atshichlut Mountain region } \\
\hline 333-......... & .71 & 10 & 150 & .84 & 150 & 2.4 & 7 & 310 & 3.5 & N10 & $\mathrm{N} 20$ & 69 \\
\hline 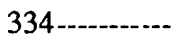 & N.030 & 50 & 31 & .60 & 150 & 27 & N5 & 77 & 1.6 & N10 & $\mathrm{N} 20$ & 66 \\
\hline 335 -......--- & .13 & 30 & 170 & .04 & 300 & 52 & 15 & 65 & 2.2 & N10 & $\mathrm{N} 20$ & 95 \\
\hline 336--------- & 2.2 & 50 & 37 & 1.8 & 150 & 18 & 20 & 240 & 5.0 & N10 & $\mathrm{N} 20$ & 570 \\
\hline \multicolumn{13}{|c|}{ (Area 5)-Togiak River } \\
\hline $024-\cdots-3$ & & 70 & 510 & 10.4 & $\mathrm{G} 5,000$ & 3.5 & 15 & 28 & 1.2 & N10 & $\mathrm{N} 20$ & $\mathrm{G} 1,400$ \\
\hline 024A-......- & 4.7 & 100 & 31 & 1.1 & 1,000 & 1.9 & 5 & 50 & 1.4 & N10 & N20 & 700 \\
\hline 024B & .33 & 15 & 120 & .06 & G5,000 & 6.8 & 20 & 37 & 1.1 & N10 & N20 & 97 \\
\hline \multicolumn{13}{|c|}{ (Area 6)-Ongivinuck River } \\
\hline 338--------- & .17 & 150 & 29 & .82 & 1,000 & .24 & 70 & 17 & N.60 & N10 & $\mathrm{N} 20$ & 61 \\
\hline 029 & .13 & 500 & 38 & 13.4 & 1,000 & .61 & 200 & 7.9 & 9.1 & N10 & $\mathrm{N} 20$ & 52 \\
\hline 029A- & .054 & 500 & 36 & 1.4 & 1,000 & 2.5 & 150 & 10 & 60 & N10 & $\mathrm{N} 20$ & 48 \\
\hline
\end{tabular}


shown on figure 1 and listed in table 1 , are numbered 1 through 6. Although these areas have distinctive geochemical signatures and geologic features, they are similar in several important respects. All the areas are underlain by Jurassic and Early Cretaceous volcanic and volcaniclastic sedimentary rocks of the Togiak terrane and, with the exception of area 5 (Togiak River), are spatially associated with Cretaceous and Tertiary stocks of intermediate composition. Additionally, all areas except area 5 are characterized by distinct, generally pervasive Fe staining.

The Rainbow basin area (area 1) is located near the eastern border of the Goodnews Bay quadrangle between Lake Nerka and Mt. Waskey. Stream-sediment and nonmagnetic heavy-mineral concentrate samples collected in this area during the reconnaissance survey of the region were anomalous in $\mathrm{Ag}, \mathrm{As}, \mathrm{Au}, \mathrm{Bi}, \mathrm{Cu}, \mathrm{Mo}, \mathrm{Pb}, \mathrm{Sb}, \mathrm{Sn}$, $\mathrm{W}$, and (or) $\mathrm{Zn}$. There is little record of prospecting in this part of the quadrangle, although small quantities of placer gold were reported in streams entering Lake Elva and in creeks that drain the ridge on the southwest side of Sunshine Valley (Hoare and Cobb, 1977) some 10 and $25 \mathrm{~km}$, respectively, south of Rainbow basin. In addition, placer gold and a solitary occurrence of molybdenite are reported several kilometers to the east in the adjacent Dillingham quadrangle (Eberlein and others, 1977). Rock samples were collected at the head of a glacial valley roughly $3 \mathrm{~km}$ northwest of Rainbow basin. Fe-stained and hornfelsed argillite at the upper part of the basin form a prominent halo above and around a highly oxidized granitic stock exposed in the cirque basin floor. Quartz veins with sulfides up to $50 \mathrm{~mm}$ in thickness as well as disseminated sulfides were noted in the hornfelsed aureole. In places, the mineralized veins are cut by $30-$ to $90-\mathrm{cm}$-wide felsic dikes. Samples of quartz-arsenopyrite-pyrite veins and stockworks in granite and silicified and hornfelsed argillite collectively contain concentrations of up to $1.8 \mathrm{ppm} \mathrm{Ag},>3,800 \mathrm{ppm}$ As, $1.4 \mathrm{ppm} \mathrm{Au}, 1,500 \mathrm{ppm} \mathrm{B}, 400 \mathrm{ppm} \mathrm{Bi}, 780 \mathrm{ppm}$ $\mathrm{Cu}, 21 \mathrm{ppm} \mathrm{Mo,} 303 \mathrm{ppm} \mathrm{Ni}, 64 \mathrm{ppm} \mathrm{Sb}$, and $20 \mathrm{ppm}$ Sn (table 1).

Lone Mountain (area 2) is located several kilometers southwest of the Kashaiak Mountains near the west bank of the Togiak River. Geochemical anomalies of As, $\mathrm{Bi}, \mathrm{Cu}, \mathrm{Pb}, \mathrm{Mo}, \mathrm{W}$, or $\mathrm{Zn}$ were detected in sediment and concentrate samples collected in the area. Rock samples were collected on the east side of Lone Mountain at an area marked by conspicuous Fe-stained hornfels surrounding an equally oxidized felsic stock. The hornfels contains disseminated pyrite and small quartz-pyrite veinlets. In places, the hornfels has been weathered to gossan. Quartz veins (up to $12 \mathrm{~mm}$ in width) also were found within the intrusive stock near the contact with the altered sedimentary units. An Fe-carbonate-cemented breccia composed of sedimentary clastic material was collected from float located $30 \mathrm{~m}$ from the intrusive contact. This sample contained $460 \mathrm{ppm} \mathrm{As,} 0.15 \mathrm{ppm} \mathrm{Au}$, $1.9 \mathrm{ppm} \mathrm{Hg}$, and $11 \mathrm{ppm} \mathrm{Sb}$. Concentrations of up to 1.2 ppm Ag, 0.01 ppm Au, 26 ppm Bi, 900 ppm Cu, >5,000 ppm Mn, $7.2 \mathrm{ppm} \mathrm{Mo,} 30 \mathrm{ppm} \mathrm{Sn,} \mathrm{and} 50 \mathrm{ppm}$ W were determined in outcrop samples of Fe-stained hornfels containing thin sulfide-bearing veinlets.

Area 3 (Trail Creek) is roughly $11 \mathrm{~km}$ northeast of Kagati Lake near the northern limit of the Goodnews Bay quadrangle. The only documented mineral occurrence in the immediate region is the Kagati Lake mercury prospect $3 \mathrm{~km}$ to the south. It consists of small mineralized veins and fractures that cut a quartz monzonite stock of probable Tertiary age. Ore minerals include cinnabar, realgar, stibnite, and subordinate amounts of orpiment and secondary antimony minerals (Sainsbury and MacKevett, 1965). Geochemical anomalies occur for As, $\mathrm{Au}, \mathrm{Cu}$, and $\mathrm{Mo}$ in stream-sediment samples taken from an unnamed drainage northeast of the divide between area 3 and the Kagati Lake deposit and which flows northeast into Trail Creek. In addition, significant Ag, $\mathrm{Cu}, \mathrm{Pb}, \mathrm{Sb}$, and $\mathrm{Zn}$ anomalies occur in a concentrate sample collected about a kilometer south of the Trail Creek tributary. Exposed graywacke is commonly highly silicified and $\mathrm{Fe}$ stained, both along the ridge above and at stream level close to the head of the Trail Creek tributary. Clay alteration and weakly disseminated pyrite characterize some of the Fe-stained outcrops. Thin quartz veinlets were observed to contain pyrite, arsenopyrite, and tourmaline. Samples for geochemical analysis were collected near the contact between a granitoid stock and associated hornfels. Silicified sedimentary rock samples have concentrations of up to $0.28 \mathrm{ppm} \mathrm{Ag},>3,800$ ppm As, 0.15 ppm Au, >2,000 ppm B, 11 ppm Bi, $>5,000 \mathrm{ppm} \mathrm{Mn,} 5.4 \mathrm{ppm} \mathrm{Sb}$, and $230 \mathrm{ppm} \mathrm{Zn}$.

Area 4 (Atshichlut Mountain) is situated on the west side of the Kemuk River, several kilometers south of Atshichlut Mountain in the east-central part of the Goodnews Bay quadrangle. Area 4 is part of a large area near Pistuk Peak and Togiak Lake that contains streamsediment copper anomalies. The distribution of samples containing anomalous $\mathrm{Cu}$ defines a large discontinuous belt that encircles the Late Cretaceous Pistuk Peak quartz monzonite stock and related hornfels zone west of Togiak Lake. Hoare and Cobb (1977) report two known copper-mineral occurrences within this region: (1) chalcopyrite and malachite in a small quartz vein within the centrally placed granitoid stock, near the contact with hornfelsed sediments; and (2) traces of copper minerals in a large north-trending fault zone cutting fine-grained tuff and tuffaceous sedimentary rocks. Anomalous rock samples were collected from large debris fans to the west of the Pistuk Peak stock near the head of a steep, Fe-stained drainage basin. These fans contained blocks of volcanic sandstone and Fe-stained, strongly bleached, 
highly silicified argillite. Milky quartz veins, disseminated pyrite, and thin pyrite veinlets occur within the argillite. The altered argillite contains up to $27 \mathrm{ppm} \mathrm{Ag}, 150$ ppm As, 0.40 ppm Au, >5,000 ppm Ba, 1.8 ppm Hg, 52 ppm Mo $310 \mathrm{ppm} \mathrm{Pb}$, and $570 \mathrm{ppm} \mathrm{Zn}$. The highly anomalouls $\mathrm{Ag}, \mathrm{Ba}, \mathrm{Mo}$, and $\mathrm{Pb}$ values from this area differ notably from anomalous element signatures from the other areas described in the eastern Goodnews Bay quadrangle.

Area 5 (Togiak River) is located approximately 6 $\mathrm{km}$ southeast of Lone Mountain on the west bank of the Togiak River. Mineralized rocks in the area consist of a 30- to 40-cm-thick quartz vein, exposed for $7 \mathrm{~m}$ in altered pillow lava. About 30 percent of the vein consists of nearly black, coarsely crystalline sphalerite with minor amounts of pyrite and chalcopyrite (Berg and Cobb, 1967). Samples from oxidized sphalerite-rich vein material and nearby oxidized, bleached volcanic rocks (basalt?) contain elemental concentrations of up to $3 \mathrm{ppm}$ $\mathrm{Ag}, 110 \mathrm{ppm}$ As, $0.35 \mathrm{ppm} \mathrm{Au}, 390 \mathrm{ppm} \mathrm{Cd}, 510 \mathrm{ppm}$ $\mathrm{Cu}, 10.4 \mathrm{ppm} \mathrm{Hg},>5,000 \mathrm{ppm} \mathrm{Mn}, 6.8 \mathrm{ppm} \mathrm{Mo}$, and $>1,400 \mathrm{ppm} \mathrm{Zn}$. Despite the massive sphalerite, anomalous $\mathrm{As}, \mathrm{Sb}$, and $\mathrm{Hg}$ values are suggestive of epigenetic mineralization similar to other areas in the eastern Goodnews Bay quadrangle.

The Ongivinuck River area (area 6) is situated between the Togiak River and the Ongivinuck River basins, about $8 \mathrm{~km}$ south of Togiak Lake. Samples of diorite and hornfelsed sediment collected in area 6 in a prior stucly (Coonrad and others, 1978) were highly enriched in mercury. A sample of sheared diorite contained $>10 \mathrm{ppm} \mathrm{Hg}$. Samples collected during this followup study included small quartz veinlets within and parallel to an altered mafic dike that cuts the diorite stock. The veinlets contained up to $0.23 \mathrm{ppm} \mathrm{Ag}, 1,100 \mathrm{ppm} \mathrm{As}$, $0.25 \mathrm{ppm} \mathrm{Au}, 500 \mathrm{ppm} \mathrm{Cr}, 1.4 \mathrm{ppm} \mathrm{Hg}$, and $60 \mathrm{ppm} \mathrm{Sb}$, while the host dike contained $13.4 \mathrm{ppm} \mathrm{Hg}$, and 500 ppm Cr.

\section{SUMMARY}

A distinct spatial relationship exists between the observed mineral occurrences (with the exception of area 5 ) and the highly oxidized sedimentary rocks in the vicinity of granitic intrusions. Although mineralized veins are generally small and discontinuous, they are the basis for significant rock anomalies and probably account for many of the regional stream-sediment geochemical anomalies. Altered and oxide-stained sedimentary rocks and associated granitic stocks examined in this study were first noted in the region by Mertie (1938) and are geochemically similar to the "red spots" discussed by Frost (1990) in the Bethel quadrangle to the north. "Red spots" are described as oxidized pyrite-bearing rhyolite dikes and sulfide-rich quartz veins that occur as dike/ vein networks hosted in volcanic, volcaniclastic, and sedimentary rocks of the Togiak and Tikchik terranes in the southeastern part of the Bethel quadrangle. Felsic dikes were not normally observed in our study of specific areas in the eastern Goodnews Bay quadrangle, but the dike/vein systems described by Frost (1990) bear a collective trace-element signature $(\mathrm{Ag}, \mathrm{As}, \mathrm{Au}, \mathrm{Cu}, \mathrm{Hg}$, $\mathrm{Mo}, \mathrm{Pb}, \mathrm{Sb}$, and $\mathrm{W}$ ) that is nearly identical to those of the rock and sediment anomalies found in the eastern half of the Goodnews Bay quadrangle. Additional studies are required to determine the extent and significance of the mineralization.

\section{REFERENCES CITED}

Berg, H.C., and Cobb, E.H., 1967, Metalliferous lode deposits of Alaska: U.S. Geological Survey Bulletin 1246, 254 p.

Box, S.E., 1985, Terrane analysis of the northern Bristol Bay region, southwestern Alaska, in Bartsch-Winkler, Susan, ed., The U.S. Geological Survey in Alaska: Accomplishments during 1984: U.S. Geological Survey Circular 967, p. 32-37.

Cieutat, B.A., Goldfarb, R.J., and Speckman, W.S., 1988, Analytical results and sample locality map of stream-sediment, heavy-mineral concentrate, and organic material samples from the Goodnews, Hagemeister Island, and Nushagak Bay quadrangles, southwest Alaska: U.S. Geological Survey Open-File Report 88-591, 187 p.

Coonrad, W.L., Hoare, J.M., Taufen, P.M., and Hessin, T.D., 1978, Geochemical analysis of rock samples in the Goodnews and Hagemeister Island quadrangles region, southwestern Alaska: U.S. Geological Survey Open-File Report 78-9-H, scale 1:250,000.

Eberlein, G.D., Chapman, R.M., Foster, H.L., and Gassaway J.S., 1977, Table describing known metalliferous and selected nonmetalliferous mineral deposits in central Alaska: U.S. Geological Survey Open-File Map 77-168D, scale $1: 1,000,000$

Frost, T.P., 1990, Geology and geochemistry of mineralization in the Bethel quadrangle, southwestern Alaska, in Goldfarb, R.J., Nash, J.T., and Stoeser, J.W., eds, Geochemical studies in Alaska by the U.S. Geological Survey, 1989: U.S. Geological Survey Bulletin 1950, p. C1-C9.

Grimes, D.J., and Marranzino, A.P., 1968, Direct-current arc and alternating current spark emission spectrographic field methods for the semiquantitative analysis of geologic materials: U.S. Geological Survey Circular 591, 6 p.

Hoare, J.M., and Cobb, E.H., 1977, Mineral occurrences (other than mineral fuels and construction materials) in the Bethel, Goodnews, and Russian Mission quadrangles, Alaska: U.S. Geological Survey Open-File Report 77-156, $98 \mathrm{p}$.

Hoare, J.M., and Coonrad, W.L., 1978, Geologic map of the Goodnews and Hagemeister Island quadrangles region, southwestern Alaska: U.S. Geological Survey Open-File Report 78-9-B, scale 1:250,000. 
Jones, J.L., and Kilburn J.E., 1991, Geochemical maps showing the distribution of selected elements determined in heavy-mineral-concentrate samples from the Goodnews Bay, Hagemeister Island, and Nushagak Bay quadrangles, southwest Alaska: U.S. Geological Survey Miscellaneous Field Studies Map, scale 1:250,000, [in press].

Kennedy, K.R., and Crock, J.G., 1987, Determination of mercury in geological materials by continuous-flow, cold-vapor, atomic absorption spectrophotometry: Analytical Letters, v. 20 , p. $899-908$.

Kilburn, J.E., and Jones, J.L., 1991, Geochemical map showing the distribution of selected elements determined in stream sediments from the Goodnews Bay, Hagemeister Island, and Nushagak Bay quadrangles, Alaska: U.S. Geological Survey Miscellaneous Field Studies Map, scale 1:250,000, [in press].

Mertie, J.B., 1938, The Nushagak District, Alaska: U.S. Geological Survey Bulletin 903, p. 75-91.

Motooka, J.M. 1988, An exploration geochemical technique for the determination of preconcentrated organometallic halides by ICP-AES: Applied Spectroscopy, v. 42, no. 7, p. 1293-1296.

Motooka, J.M., and Grimes, D.J., 1976, Analytical precision of one-sixth order semiquantitative spectrographic analysis: U.S. Geological Survey Circular 738, 25 p.

O'Leary, R.M., and Meier, A.L., 1986, Analytical methods used in geochemical exploration, 1984: U.S. Geological Survey Circular 948, 48 p.

Sainsbury, C.L., and MacKevett, E.M., 1965, Quicksilver deposits of southwestern Alaska: U.S. Geological Survey Bulletin 1187, 89 p.

Slaughter, K.E., Kilburn, J.E., and Adrian, B.M., 1991, Analytical results and sample locality map of rock samples from the eastern Goodnews Bay quadrangle, southwest Alaska: U.S. Geological Survey Open-File Report [in press].

Reviewers: Karen Duttweiler Kelley and Richard M. O'Leary 


\title{
Early Middle Miocene Mollusks and Benthic Foraminifers From Kodiak Island, Alaska
}

\author{
By Louie Marincovich, Jr. and Shigehiro Moriya
}

\begin{abstract}
The type Narrow Cape Formation on Kodiak Island is of early middle Miocene age (16 to $15 \mathrm{Ma}$ ), based on the presence of mollusk species known in well-dated faunas in eastern Asia and western North America. Mollusks and benthic foraminifers suggest a cold-temperate paleoclimate at shelf depths. The presence of some deep-water foraminifers may be due to regional cooling that caused upslope migration or to changed depth tolerances compared with modern analogues. The presence of warm-temperate to tropical mollusks at some horizons permits correlations with faunas at lower latitudes. These warm-water mollusks imply that extensive but brief incursions of warm water extended into the western Gulf of Alaska during the early middle Miocene.
\end{abstract}

\section{INTRODUCTION}

The type Narrow Cape Formation (Moore, 1969) crops out at Narrow Cape, along the southeastern margin of Kodiak Island, western Gulf of Alaska (fig. 1). The formation is broadly folded into a northeast-trending syncline that is well exposed in sheer coastal cliffs. Nearly the entire stratigraphic sequence crops out in both limbs of the syncline along the coast extending northwestward from Narrow Cape, and the lower to middle parts of the formation crop out along the coast northeast of the cape (fig. 1). The Narrow Cape is mainly composed of sandstone and sandy siltstone, with interbedded conglomerate beds in its lower and middle parts. It is in fault contact with Paleocene basement rocks to the northwest and overlies the Sitkalidak Formation of Eocene age to the southeast with angular unconformity (fig. 1; Moore, 1967, 1969; Clendenen and others, 1991). When originally described, the formation was thought to be about $700 \mathrm{~m}$ thick (Moore 1969), but it is now known to be approximately $570 \mathrm{~m}$ thick, based on recent field investigations by the authors and H.E. Clifton.

Mollusks and benthic foraminifers are abundantly present in the type Narrow Cape Formation. These faunas and associated sedimentary facies indicate that most strata were deposited under shallow-marine conditions.
The molluscan fauna contains both western North American and eastern Asian taxa (Allison, 1978) that permit correlations with early middle Miocene faunas from Japan to California. Although mollusks were reported from beds at Narrow Cape (cited as "Tonky [Narrow] Cap") over 140 years ago (Grewingk, 1850), the faunal composition of these beds has never been studied in detail. The presence of abundant mollusks (Moore, 1969; Allison, 1978), and sand-dollar echinoids (Wagner, 1974) has been noted in modern times. The Narrow Cape microfauna has not been studied previously.

The fieldwork phase of this study produced the first stratigraphically well-located collections of megaand microfossils from the type Narrow Cape Formation. It is now possible to date the formation as early middle Miocene in age. We provide preliminary paleoecological and paleoclimatic interpretations that allow placement of the Narrow Cape faunas within the framework of North Pacific Neogene bioevents.

\section{MOLLUSCAN DATA}

The Narrow Cape Formation contains a predominantly cold-temperate, inner-shelf molluscan fauna. Many of these genera still are common in the modern cold-temperate Gulf of Alaska molluscan fauna. The most common Narrow Cape mollusks include the bivalves Acila (Truncacila) sp., Clinocardium spp., Mya spp., Mytilus middendorffi Grewingk, Pseudocardium sp., Serripes sp., and Spisula sp., as well as the gastropods Beringius crebricostatus (Dall), Buccinum sp., Colus sp., Crepidula sp., Neptunea spp., and Priscofusus sp. These taxa imply that the Narrow Cape molluscan fauna lived in inner-shelf depths of about 10 to $50 \mathrm{~m}$. Paleobathymetric fluctuations throughout the stratigraphic sequence are evident based on field identifications of mollusks. Further analysis may show in greater detail the relationship between molluscan depth facies and the series of Narrow Cape transgressions and regressions, noted below, that are recognized on the basis of benthic foraminiferal and sedimentological data. 
Ironically, dating of the predominantly coldtemperate Narrow Cape Formation fauna is based on the presence of a few warm-water mollusk species in several beds. The five age-diagnostic species cited below are known primarily in warm-temperate to tropical faunas in middle latitudes. The presence of these warm-water species in the Narrow Cape fauna coincided with the worldwide 16- to 15-Ma Neogene climatic optimum and indicates that warm water masses briefly encroached into the western Gulf of Alaska at that time.

The mollusk species useful for dating and correlating the Narrow Cape Formation fauna include the gastropods Ficus modesta (Conrad), Musashia miensis (Araki), and Turritella sagai Kotaka, and the bivalves Anadara devincta (Conrad) and Dosinia whitneyi
(Gabb). Ficus modesta has been reported previously only in upper Oligocene to lower middle Miocene strata of Oregon and California (Weaver, 1942; Moore, 1963; Hickman, 1969; Addicott, 1973). Its latest occurrence is in the Astoria Formation of Oregon, whose youngest beds are dated at 14.5 to $14.0 \mathrm{Ma}$ based on the presence of diatoms with well-documented age ranges (Barron, 1981). This species helps to assign a minimum age to the Narrow Cape fauna. No coeval Ficus species are reported from the northwestern Pacific.

The maximum age for the Narrow Cape Formation fauna is inferred from the the presence of Musashia miensis, which has been reported previously only in Miocene and Pliocene faunas of Honshu, Japan (Shikama, 1967). Its oldest occurrences are in earliest middle

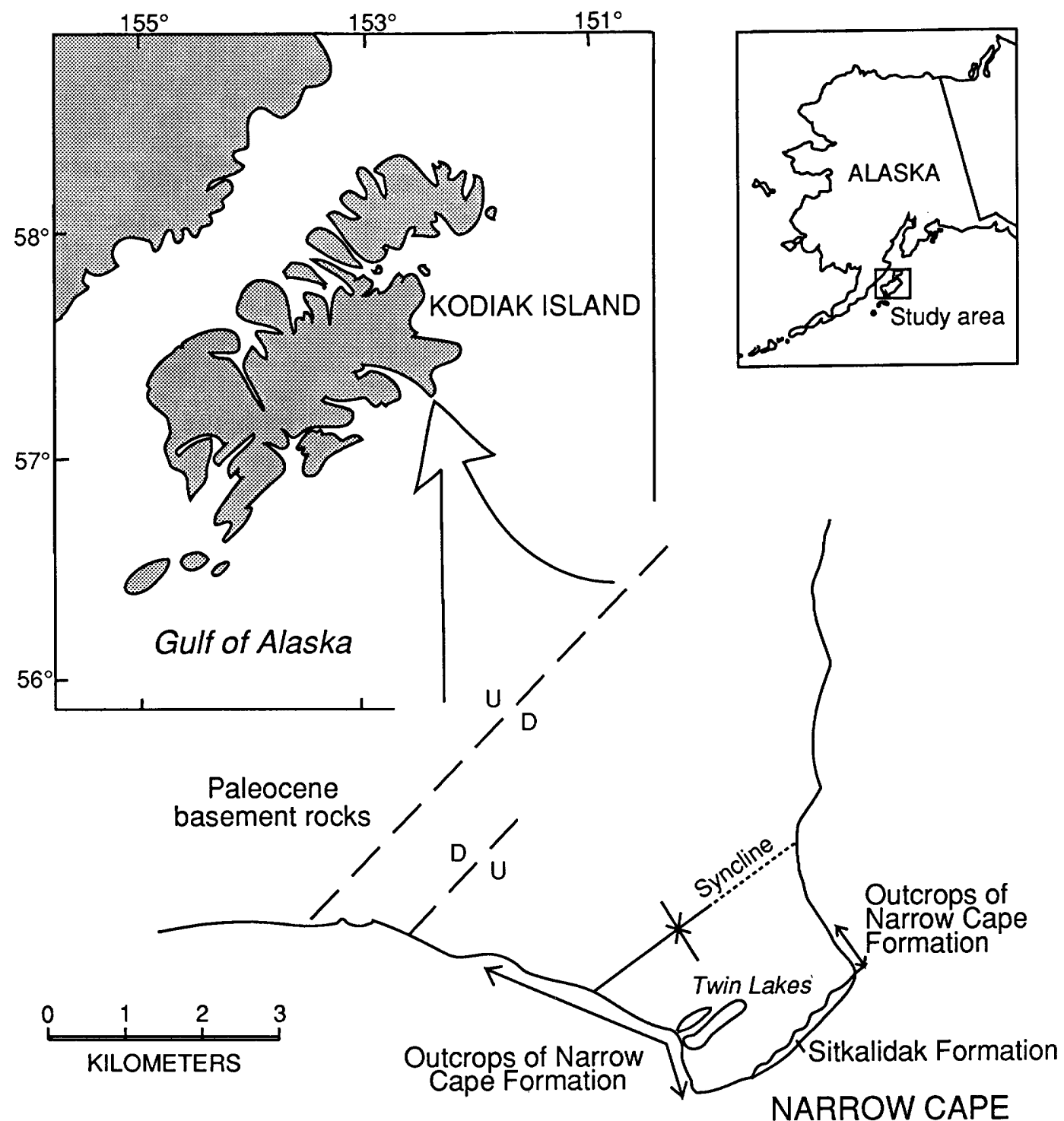

Figure 1. Location of Narrow Cape Formation on Kodiak Island and outcrops examined for this study. Geology from Moore (1967). Fault symbols: D, relatively downthrown side. U, relatively upthrown side. Syncline, dashed where uncertain. 
Miocene faunas, including the Kadonosawa Formation and the Mitsugano Tuffaceous Sandstone and Mudstone Member in the upper part of the Oi Formation on Honshu (Shikama, 1967; Shibata, 1970; K. Chinzei, written commun., 1990). Each of these formations contains the "Kadonosawa fauna" of mollusks that developed in Japan during the earliest middle Miocene climatic optimum at about 16 to $15 \mathrm{Ma}$ (Tsuchi, 1990). Based on planktonic foraminifers and paleomagnetic data, the Mitsugano occurrence has been assigned to magnetic epoch 16 , which has an age range of 17.6 to $15.2 \mathrm{Ma}$ (Hayashida, 1986). The youngest occurrences of this species are cited in lower Pliocene strata of east-central Honshu: the "Fukazawa bed" of the upper Miura Group and the "Tomiya tuffaceous bed of the lower Seki Group" (Shikama, 1967). The most similar eastern Pacific species is Musashia indurata (Conrad), which is known from the upper lower and lower middle Miocene Astoria Formation of Oregon and Washington (Weaver, 1942; Moore, 1963). Devyatilova and Volobueva (1981) reported $M$. indurata in the Rategin Formation of the Koryak Uplands, Far-eastern U.S.S.R., for which they cited an Oligocene age, but the poor preservation of their one figured specimen makes this identification impossible to verify. No other species similar to $M$. miensis is reported from the Far-eastern U.S.S.R.

Turritella sagai is principally known in Japanese warm-temperate to subtropical, inner-shelf faunas (Kotaka, 1959). However, T. sagai also is present, sometimes prolifically, as a thermally anomalous taxon in cold-temperate faunas in the lower part of the Bear Lake Formation on the Alaska Peninsula, to the southwest of Kodiak Island (Marincovich and Kase, 1986; Marincovich, 1988a, b). Occurrences of T. sagai in Japan have been dated at 16 to $15 \mathrm{Ma}$ using associated microfossils and radiometric ages (Marincovich and Kase, 1986). Specimens in the type Narrow Cape Formation represent the easternmost record of $T$. sagai.

Moore (1963) reported occurrences of Anadara devincta ranging from Japan to California, and Moore and Addicott (1987) believed that the peak abundance of this species was in the middle of the Newportian (Molluscan) Stage, at about 16 to $15 \mathrm{Ma}$. The best documented occurrences are those in the upper lower Miocene and lower middle Miocene Astoria Formation of Oregon and Washington.

Dosinia whitneyi is widely distributed in upper Oligocene to middle Miocene strata of the northeastern Pacific, from Kodiak Island to southern California (Moore, 1963; Moore and Addicott, 1987). Its only previous report from Alaska is in the type Narrow Cape Formation (Marincovich in Moore and Addicott, 1987), although the presence of Dosinia in this formation was noted earlier by Allison (1978). Moore and Addicott (1987) noted the presence of $D$. whitneyi in eastern
Pacific faunas representing three molluscan stages: the Juanian Stage (late Oligocene to earliest Miocene), the Pillarian Stage (early Miocene), and the Newportian Stage (early and middle Miocene). The oldest specimens, of late Oligocene age, are known from the Wygal Sandstone Member of the Temblor Formation in southern California (Addicott, 1973; Moore and Addicott, 1987). The youngest specimens are those in the Astoria Formation of Oregon (Moore, 1963; Moore and Addicott, 1987).

The Narrow Cape Formation molluscan fauna is inferred to have an age of 16 to $15 \mathrm{Ma}$, or earliest middle Miocene. There is no discernible difference in age between the stratigraphically higher or lower parts of the formation. The Narrow Cape species with the narrowest chronostratigraphic range is the gastropod Turritella sagai, which has an age range of 16 to $15 \mathrm{Ma}$ in Japan, based on associated planktonic microfossils and radiometric ages. Three other species, the gastropod Ficus modesta and the bivalves Anadara devincta and Dosinia whitneyi, have reliable records in northeastern Pacific faunas no younger than North Pacific diatom zone XXI, which has an age range of about 14.5 to $14.0 \mathrm{Ma}$. In addition, the gastropod Musashia miensis has its oldest occurrences in the Kadonosawa Formation and in other coeval Japanese faunas representative of the warm-water Kadonosawa fauna that developed in Japan during the Neogene climatic optimum at 16 to $15 \mathrm{Ma}$. Thus, the 16to 15-Ma inferred age of the Narrow Cape molluscan fauna is based on species that occur in well-dated faunas of both the northwestern and the northeastern Pacific.

\section{BENTHIC FORAMINIFERAL DATA}

Of the 108 samples collected for microfossil analysis, 73 contain benthic foraminifers. Seventy species and species groups make up this foraminiferal fauna, and many are useful as paleoenvironmental indicators. At present they are not useful age indicators, because most taxa are identified only to the genus level and some species identifications are preliminary.

Occurrences of foraminiferal taxa correlate closely with sedimentary facies observed in the field, supplemented by analysis of grain sizes of residues that remained after processing for microfossils. The Narrow Cape Formation is composed of at least 20 shallowingupward sequences representing repeated transgressions and regressions (Clifton, 1990). Each sequence, except for the uppermost three sequences, is bounded above and below by erosional surfaces and begins with a transgressive lag of relatively coarse clasts. A series of facies representing changes upsection from deeper to shallower marine conditions occurs in each sequence. The shallowest facies at the uppermost part of a sequence is cut by 
the transgressive basal lag of the overlying sequence. These sequences range in thickness from 7 to $40 \mathrm{~m}$. The thickness and lithofacies composition of a particular sequence seem to depend on water depth and the magnitude of the transgression. Although the thicknesses and lithologic compositions of sequences vary, an idealized shallowing-upward sequence is shown in figure 2.

Benthic foraminiferal faunal changes correspond to lithofacies changes in shallowing-upward sequences. The deepest facies (siltstone) just above the transgressive lag (fig. 2) contains both shallow- and deep-marine species, including shallow-water taxa such as Cibicides spp.,
Cribrostomoides spp., Elphidium spp., and deeper water taxa such as Nonionella stella Cushman \& Moyer, Nonionellina labradorica (Dauson), Cassidulina spp., Epistominella pacifica (Cushman), Cyclammina spp., and Melonis pompilioides s. l. (Fichel \& Moll). The shallow marine $(0-50 \mathrm{~m})$ bivalve $M y a$ sp. also is dominant in this facies. In the overlying massive siltstone (fig. 2), taxa such as Cibicides sp., Elphidium spp., and Cribrostomoides spp. are dominant, whereas relatively deep-water (outer shelf and deeper) taxa such as Melonis pompilioides s. l., Cyclammina spp., Epistominella pacifica, Nonionellina labradorica, and Nonionella stella

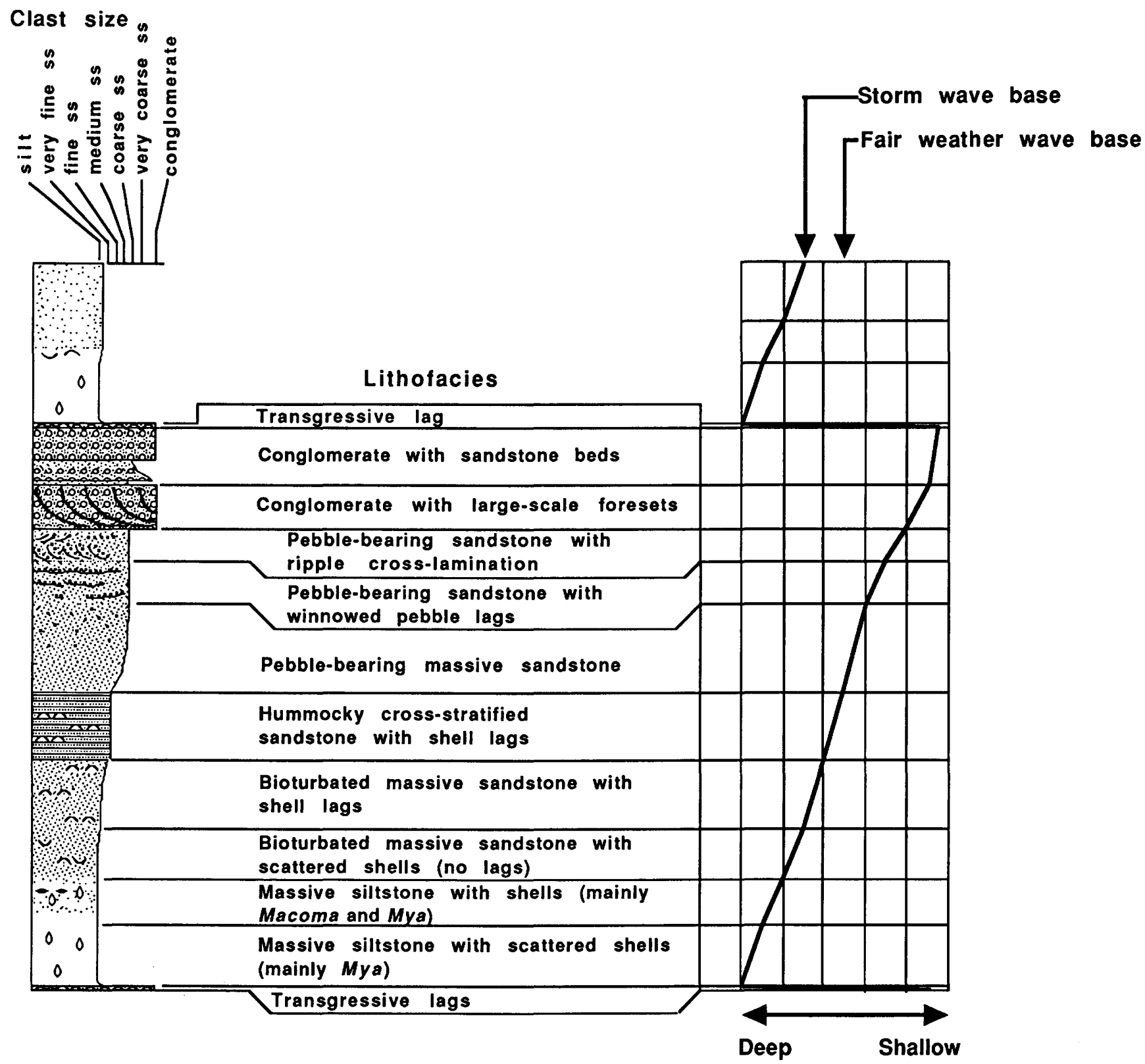

Figure 2. An idealized shallowing-upward transgressive-regressive sequence within Narrow Cape Formation. Individual sequences in outcrop usually exhibit only part of this idealized sequence. Based upon field observations of $H$. E. Clifton and the authors (1989). ss, sandstone. 
are absent. This same foraminiferal facies is present in the overlying bioturbated massive sandstone (fig. 2), although abundances of calcareous taxa are much lower; this facies is inferred to have been deposited close to (probably just below) storm wave base. The next overlying facies, of bioturbated massive sandstone with shell lags (fig. 2), contains only rare Cribrostomoides spp. Judging from the presence of storm-generated shelly lags, it is inferred that this facies was deposited just above storm wave base, although any hummocky crossstratification that may have been present has been completely destroyed by intense bioturbation. This facies is overlain in turn by a hummocky cross-stratified sandstone facies, two storm-dominated shoreface facies with abundant pebbles, a wave-dominated shoreface facies of pebbly sandstone with ripple cross-lamination, and two conglomerate-bearing deltaic facies (fig. 2). No foraminifers are present in these facies, however, probably because current and wave energy was very high.

The Narrow Cape Formation foraminiferal genera and species, except for Melonis pompilioides s. $l$. and Cyclammina spp., commonly live at shelf depths in the Gulf of Alaska today. Epistominella pacifica, Nonionellina labradorica, and Nonionella stella are dominant species in the modern Gulf of Alaska and are also present in midlatitude areas ranging from Japan to California. Their bathymetrical distributions are strongly influenced by water temperature, so that occurrences are much shallower in the cool Gulf of Alaska than in warmer midlatitude areas (Bergen and O'Neil, 1979). Thus, the Narrow Cape occurrences of these taxa in inferred shallow-water deposits imply the presence of relatively cold surface water.

\section{SUMMARY AND CONCLUSIONS}

The type Narrow Cape Formation is of early middle Miocene age (16 to $15 \mathrm{Ma}$ ), based on its molluscan fauna. Mollusks and benthic foraminifers suggest that the bulk of the type Narrow Cape Formation was deposited within the shelf zone in a cold-temperate marine environment. Notable exceptions are the presence of warm-temperate to tropical mollusks at some horizons, and the presence in some beds of inner-shelf mollusks and foraminifers with middle-shelf to bathyal foraminifers.

The presence of warm-temperate to tropical mollusks at some horizons implies incursions of warm surface waters into the western Gulf of Alaska during Narrow Cape Formation deposition. These warm-water episodes presumably were brief. Modern analogues of the warm-water Narrow Cape taxa reproduce by planktonic larvae, as do most modern and fossil mollusks (Jablonski and Lutz, 1983). Consequently, warm-water taxa could have traveled from lower latitudes to Alaska in one spring or summer, moving at the speed of surface currents. Each of the warm-water Narrow Cape taxa, with the exception of Ficus modesta, is represented by numerous adults, which indicates that individuals lived there for more than one year. It is possible for warmwater mollusks to colonize cooler water provinces during warm climatic episodes such as El Niños, and to continue to dwell and grow in a cooler habitat even after warm waters recede (Zinsmeister, 1974). This colonization can occur even when the prevailing summer water temperatures are too low for reproduction. In such cases, a single generation of warm-water mollusks may dwell in a normally unsuitable habitat, but they cannot reproduce. Such an event is likely to have happened in the case of the Narrow Cape warm-water mollusks. Benthic foraminifers from horizons containing warm-water mollusks are presently identified only to genus and are not indicative of paleoclimatic conditions. Further work on groups such as bolivinids and buliminids may identify warmwater species.

Autochthonous inner-shelf mollusks and foraminifers anomalously cooccur with middle-shelf to abyssal foraminifers in some beds. One common example is the presence of the bivalve $M y a$ sp. (0 to $50 \mathrm{~m}$ modern depth range) with deeper water foraminifers such as Epistominella pacifica, Nonionellina labradorica, Bulimina spp., Cyclammina spp., and Melonis pompilioides s. l. Both Epistominella pacifica and Nonionellina labradorica are very common species in the Gulf of Alaska today, where they dominate outer-shelf to upper bathyal environments (150 to $300 \mathrm{~m}$ deep) (Todd and Low, 1967; Bergen and O'Neil, 1979; Echols and Armentrout, 1980). There are very few records of these two species in depths shallower than $50 \mathrm{~m}$. Their bathymetrical distributions are controlled by water temperature and thus are much shallower in the modern Gulf of Alaska than in Japan or California. The presence of these stenothermal species in relatively shallow Narrow Cape Formation deposits is evidently due to upslope migration caused by regional cooling.

Cyclammina spp. and Melonis pompilioides s. l. are especially anomalous in inferred Narrow Cape innershelf deposits, because the former lives at depths no shallower than $4,000 \mathrm{~m}$ in the North Pacific (Smith, $1963,1973)$, and the latter is commonly reported from lower bathyal to abyssal zones deeper than $2,000 \mathrm{~m}$ in the North Pacific (Smith, 1973; Bergen and O'Neil, 1979; Hasegawa, 1984). However, Melonis pompilioides $s$. $l$. has been reported from Japanese Tertiary faunas associated with shallow benthic foraminifers (Asano, 1958; Chiji, 1960; Hasegawa, 1979, 1984; Konda, 1980). These occurrences suggest that $M$. pompilioides s. l. may have inhabited sublittoral to upper bathyal depths until the Pliocene (Hasegawa, 1984). 
The presence of cold-temperate mollusks and foraminifers in the Narrow Cape Formation during the peak of Neogene warming is due to regional cooling in the Gulf of Alaska. The tectonically induced onset of marine glaciation during the early middle Miocene in the northeastern Gulf of Alaska is documented by the sequence of molluscan faunas and sedimentary facies in the Yakataga Formation (Plafker, 1987; Marincovich, 1990). The prevailing counterclockwise flow of the Alaska Gyre introduced cold water into the western Gulf of Alaska and allowed the development of the predominantly cold-temperate Narrow Cape fauna.

\section{REFERENCES CITED}

Addicott, W.O., 1973, Oligocene marine biostratigraphy and paleontology of the lower part of the type Temblor Formation, California: U.S. Geological Survey Professional Paper 791, 48 p.

Allison, R.C., 1978, Late Oligocene through Pleistocene molluscan faunas in the Gulf of Alaska region: Veliger, v. 21, no. 2 , p. 171-188.

Asano, K., 1958, Some Paleogene smaller foraminifera from Japan: Tohoku University Science Reports, Series 2 (Geology), v. 29, p. 43-75.

Barron, J.A., 1981, Marine diatom biostratigraphy of the Montesano Formation near Aberdeen, Washington: Geological Society of America Special Paper 184, p. 113-126.

Bergen, F.W., and O'Neil, P., 1979, Distribution of Holocene foraminifera in the Gulf of Alaska: Journal of Paleontology, v. 53, no. 6, p. 1267-1292.

Chiji, M., 1960, Microbiostratigraphy of the Neogene formation in the "Nadaura" district, Toyama Prefecture, Japan: Osaka Museum of Natural History Bulletin, no. 12, p. 6395 [in Japanese with English abs.].

Clendenen, W.S., Sliter, W.V., and Byrne, T., 1991, Tectonic implications of the Albatross sedimentary sequence, Sitkinak Island, Alaska, in Bradley, D.C., and Ford, A.B., Geologic studies in Alaska by the U.S. Geological Survey, 1990: U.S. Geological Survey Bulletin [in press].

Clifton, H.E., 1990, Variation in sequence development in transgressive-regressive successions on the western margin of North America: Sediments 1990 (International Sedimentological Congress, 13th), Nottingham, England, Abstracts of Papers, p. 96.

Devyatilova, A.D., and Volobueva, V.I., 1981, Atlas of Paleogene and Neogene fauna of the northeast USSR: Moscow, Central Combined Thematic Expedition of the Northeast Industrial Geological Society, 219 p. [in Russian].

Echols, J., and Armentrout, J.M., 1980, Holocene foraminiferal distribution patterns on the shelf and slope, YakatagaYakutat area, northern Gulf of Alaska, in Field, M.E., and others, eds., Quaternary depositional environments of the Pacific Coast (Pacific Coast Paleogeography Symposium, 4th): Los Angeles, California, Pacific Section, Society of Economic Paleontologists and Mineralogists, p. 281-303.

Grewingk, C., 1850, Beitrag zur Kenntniss der orographischen und geognostischen Beschaffenheit der Nord-West-Küste Amerikas mit den anliegenden Inseln: Mineralogische Gesellschaft zu St. Petersburg, Verhandlung, 1848-49, p. 76-324.

Hasegawa, S., 1979, Foraminifera of the Himi Group, Hokuriku Province, Central Japan: Tohoku University Science Reports, Series 2 (Geology), v. 49, no. 2, p. 89-163.

1984 , Notes on the taxonomy and paleoecology of Melonis pompilioides and its allied taxa from Japan: Benthos 83 (International Symposium on Benthic Foraminifera, 2nd), p. 299-304.

Hayashida, A., 1986, Timing of rotational motion of Southwest Japan inferred from paleomagnetism of the Setouchi Miocene Group: Journal of Geomagnetism and Geoelectricity, v. 38 , no. 5 , p. $295-310$.

Hickman, C.J.S., 1969, The Oligocene marine molluscan fauna of the Eugene Formation in Oregon: University of Oregon, Museum of Natural History Bulletin 16, $112 \mathrm{p}$.

Jablonski, D., and Lutz, R.A., 1983, Larval ecology of marine benthic invertebrates: paleobiological implications: Biological Review, v. 58, p. $21-89$.

Konda, I., 1980, Benthonic foraminiferal biostratigraphy of the Pacific side province, Central Japan: Kyoto University, Faculty of Science Memoirs (Geology and Mineralogy), v. 47 , no. 1, p. 1-42.

Kotaka, T., 1959, The Cenozoic Turritellidae of Japan: Tohoku University Science Reports, Series 2 (Geology), v. 31, no. $2,135 \mathrm{p}$.

Marincovich, L., Jr., 1988a, Miocene mollusks from the lower part of the Bear Lake Formation on Ukolnoi Island, Alaska Peninsula, Alaska: Natural History Museum of Los Angeles County, Contributions in Science no. 397, 20 p.

-1988 b, Recognition of an earliest middle Miocene warm-water event in a southwestern Alaskan molluscan fauna: Sendai, Japan, Saito Ho-on Kai Special Publication (Professor Tamio Kotaka Commemorative Volume), p. 124.

1990, Molluscan evidence for early middle Miocene marine glaciation in southern Alaska: Geological Society of America Bulletin, v. 102, no. 11, p. 1591-1599.

Marincovich, L., Jr., and Kase, T., 1986, An occurrence of Turritella (Hataiella) sagai in Alaska: implications for the age of the Bear Lake Formation: Bulletin of the National Science Museum [Tokyo], Series C (Geology \& Paleontology), v. 12, no. 2, p. 61-66.

Moore, E.J., 1963 [1964], Miocene marine mollusks from the Astoria Formation in Oregon: U.S. Geological Survey Professional Paper 419, 109 p.

Moore, E.J., and Addicott, W.O., 1987, The Miocene Pillarian and Newportian (molluscan) Stages of Washington and Oregon and their usefulness in correlations from Alaska to California: U.S. Geological Survey Bulletin 1664-A, 18 p.

Moore, G.W., 1967, Preliminary geologic map of Kodiak Island and vicinity, Alaska: U.S. Geological Survey openfile report 67-271, 1 sheet

1969, New formations on Kodiak and adjacent islands, Alaska: U.S. Geological Survey Bulletin 1274-A, p. 2735.

Plafker, G., 1987, Regional geology and petroleum potential of the northern Gulf of Alaska continental margin, in Scholl, 
D.W., Grantz, A., and Vedder, J.G., eds., Geology and resource potential of the continental margin of western North America and adjacent ocean basins: Houston, Texas, Circum-Pacific Council for Energy and Mineral Resources Earth Science Series, v. 6, p. 229-268.

Shibata, H., 1970, Molluscan fauna of the First Setouchi Series, Southwest Japan, Part 1, Fauna of the Ichishi Group: Nagoya University Journal of Earth Sciences, v. 18, p. 27-84.

Shikama, T., 1967, System and evolution of Japanese fulgorarid Gastropoda: Yokohama National University Science Reports, sec. 2, no. 13, p. 23-132.

Smith, P.B., 1963, Possible Pleistocene-Recent boundary in the Gulf of Alaska, based on benthonic foraminifera: U.S. Geological Survey Professional Paper 475-C, p. 73-77.

1973, Foraminifera from the North Pacific Ocean: U.S. Geological Survey Professional Paper 766, 27 p.

Todd, R., and Low, D., 1967, Recent foraminifera from the
Gulf of Alaska and southeastern Alaska: U.S. Geological Survey Professional Paper 573-A, 46 p.

Tsuchi, R., 1990, Accelerated evolutionary events in Japanese endemic molluscs during the latest Neogene, in Tsuchi, R., ed., Pacific Neogene Events, their timing, nature and interrelationship: Tokyo, Japan, University of Tokyo Press, p. 85-97.

Wagner, C.D., 1974, Fossil and Recent sand dollar echinoids of Alaska: Journal of Paleontology, v. 48, no. 1, p. 105123.

Weaver, C.E., 1942 [1943], Paleontology of the marine Tertiary formations of Oregon and Washington: University of Washington Publications in Geology, v. 5, pt. 1-3, 789 p.

Zinsmeister, W.J., 1974, A new interpretation of thermally anomalous molluscan assemblages of the California Pleistocene: Journal of Paleontology, v. 48, no. 1, p. 84-94.

Reviewers: William P. Elder and William V. Sliter 


\title{
Reconnaissance Sandstone Petrology and Provenance of the Cantwell Formation, Central Alaska
}

\author{
By Hugh McLean and Richard G. Stanley
}

\begin{abstract}
Reconnaissance study of detrital modes of sandstones in the Paleocene Cantwell Formation indicates that framework components were largely derived from local sources. Most of the sandstones classify on ternary plots as quartzose lithic arenites that contain abundant siliceous sedimentary and metasedimentary rocks, including chert. Subordinate lithic fragments reflect local sediment input from granitic, volcanic, and schistose metamorphic sources. Limeclasts and K-feldspar are minor local constituents. On ternary diagrams that are reportedly provenance sensitive, Cantwell sandstones reflect a recycled-orogen tectonic setting.

Although sandstone compositions vary within the region studied (as do conglomerate compositions reported by previous workers), no consistent trends were noted. Additional studies are needed to determine the regional distribution of complex nonmarine facies and relations between sedimentary facies and composition.

Low visible porosity and permeability due to an abundance of tightly packed, chemically stable framework grains, rather than pore-filling authigenic cements, diminish the hydrocarbon reservoir potential of sandstones of the Cantwell Formation.
\end{abstract}

\section{INTRODUCTION}

The Cantwell Formation is a sequence of nonmarine sedimentary and volcanic rocks of Paleocene age that is well exposed in the mountainous terrain of central Alaska (fig. 1). Most of the known Cantwell exposures crop out in an east-west-trending belt that lies between the Foraker River on the west and the Wood River on the east. The outcrop belt is transected by the northflowing Nenana River, along which railroad and highway cuts provide accessible outcrops (fig. 2).

We initially examined the variation in sandstone composition on a regional scale to determine if a correlation existed between thermal maturity of argillaceous beds and authigenic minerals of associated sandstone interbeds. We found that considerable regional variation in composition existed within our suite of samples, and that stratigraphic variations at a single site were as significant as regional variations. Unfortunately, we found few authigenic minerals to correlate with our yet-to-be published thermal maturity data. The results reported herein provide preliminary data on sandstone composition, including an interpretation of provenance and tectonic setting of the Cantwell sedimentary basin.

We point-counted 24 thin sections selected from rocks collected during helicopter and vehicle reconnaissance in the summers of 1984 and 1986.

In a study of the geology of the Mt. Galen area (fig. 2), Decker (1975) included point counts of 28 Cantwell sandstone thin sections collected from approximately $1,200 \mathrm{~m}$ of measured section. Decker also discussed variations in clast compositions of interbedded conglomerates. Hickman and others (1990) included two ternary diagrams to illustrate the composition of 20 Cantwell

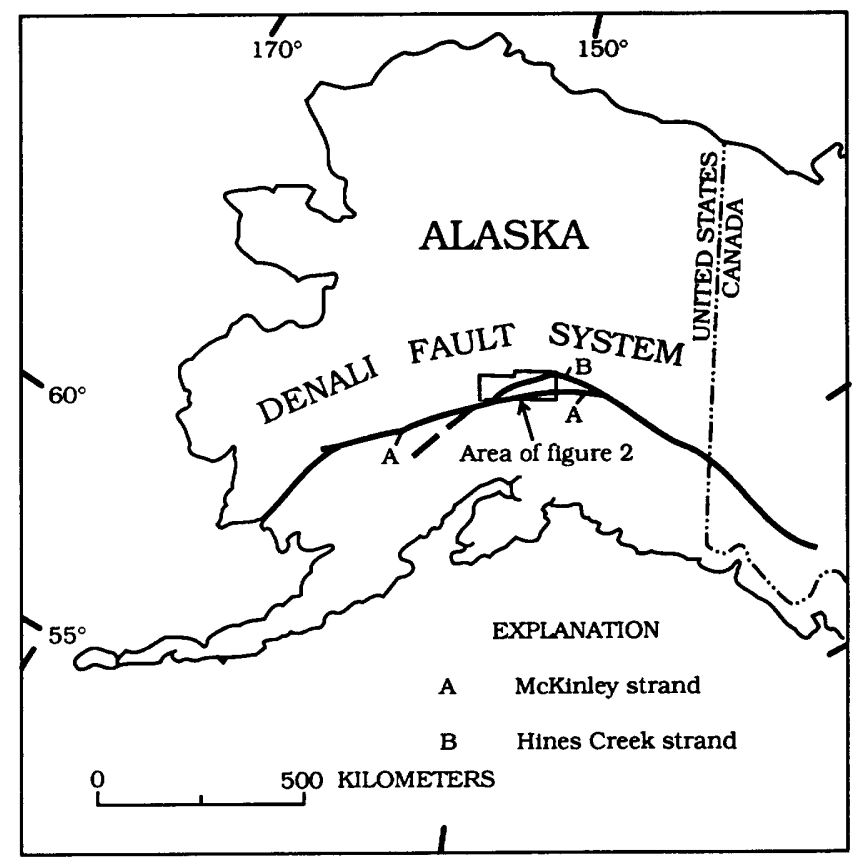

Figure 1. Index map of Alaska showing location of Denali fault system. Segment A is McKinley strand, B is Hines Creek strand. 
sandstones in their discussion of the tectonic setting of the Cantwell basin.

\section{GEOLOGIC SETTING}

Most outcrops of the Cantwell Formation occur in a narrow east-west trending synclinorium flanked by the Hines Creek and McKinley strands of the Denali fault system (fig. 1). Small patches of the Cantwell also occur locally north of the Hines Creek fault and south of the McKinley fault (Csejtey and others, 1984, 1986). The outcrops of the Cantwell Formation shown in figure 2 represent mapping in the Mt. McKinley 1:250,000 quadrangle by Reed (1961) and mapping in the Healy quadrangle by Csejtey and others (1986).

Two lithic units comprise the Cantwell Formation: a lower unit of sedimentary rocks and an upper unit of volcanic rocks (Wolfe and Wahrhaftig, 1970). The sedimentary rocks consist of well-indurated sandstone, conglomerate, mudstone, and minor bituminous coal that accumulated in fluvial, alluvial-fan, and lacustrine environments (Decker, 19.75; Sherwood and others, 1979). In places, however, the sedimentary rocks contain thin volcanic flows and tuffs and are intruded by dikes and sills ranging in composition from diabase to rhyolite. Because of structural complications, preserved thicknesses of the sedimentary part of the Cantwell Formation vary; however, Hickman and others (1990) report sections near the Nenana River that are 3,700 and 4,000 m thick.

The volcanic rocks in the upper part of the Cantwell Formation consist mainly of andesite and rhyolite flows with subordinate basalt flows, felsic pyroclastic rocks, and related intrusive rocks. Gilbert and others (1976) named the volcanic rocks the Teklanika Formation and reported a minimum thickness of $3,750 \mathrm{~m}$.

Sedimentary rocks of the Cantwell Formation unconformably overlie a complex assemblage of rocks that range in age from Precambrian(?) to Cretaceous that comprise several tectonostratigraphic terranes (Csejtey and others,1986; Jones and others, 1983, 1987).

Cantwell strata east of the Nenana River unconformably overlie Late Devonian metasedimentary marine and metavolcanic rocks that are informally called the Yanert Fork sequence. The Yanert Fork sequence consists mainly of black carbonaceous shale with intercalated sandstone and siltstone that is regionally metamorphosed into siliceous mudstone, argillite, slate, phyllite, semischist, and impure quartzite, with minor chert, metachert, metatuff, and metabasalt. Cantwell strata also unconformably overlie intensely deformed Late Triassic calcareous rocks that include shale, argillite, sandstone, siltstone, and limestone, which are metamorphosed into greenschist and amphibolite facies. These rocks uncon- formably overlie the Yanert Fork sequence.

East of the Nenana River and north of the Hines Creek fault, the Cantwell strata unconformably overlie schistose felsic metavolcanic rocks of Late Devonian age, as well as the Precambrian and Paleozoic Birch Creek Schist of former usage (Csejtey and others, 1986). The phyllite and the schist assemblage are probably metamorphosed rhyolite, dacite, and minor basalt, siltstone, black chert, and limestone.

In the central and southern parts of the outcrop belt, the Cantwell strata unconformably overlie isoclinally folded and locally highly metamorphosed Late Jurassic and Early Cretaceous flysch. The flysch sequence consists of phyllite, pelitic schist, and paragneiss, all of which formed from metamorphosed argillite, graywacke, polymict pebble conglomerate, and interbeds of radiolarian chert and impure limestone.

Wolfe and Wahrhaftig (1970) assigned a Paleocene age to plant fossils collected by Chaney (1937) from a locality near the base of the Cantwell Formation at a site 2 to $3 \mathrm{~km}$ west of the Teklanika River. Volcanic rocks in the upper part of the Cantwell also yield Paleocene radiometric ages (Gilbert and others,1976).

\section{METHODS}

Detrital modes tend to be strongly influenced by provenance and tectonic setting according to Dickinson and Suczek (1979), Dickinson and others (1983), and Dickinson (1984). Detrital modes for this study are based on a slightly modified version of the point-counting techniques outlined by Dickinson (1970). We counted approximately 300 quartz, feldspar, and lithic-fragment grains in generally medium-grained rocks stained for potassium feldspar. Modes of QtFL, QmFLt, QpLvLs, and QmPK are shown in ternary form in figure 3, where these symbols are also defined. Detrital modes and relative percentages are shown in tables 1 and 2; normalized point-count values of various constituents are also listed in the latter table.

Few polycrystalline grains in Cantwell sandstones contain crystals larger than $0.0625 \mathrm{~mm}$, which is the size limit invoked by the so-called Gazzi-Dickinson method (Ingersoll and others, 1984). We accordingly used the traditional method of counting lithic fragments rather than applying the Gazzi-Dickinson method. Because carbonate rocks are part of the pre-Cantwell complex, we include limeclasts in the population of sedimentary lithic fragments (Ls) rather than relegating them to miscellaneous components as suggested by Dickinson (1984). Limeclast percentages appear in the $\mathrm{CO} 3$ column of table 2. Polycrystalline quartz ( $Q p$ of fig. 3) includes a variety of foliated and unfoliated crystal aggregates. These finely crystalline textures may include vein quartz, 


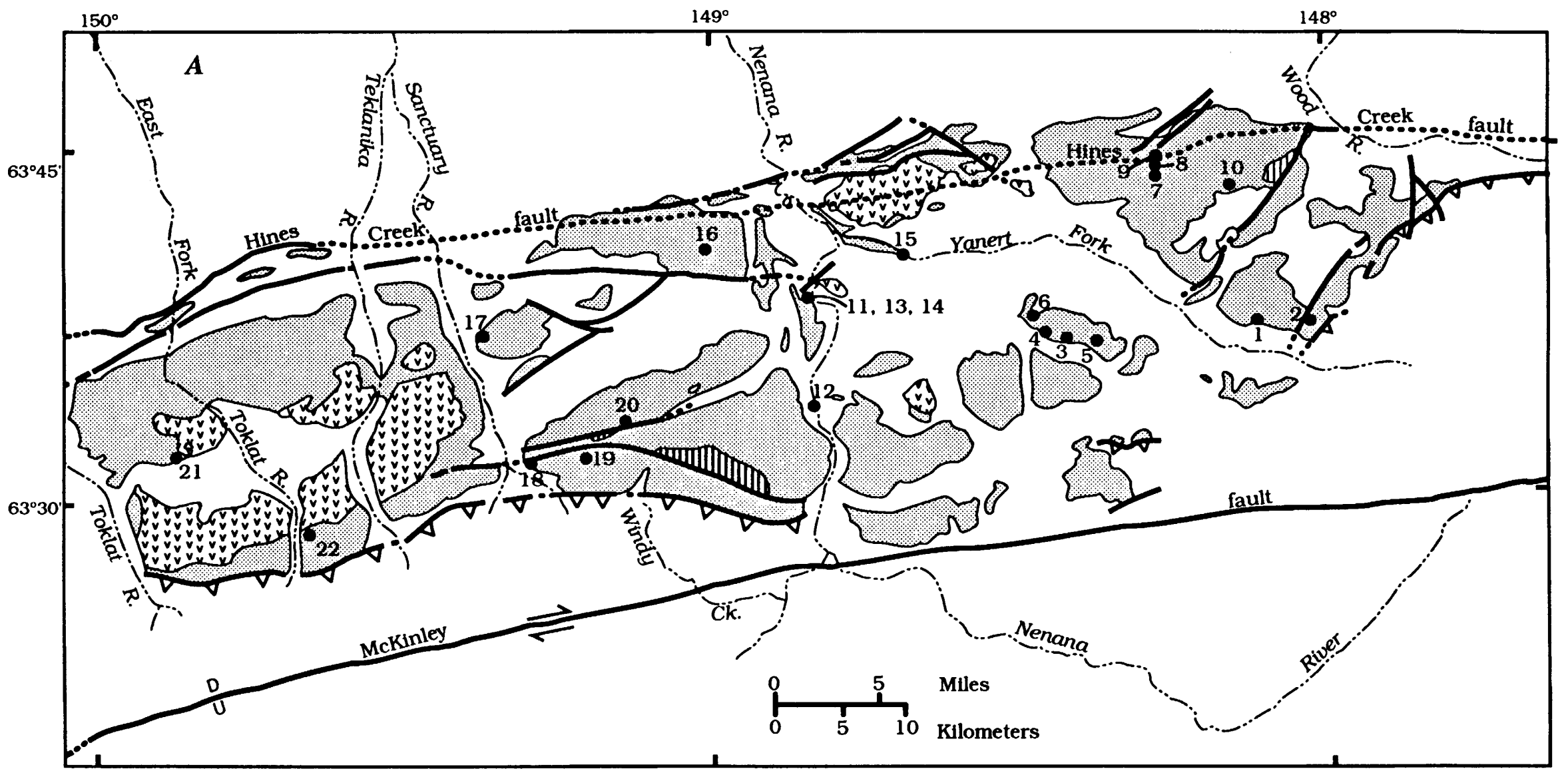

EXPLANATION

Sedimentary rocks, lower unit of the Cantwell Formation

Volcanic rocks,

upper unit of the Cantwell Formation

Inliers, pre-Cantwell rocks

\section{Contact}

Fault-Dashed where inferred, dotted where concealed. Arrows indicate relative direction of horizontal movement. $U$, upthrown side; $D$, downthrown side.

Thrust fault-Dashed where inferred, dotted where concealed. Sawteeth on upper plate

- 10 Sample locality-Numbers refer to tables 1 and 2 


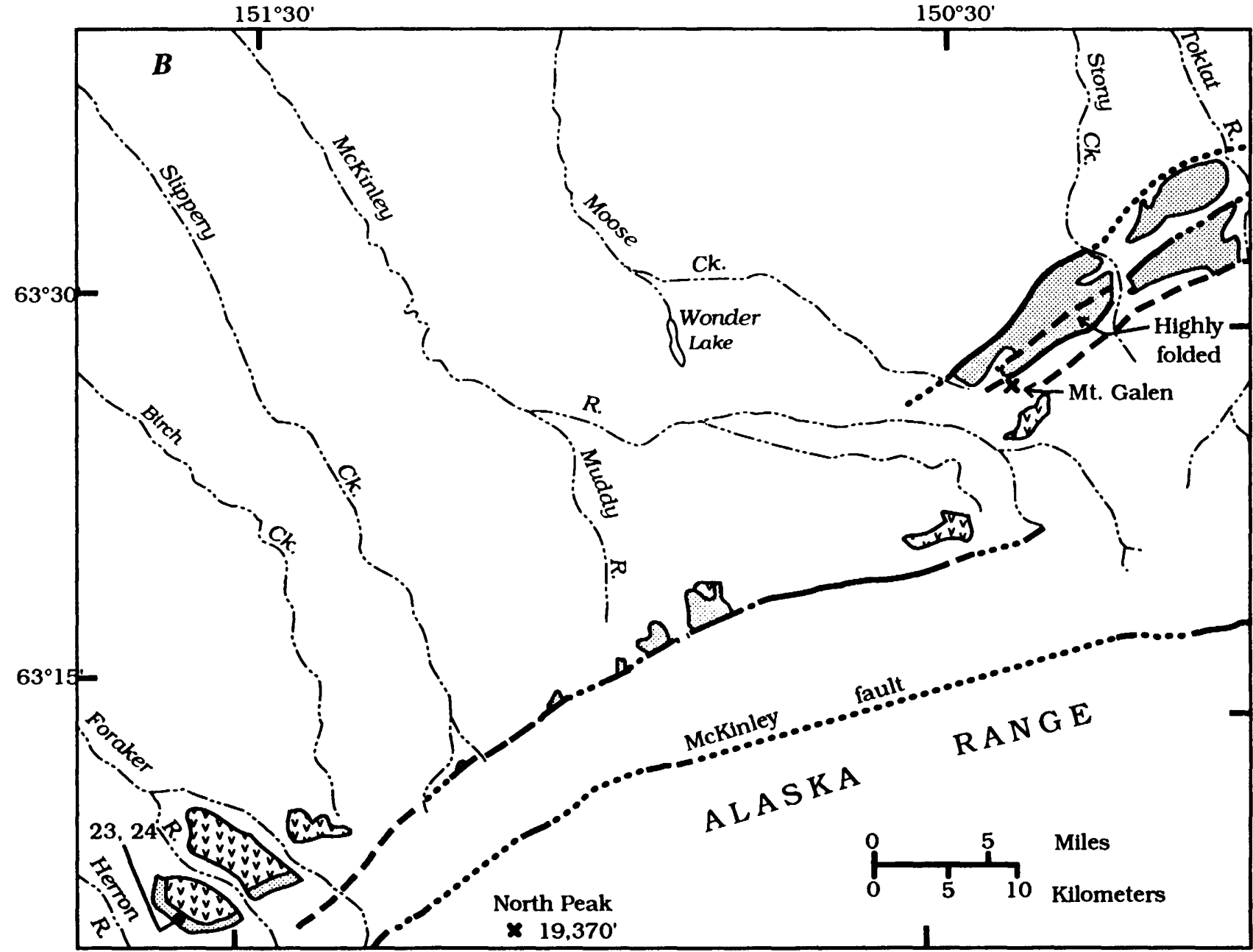

Figure 2. Location of sample localities and distribution of outcrops of the Cantwell Formation. $A$, Locality map of east part of study area. B, Locality map of west part of study area 

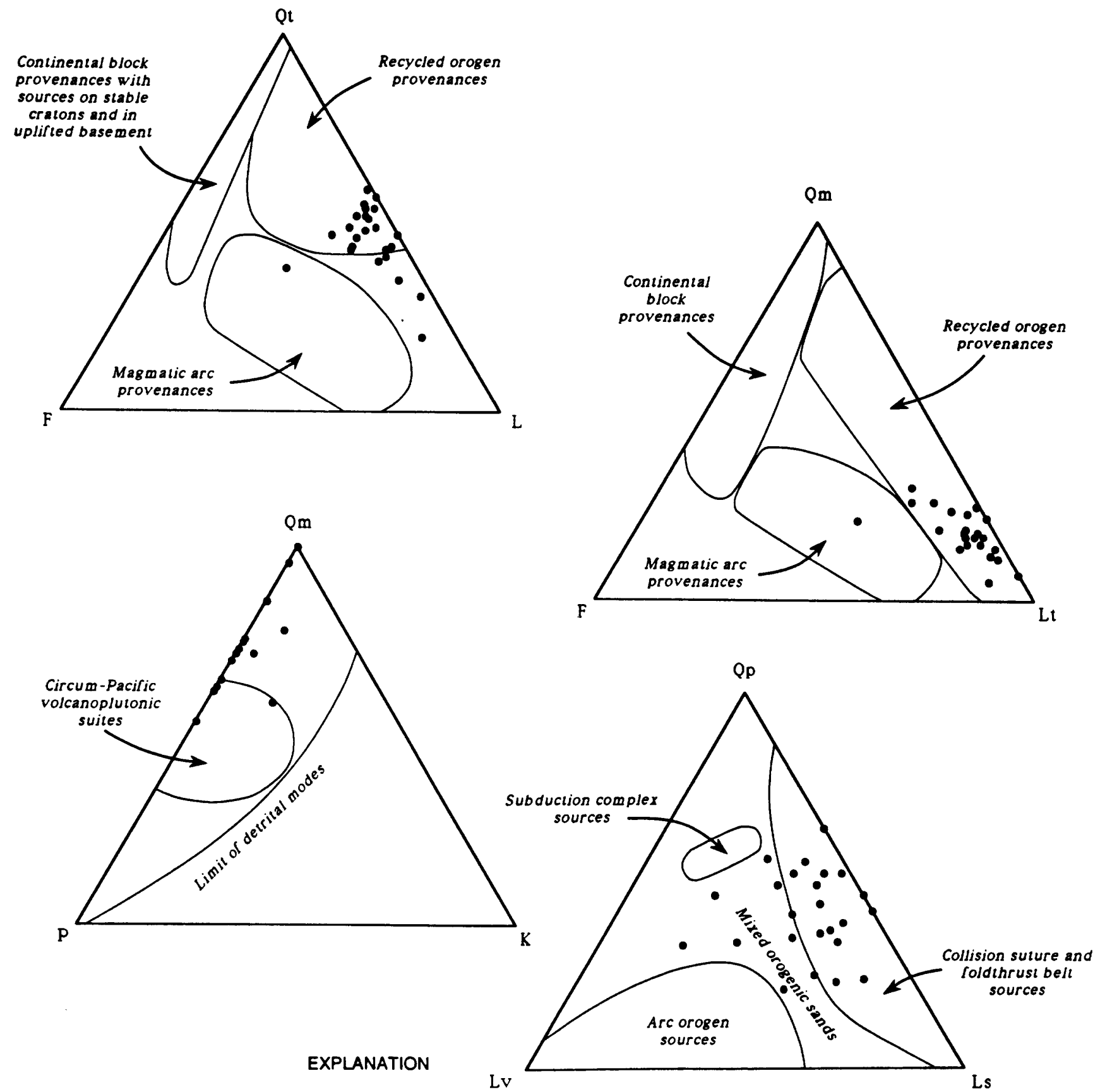

$\begin{array}{ll}\text { Qt } & \text { Total quartzose grains } \\ \text { Qm } & \begin{array}{l}\text { Monocrystalline quartz grains } \\ \text { Polycrystalline quartz grains including }\end{array} \\ \text { Qp } & \text { Total feldspar grains } \\ \text { F } & \text { Plagioclase grains } \\ \text { K } & \text { Potassium-feldspar grains } \\ \text { L } & \text { Total lithic fragments excluding chert } \\ \text { Lt } & \text { Total lithic fragments including chent } \\ \text { Lv } & \text { Volcanic-rock fragments } \\ \text { Ls } & \text { Sedimentary-rock fragments }\end{array}$

Figure 3. Detrital framework modes of Cantwell sandstones plotted on standard ternary diagrams, with provenance fields of Dickinson (1984). 
Table 1. Detrital modes of the sandstones of the Cantwell Formation. See figure 3 for explanation of symbols

[Values of $\mathrm{Qm}, \mathrm{P}$, and $\mathrm{K}$ were not calculated if their sum was less than 100]

\begin{tabular}{|c|c|c|c|c|c|c|c|c|c|c|c|}
\hline Field No. & $\mathrm{F}$ & L & Qm & $\mathrm{F}$ & $\mathrm{Lt}$ & Qp & Lv & Ls & Qm & $P$ & K \\
\hline 1 - 86 AST 41 -..-- 54 & 4 & 42 & 18 & 4 & 78 & 52 & 6 & 42 & $*$ & $*$ & $*$ \\
\hline 2 - 86 AST 48 & 30 & 32 & 21 & 30 & 49 & 46 & 34 & 20 & 54 & 46 & 0 \\
\hline 3 - 36 AST 32 & 6 & 53 & 19 & 6 & 75 & 34 & 35 & 31 & 75 & 25 & 0 \\
\hline 4 - 56 AST 28 & 7 & 41 & 18 & 7 & 75 & 49 & 9 & 42 & 72 & 28 & 0 \\
\hline 5 - 86 AST 37 & 10 & 44 & 26 & 10 & 64 & 34 & 12 & 54 & 73 & 27 & 0 \\
\hline 6 - 66 AST 18 & 0 & 53 & 7 & 0 & 93 & 52 & 2 & 46 & $*$ & $*$ & * \\
\hline 7 - & 5 & 44 & 15 & 5 & 80 & 49 & 18 & 33 & 76 & 24 & 0 \\
\hline 8 -..--86 AST 86 & 0 & 43 & 22 & 0 & 78 & 46 & 0 & 54 & 100 & 0 & 0 \\
\hline 9 - 944 AST 182 & 8 & 52 & 15 & 8 & 77 & 35 & 22 & 43 & 65 & 35 & 0 \\
\hline 10 - 49 AST 91 - 46 & 4 & 47 & 12 & 4 & 84 & 44 & 11 & 45 & $*$ & $*$ & * \\
\hline 11 -----84 AST 169 & 13 & 44 & 30 & 13 & 57 & 23 & 18 & 59 & 70 & 30 & 0 \\
\hline 12 & 3 & 53 & 17 & 3 & 80 & 33 & 48 & 19 & $*$ & $*$ & * \\
\hline 13 -.--86 AST 160 ------ 59 & 1 & 40 & 25 & 1 & 74 & 55 & 9 & 36 & 96 & 4 & 0 \\
\hline 14 & 7 & 45 & 24 & 7 & 69 & 39 & 8 & 53 & 78 & 14 & 8 \\
\hline 15 - 86 AST 73 & 4 & 41 & 23 & 4 & 73 & 42 & 0 & 58 & 86 & 14 & 0 \\
\hline 16 -.--86 AST 171 - 52 & 5 & 43 & 15 & 5 & 80 & 56 & 17 & 27 & $*$ & $*$ & $*$ \\
\hline 17 --- 86 AST 156 -ב--- 47 & 15 & 38 & 26 & 15 & 59 & 37 & 12 & 51 & 63 & 37 & 0 \\
\hline 18 ---86 AST 166A ㄱ.-.- 20 & 8 & 72 & 5 & 8 & 87 & 21 & 31 & 48 & $*$ & $*$ & $*$ \\
\hline 19 -..--86 AST 102 --.---- 44 & 12 & 44 & 19 & 12 & 69 & 41 & 19 & 40 & 62 & 38 & 0 \\
\hline 20 -.--86 AST 107 -ב..-- 54 & 2 & 44 & 14 & 2 & 84 & 64 & 0 & 36 & $*$ & $*$ & $*$ \\
\hline 21 -.--86 AST 7--.---- 31 & 3 & 67 & 11 & 3 & 86 & 24 & 11 & 65 & $*$ & $*$ & $*$ \\
\hline 22 --.--86 AST 66 & 6 & 59 & 17 & 7 & 76 & 25 & 22 & 53 & 72 & 24 & 4 \\
\hline 23 -.--86 AST 54 & 10 & 41 & 14 & 10 & 76 & 52 & 13 & 35 & 59 & 26 & 15 \\
\hline 24 ----86 AST 145 ------ 43 & 5 & 52 & 17 & 5 & 78 & 36 & 15 & 49 & 76 & 24 & 0 \\
\hline Mean -..-- 46 & 7 & 47 & 18 & 7 & 75 & 41 & 16 & 43 & 74 & 25 & 1 \\
\hline
\end{tabular}

quartzite, and completely recrystallized chert and (or) felsic volcanic groundmass.

\section{SANDSTONE PETROLOGY}

\section{Texture}

Sandstone textures of the Cantwell Formation vary from moderately to poorly sorted. Grains characteristically are subrounded to subangular and are tightly packed. The sandstones contain little intergranular matrix or cement. Framework grains consist mainly of quartz, chert, and an assortment of siliceous and siliciclastic sedimentary and unfoliated quartzose metasedimentary rock fragments. Relatively ductile rock frag- ments tend to be deformed against adjacent resistant grains, resulting in long and concavo-convex types of grain contacts. Clast-supported conglomerate beds also have similar tightly compressed textures, as noted by Wolfe and Wahrhaftig (1970) and Decker (1975). Visible porosity is negligible owing to tightly packed framework grains and, to a lesser extent, to infilling of former intergranular pore space by authigenic cements such as quartz and chlorite.

\section{Composition}

Mean detrital modes (table 1) for the group of 24 samples are $\mathrm{Qt}_{46} \dot{\mathrm{F}}_{7} \mathrm{~L}_{47}$, where $\mathrm{Qt}$ includes monocrystalline and polycrystalline quartz as well as chert and 
Table 2. Normalized framework percentages of the Cantwell Formation

[Qm, monocrystalline quartz; Qp, polycrystalline quartz; Qtzite, quartzite; Plag, plagioclase feldspar; Kspar, potassium feldspar; Sedrxs, sedimentary-rock fragments; CO3, carbonate-rock fragments (limeclasts); Volc, volcanic-rock fragments; Granite, granitic-rock fragments; Misc, miscellaneous mineral grains; Cmt/Mtrx, cement and (or) pore-filling matrix]

\begin{tabular}{|c|c|c|c|c|c|c|c|c|c|c|c|c|c|c|c|}
\hline Map No. Field No. & $\begin{array}{c}\text { Total } \\
\text { grains } \\
\text { counted }\end{array}$ & Qm & Qp & Chert & Qtzite & Plag & Kspar & Sedrxs & $\mathrm{CO} 3$ & Schist & Volc & Granite & Mica & Misc & $\begin{array}{l}\mathrm{Cmt} / / \\
\text { Mtrx }\end{array}$ \\
\hline 1---86 AST 41 ----- & 442 & 15 & 23 & 8 & 0 & 4 & 0 & 25 & 0 & 7 & 4 & 1 & 2 & 0 & 11 \\
\hline 2---86 AST 48 --.-- & 428 & 16 & 11 & 2 & 1 & 23 & 0 & 4 & 1 & 7 & 10 & 1 & 5 & 0 & 19 \\
\hline 3-86 AST 32 & 435 & 16 & 11 & 6 & 1 & 5 & 0 & 14 & 2 & 10 & 19 & 1 & 1 & 2 & 12 \\
\hline 4-86 AST 28 & 525 & 15 & 21 & 7 & 1 & 6 & 0 & 23 & 1 & 5 & 5 & 1 & 2 & 0 & 13 \\
\hline 5-1 86 AST 37 - & 503 & 21 & 14 & 1 & 1 & 8 & 0 & 25 & 1 & 4 & 6 & 1 & 2 & 1 & 15 \\
\hline 6-18 AST 18 & 461 & 7 & 21 & 14 & 1 & 0 & 0 & 45 & 0 & 1 & 2 & 1 & 0 & 1 & 7 \\
\hline 7 86 AST 82 & 361 & 13 & 21 & 10 & 1 & 4 & 0 & 18 & 2 & 5 & 11 & 1 & 4 & 0 & 10 \\
\hline 8---- 86 AST 86 --..-- & 480 & 18 & 21 & 8 & 1 & 1 & 0 & 33 & 0 & 3 & 1 & 0 & 1 & 0 & 13 \\
\hline 9---84 AST 182 & 453 & 14 & 18 & 4 & 0 & 7 & 0 & 18 & 9 & 3 & 14 & 1 & 1 & 1 & 10 \\
\hline 10-86 AST 91 & 455 & 11 & 16 & 17 & 1 & 4 & 0 & 33 & 0 & 0 & 8 & 0 & 1 & 0 & 9 \\
\hline 11 & 411 & 24 & 8 & 1 & 0 & 10 & 0 & 14 & 9 & 3 & 7 & 1 & 5 & 3 & 15 \\
\hline 12 & 400 & 13 & 16 & 0 & 1 & 3 & 0 & 6 & 0 & 7 & 26 & 1 & 1 & 7 & 19 \\
\hline 13-86 AST 160 & 160 & 20 & 24 & 4 & 1 & 1 & 0 & 18 & 4 & 6 & 4 & 0 & 1 & 0 & 17 \\
\hline 14------84 AST 167 ------- & 434 & 19 & 17 & 2 & 1 & 3 & 2 & 12 & 14 & 5 & 4 & 0 & 5 & 0 & 16 \\
\hline 15- 86 AST 73 - & 503 & 21 & 21 & 1 & 0 & 3 & 0 & 18 & 11 & 2 & 1 & 0 & 1 & 0 & 21 \\
\hline 16---86 AST 171 & 407 & 14 & 21 & 12 & 1 & 4 & 0 & 16 & 13 & 1 & 10 & 1 & 0 & 0 & 7 \\
\hline 17--86 AST 156 & 522 & 21 & 15 & 2 & 1 & 12 & 0 & 23 & 1 & 1 & 5 & 1 & 1 & 0 & 17 \\
\hline 18--86 AST 166A ---- & 403 & 4 & 12 & 1 & 0 & 7 & 1 & 34 & 1 & 6 & 21 & 2 & 1 & 1 & 9 \\
\hline 19-86 AST 102 & 454 & 16 & 14 & 7 & 0 & 10 & 0 & 20 & 2 & 6 & 10 & 1 & 3 & 0 & 11 \\
\hline 20--- 86 AST 107 --.-- & 573 & 12 & 24 & 8 & 1 & 1 & 0 & 9 & 1 & 18 & 1 & 1 & 6 & 5 & 13 \\
\hline 21- 86 AST 7 & 400 & 10 & 14 & 3 & 1 & 3 & 0 & 47 & 0 & 2 & 8 & 0 & 1 & 0 & 11 \\
\hline 22---86 AST 66 - & 429 & 12 & 11 & 3 & 0 & 4 & 1 & 18 & 9 & 4 & 12 & 0 & 1 & 1 & 24 \\
\hline 23-1.-86 AST 54 & 400 & 13 & 23 & 8 & 1 & 6 & 3 & 18 & 1 & 8 & 8 & 1 & 1 & 0 & 9 \\
\hline 24--86 AST 145 & 476 & 14 & 17 & 4 & 1 & 4 & 0 & 28 & 1 & 4 & 9 & 0 & 1 & 3 & 14 \\
\hline Mean - & -......--.. & 15 & 17 & 5 & 1 & 5 & 2 & 22 & 5 & 5 & 9 & 1 & 2 & 2 & 13 \\
\hline
\end{tabular}

quartzite. Monocrystalline quartz (Qm of tables 1 and 2) is subrounded to subangular, commonly with undulose extinction. The quartz ranges in clarity from clear with no inclusions to heavily clouded by tiny opaque inclusions. Plagioclase feldspar is a subordinate framework constituent, and all feldspars tend to be subangular. They are variably altered by albitization and by replacement with sericite, carbonate, and (more rarely) zeolite minerals. Some rocks, however, contain grains of relatively fresh oligoclase. Potassium feldspar (orthoclase) was observed in only three samples, where the abundance ranged from 1 to 3 percent (table 2). In contrast, Decker
(1975) reported no K-feldspar and only trace amounts of plagioclase in his study of the Mt. Galen area (fig. 2).

Sedimentary-rock fragments are the predominant lithic constituents in Cantwell sandstones (see Ls in fig. 3). Siliciclastic rocks include fragments of argillaceous mudstone and siltstone, very fine grained quartzofeldspathic wacke, and dark-brown to nearly opaque carbonaceous mudstones and well-rounded, erosion-resistant, recrystallized cherty quartz with variable clay-mineral content. The most abundant sedimentary lithic fragment, however, is a cryptocrystalline, nearly isotropic rock that grades from translucent impure chert to nearly opaque 
cherty mudstone. The cherty mudstones commonly contain quartz-filled ghosts of microfossils (diatoms and radiolarians?). Limeclasts composed of micritic limestone or marble(?) are a minor component of most rocks, forming as much as 14 percent by volume in one sample (table 2)

Detrital modes of volcanic-rock fragments range from 0 to 48 percent ( $\mathrm{Lv}$ in table 1). Common textures include felsic groundmass and aphanitic greenstone groundmass. Altered, fine-grained, plagioclase-phyric andesite is a minor component. Lv also includes microcrystalline grains of uncertain origin that are composed of murky chlorite and clay.

Schistose metapelitic rocks range from 0 to 18 percent (schist in table 2) and include very fine grained quartz-mica schist, mica schist, and quartz-opaque oxide schist, as well as minor amounts of phyllitic schist.

Miscellaneous grains include muscovite and brown biotite, opaque grains, garnet, greenish hornblende, quartz and plagioclase granulite, and epidote. Only one sample contained broken calcareous shell fragments.

\section{Authigenic Minerals}

Although the Cantwell Formation has apparently been deeply buried, folded, and intruded by local swarms of mafic dikes, by sills, and by small granitic bodies, authigenic minerals are rare. The abundance of chemically stable framework grains and the low porosity resulting from mechanical compaction have apparently impeded the development of authigenic minerals. Principal authigenic minerals include polycrystalline quartz and a mix of clay and chlorite as pseudomatrix. Authigenic intergranular calcite mainly occurs in rocks that also contain limeclasts.

\section{Provenance of Conglomerates}

Previous reconnaissance studies of Cantwell conglomerates have noted stratigraphic and regional differences in clast composition. Csejtey and others (1986) interpreted fossiliferous limestone clasts west and southwest of the Teklanika River as being derived from Devonian and Ordovician to Devonian beds located just south of Cantwell outcrops in the Healy 1:250,000 quadrangle. They also observed that some conglomerate contains limestone clasts similar to nearby Triassic outcrops (located within $10 \mathrm{~km}$ ), and that the ubiquitous black argillite and sandstone clasts were probably derived from Late Jurassic to Early and (or) Late Cretaceous flyschlike rocks within the quadrangle.

In the Mount Galen area, Decker (1975) concluded that the metamorphic phyllite clasts in his lower unit were derived from now unexposed Paleozoic(?) rocks located north of the present Cantwell outcrop belt, whereas the sedimentary rock rich upper unit was derived from a southern source. The coarseness and angularity of diabase conglomerate in the Mount Galen area argue for local northern sources. The general paucity of schist debris in Cantwell conglomerates suggests both that the Birch Creek Schist and Totatlanika Schist, which are locally overlain by Cantwell strata, were not a major source of detrital material and that paleoflow was generally toward the schist terrane.

\section{Provenance of Sandstones}

The diversity of rock fragments in sandstones of the Cantwell Formation corresponds to the complex assemblage of underlying rocks. Exotic lithic fragments are notably absent. Locally abundant schistose debris, volcanic and metavolcanic fragments, and limeclasts could reflect nearby Late Devonian and (or) Triassic sources. Local exposures of pre-Cantwell Formation plutonic rocks may have supplied limited amounts of $\mathrm{K}$ feldspar, and the Mesozoic flysch sequence that is regionally exposed on both sides of the McKinley strand of the Denali fault system may have provided much of the pelitic debris. The complex of rocks that unconformably underlie the Cantwell Formation records repeated cycles of sedimentation, burial, and regional metamorphism, and Cantwell sandstones reflect recycling of these stratified oceanic and continental rocks.

Not surprisingly, the detrital modes and provenance fields shown in figure 3 suggest that the Cantwell Formation is composed of collision-derived sediment shed from a so-called recycled orogen (orogenic belt). According to Dickinson and Suczek (1979) and Dickinson (1984), sands deposited in such tectonic settings typically have intermediate quartz contents, a high ratio of quartz to feldspar, and an abundance of sedimentary and metasedimentary lithic fragments, all of which are characteristic of the Cantwell Formation.

\section{PETROLEUM RESERVOIR POTENTIAL OF CANTWELL SANDSTONES}

As noted above, sandstones in the Cantwell Formation typically consist of tightly packed framework grains with little or no primary intergranular porosity. Porespace reduction has been accomplished principally by compaction of ductile grains. Simple pore filling by authigenic cement has been of little importance in further reducing porosity in these rocks.

Most (but not all) Cantwell Formation sandstones are composed mainly of chemically stable framework 
grains (such as quartz and sedimentary-rock fragments) and generally contain only minor amounts of unstable grains (such as plagioclase and fine-grained volcanicrock fragments) that might dissolve during diagenesis to create secondary porosity (see, for example, Hayes, 1979). Thus, although organic geochemical data indicate that Cantwell mudstones and coals are potential source rocks of oil and gas (Stanley, 1987), the petroleum resource potential of the Cantwell Formation appears bleak because of the lack of porous reservoir rocks.

\section{PALEOGEOGRAPHY AND PALEOTECTONICS}

No detailed studies of the stratigraphy and sedimentology of the Cantwell Formation have been published. However, available information indicates that the Cantwell accumulated in a variety of nonmarine environments, including alluvial fan, fluvial, and lacustrine. Abrupt facies changes suggest that the Cantwell depositional basin was one of considerable local (internal) topographic and structural relief, and that a considerable portion of the detrital grains in both conglomerates and sandstones were derived from nearby sources (Wolfe and Wahrhaftig, 1970; Wahrhaftig and others, 1975; Decker, 1975; Hickman and others, 1977, 1978; Sherwood and others, 1979; Csejtey and others, 1982, 1984). The lithology of conglomerate clasts varies greatly from place to place, suggesting that the clasts were derived from a number of geologically different source areas and were deposited by a number of different river systems. Wolfe and Wahrhaftig (1970) noted that conglomerate clast compositions suggest derivation from at least three local sources: (1) Mesozoic flysch in the Talkeetna Mountains or southern Alaska Range, (2) Precambrian and Paleozoic schists in the northern Alaska Range, and (3) Devonian limestone near the crest of the Alaska Range. While many clasts obviously came from nearby source areas, many other clasts, including the ubiquitous white vein quartz and black chert, originated from unknown and perhaps distant sources (Csejtey and others, 1986).

There is considerable disagreement as to the paleogeographic and paleotectonic setting of Cantwell deposition. Sherwood and others (1979) believed that the depositional basin did not extend much beyond the present outcrop limits of the Cantwell Formation, and they suggested that the deposition and subsequent deformation of the Cantwell were controlled by movement along nearby right-lateral strike-slip faults such as the McKinley strand of the Denali fault system. This interpretation contrasts with that of Csejtey and others $(1984,1986)$, who argued that (1) the present Cantwell exposures are only erosional remnants of much more extensive deposits, (2) Cenozoic offset on the McKinley fault has been no more than $10 \mathrm{~km}$, and (3) Cantwell deposition was controlled in part by south-side-up vertical slip along the McKinley fault.

Also unclear is the tectonic significance of the volcanic rocks in the upper part of the Cantwell Formation. On the basis of previously published mineralogic and petrologic data, Moll-Stalcup (1990) proposed that Cantwell volcanism was part of an anomalously wide continental magmatic arc related to rapid northward subduction of the Kula plate beneath southern Alaska during the Late Cretaceous and early Tertiary. An alternative interpretation, suggested by Hickman and others (1990), is that the volcanic and sedimentary rocks of the Cantwell accumulated in an intermontane pull-apart basin formed by strike-slip movement on the Denali fault and the west end of the Hines Creek fault.

The results of our petrographic study corroborate earlier studies in that they indicate derivation of sediment from local rather than exotic source areas, but our study provides little new information on paleogeography or paleotectonics. Further insights into the history of Cantwell deposition and its implications for the history of the Denali fault system will require better age control and stratigraphic correlation within the Cantwell Formation, as well as detailed knowledge of sediment-transport directions and lateral variations in thickness and facies.

Acknowledgments.-Mark Johnsson provided computer-drawn illustrations of the provenance fields in figure 3. Computer graphics were done by Laura Zink, and tabular material was assembled by Chris Hamilton.

\section{REFERENCES CITED}

Chaney, R.W. 1937, Age of the Cantwell Formation [abs.]: Geological Society of America Proceedings, 1936, p. 355356.

Csejtey, Béla, Jr., Cox, D.P., Evarts, R.C., Stricker, G.D., and Foster, H.L., 1982, The Cenozoic Denali fault system and the Cretaceous accretionary development of southern Alaska: Journal of Geophysical Research, v. 87, no. B5, p. 3741-3754.

Csejtey, Béla, Jr., Yeend, W.E., and Goerz, D.J., III, 1984, Occurrence of the Cantwell(?) Formation south of the Denali fault system in the Healy quadrangle, southern Alaska, in Coonrad, W.L., and Elliott, R.L., eds., The U. S. Geological Survey in Alaska: Accomplishments during 1981: U.S. Geological Survey Circular 868, p. 77-79.

Csejtey, Béla, Jr., Mullen, M.W., Cox, D.P., Gilbert, W.G., Yeend, W.E., Smith, T.E., Wahrhaftig, Clyde, Craddock, Campbell, Brewer, W.M., Sherwood, K.W., Hickman, R.G., Stricker, G.D,. St. Aubin, D.R, and Goerz, D.J., III, 1986, Geology and geochronology of the Healy quadrangle, Alaska: U.S. Geological Survey Open-File Report 86-396, 92 p., scale 1:250,000, 4 map sheets.

Decker, J.E., 1975, Geology of the Mt. Galen area, Mount McKinley National Park, Alaska: Fairbanks, University of Alaska, M.S. thesis, 77 p. 
Dickinson, W.R., 1970, Interpreting the detrital modes of graywacke and arkose: Journal of Sedimentary Petrology, v. 40 , p. $695-707$.

-1984, Interpreting provenance relations from detrital modes of sandstones, in Zuffa, G.G., ed., Provenance of arenites: Boston, D. Reidel, p. 333-362.

Dickinson, W.R., Beard, L.S., Brakenridge, G.R., Erjavec, J.L., Ferguson, R.C., Inman, K.F., Knepp, R.A., Lindberg, F.A., and Ryberg, P.T., 1983, Provenance of North American sandstones in relation to tectonic setting: Geological Society of America Bulletin, v. 94, p. 222-235.

Dickinson, W.R., and Suczek, C., 1979, Plate tectonics and sandstone composition: American Association of Petroleum Geologists Bulletin, v. 63, p. 2164-2182.

Gilbert, W.G., Ferrell, V.M., and Turner, D.L., 1976, The Teklanika Formation-new Paleocene volcanic formation in the central Alaska Range: Alaska Geological and Geophysical Survey Geologic Report 47, 16 p.

Hayes, J.B., 1979, Sandstone diagenesis-the hole truth, in Scholle, P.A., and Schluger, P.R., eds., Aspects of diagenesis: Society of Economic Paleontologists and Mineralogists Special Publication no. 26, p. 127-139.

Hickman, R.G.,. Sherwood, K.W., and Craddock, Campbell, 1990, Structural evolution of the early Tertiary Cantwell basin, south central Alaska: Tectonics, v. 9, p.1433-1449.

Hickman, R.G., Craddock, Campbell, and Sherwood, K.W., 1978, The Denali fault system and the tectonic development of southern Alaska: Tectonophysics, v. 47, p. 247273.

-1977, Structural geology of the Nenana River segment of the Denali Fault system, central Alaska Range: Geological Society of America Bulletin, v. 88, no. 9, p. 12171230.

Ingersoll, R.V., Bullard, T.F., Ford, R.L., Grimm, J.P., Pickle, J.D., and Sares, S.W., 1984, The effect of grain size in detrital modes: a test of the Gazzi-Dickinson point count- ing method: Journal of Sedimentary Petrology, v. 54, p. 103-116.

Jones, D.L., Silberling, N.J., Coney, P.J., and Plafker, George, 1987, Lithotectonic terrane map of Alaska (west of the 141st meridian): U.S. Geological Survey Miscellaneous Field Studies Map MF-1874-A, scale 1:2,500,000.

Jones, D.L., Silberling, N.J., Gilbert, W.G., and Coney, P.J., 1983, Tectono-stratigraphic map and interpretive bedrock geologic map of the Mount McKinley region, Alaska: U.S. Geological Survey Open-File Report 83-11, scale $1: 250,000,2$ sheets.

Moll-Stalcup, E.J., 1990, Latest Cretaceous and Cenozoic magmatism in mainland Alaska: U.S. Geological Survey Open-File Report 90-84, 82 p.

Reed, J.C., 1961, Geology of the Mount McKinley quadrangle, Alaska: U.S. Geological Survey Bulletin, 1108-A, 36 p.

Sherwood, K.S., Hickman, R.G., and Craddock, Campbell, 1979, Structural evolution of the Paleocene Cantwell basin along the Denali fault system [abs.]: Geological Society of America Abstracts with Programs, v. 11, no. 7, p. 515-516.

Stanley, R.G., 1987, Thermal maturity and petroleum-source potential of the Cantwell Formation (Paleocene), Alaska Range, in Hamilton, T.D., and Galloway, J.P., eds., Geologic studies in Alaska by the U.S. Geological Survey during 1986: U.S. Geological Survey Circular 998, p. 104 107.

Wahrhaftig, Clyde, Turner, D.L., Weber, F.R., and Smith, T.E., 1975, Nature and timing of movement on Hines Creek strand of the Denali fault system, Alaska: Geology, v. 3, p. $463-466$.

Wolfe, J.A., and Wahrhaftig, Clyde, 1970, The Cantwell Formation of the central Alaska Range: U.S. Geological Survey Bulletin 1294-A, p. 41-55.

Reviewers: Susan Bartsch-Winkler and Clyde Wahrhaftig 


\title{
${ }^{40} \mathrm{Ar} /{ }^{39} \mathrm{Ar}$ Isotopic Ages from the Combined Wrangellia-Alexander Terrane along the Border Ranges Fault System in the Eastern Chugach Mountains and Glacier Bay, Alaska
}

\author{
By S.M. Roeske, T.L. Pavlis, L.W. Snee, and V.B. Sisson
}

\begin{abstract}
The Border Ranges fault system, one of the major tectonic boundaries of southern Alaska, has a long and complex history of displacement since the Early Jurassic. We initiated this geochronologic study to date one phase of deformation on the Border Ranges fault system, a late Mesozoic strike-slip event for which we have evidence in the eastern Chugach Mountains and northern Glacier Bay. The ${ }^{40} \mathrm{Ar} /{ }^{39} \mathrm{Ar}$ spectra from eight samples of plutonic and metamorphic rocks deformed by high-angle retrograde shear zones show little disturbance of the isotopic systems following initial cooling after crystallization. Stepwise heating of hornblendes from four samples of quartz diorite of the Tonsina-Chichagof belt and from one sample of the Strelna Metamorphics in the eastern Chugach Mountains gave plateau dates that range from 148 to $144 \mathrm{Ma}$. Hornblendes from two quartz diorites that intrude Alexander terrane carbonate rocks in northern Glacier Bay have plateau dates of 120 and $123 \mathrm{Ma}$. Muscovite from a faultbounded trondhjemite body in Glacier Bay has a plateau date of $162 \mathrm{Ma}$. The plateau dates from the eastern Chugach Mountains and northern Glacier Bay are similar to previously published K-Ar dates of the major plutonic belts in these regions. These results indicate that the Ar systematics of the Late Jurassic and Early Cretaceous plutons and metamorphic rocks along the eastern and southeastern segments of the Border Ranges fault system have not been affected by a major reheating event.
\end{abstract}

\section{INTRODUCTION}

The major tectonic boundary of southern Alaska is the Border Ranges fault system (Plafker and others, 1989), a >2,000-km-long network of low- and high-angle faults that separate crystalline rocks of the Peninsular and combined Wrangellia-Alexander terranes from the accretionary complex of the Chugach terrane (fig. 1). The Border Ranges fault system has been interpreted as the site of late Mesozoic subduction (MacKevett and
Plafker, 1974; Plafker and others, 1977, 1989; and many others) because mid- to late Mesozoic blueschist facies rocks and late Mesozoic mélanges (the McHugh and Uyak Complexes of southern Alaska and the Kelp Bay Group of southeast Alaska) occur outboard of the fault system. Immediately inboard of the fault system, elongate bodies of calc-alkaline plutonic rocks locally intrude crystalline rocks along the entire length of the fault. These plutonic suites span a wide range of ages but are similar in that they are primarily diorites and tonalites and many are truncated at the Border Ranges fault system. The plutonic rocks have been interpreted as the roots of ancient island-arc systems and are thought to be related to subduction from the south or west (in present-day coordinates) (MacKevett, 1978; Hudson, 1983; Burns, 1985; Plafker and others, 1989). In the eastern Chugach Mountains and southeast Alaska, Late Jurassic and Early Cretaceous plutonic rocks are juxtaposed along high-angle faults with the McHugh Complex. This juxtaposition of an island-arc sequence with very low grade accretionary complex rocks requires that tens of kilometers of the forearc have been eliminated, if the accretionary complex was formed in a subduction zone related to the emplacement of the plutonic rocks. This study was initiated in order to investigate the late Mesozoic to earliest Cenozoic structural evolution of the eastern and southeastern sections of the Border Ranges fault system in order to determine the relative roles that strike-slip and thrust deformation may have played in tectonic erosion of the forearc. Our detailed field studies in the eastern Chugach Mountains and in Glacier Bay have documented that at these sites the Border Ranges fault system is a $10-\mathrm{km}$-wide zone of high- and lowangle retrograde ductile shear zones and brittle faults, along which slivers of the McHugh Complex have been shuffled with Jurassic and Cretaceous plutonic rocks and basement rocks of the combined Wrangellia-Alexander terrane (Pavlis and others, 1989; Roeske and others, 
1990a, b). Excellent exposure allows us to observe the progressive mylonitization and alteration of the plutons to S-C mylonites [mylonites with shear bands (C) oblique to foliation (S)] and greenschist phyllonites. The broad retrograde shear zone is characterized by domainal development of high-angle retrograde shear zones, with local development of south-dipping low-angle shear zones. We calculated the extension direction in the highangle shear zones by measuring the $\mathrm{S}$ and $\mathrm{C}$ planes' orientations, determining their line of intersection graphically, and then assuming that slip occurred in the shear plane at approximately $90^{\circ}$ from the line of intersection (Marshak and Mitra, 1988). These calculated extension directions are parallel to mineral lineations within the shear zones; both are subhorizontal. Kinematic indicators, including bending of foliation in ductile shear zones, S-C asymmetries, "tails" on porphyroclasts, and slickenlines, show that the major phase of movement along the high-angle shear zones and faults was dextral simple shear (Pavlis and others, 1989; Roeske and others, 1990a, b). To refine the timing of this deformation event, we have undertaken an ${ }^{40} \mathrm{Ar} /{ }^{39} \mathrm{Ar}$ study of rocks in

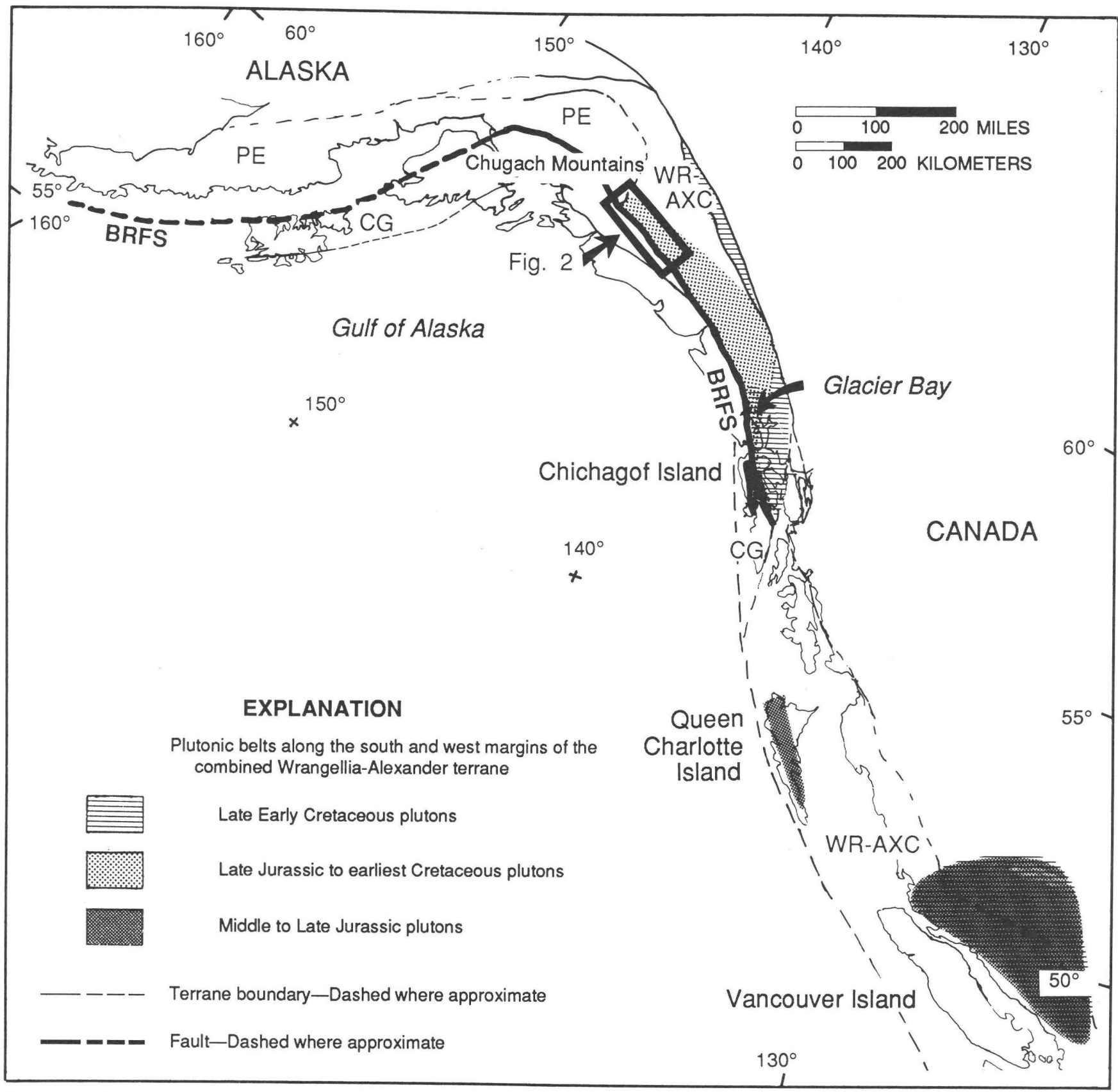

Figure 1. Major terranes and tectonic and geographic features of southern Alaska and western Yukon and British Columbia. WR-AXC, combined Wrangellia-Alexander terrane; PE, Peninsular terrane; CG, Chugach terrane; BRFS, Border Ranges fault system (dashed where approximate). 
and adjacent to the fault zone. The preliminary results presented here are from plutonic rocks and the country rock that they intrude: schists and gneisses of the combined Wrangellia-Alexander terrane.

\section{PREVIOUS GEOCHRONOLOGY ALONG THE SOUTHERN AND WESTERN MARGINS OF THE COMBINED WRANGELLIA-ALEXANDER TERRANE}

\section{Middle Jurassic to Earliest Cretaceous Plutonic Rocks}

MacKevett (1978) identified an extensive group of Late Jurassic to Early Cretaceous plutonic rocks in the eastern Chugach Mountains-the Chitina Valley batholith. Plutons of this group are dominantly quartz diorite, quartz monzodiorite, tonalite, and granodiorite. This plutonic belt extends to the western Yukon Territory and southeast Alaska, based on similar ages and compositions for the whole group (Loney and others, 1967; Dodds and Campbell, 1988; Karl and others, 1988). Hudson (1979) named the belt the Tonsina-Chichagof belt; the segment of the belt that intrudes the combined Wrangellia-Alexander terrane in Canada is referred to as the Saint Elias plutonic group (Dodds and Campbell, 1988). Concordant biotite and hornblende K-Ar dates from single samples range from approximately 160 to $130 \mathrm{Ma}$, with most of the hornblende K-Ar dates falling between 140 and $160 \mathrm{Ma}$. The plutonic rocks are weakly to strongly foliated, and they typically have concordant contacts with the greenschist to amphibolite facies country rock (MacKevett, 1978; Winkler and others, 1981; Dodds and Campbell, 1988).

Recent work along the Border Ranges fault system in the northern Chugach Mountains demonstrated that the combined Wrangellia-Alexander terrane now exposed in a structural flap west of the Taral fault (fig. 2) was intensely deformed and metamorphosed in the Cre-

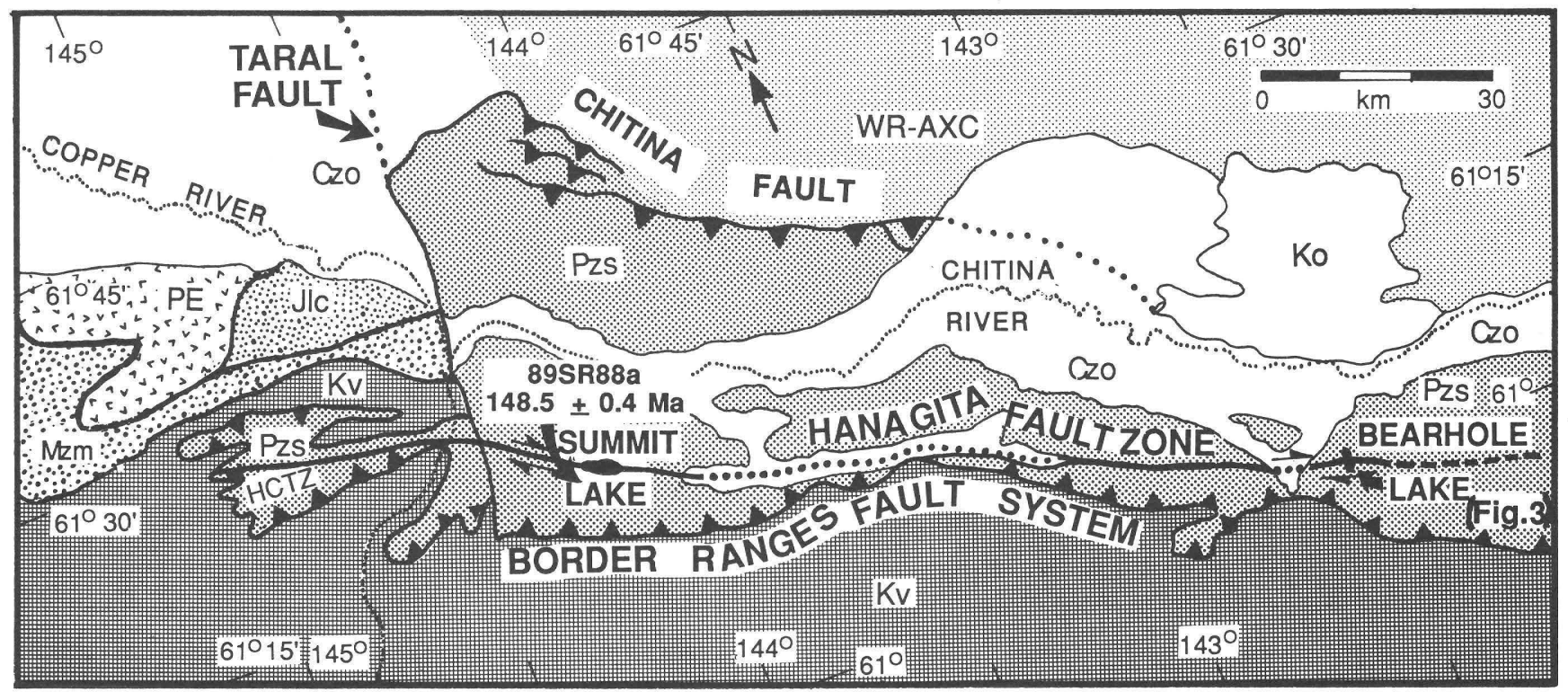

EXPLANATION

\section{Terrane or lithologic boundary}

- Fault - Terrane or lithologic boundary. Dotted where covered. Arrows indicate direction of relative movement.

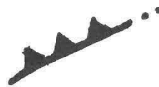

Thrust fault - Terrane or lithologic boundary. Sawteeth on upper plate. Dotted where covered.

Figure 2. Generalized geologic map of the eastern Chugach Mountains, adapted from MacKevett (1978), Winkler and others (1981), and Plafker and others (1989) (see fig. 1 for location). Terranes: WR-AXC, combined WrangelliaAlexander terrane; PE, Peninsular terrane. Lithologic units: $P_{\text {zS }}$, Strelna Metamorphics of Plafker and others (1989) (Paleozoic); Jlc, schist of Liberty Creek (Jurassic); Mzm,
McHugh Complex (Mesozoic); Kv, Valdez Group (Cretaceous); Ko, overlap deposits (Cretaceous); Czo, overlap deposits (Cenozoic). Tectonic features: HCTZ, Haley Creek tectonic zone. Sample number indicates location of ${ }^{40} \mathrm{Ar} /{ }^{39} \mathrm{Ar}$ date discussed in text. The number (in $\mathrm{Ma}$ ) is the plateau date from the hornblende separate of this sample. 
taceous (Pavlis and Crouse, 1989; Plafker and others, 1989). A U-Pb zircon date from one of these mylonitic plutons is $153 \pm 4 \mathrm{Ma}$ (Plafker and others, 1989), but hornblende and white mica $\mathrm{K}$-Ar dates from the metadiorites and metatrondhjemites in the region range from 149 to $112 \mathrm{Ma}$ (Winkler and others, 1981; Plafker and others, 1989). The spread in $\mathrm{K}-\mathrm{Ar}$ dates in this region probably reflects partial resetting of mineral dates during the Cretaceous event (described above) and (or) an Eocene thermal event that affected the accretionary prism to the south (Hudson and Plafker, 1982).

The geochemistry of the Late Jurassic plutons shows that they are calc-alkaline (Hudson, 1983; Dodds and Campbell, 1988; Plafker and others, 1989). The plutons were intruded during the beginning of a major regional orogeny (MacKevett, 1978) and are interpreted as the roots of an island arc (Hudson, 1983; Plafker and others, 1989). The polarity of this arc is uncertain, but Plafker and others' (1989) preferred model is north-to northeast-directed subduction, based on the presence of coeval volcanic detritus in the adjacent McHugh Complex.

This plutonic group may extend farther south in the combined Wrangellia-Alexander terrane (fig. 1). KAr hornblende dates from two plutons on the Queen Charlotte Islands indicate that plutons as old as $166 \pm 3$ Ma and $164 \pm 3 \mathrm{Ma}$ intrude Wrangellia there (Anderson and Reichenbach, 1989), and plutons with U-Pb dates of 173 to $145 \mathrm{Ma}$ intrude Wrangellia on the mainland east of Vancouver Island (Friedman, 1990). Another possible interpretation of the spread of dates is that there are two plutonic suites, one Middle to Late Jurassic and one Late Jurassic to earliest Cretaceous in age, that overlap in southeast Alaska and may overlap in British Columbia. Karl and others (1988) reported four hornblende $\mathrm{K}-\mathrm{Ar}$ dates from western Chichagof Island ranging from 182 to $169 \mathrm{Ma}$, suggesting that a distinctly older group of plutons occurs in the same location as the Late Jurassic plutons identified by Loney and others (1975) and by Karl and others (1988).

\section{Late Early Cretaceous Plutons}

The late Early Cretaceous belt of plutons in eastern and southeast Alaska has a distinctly different trend than the Late Jurassic belt (fig. 1). The former's trend is well inboard of the Border Ranges fault system in eastern Alaska but extends westward to the fault system in southeast Alaska. The southern segment of this belt consists primarily of foliated biotite and hornblende diorite to tonalite. The plutons are typically elongate parallel to the regional fabric and have concordant contacts (Brew and Morrell, 1983; Hudson, 1983). Hudson (1983) refers to these plutons as the Nutzotin-Chichagof belt; this group of plutons includes the Muir-Chichagof belt of Brew and Morrell (1983) and the Kluane Ranges plutonic group of Dodds and Campbell (1988). K-Ar dates from these plutons range from 120 to $103 \mathrm{Ma}$; concordant biotite-hornblende pairs from samples along the entire length of the belt are tightly clustered between 115 and $107 \mathrm{Ma}$ (MacKevett and others, 1974; Richter and others, 1975; Dodds and Campbell, 1988). U-Pb dates from the mainland of southern British Columbia range from 131 to $102 \mathrm{Ma}$, indicating a possible continuation of this group of plutons to the southern extent of Wrangellia (Friedman and Armstrong, 1990).

The late Early Cretaceous plutons are similar in many respects to the Late Jurassic group as they are also calc-alkaline and are interpreted to be the roots of an island arc (Richter and others, 1975; Hudson, 1983; Dodds and Campbell, 1988; Armstrong, 1988; Friedman and Armstrong, 1990). The abundance of Early Cretaceous fossils in the Chugach terrrane and the existence of a mid-Cretaceous forearc basin have been used as evidence for northeast-directed (present coordinates) subduction (Plafker and others, 1977; Pavlis and others, 1988). Plafker and others (1989) suggest that the late Early Cretaceous plutons represent an inland shift of the Late Jurassic arc.

\section{METHODS}

Mineral separates of 60 to 120 mesh size (250 to $125 \mu$ ) were prepared by standard heavy-liquid, magneticseparator, and paper-shaking methods, cleaned with reagent-grade acetone and deionized water in an ultrasonic bath, and finally air dried. These separates were then picked by hand to greater than 99 percent purity. Individual samples, ranging from 17 to $400 \mathrm{mg}$ in mass, were wrapped in aluminum-foil boats and sealed in silica vials along with the monitor minerals prior to irradiation.

All samples were irradiated simultaneously for 30 total hours at a power level of $1 \mathrm{MW}$ in the TRIGA reactor at the U.S. Geological Survey in Denver, Colorado. The argon isotopic composition of the samples was measured in static mode on a Mass Analyzer Products 215 Rare Gas mass spectrometer using a Faraday cup with a sensitivity of $9.736 \times 10^{-13}$ moles $/ \mathrm{V}$ and a detection limit of $5 \times 10^{-17}$ moles Ar. Analyses were corrected for volume, mass fractionation, trap current, radioactive decay of ${ }^{37} \mathrm{Ar}$ and ${ }^{39} \mathrm{Ar}$, and interfering isotopes of argon. Corrections for irradiation-produced ${ }^{40} \mathrm{Ar}$ (from K) and ${ }^{39} \mathrm{Ar}$ (from $\mathrm{Ca}$ ) were determined from production rates measured on pure $\mathrm{K}_{2} \mathrm{SO}_{4}$ and $\mathrm{CaF}_{2}$ salts irradiated with the samples, while corrections for $\mathrm{Cl}$-derived ${ }^{37} \mathrm{Ar}$ were made using the method of Roddick (1983). Production ratios determined for this study are $\mathrm{K} 37 / 39-2.34 \times 10^{-4}$, $\mathrm{K} 38 / 39-1.30 \times 10^{-2}, \mathrm{~K} 40 / 39-1.135 \times 10^{-2}, \mathrm{Ca} 39 / 37-$ 
Table 1. Argon analytical data

[Analytical data for "Radiogenic ${ }^{\circ 0} \mathrm{Ar}$ " and "K-derived ${ }^{39} \mathrm{Ar}$ " are calculated from raw data to five places right of the decimal; "F values" (radiogenic ${ }^{40} \mathrm{Ar} / \mathrm{K}$-derived ${ }^{39} \mathrm{Ar}$ ratio after all corrections for interfering isotopes have been made) are calculated to three places right of the decimal. "Radiogenic ${ }^{20} \mathrm{Ar}$," "Kderived ${ }^{39} \mathrm{Ar}$," and " $\mathrm{F}$ values" have been rounded using calculated analytical precisions. Apparent ages and errors were calculated from unrounded data and then rounded using analytical precisions. ${ }^{30} \mathrm{Ar} /$ ${ }^{37} \mathrm{Ar}$ is determined by mass spectrometry. Assuming ${ }^{37} \mathrm{Ar}$ is Ca-derived and ${ }^{39} \mathrm{Ar}$ is $\mathrm{K}$-derived, this ratio is an "apparent" K/Ca ratio when multiplied by approximately 0.5$]$

\begin{tabular}{|c|c|c|c|c|c|c|c|}
\hline \multicolumn{8}{|c|}{ 89SR126g Hornblende latitude $60^{\circ} 59^{\prime} 20^{\prime \prime}$ longitude $142^{\circ} 31^{\prime} 10^{\prime \prime}$} \\
\hline $\begin{array}{l}\text { Temp. } \\
\left({ }^{\circ} \mathrm{C}\right)\end{array}$ & $\begin{array}{c}\text { Radiogenic } \\
{ }^{40} \mathrm{Ar} \\
\text { (volts) }\end{array}$ & $\begin{array}{l}\text { K-derived } \\
{ }^{39} \mathrm{Ar} \\
\text { (volts) }\end{array}$ & $\begin{array}{c}F \\
\text { value }\end{array}$ & $\begin{array}{l}\text { Radiogenic } \\
\text { yield } \\
\text { (percent) }\end{array}$ & $\begin{array}{l}\text { Percent } \\
{ }^{39} \mathrm{Ar} \text { total }\end{array}$ & $\begin{array}{l}{ }^{39} \mathrm{Ar}{ }^{37} \mathrm{Ar} \\
\text { ratio }\end{array}$ & $\begin{array}{c}\text { Apparent age } \\
\text { and error (Ma } \\
\text { at } 1 \text { sigma) }\end{array}$ \\
\hline 500 & 0.24716 & 0.01576 & 15.7 & 48.6 & 0.5 & 0.46 & $213 \pm 5$ \\
\hline 600 & .09643 & .01498 & 6.4 & 57.4 & .4 & .35 & $90 \pm 7$ \\
\hline 700 & .3236 & .03652 & 8.9 & 39.7 & 1.1 & .52 & $123 \pm 2$ \\
\hline 750 & .19064 & .02221 & 8.6 & 83.5 & .6 & .78 & $120 \pm 2$ \\
\hline 800 & .28999 & .03422 & 8.5 & 83.5 & 1.0 & .63 & $118 \pm 2$ \\
\hline 850 & .48751 & .06272 & 7.8 & 80.1 & 1.8 & .45 & $109 \pm 2$ \\
\hline 900 & .58020 & .06822 & 8.50 & 88.4 & 2.0 & .26 & $118.5 \pm 0.7$ \\
\hline 950 & 3.6311 & .33892 & 10.71 & 96.3 & 9.8 & .17 & $148.0 \pm 0.4$ \\
\hline 975 & 11.792 & 1.1061 & 10.66 & 97.9 & 32.1 & .20 & $147.3 \pm 0.4$ \\
\hline 1000 & 6.003 & .56658 & 10.60 & 98.3 & 16.4 & .23 & $146.5 \pm 0.4$ \\
\hline 1025 & 1.2996 & .12749 & 10.19 & 96.8 & 3.7 & .23 & $141.1 \pm 0.6$ \\
\hline 1050 & 2.6153 & .25020 & 10.45 & 97.9 & 7.3 & .22 & $144.6 \pm 0.4$ \\
\hline 1100 & 4.143 & .39042 & 10.61 & 98.4 & 11.3 & .22 & $146.7 \pm 0.5$ \\
\hline 1150 & 1.118 & .10753 & 10.40 & 96.3 & 3.1 & .21 & $143.8 \pm 0.7$ \\
\hline 1200 & .4559 & .04417 & 10.3 & 92.4 & 1.3 & .21 & $143 \pm 2$ \\
\hline 1250 & 1.3645 & .13029 & 10.47 & 92.7 & 3.8 & .21 & $144.8 \pm 0.9$ \\
\hline 1450 & 1.11700 & .12838 & 8.70 & 76.9 & 3.7 & .39 & $121.1 \pm 0.7$ \\
\hline \multicolumn{3}{|c|}{ Total gas } & 10.38 & & & & $143.6 \pm 0.6$ \\
\hline
\end{tabular}

$6.66 \times 10^{-4}, \mathrm{Ca} 36 / 37-2.64 \times 10^{-4}$, and $\mathrm{Ca} 38 / 37$ $3.65 \times 10^{-5}$. The relative, approximate $\mathrm{K} / \mathrm{Ca}$ distribution of each sample may be obtained by multiplying the ${ }^{39} \mathrm{Ar} /{ }^{37} \mathrm{Ar}$ ratios given in table 1 by 0.5 . Detailed descriptions of the equations for these corrections can be obtained from Snee.

$\mathrm{J}$ values for the analyses were calculated using the irradiation monitor MMhb-1 (1.555 weight percent $\mathrm{K}$ ), with a generally accepted K-Ar age of $520.4 \mathrm{Ma}$ (Alexander and others, 1978; Samson and Alexander, 1987). Imprecisions in J were calculated from the reproducibility of split gas fractions for each monitor and are typically in the range of 0.15 to 0.35 percent (1 sigma). J values for each sample are interpolated from surrounding monitors and have uncertainties similar to those of the monitors. Note that these uncertainties are not considered in determining the presence of a plateau in a sample. Uncertainties in date calculations for individual steps were assigned using the equations of Dalrymple and others (1981). All isotopic abundances and decay constants used here were those of Steiger and Jäger (1977).

An assortment of terms have been used to describe the meaning and geological relevance of ${ }^{40} \mathrm{Ar} /{ }^{39} \mathrm{Ar}$ data. Within this paper, we use the term "date" to refer to an analytically determined number, whereas "age" refers to a date interpreted as having geologic significance. We utilize several different types of dates in this paper. A plateau date is herein defined as the mean date from three or more contiguous, concordant release steps in a sample, where concordancy is defined at the 2-sigma level (Dalrymple and Lanphere, 1969). Typically, ${ }^{40} \mathrm{Ar} /$ ${ }^{39} \mathrm{Ar}$ dates are interpreted as recording the age at which a system closed to the diffusion of Ar. Closure temperatures are a weak function of cooling rate, and for geologically relevant cooling rates closure temperatures for 
Table 1. Argon analytical data-Continued

\begin{tabular}{|c|c|c|c|c|c|c|c|}
\hline \multicolumn{8}{|c|}{ 89SR137 Hornblende latitude $60^{\circ} 57^{\prime} 10^{\prime \prime}$ longitude $142^{\circ} 31^{\prime} 20^{\prime \prime}$} \\
\hline $\begin{array}{l}\text { Temp. } \\
\left({ }^{\circ} \mathrm{C}\right)\end{array}$ & $\begin{array}{c}\text { Radiogenic } \\
{ }^{40} \AA \mathrm{r} \\
\text { (volts) }\end{array}$ & $\begin{array}{c}\text { K-derived } \\
{ }^{39} \mathrm{Ar} \\
\text { (volts) }\end{array}$ & $\begin{array}{c}F \\
\text { value }\end{array}$ & $\begin{array}{c}\text { Radiogenic } \\
\text { yield } \\
\text { (percent) }\end{array}$ & $\begin{array}{l}\text { Percent } \\
{ }^{39} \mathrm{Ar} \text { total }\end{array}$ & $\begin{array}{c}{ }^{39} \mathrm{Ar} /{ }^{37} \mathrm{Ar} \\
\text { ratio }\end{array}$ & $\begin{array}{c}\text { Apparent age } \\
\text { and error (Ma } \\
\text { at } 1 \text { sigma) }\end{array}$ \\
\hline 500 & 0.04333 & 0.00319 & 13.6 & 17.2 & 0.1 & 0.10 & $186 \pm 17$ \\
\hline 600 & .00821 & .00153 & 5 & 21.6 & .0 & .08 & $76 \pm 76$ \\
\hline 700 & .2350 & .02703 & 8.7 & 6.5 & .8 & .10 & $121 \pm 3$ \\
\hline 750 & .1305 & .01454 & 9.0 & 5.8 & .4 & .07 & $125 \pm 3$ \\
\hline 800 & .1712 & .01468 & 11.7 & 5.5 & .4 & .09 & $160 \pm 4$ \\
\hline 850 & .1689 & .01491 & 11.3 & 5.7 & .4 & .06 & $156 \pm 5$ \\
\hline 900 & .5310 & .05059 & 10.5 & 21.0 & 1.4 & .07 & $145 \pm 2$ \\
\hline 950 & 4.8138 & .45945 & 10.48 & 87.0 & 13.0 & .14 & $144.6 \pm 0.4$ \\
\hline 975 & 8.8178 & .83544 & 10.56 & 63.8 & 23.7 & .15 & $145.7 \pm 0.4$ \\
\hline 1000 & 4.3060 & .40548 & 10.62 & 48.6 & 11.5 & .15 & $146.5 \pm 0.4$ \\
\hline 1050 & 4.5946 & .43957 & 10.45 & 72.9 & 12.4 & .13 & $144.3 \pm 0.4$ \\
\hline 1100 & 10.871 & 1.0401 & 10.45 & 93.0 & 29.5 & .14 & $144.3 \pm 0.4$ \\
\hline 1150 & 1.4561 & .13934 & 10.45 & 71.7 & 3.9 & .15 & $144 \pm 1$ \\
\hline 1200 & .55403 & .05223 & 10.61 & 44.9 & 1.5 & .14 & $146 \pm 1$ \\
\hline 1250 & .34941 & .03322 & 10.5 & 32.6 & .9 & .14 & $145 \pm 2$ \\
\hline \multicolumn{3}{|c|}{ Total gas ----.- } & 10.49 & & & & $144.8 \pm 0.5$ \\
\hline \multicolumn{8}{|c|}{ 89SR123e Hornblende latitude $60^{\circ} 58^{\prime} 50^{\prime \prime}$ longitude $142^{\circ} 30^{\prime} 25^{\prime \prime}$} \\
\hline $\begin{array}{l}\text { Temp. } \\
\left({ }^{\circ} \mathrm{C}\right)\end{array}$ & $\begin{array}{c}\text { Radiogenic } \\
{ }^{40} \mathrm{Ar} \\
\text { (volts) }\end{array}$ & $\begin{array}{c}\text { K-derived } \\
{ }^{39} \mathrm{Ar} \\
\text { (volts) }\end{array}$ & $\begin{array}{c}\mathrm{F} \\
\text { value }\end{array}$ & $\begin{array}{c}\text { Radiogenic } \\
\text { yield } \\
\text { (percent) }\end{array}$ & $\begin{array}{c}\text { Percent } \\
{ }^{39} \mathrm{Ar} \text { total }\end{array}$ & $\begin{array}{c}{ }^{39} \mathrm{Ar} /{ }^{37} \mathrm{Ar} \\
\text { ratio }\end{array}$ & $\begin{array}{c}\text { Apparent age } \\
\text { and error (Ma } \\
\text { at } 1 \text { sigma) }\end{array}$ \\
\hline 500 & 0.01206 & 0.00184 & 6.6 & 9.7 & 0.0 & 0.09 & $92 \pm 36$ \\
\hline 600 & .02355 & .00586 & 4.0 & 26.0 & .2 & .11 & $57 \pm 4$ \\
\hline 700 & .06821 & .00909 & 7.5 & 10.6 & .2 & .05 & $105 \pm 9$ \\
\hline 750 & .03101 & .00574 & 5.4 & 25.6 & .2 & .02 & $76 \pm 8$ \\
\hline 800 & .05686 & .00974 & 5.8 & 26.8 & .3 & .03 & $82 \pm 8$ \\
\hline 850 & .12384 & .01420 & 8.72 & 27.7 & .4 & .08 & $122 \pm 3$ \\
\hline 900 & .42076 & .03873 & 10.9 & 64.5 & 1.0 & .12 & $150 \pm 3$ \\
\hline 950 & 5.6598 & .53879 & 10.51 & 95.3 & 14.4 & .14 & $145.6 \pm 0.4$ \\
\hline 975 & 7.499 & .7198 & 10.42 & 95.2 & 19.3 & .14 & $144.5 \pm 0.4$ \\
\hline 1000 & 2.0913 & .20080 & 10.42 & 89.2 & 5.4 & .15 & $144.4 \pm 0.4$ \\
\hline 1025 & 2.564 & .24653 & 10.40 & 94.2 & 6.6 & .15 & $144.2 \pm 0.5$ \\
\hline 1050 & 3.8733 & .37005 & 10.47 & 96.7 & 9.9 & .13 & $145.1 \pm 0.4$ \\
\hline 1100 & 14.786 & 1.4179 & 10.43 & 97.7 & 38.0 & .14 & $144.6 \pm 0.4$ \\
\hline 1150 & .66018 & .06370 & 10.36 & 92.0 & 1.7 & .13 & $143.7 \pm 0.6$ \\
\hline 1200 & .23057 & .02168 & 10.6 & 82.1 & .6 & .13 & $147 \pm 3$ \\
\hline 1250 & .33120 & .03164 & 10.5 & 79.5 & .8 & .13 & $145 \pm 3$ \\
\hline 1450 & .3472 & .03376 & 10.3 & 52.8 & .9 & .13 & $143 \pm 2$ \\
\hline \multicolumn{3}{|c|}{ Total gas } & 10.40 & & & & $144.2 \pm 0.5$ \\
\hline
\end{tabular}


Table 1. Argon analytical data-Continued

\begin{tabular}{|c|c|c|c|c|c|c|c|}
\hline \multicolumn{8}{|c|}{ 89SR130c Hornblende latitude $60^{\circ} 58^{\prime} 30^{\prime \prime}$ longitude $142^{\circ} 30^{\prime} 45^{\prime \prime}$} \\
\hline $\begin{array}{l}\text { Temp. } \\
\left({ }^{\circ} \mathrm{C}\right)\end{array}$ & $\begin{array}{c}\text { Radiogenic } \\
{ }_{40} \mathrm{Ar} \\
\text { (volts) }\end{array}$ & $\begin{array}{c}\text { K-derived } \\
{ }^{39} \mathrm{Ar} \\
\text { (volts) }\end{array}$ & $\begin{array}{c}\mathrm{F} \\
\text { value }\end{array}$ & $\begin{array}{l}\text { Radiogenic } \\
\text { yield } \\
\text { (percent) }\end{array}$ & $\begin{array}{l}\text { Percent } \\
{ }^{39} \mathrm{Ar} \text { total }\end{array}$ & $\begin{array}{l}{ }^{39} \mathrm{Ar}{ }^{37} \mathrm{Ar} \\
\text { ratio }\end{array}$ & $\begin{array}{l}\text { Apparent age } \\
\text { and error (Ma } \\
\text { at } 1 \text { sigma) }\end{array}$ \\
\hline 500 & 0.03928 & 0.00232 & 16.9 & 9.1 & 0.1 & 0.05 & $229 \pm 55$ \\
\hline 600 & .07278 & .01698 & 4.2 & 16.5 & .9 & .10 & $61 \pm 3$ \\
\hline 700 & .1225 & .01118 & 11 & 14.8 & .6 & .09 & $151 \pm 10$ \\
\hline 750 & .06408 & .00794 & 8.1 & 38.5 & .4 & .06 & $113 \pm 8$ \\
\hline 800 & .07354 & .00713 & 10.31 & 65.5 & .4 & .08 & $143 \pm 7$ \\
\hline 850 & .09971 & .00884 & 11.3 & 73.6 & .5 & .08 & $156 \pm 4$ \\
\hline 900 & .13026 & .01129 & 11.5 & 76.1 & .6 & .09 & $159 \pm 4$ \\
\hline 950 & 1.2520 & .11519 & 10.87 & 94.5 & 6.1 & .11 & $150.1 \pm 0.7$ \\
\hline 975 & 3.5697 & .34292 & 10.41 & 97.4 & 18.1 & .12 & $144.0 \pm 0.4$ \\
\hline 1000 & 3.3425 & .32376 & 10.32 & 97.0 & 17.1 & .12 & $142.8 \pm 0.4$ \\
\hline 1025 & 2.3173 & .22385 & 10.35 & 96.9 & 11.8 & .12 & $143.3 \pm 0.5$ \\
\hline 1050 & 1.2974 & .12420 & 10.45 & 93.8 & 6.6 & .11 & $144.5 \pm 0.6$ \\
\hline 1100 & 3.1874 & .30339 & 10.51 & 94.0 & 16.0 & .10 & $145.3 \pm 0.4$ \\
\hline 1150 & 4.0868 & .38530 & 10.61 & 91.1 & 20.4 & .11 & $146.6 \pm 0.4$ \\
\hline 1250 & .0411 & .00329 & 12.5 & 19.6 & .2 & .11 & $171 \pm 17$ \\
\hline 1450 & .0557 & .00407 & 13.7 & 7.2 & .2 & .11 & $187 \pm 13$ \\
\hline \multicolumn{3}{|c|}{ Total gas -.......- } & 10.44 & & & & $144.4 \pm 0.7$ \\
\hline \multicolumn{8}{|c|}{ 89SR88a Hornblende latitude $61^{\circ} 18^{\prime} 25^{\prime \prime}$ longitude $144^{\circ} 13^{\prime} 10^{\prime \prime}$} \\
\hline $\begin{array}{l}\text { Temp. } \\
\left({ }^{\circ} \mathrm{C}\right)\end{array}$ & $\begin{array}{c}\text { Radiogenic } \\
40 \mathrm{Ar} \\
\text { (volts) } \\
\end{array}$ & $\begin{array}{c}\begin{array}{c}\text { K-derived } \\
{ }^{39} \mathrm{Ar} \\
\text { (volts) }\end{array} \\
\end{array}$ & $\begin{array}{c}\mathrm{F} \\
\text { value }\end{array}$ & $\begin{array}{c}\text { Radiogenic } \\
\text { yield } \\
\text { (percent) }\end{array}$ & $\begin{array}{l}\text { Percent } \\
{ }^{39} \mathrm{Ar} \text { total }\end{array}$ & $\begin{array}{l}{ }^{39} \mathrm{Ar} /{ }^{37} \mathrm{Ar} \\
\text { ratio }\end{array}$ & $\begin{array}{l}\text { Apparent age } \\
\text { and error (Ma } \\
\text { at } 1 \text { sigma) }\end{array}$ \\
\hline 500 & 0.16432 & 0.04855 & 3.38 & 56.5 & 1.0 & 0.25 & $48 \pm 1$ \\
\hline 600 & .37279 & .09480 & 3.93 & 83.9 & 1.9 & .65 & $56.1 \pm 0.5$ \\
\hline 700 & .8821 & .15142 & 5.82 & 61.6 & 3.1 & .52 & $82.6 \pm 0.6$ \\
\hline 800 & 2.2129 & .37105 & 5.96 & 93.3 & 7.6 & .40 & $84.5 \pm 0.2$ \\
\hline 850 & .97540 & .16188 & 6.03 & 95.8 & 3.3 & .47 & $85.3 \pm 0.5$ \\
\hline 900 & .85710 & .10270 & 8.35 & 94.0 & 2.1 & .19 & $117.1 \pm 0.5$ \\
\hline 925 & 1.3303 & .13597 & 9.78 & 94.6 & 2.8 & .16 & $136.6 \pm 0.5$ \\
\hline 950 & 1.9505 & .18746 & 10.40 & 96.4 & 3.8 & .16 & $144.9 \pm 0.5$ \\
\hline 975 & 7.235 & .6752 & 10.72 & 98.7 & 13.8 & .17 & $149.1 \pm 0.4$ \\
\hline 1000 & 7.4130 & .69228 & 10.71 & 99.0 & 14.2 & .17 & $149.0 \pm 0.4$ \\
\hline 1025 & 4.896 & .46233 & 10.59 & 98.5 & 9.5 & .20 & $147.4 \pm 0.4$ \\
\hline 1050 & 2.118 & .19985 & 10.60 & 98.2 & 4.1 & .17 & $147.5 \pm 0.7$ \\
\hline 1100 & 4.508 & .42357 & 10.64 & 98.9 & 8.7 & .17 & $148.1 \pm 0.4$ \\
\hline 1150 & 4.4192 & .41270 & 10.71 & 98.8 & 8.5 & .17 & $149.0 \pm 0.4$ \\
\hline 1200 & 1.2312 & .11956 & 10.30 & 96.5 & 2.5 & .18 & $143.5 \pm 0.5$ \\
\hline 1250 & 4.679 & .43683 & 10.71 & 97.8 & 9.0 & .17 & $149.0 \pm 0.4$ \\
\hline 1450 & 2.1583 & .20312 & 10.63 & 91.6 & 4.2 & .18 & $147.9 \pm 0.7$ \\
\hline \multicolumn{3}{|c|}{ Total gas } & 9.72 & & & & $135.6 \pm 0.4$ \\
\hline
\end{tabular}


Table 1. Argon analytical data-Continued

\begin{tabular}{|c|c|c|c|c|c|c|c|}
\hline \multicolumn{8}{|c|}{ 89SR29 Hornblende latitude $58^{\circ} 53^{\prime} 45^{\prime \prime}$ longitude $136^{\circ} 54^{\prime} 45^{\prime \prime}$} \\
\hline $\begin{array}{l}\text { Temp. } \\
\left({ }^{\circ} \mathrm{C}\right)\end{array}$ & $\begin{array}{c}\text { Radiogenic } \\
{ }^{40} \mathrm{Ar} \\
\text { (volts) }\end{array}$ & $\begin{array}{c}\text { K-derived } \\
{ }^{39} \mathrm{Ar} \\
\text { (volts) }\end{array}$ & $\begin{array}{c}F \\
\text { value }\end{array}$ & $\begin{array}{c}\text { Radiogenic } \\
\text { yield } \\
\text { (percent) }\end{array}$ & $\begin{array}{l}\text { Percent } \\
{ }^{39} \mathrm{Ar} \text { total }\end{array}$ & $\begin{array}{l}{ }^{39} \mathrm{Ar} /{ }^{37} \mathrm{Ar} \\
\text { ratio }\end{array}$ & $\begin{array}{l}\text { Apparent age } \\
\text { and error (Ma } \\
\text { at } 1 \text { sigma) }\end{array}$ \\
\hline 500 & 0.0422 & 0.00655 & 6.44 & 9.4 & 0.3 & 0.07 & $91 \pm 7$ \\
\hline 600 & .1484 & .05403 & 2.75 & 16.5 & 2.9 & .07 & $39 \pm 2$ \\
\hline 700 & .0842 & .01564 & 5.38 & 9.5 & .8 & .28 & $76 \pm 4$ \\
\hline 750 & .07482 & .01407 & 5.32 & 20.8 & .7 & .20 & $76 \pm 4$ \\
\hline 800 & .1070 & .01958 & 5.46 & 28.0 & 1.0 & .25 & $78 \pm 3$ \\
\hline 850 & .08376 & .01680 & 4.99 & 24.8 & .9 & .09 & $71 \pm 3$ \\
\hline 900 & .1721 & .02628 & 6.55 & 41.9 & 1.4 & .05 & $93 \pm 4$ \\
\hline 950 & .9679 & .11116 & 8.71 & 77.7 & 5.9 & .08 & $122.1 \pm 0.5$ \\
\hline 975 & 3.370 & .38446 & 8.77 & 91.7 & 20.4 & .09 & $122.9 \pm 0.3$ \\
\hline 1000 & 3.722 & .42498 & 8.76 & 92.3 & 22.5 & .09 & $122.8 \pm 0.3$ \\
\hline 1050 & 3.002 & .33972 & 8.84 & 93.4 & 18.0 & .08 & $123.8 \pm 0.3$ \\
\hline 1100 & 1.9058 & .21470 & 8.88 & 93.5 & 11.4 & .09 & $124.4 \pm 0.5$ \\
\hline 1150 & 1.0923 & .12338 & 8.85 & 93.3 & 6.5 & .09 & $124.1 \pm 0.4$ \\
\hline 1200 & .9458 & .10557 & 8.97 & 93.5 & 5.6 & .09 & $125.5 \pm 0.5$ \\
\hline 1250 & .2652 & .03029 & 8.75 & 58.4 & 1.6 & .09 & $123 \pm 1$ \\
\hline \multicolumn{3}{|c|}{ Total gas --1-1 } & 8.47 & & & & $118.9 \pm 0.8$ \\
\hline \multicolumn{8}{|c|}{ 89GP33 Hornblende latitude $58^{\circ} 52^{\prime} 40^{\prime \prime}$ longitude $136^{\circ} 47^{\prime} 45^{\prime \prime}$} \\
\hline $\begin{array}{l}\text { Temp. } \\
\left({ }^{\circ} \mathrm{C}\right)\end{array}$ & $\begin{array}{c}\text { Radiogenic } \\
{ }^{40} \mathrm{Ar} \\
\text { (volts) }\end{array}$ & $\begin{array}{c}\text { K-derived } \\
{ }^{39} \mathrm{Ar} \\
\text { (volts) }\end{array}$ & $\begin{array}{c}F \\
\text { value }\end{array}$ & $\begin{array}{l}\text { Radiogenic } \\
\text { yield } \\
\text { (percent) }\end{array}$ & $\begin{array}{l}\text { Percent } \\
{ }^{39} \mathrm{Ar} \text { total }\end{array}$ & $\begin{array}{c}{ }^{39} \mathrm{Ar} /{ }^{37} \mathrm{Ar} \\
\text { ratio }\end{array}$ & $\begin{array}{l}\text { Apparent age } \\
\text { and error (Ma } \\
\text { at } 1 \text { sigma) }\end{array}$ \\
\hline 500 & 0.1136 & 0.00297 & 38.2 & 38.6 & 0.1 & 0.09 & $482 \pm 13$ \\
\hline 600 & .13507 & .02982 & 4.53 & 46.5 & .8 & .25 & $64 \pm 4$ \\
\hline 750 & .12663 & .01617 & 7.83 & 66.0 & .4 & .33 & $110 \pm 3$ \\
\hline 800 & 1855 & .02198 & 8.44 & 76.4 & .6 & .29 & $118 \pm 3$ \\
\hline 850 & .1035 & .01389 & 7.40 & 68.1 & .4 & 19 & $104 \pm 5$ \\
\hline 900 & .6153 & .06538 & 9.41 & 86.9 & 1.8 & .13 & $131.3 \pm 0.9$ \\
\hline 950 & 5.3841 & .6125 & 8.79 & 96.2 & 16.6 & .15 & $123.0 \pm 0.3$ \\
\hline 975 & 12.841 & 1.4875 & 8.63 & 98.2 & 40.3 & .19 & $120.8 \pm 0.3$ \\
\hline 1000 & 5.736 & .6665 & 8.61 & 98.8 & 18.1 & .20 & $120.5 \pm 0.3$ \\
\hline 1025 & 1.2326 & .14315 & 8.61 & 96.4 & 3.9 & 17 & $121 \pm 1$ \\
\hline 1050 & 1.834 & .2117 & 8.66 & 96.8 & 5.7 & .15 & $121.3 \pm 0.4$ \\
\hline 1100 & 2.471 & .27919 & 8.85 & 95.6 & 7.6 & .10 & $123.8 \pm 0.4$ \\
\hline 1150 & .641 & .06885 & 9.31 & 83.9 & 1.9 & .01 & $129.9 \pm 0.6$ \\
\hline 1200 & 2019 & .02156 & 9.37 & 49.3 & .6 & .01 & $131 \pm 2$ \\
\hline 1250 & .2595 & .02886 & 8.99 & 50.0 & .8 & .02 & $126 \pm 2$ \\
\hline 1450 & .1872 & .02053 & 9.12 & 28.6 & .6 & .02 & $127 \pm 3$ \\
\hline \multicolumn{3}{|c|}{ Total gas - } & 8.69 & & & & $121.6 \pm 0.5$ \\
\hline
\end{tabular}


Table 1. Argon analytical data-Continued

\begin{tabular}{|c|c|c|c|c|c|c|c|}
\hline \multicolumn{8}{|c|}{ 89GP71 White Mica Latitude $58^{\circ} 55^{\prime} 30^{\prime \prime}$ Longitude $137^{\circ} 00^{\prime} 30^{\prime \prime}$} \\
\hline $\begin{array}{l}\text { Temp. } \\
\left({ }^{\circ} \mathrm{C}\right)\end{array}$ & $\begin{array}{c}\text { Radiogenic } \\
{ }^{40} \mathrm{Ar} \\
\text { (volts) }\end{array}$ & $\begin{array}{c}\text { K-derived } \\
{ }^{39} \mathrm{Ar} \\
\text { (volts) }\end{array}$ & $\begin{array}{c}F \\
\text { value }\end{array}$ & $\begin{array}{c}\text { Radiogenic } \\
\text { yield } \\
\text { (percent) }\end{array}$ & $\begin{array}{l}\text { Percent } \\
{ }^{39} \mathrm{Ar} \text { total }\end{array}$ & $\begin{array}{c}{ }^{39} \mathrm{Ar} /{ }^{37} \mathrm{Ar} \\
\text { ratio }\end{array}$ & $\begin{array}{c}\text { Apparent age } \\
\text { and error (Ma } \\
\text { at } 1 \text { sigma) }\end{array}$ \\
\hline 500 & 0.05907 & 0.00631 & 9.367 & 36.9 & 0.1 & 52.39 & $130 \pm 9$ \\
\hline 600 & .1043 & .01845 & 5.652 & 32.0 & .2 & 29.18 & $80 \pm 3$ \\
\hline 700 & .5002 & .08553 & 5.848 & 50.3 & .8 & 54.83 & $82.8 \pm 0.7$ \\
\hline 750 & .94498 & .12614 & 7.492 & 79.1 & 1.1 & 289.94 & $105.4 \pm 0.6$ \\
\hline 800 & 5.2422 & .5031 & 10.42 & 91.0 & 4.6 & 739.65 & $145.0 \pm 0.4$ \\
\hline 850 & 27.179 & 2.3122 & 11.76 & 81.2 & 21.0 & 415.92 & $162.7 \pm 0.4$ \\
\hline 900 & 23.160 & 1.9700 & 11.76 & 80.9 & 17.9 & 321.64 & $162.7 \pm 0.4$ \\
\hline 950 & 15.727 & 1.3532 & 11.62 & 92.8 & 12.3 & 375.13 & $161.0 \pm 0.4$ \\
\hline 1000 & 15.735 & 1.3521 & 11.64 & 96.1 & 12.3 & 508.13 & $161.2 \pm 0.4$ \\
\hline 1050 & 25.468 & 2.1689 & 11.74 & 98.3 & 19.7 & 581.81 & $162.6 \pm 0.4$ \\
\hline 1100 & 10.908 & .9376 & 11.63 & 97.7 & 8.5 & 497.25 & $161.1 \pm 0.4$ \\
\hline 1250 & 1.666 & .18682 & 8.920 & 81.4 & 1.7 & 90.01 & $124.8 \pm 0.4$ \\
\hline \multicolumn{2}{|c|}{ Total gas } & --- & 11.50 & & & & $159.3 \pm 0.4$ \\
\hline
\end{tabular}

hornblende and muscovite are $480-580{ }^{\circ} \mathrm{C}$ (Harrison, 1981) and $270-325^{\circ} \mathrm{C}$ (Snee and others, 1988), respectively. Data are listed in table 1; all raw data are available from the authors.

\section{EASTERN CHUGACH MOUNTAINS}

\section{Description of Samples and Their Field Relations}

Five samples from the eastern Chugach Mountains were collected from two sites along the Border Ranges fault system: Summit Lake in the southeastern section of Valdez B-1, and Bearhole Lake in the northeasternmost corner of Bering Glacier D-5 (figs. 2, 3). The sample from Summit Lake is from Winkler and others' (1981) unit Kag, informally named the Uranatina River metaplutonic unit, part of the Haley Creek metamorphic assemblage (Plafker and others, 1989). The metaplutonic rocks have been interpreted as deformed equivalents of the Late Jurassic Chitina Valley batholith, which occurs in the McCarthy and Bering Glacier quadrangles to the east (see above); we tested this interpretation by obtaining hornblende dates from the least deformed parts of a diorite near Summit Lake and from two diorite bodies along Bearhole Creek. We also measured hornblende dates from a gneiss in the contact zone of one of the plutons and from a schist that is part of the regionally metamorphosed Strelna Metamorphics of Plafker and others (1989).
The sample from Summit Lake (89SR88a) is from the margin of an elongate, heterogeneous pluton that intrudes calcareous schists and biotite-quartz schists of the Strelna Metamorphics. Both the pluton and the country rocks are cut by numerous ductile and brittle high-angle faults, and retrograde metamorphism associated with the faults ranges from prehnite-pumpellyite to upper greenschist facies (Roeske and others, 1990b). The pluton is dominantly diorite and tonalite with lesser amounts of granodiorite, trondhjemite, and gabbro. The margin phase sampled is a coarse hornblende-biotite diorite. Alteration of the rock is locally intense along shear zones, producing prehnite, calcite, titanite, and white mica. The amphibole is very coarse (5-15 mm long), euhedral to subhedral, brown-green hornblende, deformed by kink bands. The biotite commonly occurs as fine inclusions within the hornblende, both as subhedral grains and as fine fibers along cleavage fractures.

The two samples from the Bearhole Creek drainage (89SR130c and 89SR137) are from plutonic rocks that have similar mineralogy but are separated by a highangle fault zone, which we refer to as the Hanagita fault zone, that contains slivers of the McHugh Complex (fig. 3). Sample 89 SR 137c is from a biotite-hornblende quartz diorite that is overall much more altered and strongly deformed than the hornblende diorite to the north of the fault zone (89SR130c); the latter pluton is most intensely altered on the margins, whereas the former has numerous shear zones and their associated alteration zones throughout. Consequently, although the two samples that 
we dated are from the freshest parts of the plutons, sample 89SR137 is more altered and deformed than 89SR130c. The biotite in 89SR137 is extensively replaced by epidote and chlorite and the plagioclase is heavily sericitized. Minor kink bands in the biotite and undulatory extinction in the quartz in 89SR137 indicate some solid-state deformation affected the sample, but the hornblende appears to be unaffected. In contrast, 89SR130c shows no sign of deformation, and both the plagioclase and biotite are very fresh. The hornblendes in both samples are anhedral and range in size from 0.5 to $5 \mathrm{~mm}$, with most 1-2 $\mathrm{mm}$ long. Many parts of this pluton have a foliation defined by aligned hornblende and plagioclase; petrographic observations show that this fabric is a flow foliation, imparted when the pluton was still molten or partially molten (see, for example, Paterson and others, 1989).

The dioritic pluton (89SR130c) intrudes a coarse hornblende-plagioclase-clinopyroxene gneiss (sample 89SR 123e) (fig. 3). This mafic gneiss only occurs on the margins of the tonalite, and its high-angle fabric is parallel to the foliation in the adjacent tonalites. The mafic gneiss unit, which locally contains coarse garnets and biotites, intermingles with and grades into the Strelna Metamorphics, consisting of quartz-biotite-calcareous schists, carbonate rocks, and amphibole-biotite schists

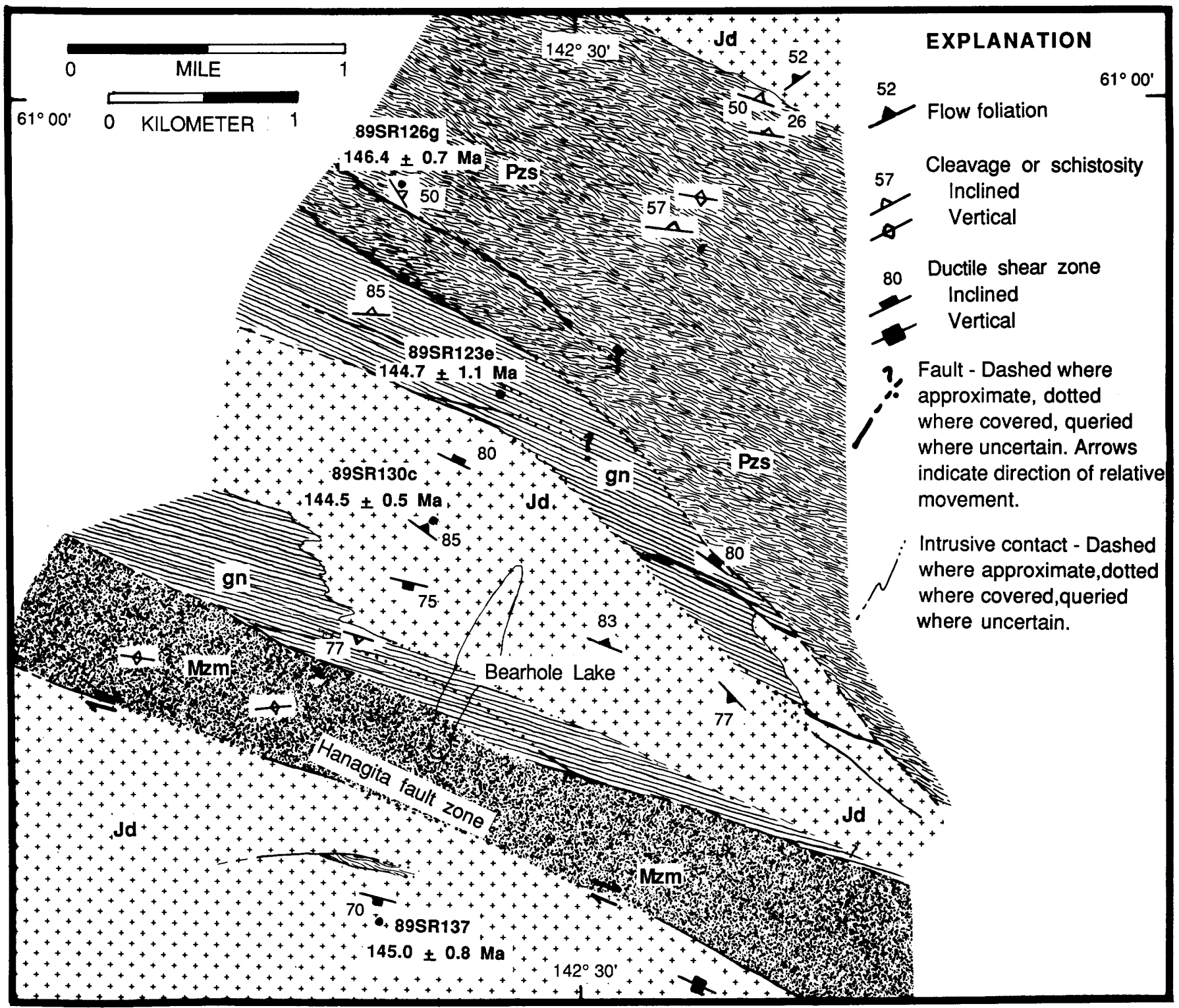

Figure 3. Detailed geologic map of Bearhole Lake region, eastern Chugach Mountains (unpub. data of S.M. Roeske, T.L. Pavlis, and V.B. Sisson, 1989) (see fig. 2 for location). Lithologic units: PzS, Strelna Metamorphics of Plafker and others (1989) (Paleozoic); gn, mafic gneiss; Jd, diorite and quartz diorite (Late Jurassic); Mzm, McHugh Complex (Mesozoic). Sample numbers indicate locations of samples providing ${ }^{40} \mathrm{Ar} /{ }^{39} \mathrm{Ar}$ dates discussed in text. Numbers (in $\mathrm{Ma}$ ) are plateau dates from the hornblende separates for each sample. 
(sample $89 \mathrm{SR} 126 \mathrm{~g}$ ) in this region. Numerous brittle faults crosscut the northern margin of the pluton, and alteration associated with them has strongly affected the feldspars in 89SR123e and 89SR126g. Sample $89 \mathrm{SR} 126 \mathrm{~g}, 800 \mathrm{~m}$ from intrusive rocks, is from a zone of moderately north-dipping schists that mineralogically, texturally, and structurally appear to be part of the regionally metamorphosed Strelna Metamorphics. The sample is a plagioclase-biotite-amphibole schist with minor amounts of quartz and white mica. The amphibole in this sample has numerous inclusions of biotite and is paler green than amphibole in the gneiss. The amphi-
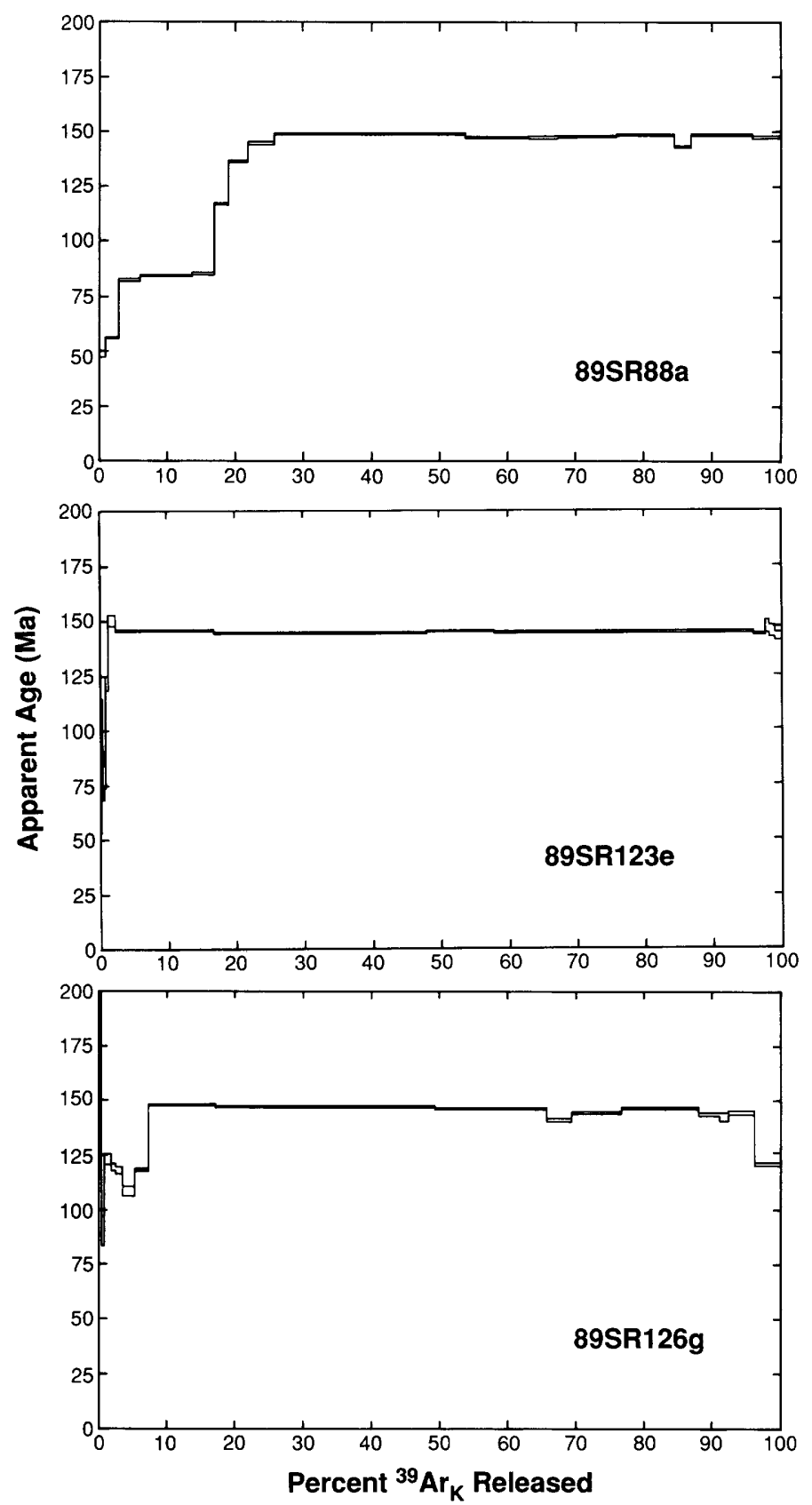

boles in both samples are anhedral and range in size from 0.4 to $1.5 \mathrm{~mm}$.

\section{Interpretation of Age Spectra}

Interpretation of the age spectra from the amphiboles in the eastern Chugach Mountains is straightforward because all of the samples produced plateaus over the range of ${ }^{39} \mathrm{Ar} /{ }^{37} \mathrm{Ar}$ ratios (apparent $\mathrm{K} / \mathrm{Ca}$ ) to be expected for hornblendes (fig. 4, table 1). The spectra indicate that these rocks have not been affected by reheating above approximately $500{ }^{\circ} \mathrm{C}$ (McDougall and Harrison, 1988) since their cooling following crystallization in the Late Jurassic. Two of the five spectra, 89SR88a and 89SR126g, do have younger dates at lower temperature intervals. However, because the apparent $\mathrm{K} /$ $\mathrm{Ca}$ ratio $\left({ }^{39} \mathrm{Ar} /{ }^{37} \mathrm{Ar}\right)$ for these temperature steps is much greater than for the higher temperature steps (table 1), it is likely that a different phase released the argon gas at these temperature intervals. Both of these samples have numerous biotite inclusions in the amphiboles that may

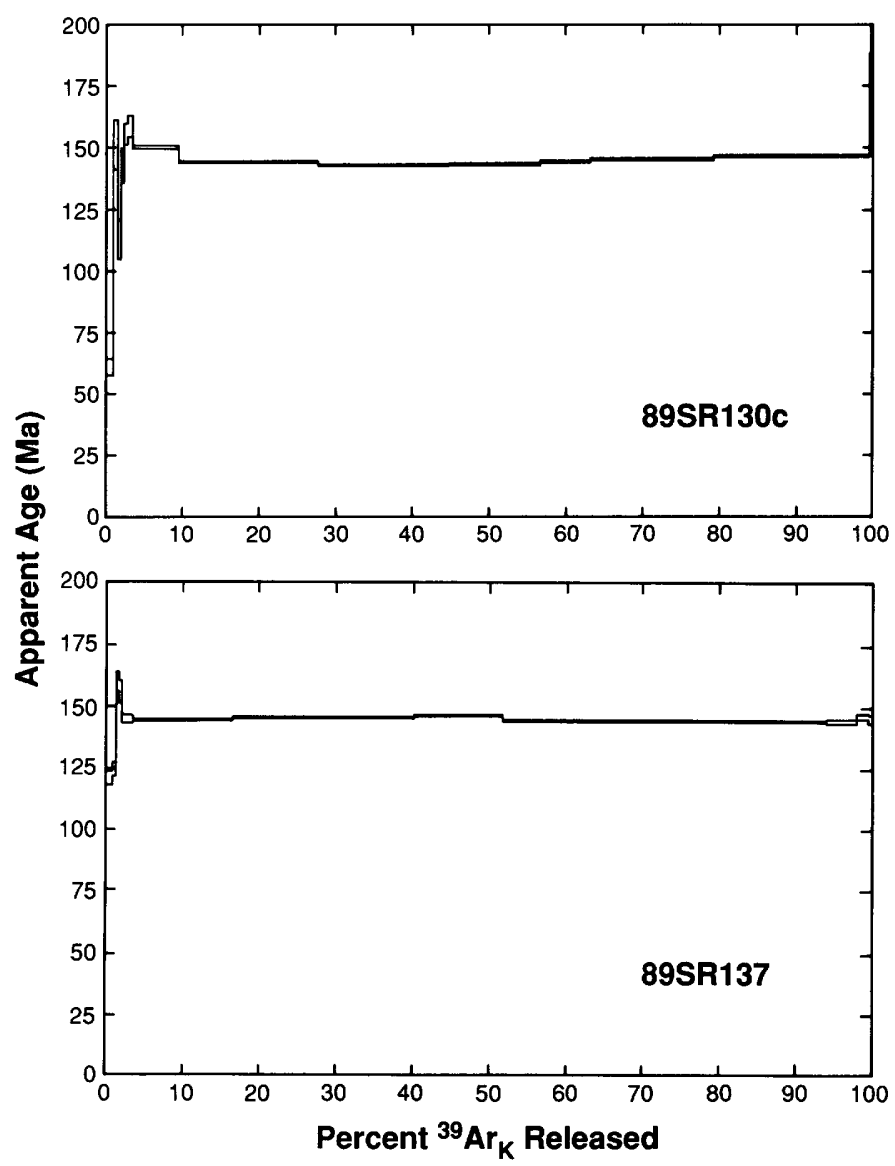

Figure 4. ${ }^{40} \mathrm{Ar} /{ }^{39} \mathrm{Ar}$ age spectra for hornblende separates from five samples collected at Summit Lake and Bearhole Lake field areas. See figures 2 and 3 for locations and plateau dates. 
contribute a component to the argon released. Three lower apparent age steps that may be meaningful are those for $900-950{ }^{\circ} \mathrm{C}$ in 89 SR88a. The apparent $\mathrm{K} / \mathrm{Ca}$ of these steps is the same as for the steps that produced the plateau at $148 \mathrm{Ma}$, but the dates climb from 117 to $145 \mathrm{Ma}$. This sample was the only one that contained amphiboles that were clearly tectonically deformed at temperatures above the brittle-ductile transition (see above), and the younger dates at lower temperature intervals may be derived from the deformed sections of the hornblendes.

\section{GLACIER BAY}

\section{Description of Samples and Their Field Relations}

The three samples dcted are from plutonic rocks in northern Glacier Bay that occur within or to the east of the Border Ranges fault systern (fig. 5). The Border Ranges fault system in this region is a 10 - to $15-\mathrm{km}$-wide zone of high-angle ductile shear zones and brittle faults (Pavlis and others, 1989). Brew and Morrell (1979) named this zone of faulting the Tarr Inlet suture zone, and workers have debated whether the lithologies within the fault zone are part of the Chugach terrane, the Wrangellia terrane, or both (see summary by Decker and Plafker, 1982). Much of the confusion over the corrslation of the rocks in the shear zone is due to the obliteration of earlier histories by extensive deformation and metamorphism associated with the development of the high-angle retrograde fabric. Two of the samples (89SR29 and 89GP33) are from hornblendebiotite quartz diorites that intrude greenschist- and amphibolite-facies Paleozoic carbonate and metabasite rocks of the Alexander terrane; the third (89GP71) is from a muscovite trondhjemite that intrudes greenstones and siliceous metasedimentary and carbonate rocks of unknown affinity.

The two quartz diorites have similar mineral contents but differ greatly in the degree of alteration. Sample 89GP33, which is the sample farthest from the Border Ranges fault system, has the least alteration and deformation of the three from Glacier Bay. The pluton has no obvious fabric, and the only alteration observed is sericitization of the feldspar. The hornblende in 89GP33 is subhedral to anhedral and ranges in size from 1 to $2.5 \mathrm{~mm}$ across; many have cores of paler green amphibole or clinopyroxene. Sample 89 SR 29 is from a quartz dioritic to dioritic pluton that is cut ty one of the eastern strands of the Border Ranges fault system, and the extensive alteration in the sample reflects the pervasive alteration associated with the shear zones. The biotite in this sample has been replaced by chlorite and white mica, and the amphibole is extensively rimmed by chlorite. The plagioclase is almost entirely replaced by sericite, but its original outline is still recognizable, and a clear preferred orientation of the long axis gives the sample a strong fabric. This fabric, which is parallel to elongate mafic enclaves, has a similar orientation to the ductile shear zones in the adjacent Border Ranges fault system, but neither the feldspar nor the amphibole in sample 89SR29 show any solid-state deformation. The trondhjemitic pluton (89GP71) lies in the heart of the shear zones and brittle faults associated with the Border Ranges fault system (fig. 5). On one side of the pluton is an intrusive contact between it and a hornblende quartz diorite; the other contacts are brittle to brittle-ductile faults. Other plutons of similar composition occur in fault-bounded slices within the broad shear zone, but none was found outside of the Border Ranges fault system. The pluton is composed primarily of plagioclase, with less than 10 percent each of muscovite and quartz. The muscovite ranges from 0.4 to $1 \mathrm{~mm}$ long, and its random orientation suggests it is a primary igneous phase. All of the phases are deformed, but the alteration is confined to minor calcite and white mica in the plagioclase. The muscovite has kink bands and undulatory extinction, and the plagioclase is cut by cataclastic zones that contain rounded plagioclase grains in a very fine matrix.

\section{Interpretation of Age Spectra}

Despite the extensive alteration and deformation seen in two out of three of the samples from Glacier Bay, the age spectra are as simple as those from the eastern Chugach Mountains (fig. 6). All three samples yielded plateaus over a wide temperature range, indicating that the hornblendes and muscovite have remained thermally undisturbed since crystallization and cooling. The 162-Ma date from the muscovite in the deformed trondhjemite is especially intriguing. Muscovite has a much lower blocking temperature than hornblende (270 $325{ }^{\circ} \mathrm{C}$, compared with approximately $500{ }^{\circ} \mathrm{C}$ for hornblende)(Snee and others, 1988); thus, this particular block of rocks in the Border Ranges fault system has not been affected by any major heating events since the Middle Jurassic. The younger dates at the lower temperature intervals for this sample may indicate some argon was lost from these highly deformed crystals. The most heavily chloritized sample, 89SR29, has several lower temperature steps with younger dates, which correspond to higher apparent $\mathrm{K} / \mathrm{Ca}$ ratios. These younger dates probably are caused by chlorite contamination of the mineral separate.

\section{DISCUSSION: COMPARISON OF ${ }^{40} \mathrm{AR} /{ }^{39} \mathrm{AR}$ DATES WITH PREVIOUSLY PUBLISHED ${ }^{40} \mathrm{Ar} /{ }^{39} \mathrm{Ar}$ AND K-AR DATES}

The ${ }^{40} \mathrm{Ar} /{ }^{39} \mathrm{Ar}$ dates obtained in this study show that the Late Jurassic and Early Cretaceous plutons and 


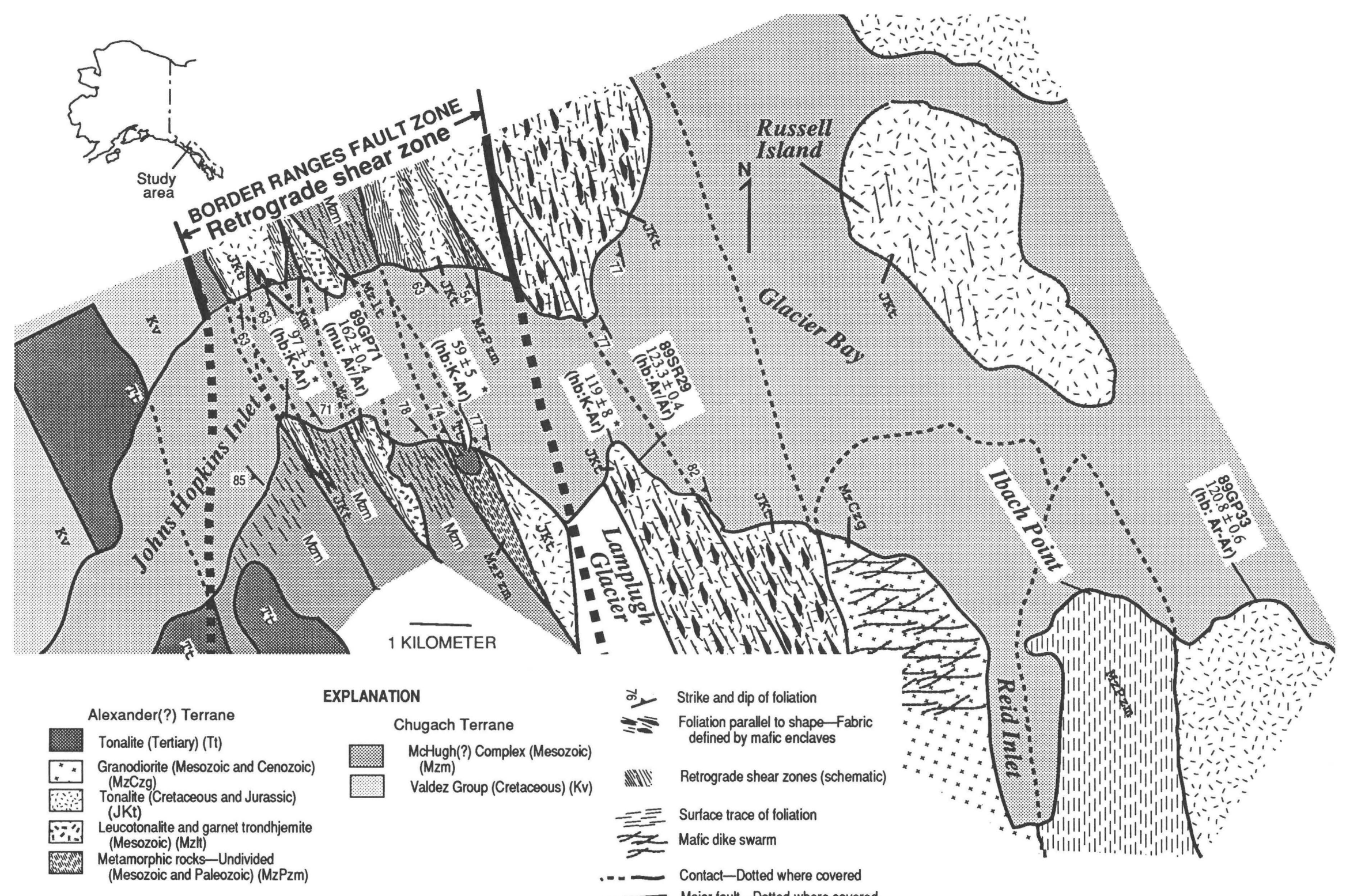

Figure 5. Geologic map showing area of retrograde shear zone of northern Glacier Bay (see fig. 1 for location), from unpub. mapping of T.L. Pavlis, V.B. Sisson, K. Smart, and S.M. Roeske (1989 and 1990); and Brew and others (1978). Sample numbers indicate locations of samples providing isotopic dates discussed in text. Numbers (in Ma) are plateau dates for each sample; *, Decker and Plafker (1982). 
metamorphic rocks along the eastern and southern sections of the Border Ranges fault system have not been affected by a major reheating event since their original cooling after crystallization. The cooling ages from the eastern Chugach Mountains are very similar to three hornblende plateau ages of 138,145 , and $146 \mathrm{Ma} \mathrm{ob}-$ tained by Welsh (1986) from rocks just north of the Border Ranges fault system approximately $50 \mathrm{~km}$ west of
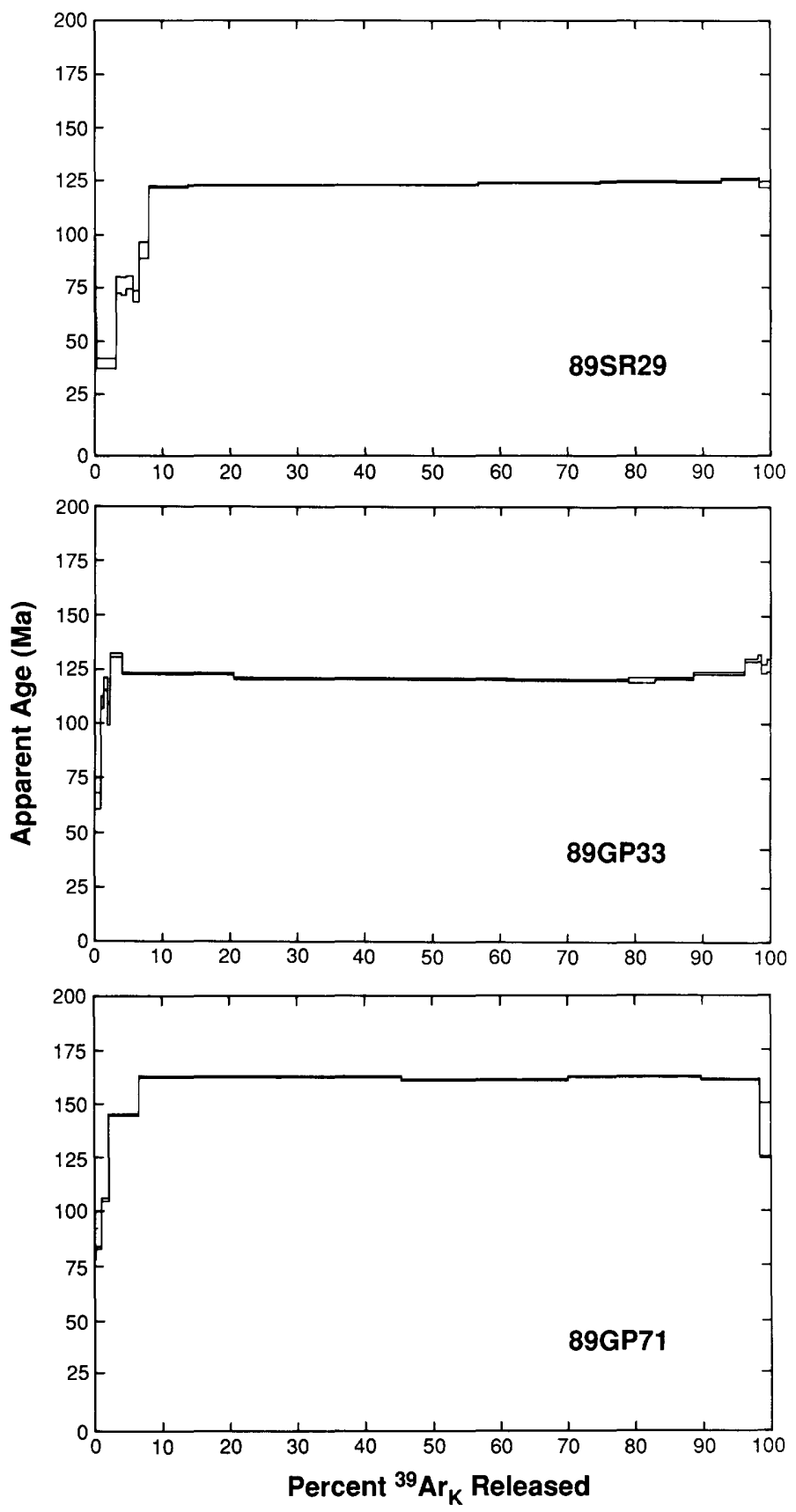

Figure 6. ${ }^{40} \mathrm{Ar} /{ }^{39} \mathrm{Ar}$ age spectra for two hornblende (89SR29, 89GP33) separates and one muscovite (89GP71) separate from samples collected in northern Glacier Bay field area. See figures 1 and 5 for locations and plateau dates.
Bearhole Lake. The ${ }^{40} \mathrm{Ar} /{ }^{39} \mathrm{Ar}$ dates are also identical to the oldest of the previously published $\mathrm{K}$-Ar dates and support the interpretation that this region was affected by a major thermal event associated with the emplacement of the Late Jurassic Chitina Valley batholith (MacKevett, 1978; Winkler and others, 1981; Plafker and others, 1989).

The cooling ages of the plutons from northern Glacier Bay are more anomalous with respect to the published K-Ar dates from the region, compared with the ${ }^{40} \mathrm{Ar} /{ }^{39} \mathrm{Ar}$ cooling ages from the eastern Chugach Mountains. The 123- and 120-Ma dates lie at the upper limit of dates of plutons from the Nutzotin-Chichagof belt (see above), but all of the previously published dates are $\mathrm{K}-\mathrm{Ar}$ derived, and the total gas date of the altered sample (89SR29) is $118 \mathrm{Ma}$, statistically identical to a hornblende K-Ar date from this same altered pluton (Decker and Plafker, 1982; fig. 5). The only other plutons along the Border Ranges fault system with similar dates are from the western Chugach Mountains. $\mathrm{Rb}-\mathrm{Sr}$ and ${ }^{40} \mathrm{Ar} /$ ${ }^{39} \mathrm{Ar}$ dates from plutonic and metamorphic rocks in this region fall between 117 and $129 \mathrm{Ma}$ (Rubenstone and others, 1987; Pavlis and others, 1988; T.L. Pavlis, unpub. data). The Early Cretaceous plutons in the western Chugach Mountains are restricted to the Border Ranges fault system and intrude the McHugh Complex; thus, they are localized in a forearc setting, as opposed to the widespread occurrence of the foliated plutons of the Muir-Chichagof belt (Brew and Morrell, 1983; fig. 1). The Early Cretaceous plutons in southern British Columbia (see above) could be related to the coeval group of plutons in southeast Alaska, but spatial continuity is difficult to prove because the predominantly younger Coast Plutonic Complex occurs between the two regions.

The correlation of the trondhjemite with a muscovite cooling age of $162 \mathrm{Ma}$ to other plutonic belts is also a dilemma. Because muscovite has a lower blocking temperature than hornblende, it seems unlikely that the pluton is part of the Tonsina-Chichagof belt. Another possibility is that the pluton is part of the slightly older (Middle Jurassic) group of plutons intruding the combined Wrangellia-Alexander terrane on Chichagof and Queen Charlotte Islands and on the mainland of southern British Columbia. Correlation of this single pluton with any group is tenuous, however, because of its occurrence as a fault-bounded block in the middle of a $10-\mathrm{km}$-wide fault zone that may have had major displacement along it (Pavlis and others, 1989).

\section{CONCLUSIONS}

The cooling ages obtained from the deformed plutonic and metamorphic rocks of this study provide a constraint on the maximum age of the strike-slip event on 
these sections of the Border Ranges fault system. In northern Glacier Bay, the retrograde shear zone deforms a pluton with a hornblende cooling age of $120 \mathrm{Ma}$. A pluton on the western margin of the shear zone has a hornblende $\mathrm{K}-\mathrm{Ar}$ date of $97 \pm 5 \mathrm{Ma}$ (Decker and Plafker, 1982; fig. 5). Because of the extreme alteration of most of the plutonic rocks within the retrograde shear zone, this date is difficult to interpret. It may reflect partial loss of argon from the hornblende or contamination by chlorite, or it could be an emplacement age. A minimum age of the retrograde shear zones is derived from the late Paleocene K-Ar date of an undeformed hornblende diorite that intrudes rocks in the ductile shear zone (fig. 5). The cooling ages from the eastern Chugach Mountains constrain the development of the high-angle shear zones to a broader time span: younger than $145 \mathrm{Ma}$ (this study) and older than $52 \mathrm{Ma}$ (Plafker and others, 1989). A tighter time constraint is provided by the Valanginian to Hauterivian(?) age of radiolarians collected from a section of the McHugh Complex that is involved in the high-angle faulting (fig. 3) (C. Blome, written commun., 1990). This fossil age indicates that these faults started or continued their activity after $130 \mathrm{Ma}$ in the eastern Chugach Mountains.

The similarity of location, timing, and structural history of these major high-angle retrograde shear zones in northern Glacier Bay and in the eastern Chugach Mountains strongly suggests that a strike-slip fault zone existed along the outer margin of the combined Wrangellia-Alexander terrane sometime during the midCretaceous to early Tertiary. We hope to accurately date the exact timing of the movement by ${ }^{40} \mathrm{Ar} /{ }^{39} \mathrm{Ar}$ analysis of white micas and amphiboles that recrystallized within the ductile shear zones.

\section{REFERENCES CITED}

Alexander, E.C.J., Mickelson, G.M., and Lanphere, M.A., 1978, MMhb-1: A new ${ }^{40} \mathrm{Ar}-{ }^{39} \mathrm{Ar}$ dating standard, in Zartman, R.E., ed., Short Papers of the Fourth International Conference, Geochronology, Cosmochronology, Isotope Geology: U.S. Geological Survey Open-File Report 78-701, p. 6-8.

Anderson, R.G., and Reichenbach, I., 1989, A note on the geochronometry of Late Jurassic and Tertiary plutonism in the Queen Charlotte Islands, British Columbia, in Current research, part H: Geological Survey of Canada Paper 89-IH, p. 105-112.

Armstrong, R.L., 1988, Mesozoic and early Cenozoic magmatic evolution of the Canadian Cordillera, in Clark, S.P., Jr., Burchfiel, B.C., and Suppe, J., eds., Processes in continental lithospheric deformation: Geological Society of America Special Paper 218, p. 55-91.

Brew, D.A., Johnson, B.R., Grybeck, Donald, Griscom, Andrew, Barnes, D.F., Kimball, A.L., Still, J.C., and Rataj, J.I., 1978, Mineral resources of the Glacier Bay National
Wilderness Study Area, Alaska: U.S. Geological Survey Open-File Report 78-494, 670p., 7 sheets.

Brew, D.A., and Morrell, R.P., 1979, The Wrangell terrane ("Wrangellia") in southeastern Alaska: the Tarr Inlet suture zone with its northern and southern extensions, in Johnson, K.M., and Williams, J.R., eds., The United States Geological Survey in Alaska: Accomplishments during 1978: U.S. Geological Survey Circular 804-B, p. B121-B123.

-1983, Intrusive rocks and plutonic belts of southeast Alaska, U.S.A., in Roddick, J.A., ed., Circum-Pacific plutonic terranes: Geological Society of America Memoir 159 , p. 171-193.

Burns, L.E., 1985, The Border Ranges ultramafic and mafic complex, south-central Alaska: Cumulate fractionates of island arc volcanics: Canadian Journal of Earth Science, v. 22, p. 1020-1038.

Dalrymple, G.B., Alexander, E.C.J., Lanphere, M.A., and Kraker, G.P., 1981, Irradiation of samples for ${ }^{40} \mathrm{Ar} /{ }^{39} \mathrm{Ar}$ dating using the Geological Survey TRIGA reactor: U.S. Geologcial Survey Professional Paper 1176, 55 p.

Dalrymple, G.B., and Lanphere, M.A., 1969, Potassium-argon dating: San Francisco, W.H. Freeman, 269 p.

Decker, J.E., and Plafker, G., 1982, Correlation of rocks in the Tarr Inlet suture zone with the Kelp Bay Group, in Coonrad, W.L., ed., The United States Geological Survey in Alaska: Accomplishments during 1980: U.S. Geological Survey Circular 844, p. 119-123.

Dodds, C.J., and Campbell, R.B., 1988, Potassium-argon ages of mainly intrusive rocks in the Saint Elias Mountains, Yukon and British Columbia: Geological Survey of Canada Paper 87-16, 43 p.

Friedman, R.M., 1990, U-Pb dating of Jurassic, Cretaceous, and Tertiary igneous rocks from the southern coast belt $\left(49^{\circ}-51^{\circ} \mathrm{N}\right)$, southwestern British Columbia [abs.]: Geological Association of Canada Abstracts with Programs, v. 15 , p. A41.

Friedman, R.M., and Armstrong, R.L., 1990, U-Pb dating, southern Coast Belt, British Columbia [extended abs.]: Project Lithoprobe southern Canadian Cordilleran Workshop 1990, University of Calgary, p. 146-155.

Harrison, T.M., 1981, Diffusion of ${ }^{40} \mathrm{Ar}$ in hornblende: Contributions to Mineralogy and Petrology, v. 78, p. 324-331.

Hudson, T.G., 1979, Mesozoic plutonic belts of southern Alaska: Geology, v. 7, p. 230-234.

-1983, Calc-alkaline plutonism along the Pacific rim of southern Alaska, in Roddick, J.A., ed., Circum-Pacific plutonic terranes: Geological Society of America Memoir 159 , p. $159-169$.

Hudson, T.G., and Plafker, G., 1982, Paleogene metamorphism of an accretionary flysch terrane, eastern Gulf of Alaska: Geological Society of America Bulletin, v. 93, p. 1280 1290.

Karl, S.M., Johnson, B.R., and Lanphere, M.A., 1988, New KAr ages for plutons on western Chichagof Island and on Yakobi Island, in Galloway, J.P., and Hamilton, T.D., eds., Geologic studies in Alaska by the U.S. Geological Survey during 1987: U.S. Geological Survey Circular 1016, p. 164-168.

Loney, R.A., Brew, D.A., and Lanphere, M.A., 1967, PostPaleozoic radiometric ages and their relevance to fault 
movements, northern southeastern Alaska: Geological Society of America Bulletin, v. 78, p. 511-526.

Loney, R.A., Brew, D.A., Muffler, L.J.P., and Pomeroy, J.S., 1975, Reconnaissance geology of Chichagof, Baranof, and Kruzof Islands, southeastern Alaska: U.S. Geological Survey Professional Paper 792, 105 p.

MacKevett, E.M., Jr., 1978, Geologic map of the McCarthy quadrangle, Alaska: U.S. Geological Survey Miscellaneous Investigations Series Map I-1032, scale 1:250,000, 1 sheet.

MacKevett, E.M., Jr., and Plafker, G., 1974, The Border Ranges fault in south-central Alaska: U.S. Geological Survey Journal of Research, v. 2, p. 323-329.

MacKevett, E.M., Jr., Robertson, E.C., and Winkler, G.R., 1974, Geology of the Skagway B-3 and B-4 quadrangles, southeastern Alaska: U.S. Geological Survey Professional Paper 832, 33 p.

Marshak, S., and Mitra, G., 1988, Basic methods of structural geology: Englewood Cliffs, New Jersey, Prentice Hall, $446 \mathrm{p}$.

McDougall, I., and Harrison, T.M., 1988, Geochronology and thermochronology by the ${ }^{40} \mathrm{Ar} /{ }^{\beta 9} \mathrm{Ar}$ method: New York, Oxford University Press, 212 p.

Paterson, S.R., Vernon, R.H., and Tobisch, O.T., 1989, A review of criteria for the identification of magmatic and tectonic foliations in granitoids: Journal of Structural Geology, v. 11, p. 349-363.

Pavlis, T.L., and Crouse, G.W., 1989, Late Mesozoic strike slip movement on the Border Ranges fault system in the eastern Chugach Mountains, southern Alaska: Journal of Geophysical Research, v. 94 , p. $4321-4332$.

Pavlis, T.L., Monteverde, D.H., Bowman, J.R., Rubenstone, J.L., and Reason, M.D., 1988, Early Cretaceous neartrench plutonism in southern Alaska: a tonalite-trondhjemite intrusive complex injected during ductile thrusting along the Border Ranges fault system: Tectonics, v. 7, p. 1179-1199.

Pavlis, T.L., Roeske, S.M., Sisson, V.B., and Smart, K., 1989, Evidence for Cretaceous dextral strike-slip on the Border Ranges fault, in Glacier Bay National Park, Alaska [abs.]: Eos (American Geophysical Union, Transactions), v. 70, p. 1337.

Plafker, G., Jones, D.L., and Pessagno, E.A., Jr., 1977, A Cretaceous accretionary flysch and melange terrane along the Gulf of Alaska margin, in Blean, K.M., ed., The United States Geological Survey in Alaska: Accomplishments during 1976: U.S. Geological Survey Circular 751-B, p. B41-B43.

Plafker, G., Nokleberg, W.J., and Lull, J.S., 1989, Bedrock geology and tectonic evolution of the Wrangellia, Peninsular, and Chugach terranes along the Trans-Alaska Crustal Transect in the Chugach Mountains and southern Copper River basin, Alaska: Journal of Geophysical Research, v. 94 , p. $4255-4295$.

Richter, D.H., Lanphere, M.A., and Matson, N.A., Jr., 1975, Granitic plutonism and metamorphism, eastern Alaska Range, Alaska: Geological Society of America Bulletin, v. 86 , p. 819-829.

Roddick, J.C., 1983, High precision intercalibration of Ar-Ar standards: Geochimica et Cosmochimica Acta, v. 47, p. 887-898.

Roeske, S.M., Pavlis, T.L., and Sisson, V.B., 1990b, Cretaceous dextral strike-slip along the Border Ranges fault system in the Eastern Chugach Mountains, southern Alaska [abs.]: Eos (American Geophysical Union, Transactions), v. 71, p. 1589.

Roeske, S.M., Pavlis, T.L., Sisson, V.B., and Smart, K., 1990a, Cretaceous strike-slip along the Border Ranges fault system in eastern and southeastern Alaska [abs.]: Geological Association of Canada Abstracts with Programs, v. 15, p. A113.

Rubenstone, J.L., Bowman, J.R., Pavlis, T.L., Reason, M., and Onstott, T.C., 1987, Isotope systematics of a Cretaceous tonalite-trondhjemite complex in southern Alaska [abs.]: Geological Society of America Abstracts with Programs, v. 19 , p. 445 .

Samson, S.D., and Alexander, E.C., 1987, Calibration of the interlaboratory ${ }^{40} \mathrm{Ar} /{ }^{39} \mathrm{Ar}$ dating standard, MMhb-1: Chemical Geology, v. 66, p. 27-34.

Snee, L.W., Sutter, J.F., and Kelly, W.C., 1988, Thermochronology of economic mineral deposits: dating the stages of mineralization at Panasqueira, Portugal, by high-precision ${ }^{40} \mathrm{Ar} /{ }^{39} \mathrm{Ar}$ age-spectrum techniques on muscovite: Economic Geology, v. 83, p. 335-354.

Steiger, R.M., and Jäger, E., 1977, Subcommission on geochronology: Convention on the use of decay constants in geoand cosmo-chronology: Earth and Planetary Science Letters, v. 36, p. 359-362.

Welsh, T.F., $1986,{ }^{40} \mathrm{Ar} /{ }^{\beta 9} \mathrm{Ar}$ correlation study of the Haley Creek Complex with the Strelna Formation: Princeton, New Jersey, Princeton University, B.S. thesis, 30 p.

Winkler, G.R., Silberman, M.L., Grantz, A., Miller, R.J., and MacKevett, E.M., Jr., 1981, Geologic map and summary geochronology of the Valdez quadrangle: U.S. Geological Survey Open-File Report 80-892-A, scale 1:250,000, 2 sheets.

Reviewers: Marvin A. Lanphere and George Plafker 


\title{
Reevaluation of Coal Resources in the Late Cretaceous- Tertiary Sagavanirktok Formation, North Slope, Alaska
}

\author{
By Stephen B. Roberts, Gary D. Stricker, and Ronald H. Affolter
}

\begin{abstract}
Coal deposits within the Sagavanirktok Formation underlie more than $18,000 \mathrm{~km}^{2}$ in the east-central North Slope, Alaska. The major coal-bearing interval is restricted to Late Cretaceous (Maastrichtian?) and Paleocene sedimentary rocks of an east- to northeast-prograding deltaic system.

Coal-bearing rocks crop out along an $80-\mathrm{km}$-long belt between the White Hills and Kavik River and are composed of clast-supported conglomerate, sandstone, siltstone, shale (mudstone), carbonaceous shale, and coal as thick as $7.1 \mathrm{~m}$. The coal-bearing units extend northward to the Arctic coast and offshore, and eastward to about the Canning River, where the coals pinch out in the Staines Tongue and a lower unnamed tongue of the Sagavanirktok Formation. The major coal-bearing interval ranges from 220 to more than $900 \mathrm{~m}$ in thickness, and 50 percent of the subsurface coals are $1.5 \mathrm{~m}$ thick or greater. Chemical analyses of 55 coal outcrop samples indicate that the apparent rank varies from lignite $A$ to subbituminous $B$, with the majority of coals being subbituminous $C$. Mean ash and total sulfur contents are 11.08 and 0.38 percent, respectively.

Evaluation of geophysical log data from 48 drill holes penetrating coals in the Sagavanirktok Formation has resulted in a hypothetical coal resource estimate of 610 billion metric tons. This estimate represents a more than tenfold increase from previous estimates of 45-55 billion metric tons $(t)$ for this region of the North Slope.
\end{abstract}

\section{INTRODUCTION}

Low-sulfur coal deposits in the Late Cretaceous and Tertiary Sagavanirktok Formation underlie a vast part of the east-central North Slope. Though reports of coal in this region date back to the early 1950's, more recent petroleum-industry drilling in the Prudhoe Bay and Kuparuk River oil fields has confirmed the presence of significant coal deposits in Upper Cretaceous and Tertiary strata. However, there are few published data on the distribution and quantity of these resources. Additionally, coal resource estimates have previously been quite conservative owing to the paucity of surface exposures and the low density of subsurface control in many areas.

In 1985, the U.S. Geological Survey initiated a study of coal resources in the Sagavanirktok Formation. The study area encompasses more than $18,000 \mathrm{~km}^{2}$ between the National Petroleum Reserve in Alaska (NPRA) and the Arctic National Wildlife Refuge (ANWR) (fig. 1). The western border of the study area is placed at the terminology-change boundary suggested by Molenaar and others (1986), which separates strata of the Colville Group (west of the boundary) from strata assigned to the Sagavanirktok and Canning Formations. The eastern border, which approximates the Canning River, is the estimated eastward extent of the primary coal-bearing interval, as extrapolated from subsurface data and coal isopach maps. The northern and southern borders are the Arctic coast and approximate outcrop limits of the Sagavanirktok Formation, respectively. This report presents a brief summary of coal distribution and analyses, and our preliminary assessment of hypothetical coal resources in the Sagavanirktok Formation.

\section{GEOLOGIC SETTING}

Gryc and others (1951) named the Sagavanirktok Formation for exposures of coal-bearing sedimentary rocks along the Sagavanirktok River near Franklin Bluffs (fig. 1). Detterman and others (1975) included all strata above the Cretaceous Prince Creek Formation and below Quaternary surficial deposits in the Sagavanirktok Formation and assigned a Tertiary age to the unit. Molenaar (1983) later interpreted the Sagavanirktok Formation to be diachronous, resulting from deposition within an eastto northeast-prograding deltaic system. Subsequently, Molenaar and others (1986) included beds as old as Late Cretaceous within the Sagavanirktok Formation, noting that the lowermost part of the formation is older to the west and south. Eastward, toward the ANWR, the Sagavanirktok Formation thickens and intertongues with 
marine shales of the Canning Formation (fig. 2). The Staines Tongue of the Sagavanirktok Formation and the Mikkelsen Tongue of the Canning Formation were defined in the subsurface in the Mobil Oil Corporation West Staines State No. 2 well, approximately $20 \mathrm{~km}$ west of the Canning River (Molenaar and others, 1987).
To the south and west, both tongues grade into the main body of the Sagavanirktok Formation. Palynomorph data indicate a Paleocene age for the Staines Tongue and an Eocene age for the Mikkelsen Tongue (Molenaar and others, 1987). The minimum thickness of the Sagavanirktok Formation in the study area is about $730 \mathrm{~m}$
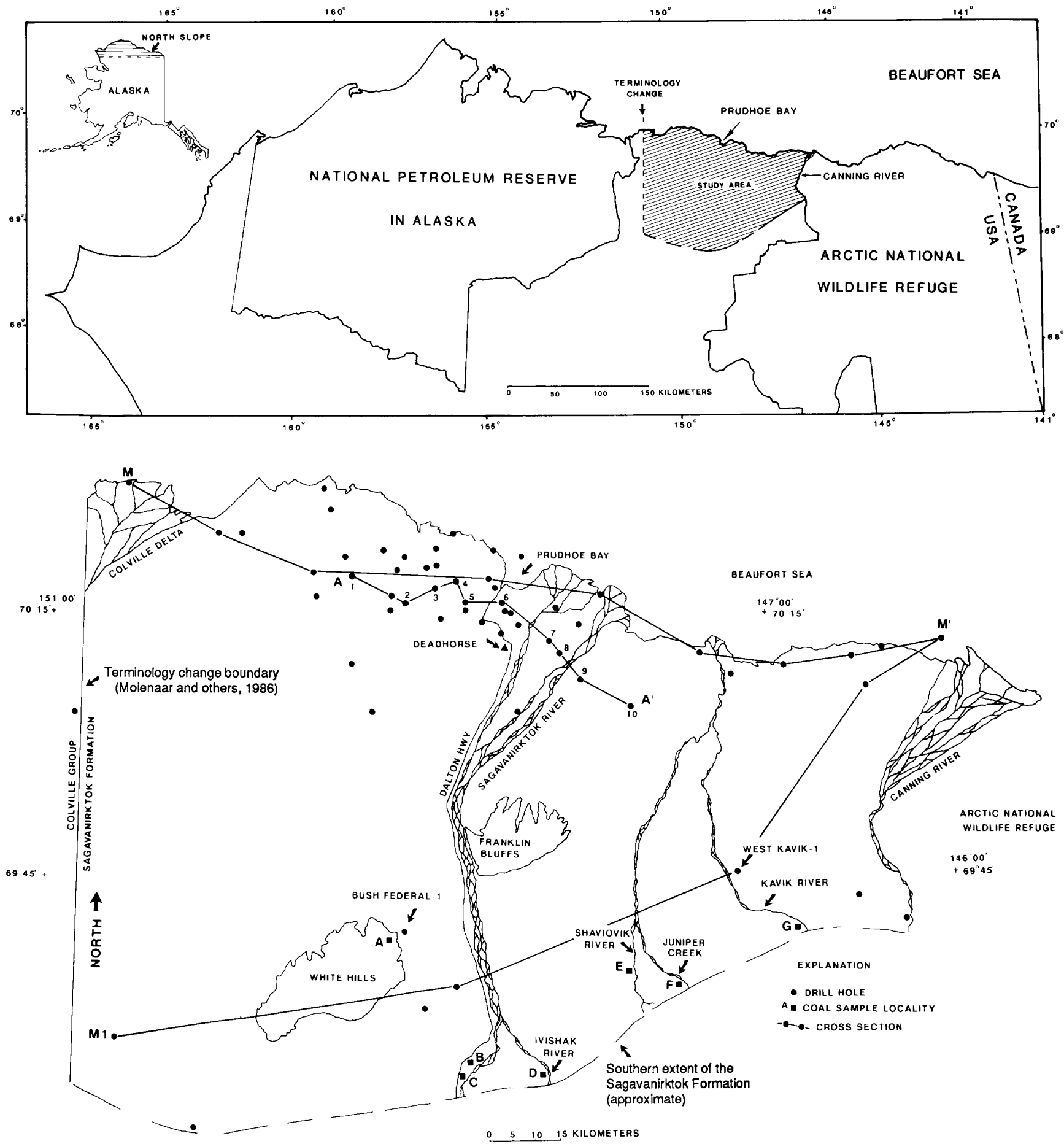

Figure 1. Index maps showing study area, locations of drill holes, cross sections, and coal-sample localities, east-central North Slope, Alaska. 
(Molenaar and others, 1986), and the maximum thickness, which includes one or more tongues of the Canning Formation (fig. 2), is about $2,750 \mathrm{~m}$ (Bird and Molenaar, 1987).

\section{COAL DISTRIBUTION}

Outcrops of coal-bearing rocks within the study area occur along an $80-\mathrm{km}$-long belt extending from the
White Hills eastward to the Kavik River (fig. 1). The coalbeds are associated with fluvio-deltaic deposits composed of conglomerate, sandstone, siltstone, shale, and carbonaceous shale. Coals that crop out in this area range in thickness (excluding partings) from $<0.4 \mathrm{~m}$ to a maximum of $7.1 \mathrm{~m}$ measured at sample locality E (fig. 1; Roberts and others, 1991).

The coal deposits extend northward in the subsurface from the outcrop belt to the Arctic coast and offshore (Affolter and Stricker, 1987). Borehole geophysi-

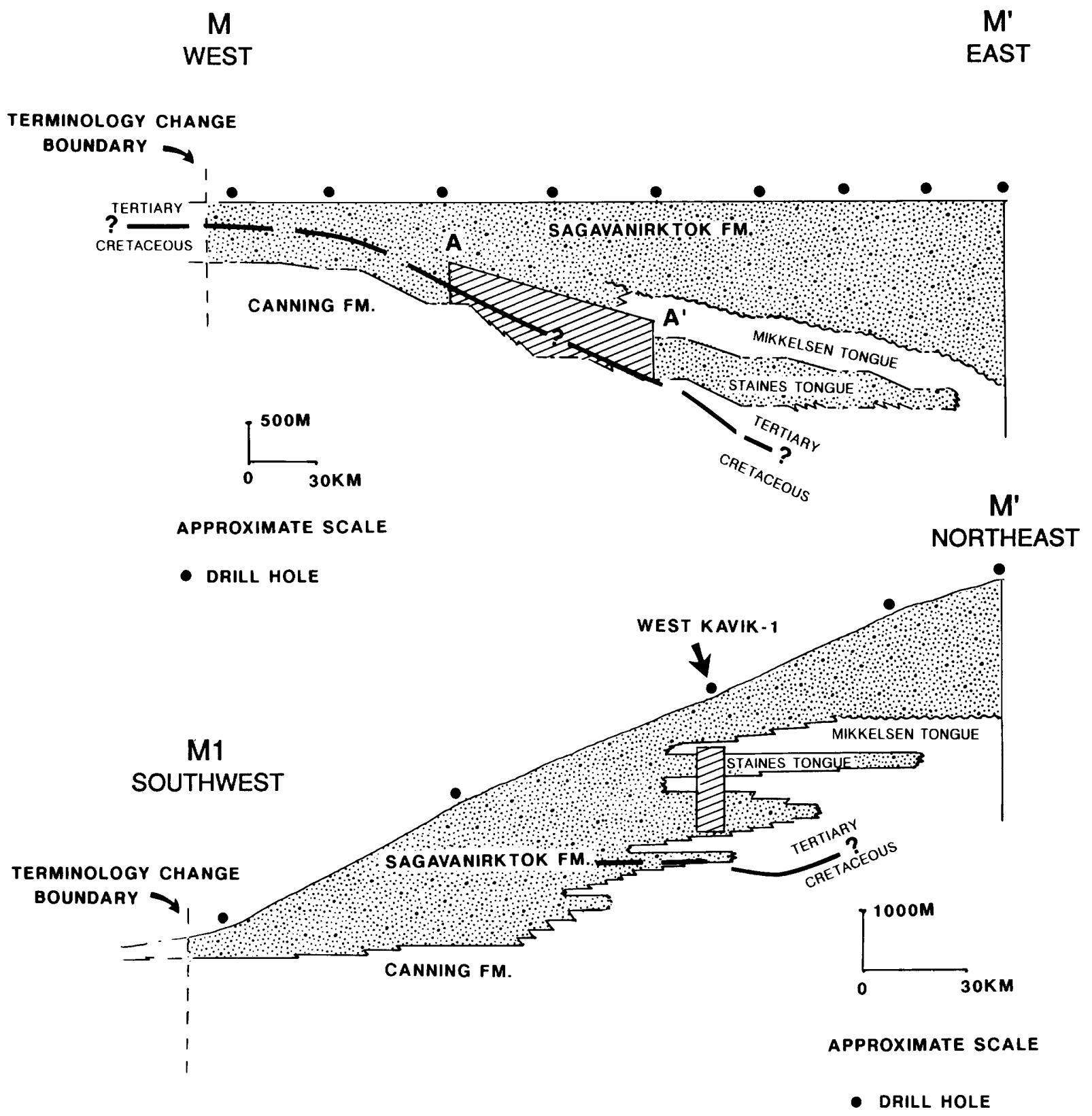

Figure 2. Cross sections showing general stratigraphy of the Sagavanirktok and Canning Formations along the Arctic coast $\left(M-M^{\prime}\right)$ and in the southern part of the study area $\left(M 1-M^{\prime}\right)$. Intervals depicted on cross section $A-A^{\prime}$ and in West Kavik-1 drill hole (figs. 3,4$)$ are shown as hachured areas in $M-M^{\prime}$ and $M 1-M^{\prime}$, respectively. Time lines dashed where approximate, queried where uncertain. Modified from Molenaar and others (1986). 
cal log data indicate that the primary coal-bearing interval in the Sagavanirktok Formation ranges from 220 to more than $900 \mathrm{~m}$ in thickness and is restricted to Late Cretaceous (Maastrichtian?) and early Tertiary (Paleocene) strata (Roberts and others, 1990). The majority of the coals are probably Paleocene in age. Minor coal deposits also occur in Eocene to Pliocene(?) age strata of the Sagavanirktok Formation throughout the study area, and to the east in the ANWR coastal-plain region (Bird and Molenaar, 1987). However, we feel these coals have a negligible resource potential, and thus we have limited our appraisal to the Late Cretaceous and Paleocene de- posits. It's also important to note that Late Cretaceous coals occur in laterally equivalent Colville Group strata west of the study area. However, current data are insufficient for extending the resource assessment to that region.

Along the Arctic coast, the coal-bearing interval becomes younger eastward and extends downdip from the main part of the Sagavanirktok Formation into the Staines Tongue. In the vicinity of Prudhoe Bay, the coal-bearing interval can be divided into upper and lower coal zones (fig. 3), although these coal-zone designations become more tenuous to the south and west of Prudhoe Bay.

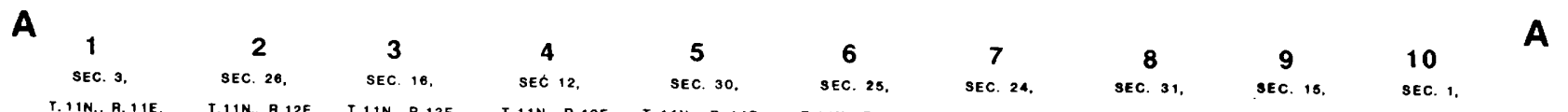
T.11N., R.12E. T.11N., R.13E. T.11N., R.13E. T.11N., R.14E. T.11N., R.14E. T.10N., R.15E. T.1ON., R.18E. T.9N., R.16E. T. QN., R.17E.

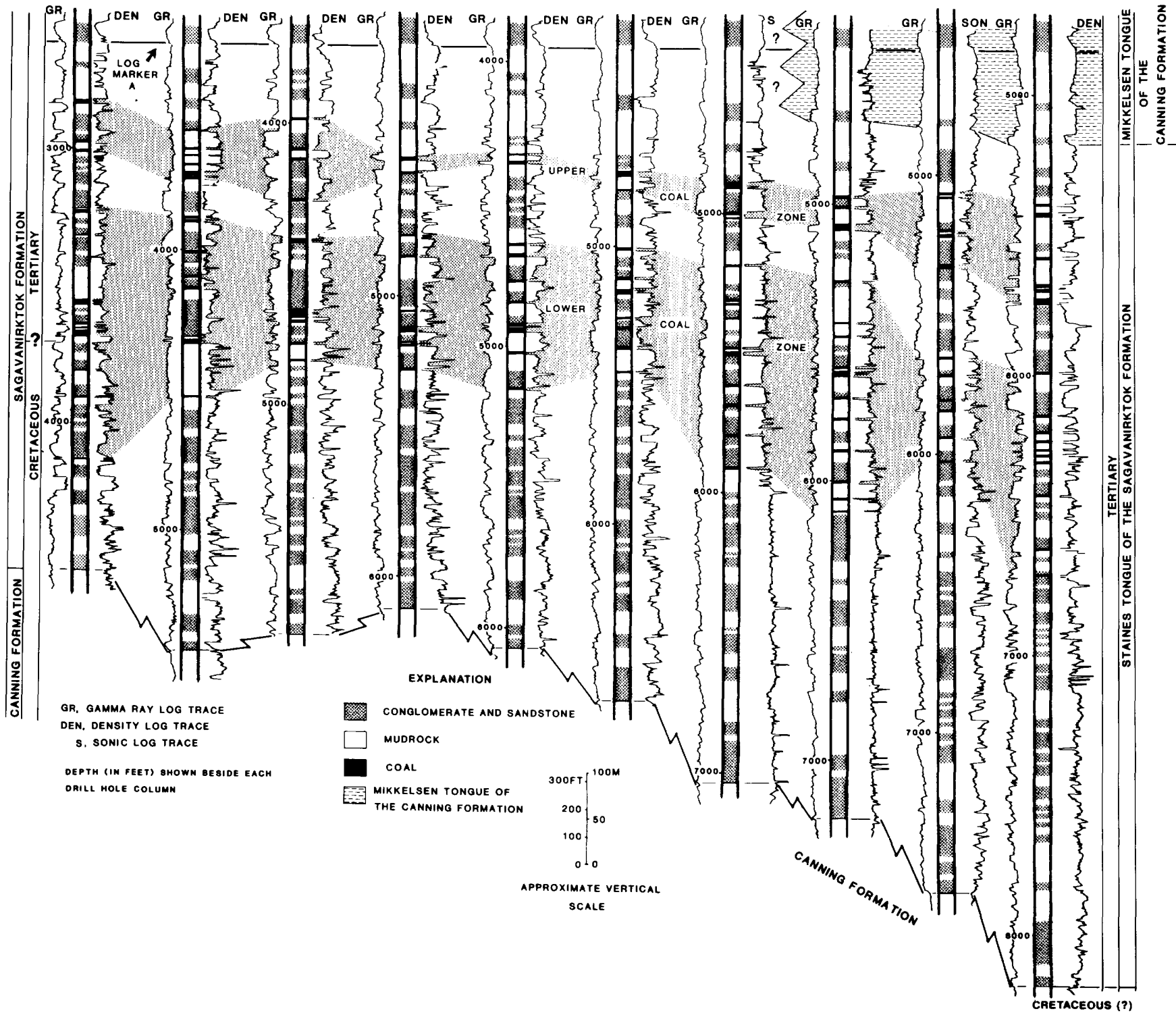

Figure 3. Cross section from well data, showing subsurface coalbeds along the Arctic coast near Prudhoe Bay, North Slope, Alaska. See figures 1 and 2 for location of cross section. Modified from Roberts (1991). 


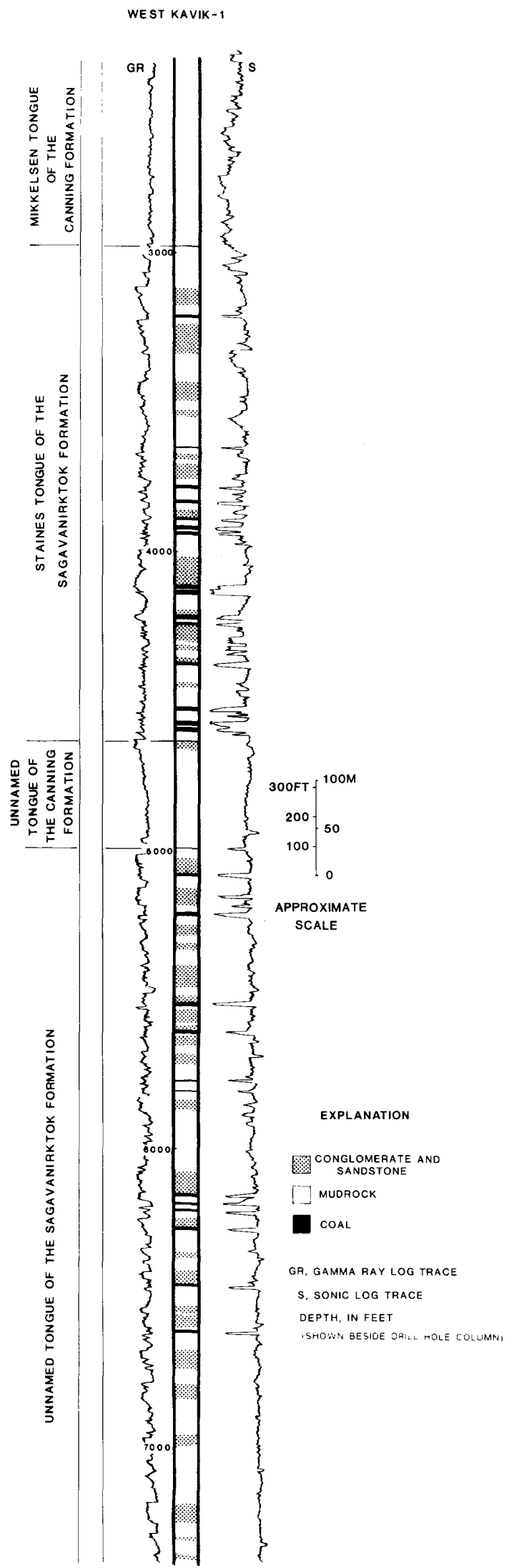

In the south-central part of the study area, coal occurs from the surface to a depth of about $975 \mathrm{~m}$ in the Bush Federal-1 well (fig. 1). Coal outcrops are also present stratigraphically higher in the nearby White Hills. In the West Kavik-1 well, some $75 \mathrm{~km}$ east of the Bush Federal-1 well (fig. 1), coal is present in both the Staines Tongue and a lower unnamed tongue of the Sagavanirktok Formation (fig. 4). Both tongues, and consequently the coal deposits, are interpreted to pinch out at or just east of the Canning River.

The identification of subsurface coalbeds (figs. 3, 4) is based on interpretations of density, sonic, and neutronporosity logs from oil and gas test wells. Resistivity and natural-gamma logs, which usually are effective tools for coalbed identification, were not as diagnostic. Coalbed thicknesses were determined primarily from density and sonic logs. Net thicknesses of subsurface coalbeds (excluding partings) range from about 0.8 to $6.7 \mathrm{~m}$, which is similar to the range of thicknesses ( $<0.4$ to $7.1 \mathrm{~m}$ ) observed in the surface exposures. In addition, 50 percent of the subsurface coals are $1.5 \mathrm{~m}$ thick or greater, compared with 40 percent of the surface coalbeds.

\section{COAL ANALYSES}

Fifty-five coal samples from seven outcrop localities (fig. 1) were collected for chemical analyses. Most of the coal samples were collected from trenched outcrops, although coalbeds at the north end of Sagwon Bluffs (fig. 1, loc. B) were recovered as core using shallow, hand-operated drilling equipment (Roberts and others, 1988). Coal analyses were provided by Dickenson Laboratories, Inc., of El Paso, Texas (38 samples), and Geochemical Testing of Somerset, Pennsylvania (17 samples). Apparent rank determinations were calculated at equilibrium moisture using the appropriate Parr formula in ASTM designation D388-88 (American Society for Testing and Materials, 1988). The apparent rank of the coal ranges from lignite $A$ to subbituminous $B$, with the majority of the coals being subbituminous $C$. Proximate and ultimate analysis, forms of sulfur, heat-of-combustion (Btu/lb), ash-fusion temperatures, and equilibrium-moisture values were determined for each sample (Roberts and others, 1991); a summary of the chemical analyses (based on equilibrium moisture) is shown in table 1.

Figure 4. Columnar section from well data, showing coalbeds in West Kavik-1 well in the southeastern part of the study area (sec. 20, T. 4 N., R. 20 E.). See figures 1 and 2 for location of well. Stratigraphic terminology from Molenaar and others (1986). 
Table 1. Summary of chemical analyses for 55 coal outcrop samples in the Sagavanirktok Formation, east-central North Slope, Alaska

[Moisture, ash, and sulfur values in percent]

\begin{tabular}{|c|c|c|c|c|c|c|c|c|}
\hline & $\begin{array}{c}\text { Location } \\
A\end{array}$ & $\begin{array}{c}\text { Location } \\
\text { B }\end{array}$ & $\begin{array}{l}\text { Location } \\
\text { C }\end{array}$ & $\begin{array}{l}\text { Location } \\
\text { D }\end{array}$ & $\begin{array}{c}\text { Location } \\
E\end{array}$ & $\begin{array}{l}\text { Location } \\
\mathrm{F}\end{array}$ & $\begin{array}{l}\text { Location } \\
G\end{array}$ & Total \\
\hline Number of samples & 3 & 7 & 3 & 8 & 25 & 4 & 5 & 55 \\
\hline \multicolumn{9}{|c|}{ Equilibrium } \\
\hline \multicolumn{9}{|l|}{ Moisture } \\
\hline Mean--- & 28.63 & 21.60 & 21.44 & 20.41 & 26.10 & 19.51 & 20.00 & 23.55 \\
\hline Minimum -........ & 25.55 & 16.20 & 21.06 & 16.18 & 21.32 & 18.57 & 17.00 & 16.18 \\
\hline Maximum -------- & 32.97 & 24.44 & 21.97 & 23.44 & 28.80 & 21.50 & 21.83 & 32.97 \\
\hline \multicolumn{9}{|l|}{ Ash } \\
\hline 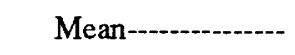 & 2.42 & 8.00 & 16.51 & 20.41 & 10.07 & 5.12 & 12.27 & 11.08 \\
\hline Minimum -------- & 1.72 & 2.67 & 10.54 & 16.18 & 1.19 & 1.79 & 2.84 & 1.19 \\
\hline Maximum --------- & 3.27 & 16.36 & 22.89 & 23.44 & 47.11 & 13.64 & 38.23 & 47.11 \\
\hline \multicolumn{9}{|l|}{ Sulfur } \\
\hline Mean-.............. & .20 & .12 & .20 & .21 & .47 & .11 & 1.04 & .38 \\
\hline Minimum --------- & .20 & .08 & .13 & .13 & .10 & .09 & .33 & .08 \\
\hline Maximum --------- & .20 & .17 & .30 & .37 & 1.63 & .13 & 2.16 & 2.16 \\
\hline \multicolumn{9}{|l|}{$\mathrm{Btu} / \mathrm{lb}$} \\
\hline Mean-............-. & 7,500 & 8,660 & 7,380 & 7,130 & 7,690 & 8,960 & 7,490 & 7,780 \\
\hline Minimum --------- & 7,200 & 6,310 & 6,460 & 5,080 & 3,340 & 7,900 & 4,570 & 3,340 \\
\hline Maximum -------- & 7,610 & 9,510 & 8,240 & 9,460 & 9,100 & 9,740 & 8,650 & 9,740 \\
\hline
\end{tabular}

\section{COAL RESOURCES}

The total-coal-thickness and overburden maps (fig. 5) were generated from geophysical and drill-cuttings log information for 48 oil exploratory wells (fig. 1). Total coal thickness (that is, the cumulative thickness of all coalbeds in the coal-bearing interval) was determined for each data point and provided the basis for the resource assessment. Hypothetical resource estimates were calculated using a combination of the extrapolated coal-zone method (Wood and others, 1983) and methodology utilized by Sable and Stricker (1987) for NPRA coal resources. The estimates were derived using the following formula:

where

$$
R=A \times T \times C,
$$

$R$ is the hypothetical resource estimate;

$A$ is the area underlain by coal;

$T$ is the total coal thickness (based on the total coal isopach map); and

$C$ is a weight/volume conversion factor.

Based on the apparent ranks determined from the 55 outcrop samples, we applied a conversion factor $C$ of $13,000 \mathrm{t} / \mathrm{hm}^{2}-\mathrm{m}$ for subbituminous coal (Wood and oth- ers, 1983). A summary of total hypothetical coal resources for the Sagavanirktok Formation, subdivided into four overburden categories, is shown in table 2.

\section{SUMMARY}

The thickest concentrations of Late Cretaceous and early Tertiary (Paleocene) coal in the Sagavanirktok Formation occur in the southeastern part of the study area, between the Kavik River and White Hills (fig. 1). By our estimates, approximately 33 percent of the total hypothetical coal resources occur within a depth of $150 \mathrm{~m}$, while the majority of the coal (approximately 50 percent) is found at depths between 300 and $1,800 \mathrm{~m}$. Chemical analyses of 55 outcrop samples indicate that these deposits are dominantly low-sulfur (mean 0.38 percent), medium-ash (mean 11.08 percent), subbituminous $\mathrm{C}$ coals.

Total hypothetical coal resources for all of Alaska, excluding coal deposits in the Sagavanirktok Formation, have been estimated at 4.4 trillion $\mathrm{t}$ ( 4.0 trillion short tons) (Stricker, 1990). Our total hypothetical coal resource estimate of 610 billion $t$ for the Sagavanirktok 
Table 2. Hypothetical coal-resource estimates for Late Cretaceous and early Tertiary coal deposits in the Sagavanirktok Formation, eastcentral North Slope, Alaska

\begin{tabular}{ccc}
\hline $\begin{array}{c}\text { Oveburden } \\
\text { (meters) }\end{array}$ & $\begin{array}{c}\text { Area } \\
\text { (kilometers) }\end{array}$ & $\begin{array}{c}\text { Metric tons } \\
\text { of coal (x102) }\end{array}$ \\
\hline $0-150$ - & 5,920 & 190 \\
$150-300$ & 3,360 & 85 \\
$300-1,800$ & 7,870 & 320 \\
$>1,800$ & 1,520 & 15 \\
Total & 18,670 & 610 \\
\hline
\end{tabular}

Formation represents a 10 percent increase in the total coal resource estimates for Alaska, as well as more than a tenfold increase over previous estimates of 45-55 billion $\mathrm{t}$ (50-60 billion short tons) for the Sagavanirktok Formation of this region (see, for example, Sanders, 1975; Tailleur and Brosgé, 1975). It is important to bear in mind, however, that this resource figure is based in large part on extrapolated coal-thickness trends through areas with little data. In areas of concentrated drilling, such as the Kuparuk River and Prudhoe Bay oil fields, incorporation of additional well data should lead to im- proved coal correlations and, thus, to more refined resource categorization (that is, identified resources; Wood and others, 1983). However, acquisition of significant additional data for other parts of the study area, such as the extensive region between the White Hills and the western boundary, seems unlikely, and resource estimates in those areas will probably remain hypothetical well into the future.

\section{REFERENCES CITED}

Affolter, R.H., and Stricker, G.D., 1987, Offshore Alaska coal, in Scholl, D.W., Grantz, Arthur, and Vedder, J.G., eds., Geology and resource potential of the continental margin of western North America and adjacent ocean basinsBeaufort Sea to Baja California: Houston, Texas, CircumPacific Council for Energy and Mineral Resources, Earth Science Series, v. 6, p. 639-647.

American Society for Testing and Materials, 1988, Standard classification of coals by rank (ASTM designation D-38888): 1988 Annual Book of ASTM Standards, sec. 5, p. 182-185.

Bird, K.J., and Molenaar, C.M., 1987, Stratigraphy, in Bird, K.J., and Magoon, L.B., eds., Petroleum geology of the northern part of the Arctic National Wildlife Refuge, northeastern Alaska: U.S. Geological Survey Bulletin 1778 , p. $37-59$.
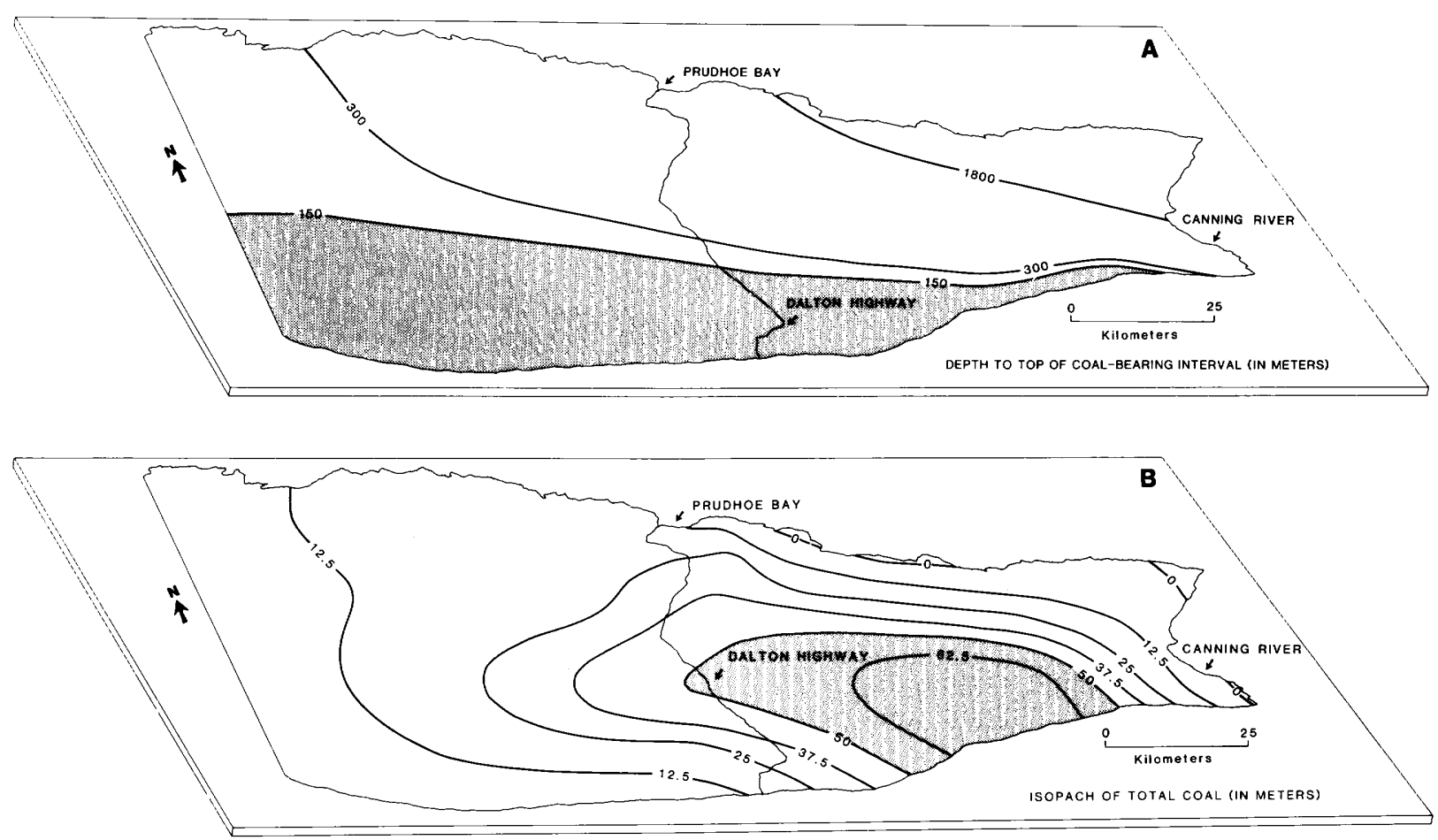

Figure 5. Diagrammatic maps showing overburden $(A)$ and total coal thickness $(B)$ for Late Cretaceous and Paleocene coal deposits in the study area. Shaded areas highlight shallower and thicker coal regions in $A$ and $B$, respectively. Owing to perspective view, the scale bar represents the east-west dimension only; the north-south dimension is approximately 50 percent of the east-west dimension. 
Detterman, R.L., Reiser, H.N., Brosgé, W.P., and Dutro, J.T., Ir., 1975, Post-Carboniferous stratigraphy, northeastern Alaska: U.S. Geological Survey Professional Paper 886, $46 \mathrm{p}$.

Gryc, George, Patton, W.W., Jr., and Payne, T.G., 1951, Present Cretaceous stratigraphic nomenclature of northern Alaska: Washington Academy of Sciences Journal, v. 41, no. 5, p. 159-167.

Molenaar, C.M., 1983, Depositional relations of Cretaceous and lower Tertiary rocks, northeastern Alaska: American Association of Petroleum Geologists Bulletin, v. 67, no. 7, p. 1066-1080.

Molenaar, C.M., Bird, K.J., and Collett, T.S., 1986, Regional correlation sections across the North Slope of Alaska: U.S. Geological Survey Miscellaneous Field Studies Map MF-1907, 1 pl.

Molenaar, C.M., Bird, K.J., and Kirk, A.R., 1987, Cretaceous and Tertiary stratigraphy of northeastern Alaska, in Tailleur, I.L., and Weimer, Paul, eds., Alaskan North Slope geology: Bakersfield, California, Pacific Section, Society of Economic Paleontologists and Mineralogists, v. 1, p. 513-528.

Roberts, S.B., 1991, Cross section showing subsurface coal beds in the Sagavanirktok Formation, vicinity of Prudhoe Bay, east-central North Slope, Alaska: U.S. Geological Survey Coal Investigations Map C-139A, 1 pl.

Roberts, S.B., Clark, A.C., and Carey, M.A., 1988, Analyses of seven core samples from two Tertiary coal beds in the Sagwon Member of the Sagavanirktok Formation, North Slope, Alaska: U.S. Geological Survey Open-File Report 88-21, 6 p.

Roberts, S.B., Stricker, G.D., and Affolter, R.H., 1990, 200+ billion tons of low-sulfur coal in the Sagavanirktok Formation, North Slope, Alaska [abs.]: American Association of Petroleum Geologists Bulletin v. 74, no. 8, p. 1343.

1991, Stratigraphy and chemical analyses of coal beds in the Upper Cretaceous and Tertiary Sagavanirktok Formation, east-central North Slope, Alaska: U.S. Geological Survey Coal Investigations Map C-139B, 1 pl. [in press].

Sable, E.G., and Stricker, G.D., 1987, Coal in the National Petroleum Reserve in Alaska (NPRA): framework geology and resources, in Tailleur, I.L., and Weimer, Paul, eds., Alaskan North Slope geology: Bakersfield, California, $\mathrm{Pa}-$ cific Section, Society of Economic Paleontologists and Mineralogists, v. 1, p. 195-215.

Sanders, R.B., 1975, Coal resources of Alaska, in Rao, P.D., and Wolff, E.N., eds., Focus on Alaska's coal '75-Proceedings of the conference: Mineral Industry Research Laboratory Report no. 37, p. 21-32.

Stricker, G.D., 1990, Alaska has 4.0 trillion tons of low-sulfur coal; is there a future for this resource? [abs.]: American Association of Petroleum Geologists Bulletin, v. 74, no. 5, p. 772.

Tailleur, I.L., and Brosgé, W.P., 1975, Coal resources of northern Alaska may be nation's largest, in Rao, P.D., and Wolff, E.N., eds., Focus on Alaska's coal '75-Proceedings of the conference: Mineral Industry Research Laboratory Report no. 37, p. 219-226.

Wood, G.H., Jr., Kehn, T.M., Carter, M.D., and Culbertson, W.C., 1983, Coal resource classification system of the U.S. Geological Survey: U.S. Geological Survey Circular 891,65 p.

Reviewers: Michael E. Brownfield and Timothy S. Collett 


\title{
Fluvial Facies Architecture in the Tertiary Usibelli Group of Suntrana, Central Alaska
}

\author{
By Richard G. Stanley, Romeo M. Flores, and Thomas J. Wiley
}

\begin{abstract}
Fluvial deposits in the type section of the Tertiary Usibelli Group at Suntrana, Alaska, exhibit varying types of facies architecture that probably reflect differences in the sediment loads, flow discharges, and channel patterns of the rivers that deposited them. Detailed field drawings and interpretations were made of three examples: (1) lenticular conglomerates and sandstones deposited by gravelrich braided streams; (2) fining-upward sequences of sandstone and minor conglomerate deposited by distal, sandrich braided streams, overlain by muddy abandoned-channel deposits and capped by thick coals; and (3) fining-upward sequences mostly of sandstone deposited by mixedload (sandy and muddy) streams, overlain by thick muddy overbank deposits with well-developed crevasse-splay sandstones and thin interbeds of coal. These contrasting facies architectural styles probably were deposited by an ancient river system that flowed generally southward through central Alaska, before late Cenozoic uplift of the Alaska Range.
\end{abstract}

\section{INTRODUCTION}

The Tertiary Usibelli Group (Wahrhaftig, 1987) is a sequence of coal-bearing fluvial and lacustrine deposits that crops out widely in the northern foothills of the Alaska Range. In the Nenana coal field (fig. 1), the Usibelli Group contains at least 1.4 billion tons of minable subbituminous coal, parts of which are being mined by the Usibelli Coal Mine, Inc. (Merritt, 1985a). The Usibelli Group is present and may be prospective for oil and gas in the subsurface of the middle Tanana basin (Miller and others, 1959; Kirschner, 1988; Stanley and others, 1990), where it has been penetrated by two dry exploratory wells, the Union Nenana No. 1 and the ARCO Totek Hills No. 1 (fig. 1).

In order to better understand the depositional setting and resource potential of fluvial deposits in the Usibelli Group, we investigated their sedimentology in outcrops in the Nenana coal field. Our work builds on and adds to previous studies by Wahrhaftig and others
(1969), Wahrhaftig (1970, 1987), Stevens (1971), Buffler and Triplehorn (1976), Selleck and Panuska (1983), and Merritt (1985a, b).

This paper presents the initial results of an investigation of the facies architecture of fluvial deposits in the type section of the Usibelli Group at Suntrana, about 120 km southwest of Fairbanks (fig. 1). By "facies architecture," we mean the lateral and vertical arrangement of outcrop-scale packages of sedimentary rock that can be (1) defined on the basis of grain size, sedimentary structures, internal sequence, and external geometry and (2) interpreted as depositional elements such as channels, bars, overbank fines, and coal swamps. Our approach to facies architectural analysis is similar in some respects to that advocated by Miall (1985). At Suntrana, we studied and made field drawings of three contrasting examples of fluvial facies architecture in good outcrops in

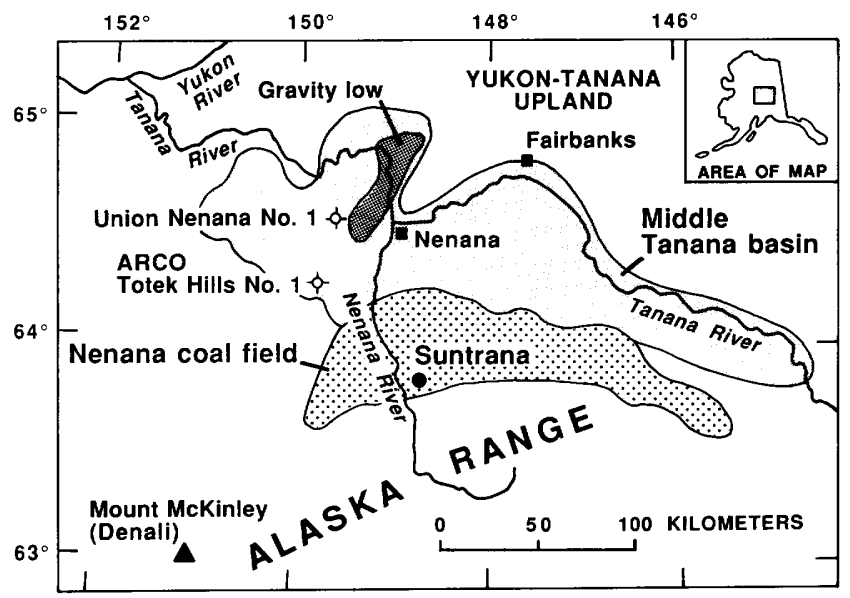

Figure 1. Index map showing location of type section for the Usibelli Group at Suntrana, exploratory wells drilled for petroleum, Nenana coal field (from Merritt and Hawley, 1986), and middle Tanana basin (from Miller and others, 1959). Gravity low corresponds to deepest part of middle Tanana basin; values of Bouguer gravity in low range from -35 to $-55 \mathrm{mGal}$ in relation to surrounding areas (Barnes, 1961; Valin and others, 1991). 
roadcuts, badlands, and cutbanks along creeks. The results provide new information on the complexity of lateral and vertical facies relationships and the diversity of depositional styles exhibited by these rocks.

\section{STRATIGRAPHIC AND SEDIMENTOLOGIC SETTING}

The Usibelli Group at Suntrana is $585 \mathrm{~m}$ thick and consists of about 64 percent conglomerate and sandstone, 23 percent mudstone and siltstone, and 13 percent subbituminous and lignite coal (Stanley and others, 1990). The group is divided into five formations; in ascending stratigraphic order, these are the Healy Creek, Sanctuary, Suntrana, Lignite Creek, and Grubstake Formations (fig. 2). Fossil plant leaves and pollen indicate that the Usibelli Group at Suntrana is entirely of Miocene age, although elsewhere in the Nenana coal field it is as old as Eocene (Wahrhaftig and others, 1969; Wolfe and Tanai, 1980; Csejtey and others, 1986; Wahrhaftig, 1987). The Usibelli Group rests nonconformably on the Precambrian or Paleozoic Birch Creek Schist of former usage (Wahrhaftig, 1968, 1970), which is interpreted to be part of the Yukon-Tanana terrane (Jones and others, 1987). The Usibelli Group is unconformably overlain by the Miocene and Pliocene Nenana Gravel, which was de- posited by north-flowing braided streams on alluvial fans that developed along the northern flank of the Alaska Range as it was uplifted during late Miocene and Pliocene time (Wahrhaftig, 1987).

The Healy Creek, Suntrana, and Lignite Creek Formations consist mainly of repeated fining-upward sequences of conglomerate, sandstone, siltstone, mudstone, and coal that were deposited by a variety of fluvial systems ranging from low-sinuosity, gravelly braided streams to high-sinuosity (meandering), mixed-load streams (Buffler and Triplehorn, 1976; Selleck and Panuska, 1983; Stanley and others, 1989). During much of Eocene, Oligocene, and Miocene time these streams flowed generally to the south, across the future site of the Alaska Range, toward Cook Inlet and the Gulf of Alaska (Wahrhaftig, 1987). The sandstones are mainly quartzofeldspathic, while the conglomerate clast assemblages are complex and composed mainly of resistant sedimentary, igneous, and low- to medium-grade metamorphic rock types (Stevens, 1971). Pebble counts, heavy minerals, and available paleocurrent measurements suggest that much of the sediment in the fluvial deposits of the Usibelli Group was derived from the Yukon-Tanana Upland (fig. 1; Stevens, 1971; Buffler and Triplehorn, 1976). Compared with the Healy Creek and Suntrana Formations, the Lignite Creek Formation contains sandstones that are more arkosic and richer in

\begin{tabular}{|c|c|c|c|c|c|c|}
\hline \multicolumn{2}{|c|}{ UNIT } & AGE & $\begin{array}{l}\text { THICKNESS, } \\
\text { IN METERS }\end{array}$ & GENERALIZED LITHOLOGY & $\begin{array}{l}\text { DEPOSITIONAL } \\
\text { SETTING }\end{array}$ & $\begin{array}{l}\text { DRAWINGS OF } \\
\text { FACIES } \\
\text { ARCHITECTURE }\end{array}$ \\
\hline \multicolumn{2}{|c|}{ Nenana Gravel } & $\begin{array}{l}\text { Pliocene and } \\
\text { Miocene }\end{array}$ & 1,040 & $\begin{array}{l}\text { Poorly consolidated, brown- to tan- } \\
\text { weathering conglomerate with lenses of } \\
\text { sandstone and minor mudstone. }\end{array}$ & Alluvial fan & \\
\hline \multirow{8}{*}{$\begin{array}{l}0 \\
\frac{0}{3} \\
0 \\
\frac{1}{0} \\
\overline{\bar{c}} \\
\overline{0} \\
\frac{0}{n} \\
D\end{array}$} & $\begin{array}{l}\text { Grubstake } \\
\text { Formation }\end{array}$ & late Miocene & 27 & $\begin{array}{l}\text { Unconformity } \\
\text { Dark-gray shale, mudstone, and } \\
\text { siltstone, laminated to bioturbated; thin } \\
\text { sandstone interbeds increase upward in } \\
\text { frequency, thickness, and grain size. }\end{array}$ & Lacustrine & \\
\hline & \multirow{2}{*}{$\begin{array}{l}\text { Lignite } \\
\text { Creek } \\
\text { Formation }\end{array}$} & \multirow{2}{*}{$\begin{array}{l}\text { late and middle } \\
\text { Miocene }\end{array}$} & \multirow[b]{2}{*}{179} & \multirow{2}{*}{$\begin{array}{l}\text { Interbedded, poorly consolidated, tan- to } \\
\text { buff-weathering sandstone, } \\
\text { conglomerate, mudstone, and lignite; } \\
\text { arranged in fining-upward sequences. }\end{array}$} & \multirow[b]{2}{*}{ Fluvial } & \\
\hline & & & & & & Fig. 5 \\
\hline & \multirow[b]{2}{*}{$\begin{array}{l}\text { Suntrana } \\
\text { Formation }\end{array}$} & \multirow[b]{2}{*}{ middle Miocene } & \multirow[b]{2}{*}{210} & \multirow{2}{*}{$\begin{array}{l}\text { Interbedded, poorly consolidated, white- } \\
\text { weathering sandstone, conglomerate, } \\
\text { mudstone, siltstone, and coal; in part } \\
\text { arranged in fining-upward sequences. }\end{array}$} & \multirow[b]{2}{*}{ Fluvial } & \\
\hline & & & & & & Fig. 4 \\
\hline & $\begin{array}{l}\text { Sanctuary } \\
\text { Formation }\end{array}$ & middle Miocene & 33 & $\begin{array}{l}\text { Brown shale, mudstone, and siltstone } \\
\text { with thin interbeds of sandstone; } \\
\text { sandstone beds increase upward in } \\
\text { frequency and thickness. }\end{array}$ & Lacustrine & \\
\hline & \multirow{2}{*}{$\begin{array}{l}\text { Healy } \\
\text { Creek } \\
\text { Formation }\end{array}$} & \multirow{2}{*}{$\begin{array}{l}\text { middle and } \\
\text { early Miocene }\end{array}$} & \multirow{2}{*}{136} & \multirow{2}{*}{$\begin{array}{l}\text { Interbedded, poorly consolidated, white- } \\
\text { weathering sandstone, conglomerate, } \\
\text { mudstone, siltstone, and coal; fining- } \\
\text { upward sequences in upper } 100 \text { meters. }\end{array}$} & \multirow{2}{*}{ Fluvial } & \\
\hline & & & & & & Fig. 3 \\
\hline \multicolumn{2}{|c|}{$\begin{array}{l}\text { Birch Creek } \\
\text { Schist of } \\
\text { former usage }\end{array}$} & $\begin{array}{l}\text { Paleozoic or } \\
\text { Precambrian }\end{array}$ & Unknown & Quartz-mica schist and quartzite. & (Metamorphic) & \\
\hline
\end{tabular}

Figure 2. Generalized stratigraphy at Suntrana (not to scale), showing approximate stratigraphic positions of drawings of facies architecture (figs. 3-5). 
unstable heavy minerals, and conglomerate clast assemblages that are richer in volcanic and plutonic rocks. These differences can be explained by a change in source area, possibly associated with an episode of uplift in the Yukon-Tanana Upland and exposure by erosion of a new suite of rocks (Stevens, 1971; Wahrhaftig, 1987) or, alternatively, by climatic cooling and a decrease in chemical weathering (Dickson, 1982).

The Sanctuary and Grubstake Formations consist mainly of mudstone and fine sandstone that accumulated in large, shallow lakes (Wahrhaftig and others, 1969; Wahrhaftig, 1987). Mudstones of lacustrine origin in the Sanctuary and Grubstake Formations are finely laminated and bioturbated, and they occur interbedded with thin, normally graded, plane-laminated and rippled beds of fine sandstone interpreted as turbidity-current deposits (Selleck and Panuska, 1983; Stanley and others, 1990). In both formations, sandstone interbeds increase upward in thickness and frequency, perhaps recording the progradation of stream deltas into deeper water from the lake margins.

\section{METHODS}

We examined and made detailed drawings of outcrops of three different types of fluvial facies architecture at Suntrana (figs. 3-5), from parts of the Healy Creek, Suntrana, and Lignite Creek Formations. The locations of the drawings were selected largely on the basis of quality of outcrop, ease of accessibility, and distinct differences in facies architectural types. Stratigraphic thicknesses were determined with a Jacob's staff in short measured sections; horizontal measurements were made with a cloth tape. In the discussions below, each facies architectural type is briefly described and interpreted in terms of depositional processes and environments.

\section{TYPE 1: BRAIDED-STREAM CONGLOMERATES AND SANDSTONES}

The lower $40 \mathrm{~m}$ of the Healy Creek Formation at Suntrana consists mainly of amalgamated, basally scoured, lenticular pebble-cobble conglomerates and sandstones; the lowermost beds rest in sharp, erosional contact on schist (fig. 3). The conglomerates generally are normally graded, clast supported, and crudely imbricated. The sandstones exhibit abundant tabular and trough crossbedding in sets generally less than $70 \mathrm{~cm}$ thick. Ripples and small-scale cross-lamination are common. Also present are several concave-upward scour surfaces with as much as $300 \mathrm{~cm}$ of erosional relief, which we interpret as channel floors.

By analogy with similar sediments in both modern and ancient environments (Miall, 1978), the conglomerates and sandstones were likely deposited by migrating longitudinal gravel bars and sandy transverse bars in

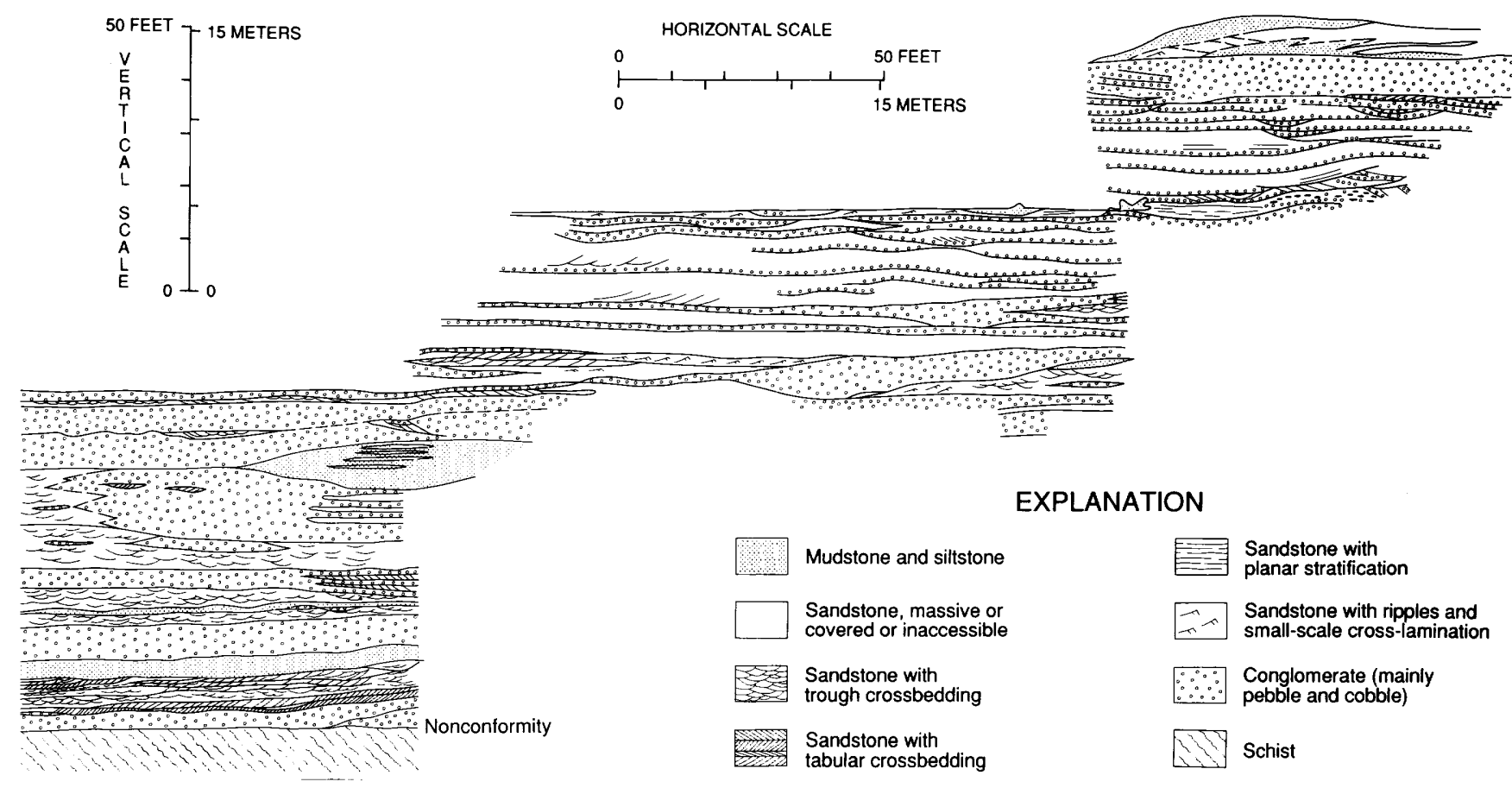

Figure 3. Field drawing of facies architecture type 1, from lowest $40 \mathrm{~m}$ of Healy Creek Formation at Suntrana. No vertical exaggeration. 
shallow, low-sinuosity channels of high-energy, braided streams. The streams may have occurred on a "wet" alluvial fan or, alternatively, on a proximal braid plain; detailed paleocurrent data combined with mapping of lateral variations in thickness and facies should provide further insights into the local paleogeography of these deposits.

Minor amounts of brown mudstone and siltstone occur in beds and channel-form lenses that have sharp and scoured contacts with the underlying strata. These probably represent quiet-water deposition of suspended sediment in abandoned stream channels.

\section{TYPE 2: FINING-UPWARD CHANNEL SANDSTONES AND CONGLOMERATES, OVERLAIN BY MUDDY ABANDONED CHANNELS AND THICK COALS}

The Suntrana Formation includes several well developed, fining-upward sequences (Wahrhaftig, 1987). Each fining-upward sequence consists of a lower coarsegrained unit composed of conglomerate and sandstone, and an upper fine-grained unit composed of mudstone, siltstone, and fine sandstone, capped by thick coals. We studied in detail two such fining-upward sequences between Coal No. 2 and Coal No. 4 (nomenclature of Wahrhaftig and others, 1969), located about 222-273 m stratigraphically above the base of the formation (fig. 4).

Within the lower coarse-grained units, grain size decreases generally upward, from pebble and granule conglomerate and coarse-grained sandstone near the base to fine-grained sandstone near the top. The conglomerate beds are basally scoured and normally graded. The sandstones are commonly cross-stratified; the scale of crossstratification generally decreases upward, from trough and tabular sets as much as $150 \mathrm{~cm}$ thick near the base to small-scale sets only a few centimeters thick near the top. Macerated, dark-colored plant fragments are locally abundant along laminations; large coal clasts also occur. These conglomerates and sandstones resemble deposits reported from modern distal braided rivers such as the Donjek in the southwest Yukon, Canada (Rust, 1972; Miall, 1978). By analogy with such rivers, the conglomerates and sandstones that we studied (fig. 4) probably were deposited in high-energy fluvial channels that were filled by migrating longitudinal gravel bars and sandy transverse, linguoid, and side-channel bars (Rust, 1972; Miall, 1977, 1978; Ferguson and Werritty, 1983). The upward decreases in grain size and scale of cross-stratification reflect decreasing flow resulting from switching and lateral migration of the stream channels.

The overlying mudstones, siltstones, and rippled fine-grained sandstones are poorly exposed but appear mainly in channel-form lenses with scoured lower con- tacts (fig. 4). These fine-grained sediments occupy a series of crosscutting channels that suggest a complex history of channel abandonment (recorded by the mudstones) and reoccupation (recorded by the sandstones), perhaps by small, high-sinuosity (meandering) streams that flowed across the flood plain marginal to the main river channels (represented by the underlying conglomerates and sandstones).

The fining-upward sequences are capped by Coals No. 3 and No. 4, each about $5 \mathrm{~m}$ thick. These coals are poorly exposed; much of Coal No. 4 has burned, resulting in an abundance of bright red, orange, and yellow clinker that covers parts of the outcrop (fig. 4). Petrologic studies suggest that the coals formed from woody tree-vegetation peats that accumulated in poorly drained, forest-moor swamps (Merritt, 1985a).

\section{TYPE 3: FINING-UPWARD CHANNEL SANDSTONES OVERLAIN BY THICK OVERBANK MUDS AND THIN COALS}

Fluvial, fining-upward sequences composed of conglomerate, sandstone, mudstone, and coal also occur in the Lignite Creek Formation; two such sequences, about 405-453 $\mathrm{m}$ above the base of the formation, were studied in detail (fig. 5). Each fining-upward sequence consists of two components: a lower coarse-grained unit composed of pebble and cobble conglomerate and coarse- to fine-grained sandstone; and an upper finegrained unit composed mainly of fine-grained sandstone, siltstone, and mudstone, with thin interbeds of coal.

In the interval that we studied, the conglomerates and sandstones rest in sharp erosional contact on the underlying mudstones and coals. The conglomerates generally are clast supported and imbricated, while the sandstones show trough and tabular crossbedding, ripples and small-scale cross-lamination, and convolute stratification. Both grain size and the scale of cross-stratification decrease upward. These deposits resemble those reported from high-energy channel deposits in several modern sandy streams (Ashley, 1978; Levey, 1978; Walker and Cant, 1984). By analogy with their presumed modern counterparts, the conglomerates that we studied (fig. 5) most likely represent gravel lags and longitudinal gravel bars, while the sandstones probably record a variety of migrating sandy bedforms, including sinuous-crested dunes, straight-crested sand waves, and transverse or oblique bars (Ashley, 1978; Levey, 1978; Walker and Cant, 1984). The upward decreases in grain size and in scale of cross-stratification probably reflect decreasing flow as the main river channels shifted laterally or were abandoned.

Convolute stratification is common in places (fig. 5 ), and consists mainly of complicated soft-sediment 
folds involving trough and tabular crossbedded sandstone. In places, the folded sandstones are intruded by small sandstone diapirs that probably formed as a result of dewatering. The events that caused the folding and diapirism are unknown but may have included (1) shaking by earthquakes, (2) slumping due to undercutting by channel erosion or oversteepening of channel margins, and (3) liquefaction and frictional drag induced by flood events.

The upper fine-grained units are thick but poorly exposed. The mudstones and siltstones are brown to bluish-brown, and in places they contain thin, subvertical tubes of carbonaceous material, arranged in downward- branching networks, that we interpret as root remains. By analogy with similar sediments in both modern and ancient fluvial environments (Miall, 1977, 1978, 1985), these mudstones and siltstones are interpreted as overbank deposits and probably represent quiet-water deposition of fine-grained sediment in ponds, swales, marshes, and swamps on flood-plain areas away from the active, high-energy fluvial channels discussed above. Near the top of the interval shown in figure 5, the flood-plain mudstones and siltstones enclose packets of obliquely dipping, thin beds of fine- to medium-grained sandstone with ripples and small-scale cross-lamination, interpreted as crevasse-splay deposits.

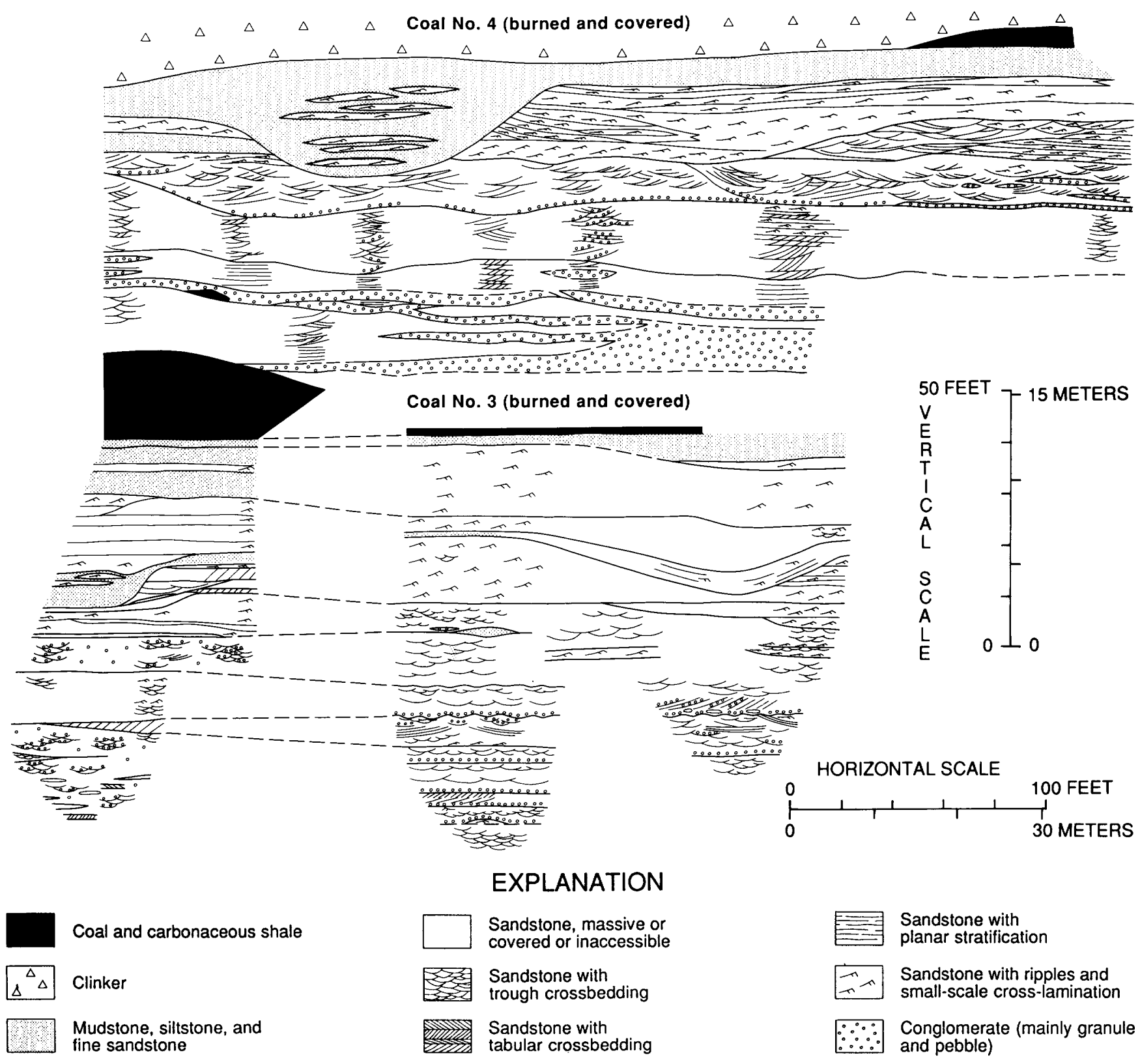

Figure 4. Field drawing of facies architecture type 2, from part of Suntrana Formation at Suntrana. Vertical exaggeration about 2 times. Coal No. 2, not shown, is buried in rubble just below lowest part of drawing. 
Coals occur as interbeds in the overbank mudstones and siltstones and generally are less than $1 \mathrm{~m}$ thick (fig. 5). Coals in this interval are flaky and appear to consist of mats of branches and twigs, unlike the blocky-fracturing, thoroughly macerated coals in facies architecture type 2 (fig. 4). Petrographic data suggest that these thin coals may have formed under slightly drier conditions than did thicker coals in other parts of the Usibelli Group (Merritt, 1985a). In general, coals in the Lignite Creek Formation are much thinner than coals in the Suntrana Formation and also show higher ash contents (Merritt, 1985a). We speculate that suspended-sediment loads were higher during deposition of the Lignite Creek than during deposition of the Healy Creek and Suntrana Formations, and that high detrital influx diluted the organic matter and perhaps even inhibited growth of the peat-forming organisms.

\section{IMPLICATIONS FOR PETROLEUM OCCURRENCE IN THE MIDDLE TANANA BASIN}

Fluvial and lacustrine deposits of the Usibelli Group in the subsurface middle Tanana basin are lithologically similar to those at Suntrana, according to mudlogs and other information from two exploratory wells (fig. 1; Hite and Nakayama, 1980; Grether and Morgan, 1988; Kirschner, 1988). Both the Union Nenana No. 1 and the
ARCO Totek Hills No. 1 were dry holes with reported shows of gas, and both were drilled in areas where the Usibelli Group is relatively thin and shallowly buried (Stanley and others, 1990). However, the deepest part of the middle Tanana basin, which corresponds to a prominent gravity low (fig. 1), has not been tested by drilling and may contain mudstones and coals that have reached temperatures high enough to generate petroleum (Stanley, 1987, 1988; Stanley and others, 1990). If petroleum deposits exist, they may occur in conglomerate and sandstone reservoirs resembling those observed in outcrop at Suntrana and discussed above. Our studies of facies architecture (figs. 3-5) suggest that such reservoirs will be variable in thickness, external geometry, and internal organization. The thickest reservoirs most likely will be in braidedstream deposits resembling type 1 (fig. 3). Sandstone reservoirs like those in types 2 and 3 (figs. 4,5 ) will be relatively thin but intimately associated with mudstones and coals that serve as both source rocks and sealing beds. Although not documented by us in outcrop, we speculate that large, thick bodies of channel sandstone like those in type 3 (fig. 5) may in places be entirely surrounded by mudstone and coal, providing excellent stratigraphic traps for hydrocarbons. Experience suggests, however, that these thick sandstone reservoirs may be internally complex and "compartmentalized" by thin zones of low-permeability rocks such as mudstone and small-scale cross-laminated fine-grained sandstone (Miall, 1988).

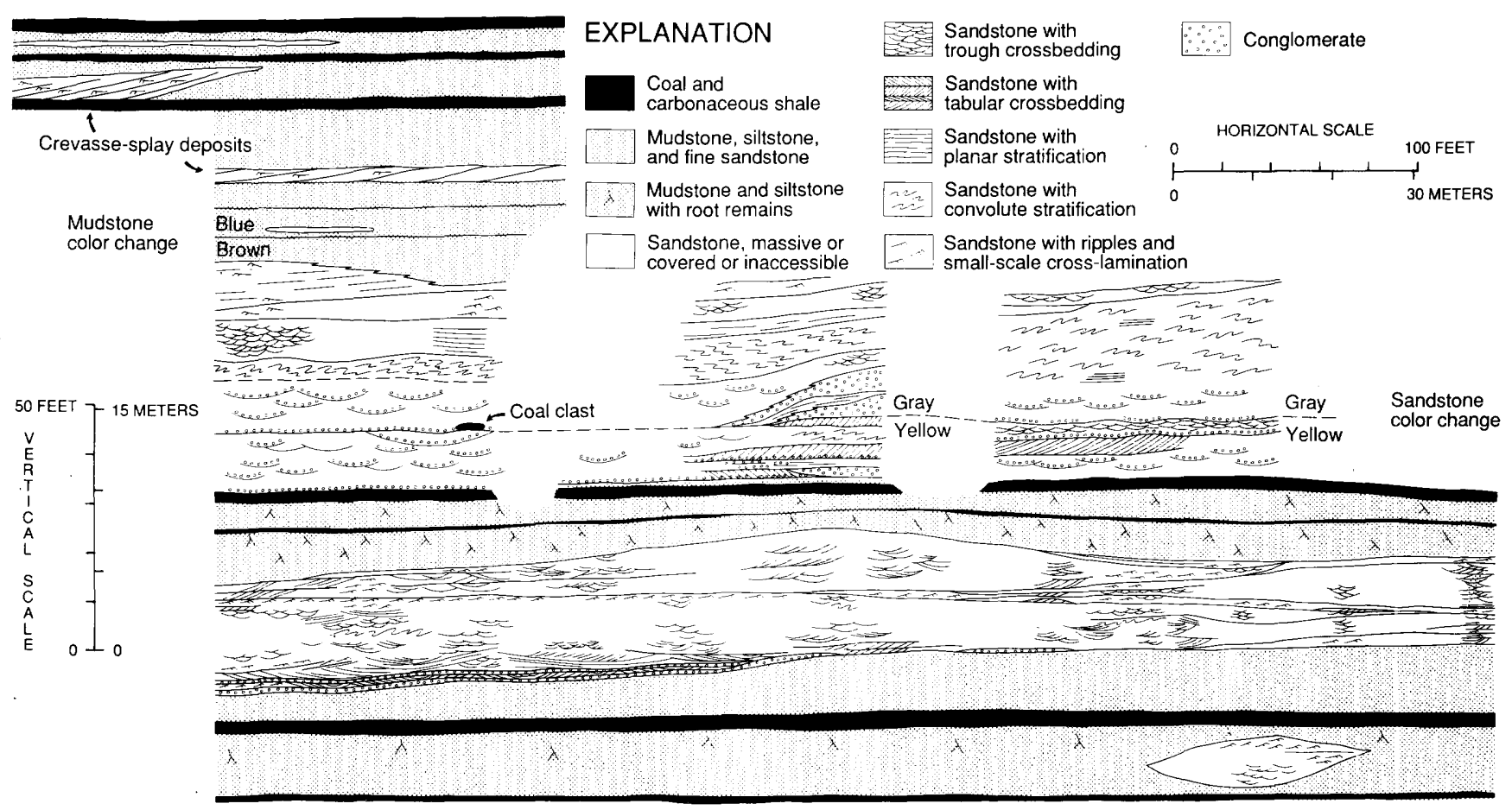

Figure 5. Field drawing of facies architecture type 3, from part of Lignite Creek Formation at Suntrana. Vertical exaggeration about 2 times. 


\section{SUMMARY AND CONCLUSIONS}

Our studies show that at least three different types of fluvial facies architecture, including one example of gravel-rich braided-stream deposits and two examples of coal-bearing fining-upward sequences, can be identified in the Usibelli Group at Suntrana. These contrasting architectural styles probably reflect differences in the sediment loads, flow discharges, gradients, and channel patterns of the rivers that deposited them. The amalgamated, lenticular conglomerates and sandstones of type 1 (fig. 3) were deposited in the shallow channels of gravel-rich, high-energy, braided streams on an alluvial fan or proximal braid plain. In contrast, the conglomerates and sandstones in the fining-upward sequences of types 2 and 3 (figs. 4, 5) probably were deposited in the channels of larger, deeper, trunk rivers carrying mainly sand and mud but lesser amounts of gravel and surrounded by muddy flood-plain areas and coal swamps.

It is important to note that the facies architectural styles described above are not restricted to single formations. Braided-stream deposits resembling type 1 (fig. 3) occur not just in the Healy Creek Formation but also in the lower and middle parts of the Suntrana Formation at Suntrana. Similarly, the upper part of the Healy Creek Formation at Suntrana also includes coal-bearing finingupward sequences like those of type 2 (fig. 4). Finingupward sequences of type 3 (fig. 5) are more-or-less typical of the Lignite Creek Formation.

The fining-upward sequences of type 3 (fig. 5) differ from those of type 2 (fig. 4) in having very thick intervals of flood-plain mudstones and siltstones, welldeveloped crevasse-splay sandstones, and relatively thin coals. These differences suggest that suspended-sediment loads were greater during deposition of the fining-upward sequences of type 3 (fig. 5), but the cause of the higher influx of fines is unknown. The increase in fines occurred at about the same time as a change in provenance, noted above, from quartz-rich conglomerates and sandstones of the Suntrana Formation to more varied conglomerates and arkosic sandstones of the Lignite Creek Formation. Perhaps weathering of chemically less stable igneous and metamorphic rock types in the new source area resulted in more abundant clays, which in turn made the streams muddier than before.

Our studies corroborate previous interpretations suggesting that facies in the Usibelli Group were influenced by both sedimentary and tectonic controls. Finingupward cycles such as types 2 and 3 (figs. 4,5 ) are explainable by abandonment and lateral shifting of high-energy fluvial channels. However, the accumulation of nearly $600 \mathrm{~m}$ of the Usibelli Group during the Miocene at Suntrana implies tectonically controlled subsidence. Furthermore, tectonic uplift in the Yukon-Tanana Upland, which was apparently the source of much of the sediment in the Usibelli Group, may have controlled the style of fluvial sedimentation in addition to controlling sandstone and conglomerate composition and the amount of fine-grained sediment. Braided-stream deposits like those of type 1 (fig. 3) may have been deposited during pulses of uplift and increased stream gradients, whereas fining-upward sequences like those of types 2 and 3 (figs. 4,5 ) may have been deposited during times of tectonic stability. Alternatively, types 1 and 2 may represent the downstream or distal equivalents of the more proximal type 1 deposits.

Our findings confirm previous work indicating that fluvial sediments in the Usibelli Group were deposited by several different types of rivers. The results reported here are preliminary and provide no new information on paleogeography or paleotectonics. However, we believe that systematic evaluation of the regional stratigraphic and geographic distribution of fluvial architectural styles, combined with paleocurrents, will refine our understanding of the paleogeographic and paleotectonic setting of the Usibelli Group. In turn, this will increase knowledge of the distribution of potentially commercial coals and aid in predicting their location. Furthermore, studies of facies architecture may be of use in petroleum exploration in the middle Tanana basin.

\section{REFERENCES CITED}

Ashley, G.M., 1978, Bedforms in the Pitt River, British Columbia, in Miall, A.D., ed., Fluvial sedimentology: Canadian Society of Petroleum Geologists Memoir 5, p. 89104.

Barnes, D.F., 1961, Gravity low at Minto Flats, Alaska: U.S. Geological Survey Professional Paper 424-D, p. D254D257.

Buffler, R.T., and Triplehorn, D.M., 1976, Depositional environments of the Tertiary coal-bearing group, central Alaska, in Miller, T.P., ed., Recent and ancient sedimentary environments in Alaska, Proceedings of the Alaska Geological Society Symposium held April 2-4, 1975, Anchorage: Anchorage, Alaska Geological Society, p. H1H10.

Csejtey, Béla, Jr., Mullen, M.W., Cox, D.P., Gilbert, W.G., Yeend, W.E., Smith, T.E., Wahrhaftig, Clyde, Craddock, Campbell, Brewer, W.M., Sherwood, K.W., Hickman, R.G., Stricker, G.D., St. Aubin, D.R., and Goerz, D.J., III, 1986, Geology and geochronology of the Healy quadrangle, Alaska: U.S. Geological Survey Open-File Report 86-396, 92 p., scale 1:250,000, 4 maps.

Dickson, R.K., 1982, Uranium mineralization in the Nenana coal field, Alaska, in Short notes on Alaskan geology1981: Alaska Division of Geological and Geophysical Surveys Geologic Report 73, p. 37-42.

Ferguson, R.I., and Werritty, A., 1983, Bar development and channel changes in the gravelly River Feshie, Scotland, in Collinson, J.D., and Lewin, J., eds., Modern and ancient 
fluvial systems: International Association of Sedimentologists Special Publication 6, p. 181-193.

Grether, W.J., and Morgan, K.A., 1988, Exploration and hydrocarbon potential of interior basins, Alaska [abs.]: American Association of Petroleum Geologists Bulletin, v. 72, no. 2, p. 191-192.

Hite, D.M., and Nakayama, E.N., 1980, Present and potential petroleum basins of Alaska, in Landwehr, M.L., ed., Exploration and economics of the petroleum industry: New ideas, new methods, new developments: Dallas, Texas, Institute on Petroleum Exploration and Economics, p. 511554.

Jones, D.L., Silberling, N.J., Coney, P.J., and Plafker, George, 1987, Lithotectonic terrane map of Alaska (west of the 141st meridian): U.S. Geological Survey Miscellaneous Field Studies Map MF-1874-A, scale 1:2,500,000, 1 sheet.

Kirschner, C.E., 1988, Map showing sedimentary basins of onshore and continental shelf areas, Alaska: U.S. Geological Survey Miscellaneous Investigations Map I-1873, scale 1: $5,000,000$.

Levey, R.A., 1978, Bed-form distribution and internal stratification of coarse-grained point bars, upper Congaree River, South Carolina, in Miall, A.D., ed., Fluvial sedimentology: Canadian Society of Petroleum Geologists Memoir 5, p. 105-127.

Merritt, R.D., 1985a, Field trip guidebook: Lignite Creek and Healy Creek coal fields, Nenana basin, Alaska: American Association of Petroleum Geologists Annual Meeting, $\mathrm{Pa}$ cific Section, 60th, Anchorage, Alaska, 1985, Guidebook, $58 \mathrm{p}$.

-1985b, Coal atlas of the Nenana basin, Alaska: Alaska Division of Geological and Geophysical Surveys PublicData File 85-41, 197 p.

Merritt, R.D., and Hawley, C.C., 1986, Map of Alaska's coal resources: Fairbanks, Alaska Division of Mining and Geological and Geophysical Surveys Special Report 37, scale $1: 2,500,000$.

Miall, A.D., 1977, A review of the braided-river depositional environment: Earth-Science Reviews, v. 13, p. 1-62.

1978, Lithofacies types and vertical profile models in braided river deposits: a summary, in Miall, A.D., ed., Fluvial sedimentology: Canadian Society of Petroleum Geologists Memoir 5, p. 597-604.

-1985, Architectural-element analysis: a new method of facies analysis applied to fluvial deposits: Earth-Science Reviews, v. 22, p. 261-308.

-1988, Reservoir heterogeneities in fluvial sandstones: lessons from outcrop studies: American Association of Petroleum Geologists Bulletin, v. 72, no. 6, p. 682-697.

Miller, D.J., Payne, T.G., and Gryc, George, 1959, Geology of possible petroleum provinces in Alaska: U.S. Geological Survey Bulletin 1094, 131 p.

Rust, B.R., 1972, Structure and process in a braided river: Sedimentology, v. 18, p. 221-245.

Selleck, B.W., and Panuska, Bruce, 1983, Sedimentological models for the coal-bearing group (Oligocene-Miocene), central Alaska Range [abs.]: Geological Society of America Abstracts With Programs, v. 15, no. 6, p. 683.

Stanley, R.G., 1987, Effects of weathering on petroleum-source evaluation of coals from the Suntrana Formation near Healy, Alaska, in Hamilton, T.D., and Galloway, J.P., eds., Geologic studies in Alaska by the U.S. Geological Survey during 1986: U.S. Geological Survey Circular 998, p. $99-103$.

-1988, Hydrocarbon source potential and thermal maturity of the Sanctuary Formation (middle Miocene), northern foothills of the Alaska Range, in Galloway, J.P., and Hamilton, T.D., eds., Geologic studies in Alaska during 1987: U.S. Geological Survey Circular 1016, p 117-120.

Stanley, R.G., Flores, R.M., and Wiley, T.J., 1989, Contrasting depositional environments in Tertiary fluvial deposits of Nenana coal field, Alaska [abs.]: American Association of Petroleum Geologists Bulletin, v. 73, no. 3, p. 415.

Stanley, R.G., McLean, Hugh, and Pawlewicz, M.J., 1990, Petroleum source potential and thermal maturity of the Tertiary Usibelli Group of Suntrana, Alaska, in Dover, J.H., and Galloway, J.P., eds., Geologic studies in Alaska by the U.S. Geological Survey, 1989: U.S. Geological Survey Bulletin 1946, p. 65-76.

Stevens, C.C., 1971, A provenance study of the Tertiary sandstones in the Healy Creek and Lignite Creek coal basins, Nenana coal field, Alaska: College, Alaska, University of Alaska, M.S. thesis, 122 p.

Valin, Z.C., Bader, J.W., Barnes, D.F., Fisher, M.A., and Stanley, R.G., 1991, Simple Bouguer gravity anomaly maps of the Nenana basin area, Alaska: U.S. Geological Survey Open-File Report 91-33, 4 sheets at scale $1: 250,000,1$ sheet at scale 1:500,000.

Wahrhaftig, Clyde, 1968, Schists of the central Alaska Range: U.S. Geological Survey Bulletin 1254-E, 22 p.

1970, Geologic map of the Healy D-4 quadrangle, Alaska: U.S. Geological Survey Geologic Quadrangle Map GQ-806, scale 1:63,360.

1987, The Cenozoic section at Suntrana, Alaska, in Hill, M.L., ed., Geological Society of America, Cordilleran Section, Centennial Guide, v. 1, p. 445-450.

Wahrhaftig, Clyde, Wolfe, J.A., Leopold, E.B., and Lanphere, M.A., 1969, The coal-bearing group in the Nenana coal field, Alaska: U.S. Geological Survey Bulletin 1274-D, $30 \mathrm{p}$.

Walker, R.G., and Cant, D.J., 1984, Sandy fluvial systems, in Walker, R.G., ed., Facies models (2d ed.): Toronto, Ontario, Geological Association of Canada Reprint Series 1, p. 71-89.

Wolfe, J.A., and Tanai, T., 1980, The Miocene Seldovia Point flora from the Kenai Group, Alaska: U.S. Geological Survey Professional Paper 1105, 52 p.

Reviewers: Hugh McLean and Larry Phillips 


\title{
GEOLOGIC NOTES
}

\section{A Postulated New Source for the White River Ash, Alaska}

\author{
By Robert G. McGimsey, Donald H. Richter, Gregory D. DuBois, and Thomas P. Miller
}

The White River Ash (Lerbekmo and others, 1968), product of two of the most voluminous pyroclastic eruptions in North America in the past 2,000 yr, blankets much of the Yukon Territory, Canada, and a small part of adjoining eastern Alaska. Lerbekmo and Campbell (1969) narrowed the source of the ash to an area northeast of the Mt. Bona-Mt. Churchill massif in the St. Elias Mountains of southern Alaska. Based on indirect evidence, Lerbekmo and Campbell (1969) further suggested that the vent was beneath the Klutlan Glacier, adjacent to a mound of coarse pumice, $16 \mathrm{~km}$ northeast of Mt. Bona. Recently discovered pumice and ash deposits and a possible vent structure near the summit of Mt. Churchill suggest an alternate source area.

The White River Ash is a bilobate plinian fallout deposit covering more than $340,000 \mathrm{~km}^{2}$ and containing an estimated $25-50 \mathrm{~km}^{3}$ of tephra (Bostock, 1952; Berger, 1960; fig. 1). Radiocarbon ages indicate that the northern lobe was deposited about 1,887 yr B.P. and the eastern, and larger, lobe about 1,250 yr B.P. (Lerbekmo and others, 1975). The axes of the two lobes converge near Mt. Bona [16,420 ft $(5,005 \mathrm{~m})]$ and Mt. Churchill

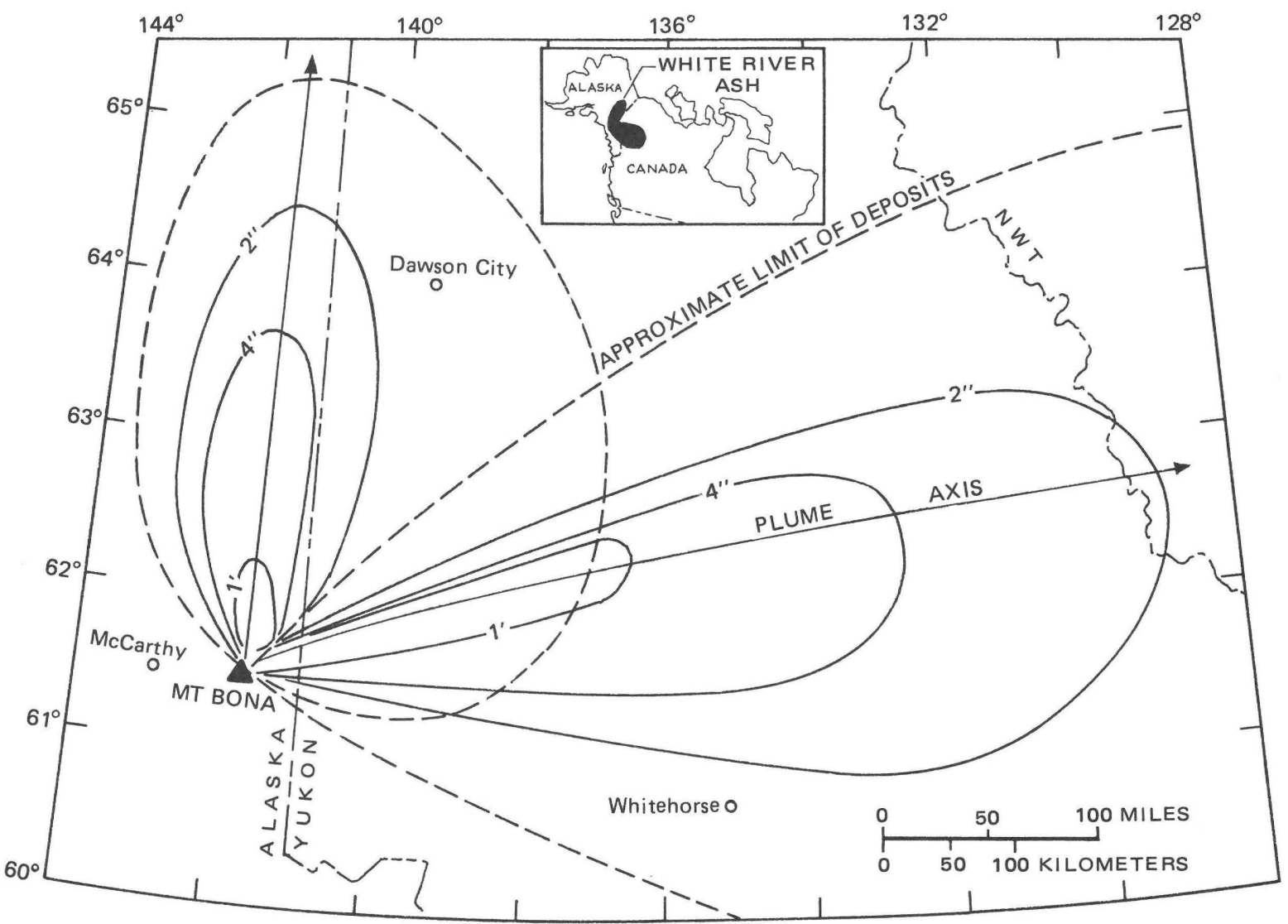

Figure 1. Isopach map of White River Ash (Lerbekmo and others, 1968) in Yukon Territory, Canada, and Alaska. Isopachs shown for $1 \mathrm{ft}, 4 \mathrm{in} .$, and 2 in. Axes of the two tephra lobes converge on area near Mt. Bona, Alaska. Modified from Lerbekmo and others (1975). 
[15,638 $\mathrm{ft}(4,766 \mathrm{~m})]$, which together form a prominent massif in the St. Elias Mountains. The Klutlan Glacier, a large valley glacier that flows eastward into Canada, has its principal source on the eastern flank of the massif.

Careful field studies by Lerbekmo and Campbell (1969) in search of the source of the White River Ash led to the discovery of a 90-m-high mound of White River pumice adjacent to the Klutlan Glacier at an elevation of about $8,000 \mathrm{ft}(2,438 \mathrm{~m})$ (fig. 2). Some of the pumice clasts are as much as $50 \mathrm{~cm}$ in diameter, but the modal size is less than $10 \mathrm{~cm}$. Based on interpretation of the mound as a remnant pumice cone and a change in gradient of the glacier adjacent to the mound, Lerbekmo and Campbell (1969) concluded that the source vent of the White River Ash lies under the Klutlan Glacier, near the pumice mound, at about the 7,700 $\mathrm{ft}(2,347 \mathrm{~m})$ level (fig. 2).

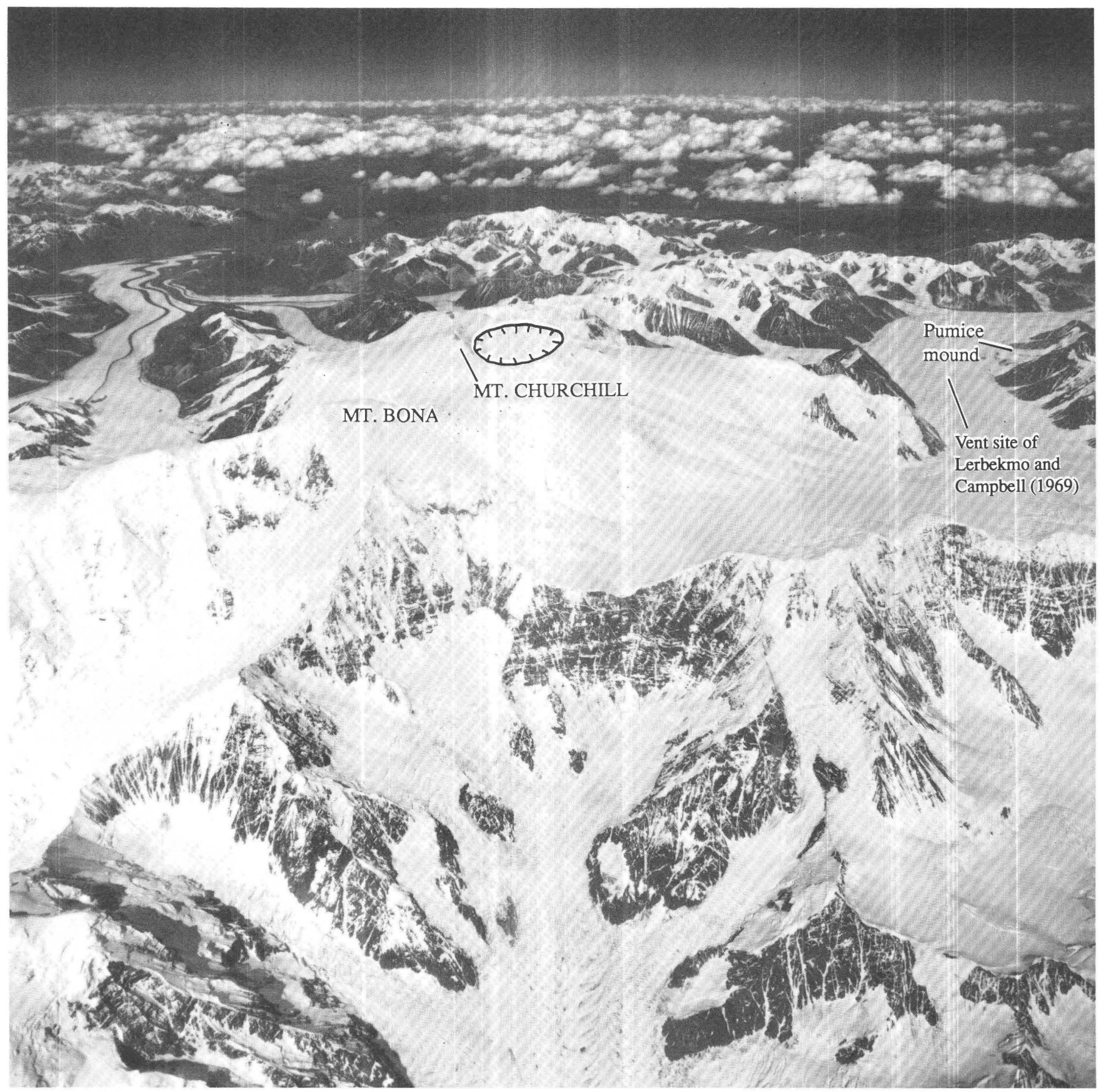

Figure 2. Oblique aerial photograph of Mt. Bona-Mt. Churchill area, view to the northwest, showing location of postulated caldera and source of White River Ash (Lerbekmo and others, 1968) on Mt. Churchill, and the pumice mound of Lerbekmo and Campbell (1969) adjacent to Klutlan Glacier. U.S. Army-Air Force trimetrogon oblique photograph, June $16,1948$. 
Aerial photographs and the modern topographic maps of the Mt. Bona-Mt. Churchill massif suggest an alternate source area $12 \mathrm{~km}$ southwest of the pumice mound. A $4.2 \mathrm{~km} \times 2.7 \mathrm{~km}$ elliptical, gently sloping, ice-filled depression is located at about $14,500 \mathrm{ft}(4,420$ $\mathrm{m}$ ) on the east side of Mt. Churchill (fig. 3). The high point of Mt. Churchill $[15,638 \mathrm{ft}(4,766 \mathrm{~m})]$ forms the western margin of the depression, and a lower curved ridge forms most of the southeastern rim. Maximum relief from the floor of the depression to the highest point (Mt. Churchill) on its rim is over $300 \mathrm{~m}$. The topographic map and aerial photographs show that ice not only fills the summit depression, but also covers almost the entire summit region of the massif. An apparent excep- tion was a very small ice-free area, less than $400 \mathrm{~m}$ long, on the southeastern rim of the depression.

In May 1990, a U.S. Geological Survey field party ascended Mt. Churchill from the Klutlan Glacier to search for rock exposures in an attempt to ascertain the nature of the ice-filled depression. The four-member field party was landed by ski plane at the $8,200-\mathrm{ft}$ level $(2,500 \mathrm{~m})$ of the Klutlan Glacier, where base camp was established. Gear and supplies were ferried to camps placed at $10,000 \mathrm{ft}$ $(3,048 \mathrm{~m})$ and $12,500 \mathrm{ft}(3,810 \mathrm{~m})$ on the east flank of Mt. Churchill. From the high camp, the party climbed to the large depression adjacent to the summit of Mt. Churchill.

Five areas of bedrock, extending over a length of about $2.4 \mathrm{~km}$, were discovered along the southeastern

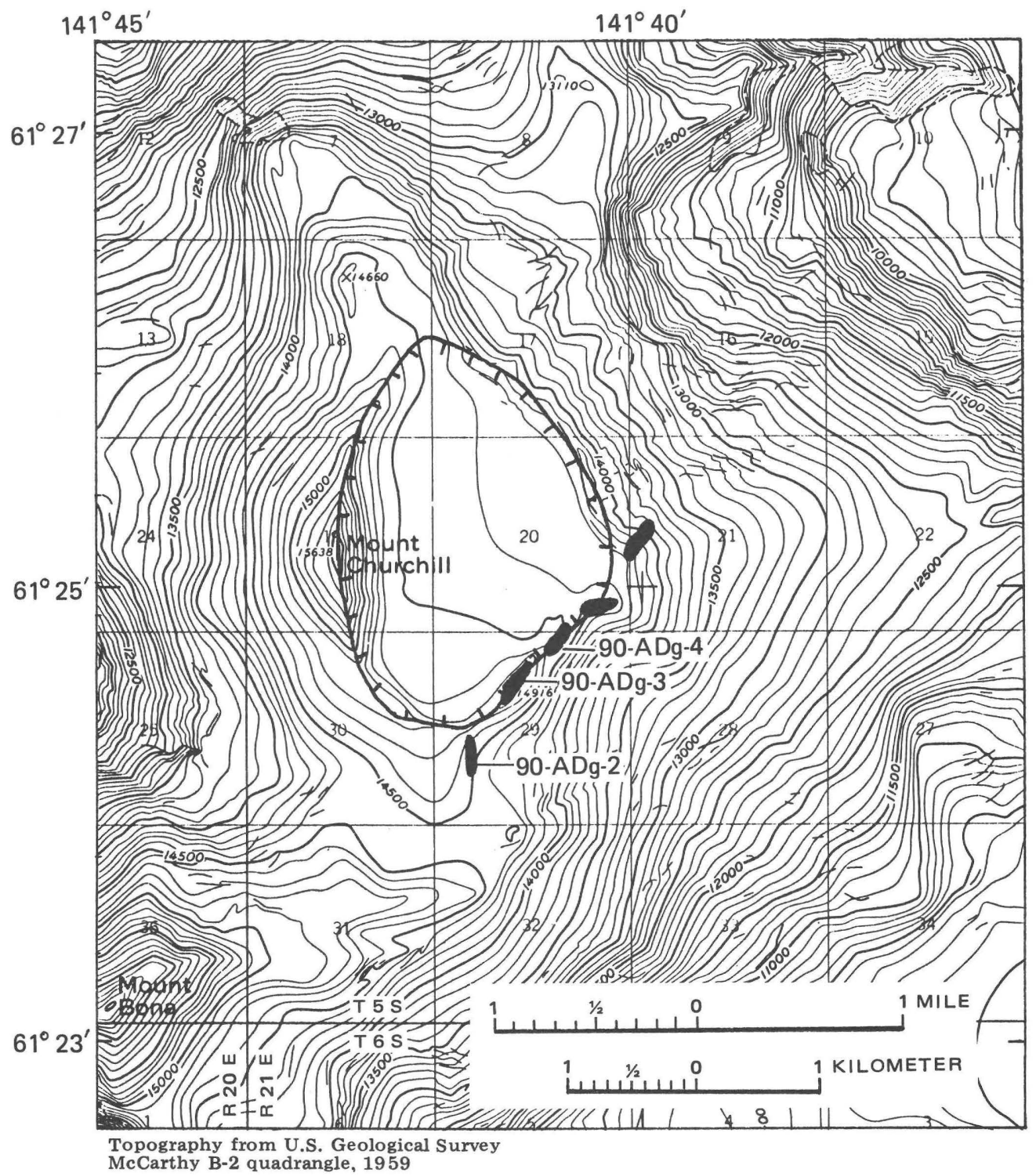

Figure 3. Topographic map of Mt. Churchill showing postulated caldera, outcrops examined (black), and locations of samples. From the U.S. Geological Survey McCarthy B-2 topographic map. 
rim of the depression (figs. 3, 4). The exposures are predominantly of pumice, ranging from lapilli to blocks as much as $50 \mathrm{~cm}$ in diameter, but also contain similarsized clasts of granite, andesitic lava, and crystal-rich felsic lava (figs. 5, 6). At one locality, a flow-banded dacite flow or dome is exposed through a cover of pumice and lithic clasts. Hydrothermally altered, yellow-orange clasts of pumice and lithic fragments are scattered throughout the tephra deposits. Underlying the surface accumulation of loose pumice is an ash-and-pumice zone consisting of pumice disseminated in an ash matrix. The ash was solidly frozen $15 \mathrm{~cm}$ below the surface. The absence of ash at the surface most likely is the result of eolian winnowing of the exposed ridge. During the ascent, pumice up to $15 \mathrm{~cm}$ in diameter was observed lying on top of the snow surface on gentle slopes $300 \mathrm{~m}$ below the ridge crest, apparently transported by high winds.

Although the Mt. Churchill pumice and the White River Ash pumice are megascopically similar, the available samples do show some differences in chemistry and mineralogy (table 1). All the pumices and associated volcanic rocks are calc-alkaline dacites. The Mt. Churchill samples (including the flow or dome) contain 64.1 to 67.0 percent $\mathrm{SiO}_{2}$, whereas White River Ash pumice, from the mound on the Klutlan Glacier, contains 69.2 percent $\mathrm{SiO}_{2}$. However, 66 analyzed samples of White River Ash (Lerbekmo and Campbell, 1969) indicate an average $\mathrm{SiO}_{2}$ content of 67.4 percent, almost identical to the silica content of the Mt. Churchill pumice. In addition, the Mt. Churchill pumice contains minor biotite, a mineral phase that has not been reported from the White River Ash. If the Mt. Churchill and White River Ash pumices are products of the same eruption(s), these chemical and mineralogical differences may be due to an inadequate sample base, or an intrinsic inhomogeneity in the magma chamber (Downes, 1985), or both.

We believe that the ice-filled depression on Mt. Churchill is a small caldera and the source of the White River Ash. The abundance and size of the pumice together with the presence of large angular lithic blocks strongly suggest that the Churchill deposits are of near-

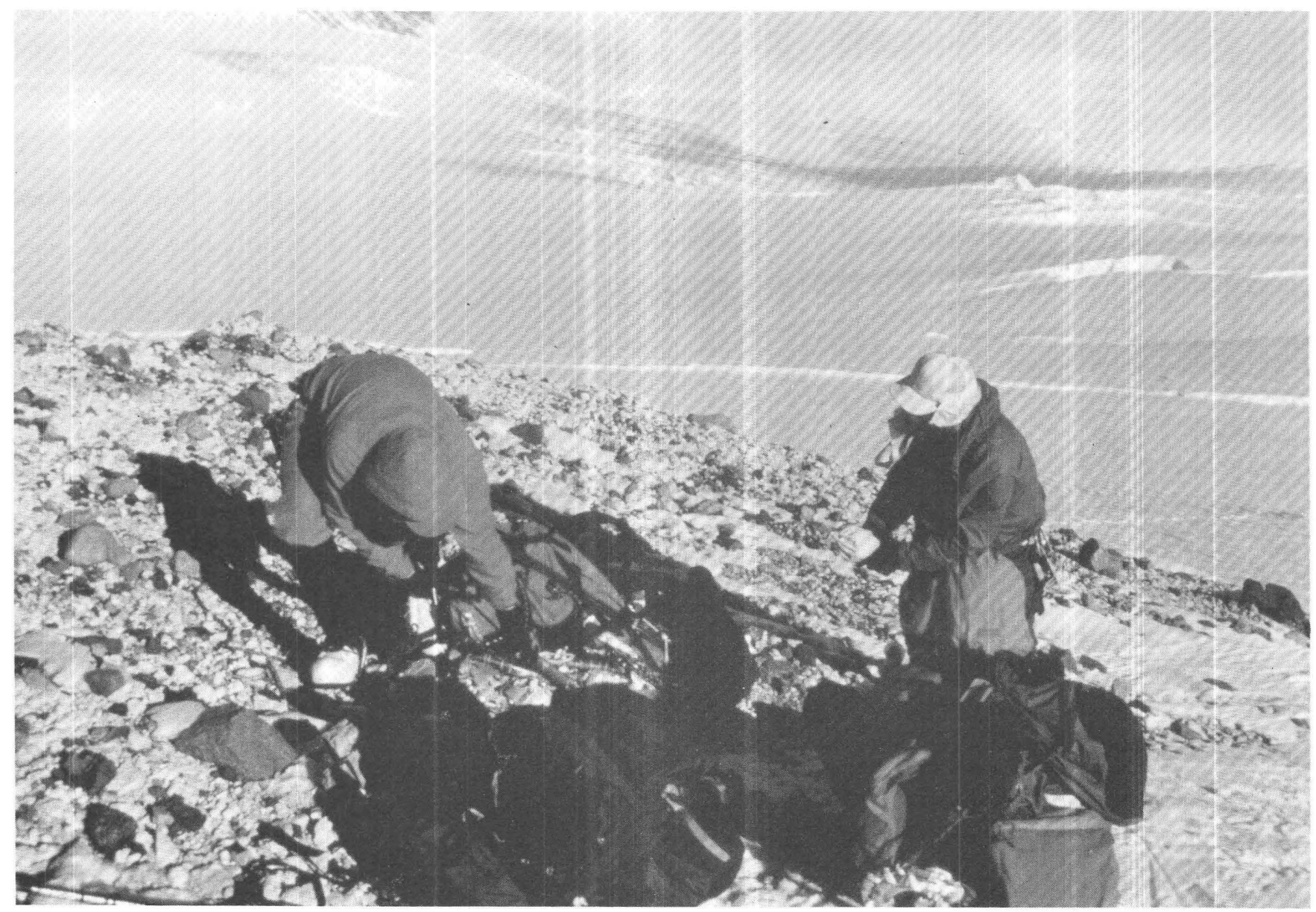

Figure 4. Outcrop of pumice and lithic blocks on southeast rim of postulated caldera on Mt. Churchill. View toward the east. Photograph by Tom Brigham. 


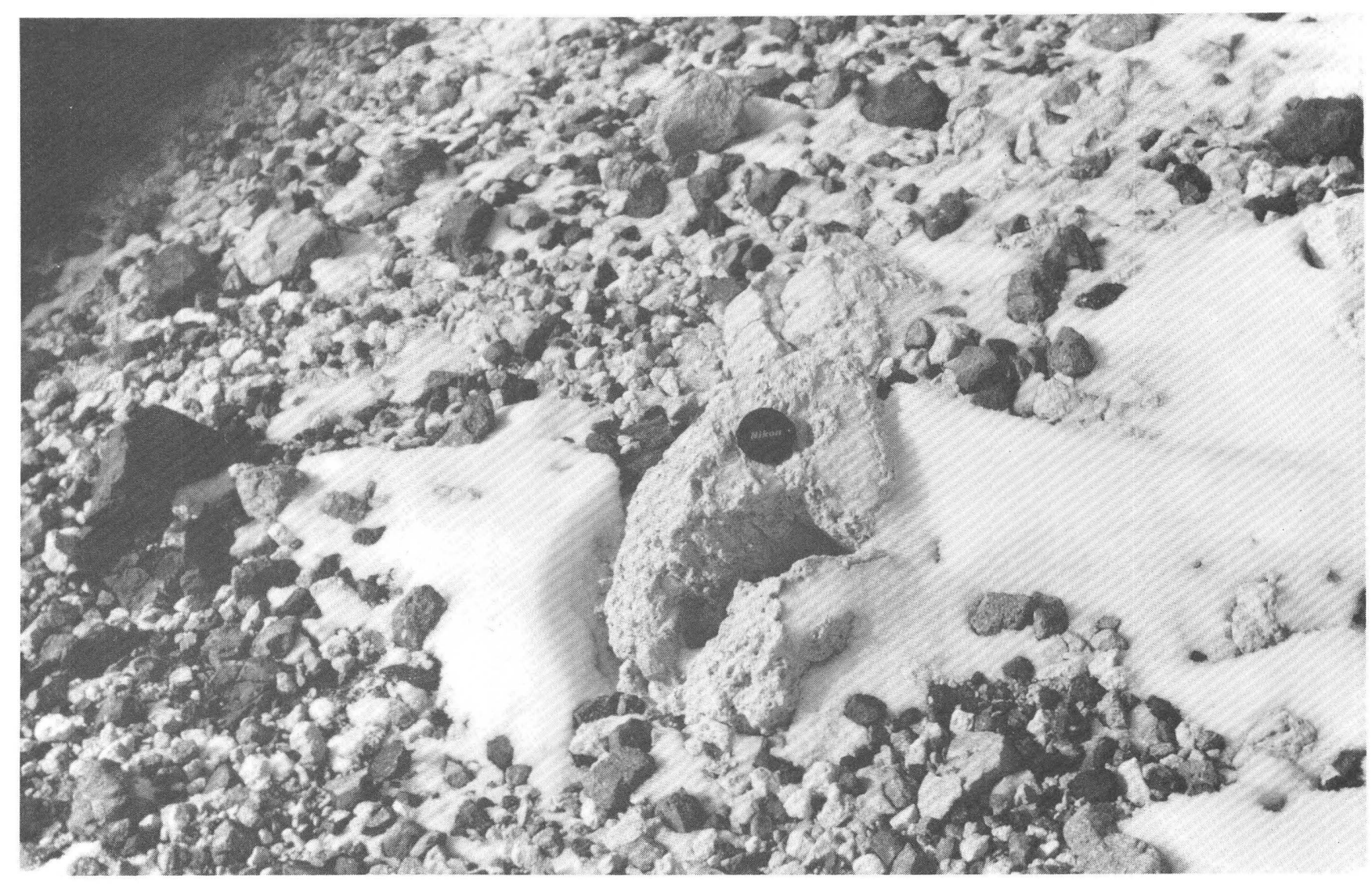

Figure 5. Large dacite pumice block along ridge at $14,700 \mathrm{ft}(4,480 \mathrm{~m})$. Dark angular clasts and blocks are lithic fragments. Camera lens cap, $6 \mathrm{~cm}$ in diameter.

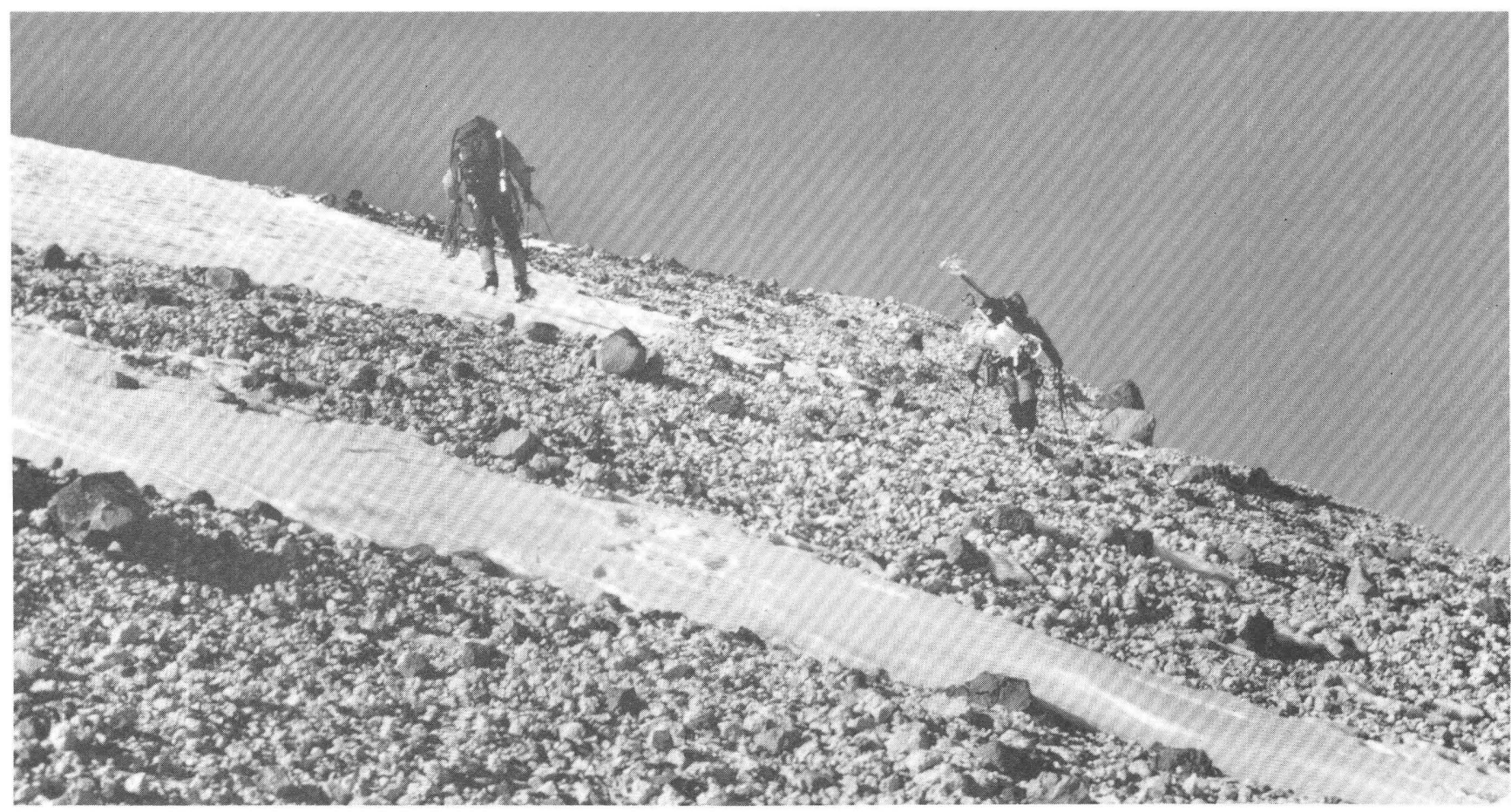

Figure 6. Pumice and lithic lapilli and blocks on southeast rim of depression adjacent to Mt. Churchill. Note large lithic blocks (as large as $50 \mathrm{~cm}$ in diameter) on skyline and center foreground. View toward the north. 
Table 1. Chemical and modal analyses, in weight percent, of White River Ash and Mt. Churchill volcanic rocks

[Analyses of samples 2, 3, and 4 by U.S. Geological Survey X-ray spectroscopy (analysts D.F. Siems and J.E. Taggart) and rapid-rock methods $\left(\mathrm{Fe}_{2} \mathrm{H}_{2} \mathrm{O}^{+}, \mathrm{H}_{2} \mathrm{O}, \mathrm{CO}_{2}\right.$ ) (analyst S.T. Pribble)]

\begin{tabular}{|c|c|c|c|c|c|}
\hline & \multicolumn{5}{|c|}{ Sample (see footnotes for descriptions) } \\
\hline & 1 & 2 & 3 & 4 & 5 \\
\hline $\mathrm{SiO}_{2}$ & 67.4 & 66.1 & 62.9 & 64.9 & 68.1 \\
\hline $\mathrm{Al}_{2} \mathrm{O}_{3}$ & 15.1 & 16.2 & 19.2 & 16.4 & 15.4 \\
\hline $\mathrm{Fe}_{\mathrm{T}} \mathrm{O}_{3} \ldots$ & & 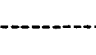 & 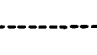 & 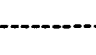 & 2.89 \\
\hline $\mathrm{Fe}_{2} \mathrm{O}_{3}$ & 2.2 & 1.55 & 1.71 & 3.4 & -- \\
\hline $\mathrm{FeO}$ & 2.0 & 1.40 & 1.48 & .27 & -- \\
\hline MgO-- & 2.0 & 1.36 & 1.51 & 1.70 & 1.16 \\
\hline $\mathrm{CaO}$ & 4.1 & 4.18 & 4.39 & 4.78 & 3.36 \\
\hline $\mathrm{Na}_{2} \mathrm{O}$ & 4.1 & 4.16 & 4.04 & 4.36 & 4.23 \\
\hline $\mathrm{K}_{2} \mathrm{O}$ & 2.5 & 2.51 & 2.25 & 2.10 & 2.68 \\
\hline $\mathrm{H}_{2} \mathrm{O}^{+} \ldots$ & -- & .49 & .52 & .02 & -- \\
\hline $\mathrm{H}_{2} \mathrm{O}^{-}$ & - & .13 & .13 & .03 & -- \\
\hline $\mathrm{TiO}_{2}$ & .5 & .42 & .48 & .57 & .37 \\
\hline $\mathrm{P}_{2} \mathrm{O}_{5} \ldots$ & -- & .14 & .13 & .22 & .14 \\
\hline 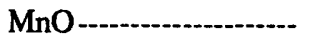 & -- & .05 & .05 & .05 & .05 \\
\hline $\mathrm{CO}_{2}$ & -- & .04 & .05 & .02 & -- \\
\hline \multicolumn{6}{|c|}{$\operatorname{LOI}\left(925^{\circ} \mathrm{C}\right)$} \\
\hline 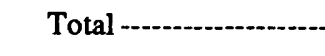 & -.-.-. & 98.73 & 98.76 & 98.84 & 99.44 \\
\hline \multirow[t]{2}{*}{$\begin{array}{l}\mathrm{SiO}_{2} \text { normalized } \\
\text { volatile-free }\end{array}$} & & 67.0 & 65.8 & 64.1 & 69.2 \\
\hline & & \multicolumn{3}{|c|}{ Modes (volume percent) } & \\
\hline Plagioclase -..-- & -..---. & 9.1 & -- & 25.1 & 8.2 \\
\hline Hornblende - & -...-... & 2.9 & -- & 4.6 & 2.7 \\
\hline Biotite --.......... & & 1.2 & - & 0 & 0 \\
\hline Clinopyroxene -..-..- & & 0 & -- & 1.2 & 0 \\
\hline Orthopyroxene & & 0 & - & .6 & 0 \\
\hline 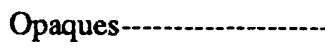 & & .4 & -- & .4 & .6 \\
\hline Groundmass & - & 86.4 & -- & 68.1 & 88.5 \\
\hline
\end{tabular}

1. Mean chemical composition of 66 whole-ash samples of White River Ash (Lerbekmo and Campbell, 1969)

2. Dacite pumice lapillus, Mt. Churchill.Sample $90-\mathrm{ADg}_{\mathrm{g}}-2$

3. Dacite ash, Mt. Churchill.Sample $90-\mathrm{ADg}-4$

4. Flow-banded dacite, Mt. Churchill. Sample 90-ADg-3

5. Dacite pumice, White River Ash, Klutlan Glacier.Sample 84-ARh-66 
vent origin. If the Churchill deposits are the White River Ash, as this preliminary evidence suggests, it is untenable to consider that the Churchill deposits may have come from a vent $12 \mathrm{~km}$ to the east and $2,135 \mathrm{~m}$ lower, near the pumice mound along the Klutlan Glacier. Moreover, the pumice mound contains no lithic debris or hydrothermally altered pumice that would likely occur on a cone proximal to a vent. The flat-floored depression on Mt. Churchill, on whose rim the volcanic deposits are located, is a striking feature viewed at ground level and easily discernible on the oblique photograph (fig. 2). It has neither the morphology nor the location of a typical glacial cirque, but it does have a form suggestive of a caldera. The pumice mound alongside the Klutlan Glacier can be reasonably accounted for by glacier transport, debris avalanche, or pumice flow.

Acknowledgments.-Climbers Tom Brigham and John Kress, serving as U.S. Geological Survey volunteers, ably assisted with the technical aspects of the ascent. Ken Bunch of Gulkana Air Service transported the field party to and from base camp on the Klutlan Glacier. Wrangell-St. Elias National Park personnel provided an overflight to check on the party's progress and safety.

\section{REFERENCES CITED}

Berger, A.R., 1960, On a recent volcanic ash deposit, Yukon Territory: Proceedings of the Geological Association of Canada, v. 12, p. 117-118.

Bostock, H.S., 1952, Geology of the northwest Shakwak Valley, Yukon Territory: Geological Survey of Canada Memoir $267,54 \mathrm{p}$.

Downes, Hilary, 1985, Evidence for magma heterogeneity in the White River Ash (Yukon Territory): Canadian Journal of Earth Science, v. 22, p. 929-934.

Lerbekmo, J.F., and Campbell, F.A., 1969, Distribution, composition, and source of the White River Ash, Yukon Territory: Canadian Journal of Earth Sciences, v. 6, p. 109116.

Lerbekmo, J.F., Hanson, L.W., and Campbell, F.A., 1968, Application of particle size distribution to determination of source of a volcanic ash deposit: International Geological Congress, 23rd, Prague, Proceedings, sec. 2, p. 283-295.

Lerbekmo, J.F., Westgate, J.A., Smith, D.G.W., and Denton, G.H., 1975, New data on the character and history of the White River volcanic eruption, Alaska, in Suggate, R.P. and Cresswell, M.M., eds., Quaternary studies: Wellington, Royal Society of New Zealand, p. 203-209.

Reviewers: Steven W. Nelson and James R. Riehle 


\title{
Preliminary Interpretation of Vegetation and Paleoclimate in Northern Alaska during the Late Pliocene Colvillian Marine Transgression
}

\author{
By Robert E. Nelson and L. David Carter
}

The informally named Colvillian marine transgression is the oldest of the presently recognized eustatic high-sea-level events in northern Alaska that have occurred since the opening of the Bering Strait shortly before 3.0 Ma (Carter and others, 1986a; Dinter and others, 1990; Brigham-Grette and Carter, in press). A minimum age for the Colvillian transgression is provided by the next younger high-sea-level event, the informally named Bigbendian transgression, which is now dated at 2.48 Ma (Carter and Hillhouse, 1991). The Colvillian transgression thus occurred after climatic cooling initiated late Cenozoic glaciation at about 3.1 Ma and before the first major glaciation of the Northern Hemisphere at about 2.4 Ma (Raymo and others, 1989). Information about the vegetation and climate of the Arctic Ocean borderland during this period of transition is important for understanding global climatic cooling and the evolution of the modern Arctic environment. This paper presents pollen analyses of Colvillian sediment that suggest that North Slope vegetation during this high-sea-level event was open boreal forest or spruce-birch woodland with scattered pine and rare fir and hemlock. Climate during the Colvillian transgression was evidently much warmer than the present climate, which is too cold for the growth of trees, and possibly slightly warmer than during the succeeding Bigbendian transgression, which was characterized by an absence of sea ice and probably also permafrost (Carter and others, 1986b; Repenning and others, 1987).

Deposits of the Colvillian transgression are assigned to the Gubik Formation (Dinter and others, 1990), which is well exposed in bluffs along the lower Colville River and its tributaries (fig. 1). At the sites discussed here, Colvillian gravelly sand 2 to $2.5 \mathrm{~m}$ thick, including a few finer grained interbeds, unconformably overlies Cretaceous sandstone of the Prince Creek Formation (Brosgé and Whittington, 1966). At site 1 (fig. 2), Colvillian strata are overlain by sandy, pebbly silt of the younger Bigbendian transgression and are clearly differentiated from the younger sediment by the lithologic contrast and the extent of amino-acid diagenesis in fossil mollusks. The amount of diagenesis is expressed as the quotient D-alloisoleucine/L-isoleucine (aIle/Ile), which is a function of the time elapsed and the ground-temperature history since the death of the mollusk (Brigham, 1985; Miller and Brigham-Grette, 1989). Colvillian beds at site 2 (fig. 2) are overlain by undated fluvial sediment and are correlated with the Colvillian beds at site 1 because measurements of alle/lle at the two sites are statistically indistinguishable.

Five samples of Colvillian sediment were taken for pollen analysis (fig. 2). Four of the samples were from thin strata of silty fine-grained sand and the fifth was from clayey fine-grained sand. Pollen was extracted following standard procedures: utilizing 5 percent $\mathrm{KOH}, 10$ percent $\mathrm{HCl}$ followed by prolonged digestion in 48 percent HF, acetolysis for 5 minutes, and screening with a $10-\mu \mathrm{m}$ mesh to remove fine debris. Residues were mounted in silicone oil and counted at a magnification of $400 \times$. At least 300 identifiable grains were counted in each sample; Moriya (1976) and a modern reference col-

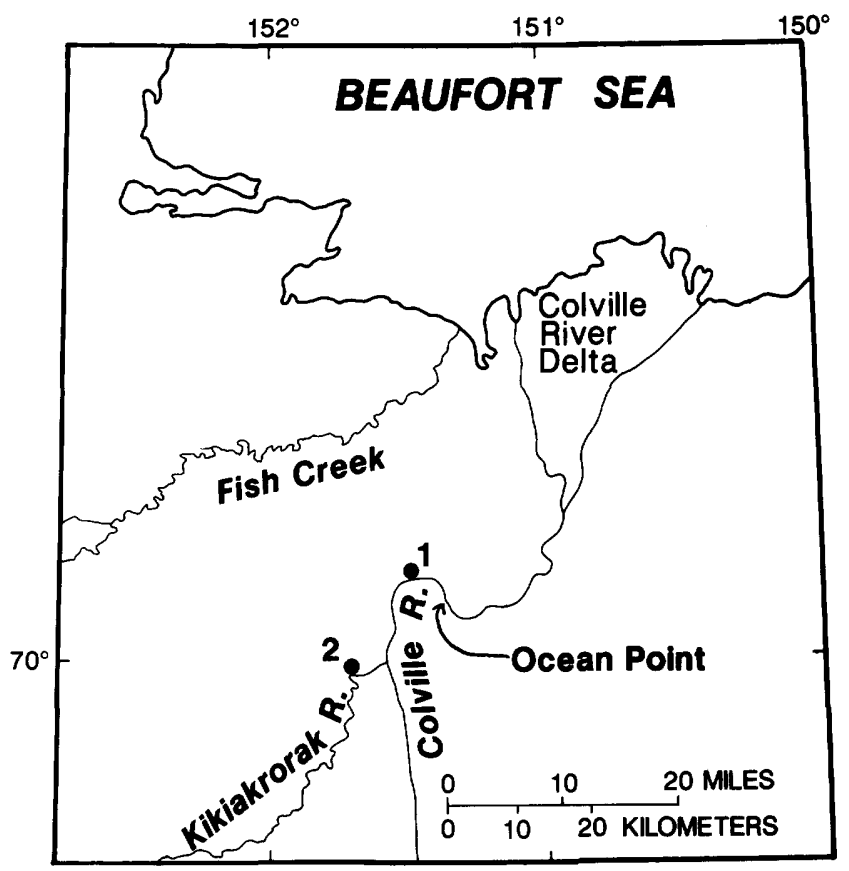

Figure 1. Location of sites discussed in text. 
lection of nearly 400 pollen types were used as guides for unknown grains. Partial grains were excluded from the counts, as were grains too degraded, crumpled, or obscured to be identifiable. Pollen and spore percentages were calculated based on the total number of identifiable Neogene pollen grains.

Spruce (Picea) pollen ranges from 13.9 to 33.8 percent (table 1), and birch (Betula), codominant with spruce, ranges from 27.4 to 36.0 percent. Pine (Pinus) is negligible ( $<2.5$ percent) in two samples, but between 8.5 and 10.2 percent in the other three. Alder (Alnus) exceeds 10 percent in only one sample. Pollen of cottonwood or aspen (Populus) and willow (Salix) is present in nearly all samples, although their relative abundance is no more than 2.5 percent each. Pollen grains of fir (Abies) and hemlock (Tsuga) are each present in three of the five samples. Rare grains of hazel (Corylus) in three of the five samples and a single grain of hickory (Carya) are enigmatic, because these taxa are unexpected in the absence of other hardwoods such as walnut (Juglans), and their presence is inconsistent with the remainder of the flora. However, hazel was also reported in the absence of other deciduous hardwoods in the Lava Camp flora that is thought to be late Miocene (Hopkins and others, 1971).

Grass (Poaceae) and sedge (Cyperaceae) are the only individual herb taxa of quantitative significance, accounting for 8.5 to 24.7 percent of the pollen total com- bined. The spore flora is varied and includes representatives of both vascular (ferns and clubmosses) and nonvascular (Sphagnum) plants.

These Colvillian pollen spectra suggest that nearby vegetation was open boreal forest or spruce-birch woodland with scattered pine, and with rare fir and hemlock. Heaths and perhaps shrub and dwarf birch dominated the understory vegetation, although grass and sedge were locally common. Other herbaceous taxa were only sporadically represented. Clubmosses (Lycopodium spp.) were also common on the landscape, as were ferns producing both trilete and monolete spores.

Local substrates were moist, as evidenced by significant levels of Sphagnum spores in all samples. Four of the five samples also contained distinctive spores of Selaginella selaginoides, which is found on "[d]amp mossy ground and open damp woods" (Hultén, 1968, p. 31), and whose modern distribution is almost exclusively within the boreal-forest region (Hultén, 1968; Welsh, 1974).

Alders are a minor element in the Colvillian pollen floras, and virtually all grains show weak arc development, suggesting that these were shrub alders (Alnaster) rather than arboreal forms. These may have been restricted to slopes or stream margins, but apparently they were not abundant in the vegetation. Willows and cottonwood/aspen are typically underrepresented in modern pollen rain (Faegri and Iversen, 1975) and were probably much more
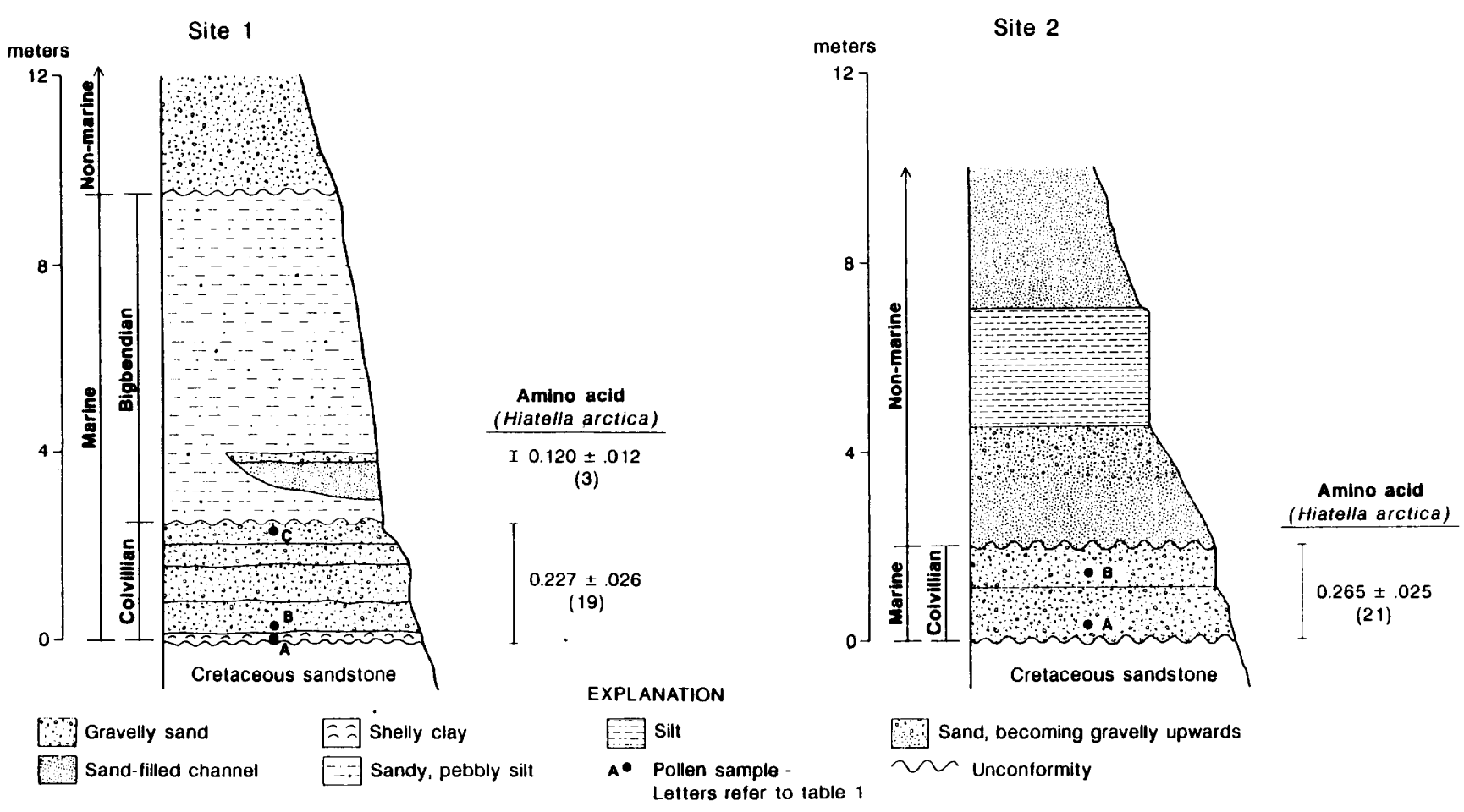

Figure 2. Stratigraphy and location of pollen samples at sites 1 and 2. Amino-acid values indicate mean and standard deviation for aIle/Ile measurements of total acid hydrolysate for shells of mollusk Hiatella arctica. Numbers in parentheses indicate number of samples analyzed. Analyses performed at the Amino Acid Geochronology Laboratory, Institute of Arctic and Alpine Research, University of Colorado at Boulder. 
Table 1. Pollen and spore counts of five samples of Colvillian age

[All values expressed as percent of total pollen (excluding indeterminate grains). -, not present; + , present but $<1$ percent of total pollen; *, other woody taxa. Abbreviations: Co, Corylus; Ca, Carya; La, Larix]

\begin{tabular}{|c|c|c|c|c|c|}
\hline & \multicolumn{3}{|c|}{ Site 1} & \multicolumn{2}{|c|}{ Site 2} \\
\hline & Sample A & Sample B & Sample C & Sample A & Sample B \\
\hline \multicolumn{6}{|l|}{ Pollen: } \\
\hline Abies-1 & - & + & - & + & + \\
\hline Tsuga mertensiana & - & + & + & - & - \\
\hline Other Tsuga -- & - & + & + & - & + \\
\hline Pinus- & 2.3 & 8.8 & 8.5 & 10.2 & 1.2 \\
\hline Picea-1 & 25.1 & 30.5 & 18.7 & 33.8 & 13.9 \\
\hline Alnus-- & 5.1 & 6.6 & 5.7 & 7.5 & 16.3 \\
\hline Betula-- & 36.0 & 27.4 & 33.5 & 27.5 & 32.2 . \\
\hline Ericales - & 5.1 & 6.0 & 8.2 & 6.9 & 6.6 \\
\hline Salix & 1.6 & 1.6 & 2.2 & - & + \\
\hline Populus & 1.3 & 2.5 & + & 1.3 & + \\
\hline Other woody taxa* & Co & $\mathrm{Ca}, \mathrm{La}$ & Co & - & Co \\
\hline Poaceae - & 7.7 & 4.4 & 8.9 & 4.6 & 14.8 \\
\hline Cyperaceae -----'-- & 10.3 & 6.6 & 10.4 & 3.9 & 9.9 \\
\hline Other herbs - - & 3.2 & 1.9 & 1.6 & 2.6 & + \\
\hline 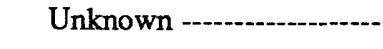 & + & 1.9 & + & + & 1.2 \\
\hline Indeterminate --.-- & 9.6 & 7.2 & 8.5 & 13.8 & 9.3 \\
\hline \multicolumn{6}{|l|}{ Spore and algae types: } \\
\hline Sphagnum --- & 10.0 & 14.5 & 19.6 & 17.4 & 14.5 \\
\hline Lycopodium selago & - & + & + & + & + \\
\hline Other Lycopodium ------- & 6.8 & 4.7 & 2.2 & 7.8 & 4.5 \\
\hline Selaginella selaginoides & + & - & + & 1.3 & + \\
\hline Other Selaginella & + & - & - & + & - \\
\hline cf. Osmunda & 2.6 & 1.9 & + & - & + \\
\hline Other trilete spores & 19.0 & 11.9 & 23.4 & 8.8 & 11.1 \\
\hline Monolete fern spores --.--- & 3.9 & 2.2 & 7.3 & 5.6 & 1.2 \\
\hline Pediastrum colonies ------ & + & - & + & - & 2.7 \\
\hline $\begin{array}{l}\text { Pre-Neogene pollen and } \\
\text { spores }\end{array}$ & 28.6 & 25.5 & 8.5 & 11.8 & 4.8 \\
\hline
\end{tabular}

abundant on the Colvillian landscape than is suggested by their contribution to the pollen floras. Willows were probably most common along streams, whereas Populus may have been derived from aspen ( $P$. tremuloides) in the forest and cottonwood ( $P$. balsamifera) along the streams.

None of the conifers present in the Colvillian pollen floras occur today on the North Slope, and several have their present northern limits far to the south (Viereck and Little, 1972). Spruce extends as far north as the south flank of the Brooks Range in Alaska and into the Mackenzie Delta area in Canada. Larch occurs in central
Alaska along the Yukon River and some of its tributaries. The nearest species of pine (Pinus contorta) grows in southeastern Alaska and extends into central Yukon Territory. Mountain hemlock (Tsuga mertensiana) reaches its northern limit in the vicinity of Anchorage, as does western hemlock (Tsuga heterophylla). Fir (Abies) grows only as far north as Juneau in southeastern Alaska, but it extends into central Yukon Territory, Canada, where it occurs to treeline (Porsild and Cody, 1980). Although some of these taxa may have had different ecological tolerances in late Pliocene time than they do at present, 
the occurrence of taxa in the Colvillian pollen floras that are $1,000 \mathrm{~km}$ or more north of their present limits suggests that the North Slope climate during the Colvillian transgression was considerably warmer than now, and possibly warmer than the modern Anchorage area (1.5 ${ }^{\circ} \mathrm{C}$ mean annual air temperature), which is north of the present limits of pine. If this conclusion is even approximately correct, then permafrost was probably not present on the North Slope during the Colvillian transgression.

The forested conditions suggested here for the Colvillian landscape are similar to those interpreted from pollen floras of Bigbendian age by Nelson and Carter (1985). The principal differences in the pollen floras are that pine percentages in the Colvillian samples are generally higher, and that hemlock was not present at all in the younger sediment. Also, the Bigbendian samples had much higher percentages of Ericales and a wider diversity of herbs than were found in the Colvillian samples. This suggests a more closed aspect to the Colvillian forest. Moreover, a close reexamination of the Bigbendian pollen data suggests that Nelson and Carter's (1985) conclusion about the nature of the vegetation should be modified. The presence of significant percentages (generally 10-30 percent) of heath pollen, as well as of both grasses and sedges, indicates that there was at least a modest level of openness in the vegetation cover. The Bigbendian vegetation was most likely open spruce-birch woodland or even parkland, with rare, scattered pine possibly present in favorable sites.

These probable differences in the composition and character of the vegetation suggest that climate may have been slightly warmer during the Colvillian transgression than during the Bigbendian transgression. A preliminary interpretation or working hypothesis is that these differences may represent evidence for a gradual restriction of boreal forest and the concomitant development of lowland tundra as climate gradually cooled following the initiation of late Cenozoic glaciation about 3.1 Ma (Raymo and others, 1989). These differences are subtle, however, and additional samples from more sites may suggest other interpretations.

\section{REFERENCES CITED}

Brigham, J.K., 1985, Marine stratigraphy and amino-acid geochronology of the Gubik Formation, western Arctic Coastal Plain, Alaska: U.S. Geological Survey Open-File Report 85-381, 218 p.

Brigham-Grette, Julie, and Carter, L.D., in press, Pliocene marine transgressions of northern Alaska: Circumarctic correlations and paleoclimatic interpretations: Arctic.

Brosgé, W.P., and Whittington, C.L., 1966, Geology of the Umiat-Maybe Creek region, Alaska: U.S. Geological Survey Professional Paper 303-H, p. 501-637.

Carter, L.D., Brigham-Grette, Julie, and Hopkins, D.M., 1986a,
Late Cenozoic marine transgressions of the Alaskan Arctic Coastal Plain, in Heginbottom, J.A., and Vincent, J.S., eds., Correlation of Quaternary deposits and events in the area around the Beaufort Sea, abstracts of the Joint Canadian-American Workshop: Geological Survey of Canada Open-File Report 1237, p. 21-26.

Carter, L.D., Brigham-Grette, Julie, Marincovich, Louie, Jr., Pease, V.L., and Hillhouse, J.W., 1986b, Late Cenozoic Arctic Ocean sea ice and terrestrial paleoclimate: Geology, v. 14, p. $675-678$.

Carter, L.D., and Hillhouse, J.W., 1991, Age of the late Cenozoic Bigbendian marine transgression of the Alaskan Arctic Coastal Plain: Significance for permafrost history and paleoclimate, in Bradley, D.C., and Ford, A.B., eds., Geologic studies in Alaska by the U.S. Geological Survey, 1990: U.S. Geological Survey Bulletin [this volume].

Dinter, D.A., Carter, L.D., and Brigham-Grette, Julie, 1990, Late Cenozoic geologic evolution of the Alaskan North Slope and adjacent continental shelves, in Grantz, A., Johnson, L., and Sweeney, J.F., eds., The Arctic Ocean region: Boulder, Colorado, Geological Society of America, The Geology of North America, DNAG Series, v. L, p. 459-490.

Faegri, Knut, and Iversen, Johannes, 1975, Textbook of pollen analysis: New York, Hafner Press, 295 p.

Hopkins, D.M., Matthews, J.V., Wolfe, J.A., and Silberman, M.L., 1971, A Pliocene flora and insect fauna from the Bering Strait region: Palaeogeography, Palaeoclimatology, Palaeoecology, v. 9, p. 211-231.

Hultén, E., 1968, Flora of Alaska and neighboring territories: Palo Alto, California, Stanford University Press, 1,008 p.

Miller, G.H., and Brigham-Grette, Julie, 1989, Amino acid geochronology: Resolution and precision in carbonate fossils, in Rutter, N.W., Brigham-Grette, Julie, and Catto, N., guest eds., Applied Quaternary geology: Quaternary International, v. 1, p. 111-128.

Moriya, K., 1976, Flora and palynomorphs of Alaska: Tokyo, Japan, Kodansha Co., 366 p. [in Japanese].

Nelson, R. E., and Carter, L. D., 1985, Pollen analysis of a part of the Gubik Formation, Arctic Coastal Plain, Alaska: Quaternary Research, v. 24, no. 3, p. 295-306.

Porsild, A.E., and Cody, W.J., 1980, Vascular plants of continental Northwest Territories: National Museum of Canada, $667 \mathrm{p}$.

Raymo, M.E., Ruddiman, W.F., Backman, J., Clement, B.M., and Martinson, D.G., 1989, Late Pliocene variation in northern hemisphere ice sheets and North Atlantic deep water circulation: Paleoceanography, v. 4, p. 413-446.

Repenning, C.A., Brouwers, E.M., Carter, L.D., Marincovich, Louie, Jr., and Ager, T.A., 1987, The Beringian ancestry of Phenacomys (Rodentia: Cricetidae) and the beginning of the modern Arctic Ocean borderland biota: U.S. Geological Survey Bulletin 1687, 31 p.

Viereck, L.A., and Little, E.L., Jr., 1972, Alaska trees and shrubs: U.S. Department of Agriculture Forest Service Handbook 410, 265 p.

Welsh, S.A., 1974, Anderson's flora of Alaska and adjacent parts of Canada: Provo, Utah, Brigham Young University Press, 724 p.

Reviewers: Thomas A. Ager and Thomas D. Hamilton 


\title{
Electrical Resistivity Cross Sections in East-Central Alaska
}

\author{
By Jay A. Sampson, Victor F. Labson, and Carl L. Long
}

Audio-magnetotelluric (AMT) and magnetotelluric (MT) electrical resistivity soundings have been used to map the electrical resistivity structure beneath the Yukon-Tanana Upland of east-central Alaska. These methods have been employed in large-scale investigations in Alaska by Stanley (1986), Long and Miyaoka (1988), Labson and Stanley (1989), and Stanley and others (1990). Presented in this note are three cross sections constructed from MT-AMT data obtained in the Livengood, Fairbanks, Big Delta, and Tanana quadrangles (fig. 1). These cross sections complement those presented by Labson and Stanley (1989) and Stanley and others (1990) as part of the U.S. Geological Survey's TransAlaska Crustal Transect (TACT) program. The TACT program is a multidisciplinary investigation of the structure and evolution of the Alaskan crust along the TransAlaska pipeline corridor. The cross sections are con- structed from horizontally layered resistivity-depth models for each of the MT-AMT stations. The models are derived from one-dimensional resistivity inversions (Bostick, 1977) of the apparent resistivity curves for which $E$ (the true electric field) is inferred to be parallel to strike. The resulting depth and resistivity values are fitted to a continuous grid and then contoured. The Bostick one-dimensional inversions are believed to portray the main features of the resistivity structure and serve as the starting models for future two-dimensional models.

The cross sections present MT and AMT measurements along profiles from Delta Junction to the Yukon River (A-A', fig. 2), Manley Hot Springs to Livengood (B-B', fig. 3), and across the White Mountain National Recreation Area (C-C', fig. 4). Section A-A' overlaps by $100 \mathrm{~km}$ Labson and Stanley's (1989) and Stanley and others' (1990) cross section C-C', which crosses the

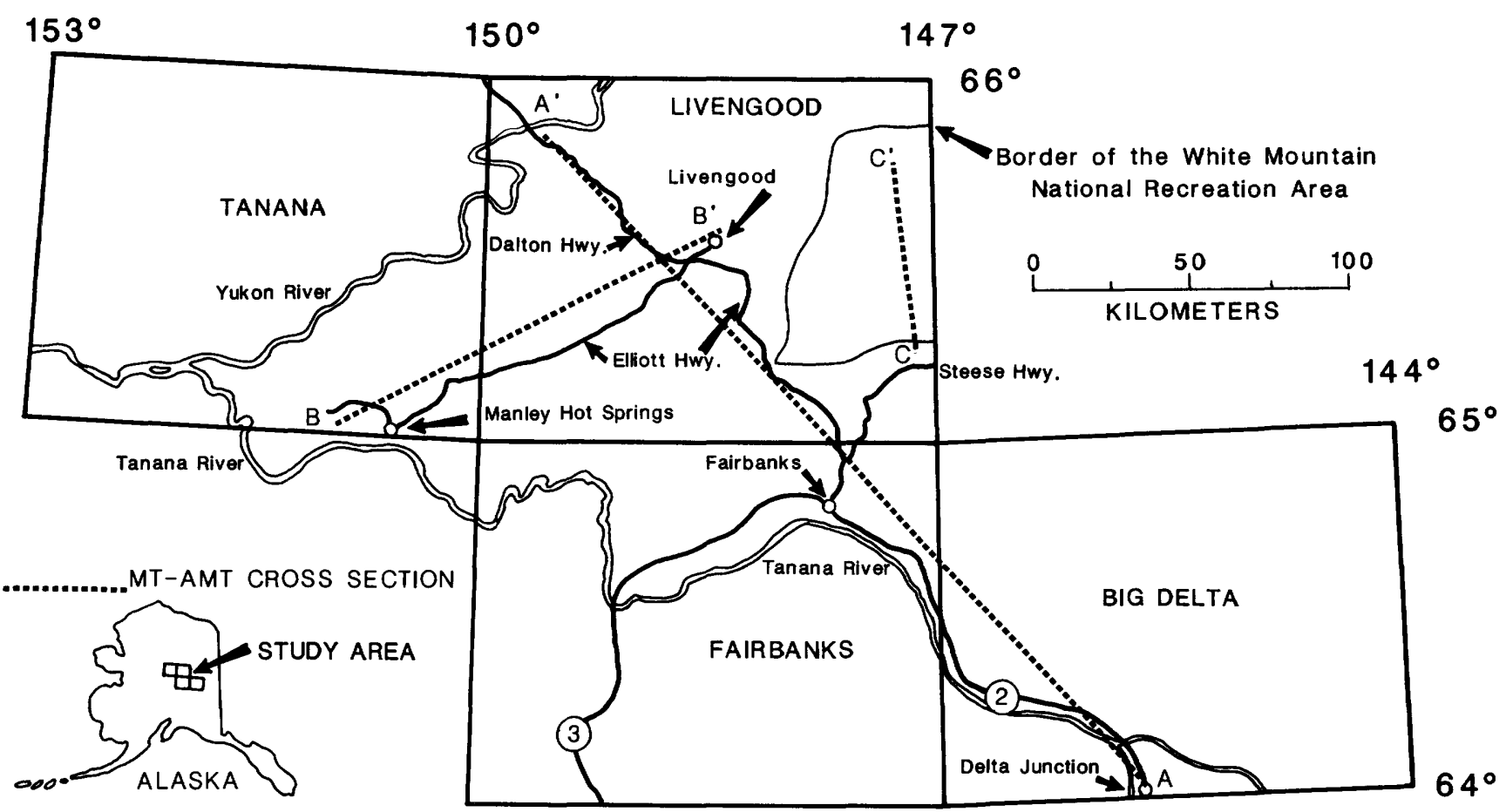

Figure 1. Locations of Trans-Alaska Crustal Transect MT and AMT cross sections A-A', B-B', and C-C'. Names of $1: 250,000$-scale quadrangles shown. 
Alaska Range and the Denali fault. A conductor similar to that mapped by Labson and Stanley (1989) and interpreted to be a sequence of carbonaceous Paleozoic and Mesozoic marine sediments extends to the north under a substantial portion of cross section A-A'.

\section{CROSS SECTION A-A'}

Owing to the extended length $(282 \mathrm{~km})$ of cross section A-A' (figs. 1, 2), we have divided it into three segments for discussion purposes. The southernmost segment (the first half of which overlaps by $100 \mathrm{~km}$ Labson and Stanley's (1989) and Stanley and others' (1990)

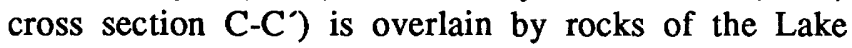
George subterrane of the Yukon-Tanana terrane (Nokleberg and others, 1989). The Lake George subterrane was described by Nokleberg and pthers (1989) as being Paleozoic in age and composed of augen gneiss, granitic gneiss, and pelitic schist units. Rocks of this type are moderately resistive $(31-300 \Omega \cdot \mathrm{m})$ and form a 5 to 10 $\mathrm{km}$ thick surficial layer along this segment of cross section $\mathrm{A}-\mathrm{A}^{\prime}$. A comprehensive description of the geology of the terranes, subterranes, and units mentioned in this note can be found in Nokleberg and others (1989) and Weber (1989).

The MT-AMT cross section shows highly conductive (low resistivity) material (less than $10 \Omega \cdot \mathrm{m}$ ) at depths greater than 10 to $15 \mathrm{~km}$ below the moderately resistive surface material. The low resistivity interval of less than $10 \Omega \cdot \mathrm{m}$ includes an intermediate contour interval of $3 \Omega \cdot \mathrm{m}$. The conductive material was interpreted by Stanley and others (1990) to be a graphite-rich sedimentary complex, and they proposed that much of the conductive section may be related to underplated marine sediments. W.D. Stanley, oral commun. 1990, rejects an alternate interpretation that this highly conductive unit is the result of hot fluids, largely because conductive units outcrop at the surface where no evidence of high temperatures exist. High conductivity due to metallic mineralization is also ruled out by Stanley on the basis of the wide distribution of the conductive units, of correlation with surface outcrops of Mesozoic black shales, and of thin-section analysis. It is difficult to determine the true thickness of this highly electrically conductive material. The depth of penetration of naturally occurring electric and magnetic energy used by the MT method is proportional to the resistivity of the subsurface material. Resistive material permits deep penetration of the natural source energy, whereas conductive material attenuates the energy and limits the depth of penetration. Data for this study were collected to a minimum frequency of $0.001 \mathrm{~Hz}$. At that frequency, the approximate depth of penetration would be $11 \mathrm{~km}$ in $1 \Omega \cdot \mathrm{m}$ material, $19 \mathrm{~km}$ in $3 \Omega \cdot \mathrm{m}$ material, or $35 \mathrm{~km}$ in $10 \Omega \cdot \mathrm{m}$ material. In this study, the conductive material either is very thick (greater than 15 to $20 \mathrm{~km}$ ) or cannot be penetrated by the MT method in order to sense deeper, more resistive rocks. If the MT method cannot penetrate the conductive material, the gridding and contouring program makes the conductive layer look thicker than it actually is. Under this southernmost segment of cross section $A-A^{\prime}$, it is not clear whether MT is sensing a very thick conductive layer or the material is too conductive to be successfully penetrated by MT.

The middle segment of cross section A-A' corresponds to (from south to north) the Paleozoic Butte, Chena River, Goldstream, and Fairbanks subterranes of the Yukon-Tanana terrane (Nokleberg and others, 1989). Nokleberg and others (1989) described these subterranes

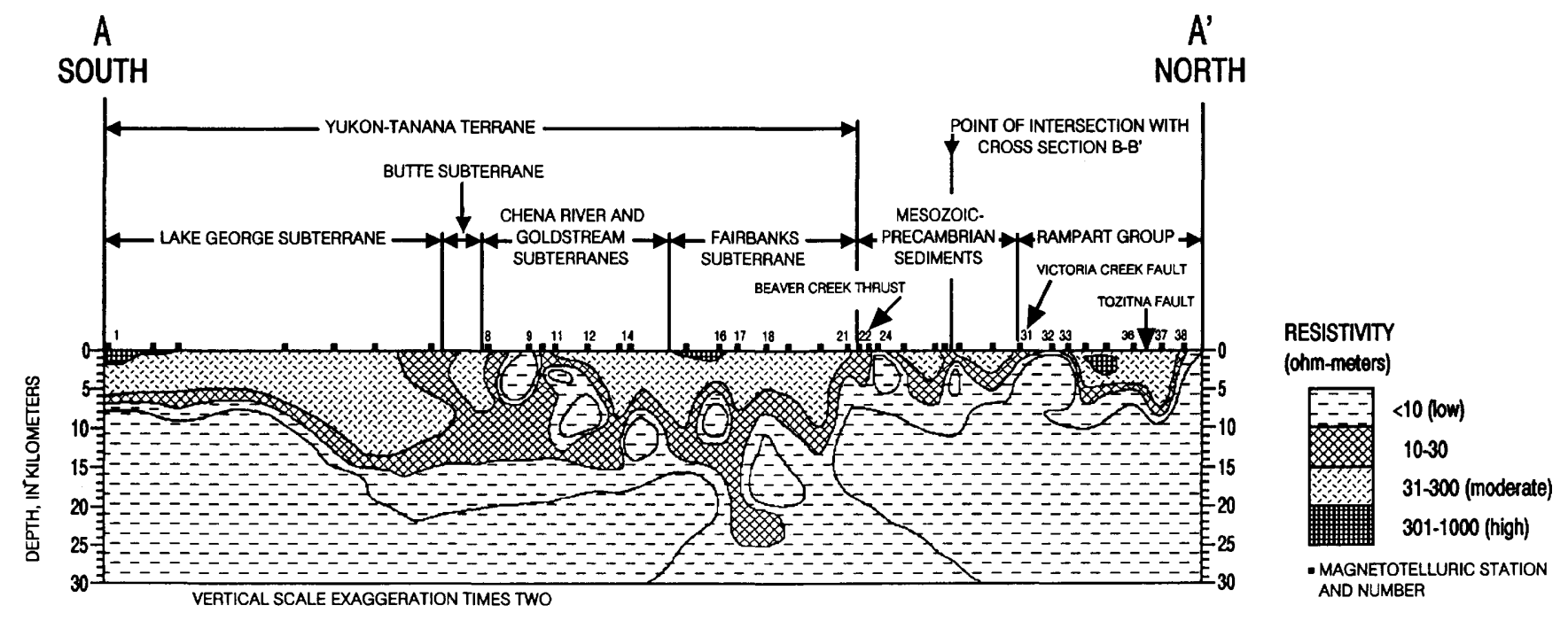

Figure 2. MT-AMT cross section A-A'. One-dimensional resistivity inversion from Delta Junction to Yukon River. 
as follows: Butte subterrane-a east-northeast-trending thrust sheet consisting of mylonitic schist, quartzite, phyllite, and greenstone; Chena River subterrane-a series of east-northeast-trending klippen and thrust sheets consisting of calc-phyllite, phyllite, and carbonate layers overlain by quartzite and argillite; Goldstream subterrane-a series of east-northeast-trending klippen consisting of pelitic schist and gneiss; and Fairbanks subterrane-a major tectonic unit that has undergone four distinct periods of metamorphism and consists mainly of quartzite, quartz-white mica schist, and quartz-biotite schist.

The materials to depths of $15 \mathrm{~km}$ under this middle segment of cross section A- $\mathrm{A}^{\prime}$ vary in resistivity from low (less than $10 \Omega \cdot \mathrm{m}$ ) to high $(301-1,000 \Omega \cdot \mathrm{m})$. The resistivity interval of $301-1,000 \Omega \cdot m$ represents the highest resistivity rocks in this cross section. These are not the extremely high resistivities that might be seen, for instance, in a Precambrian shield. The MT-AMT data indicate resistivities of less than $30 \Omega \cdot \mathrm{m}$ beneath most of the Butte subterrane to depths of possibly $15 \mathrm{~km}$. Moderately resistive material (31-300 $\Omega \cdot \mathrm{m})$ crops out in the northern half of the Butte subterrane to the south of station 8 and is possibly the result of resistive quartzites found in that subterrane. Moderately resistive material underlies most of the Goldstream and Fairbanks subterranes between stations 11 and 21 to depths of up to 10 $\mathrm{km}$. This is to be expected, considering the rock types and metamorphic history of the subterranes. Beneath the Chena River, Goldstream, and Fairbanks subterranes a linear series of four low-resistivity features (at stations 9, 12, 14 and 16) dip to the north and are perhaps conductive carbonates or the Paleozoic marine sediments. The upper limit of conductive material (less than 10 $\Omega \cdot \mathrm{m})$ which has been interpreted by Stanley and others (1990) to be carbonaceous marine sediments, appears to be present at a depth of approximately $15 \mathrm{~km}$ beneath the Butte, Chena River, and Goldstream subterranes but appears to be more resistive under the Fairbanks subterrane. The MT-AMT data indicate that the material beneath the Fairbanks subterrane between stations 17 and 18 is somewhat more resistive $(10-30 \Omega \cdot \mathrm{m})$ to depths in excess of $20 \mathrm{~km}$. High-grade metamorphism, disruption of the conductive rock fabric, or extensive Cretaceous intrusions are possible explanations for these higher resistivities beneath the Fairbanks subterrane.

The northernmost segment (stations 22 through 38) of cross section A- $\mathrm{A}^{\prime}$ (note intersection with cross section $\mathrm{B}-\mathrm{B}^{\prime}$ ) corresponds to a horizontal sequence (labeled as Mesozoic-Precambrian sediments in fig. 2) of the Mesozoic Wilber Creek unit, the Paleozoic Cascaden Ridge unit, the Proterozoic Amy Creek unit, the Paleozoic Livengood Dome chert, and the Mesozoic-Paleozoic Rampart Group (Weber, 1989). Weber (1989) described the Wilber Creek unit as a polymictic conglomerate, graywacke, quartzite, and shale; the Cascaden Ridge unit as a shale, sandstone, and conglomerate; and the Amy Creek unit as a dolomite and chert. The undated Vrain unit, which lies stratigraphically below the Wilber Creek unit and may be correlative with the Cascaden Ridge unit, is a carbonaceous black shale and should be electrically conductive. The Victoria Creek fault at station 31 is the contact between the Mesozoic-Precambrian sediments and the Rampart Group. The Rampart Group (Weber, 1989) is composed of moderately to highly resistive extrusive and intrusive mafic rocks and undifferentiated sedimentary rocks. Weber (1989) discussed the geology of this segment of cross section A- $\mathrm{A}^{\prime}$ in detail. The Tozitna fault is located between stations 36 and 37 . As expected, since this is a strike-slip fault, no resistivity contrast is seen across the fault which makes it difficult to distinguish on the cross section. The Mesozoic and older sediments are present to a thickness of $5 \mathrm{~km}$ beneath this segment (stations 22 to 31) of cross section $\mathrm{A}-\mathrm{A}^{\prime}$ and range from very conductive to moderately resistive. Areas of moderate to high resistivities between stations 33 and 38 in the Rampart Group are possibly ultramafic rocks. The outcropping Wilber Creek unit at station 24 is conductive (less than $10 \Omega \cdot \mathrm{m}$ ) and, we feel, is included in the complex of Mesozoic and older marine sediments that produce the extensive conductive zone beneath nearly the entire length of the cross section. The MT-AMT data suggest that the conductor crops out at station 24 and plunges northward to depths of possibly 15 to $20 \mathrm{~km}$ to its upper surface, perhaps along a major thrust fault. A large, shallow conductive feature is present to the north of the Victoria Creek fault below station 32. The geologic cause of this feature is not understood at this time.

\section{CROSS SECTION B-B'}

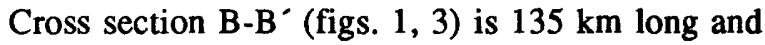
extends from $16 \mathrm{~km}$ to the northwest of Manley Hot Springs to $10 \mathrm{~km}$ to the northeast of Livengood. The cross section is divided into two segments. Stations 39 to 53 are included in the westernmost segment while stations 53 to 55 form the easternmost segment. The westernmost segment (labeled as Mesozoic-Paleozoic sediments in fig. 3) is overlain by the outcropping Cascaden Ridge (or Vrain) unit, the Wilber Creek unit, the Mesozoic Wolverine quartzite, and conductive serpentinite (F.R. Weber, oral commun., 1990). The conductive Wilber Creek unit and the more resistive Wolverine quartzite form a surficial layer of up to $5 \mathrm{~km}$ thick that varies in resistivity from less than 10 to as high as $1,000 \Omega \cdot \mathrm{m}$. Highly conductive (less than $10 \Omega \cdot \mathrm{m}$ ) Mesozoic-Precambrian rock units, prominent units of which are perhaps the Wilber Creek and Cascaden Ridge (or Vrain), most 
likely form a complex of Mesozoic and older marine sediments that produce the conductive zone beneath this westernmost segment of cross section B-B'. The thickness of this zone is difficult to determine due to the very high conductivities. These highly conductive rocks thin or become more resistive near the easternmost segment of the cross section. The resistive Manley Hot Springs pluton is exposed to the east of station 43 . Thermal alteration may have produced slightly higher resistivities in the Mesozoic and older marine sediments beneath and adjacent to the pluton. The easternmost segment (note intersection with cross section A-A) of cross section B$B^{\prime}$ is overlain by a horizontal sequence of Paleozoic and older rock units that include unnamed mafic and ultramafic rocks, the Livengood Dome chert, the Amy Creek unit, more mafic and ultramafic rocks, and finally additional rocks of the Amy Creek unit. The Amy Creek unit and the Livengood Dome chert are more resistive than either the Wilber Creek unit or the Cascaden Ridge unit (or Vrain unit). The mafic and ultramafic rocks can be conductive or resistive. The Minto fault zone occurs beneath stations 28 and 27. A conductive zone at a depth of 5 to $10 \mathrm{~km}$ plunges to the east between stations 30 and 55 and is most likely additional Mesozoic and older marine sediments.

\section{CROSS SECTION C-C'}

Cross section C-C' is $68 \mathrm{~km}$ long and is taken from Long and Miyaoka's (1988) AMT-MT data obtained in the White Mountain National Recreation Area in the northwestern part of the Yukon-Tanana Upland (fig. 4). A complete discussion and interpretation of this

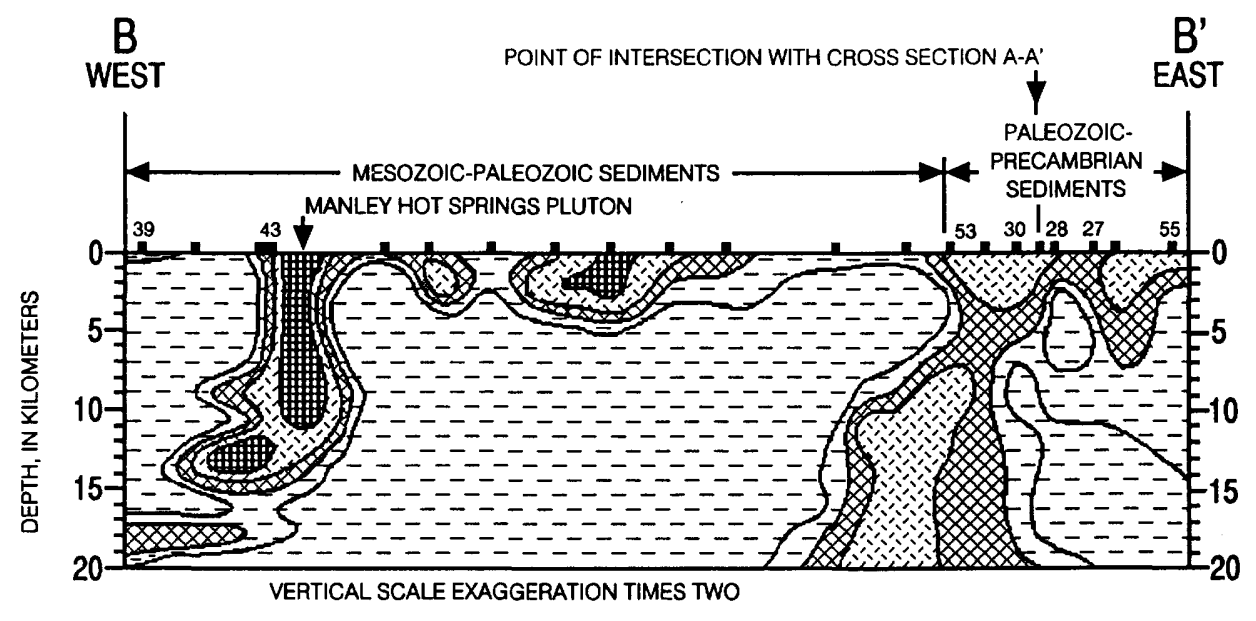

RESISTIVITY

(ohm-meters)

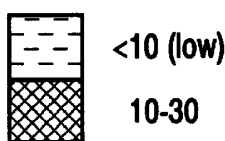

$31-300$ (moderate)

$301-1000$ (high)

- MAGNETOTELLURIC STATION AND NUMBER

Figure 3. MT-AMT cross section B-B'. One-dimensional resistivity inversion from Manley Hot Springs to Livengood.

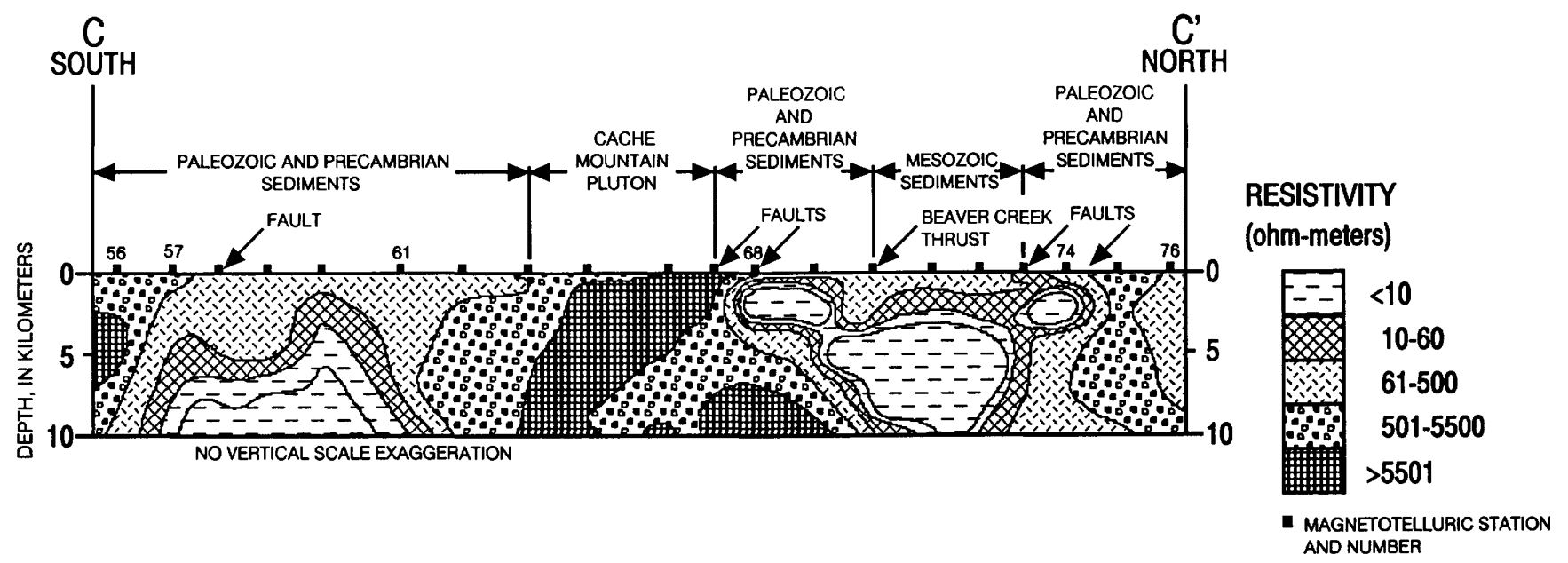

Figure 4. MT-AMT cross section C-C'. One-dimensional resistivity inversion through the White Mountain National Recreation Area. 
cross section is found in Long and Miyaoka (1988). A conductive zone (less than $10 \Omega \cdot \mathrm{m}$ ) occurs on the southern end of cross section C- $C^{\prime}$ at a depth greater than 5 $\mathrm{km}$ between stations 57 and 61 . A second conductive zone between stations 68 and 74 occurs on the north end of the same profile, north of the resistive Cache Mountain pluton. The conductive zone beneath stations 68 through 74 on cross section C-C' appears to correspond to the conductive zone north of station 24 on cross section A-A $\mathrm{A}^{\prime}$. These northward-plunging conductive zones on both cross sections occur at similar depths and may correspond to similar geologic units (in this case, the Mesozoic and older marine sediments). Additional MTAMT data (cross-profiles) would be required to confirm a direct correlation of the conductive units.

The results obtained from these one-dimensional inversions combined with the profile of Labson and Stanley (1989) have given us a greater understanding of the deep structure in the region between the Denali fault and the Yukon River. The model of carbonaceous marine sediments emplaced beneath the Yukon-Tanana terrane is supported by the MT-AMT data. The new data suggest that the conductive material underlies relatively thin upper-plate material between the overthrust Hot Springs strand of the Tintina fault system (which is marked approximately by the Beaver Creek thrust on cross section $A-A^{\prime}$ at station 21) and the Yukon River. Additional MT data were obtained in 1989 and 1990 to expand our knowledge of the resistivity structure into the area north of the Yukon River. These new data are presently being analyzed.

\section{REFERENCES CITED}

Bostick, F.X., Jr., 1977, A simple and almost exact method of MT analysis, in Workshop on electrical methods in geothermal exploration: U.S. Geological Survey Contract no. 14080001-8 -359.

Labson, V.F., and Stanley, W.D., 1989, Electrical resistivity structure beneath southern Alaska, in Alaskan geological and geophysical transect, Valdez to Coldfoot, Alaska: 28th International Geological Congress, Field Trip Guidebook T 104, p. 75-78.

Long, C.L., and Miyaoka, R., 1988, Geology and mineral resources of the White Mountain National Recreation Area, east-central Alaska: U.S. Geological Survey Open-File Report 88-284, p. 73-76.

Nokleberg, W.J., Foster, H.L., and Aleinikoff, J.N., 1989, Geology of the northern Copper River Basin, eastern Alaska Range, and southern Yukon-Tanana Upland, in Alaskan geological and geophysical transect, Valdez to Coldfoot, Alaska: 28th International Geological Congress, Field Trip Guidebook T 104, p. 34-63.

Stanley, W.D., 1986, Magnetotelluric study of a compressed flysch system in the Healy Quadrangle: U.S. Geological Survey Circular 928, U.S. Geological Survey Field Research in Alaska during 1985, p. 46-50.

Stanley, W.D., Labson, V.F., Nokleberg, W.J., Csejtey, Bela, Jr., and Fisher, M.A., 1990, The Denali fault system and the Alaska Range of Alaska: evidence for underplated Mesozoic flysch from magnetotelluric surveys: Geological Society of America Bulletin, v. 102, p. 160-173.

Weber, F.R., 1989, Geology between Fairbanks and the Yukon River, east-central Alaska, in Alaskan Geological and Geophysical Transect: 28th International Geological Congress, Field Trip Guidebook T 104, p. 84-95 .

Reviewers: David L. Campbell and Brian D. Rodriguez 


\title{
Gold Placers, Gold Source, and High Terrace Gravels in the Fortymile River Area, Alaska
}

\author{
By Warren Yeend
}

Gold-rich placers have been mined in the Fortymile River area since 1886 . Most of the productive placers known today were discovered before the turn of the century. By 1938, mining in the region was largely restricted to six drainages-Chicken Creek, Wade Creek, Walker Fork, Franklin Creek, Fortymile River, and Dome Creek (Mertie, 1938). The increase in the gold price in the early 1980's caused some increase in mining in the area but not as much as in other areas of Alaska.

The placers, located in the southeast quarter of the Eagle quadrangle near the Canadian border (fig. 1), occur as modern stream and terrace gravels. A visit to the area in July of 1990 revealed eight placer operations working modern flood-plain gravels within the drainages of Chicken, Lost Chicken, Napoleon, and Canyon Creeks, Walker and Myers Forks, and the Fortymile River.

There appears to be a diminishing supply of gold in the placers of the modern flood-plain gravels, which have been thoroughly mined by a variety of methods, including bucket dredges. However, there are many occurrences of unmined high- and intermediate-level terrace gravels (fig. 1), some containing gold in economically minable amounts. The terrace $170 \mathrm{~m}$ above Napoleon Creek yielded $1,300 \mathrm{oz}$ of gold from an area not much larger than 1/4 acre (fig. 2). Gravels on this terrace possess subrounded cobbles and boulders to $0.5-\mathrm{m}$ diameter with a high percentage of granite clasts. The gravel is approximately $40 \mathrm{~m}$ thick and rests on Tertiary sandstone, siltstone, and basalt.

Lost Chicken Hill is the location of another high terrace ( 80 to $90 \mathrm{~m}$ above Chicken Creek) with goldbearing gravels. Gold was found here at a depth of $10 \mathrm{~m}$ and mined by drifting (Mertie, 1938) in the early 1900's and by surface methods on and off to the present.

Terrace gravels along both Dome and Stonehouse Creeks have been mined intermittently, and unmined gold-bearing gravel terraces are known along Chicken Creek (Mertie, 1938).

Intermediate and high terrace gravels, 50 to $180 \mathrm{~m}$ above valley bottoms, are common bordering the major rivers and creeks in the Fortymile River area (fig. 1) and would seem to be a potential source of unmined placer gold here. Because of the difficulty of both prospecting and mining these gravels, comparatively little work has been done on them. The lack of road access eliminates the commonly used and reliable method of samplingchurn drilling. Likewise, widespread tree cover prevents the landing of a helicopter to gain easy access. Some of these terrace gravels would be most effectively prospected from a small boat. Arduous, steep foot traverses would be required to gain access to the terraces from the rivers and creeks. Hand digging would be necessary to expose the lower gravel contacts to obtain a sample (50 to $100 \mathrm{lb}$ ) to haul back to the creek for panning. Each terrace-gravel outcrop would need to be sampled at frequent intervals along the lower contact with bedrock, as it is well known that gold concentration is spotty, generally occurring in small pockets. In order to mine the once-located gold-rich terrace gravel, either the gravel would have to be transported down to the creek or the water from the creek would have to be pumped to the deposit, which could be as much as a $180-\mathrm{m}$ vertical lift. It is not surprising that these deposits have rarely been looked at or sampled.

Although it seems clear that much of the gold in the present stream flood-plain deposits has been recycled through the terrace gravels, the ultimate bedrock gold source is not clear. Gold in bedrock, seldom found in the Fortymile River area, is even more rarely found directly associated with placer deposits here. The gold source for the placers in the Fortymile River area has been suggested to be small mineralized quartz veins in metamorphic rocks. Mertie (1938) described this occurrence along Wade Creek and supposed that the gold-rich veins were associated with concealed granite. Sheared mineralized diorite and quartz diorite, quartz-calcite veins and calcite veinlets cutting greenschist-facies metamorphic rocks, and sheared granitic rocks are known to carry gold (Foster and O'Leary, 1982). Gold is also known to occur in crushed, faulted zones in the Dome and Canyon Creeks area (Foster and others, 1987). The only lode gold mine in the area (Purdy mine) consists of a rich vein of gold in calcite and quartz on the ridge northeast of Myers 


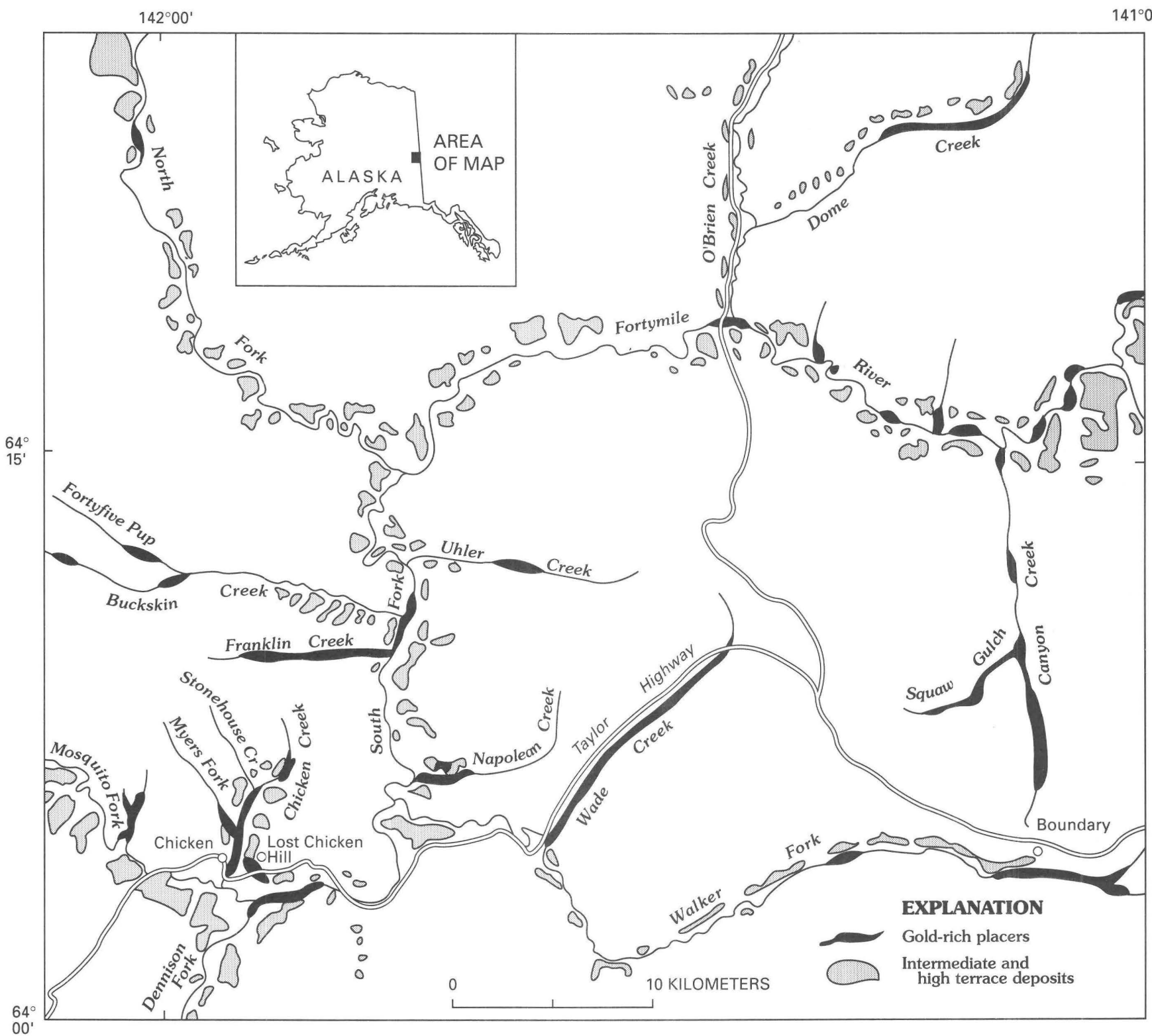

Figure 1. Terrace deposits and locations of gold-rich placers in the Fortymile River area, Alaska. Modified from Foster (1976) and Cobb (1973).

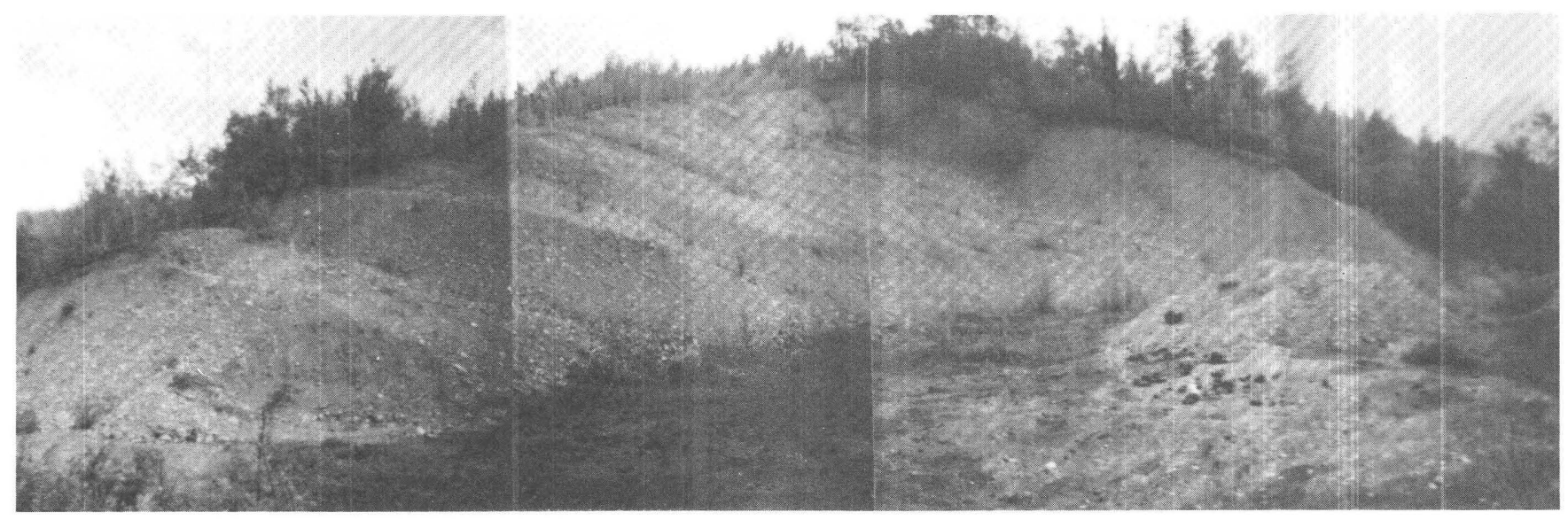

Figure 2. Terrace gravels, $40 \mathrm{~m}$ thick, resting on Tertiary sediments and basalt exposed on north side of Napoleon Creek approximately $170 \mathrm{~m}$ above creek. Terrace gravels from this locality have yielded over 1,300 oz of gold. 
Fork. Gold was mined here to a depth of $2 \mathrm{~m}$, where the vein abruptly ended (Foster, 1969). Extensive prospecting failed to find the continuation of the vein.

The major portion of the placer gold found in the Fortymile Mining District has come from the southeast quarter of the Eagle quadrangle. The geologic map of this quadrangle (Foster, 1976) clearly shows the prevalence of one rock unit mapped in this area-biotite gneiss and amphibolite-as compared with the rest of the quadrangle. The mapped unit also includes quartzbiotite gneiss and schist, quartzite, marble, and feldspathic gneiss. I would suggest that the presence of this unit is important for the occurrence of lode gold by either (1) including rock types containing gold that eventually becomes concentrated in quartz veins, or (2) as a structural environment conducive to emplacement of gold-rich plutonic rocks that give rise to gold-rich quartz veins.

\section{REFERENCES CITED}

Cobb, E.H, 1973, Placer deposits of Alaska: U.S. Geological Survey Bulletin 1374, 213 p.

Foster, H.L., 1969, Reconnaissance geology of the Eagle A-1 and A-2 quadrangles, Alaska: U.S. Geological Survey Bulletin 1271-G, 30 p.

1976, Geologic map of the Eagle quadrangle, Alaska: U.S. Geological Survey Miscelleanous Investigations Map I-922, scale 1:250,000.

Foster, H.L., and O'Leary, R.M., 1982, Gold found in bedrock of Lost Chicken Creek gold placer mine, Fortymile area, Alaska: U.S. Geological Survey Circular 844, p. 62.

Foster, H.L, Keith, T.E., and Menzie, W.D., 1987, Geology of east-central Alaska; U.S. Geological Survey Open-File Report $87-188,59 \mathrm{p}$.

Mertie, J.B., 1938, Gold placers of the Fortymile, Eagle, and Circle districts, Alaska: U.S. Geological Survey Bulletin 897-C, p. 133-261.

Reviewers: Helen L. Foster and John P. Galloway 


\title{
BIBLIOGRAPHIES
}

\section{U.S. Geological Survey Reports on Alaska Released in 1990}

\author{
Compiled by Ellen R. White
}

[Some reports dated 1989 did not become available until 1990; they are included in this listing.]

\section{ABBREVIATIONS}

B1903 Dover, J.H., and Galloway, J.P., eds., 1989, Geologic studies in Alaska by the U.S. Geological Survey, 1988: U.S. Geological Survey Bulletin 1903, 134 p.

B1946 Dover, J.H., and Galloway, J.P., eds., 1990, Geologic studies in Alaska by the U.S. Geological Survey, 1989: U.S. Geological Survey Bulletin 1946, 121 p.

C1060 Carter, L.M.H., ed., 1990, USGS research on energy resources-1990, Program and Abstracts: U.S. Geological Survey Circular 1060, 99 p. [Sixth V.E. McKelvey Forum on Mineral and Energy Resources.]

OF

U.S. Geological Survey Open-File Report

Abers, G.A., 1990, Seismic monitoring of the Shumagin seismic gap, Alaska: OF 90-334, p. 1-4.

Adam, D.P., Dieffenbach, H.L., and McCormick, Michael, 1990, A working bibliography for the Pliocene: OF 90-81, 196 p. [Keyword index shows many entries under, for example, Alaska, Aleutian Islands, Arctic, Arctic Ocean, Bering Sea, etc.]

Aleinikoff, J.N., and Nokleberg, W.J., 1989, Age of deposition and provenance of the Cleary sequence of the Fairbanks schist unit, Yukon-Tanana terrane, east-central Alaska: B1903, p. 75-83.

Aleinikoff, J.N., and Plafker, George, 1989, In search of the provenance and paleogeographic location of the White Mountains terrane: Evidence from $\mathrm{U}-\mathrm{Pb}$ data of granite boulders in the Fossil Creek Volcanics: B1903, p. 68-74.

Allen, M.S., Malcolm, M.J., Motooka, J.M., and Slaughter, K.E., 1990, Geologic description, chemical analyses and sample locality map for rock samples from the eastern part of the Lime Hills quadrangle, Alaska: OF 90-69, 49 p., scale $1: 250,000,1$ sheet.

Allen, M.S., and Slaughter, K.E., 1990, Mineralogical data and sample locality map of nonmagnetic, heavy-mineral-concentrate samples collected from the eastern part of the Lime Hills quadrangle, Alaska: OF 90-67, 64 p., scale $1: 250,000,1$ sheet.

Anima, R.J., 1990, Annotated bibliography on research conducted in coastal lagoons and estuaries of the Pacific coast of the United States: OF 90-347, 224 p. [Eleven entries for Alaska.]

Barnes, D.F., and Morin, R.L., 1990, Gravity contour map and interpretation of gravity data for the Chugach National Forest, Alaska: U.S. Geological Survey Miscellaneous
Field Studies Map MF-1645-F, 5 p., scale 1:125,000, 1 sheet.

Barnes, D.F., Morin, R.L., Gibson, H.A., and Tailleur, I.L., 1990 , Density data for drill cores from wells in the National Petroleum Reserve in Alaska: OF 90-342, 57 p.

Barnwell, C.E., Simpson, Steven, and Church, S.E., 1989, Analytical results and sample locality maps of stream-sediment and rock samples from the Cobblestone Creek area, south-eastern Chandler Lake quadrangle, Alaska: OF 89540,26 p., scale 1 inch $=1.56$ miles, 2 sheets.

Beavan, John, 1990, Crustal deformation measurements in the Shumagin seismic gap, Alaska: OF 90-54, p. 166-169.

1990, Crustal deformation measurements in the Shumagin seismic gap, Alaska: OF 90-334, p. 169-174.

Bothner, M.M., Parameter, C.M., and Brown, A.B., 1990, Plutonium and $210 \mathrm{~Pb}$ activities in two cores from Prince William Sound: OF 90-39, chap. D., 11 p.

Boyd, T.M., 1990, Analysis of the 1957 Andreanof Islands earthquake: OF 90-334, p. 55-59.

Bradley, D.C., and Kusky, T.M., 1990, Kinematics of late faults along Turnagain Arm, Mesozoic accretionary complex, south-central Alaska: B1946, p. 3-10.

Brantley, S.R., ed., 1990, The eruption of Redoubt Volcano, Alaska, December 14, 1989-August 31, 1990: U.S. Geological Survey Circular 1061, 33 p.

Brocher, T.M., and Moses, M.J., 1990, Wide-angle seismic recordings obtained during the TACT multichannel reflection profiling in the northern Gulf of Alaska: U.S. Geological Survey Open-File Report 90-663, 40 p.

Brouwers, E.M., 1990, Systematic paleontology of Quaternary ostracode assemblages from the Gulf of Alaska, part 1: families Cytherellidae, Bairdiidae, Cytheridae, Lepto- 
cytheridae, Limnocytheridae, Eucytheridae, Krithidae, Cushmanideidae: U.S. Geological Survey Professional Paper 1510,43 p., 13 pls.

Brunett, J.O., 1990, Lateral movement of contaminated ground water from Merrill Field landfill, Anchorage, Alaska: OF $89-624,20 \mathrm{p}$.

Burns, T.R., Carlson, P.R., Stevenson, A.J., Fisher, M.A., Ryan, H.F., Mann, D.M., Dobson, Maxwell, Huggett, Quentin, Parson, Lindsay, and Fannin, N.G.T., 1990, GLORIA images from the Gulf of Alaska and British Columbia-Subduction zones, transforms, and channels [abs.]: C1060, p. 11-12.

Carlson, P.R., Mann, D.M., Huggett, Q.J., and Bishop, Derek, 1990, GLORIA investigation of the exclusive economic zone in the Gulf of Alaska: OF 90-71, 17 p.

Carlson, P.R., and Reimnitz, Erk, 1990, Characterization of sample sites along the oil spill trajectory in Prince William Sound and the Gulf of Alaska: OF 90-39, chap. A, 24 p.

ceds., 1990, Bottom sediment along spill trajectory in Prince William Sound and along Kenai Peninsula, Alaska: OF 90-39, chaps. A-F, variously paged. [Each chapter issued separately.]

Cathrall, J.B., Antweiler, J.C., VanTrump, George, and Mosier, E.L. 1990, Gold analytical results and gold signatures from the Anchorage, Charley River, Healy, Iditarod, Juneau, Mt. Hayes, Mt. McKinley, Ophir, Ruby, and Talkeetna quadrangles, Alaska: OF 90-210, 25 p.

Church, S.E., and Arbogast, B.F., 1989, Geochemical maps showing the distribution of selected elements determined in nonmagnetic heavy-mineral concentrates from the Mount Katmai, and parts of the Afognak and Naknek quadrangles, Alaska: U.S. Geological Survey Miscellaneous Field Studies Map MF-2021-C, scale 1:250,000, 2 sheets.

Church, S.E., Bailey, E.A., and Riehle, J.R., 1989, Geochemical maps showing the distribution of selected elements determined in stream sediments from the Mount Katmai and parts of the Afognak and Naknek quadrangles, Alaska: U.S. Geological Survey Miscellaneous Field Studies Map MF-2021-A, scale 1:250,000, 1 sheet.

Church, S.E., and Bennett, G.J., 1989, Mineralogical maps showing the distribution of selected minerals identified in nonmagnetic heavy-mineral concentrates from the Mount Katmai and parts of the Afognak and Naknek quadrangles, Alaska: U.S. Geological Survey Miscellaneous Field Studies Map MF-2021-D, scale 1:250,000, 1 sheet.

Church, S.E., Frisken, J.G., and Wilson, F.H., 1989, Interpretation of exploration geochemical data from the Ugashik, Bristol Bay, and western Karluk quadrangles, Alaska: U.S. Geological Survey Bulletin 1858, 45 p.

Church, S.E., and Motooka, J.M., 1989, Geochemical maps showing the distribution of selected leachable metals in stream sediments from the Mount Katmai and parts of the Afognak and Naknek quadrangles, Alaska: U.S. Geological Survey Miscellaneous Field Studies Map MF-2021-B, scale $1: 250,000,2$ sheets. [Folio of the Mount Katmai area.]

Collett, T.S., 1990, Natural gas hydrates in the Prudhoe BayKuparuk River area of northern Alaska [abs.]: C1060, p.
14-16.

Collett, T.S., and Bird, K.J., 1990, Cretaceous and Tertiary Sagavanirktok Formation in the Prudhoe Bay-Kuparuk River area, northern Alaska [abs.]: C1060, p. 16-17.

Collett, T.S., Bird, K.J., Kvenvolden, K.A., and Magoon, L.B., 1989, Map showing the depth of the deepest ice-bearing permafrost as determined from well logs, North Slope, Alaska: U.S. Geological Survey Oil and Gas Investigations Map OM-222, scale 1:1,000,000, 1 sheet.

1989. The origin of natural gas hydrates on the North Slope of Alaska: B1903, p. 3-9.

Conrad, J.E., McKee, E.H., and Turrin, B.D., 1990, K-Ar and ${ }^{40} \mathrm{Ar} /{ }^{39} \mathrm{Ar}$ ages of tuff beds at Ocean Point on the Colville River, Alaska: B1946, p. 77-82.

Crovelli, R.A., and Balay, R.H., 1990, Play analysis methodologies for petroleum resource assessment [abs.]: C1060, p. 18-19. [ANWR is included.]

Detterman, R.L., Case, J.E., Church, S.E., Frisken, J.G., Wilson, F.H., and Yount, M.E., 1990, The Alaska Mineral Resource Assesment Program: Background information to accompany folio of geologic and resource maps of the Ugashik, Bristol Bay, and western part of Karluk quadrangles, Alaska: U.S. Geological Survey Circular 1046, 15 p.

Dickinson, K.A., and Vuletich, April, 1990, Diagenesis and uranium mineralization of the lower Tertiary Kootznahoo Formation in the northern part of Admiralty trough, southeastem Alaska: U.S. Geological Survey Bulletin 1888, 12 p.

Douglass, S.L., Webster, J.H., Burrell, P.D., Lanphere, M.L., and Brew, D.A., 1989, Major-element chemistry, radiometric ages, and locations of samples from the Petersburg and parts of the Port Alexander and Sumdum quadrangles, southeastern Alaska: OF 89-527, 66 p., scale 1:250,000, 1 pl.

Dover, J.H., 1990, Geology of east-central Alaska: OF 90-289, $66 \mathrm{p}$. , foldout maps and explanations.

Dover, J.H., and Galloway, J.P., 1989, Introduction: B1903, p. 1. Dover, J.H., and Galloway, J.P., 1990, Introduction: B1946, p. 1.

Downey, J.S., and Sinton, P.O., 1990, Geohydrology and ground-water geochemistry at a sub-arctic landfill, Fairbanks, Alaska: U.S. Geological Survey Water Resources Investigations 90-4022, 25 p.

Drinkwater, J.L., Brew, D.A., and Ford, A.B., 1989, Petrographic and chemical description of the variably deformed Speel River pluton, south of Juneau, southeastern Alaska: B1903, p. 104-112.

1990, Petrographic and chemical data for the large Mesozoic and Cenozoic plutonic sills east of Juneau, southeastern Alaska: U.S. Geological Survey Bulletin $1918,47 \mathrm{p}$.

Elder, W.P., Miller, J.W., and Adam, D.A., 1989, Maps showing fossil localities and checklists of Jurassic and Cretaceous macrofauna of the North Slope of Alaska: OF 89556,7 p., scale 1:5,000,000, 11 pls.

Espinosa, A.F., 1990, Seismic hazard studies, Anchorage, Alaska: OF 90-54, p. 418-419.

Ford, A.B., Brew, D.A., and Loney, R.A., 1990, The Sitkoh Bay alkalic plutonic suite: Silurian or older alkalic magmatism on eastern Chichagof Island, southeastern Alaska: OF $90-297,41$ p. 
Foster, H.L., and Igarashi, Yaeko, 1990, Fossil pollen from nonmarine sedimentary rocks of the eastern YukonTanana region, east-central Alaska: B1946, p. 11-20.

Fouch, T.D., Brouwers, E.M., McNeil, D.H., Marincovich, Louie, Jr., Bird, K.J., and Rieck, H., 1990, New information on the Nuwok Member of the Sagavanirktok Formation; implications for petroleum geology of the North Slope and Beaufort Sea-Evidence from Carter Creek, Arctic National Wildlife Refuge (ANWR), Alaska.[abs.]: C1060, p. 30-31.

Frost, T.P., Motooka, J.M., and Bradley, Leon, 1990, Geochemical results, sample localities, and descriptions of some rocks from the Proterozoic Kilbuck terrane, Goodnews quadrangle, southwestern Alaska: OF 90-681, 8 p.

Galloway, J.P., and Kra, Renee, 1990, Development of an Alaskan radiocarbon data base as a subset of the International Radiocarbon Data Base (IRDB): B1946, p. 83-87.

Gamble, B.M., Bailey, E.A., and Reed, B.L., 1989, Gold occurrences near Snowcap Mountain, Lime Hills B-2 quadrangle, Alaska: OF 89-646, 9 p.

Goldfarb, R.J., O'Leary, R.M., Sutley, S.J., and Tripp, R.B., 1989, Geochemical survey of the Cordova and Middleton Island $1^{\circ} \times 3^{\circ}$ quadrangles, south-central Alaska: U.S. Geological Survey Bulletin 1865, 32 p., scale 1:250,000, 3 sheets.

Gonzalez, F.I., and Bernard, E.N., 1990, Deep ocean tsunami and seismic wave observations: Three recent Gulf of Alaska events: OF 90-98, p. 131-134. [The 7th U.S.-Japan Seminar on Earthquake Prediction, Workshop XLVI, Morro Bay, Calif., 1988.]

Grantz, Arthur, Sliter, R.W., Mann, D.M., and May, S.D., 1990, Multichannel seismic reflection data collected in 1982 in the eastern Chukchi Sea: OF 90-273, 5 p., scale $1: 1,000,000,1$ sheet.

Gray, J.E., Detra, D.E., Eppinger, R.G., Hill, R.H., Slaughter, K.E., and Sutley, S.J., 1990, Geochemical data and sample locality maps for stream-sediment and heavy-mineral-concentrate samples and mineralogical data of nonmagnetic, heavy-mineral-concentrate samples, collected near five cinnebar-stibnite mineral occurrences in the Kuskokwim region, southwestern Alaska: OF 90-299-A (paper version, 73 p.), 90-299-B (diskette version).

Grebmeier, J.M., 1990, A radionuclide tracer and sediment oxygen uptake rates used to identify potential contamination zones on the Alaskan shelf in response to the Exxon Valdez oil spill: OF 90-39, chap. C, 13 p.

Griscom, Andrew, and Sauer, P.E., 1990, Interpretation of magnetic maps of the northern Gulf of Alaska, with emphasis on the source of the slope anomaly: OF 90-348, $18 \mathrm{p}$.

Hall, R.K., Karl, H.A., Carlson, P.R., Cooper, A.K., Gardner, J.V., Hunter, R.E., Marlow, M.S., and Stevenson, A.J., 1989, Bathymetric map of the Bowers Basin and Aleutian Basin east of the U.S.-U.S.S.R. 1867 Convention Line, Bering Sea: OF 89-548, 9 p., scale 1:2,000,000, 1 sheet.

Hooper, R.J., Brew, D.A., Himmelberg, G.R., Stowell, H.H., Bauer, R.L., and Ford, A.B., 1990, The nature and significance of post-thermal-peak shear zones west of the great tonalite sill near Juneau, southeastern Alaska: B1946, p. 88-94.

Howell, D.G., 1990, The search for subtle traps across onshore
Alaska [abs.]: C1060, p. 38.

Karl, S.M., and Aleinikoff, J.N., 1990, Proterozoic U-Pb zircon age of granite in the Kallarichuk Hills, western Brooks Range, Alaska: Evidence for Precambrian basement in the schist belt: B1946, p. 95-100.

Karl, S.M., Aleinikoff, J.N., Dickey, C.F., and Dillon, J.T., 1989, Age and chemical composition of Proterozoic intrusive rocks at Mount Angayukaqsraq, western Brooks Range, Alaska: B1903, p. 10-19.

Karl, S.M., Brew, D.A., and Wardlaw, B.R., 1990, Significance of Triassic marble from Nakwasina Sound, southeastern Alaska: B1946, p. 21-28.

Karl, S.M., Dumoulin, J.A., Ellersieck, Inyo, Harris, A.G., and Schmidt, J.M., 1989, Preliminary geologic map of the Baird Mountains and part of the Selawik quadrangles, Alaska: OF 89-551, 65 p., scale 1:250,000, 1 sheet.

Karl, S.M., and Koch, R.D., 1990, Maps and preliminary interpretation of anomalous rock geochemical data from the Petersburg quadrangle, and parts of the Port Alexander, Sitka, and Sumdum quadrangles, southeastern Alaska: U.S. Geological Survey Miscellaneous Field Studies Map MF-1970-C, 40 p., scale 1:250,000, 7 sheets.

Kaufman, D.S., and Hopkins, D.M., 1989, Late Cenozoic geologic controls on placer-gold distribution in the Nome nearshore area: B1903, p. 26-45.

Kelley, J.S., 1990, Generalized geologic map of the Chandler Lake quadrangle, north-central Alaska: U.S. Geological Survey Miscellaneous Field Studies Map MF-2144-A, 19 p., scale 1:250,000, 1 sheet.

Kelley, K.D., Slaughter, K.E., and Motooka, J.M., 1990, Results of inductively coupled plasma-atomic emission spectroscopy analyses of minus 30-mesh stream-sediment samples from within and adjacent to the National Petroleum Reserve Alaska: OF 90-501, 22 p., scale 1:500,000, 12 sheets.

Kisslinger, Carl, and Kubichek, Sharon, 1990, Central Aleutian Islands seismic network: OF 90-54, p. 13-21.

Kisslinger, Carl, Kubichek, Sharon, and Wright, Robin, 1990, Central Aleutian Islands seismic network: OF 90-334, p. 19-24.

Lahr, J.C., Stephens, C.D., Page, R.A., and Fogleman, K.A., 1990, Alaska seismic studies: OF 90-54, p. 22-27. 1990, Alaska seismic studies: OF 90-334, p. 25-29.

Light, T.D., Brew, D.A., and Ashley, R.P., 1989, The AlaskaJuneau and Treadwell lode gold systems, southeastern Alaska: U.S. Geological Survey Bulletin 1857-D, p. D27D36.

Light, T.D., and Rinehart, C.D., 1989, Molybdenite in the $\mathrm{Hu}$ ron Creek pluton, western Livengood quadrangle, Alaska: B1903, p. 54-61.

Light, T.D., Tripp, R.B., and King, H.D., 1990, Interpretation of reconnaissance geochemical data from the Healy quadrangle, Alaska: U.S. Geological Survey Bulletin 1894, 36 p., scale 1:250,000, 3 sheets.

Lisowski, M., Savage, J.C., and Prescott, W.H., 1990, Crustal strain: OF $90-334$, p. $210-214$. [Has section on Shumagin seismic gap.]

Luepke, Gretchen, and Escowitz, E.C., 1989, Grain-size, heavy-mineral, and geochemical analyses of sediments from the Chukchi Sea, Alaska: U.S. Geological Survey 
Bulletin 1896, 12 p.

Lull, J.S., and Plafker, George, 1990, Geochemistry and paleotectonic implications of metabasaltic rocks in the Valdez Group, southern Alaska: B1946, p. 29-38.

Magoon, L.B., 1990, Identified petroleum systems within the United States-1990, in Magoon, L.B., ed., The petroleum system-status of research and methods, 1990: U.S. Geological Survey Bulletin 1912, p. 2-9.

Magoon, L.B., and Kirschner, C.E., 1990, Alaska onshore national assessment program; geology and petroleum resource potential of six onshore Alaska provinces: OF 88450-T, $47 \mathrm{p}$.

Malcolm, M.J., Allen, M.S., and Slaughter, K.E., 1990, Analytical results and sample locality. map of the nonmagnetic, heavy-mineral-concentrate samples collected from the eastern part of the Lime Hills quadrangle, Alaska: OF 90-68, 83 p., scale 1:250,000, 1 sheet.

Marincovich, Louie, Jr., 1990, Summary of marine Pliocene sites in southern and western Alaska: OF 90-82, 25 p.

Marincovich, Louie, Jr., and Powell, C.L., II, 1989, Preliminary Tertiary molluscan biostratigraphy of the Alaska Peninsula, southwestern Alaska: OF 89-674, 2 sheets.

Marincovich, Louie, Jr., and Wiggins, V.D., 1990, Oligocene age of strata on Unga Island, Shumagin Islands, southwestern Alaska: B1946, p. 39-43.

Miller, M.L., 1990, Mafic and ultramafic rocks of the Dishna River area, north-central Iditarod quadrangle, west-central Alaska: B1946, p. 44-50.

Miyaoka, R.T., 1990, Fossil locality map and fossil data for the southeastern part of the Charley River quadrangle, eastcentral Alaska: U.S. Geological Survey Miscellaneous Field Studies Map MF-2007, 46 p., scale 1:100,000, 1 sheet.

Miyaoka, R.T., and Dover, J.H., 1990, Shear sense in mylonites, and implications for transport of the Rampart assemblage (Tozitna terrane), Tanana quadrangle, east-central Alaska: B1946, p. 51-64.

Moll-Stalcup, E.J., 1990, Latest Cretaceous and Cenozoic magmatism in mainland Alaska: OF 90-84, $82 \mathrm{p}$.

Moore, T.E., and Murphy, J.M., 1989, Nature of the basal contact of the Tozitna terrane along the Dalton Highway, northeast Tanana quadrangle, Alaska: B1903, p. 46-53.

Motooka, J.M., Allen, M.S., Malcolm, M.J., and Slaughter, K.E., 1990, Analytical results and sample locality map for stream-sediment samples collected from the eastern part of the Lime Hills quadrangle, Alaska: OF 90-70, 103 p., scale $1: 250,000,1$ sheet.

Nelson, W.H., and Csejtey, Béla, Jr., 1990, Stratigraphy and structure of the Ekokpuk Creek area, north-central Brooks Range, Alaska: U.S. Geological Survey Bulletin 1848, 8 p.

Newberry, R.J., and Brew, D.A., 1989, Epigenetic hydrothermal origin of the Groundhog Basin-Glacier Basin silvertin-lead-zinc deposits, southeastern Alaska: B1903, p. 113-121.

Nokleberg, W.J., Lange, I.M., Singer, D.A., Curtin, G.C., Tripp, R.B., Campbell, D.L., and Yeend, Warren, 1990, Metalliferous mineral resource assessment of the Mount Hayes quadrangle, eastern Alaska Range, Alaska: U.S. Geological Survey Miscellaneous Field Studies Map MF-
1996-A, 22 p., scale 1:250,000, 4 sheets.

Patrick, L.D., and Snyder, E.F., 1990, Alaska; water supply and use: U.S. Geological Survey Water-Supply Paper 2350, p. 149-156.

Patton, W.W., Jr., Box, S.E., and Grybeck, Donald, 1989, Ophiolites and other mafic-ultramafic complexes in Alaska: OF 89-648, 27 p., 1 sheet.

Phillips, R.L., 1990, Summary of Late Cretaceous environments near Ocean Point, North Slope, Alaska: B1946, p. 101-106.

Phillips, R.L., Barnes, P.W., Hunter, R.E., Reiss, T.E., and Rearic, D.M., 1988, Geologic investigations in the Chukchi Sea, 1984, NOAA ship Surveyor cruise: OF 8825,82 p.

Phillips, R.L., Grantz, Arthur, and Mullen, M.W., 1990, Preliminary stratigraphy of piston cores from southeastern Northwind Ridge, Arctic Ocean: OF 90-51, 1 sheet.

Plafker, George, Lull, J.S., Nokleberg, W.J., Pessel, G.H., Wallace, W.K., and Winkler, G.R., 1989, Geologic map of the Valdez A-4, B-3, B-4, C-3, C-4 and D-4 quadrangles, northern Chugach Mountains and southern Copper River basin, Alaska: OF 89-569, scale 1:125,000, 1 sheet.

Quinterno, P.J., 1990, Preliminary report on benthic foraminifers from Prince William Sound, Alaska: OF 90-39, chap. $\mathrm{E}, 23 \mathrm{p}$.

Rapp, J.B., Hostettler, F.D., and Kvenvolden, K.A., 1990 , Comparison of Exxon Valdez oil with extractable material from deep-water bottom sediment in Prince William Sound and the Gulf of Alaska: OF 90-39, chap. B, 27 p.

Reimnitz, Erk, and Carlson, P.R., 1990, Conclusion and recommendations regarding Prince William Sound oil spill: OF 90-39, chap. F, 4 p.

Riehle, J.R., Bailey, E.A., Church, S.E., and Yount, M.E., 1989, Sample locality maps, analytical data, and statistical summary of analyses of rock samples from the Mount Katmai quadrangle and adjacent portions of the Naknek and Afognak quadrangles, Alaska: OF 89-570, 1 v., scale $1: 250,000,2$ sheets.

Roberts, S.B., Stricker, G.D., and Affolter, R.H., 1990, 200+ billion tons of low sulfur coal in the Sagavanirktok Formation, North Slope, Alaska [abs.]: OF 90-656, p. 4.

Schneider, J.L., ed., 1989, 1989 annual report on Alaska's mineral resources: U.S. Geological Survey Circular 1040, 70 p. [A summary of mineral resource activities in Alaska for the year 1988.]

Seitz, H.R., and Thomas, D.S., 1990, Fathometer data from Bart Lake and Lake Dorothy near Juneau, Alaska, 198889: OF 90-152, 14 p.

Severson, R.C., Crock, J.G., and Gough, L.P., 1990, An assessment of the geochemical variability for plants and soils and an evaluation of industrial emissions near the Kenai National Wildlife Refuge, Alaska: OF 90-306, 90 p.

Slaughter, K.E., Gray, J.E., Hageman, P.L., Kilburn, J.E., Love, A.H., and Peacock, T.R., 1990, Geochemical data and sample locality maps for stream water and vegetation samples collected near five cinnabar-stibnite mineral occurrences in the Kuskokwim River region, southwestern Alaska: OF 90-340-A (paper version, 24 p.), 90-340-B (diskette version).

Snyder, E.F., 1990, Activities of the Alaska district, Water Re- 
sources Division, U.S. Geological Survey, 1990: OF 90 157,21 p.

Stanley, R.G., McLean, Hugh, and Pawlewicz, M.J., 1990, Petroleum source potential and thermal maturity of the Tertiary Usibelli Group of Suntrana, central Alaska: B1946, p. 65-76.

Stricker, G.D., 1990, Alaska has 4.0 trillion tons of low sulfur coal; is there a future for this resource? [abs.]: OF $90-656$, p. 5.

Stricker, G.D., 1990, Is there a future for 4.0 trillion tons of low-sulfur Alaskan coal? [abs.]: C1060, p. 79-80.

Taber, John, 1990, Analysis of seismic data from the Shumagin seismic gap, Alaska: OF 90-54, p. 227-228.

1990, Seismic monitoring of the Shumagin seismic gap, Alaska: OF 90-54, p. 41-42.

Till, A.B., 1989, Proterozoic rocks of the western Brooks Range: B1903, p. 20-25.

Till, A.B., Yount, M.E., and Riehle, J.R., 1990, Redoubt Volcano, Cook Inlet, Alaska: A hazard assessment based on eruptive activity through 1968: OF 90-246, 34 p., scale $1: 125,000,2$ sheets.

Townshend, J.B., and others, 1989, Preliminary geomagnetic data, College Observatory, Fairbanks, Alaska: OF 89-300A-L. [Each monthly report has its own letter designation; authorship and number of pages vary.]

Townshend, J.B., and others, 1990, Preliminary geomagnetic data, College Observatory, Fairbanks, Alaska: OF 90-300A-I, K-L. [Each monthly report has its own letter designation; authorship and number of pages vary.]

Vallier, T.L., Karl, H.A., Masson, D.G., and Cherryman, John, 1989, Cruise report for EEZ-SCAN Cruise F8-88-AA: eastern Aleutian Arc oceanic plate and western Alaska Peninsula margin between $179^{\circ}$ and $158^{\circ}$ west longitude, North Pacific Ocean: OF 89-497, 5 p.

White, E.R., compiler, 1989, Reports about Alaska in non-
USGS publications released in 1988 that include USGS authors: B1903, p. 130-134.

1989, U.S. Geological Survey reports on Alaska released in 1988: B1903, p. 122-129.

-1990, Reports about Alaska in non-USGS publications released in 1989 that include USGS authors: B1946, p. 116-121.

-1990, U.S. Geological Survey reports on Alaska released in 1989: B1946, p. 110-115.

Wilson, F.H., 1989, Creation of a full color geologic map by computer: A case history from the Port Moller project resource assessment, Alaska Peninsula: B1903, p. 96-103.

1989, Geologic setting, petrology, and age of Pliocene to Holocene volcanoes of the Stepovak Bay area, western Alaska Peninsula: B1903, p. 84-95.

Winkler, G.R., compiler, 1990, Preliminary geologic map, cross sections, and summary geochronology of the Anchorage quadrangle, southern Alaska: OF 90-83, scale 1:250,000, 2 sheets.

Woods, P.F., 1990, Primary production of Big Lake, south-central Alaska [abs.]: OF 89-409, p. 109.

Yeend, Warren, 1990, Gold placers, geomorphology, and paleo-drainage of Eureka Creek and Tofty areas, Alaska: B1946, p. 107-109.

Yeend, Warren, Ager, T.A., and Kline, J.T., 1989, Stratigraphy and palynology of an Upper Tertiary terrace deposit of the ancestral Yukon River near Circle, Alaska: B1903, p. 6267.

Yeend, Warren, and Shawe, D.R., 1989, Alaska modern placers: U.S. Geological Survey Bulletin 1857-G, p. 7-9.

Yehle, L.A., Schmoll, H.R., and Dobrovolny, Ernest, 1990 , Geologic map of the Anchorage B-8 SE and part of the Anchorage B-8 NE quadrangles, Alaska: OF 90-238, 37 p., scale $1: 25,000,2$ sheets. 


\title{
Reports About Alaska in Non-USGS Publications Released in 1990 That Include USGS Authors
}

\author{
Compiled by Ellen R. White
}

[Some reports dated 1988 and 1989 did not become available until 1990; they are included in this listing. USGS authors are marked by asterisks $(*)]$

\section{ABBREVIATIONS}

AAPG American Association of Petroleum Geologists Bulletin, v. 74, no. 5.

Eos $\quad$ Eos (American Geophysical Union, Transactions), v. 71, no. 43.

GAC Geological Association of Canada, Mineralogical Association of Canada, Annual meeting, Vancouver, British Columbia, Canada, 1990, Program with Abstracts, v. 15

GSA Geological Society of America Abstracts with Programs, v. 22, no. 3.

*Aleinikoff, J.N., *Dusel-Bacon, Cynthia, *Foster, H.L., and *Nokleberg, W.J., 1990, A summary of isotopic constraints on the history of the Yukon-Tanana terrane, eastcentral Alaska: GAC, p. A1.

Anderson, J.B., and *Molnia, B.F., 1989, Glacial-marine sedimentation: American Geophysical Union, Short Course in Geology, v. 9, 127 p. [Has chapters dealing with Gulf of Alaska.]

*Armstrong, A.K., and *Kelley, J.S., 1990, Petrology and reservoir quality of the Katakturuk Dolomite, Arctic National Wildlife Refuge [abs.]: AAPG, p. 600.

*Arth, J.G., Criss, R.E., Zmuda, C.C., *Foley, N.K., *Patton, W.W., Jr., and *Miller, T.P., 1989, Remarkable isotopic and trace element trends in potassic through sodic Cretaceous plutons of the Yukon-Koyukuk basin Alaska, and the nature of the lithosphere beneath the Koyukuk terrane: Journal of Geophysical Research, v. 94, no. B11, p. $15,957-15,968$.

*Arth, J.G., Zmuda, C.C., *Foley, N.K., Criss, R.E., *Patton, W.W., Jr., and *Miller, T.P., 1989, Isotopic and trace element variations in the Ruby batholith, Alaska, and the nature of the deep crust beneath the Ruby and Angayucham terranes: Journal of Geophysical Research, v. 94, no. B11, p. $15,941-15,955$.

*Bacon, C.R., *Foster, H.L., and *Smith, J.G., 1990, Rhyolitic calderas of the Yukon-Tanana terrane, east central Alaska: volcanic remnants of a mid-Cretaceous magmatic arc: Journal of Geophysical Research, v. 95, no. B13, p. 21,451-21,461.

*Barker, Fred, and *Arth, J.G., 1990, Two traverses across the coast batholith, southeastern Alaska, in Anderson, J.L., ed., The nature and origin of Cordilleran magmatism:
Geological Society of America Memoir 174, p. 395-405.

*Barker, Fred, *Plafker, George, *Ayuso, R., and Farmer, G.L., 1990, 50 Ma flysch melt granodiorite of the eastern Gulf of Alaska [abs.]: GSA, p. 5.

*Barnes, D.F., 1990, Gravity, gravity-change, and other geophysical measurements in Glacier Bay National Park and Preserve, in Milner, A.M., and Wood, J.D., Jr., eds., Glacier Bay Science Symposium, 2d, Gustavus, Alaska, 1988, Proceedings, p. 12-18.

1990, Vertical crustal movements along the Gulf of Alaska coastline cause small temporal gravity changes [abs.]: Eos (American Geophysical Union, Transactions), v. 71 , no. 17 , p. 480 .

*Barnes, P.W., and *Reimnitz, Erk, 1990, Ice interaction with the arctic shelf and coast: Constraints on and implications for petroleum development [abs.]: AAPG, p. 605.

Beaudoin, B.C., *Nokleberg, W.J., and *Fuis, G.S., 1990, Intracrustal detachment and terrane accretion: Evidence from the Yukon-Tanana terrane, central Alaska: GAC, p. A8.

*Beyer, L.A., 1990, Borehole gravity surveys in the Cretaceous-Tertiary Sagavanirktok Formation, Kuparuk River oil field, Alaska [abs.]: AAPG, p. 610.

*Bird, K.J., 1990, Barrow Arch: A major structural feature within and adjacent to the northern Cordillera, northern Alaska-northwest Canada: GAC, p. A11.

*Blodgett, R.B., and Rohr, D.M., 1990, Silurian-Devonian gastropod biogeography of Alaska [abs.]: Geological Society of America Abstracts with Programs, v. 22, no. 7, p. A221.

*Blome, C.D., *Nelson, S.W., and *Karl, S.M., 1990, Accretionary history of the chert-rich McHugh complex, south- 
em Alaska [abs.]: Geological Society of America Abstracts with Programs, v. 22, no. 7, p. A-321-322.

Bol, A.J., *Gibbons, Helen, and Roeske, S.M., 1990, Kinematics along the Contact fault in Prince William Sound, Alaska: Orocline Formation coeval with changes in plate motions [abs.]: Eos, p. 1589.

*Box, S.E., *Moll-Stalcup, E.J., Wooden, J.L., and Bradshaw, J.Y., 1990, Kilbuck terrane, southwestern Alaska: Displaced sliver of $2.0-2.1 \mathrm{Ga}$ crust from western Canada?: GAC, p. A13-14.

*Box, S.E., and *Patton, W.W., Jr., 1989, Igneous history of the Koyukuk terrane, western Alaska: Constraints on the origin, evolution and ultimate collision of an accreted island arc terrane: Journal of Geophysical Research, v. 94, no. B11, p. 15,843-15,867.

Boyd, T.M., *Engdahl, E.R., and *Spence, W., 1990, Aftershocks of the 1957 Aleutian Islands earthquake [abs.]: Eos, p. 1469.

*Brew, D.A., 1990, Plate-tectonic setting of Glacier Bay National Park and Preserve and of Admiralty Island National Monument, southeastern Alaska, in Milner, A.M., and Wood, J.D., Jr., eds., Glacier Bay Science Symposium, 2d, Gustavus, Alaska, 1988, Proceedings, p. 1-5.

*Brew, D.A., *Ford, A.B., and Himmelberg, G.R., 1989, Evolution of the western part of the coast plutonic-metamorphic complex, south-eastern Alaska, USA: A summary, in Daly, J.S., Cliff, R.A., and Yardley, W.D., eds., Evolution of metamorphic belts: London, England, Blackwell, Geological Society Special Publication 43, p. 447-452.

*Brew, D.A., Himmelberg, G.R., *Douglass, S.L., Zen, E-An, and *Sutter, J.F., 1990, Contrasting metamorphic and emplacement environments of a distinctive $95 \mathrm{Ma}$ plutonic suite, southeastern Alaska [abs.]: GSA, p. 10.

*Brew, D.A., Himmelberg, G.R., *Loney, R.A., and *Ford, A.B., 1990, Styles of metamorphism in the southeastern Alaska part of the Cordilleran orogen [abs.], in Metamorphic styles in young and ancient orogenic belts, International Geological Correlation Program, Project 235 Metamorphism and Geodynamics, Project 304 Lower Crustal Processes, [Meeting in] Calgary, Alberta, Canada, University of Calgary, 1990, Program with Abstracts, p. 20.

*Brew, D.A., *Karl, S.M., *Barnes, D.F., and *Ford, A.B., 1990, A northern Cordilleran transect: Sitka Sound, Alaska, to Lake Atlin, British Columbia: GAC, p. A14.

*Brew, D.A., *Karl, S.M., *Barnes, D.F., *Jachens, R.C., *Ford, A.B., and Horner, Robert, 1990, Sitka Sound, Alaska, to Atlin Lake, British Columbia, Canada: A northern Cordilleran transect [abs.]: Eos, p. 1581.

*Brocher, T.M., and Christensen, N.I., 1990, Seismic anisotropy due to preferred mineral orientation observed in shallow crustal rocks in southern Alaska: Geology, v. 18, no. 8, p. 737-740.

*Brocher, T.M.. *Fisher, M.A., and *Stephens, C.D., 1990, TACT offshore: Results from the 1988 TACT seismic survey in the northern Gulf of Alaska and Prince William Sound [abs.]: Eos, p. 1581.

*Bruns, T.R., *Carlson, P.R., *Stevenson, A.J., *Fisher, M.A., *Ryan, H.F., *Mann, D.M., Dobson, Maxwell, Huggett, Quentin, Parson, Lindsay, and Fannin, N.G.T., 1990, GLORIA mosaic of the Gulf of Alaska and the British Co- lumbia margin: Deep sea channels, margin deformation, and the Queen Charlotte fault [abs.]: AAPG, p. 620.

*Bufe, C.G., Jaumé, S.C., *Nishenko, S.P., Sykes, L.R., and *Varnes, D.J., 1990, Accelerating moment release in the Alaska subduction zone: Precursors to a great thrust earthquake? [abs.]: Eos, p. 1451-1452.

*Cady, J.W., 1989, Geologic implications of topographic, gravity, and aeromagnetic data in the northern Yukon-Koyukuk province and its borderlands, Alaska: Journal of Geophysical Research, v. 94, no. B11, p. 15,821-15,841.

*Carlson, P.R., *Bruns, T.R., *Stevenson, A.J., *Mann, D.M., Huggett, Q., Wormly, U.K., and Dobson, M., 1990, Sedimentary depositional environments in the Gulf of Alaska from GLORIA images [abs.]: AAPG, p. 624.

*Carlson, P.R., Powell, R.D., *Rearic, D.M., and *Quinterno, Paula, 1990, Channel-forming processes active in Queen Inlet, Glacier Bay, Alaska, in Milner, A.M., and Wood, J.D., Jr., eds., Glacier Bay Science Symposium, 2d, Gustavus, Alaska, 1988, Proceedings, p. 41-46.

*Casadevall, T.J., 1990, The 1989-1900 eruption of Redoubt Volcano, Alaska: Impacts on aircraft operations in the vicinity of Anchorage [abs.]: Eos, p. 1700.

*Casadevall, T.J., *Neal, C.A., *McGimsey, R.G., *Doukas, M.P., and *Gardner, C.A., 1990, Emission rates of sulfur dioxide and carbon dioxide from Redoubt Volcano, Alaska during the 1989-1900 eruptions [abs.]: Eos, p. 1686.

${ }^{*}$ Chouet, B.A., *Page, R.A., Davies, J.N., *Power, J.A., *Lahr, J.C., *Harlow, D.H., and *Stephens, C.D., 1990, Forecasting the December 14, 1989 and January 2, 1900 eruptions at Redoubt Volcano, Alaska [abs.]: Eos, p. 1701.

${ }^{*}$ Chouet, B.A., *Power, John, Davies, J.N., *Miller, T.P., *Page, R.A., *Lahr, J.C., *Murray, T.L., *Harlow, D.H., *Endo, E.T., and *Stephens, C.D., 1990, A seismic model for forecasting eruptions at Redoubt Volcano, Alaska [abs.]: Eos (American Geophysical Union, Transactions), v. 71 , no. 28 , p. 954 .

*Church, S.E., *Gaccetta, J.D., and *Delevaux, M.H., 1990, $\mathrm{Pb}$-isotope results from syngenetic and epigenetic vein occurrences and implications for their genesis, YukonTanana terrane, Alaska: GAC, p. A24.

*Clark, S.H.B., and *Poole, F.G., 1989, Stratabound barite ore fields of North America (excluding Arkansas), in de Brodtkorb, M.K., ed., Nonmetalliferous stratabound ore fields: New York, Van Nostrand, p. 93-117 [Alaska: p. 97-99; [western] Canada: p. 99-102].

Clough, J.G., Robinson, M.S., Pessel, G.H., Imm, T.A., *Blodgett, R.B., *Harris, A.G., Bergman, S.C., and Foland, K.A., 1990, Geology and age of Franklinian and older rocks in the Sadlerochit and Shublik Mountains, Arctic National Wildlife Refuge, Alaska: GAC, p. A25.

Coe, R.S., Bol, A.J., *Grommé, C.S., and *Hillhouse, J.W., 1990, Early Eocene location and orientation of the KulaFarallon Ridge: Paleomagnetic results from the Resurrection Peninsula, Alaska [abs.]: Eos, p. 1589.

*Collett, T.S., 1990, Potential geologic hazards of Arctic gas hydrates [abs.]: AAPG, p. 631-632.

*Collett, T.S., *Kvenvolden, K.A., and *Magoon, L.B., 1990, Characterization of hydrocarbon gas within the stratigraphic interval of gas-hydrate stability on the North 
Slope of Alaska, U.S.A.: Applied Geochemistry, v. 5, no. 3, p. 279-287.

Crowe, D.E., *Nelson, Steven, Brown, Philip, and Shanks, W.C., III, 1988, Stable isotope and fluid inclusion investigation of massive sulfide deposits, Orca and Valdez Groups, Alaska: Evidence from syngenetic sulfide deposition [abs.]: Fluid Inclusion Research, v. 21, p. 85. [Also in Geological Society of America Abstracts with Programs, v. 20, p. 153.]

Davies, J.N., and *Miller, T.P., 1990, Monitoring and forecasting the 1989-1990 eruption of Redoubt Volcano and the role of the Alaska Volcano Observatory in communicating warnings to the public [abs.]: Eos, p. 1700.

Davies, J.N., *Miller, T.P., *Power, J.A., and Forbes, R.B., 1990, The Alaska Volcano Observatory-A multisite, multiagency consortium for volcano monitoring and research [abs.]: Eos, p. 1709.

${ }^{*}$ Dean, W.E., *Gardner, J.V., and *Hemphill-Haley, Eileen, 1989, Changes in redox conditions in deep-sea sediments of the subarctic north Pacific Ocean: Possible evidence for the presence of North Pacific deep water: Paleoceanography, v. 4 , no. 6 , p. $639-653$.

*Dinter, D.A., *Carter, L.D., and Brigham-Grette, Julie, 1990, Late Cenozoic geologic evolution of the Alaskan North Slope and adjacent continental shelves, in Grantz, Arthur, Johnson, L., and Sweeney, J.F., eds., The Arctic Ocean regions: Boulder, Colorado, Geological Society of America, The Geology of North America, DNAG Series, v. L, p. $459-487$.

*Doukas, M.P., *Murray, T.L., *Wieprecht, D., and *Dzurisin, D., 1990, A combination video/35mm time-lapse system for recording visual changes of the lava dome at Redoubt Volcano [abs.]: Eos, p. 1710.

*Dover, J.H., 1990, Parauthochthonous geologic framework of east-central Alaska: GAC, p. A34.

*Drew, L.J., and *Brew, D.A., 1990, Using mineral deposit models to assess the undiscovered mineral resources of the Tongass National Forest, southeastern Alaska [abs.], in IAGOD [International Association on the Genesis of Ore Deposits] Symposium, 8th, Ottawa, Ontario, Canada, 1990, Program with Abstracts, p. A229.

*Dumoulin, J.A., and *Harris, A.G., 1990, Devonian-Mississippian carbonate sequence in the Maiyumerak Mountains, western Brooks Range, Alaska [abs.]: AAPG, p. 645-646.

*Dusel-Bacon, Cynthia, and *Douglass, S.L., 1990, New thermobarometric evidence for high pressure, medium temperature metamorphism of two subterranes of the Yukon-Tanana composite terrane (YTT) in easternmost Alaska: GAC, p. A35.

Eichelberger, J.C., Ballard, S., Carrigan, C.R., Goodliffe, A., *Hildreth, W., *Iwatsubo, E., Kasameyer, P.W., *Keith, T.E.C., Kienle, J., Papike, J.J., Pollard, D.D., Stone, D.B., Wallmann, P.C., *Ward, P.L., Wilt, M., and *Yount, M.E., 1990, Geophysics at Katmai; geophysical expedition to Novarupta Volcano, Katmai Natinal Park, Alaska: Eos (American Geophysical Union, Transactions), v. 71, no. 22, p. 733-735.

Eichelberger, J.C., *Neal, C.A., *Paskievitch, J.F., Papike, J.J., and ${ }^{*}$ Hildreth, W., 1990, Geophysical expedition to Novarupta II [abs.]: Eos, p. 1690.
Ekström, Göran, and *Engdahl, E.R., 1989, Earthquake source parameters and stress distribution in the Adak Island region of the central Aleutian Islands, Alaska: Journal of Geophysical Research, v. 94, no. B11, p. 15,499-15,519.

*Engdahl, E.R., Billington, S., and Kisslinger, C., 1989, Teleseismically recorded seismicity before and after the May 7, 1986, Andreanof Islands, Alaska, earthquake: Journal of Geophysical Research, v. 94, no. B11, p. $15,481-15,498$.

*Ferrians, O.J., Jr., *Nichols, D.R., and Williams, J.R., 1989, Copper River basin, in American Geophysical Union, Field Trip Guidebook T102, p. 39-43. [International Geological Congress, 28th, Washington, D.C., 1989.]

*Fierstein, Judy, and *Hildreth, Wes, 1990, Contemporaneity of pyroclastic flows and falls; evidence from the eruption of Novarupta (Alaska) in 1912 [abs.]: Eos, p. 1690.

Flueh, E.R., *Mooney, W.D., *Fuis, G.S., and *Ambos, E.L., 1989, Crustal structure of the Chugach Mountains, southern Alaska: A study of peg-leg multiples from a low-velocity zone: Journal of Geophysical Research, v. 94, no. B11, p. 16,023-16,035.

*Ford, A.B., *Brew, D.A., and *Koch, R.D., 1990, Alkalic plutonism of the Sitkoh Bay area (Chichagof Island), SE Alaska-Perplexities of age relations [abs.]: Eos, p. 1699.

*Forester, R.M., Delorme, L.D., and *Ager, T.A., 1989, A lacustrine record of late Holocene climate change from south-central Alaska, in Peterson, D.H., ed., Aspects of climate variability in the Pacific and the western Americas: American Geophysical Union, Geophysical Monograph 55, p. $33-40$.

*Fuis, G.S., and Clowes, R.M., 1990, A comparison of deep structure around the western margin of the North American Cordillera: Southern Alaska, Vancouver Island, and California [abs.]: Eos, p. 1582.

${ }^{*}$ Gardner, C.A., *Waitt, R.B., and *Neal, C.A., 1990, Stratigraphy of proximal pyroclastic deposits from the eruption of Redoubt Volcano, Alaska, December 14, 1989-April 21, 1990 [abs.]: Eos, p. 1706.

${ }^{*}$ Gerlach, T.M., Westrich, H.R., and ${ }^{*}$ Casadevall, T.J., 1990, High sulfur and chlorine magma during the 1989-90 eruption of Redoubt Volcano, Alaska [abs.]: Eos, p. 1702.

*Goldfarb, R.J., *Gent, C.A., *Gray, J.E., *Miller, M.L., and *Pickthorn, W.J., 1990, Oxygen, hydrogen, and sulfur isotope studies of $\mathrm{Hg}-\mathrm{Sb}$ epithermal systems, southwestern Alaska: GAC, p. A48.

*Goldfarb, R.J., *Hofstra, A.H., ${ }^{*}$ Landis, G.P., and *Leach, D.L., 1988, H2S-rich vein-forming fluids at the Sumdum Chief gold mine, southeastern Alaska [abs.]: Fluid Inclusion Research, v. 21, p. 130. [Also in U.S. Geological Survey Circular 1016, p. 160-163.]

*Goldfarb, R.J., *Leach, D.L., and *Pickthorn, W.J., 1988, Application of fluid inclusion and stable isotope techniques of Tertiary mesothermal gold deposits, southern Alaska, USA [abs.]: Fluid Inclusion Research v. 21, p. 130. [Also in Bicentennial Gold 88, Geological Society of Australia, Abstracts, Series 23, p. 430-441.]

Goodwin, E.B., *Fuis, G.S., *Nokleberg, W.J., and *Ambos, E.L., 1989, The crustal structure of the Wrangellia terrane along the east Glenn Highway, eastern-southern Alaska: Journal of Geophysical Research, v. 94, no. B11, p. 
16,037-16,057.

Gottschalk, R.R., and Avé Lallemant, H.G., Oldow, J.S., and *Snee, L.W., $1990,{ }^{40} \mathrm{Ar} /{ }^{39} \mathrm{Ar}$ thermochronology of metamorphic rocks in the south-central Brooks Range fold and thrust belt, Alaska [abs.]: Geological Society of America Abstracts with Programs, v. 22, no. 7, p. A-326.

*Grantz, Arthur, 1990, Preliminary results and logistic implications of a geological and geophysical icebreaker cruise to the Northwind Ridge, Arctic Ocean basin: Arctic research, advances and prospects, Conference of Arctic and Nordic Countries on Coordination of Research in the Arctic, Leningrad, 1988, Proceedings: Moscow, USSR, "Nauka", Pt. I, p. 343-345.

*Grantz, Arthur, *May, S.D., and *Hart, P.E., 1990, Geology of the Arctic continental margin of Alaska, in Grantz, Arthur, Johnson, L., and Sweeney, J.F., eds., The Arctic Ocean regions: Boulder, Colorado, Geological Society of America, The Geology of North America, DNAG Series, v. L, p. 257-288, pls. 1, 8, 9, and 11 .

*Grantz, Arthur, Johnson, L., and Sweeney, J.F., eds., 1990, The Arctic Ocean regions: Boulder, Colorado, Geological Society of America, The Geology of North America, DNAG Series, v. L, 644 p., 3 microfiches, 11 pls.

*Hamilton, T.D., 1990, Late Cenozoic glaciation of northern Alaska: Arctic research, advances and prospects, Conference of Arctic and Nordic Countries on Coordination of Research in the Arctic, Leningrad, 1988, Proceedings: Moscow, USSR, "Nauka", Pt. II, p. 55-56.

*Hampton, M.A., 1989, Geotechnical properties of sediment on the Kodiak continental shelf and upper slope, Gulf of Alaska: Marine Geotechnology, v. 8, no. 2, p. 159-180.

*Harlow, D.H., *Power, J., *Chouet, B., *Lahr, J.C., and *Page, R.A., 1990, Earthquake families and their implications for the eruption dynamcis of Redoubt Volcano, Alaska: December 13, 1989 to January 3, 1990 [abs.]: Eos, p. 1701.

*Hein, J.R., Yeh, H.-W., and *Barron, J.A., 1990, Eocene diatom chert from Adak Island, Alaska: Journal of Sedimentary Petrology, v. 60 , no. 2 , p. 250-257.

*Hildreth, Wes, 1990, The Katmai eruption of 1912: Was the magma stored beneath Novarupta, Trident, or Mount Katmai? Petrochemical temporal evidence [abs.]: Eos, p. 1691.

*Hoblitt, R.P., and *Murray, T.L., 1990, Lightning detection and location as a remote eruption monitor at Redoubt Volcano, Alaska [abs.]: Eos, p. 1701.

Houston, Heidi, and *Engdahl, E.R., 1989, A comparison of the spatio-temporal distribution of moment release for the 1986 Andreanof Islands earthquake with relocated seismicity: Geophysical Research Letters, v. 16, no. 12, p. 1421-1424.

*Howell, D.G., *Johnsson, M.J., and *Bird, K.J., 1990, Geodynamics and petroleum potential, Brooks Range, Alaska: GAC, p. A61.

*Howell, D.G., *Johnsson, M.J., Underwood, M.B., Brocculeri, T., and Lu, H., 1990, Deformational style of the Kandik area, east-central Alaska: Evidence from stratigraphic, structural, and paleothermal relations [abs.]: Eos, p. 1617.

*Janda, R.J., *Major, J.J., *Pierson, T.C., *Waitt, R.B., Jr., and *Miller, T.P., 1990, Downstream changes in 1989-90 de- bris flows and floods from glacier-clad Redoubt Volcano, Alaska [abs.]: Eos, p. 1706.

*Johnson, M.J., *Bird, K.J., *Howell, D.G., *Magoon, L.B., *Stanley, R.G., *Valin, Z.C., *Harris, A.G., and *Pawlewicz, M.J., 1990, Preliminary thermal maturity map of sedimentary rocks in Alaska [abs.]: Eos, p. 1617.

*Johnson, M.J., *Howell, D.G., and *Bird, K.J., 1990, Petrography of Early Cretaceous sandstones of the Kandik basin: Implications for paleogeography of northern Alaska [abs.]: Geological Society of America Abstracts with Programs, v. 22 , no. 7, p. A-325-326.

*Jones, J.E., *Molnia, B.F., *Schoonmaker, J.W., Jr., 1990, The Malaspina Glacier radar study-A SLAR investigation of glacial and periglacial features, in Milner, A.M. and Wood, J.D., Jr., eds., Glacier Bay Science Symposium, 2d, Gustavus, Alaska, 1988, Proceedings, p. 34-40

*Jones, J.E., *Molnia, B.F., *Schoonmaker, J.W., Jr., Taylor, T.E., and *Krimmel, R.M., 1989, Radar mapping of glaciers for global change investigations [abs.], in Global change, Arctic Science Conference, 40th, Fairbanks, Alaska, University of Alaska, 1989, Proceedings: American Association for the Advancement of Science, Arctic Division, p. 23.

Kamata, Hiroki, and *Waitt, R.B., 1990, Volcanic-hazards assessment of Augustine Volcano in the Aleutian Island arc, U.S.A.-A case study of the 1976 eruption [abs.]: Eos (American Geophysical Union, Transactions), v. 71, no. 28, p. 960.

*Karl, S.M., and *Long, C.L., 1990, Folded Brookian thrust faults: Implications of three geologic/geophysical transects in the western Brooks Range, Alaska: Journal of Geophysical Research, v. 95, no. B6, p. $8581-8592$.

Kaufman, D.S., Farmer, G.L., Miller, G.H., *Carter, L.D., and Brigham-Grette, J., 1990, Strontium isotope dating of upper Cenozoic marine deposits, northwestern Alaska [abs.]: AAPG, p. 692.

*Keith, T.E.C., *Thompson, J.M., Hutchinson, R.A., *White, L.D., and *Nathenson, M., 1990, Geochemistry of streams and springs, Valley of Ten Thousand Smokes, Katmai National Park, Alaska [abs.]: Eos, p. 1691.

${ }^{*}$ Kirschner, C.E., and *Grantz, Arthur, 1990, Impact origin of the Avak structure, Arctic Alaska, and genesis of the Barrow gas field [abs.]: AAPG, p. 696.

Krumhardt, A.P., and *Harris, A.G., 1990, Conodont biostratigraphy and biofacies of the Wahoo Limestone (Carboniferous), Sadlerochit Mountains, northeast Brooks Range, Alaska [abs.]: AAPG, p. 698.

1990 , Conodont biostratigraphy and biofacies of the Wahoo Limestone (Carboniferous), Sadlerochit Mountains, northeast Brooks Range, Alaska [abs.]: Geological Society of America, South-Central Section, Abstracts with Program, v. 22, no. 1, p. 12.

Kusky, T.M., and *Bradley, D.C., 1990, Kinematics of late structures in melange of the McHugh complex, Kenai Peninsula, Alaska [abs.]: Eos, p. 1590.

*Kvenvolden, K.A., and *Grantz, Arthur, 1990, Gas hydrates of the Arctic Ocean region, in Grantz, Arthur, Johnson, L., and Sweeney, J.F., eds., The Arctic Ocean regions: Boulder, Colorado, Geological Society of America, The Geology of North America, DNAG Series, v. L, p. 539-549. 
*Lahr, J.C., *Power, J., *Harlow, D.H., and *Page, R.A., 1990, Spatial and termporal distribution of seismicity associated with the recent eruption of Redoubt Volcano, Alaska [abs.]: Eos, p. 1709.

Lange, I.M., *Nokleberg, W.J., Newkirk, S.R., *Aleinikoff, J.N., *Church, S.E., and Krouse, H.R., 1990, Metallogenesis of Devonian volcanogenic massive sulfide deposits and occurrences, southern Yukon-Tanana terrane, eastern Alaska Range, Alaska, in Pacific Rim Congress 90, Gold Coast, Queensland, Australia, 1990: Parkville, Victoria, Australia, Australasian Institute of Mining and Metallurgy, v. 2, p. 443-450.

Levander, A.R., *Fuis, G.S., *Criley, E.E., *Kohler, W.M., *Mooney, W.D., Asudeh, I., Fowler, J.C., and Henrys, S.A., 1990, The 1990 seismic survey of the Brooks Range, arctic Alaska [abs.]: Eos, p. 1589.

*Loney, R.A., and *Himmelberg, G.R., 1989, The Kanuti ophiolite, Alaska: Journal of Geophysical Research, v. 94, no. B11, p. $15,869-15,900$.

Lu, Huang, *Howell, D.G., and *Bird, K.J., 1990, Post-Albian duplex faulting along the Brooks Range front, Atigun Gorge, Alaska North Slope [abs.]: Eos, p. 1589-1590.

*Magoon, L.B., and *Anders, D.E., 1990, Oil-source rock correlation using carbon isotope data and biological marker compounds, Cook Inlet, Alaska Peninsula, Alaska [abs.]: AAPG, p. 711.

*Major, J.J., and *Janda, R.J., 1990, Channel instability induced by debris flows and floods during the 1989-90 eruptions of Redoubt Volcano, Alaska [abs.]: Eos, p. 1706.

*Major, J., *Janda, R., *Pierson, T., *Waitt, R., *LaHusen, R., *Scott, W., *Trabant, D., *Brabets, T., and *Miller, T., 1990 , Debris flows and floods generated by eruption of Redoubt Volcano, Alaska: Consequences of interaction between snow and ice and volcanic debris [abs.]: Geological Society of America Abstracts with Programs, v. 22, no. 7, p. A-55.

March, G.D., *Power, J., *Harlow, D.H., and *Lahr, J.C., 1990, Aquisition, processing, storage, and display of seismic data during the 1989-90 eruption of Redoubt Volcano, Alaska [abs.]: Eos, p. 1709.

*Marincovich, Louie, Jr., 1990, Molluscan evidence for early middle Miocene marine glaciation in southern Alaska: Geological Society of America Bulletin, v. 102, no. 11, p. 1591-1599. [Includes areas in southeastern Alaska.]

*Marincovich, Louie, Jr., *Brouwers, E.M., Hopkins, D.M., and McKenna, M.C., 1990, Late Mesozoic and Cenozoic paleogeographic and paleoclimatic history of the Arctic Ocean Basin, based on shallow-water marine faunas and terrestrial vertebrates, in Grantz, Arthur, Johnson, L., and Sweeney, J.F. eds., The Arctic Ocean regions: Boulder, Colorado, Geological Society of America, The Geology of North America, DNAG Series, v. L, p. 403-426. [Includes section on northern Alaska.]

*Marlow, M.S., *Cooper, A.K., *Dadisman, S.V., *Geist, E.L., and ${ }^{*}$ Carlson, P.R., 1990, Bowers swell: Evidence for a zone of compressive deformation concentric with Bowers Ridge, Bering Sea: Marine and Petroleum Geology, v. 7, no. 4, p. 398-409.

*May, S.D., and *Grantz, Arthur, 1990, Sediment thickness in the southern Canada basin: Marine Geology, v. 93, no. 1/
4, p. 331-347.

*McGimsey, R.G., and *Gardner, C.A., 1990, Tephra from the 1989-90 eruption of Redoubt Volcano, Alaska: What will be preserved in the geologic record? [abs.]: Eos, p. 1707.

*Miller, M.L., *Bradshaw, J.Y., Kimbrough, D.L., and *Stern, T.W., 1990, $2.06 \mathrm{Ga}$ rocks of the Idono complex-westcentral Alaska: GAC, p. A88.

*Miller, T.P., 1989, Contrasting plutonic rock suites of the Yukon-Koyukuk basin and the Ruby geanticline, Alaska: Journal of Geophysical Research, v. 94, no. B11, p. 15,969-15,987.

*Miller, T.P., and Davies, J.N., 1990, The 1989-90 eruption of Redoubt Volcano: A chronological summary of events and effects [abs.]: Eos, p. 1700.

${ }^{*}$ Miller, T.P., *Waitt, R.B., and ${ }^{*}$ Gardner, C.A., 1990, Episodic dome growth and destruction, Redoubt Volcano, 1989-90 [abs.]: Eos, p. 1705.

*Molenaar, C.M., *Bird, K.J., and *Magoon, L.B., 1990, Petroleum geology of the coastal plain of the Arctic National Wildlife Refuge, northeastern Alaska [abs.]: AAPG, p. 723.

*Moll-Stalcup, Elizabeth, and *Arth, J.G., 1989, The nature of the crust in the Yukon-Koyukuk province as inferred from the chemical and isotopic composition of five Late Cretaceous to Early Tertiary volcanic fields in westem Alaska: Journal of Geophysical Research, v. 94, no. B11, p. 15,989-16,020.

*Moll-Stalcup, E.J., *Wooden, J.L., *Bradshaw, J.Y., and *Box, S.E., 1990, A Sr, Nd, and Pb isotopic study of 2.07 Ga metaigneous rocks from the Kilbuck terrane, southwestern Alaska [abs.]: GAC, p. A89.

*Molnia, B.F., 1990, Neoglacial history of the Malaspina Glacier, Alaska-inferences from two types of radar analyses [abs.]: Geological Society of America Abstracts with Programs, v. 22, no. 7, p. A-177-178.

*Molnia, B.F., and *Jones, J.E., 1990, Radar remote sensing of glacial features, Malaspina Glacier, Alaska [abs.]: AAPG, p. 723.

*Molnia, B.F., *Trabant, D.C., *Post, Austin, and FrankMolnia, D.G., 1990, Bering Glacier, Alaska: Factors influencing the potential for an irreversible calving retreat [abs.]: Eos, p. 1314.

*Moore, T.E., Wallace, W.K., *Bird, K.J., *Karl, S.M., and Mull, C.G., 1990, Paleozoic and Mesozoic history of northern Alaska: GAC, p. A90.

*Murray, T.L., *Power, J., and *Endo, E.T., 1990 Applications of a real-time seismic amplitude measurement system (RSAM) during the 1989-1990 eruption of Redoubt Volcano, Alaska [abs.]: Eos, p. 1709.

*Neal, C.A., *Gardner, C.A., *Waitt, R.B., and *Miller, T.P., Characteristics of proximal pyroclastic deposits from the eruption of Redoubt Volcano, Alaska, January 2, 1990April 21, 1990 [abs.]: Eos, p. 1706.

*Nelson, S.W., 1989, Geology along the Copper Trail: Alaska Geographic, v. 16, no. 4, p. 19-22.

Newberry, R.J., and *Brew, D.A., 1988, Geology and geochemistry of the Alaska-Juneau (AJ) mine area, Juneau, Alaska [abs.]: Fluid Inclusion Research, v. 21, p. 270271. [Also in Schafer, R.W., and others, eds., 1987, Bulk mineable precious metal deposits of the western United 
States, Symposium, Proceedings: Reno, Nevada, Geological Society of Nevada, p. 741.]

*Newberry, R.J., *Brew, D.A., and Crafford, T.C., 1990, Genesis of the Greens Creek (GC) volcanogenic massive sulfide (VMS) deposit, S.E. Alaska: A geochemical study: GAC, p. A96.

*Nishenko, S.P., and Jacob, K.H., 1990, Seismic potential of the Queen Charlotte-Alaska-Aleutian seismic zone: Journal of Geophysical Research, v. 95, no. 3, p. 2511-2532.

*Nokleberg, W.J., *Dusel-Bacon, Cynthia, *Lanphere, M.A., *Aleinikoff, J.N., and *Labson, V.F., 1990, Structure and tectonics of the Yukon-Tanana, southern Wickersham, and Seventymile terranes along the Trans-Alaska Transect (TACT), east-central Alaska: GAC, p. A97.

Nye, C.J., Swanson, S.E., and *Miller, T.P., 1990, The 19891990 eruption of Mt. Redoubt-magma chemistry [abs.]: Eos, p. 1705.

*Page, R.A., 1989, Introduction to special section on the northern Chugach Mountains-southern Copper River basin segment of the Alaskan transect, Part 2: Journal of Geophysical Research, v. 94, no. B11, p. 16,021.

*Page, R.A., *Stephens, C.D., and *Lahr, J.C., 1989, Seismicity of the Wrangell and Aleutian Wadati-Benioff zones and the North American plate along the trans-Alaska crustal transect, Chugach Mountains and Copper River basin, southern Alaska: Journal of Geophysical Research, v. 94 , no. B11, p. $16,059-16,082$.

*Pallister, J.S., *Budahn, J.R., and *Murchey, B.L., 1989, Pillow basalts of the Angayucham terrane: Oceanic plateau and island crust accreted to the Brooks Range: Journal of Geophysical Research, v. 94, no. B11, p. 15,901-15,923.

Papike, J.J., Spilde, M.N., Shearer, C.K., Galbreath, K.C., *Keith, T.E.C., and Laul, J.C., 1990, Geochemistry and mineralogy of fumarole deposits, VTTS, Alaska: Bulk chemical and mineralogical evolution of a dacitic fissure fumarole [abs.]: Geological Society of America Abstracts with Programs, v. 22, no. 7, p. A-351-352.

Papike, J.J., Spilde, M.N., Shearer, C.K., and *Keith, T.E.C., 1990, Geochemistry and mineralogy of fumerole deposits, Valley of Ten Thousand Smokes (VTTS), Alaska: Major element mass exchange and trace element enrichment/ depletion systematics [abs.]: Eos, p. 1690-1891.

*Patton, W.W., Jr., and *Box, S.E., 1989, Introduction to special section on the Yukon-Koyukuk basin and its borderlands, western Alaska: Journal of Geophysical Research, v. 94 , no. B11, p. $15,805-15,806$.

1989. Tectonic setting of the Yukon-Koyukuk basin and its borderlands, western Alaska: Journal of Geophysical Research, v. 94 , no. B11, p. $15,807-15,820$.

*Pierson, T.C., and *Janda, R.J., 1990, A previously unrecognized type of proximal pyroclastic deposit at snow- and ice-covered volcanoes [abs.]: Geological Society of America Abstracts with Programs, v. 22, no. 7, p. A-55. [Mt. St. Helens, Nevado del Ruiz, and Redoubt.]

*Plafker, George, 1990, Regional geology and tectonic evolution of Alaska and adjacent parts of the northeast Pacific Ocean margin, in Pacific Rim Congress 90, Gold Coast, Queensland, Australia, 1990: Parkville, Victoria, Australia, Australasian Institute of Mining and Metallurgy, v. 3, p. 841-858.
1990, Regional vertical tectonic displacement of shorelines in south-central Alaska during and between great earthquakes: Northwest Science, v. 64, no. 5, p. 250-258.

*Power, J., Davies, J.N., *Page, R.A., *Lahr, J.C., *Harlow, D.H., *Chouet, B., March, G.D., and *Murray, T.L., 1990, Seismic evolution of the 1989-1990 eruption of Redoubt Volcano, Alaska [abs.]: Eos, p. 1700-1701.

*Rearic, D.M., *Barnes, P.W., and *Reimnitz, Erk, 1990, Bulldozing and resuspension of shallow-shelf sediment by ice keels: Implications for Arctic sediment transport trajectories: Marine Geology, v. 91, no. 1/2, p. 133-147. [5-year study at Harrison Bay.]

*Reed, B.L., *Menzie, W.D., McDermott, M., and *Drew, L.J., 1989, Undiscovered lode tin resources of the Seward Peninsula, Alaska: Economic Geology, v. 84, no. 7, p. 19361947.

Reger, R.D., and *Updike, R.G., 1989, Upper Cook Inlet region and Matanuska valley, in American Geophysical Union, Field Trip Guidebook T102, p. 45-54. [International Geological Congress, 28th, Washington, D.C., 1989.]

*Repenning, C.A., 1990, Of mice and ice in the late Pliocene of North America: Arctic [Joumal of the Arctic Institute of North America], v. 43, no. 4, p. 314-323.

*Reynolds, R.L., *Nicholson, A., *Goldhaber, M.B., *Coleman, S.M., King, J.W., *Rice, C.A., *Tuttle, M.L., and *Sherman, D.M., 1990, Diagnosis for greigite $\left(\mathrm{Fe}_{3} \mathrm{~S}_{4}\right.$ in Cretaceous beds, North Slope, Alaska, and Holocene sediments, Lake Michigan [abs.]: Eos, p. 1282-1283.

*Richter, D.H., *Smith, J.G., *Lanphere, M.A., *Dalrymple, G.B., *Reed, B.L., and *Shew, Nora, 1990, Age and progression of volcanism, Wrangell volcanic field, Alaska: Bulletin of Volcanology, v. 53. no. 1, p. 29-44.

*Riehle, J.R., Bowers, P.M., and *Ager, T.A., 1990, The Hayes tephra deposits, an upper Holocene marker horizon in south-central Alaska: Quaternary Research, v. 33, no. 3, p. 276-290.

Roeske, S.M., *Dusel-Bacon, Cynthia, and *Douglass, S.L., 1990, Cretaceous deformation and metamorphism in the southwest Ruby terrane, Alaska: GAC, p. A113.

Rohr, D.M., and *Blodgett, R.B., 1990, Ordovician gastropod biogeography of Alaska [abs.]: Geological Society of America Abstracts with Programs, v. 22, no. 7, p. A-221.

*Rose, S.C., *Pickthom, W.J., and *Goldfarb, R.J., 1988, Gold mineralization by metamorphic fluids in the Chandalar district, southern Brooks Range-fluid inclusion and oxygen-isotopic evidence [abs.]: Fluid Inclusion Research, v. 21, p. 328-329. [Also in U.S. Geological Survey Circular 1016$, p. $81-84$.

Sauber, J., Clark, T., Ma, C., *Lisowski, M., and Bell, L.J., 1990, Tectonic implications of the 1987-1988 Gulf of Alaska earthquakes [abs.]: Eos, p. 1480-1481.

*Scholl, D.W., and *Stevenson, A.J., 1990, Regional factors affecting petroleum potential of the Aleutian accretionary prism [abs.]: AAPG, p. 758.

*Scott, W.E., and *McGimsey, R.G., 1990, Tephra falls of the 1989-1990 eruption of Redoubt Volcano, Alaska [abs.]: Eos, p. 1707-1708.

Sisson, V.B., Pavlis, T.L., and *Dusel-Bacon, Cynthia, 1990, Metamorphic constraints on Cretaceous crustal extension 
in the Yukon crystalline terrane, east-central Alaska: GAC, p. A122.

*Stanley, W.D., *Labson, V.F., *Nokleberg, W.J., *Csejtey, Béla, Jr., and *Fisher, M.A., 1990, The Denali fault system and Alaska Range of Alaska: Evidence for underplated Mesozoic flysch from magnetotelluric surveys: Geological Society of America Bulletin, v. 102, no. 2, p. $160-173$.

*Stephens, C.D., *Marso, J.N., *Lahr, J.C., and *Rogers, J.A., 1990 , Realtime seismic spectral amplitude monitoring during the 1989-1990 eruptions of Redoubt Volcano, Alaska [abs.]: Eos, p. 1709.

*Stephens, C.D., *Page, R.A., and *Lahr, J.C., 1990, Reflected and mode-converted seismic waves within the shallow Aleutian subduction zone, southern Kenai Peninsula, Alaska: Journal of Geophysical Research, v. 95, no. B5, p. 6883-6897.

Stephens, G.C., Evenson, E.B., and *Detra, D.E., 1990, A geochemical sampling technique for use in areas of active alpine glaciation: An application from the central Alaska Range: Journal of Geochemical Exploration, v. 37, no. 3, p. 301-321.

*Stevenson, A.J., Underwood, M.B., *Scholl, D.W., and *Vallier, T.L., 1990, Sedimentation in the central segment of the Aleutian trench: Sources, transport, and depositional style [abs.]: AAPG, p. 771-772.

*Sutley, S.J., *Goldfarb, R.J., *O'Leary, R.M., and *Tripp, R.B., 1990, A comparison of geochemical exploration techniques and sample media within accretionary continental margins: An example from the Pacific Border Ranges, southern Alaska, U.S.A.: Journal of Geochemical Exploration, v. 37, no. 2, p. 255-275.

Swanson, S.E., *Miller, T.P., and Nye, C.J., 1990, Petrogenesis of lavas from the 1989-90 eruption of Mt. Redoubt [abs.]: Eos, p. 1705.

Symonds, R.B., Rose, W.I., Gerlach, T.M., *Briggs, P.H., and Harmon, R.S., 1990, Evaluation of gases, condensates, and $\mathrm{SO}_{2}$ emissions from Augustine volcano, Alaska: The degassing of a Cl-rich volcanic system: Bulletin of Volcanology, v. 52, no. 5 , p. $355-374$.

*Till, A.B., 1990, Proterozoic and Mesozoic metamorphic events in the western Brooks Range: GAC, p. A131.

*Till, A.B., *Dumoulin, J.A., *Nelson, S.W., and *Schmidt, J.M., 1990, Transect across Proterozoic to middle Paleozoic rocks in the metamorphic core of the western Brooks Range: GAC, p. A131.

*Trabant, D.C., and *Brabets, T.P., 1990, Estimates of the snow and ice volume directly influenced by the 1989-90 eruption of Redoubt Volcano [abs.]: Eos, p. 1705.

*Tripp, R.B., and *Nishi, J.M., 1989, Evidence for secondary growth of placer gold in a stream environment [abs.], in Bundtzen, T.K., ed., Placer mining in today's world, Annual Conference on Placer Mining, 11 th, Fairbanks, Alaska, 1989, Proceedings, p. 75.

*von Huene, Roland, 1989, Continental margins around the Gulf of Alaska, in Winterer, E.L., Hussong, D.M., and Decker, R.W., eds., 1989, The eastern Pacific Ocean and Hawaii: Boulder, Colorado, Geological Society of America, The Geology of North America, DNAG Series, v. N, p. 383-401.

*Waitt, R.B., *Gardner, C.A., *Janda, R.J., *Miller, T.P., *Major, J.J., *Pierson, T.C., *Neal, C.A., and *Vallance, J.W., 1990, Unusual ice conglomerate emplaced during the 15 December 1989 eruption of Redoubt Volcano, Alaska [abs.]: Eos, p. 1706.

*Waitt, R.B., *Major, J.J., *Miller, T.P., and *Trabant, D.C., 1990, Effects of eruptions of Redoubt Volcano, Alaska between December 1989 and April 1990 on Drift Glacier [abs.]: Eos, p. 1705.

Wallman, P.C., Pollard, D.D., *Hildreth, Wes, and Eichelberger, J.C., 1990, New structural limits on magma chamber locations at the Valley of Ten Thousand Smokes, Katmai National Park, Alaska: Geology, v. 18, no. 12, p. 1240-1243. [Cover is a color airphoto of Novarupta and vicinity.]

*Ward, P.L., and *Pitt, A.M., 1990, $A P$ and $S$ travel-time delay under Trident Volcano, Katmai National Park, Alaska [abs.]: Eos, p. 1691.

*Weber, F.R., 1990, Correlation across the western part of the Tintina fault system and their implications for displacement history: GAC, p. A138. [Yukon-Tanana Upland.]

*Wiley, T.J., 1988, Deformed Mesozoic basins of east-central Alaska [abs.], in Howell, D.G., and Wiley, T.J., eds., International Tectonostratigraphic Terrane Conference, 4th, Nan-Ching, China, 1988, Provisional [abstracts and papers], p. 118-119.

*Yeend, Warren, 1989, Highlights of the placer geology of the Circle mining district, east-central Alaska, in Bundtzen, T.K., ed., Placer mining in today's world, Annual Conference on Placer Mining, 11th, Fairbanks, Alaska, 1989, Proceedings, p. 69-74.

Zullo, V.A., and *Marincovich, Louie, Jr., 1990, Balanoid barnacles from the Miocene of the Alaska Peninsula, and their relevance to the extant boreal barnacle fauna: Journal of Paleontology, v. 64, no. 1, p. 128-135. 


\section{Anchorage}

U.S. Geological Survey 4200 University Drive

Anchorage, AK 99508-4667

Bradley, Dwight C.

Carter, L. David

DuBois, Gregory D.

Karl, Susan M.

McGimsey, Robert G.

Miller, Thomas P.

Richter, Donald H.

\section{Denver}

U.S. Geological Survey, MS-

Box 25046 Denver Federal Center

Lakewood, CO 80225-0046

Affolter, Ronald H. MS-972

Antweiler, Robert C. MS-408

Cathrall, John B. MS-973

Dickinson, Kendell A. MS-939

Flores, Romeo M. MS-972

Goldfarb, Richard J. MS-973

Gray, John E. MS-973

Kilburn, James E. MS-973

Labson, Victor F. MS-964

Long, Carl L. MS-964

Roberts, Stephen B. MS-972

Sampson, Jay A. MS-964

Skipp, Gary L. MS-916

Snee, Lawrence W. MS-905

Stricker, Gary D. MS-972

\section{Menlo Park}

U.S. Geological Survey, MS345 Middlefield Road Menlo Park, CA 94025-3591

Csejtey, Béla, Jr. MS-904 Bird, Kenneth J. MS-999

Elder, William P. MS-915

Galloway, John P. MS-904

Hillhouse, John W. MS-937

Howell, David G. MS-902

Huebner, Mark MS-434

Johnsson, Mark J. $\quad$ MS-999

Marinkovich, Louie, Jr. MS-915

McLean, Hugh $\quad$ MS-999

Sliter, William V. MS-915

Stanley, Richard G. $\quad$ MS-999

White, Ellen R. MS-955

Wiley, Thomas J. MS-999

Yeend, Warren MS-904

\section{Reston}

U.S. Geological Survey

National Center, MS-

12201 Sunrise Valley Drive

Reston, VA 22092-0001

Blodgett, Robert B. MS-970

Harris, Anita G. MS-970

\section{Spokane}

U.S. Geological Survey

West 920 Riverside Avenue, Room 656

Spokane, WA 99201-1087

Box, Steven E.

Outside

Byrne, Tim

Department of Geology and Geophysics

University of Connecticut

Storrs, CT 06269-2045

Clendenen, William S.

Exxon Production Research Co.

P.O. Box 2189, ST-4143

Houston, TX 77252-2189

Clough, James G.

State of Alaska, Division of Geological and Geophysical Surveys

794 University Avenue, Suite 200

Fairbanks, AK 99709-3645

Dijkmans, Jos W.A.

Rijksuniversiteit Utrecht

Instituut voor Ruimtelijk Onderzoek

Heidelberglann 2

Postbus 80.115

3508 TC Utrecht

The Netherlands

Huafu, Lu

Department of Earth Sciences

Nanjing University

Nanjing 210008

Peoples Republic of China

Kusky, Timothy $\mathrm{M}$.

Department of Geosciences

University of Houston

Houston, TX 77204-5503 


\section{Outside (Continued)}

Lipkin, Robert

Alaska Natural Heritage Program

707 A Street, Suite 208

Anchorage, AK 99501

Moriya, Shigehiro

Japan Petroleum Exploration Company, Ltd.

JAPEX Research Center

1-2-1 Hamada, Chiba 260, Japan

Nelson, Robert E.

Department of Geology

Colby College

Waterville, ME 04901

Pavlis, Terry L.

Department of Geology and Geophysics

University of New Orleans

New Orleans, LA 70148
Robinson, Mark S.

State of Alaska, Division of Geological and Geophysical Surveys

794 University Avenue, Suite 200

Fairbanks, AK 99709-3645

Roeske, Sarah

Department of Geology, Mail ID \#0995

University of California, Davis

Davis, CA 95616

Sisson, Virginia B.

Department of Geology and Geophysics

P.O. Box 1892

Rice University

Houston, TX 77251

Underwood, Michael B.

Department of Geological Sciences

University of Missouri

Columbia, MO 65211 


\section{SELECTED SERIES OF U.S. GEOLOGICAL SURVEY PUBLICATIONS}

\section{Periodicals}

Earthquakes \& Volcanoes (issued bimonthly).

Preliminary Determination of Epicenters (issued monthly).

\section{Technical Books and Reports}

Professional Papers are mainly comprehensive scientific reports of wide and lasting interest and importance to professional scientists and engineers. Included are reports on the results of resource studies and of topographic, hydrologic, and geologic investigations. They also include collections of related papers addressing different aspects of a single scientific topic.

Bulletins contain significant data and interpretations that are of lasting scientific interest but are generally more limited in scope or geographic coverage than Professional Papers. They include the results of resource studies and of geologic and topographic investigations; as well as collections of short papers related to a specific topic.

Water-Supply Papers are comprehensive reports that present significant interpretive results of hydrologic investigations of wide interest to professional geologists, hydrologists, and engineers. The series covers investigations in all phases of hydrology, including hydrogeology, availability of water, quality of water, and use of water.

Circulars present administrative information or important scientific information of wide popular interest in a format designed for distribution at no cost to the public. Information is usually of short-term interest.

Water-Resources Investigations Reports are papers of an interpretive nature made available to the public outside the formal USGS publications series. Copies are reproduced on request unlike formal USGS publications, and they are also available for public inspection at depositories indicated in USGS catalogs.

Open-File Reports include unpublished manuscript reports, maps, and other material that are made available for public consultation at depositories. They are a nonpermanent form of publication that may be cited in other publications as sources of information.

\section{Maps}

Geologic Quadrangle Maps are multicolor geologic maps on topographic bases in 71/2-or 15 -minute quadrangle formats (scales mainly $1: 24,000$ or $1: 62,500$ ) showing bedrock, surficial, or engineering geology. Maps generally include brief texts; some maps include structure and columnar sections only.

Geophysical Investigations Maps are on topographic or planimetric bases at various scales; they show results of surveys using geophysical techniques, such as gravity, magnetic, seismic, or radioactivity, which reflect subsurface structures that are of economic or geologic significance. Many maps include correlations with the geology.

Miscellaneous Investigations Series Maps are on planimetric or topographic bases of regular and irregular areas at various scales; they present a wide variety of format and subject matter. The series also includes $71 / 2$-minute quadrangle photogeologic maps on planimetric bases which show geology as interpreted from aerial photographs. Series also includes maps of Mars and the Moon.
Coal Investigations Maps are geologic maps on topographic or planimetric bases at various scales showing bedrock or surficial geology, stratigraphy, and structural relations in certain coal-resource areas.

Oil and Gas Investigations Charts show stratigraphic information for certain oil and gas fields and other areas having petroleum potential.

Miscellaneous Field Studies Maps are multicolor or black-andwhite maps on topographic or planimetric bases on quadrangle or irregular areas at various scales. Pre-1971 maps show bedrock geology in relation to specific mining or mineral-deposit problems; post-1971 maps are primarily black-and-white maps on various subjects such as environmental studies or wilderness mineral investigations.

Hydrologic Investigations Atlases are multicolored or black-andwhite maps on topographic or planimetric bases presenting a wide range of geohydrologic data of both regular and irregular areas; principal scale is $1: 24,000$ and regional studies are at $1: 250,000$ scale or smaller.

\section{Catalogs}

Permanent catalogs, as well as some others, giving comprehensive listings of U.S. Geological Survey publications are available under the conditions indicated below from the U.S. Geological Survey, Books and Open-File Reports Section, Federal Center, Box 25425, Denver, CO 80225. (See latest Price and Availability List.)

"Publications of the Geological Survey, 1879-1961" may be purchased by mail and over the counter in paperback book form and as a set of microfiche.

"Publications of the Geological Survey, 1962-1970" may be purchased by mail and over the counter in paperback book form and as a set of microfiche.

"Publications of the U.S. Geological Survey, 1971- 1981" may be purchased by mail and over the counter in paperback book form (two volumes, publications listing and index) and as a set of microfiche.

Supplements for 1982,1983, 1984, 1985, 1986, and for subsequent years since the last permanent catalog may be purchased by mail and over the counter in paperback book form.

State catalogs, "List of U.S. Geological Survey Geologic and Water-Supply Reports and Maps For (State)," may be purchased by mail and over the counter in paperback booklet form only.

"Price and Availability List of U.S. Geological Survey Publications," issued annually, is available free of charge in paperback booklet form only.

Selected coples of a monthly catalog "New Publications of the U.S. Geological Survey" available free of charge by mail or may be obtained over the counter in paperback booklet form only. Those wishing a free subscription to the monthly catalog "New Publications of the U.S. Geological Survey" should write to the U.S. Geological Survey, 582 National Center, Reston, VA 22092.

Note.--Prices of Government publications listed in older catalogs, announcements, and publications may be incorrect. Therefore, the prices charged may differ from the prices in catalogs, announcements, and publications. 
